Universidade de São Paulo

Instituto de Geociências

\title{
A origem da diversidade geoquímica do Sienito Pedra Branca (MG) a partir da evolução textural e da química de minerais
}

\author{
Bruna Borges Carvalho
}

Orientador: Prof. Dr.Valdecir de Assis Janasi

\section{DISSERTAÇÃO DE MESTRADO}

Programa de Pós-Graduação em Mineralogia e Petrologia 


\section{Pedra Branca}

Rodeado de amigos,

passo a passo por Pocinhos, de tardezinha cheguei lá.

Como é alto, no horizonte vejo longe, sinto a beleza do lugar.

O silêncio é intrigante, eu não sabia antes, como é bom se afastar.

Revoadas cortam o céu em rotas não distantes.

Decidem por si próprias,

a hora de ir, a hora de voltar.

Dão mais vida ao arrebol,

anunciando o fim de mais um dia.

Já é noite.

O céu sem lua aqui de cima é mais escuro,

vemos estrelas despencando sem cessar,

passamos horas observando,

parece um teto a desabar.

A cada estrela que se joga, é uma história a contar.

Reunidos em seu cume.

ouvimos o vento se aproximando ele chega assoviando, o frio agora é de rachar.

Pela madrugada,

hipnotizados com o fogo da fogueira, seguimos bebendo vinho, e nâo paramos de cantar.

Surgem os primeiros raios de luz na escuridão, antecipando a aurora.

O Sol vem surgindo lentamente,

vai aquecendo a ferra sutilmente,

e as cores voltam a vibrar.

O momento é único, não há como eternizá-10

os pássaros reiniciam sua jornada,

e mais uma vez exalam liberdade

Vendo tudo por cima aqui de cima.

2. mesmo com os pés no chão,

nos sentiphos da mesma forma, livres

Livres da roda, livres das falsas oportunidades,

das obrigações de nossa sociedade.

Atingimos o meio do dia.

Temos que chegar,

e diga-se de passagem, obrigados

pelas imposições que nos fazem retornar

à complexidade da vida louca da cidade.

Mas quando lá meus camaradas,

ancorarmos novamente,

é para cá, que tranquilamente nossas mentes,

diariamente irão voltar. 


\section{Agradecimentos}

Gostaria de agradecer imensamente minha familia, em primeiro lugar minha mãe, que é modelo de mulher para mím, e meu pai que sempre apoiou minhas escolhas. Minha irmã que sempre me deu força nas horas mais dificeis.

Ao meu orientador e amigo Valdecir, quero agradecer muito por sua paciêncía e seu incentivo ao meu aprendizado durante todos esses 7 anos que trabalhamos juntos! Muito obrigada por tudo, e quero que saiba que te admiro muito, você é um profissional incrivel, um amante da geología.

Quero agradecer também a todos os funcionários do lGe porque sem eles nada funcionaria. Em especial algumas pessoas me ajudaram muito não apenas nestes doís anos de mestrado, mas durante toda minha graduação: Angélica, Marcos (microssonda), Zé Paulo (LTA), Paulinho (laminação..) e da FRX. Sandra e todo pessoal do laboratório de quimica, Zé Carlos e outros...

Alguns professores que sempre estiveram a minha disposição.. Silvio, Renato Moraes e Marcos Egydio. Com certeza devo incluir os novos professores Lucelene Martins, Adriana Alves, Carlos Ghroman e Rogério Azzone que sempre me ajudaram e incentivaram no instituto ou nos trabalhos de campo na Pedra Branca. Obrigada GENTE!

Amigos pós-graduandos e de todas as horas que sempre deram aquele help nos mais diversos momentos: Frederico Vilalva (querido vizinho e colega de sala, sempre me ensinando alguma coisa..valeu!), Hélice (amiga há tempos.. é muito legal ver o quanto evoluimos nessa caminhada geológica), Pulga, Lua, Cofrinho, Lisa, Angela, Harry, GG, Popó, Meninão.

Tchitcho, Brenda, Cauê, Mikuin sempre dispostos a falar do "Sienito Pedra Branca", e a me ensinar algo seja sobre geologia ou sobre a vida!.

Quero agradecer ao meu amor e companheiro, Renato, muito obrigada pelo seu amor, cumplicidade e amizade sincera ao longo destes 7 anos. Obrigada pelo incentivo que ve me deu sempre para estudar a Pedra Branca e obrigada por acreditar em mím, isso é que me faz ter confiança em mím mesma! Você é mais que especial na minha vida. 
Title: "Origin of geochemical diversity in Pedra Branca Syenite (MG) from textural evolution and mineral chemistry."

Author: Bruna Borges Carvalho.

Program: Mineralogy and Petrology.

Year: 2011.

Keywords: syenite, mineral chemistry, geochemistry, petrogenesis. 


\section{Resumo}

O Sienito Pedra Branca, com cerca de $90 \mathrm{Km}^{2}$, é um plúton tardi-orogênico com idade de $610 \mathrm{Ma}$ intrusivo na Nappe Socorro-Guaxupé, e é truncado a oeste por rochas alcalinas (fonolitos e nefelina sienitos) do Maciço de Poços de Caldas, de idade cretácea.

O plúton é formado por quatro unidades sieníticas, que intrudiram em três pulsos principais. O primeiro pulso é representado pela unidade Sienito Laminado Saturado a Insaturado (SLSI) de tendência alcalina que aflora na parte $\mathrm{N}$ e S-SE do plúton. O segundo pulso consiste na intrusão do Sienito Laminado Supersaturado (SLS), que trunca o interior do SLSI. O último pulso trunca internamente SLS, e constitui o centro do plúton, denominado Sienito Supersaturado Interno (SSI). Externamente ao plúton, separado por um septo de granitos, está o Sienito Supersaturado Externo (SSE), que pode estar associado ao segundo ou terceiro pulso.

O Sienito Pedra Branca é dominado por sienitos hipersolvus com índice de cor entre 20-25, nos quais as variações mineralógicas mostram diferentes condições de cristalização. O SLSI atingiu condições mais oxidantes que os sienitos supersaturados, como demonstrado por suas paragêneses máficas (egirina-augita + flogopita + hematita + magnetita versus diopsídio + flogopita \pm hornblenda + ilmeno-hematita \pm magnetita). Embora em todos os sienitos a cristalização tenha ocorrido sob condições oxidantes, o Mg\# maior dos minerais máficos e as maiores proporções do componente hematita nos óxidos romboédricos indicam que a fugacidade de oxigênio foi mais elevada nos SLSI.

Dois tipos principais de enclaves são encontrados. Enclaves máficoultramáficos são encontrados em todas as unidades, enquanto os microgranulares são exclusivos dos sienitos supersaturados, e têm composições variáveis nos campos dos sienitos, monzonitos e dioritos. Os enclaves monzoníticos e dioríticos são interpretados com produtos de magmas básicos que interagiram com o sienito hospedeiro em câmaras magmáticas mais profundas, e foram trazidos durante a ascensão.

Característica particular dos sienitos supersaturados é a presença de cristais de plagioclásio corroídos, englobados por feldspato alcalino, que possuem composições semelhantes à do plagioclásio presente nos enclaves dioríticos $\left(A n_{25-35}\right)$.

Estimativas de temperatura liquidus utilizando a saturação em apatita mostraram altas temperaturas dos magmas sieníticos, entre 1040 e $1160^{\circ} \mathrm{C}$. Já estimativas de pressão e $\mathrm{fO}_{2}$ foram frustradas devido à ausência de plagioclásio 
magmático nestas rochas (limita o uso do barômetro de $\mathrm{Al}$ na hornblenda) e à ausência de equilíbrio para os óxidos de Fe-Ti (pares ilmeno-hematita + magnetita).

As unidades do Sienito Pedra Branca mostram uma pequena variação composicional e diferem principalmente conteúdo de $\mathrm{Al}_{2} \mathrm{O}_{3}$, compartilhando assinaturas geoquímicas com elevados teores em LILE como Ba (4000-10000 ppm) e $\mathrm{Sr}$ (2000-4500 ppm), além de outros elementos como $\mathrm{P}_{2} \mathrm{O}_{5}$ (1-2\%) e elementos terras raras leves $(\mathrm{La}=100-380 \mathrm{ppm})$.

As semelhanças geoquímicas entre as unidades indicam que, apesar de suas diferenças, elas têm origem comum. Os modelos de gênese de magmas potássicos da literatura sugerem como área fonte mais provável dessas rochas o manto enriquecido. As altas razões LILE/HFSE, demonstradas pelas pronunciadas anomalias negativas em $\mathrm{Nb}$ - $\mathrm{Ta}$, Ti e Hf-Zr, indicam vinculo com áreas ativas onde a injeção de fluidos ricos em REE e LILE durante a subducção gera metassomatismo no manto superior.

As assinaturas isotópicas com $\varepsilon \mathrm{Nd}_{(t)}$ pouco negativo $(-7.6$ a -8.1$)$ e razões ${ }^{87} \mathrm{Sr}^{86} \mathrm{Sr}_{(\mathrm{t})}=0.7077-0.7078$ associadas ao elevado conteúdo de $\mathrm{Ba}, \mathrm{Sr}$ e ETR, reforçam que estes magmas estão associados à fusão parcial de horizontes enriquecidos do manto litosférico.

A associação de sienitos insaturados e supersaturados em sílica, em paralelo com a presença de enclaves dioríticos exclusivamente nos sienitos supersaturados sugerem que a violação da barreira térmica ocorreu devido à interação de magmas saturados de tendência alcalina com magmas básicos. A falta de evidências de interação in situ (e.g. diques sin-plutônicos) e a ocorrência de rochas microgranulares mais máficas apenas como enclaves retrabalhados indicam que a interação entre os magmas e consequentes mudanças composicionais deve ter ocorrido em níveis mais profundos da crosta.

Palavras-chave: sienito, química mineral, geoquímica, petrogênese;

\section{Abstract}

The Pedra Branca Syenite, with about $90 \mathrm{Km}^{2}$ in area, is a $610 \mathrm{Ma}$ lateorogenic pluton intrusive in the Socorro-Guaxupé Nappe and truncated to the west by alkaline rocks (phonolite and nepheline syenite) from the cretacic Poços de Caldas Massif.

The pluton is made up of four syenite units that intruded as three main magmatic pulses. The first pulse is represented by the laminated silica-saturated to undersaturated syenite (SLSI) with alkaline tendency that occurs at N and S-SE of the 
plúton. The second pulse corresponds to the laminated oversaturated syenite (SLS), which truncates SLSI. The last pulse, named internal oversaturated syenite (SSI), cuts SLS internally and makes up the pluton's core. Externally, separated from the main pluton by a granite septum, occurs the external oversaturated syenite (SSE) that may be associated to the second or third pulse.

The Pedra Branca Syenite is dominated by hypersolvus syenites with color indices 20-25, whose mineralogical variations show contrasts in crystallization conditions. The SLSI reached more oxidizing conditions than the oversaturated syenites, as recorded by their mafic assemblages (egirine-augite + phlogopite + hematite + magnetite versus diopside + phlogopite \pm hornblende + ilmeno-hematite \pm magnetite). Although in all syenites the crystallization occurred under oxidizing conditions, the SLSI have higher Mg\# in the mafic minerals and grater proportions of the hematite component in the rhombohedral oxides, indicating higher oxygen fugacity, close to the HM buffer.

Two main types of enclaves are present in the Pedra Branca Syenite. The mafic-ultramafic enclaves occur in all units, while microgranular enclaves are exclusive of silica-oversaturated syenites, and have compositions varying in the compositional fields of syenites, monzonites and diorites. Monzonitic and dioritic enclaves are interpreted as products of basic magmas that interacted with the syenitic host in deeper magma chambers and were carried during ascension.

Another particular feature of the silica-oversaturated syenites is the presence of corroded plagioclase included in alkali-feldspars, which have compositions similar to the plagioclase crystals from the diorite enclaves $\left(A n_{25-35}\right)$.

Estimatives of liquidus temperatures using apatite saturation showed high temperatures for the syenitic liquids, between 1040 and $1160^{\circ} \mathrm{C}$. Pressure and $\mathrm{fO}_{2}$ estimates were frustrated by the lack of magmatic plagioclase (restricting the use of the $\mathrm{Al}$ in hornblende barometers) and the lack of equilibrium between the $\mathrm{Fe}$ - $\mathrm{Ti}$ oxides (ilmeno-hematite + magnetite).

The Pedra Branca Syenite units show small compositional variations, and differ mostly in $\mathrm{Al}_{2} \mathrm{O}_{3}$ content (higher in silica-oversaturated syenites), sharing geochemical signatures with high contents of LILE such as $\mathrm{Ba}$ (4000-10000 ppm) and Sr (2000$4500 \mathrm{ppm})$, plus other elements as $\mathrm{P}_{2} \mathrm{O}_{5}(1,0-2 \%)$ and light rare earth elements ( $\mathrm{La}=$ 100-300 ppm).

Geochemical similarities between the units indicate that despite their differences, they have common origin. Models of potassic magmas genesis in the literature suggest as most likely source areas the enriched mantle. The high LILE/HFSE ratios, highlighted by strong negative anomalies of $\mathrm{Nb}-\mathrm{Ta}, \mathrm{Ti}$ and $\mathrm{Zr}$ - $\mathrm{Hf}$ in 
spiderdiagrams are suggestive of links with active areas where rich-REE and LILE fluid injection during subduction caused metassomatism in upper mantle.

Isotopic signatures with moderately negative $\varepsilon N d(t)(-7.6$ to -8.1$)$ and ${ }^{87} \mathrm{Sr}^{86} \mathrm{Sr}_{(\mathrm{t})}=0.70767$ to 0.70779 associated with the high trace elements contents $(\mathrm{Ba}$, $\mathrm{Sr}$ and $\mathrm{REE}$ ), reinforces that these rocks are associated with partial melting of enriched horizons of the lithospheric mantle.

The association of silica undersaturated and oversaturated syenites, and the presence of dioritic enclaves only in the oversaturated units suggests that the violation of the thermal barrier may be connected to the coexistence with basic magmas. The lack of evidence of in situ interaction (e.g., synplutonic dykes) and occurrence of more mafic microgranular rocks only as reworked enclaves indicates that the magma interaction and consequent compositional changes must have occurred at deeper crustal.

Keywords: syenite, mineral chemistry, geochemistry, petrogenesis; 


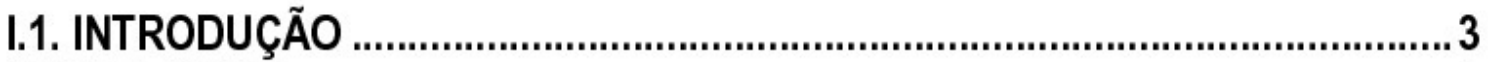

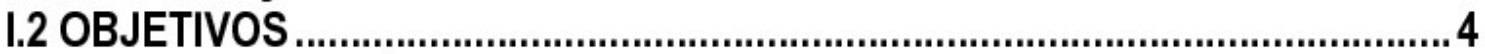

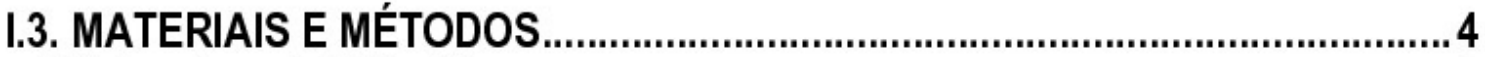

I.3.1. Levantamento Bibliográfico ................................................................................................. 4

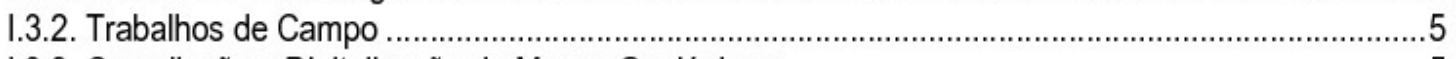

I.3.3. Compilação e Digitalização de Mapas Geológicos .....................................................................5

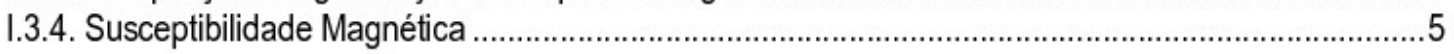

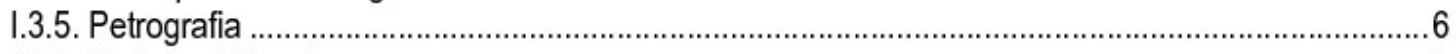

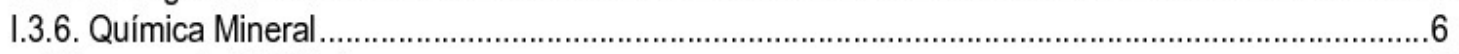

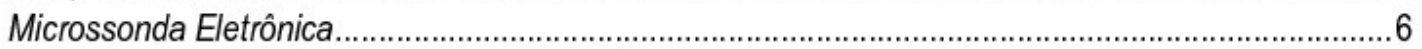

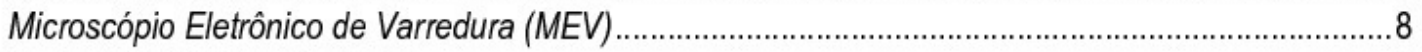

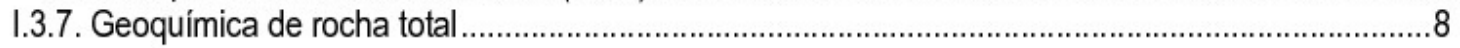

Procedimentos Analíticos e Tratamento de Amostras ......................................................................8

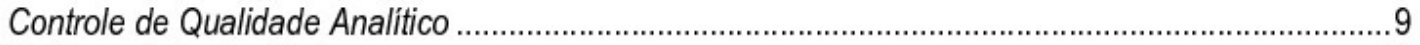

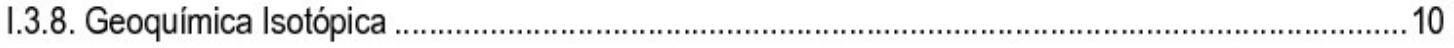

\section{CAPÍTULO II - OCORRÊNCIAS DE SIENITOS RICOS EM POTÁSSIO NO BRASIL: UMA REVISÃO...........................................................................11}

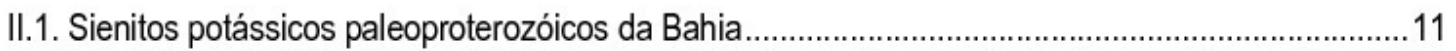

II.2. Complexos Bom Jardim e Toritama ........................................................................................ 16

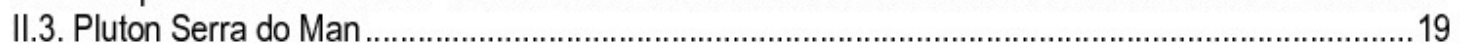

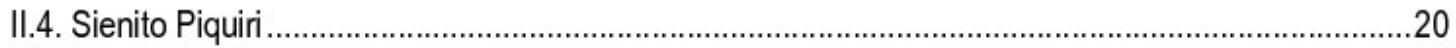

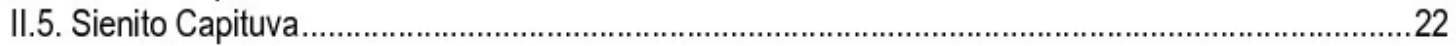

CAPÍTULO III - GEOLOGIA DO SIENITO PEDRA BRANCA.............................26

III.1. CONTEXTO GEOLÓGICO ...................................................................26

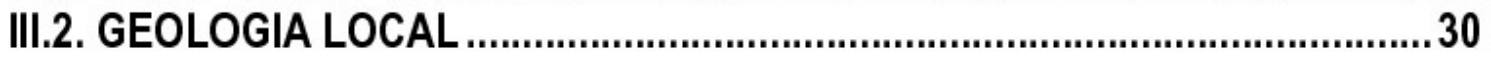

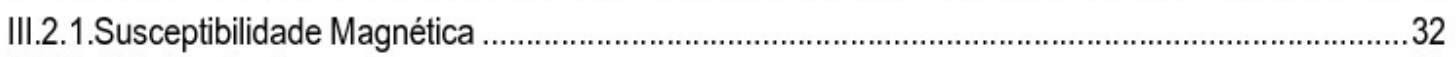

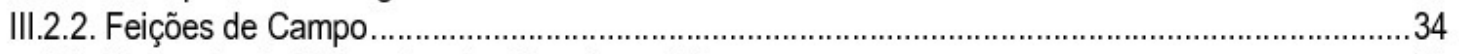

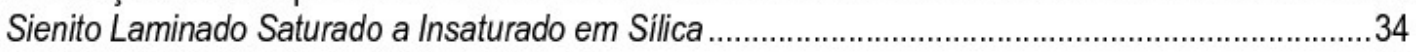

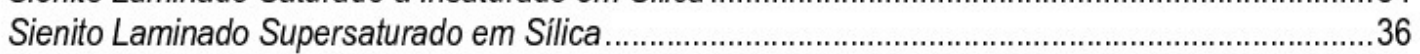

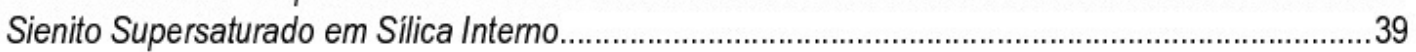

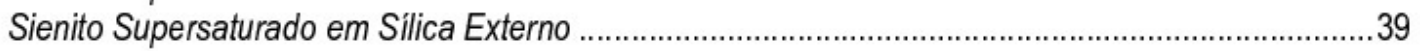

CAPITULO IV - PETROGRAFIA E QUIMICA MINERAL ...................................53

IV.1. PETROGRAFIA

Sienito Laminado Saturado a Insaturado em Sílica .............................................................................53

Sienito Laminado Supersaturado em Silica...............................................................................5 


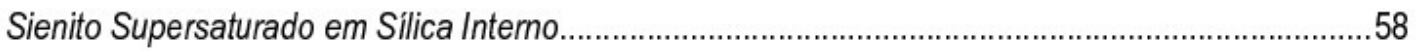

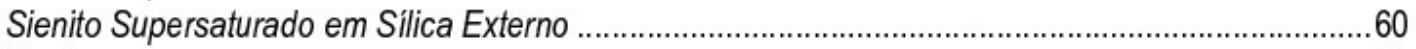

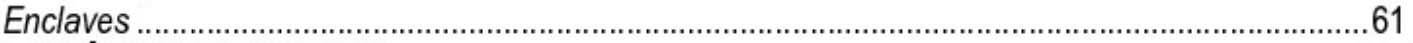

IV.2. QUÍMICA MINERAL ............................................................................. 77

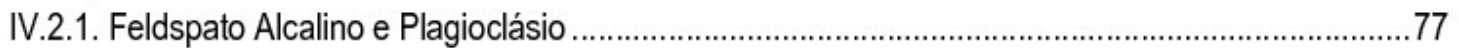

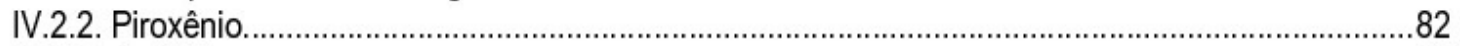

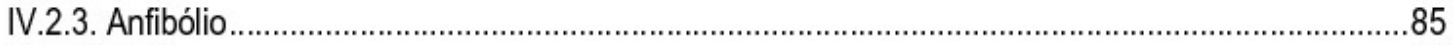

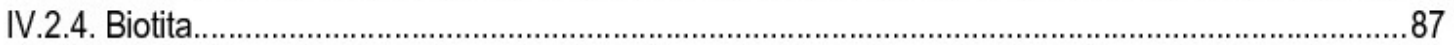

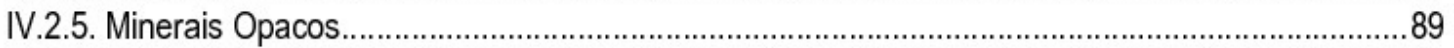

CAPITULO V - GEOQUÍMICA DE ROCHA TOTAL E ISOTÓPICA ......................93

V.1. GEOQUÍMICA DE ROCHA TOTAL ...........................................................93

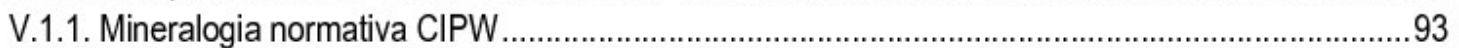

V.1.2. Índices de diferenciação e diagramas de classificação .............................................................94

V.1.3. Elementos Maiores: diagramas de variação .....................................................................96

V.1.4. Elementos Menores e Traço.........................................................................................98

V.2. COMPARAÇÃO GEOQUÍMICA COM OUTROS SIENITOS POTÁSSICOS PRÉ-CAMBRIANOS DO BRASIL.................................................................104 V.3. GEOQUÍMICA ISOTÓPICA Sr-Nd......................................................112

CAPITULO VI - PETROGÊNESE DO SIENITO PEDRA BRANCA .....................114

VI.1 CONSIDERAÇÕES SOBRE A GEOLOGIA DO PLUTON..........................114

VI.2. PARÂMETROS INTENSIVOS E CONDIÇÕES DE CRISTALIZAÇÃO........115

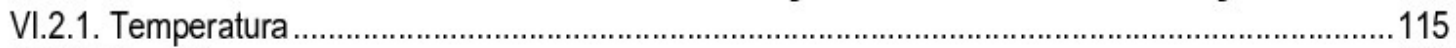

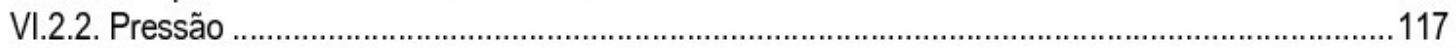

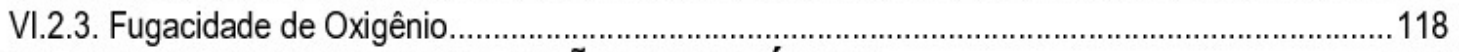

VI.3. PROCESSOS DE EVOLUÇÃO MAGMÁTICA .........................................119

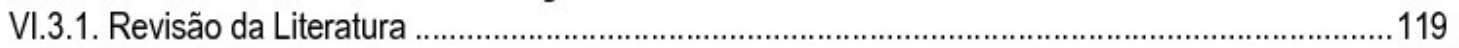

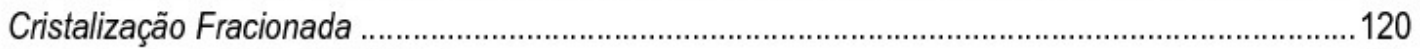

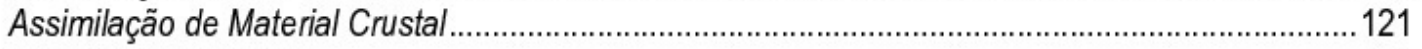

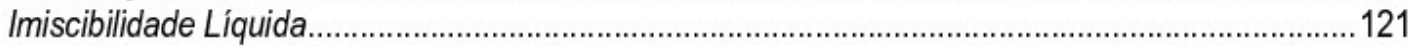

Fusão Parcial de uma fonte mantélica previamente enriquecida .................................................122

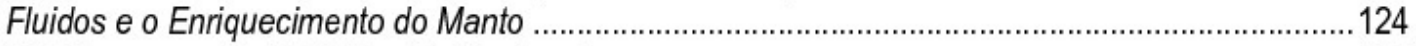

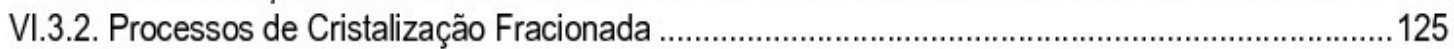

VI.3.3. Processos de Mistura e Significado dos Enclaves Microgranulares Dioríticos.........................128

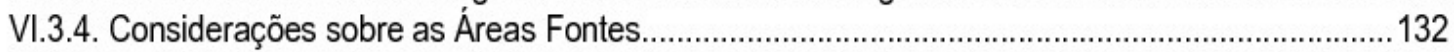

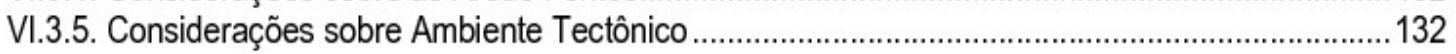

CAPITULO VII - CONSIDERAÇÕES FINAIS ................................................ 136

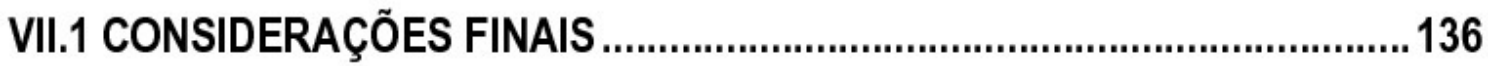

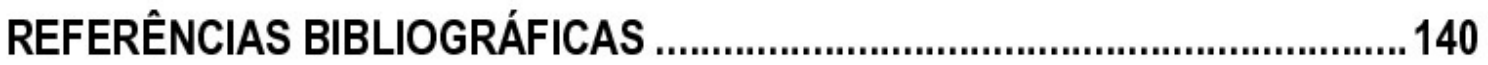




\section{ÍNDICE DE TABELAS}

Tabela 1: Condições analíticas utilizadas para as análises WDS em microssonda

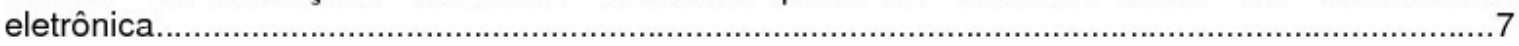

Tabela 2: Padrões e tempo de integração durante análises

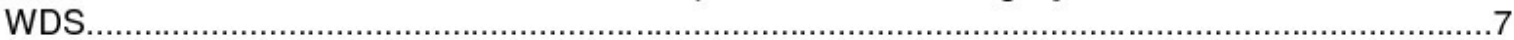

Tabela 3: Padrões e tempo de integração durante análises WDS...............................................

Tabela 4: Nomenclatura utilizada nas unidades do Sienito Pedra Branca juntamente com as

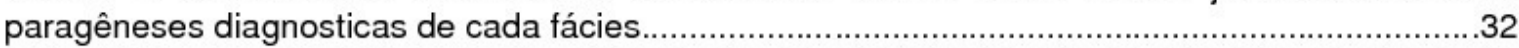

Tabela 5: Ordem de cristalização estimada para os sienitos da unidade SLSI..............................55

Tabela 6: Ordem de cristalização estimada para os sienitos da unidade SLS...............................58

Tabela 7: Ordem de cristalização estimada para os sienitos da unidade SSI..............................60

Tabela 8: Ordem de cristalização dos sienitos da unidade SSE...............................................61

Tabela 9: Dados isotópicos em amostras do Sienito Pedra Branca; as razões foram calculadas para idade de cristalização do plúton $(\mathrm{t}=610 \mathrm{Ma})$. TDM= idade-modelo $\mathrm{Sm}-\mathrm{Nd}$ segundo o método

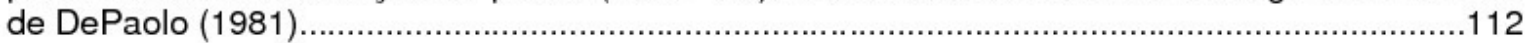

\section{ANEXO I- MAPA GEOLÓGICO E DE PONTOS DO SIENITO PEDRA BRANCA}

\section{ANEXO II - TABELAS DE QUÍMICA MINERAL}

Tabela 1: Análises WDS em cristais de feldspato do Sienito Pedra Branca.

Tabela 2: Análises WDS em cristais de piroxênio do Sienito Pedra Branca.

Tabela 3: Análises WDS em cristais de anfibólio do Sienito Pedra Branca.

Tabela 4: Análises WDS em cristais de biotita do Sienito Pedra Branca.

Tabela 5: Análises WDS em cristais de óxidos de Fe-Ti do Sienito Pedra Branca.

\section{ANEXO III - TABELAS DE QUÍMICA DE ROCHA TOTAL}

Tabela 1: Norma CIPW em rochas do Sienito Pedra Branca.

Tabela 2: Dados Geoquímicos do Sienito Pedra Branca Obtidos por FRX.

Tabela 3: Dados Geoquímicos do Sienito Pedra Branca Obtidos por ICP-OES.

Tabela 4: Dados Geoquímicos do Sienito Pedra Branca Obtidos por ICP-MS. 


\section{ÍNDICE DE FIGURAS}

Figura 1: Gráfico de barras com a diferença obtida entre os valores obtidos por ICP-OES e FRX em alguns elementos maiores. Valores em porcentagem em peso.

Figura 2: Gráfico de barras com a diferença obtida entre os valores obtidos por ICP-OES e FRX em alguns elementos traço. Valores em partes por milhão (ppm)...

Figura 3: Mapa Geológico do Batólito Itiúba e rochas encaixantes (Conceição et al., 1991); 1= falhas; 2 = sedimentos quaternários; 3= Granito Pedra Solta; 4= Sienito Itiúba; 5= Faixa Móvel Salvador Curaçá; 6= Diatexitos e Metatexitos. As bordas em azul escuro são destacadas por apresentar foliação no nodo sólido.

Figura 4: Localização dos diques de Sienito Itiúba, Santanápolis, São Felix e Anuri. Simbologia: 1= fraturas e falhas; 2= terrenos neoproterozóicos; 3= diques de sienito paleoproterozóicos; 4= terrenos granulíticos arqueano-paleoproterozóicos; $5=$ núcleos arqueanos; extraído de Conceição et (2007) 15

Figura 5: Mapa Geológico Regional do Complexo Bom Jardim (Guimarães e Silva Filho, 1998). Legenda: 1 = gnaisses e migmatitos; 2 = Complexo Bom Jardim (A) e Toritama (B); $3=$ Complexo Fazenda Nova (cálcio-alcalino de alto potássio); 4= Biotita Xistos com lentes de quartzito e mármore; 5= Anortisito Passira; 6= Augen-gnaisse; 7= Plúton Santa Cruz do Capibaribe; 8= foliação; 9= falhas geológicas.

Figura 6: Mapa Geológico do Pluton Serra do Man (Ferreira et al., 2002)

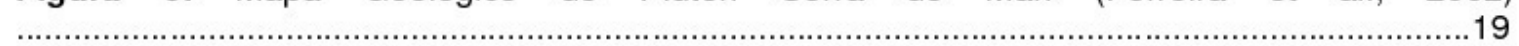

Figura 7: Mapa Geológico do Sienito Piquiri (Nardi et al., 2008).....

Figura 8: Mapa Geológico do Maciço Sienítico Capituva e rochas encaixantes (Janasi, 1993). Simbologia: 1= Gnaisses; 2= Granulitos; 3= Granitos equigranulares róseos; $4=$ Suíte composta por Mangeritos, Charnockitos e Granitos 5=Granitos cálcio-alcalinos porfiríticos; $7=$ Maciço Alcalino de Poços de Caldas; 8-15= Maciço Sienítico Capituva; 8, 9 e 11 fácies MCS; 8= sienitos laminados grossos e sienitos porfiríticos com matriz fina; $9=$ melasienitos (MS); $10=$ Sienitos Porfiríticos de matriz fina a média; 11= Sienitos laminados médios; 12= Quartzo Sienitos finos (FQS); 13= Sienitos laminados grossos; 14=Quartzo Sienitofinos a médios (FMQS); 15= corpo satélite, composto principalmente leucosienitos 24

Figura 9: À esquerda: Mapa tectônico da América do Sul. 1= Sistema Orogênico Andino; 2= Terreno Patagônia; 3= Cobertura Fanerozóica da Plataforma Sul-America; 4=Escudos da Plataforma Sul-Americana, destacando a Província Mantiqueira (5) e o Cráton São Francisco(6). À direita: Subdivisão da Província Mantiqueira. O segmento setentrional é o orógeno Araçuaí, já o segmento central compreende a porção sul do Orógeno Brasília e os Orógenos Ribeira e Apiaí. Já o segmento meridional inclui os orógenos Dom Feliciano e São Gabriel (extraído de Heilbron et al., 2004).

Figura 10: Mapa Geológico simplificado do Orógeno Brasília Sul (extraído de Campos Neto et al., 2004)

Figura 11: Mapa Geológico do extremo sul do Domínio Guaxupé, sudeste do Brasil (Janasi, 1999). 30

Figura 12: Mapa Geológico incluindo valores de susceptibilidade magnética do Sienito Pedra Branca. 
Figura 13: Histogramas de freqüência relativa dos valores de susceptibilidade magnética em amostras das diferentes unidades sieníticas do plúton ( $\mathrm{N}$ é o número de amostras e $\mathrm{X}$ é a média dos valores amostrados).

Figura 14: Simbologia utilizada para feldspato alcalino e plagioclásio analisados em amostras do Sienito Pedra Branca.

Figura 15: Diagrama classificatório dos Feldspatos do Sienito Pedra Branca. À esquerda (símbolos em cinza e verde) estão as amostras de plagioclásio de enclaves e cristais corroídos encontrados na SLS. À direita (símbolos em azul - SLS - e vermelho - SLSI) estão as amostras de feldspato alcalino.A simbologia utilizada encontra-se na figura

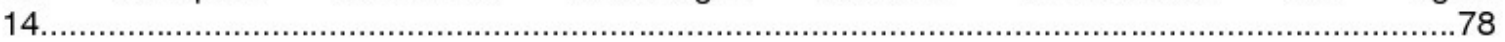

Figura 16: Fotomicrografias de feldspato alcalino, sob polarizadores cruzados, da unidade SLSI com indicação das proporções das moléculas Or e Ab, obtidas por microssonda eletrônica. 79

Figura 17: A) Imagem de elétrons retro-espalhados em feldspato alcalino; áreas em tons de cinza claro são ricas em $\mathrm{Ba}$. B, C) Fotomicrografias de feldspato alcalino, sob polarizadores cruzados, da unidade SLS com indicação das proporções das moléculas Or e Ab, obtidas por microssonda eletrônica.

Figura 18: A) Imagem de elétrons retro-espalhados de cristais de plagioclásio B) Fotomicrografias de plagioclásio inclusos feldspato alcalino, sob polarizadores cruzados, da unidade SLS com indicação das proporções das moléculas An, Or e Ab, obtidas por microssonda eletrônica.

Figura 19: Cristais de piroxênio das diferentes unidades sieníticas .83

Figura 20: Simbologia utilizada para cristais de piroxênio das amostras do Sienito Pedra Branca 83

Figura 21: Diagramas de variação química dos piroxênios do Sienito Pedra Branca; diagramas classificatórios segundo Morimoto (1988). Simbologia como na figura 20. 86

Figura 22: Cristais de anfibólio das unidades SLSI e SLS.

Figura 23: Classificação dos anfibólios do Sienito Pedra Branca, segundo Leake et al. (1997) 87

Figura 24: Diagramas de variação química das biotitas do Sienito Pedra Branca. .88

Figura 25: Minerais opacos das unidades SLSI (A) e SLS (B) vistos sob luz refletida. 89

Figura 26: Imagem de elétrons retroespalhados mostrando inclusões aciculares em feldspato. 90

Figura 27: Diagrama ternário de classificação da série magnetita-ülvoespinélio e hematitailmenita (Buddington \& Lindsley, 1964) 90

Figura 28: Cristal de bornita com finas bordas de calcosina e galena, vistos em fotomicrografia sob luz refletida (A) e imagem de elétrons retroespalhados (B); amostra PB$185 \mathrm{C}$. 91

Figura 29: Cristais de bornita em enclave, vistos sob luz transmitida $(A)$, refletida $(B)$ e em imagem de elétrons retroespalhados (C); amostra PB-246B. 
Figura 30: Diagrama Ortopiroxênio versus Quartzo normativo (A) e Anortita versus Quartzo normativo (B) para amostras de sienitos e enclaves do Sienito Pedra Branca.

Figura 31: Diagramas de classificação composicional de rochas feldspáticas segundo Frost \& Frost (2008) para rochas do Sienito Pedra Branca. .95

Figura 32: Diagrama de variação para elementos maiores utilizando sílica como índice de diferenciação para rochas do Sienito Pedra Branca. 97

Figura 33: Diagramas de variação para $\mathrm{MgO}, \mathrm{P} 2 \mathrm{O} 5$ e $\mathrm{An}$ normativa em relação a $\mathrm{Al}_{2} \mathrm{O}_{3}$ para as rochas do Sienito Pedra Branca. As rochas ultramáficas não foram incluídas nos diagramas $(A)$ e (C)

Figura 34: Diagramas de variação de elementos traço do Sienito Pedra Branca. .100

Figura 35: Padrões de elementos terras raras para amostras do Sienito Pedra Branca. No diagrama dos enclaves a área hachurada representa os padrões das diferentes unidades sieníticas...... 102

Figura 36: Diagramas multi-elementares para sienitos e enclaves do Sienito Pedra Branca, normalizados pelo manto primitivo (Sun \& McDonough, 1989). No diagrama dos enclaves a área

hachurada representa os padrões das diferentes unidades sieníticas .104

Figura 37: Diagramas de elementos maiores utilizando $\mathrm{SiO}_{2}$ como índice de diferenciação. $\mathrm{O}$ diagrama de afinidade geoquímica foi extraído de Maniar \& Piccoli (1989) . .106

Figura 38: Diagramas de elementos menores. Legenda como na figura 37 108

Figura 39: Diagrama de elementos Terras Raras. Valores normalizados pelo condrito $\mathrm{C}_{1}$ (McDonough\& Sun, 1995). Legenda como na figura 37.

Figura 40: Diagrama de elementos incompatíveis. Valores normalizados pelo manto primitivo (Sun \& McDonough, 1989). Legenda como na figura 37

Figura 41: (A) Diagrama $\varepsilon N d \times t$ (Ga) para sienitos dos plútons Pedra Branca e Capituva; DM: linha de evolução do manto empobrecido (DePaolo, 1981); (B) Diagrama $\varepsilon N d(t)$ x $87 \mathrm{Sr} / 86 \mathrm{Sr}(\mathrm{t})$; para comparação, é indicado o campo ocupado pelos granitos do Batólito PinhalIpuiúna. 113

Figura 42: (A) Diagrama de barras com as temperaturas obtidas pelo termômetro de Harrison \& e Watson (1984); (B) Diagrama $\mathrm{P}_{2} \mathrm{O}_{5}$ versus $\mathrm{SiO}_{2}$ para rochas do Sienito Pedra Branca (simbologia como na figura $\mathrm{x}$ ) e Capituva (campo hachurado em cinza), com isotermas de Watson \& Harrison (1984)....... 116

Figura 43: Termometria de Piroxênios (Lindsley, 1983) para amostra PB-59 (SSI) do Sienito Pedra Branca.

Figura 44: Estimativa de pressão do Sienito Pedra Branca em amostras do SLS, utilizando a metodologia de Anderson \& Smith (1995).

Figura 45: Diagrama de Fugacidade conforme a composição de cristais de anfibólio das unidades do Sienito Pedra Branca (Anderson \& Smith, 1995)

Figura 46: Diagrama de composições normativas dos feldspatos em amostras de sienito e enclaves. 
Figura 47: Diagramas de discriminação tectônica para o Sienito Pedra Branca; simbologia como na figura Y. (A) Diagrama ternário $\mathrm{FeO}_{\mathrm{T}}-\mathrm{MgO}-\mathrm{Al}_{2} \mathrm{O}_{3}$, campos segundo Pearce et al. (1977). (B) Diagrama binário $\mathrm{Nb}+\mathrm{Y}$ versus $\mathrm{Rb}$, campos segundo Pearce et al. (1984): Syn-COL - sincolisional, WP- intra-placa, Vulcânico, ORG-

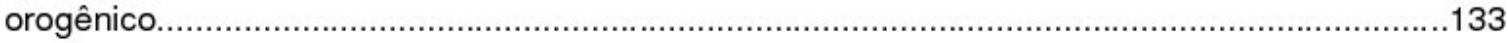

Figura 48: Diagrama $\mathrm{Nb}$ versus $\mathrm{Zr}$, para rochas potássicas com teores de $\mathrm{SiO}_{2}$ inferiores a $60 \%$ (Thompson \& Fowler, 1986). O campo hachurado em (A) representa rochas separadas de processos de subducção no espaço e/ou tempo; (B) corresponde a rochas próximas a subducção no espaço e/ou tempo

\section{ÍNDICE DE FOTOS}

PRANCHA I - FOTOS DE CAMPO

Foto 1 (PB-36A): Amostra de álcali sienito com textura inequigranular porfirítica grossa.

42

Foto 2 (PB-70A): Amostra de álcali sienito com textura inequigranular média, e intensa foliação magmática dada pelos cristais tabulares de feldspato alcalino com razão axial 4

Foto 3 (PB-189): Intensa foliação magmática em álcali sienito e par S/C formado em zona de cisalhamento sin-magmática

Foto 4 (PB-288): Álcali sienito com textura inequigranular média, rico em minerais máficos. Apatita atinge proporções modais de $5 \%$. 42

Foto 5 (PB-174): Dique sienítico com bandamento composicional evidenciado por diferentes conteúdos em voláteis.

Foto 6 (PB-188): Brecha magmática formada pela intrusão forçada de sienito róseo tardio em sienito cinza hospedeiro......

Foto 7 (PB-176): Dique ultramáfico com textura afanítica intrusivo em alcali sienito. .43

Foto 8 (PB-174): Intensa alteração hidrotermal em sienito grosso. Presença de cavidades miarolíticas e carbonato e malaquita tardios.

Foto 9 (PB-174): Veio pegmatítico tardio com intensa alteração hidrotermal. Paragênese exótica com K-feldspato, apatita, magnetita, carbonato, calcopirita e malaquita.

Foto 10 (PB-174E): Destaque para presença de cavidades miarolíticas, além de magnetita, calcopirita com malquita nas bordas

Foto 11 (PB-235): Interação entre sienitos laminados grosso e finos, e enclave de melasienito cortados por veio tardio com acumulação de máficos nas bordas.

Foto 12 (PB-175): Bandamento modal dado pelo aumento na proporção de minerais máficos em álcali sienito. As porções mais escuras constiuem-se de piroxênio e apatita.

Foto 13 (PB-174): Retrabalhamento de cumulatos máficos e feldspáticos (leucosienito) ocasionando a formação de enclaves cumuláticos, muito comuns nesta unidade.

Foto 14 (PB-197): Sienito com quarzto, textura inequigranular grossa. Foliação magmática bem marcada pelos cristais de feldspato alcalino tabular com $\mathrm{Ra}=2,5$.

Foto 15 (PB-213): Sienito com quartzo intensamente deformado por zona de cisalhamento pósmagmática.

Foto 16 (PB-212): Sienito com cristal de plagioclásio incluso em feldspato alcalino. 45 
Foto 17 (PB-246): Veios tardios de quartzo sienito em sienito supersaturado.

Foto 18 (PB-209): Veio pegmatítico intrusivo em sienito com quartzo e IC=25. Presença de cumulatos máficos e sienito bandado.

Foto 19 (PB-209): Detalhe da foto 5 mostrando veio pegmatítico com textura gráfica. .45

Foto 20 (PB-210): Cavidade miarolítica com quartzo piramidado em sienito tardio. 46

Foto 21 (PB-247): Enclave microgranular monzonítico em sienito com quartzo. Presença de veio granítico tardio. .46

Foto 22 (PB-231): Enclave cumulático ultramáfico em sienito com quartzo. .46

Foto 23 (PB-185): Enclave cumulático félsico rico em feldspato em sienito com quartzo. $\mathrm{Na}$ bordas ocorre concentração de piroxênio e apatita. . .46

Foto 24 (PB-209): Enclave microgranular ultramáfico em sienito. Destaque para captura de cristais de feldspato e concentração de máficos nos contatos com a rocha hospedeira. 46

Foto 25 (PB-185): Enclave ultramáfico com piroxênio, flogopita, apatita, titanita, magnetita, calcopirita e bornita...... 46

Foto 26 (PB-246): Enclave microgranular diorítico tabular com bordas resfriadas em sienito com quartzo.

Foto 27 (PB-209): Enclave microgranular diorítico com contatos difusos ricos em biotita em sienito com quartzo.

Foto 28 (PB-250): Enclave microgranular sienítico com sutil bandamento composicional e forma tabular.....

Foto 29 (PB-209): Enclave microgranular sienítico com contatos difusos em sienito com quartzo. Destaque para pequeno cristal de plagioclásio incluso em feldspato alcalino.

Foto 30 (PB-209): Interação complexa entre sienito $(I C=25)$ e sienito fino $(I C=20)$ com enclaves cumuláticos máficos, leucosienito fino e enclave leucocrático grosso rico em plagioclásio.

Foto $31(\mathrm{~Pb} 156)$ : Sienito e cumulatos ultramáficos com enclaves microgranulares dioríticos em seu interior.

Foto 32 (PB-209): Retrabalhamento e desagregação de banda cumulática ultramáfica e melasienitos (IC>35). Destaque para enclave microgranular félsico incluso no cumulato. 48

Foto 33 (PB-209): Nuvem de sólidos: xenólito, enclaves microgranulares e cumuáticos, vênulas máficas e minerais máficos. Destaque para xenólito de sienito laminado (SLSI) e enclave máfico (lamprofírico)

Foto 34 (PB-59): Sienito com quartzo textura equigranular fina, cor esverdeada. 49

Foto 35 (PB-130): Sienito com quartzo, textura inequigranular fina com mega-cristais de piroxênio, cor esverdeada.

Foto 36 (PB-58): Sienito supersaturado inequigranular médio. 49

Foto 37 (PB-171): Diques graníticos tardios, intrusivos em sienito supersaturado 49

Foto 38 (PB-58): Enclave microgranular incluso em sienito supersaturado. Destaque para a forma tabular e concentração de máficos nas bordas. 
Foto 39 (PB-171): Enclave microgranular sienítico em sienito supersaturado. Destaque para limites irregulares do enclave mostrando baixo contrate de viscosidade com a rocha hospedeira.

Foto 40 (PB-260): Sienito com quartzo, textura inequigranular fina e cor rósea, foliação magmática insipiente..

Foto 41 (PB-264): Sienito com quartzo, textura inequigranular média a grossa. Foliação Magmática marcada por felspato alcalino tabular $\mathrm{Ra}=2,5$

Foto 42 (PB-265): Amostra de sienito com quartzo, textura inequigranular média e cor esverdeada.

Foto 43 (PB-264): Amostra de sienito milonitizado devido a presença de zona de cisalhamento pós-magmática. Destaque para forma sigmoidal do feldspato alcalino. 51

Foto 44 (PB-264): Enclave microgranular diorítico em sienito com quartzo 52

Foto 45 (PB-259): Enclave cumulático máfico em sienito com quartzo .52

Foto 46 (PB-264): Alteração hidrotermal em sienito com quartzo. Destaque para cristais de feldspato marrom, provavelmente intactos.

Foto 47(PB-259): Cristal de pirita e biotita em sienito com quartzo .52

PRANCHA II - FOTOMICROGRAFIAS 66

Fotomicrografia 1: Egirina-augita zonada, cor verde intenso, associada a titanita, biotita e magnetita. Lado maior da foto $3,25 \mathrm{~mm}$.

Fotomicrografia 2: Egirina-augita verde intenso, apatita incolor e nefelina, intersticial em sienito. Lado maior da foto $1,30 \mathrm{~mm}$.

Fotomicrografia 3: Feldspato alcalino tabular zonado em sienito. Lado maior da foto 8,32 mm..67

Fotomicrografia 4: Feldspato alcalino com finas inclusões de hematita. Lado maior da foto 0,26 $\mathrm{mm}$.

Fotomicrografia 5: Aspecto geral dos sienitos saturados, com piroxênio como mineral máfico principal, além biotita, apatita e magnetita. Lado maior da foto $10.4 \mathrm{~mm}$

Fotomicrografia 6: Assembléia máfica de sienito com egirina-augita, hornblenda, biotita, apatita titanita, além de opacos hematita e magnetita. Lado maior da foto $10,4 \mathrm{~mm}$.

Fotomicrografia 7: Actinolita e titanita como minerais tardios em sienito saturado. Lado maior da foto $3,25 \mathrm{~mm}$

Fotomicrografia 8: Associação de minerais opacos típica do SLSI com hematita e magnetita, vistos à luz refletida. Lado maior da foto $1,30 \mathrm{~mm}$

Fotomicrografia 9: Cristal de hematita quase pura, pobre em lamelas de ilmenita, vista à luz refletida. Lado maior da foto $0,260 \mathrm{~mm}$

Fotomicrografia 10: Processo de martitização em cristais de magnetita, vistos à luz refletida. Lado maior da foto 0,260 .

Fotomicrografia 11: Cumulato ultramáfico típico da SLSI, com egirina-augita, apatita, biotita, ilmeno-hematita e titanita. Lado maior da foto $8,32 \mathrm{~mm}$ 
Fotomicrografia 12: Cristais de ilmeno-hematita em cumulato ultramáfico da SLSI, vistos à luz

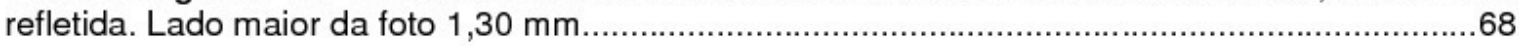

Fotomicrografia 13: Diopsídio reliquiar substituído por hornblenda, associado a titanita, apatita e opacos. Lado maior da foto $3,25 \mathrm{~mm}$.

Fotomicrografia 14: Sienito supersaturado intensamente deformado com sigmóides de titanita e anfibólio com sombra de pressão. Lado maior da foto $3.25 \mathrm{~mm}$.

Fotomicrofrafia 15: Diopsídio reliquiar em núcleos de hornblenda. Lado maior da foto 10.4 $\mathrm{mm}$.

Fotomicrografia 16: Anfibólio azul (riebeckita) em borda de hornblenda. Lado maior da foto 1,3 $\mathrm{mm}$.

Fotomicrografia 17: Feldspato alcalino pertítico zonado. Destaque para lamelas espessas no núcleo do cristal. Lado maior da foto $10,4 \mathrm{~mm}$.

Fotomicrografia 18: Feldspato alcalino zonado com núcleo pertítico e bordas homogêneas, com trilha de máficos finos marcando o limite entre as duas zonas. Lado maior da foto 10,4 mm. 69

Fotomicrografia 19: Cristal de plagioclásio zonado com bordas irregulares, incluso em feldspato alcalino pertítico. Destaque para trilhas de máficos nas bordas do feldspato alcalino marcando antigas faces. Lado maior da foto $10,4 \mathrm{~mm}$ .70

Fotomicrografia 20: Cristal de plagioclásio sericitizado com bordas irregulares incluso em feldspato alcalino. Lado maior da foto $10,4 \mathrm{~mm}$. 70

Fotomicrografia 21: Assembléia máfica com diopsídio substituído por hornblenda e apatita com allanita nas bordas. Lado maior da foto $3,25 \mathrm{~mm}$.

Fotomicrografia 22: Associação tardia de albita e carbonato entre cristais de feldspato alcalino. Lado maior da foto $1,30 \mathrm{~mm}$.

Fotomicrografia 23: Cristal de ilmeno-hematita s.s. e calcopirita vistos à luz refletida. Lado maior da foto $0,65 \mathrm{~mm}$.

Fotomicrografia 24: Cristal de ilmeno-hematita s.s. Visto à luz refletida. Lado maior da foto 0,260 $\mathrm{mm}$

Fotomicrografia 25: Diopsídio substituído por hornblenda e mineral opaco com bordas de titanita. Lado maior da foto $3,25 \mathrm{~mm}$. .71

Fotomicrografia 26: Cristal de magnetita xenomórfico com titanita nas bordas. Lado maior da foto $1,04 \mathrm{~mm}$.

Fotomicrografia 27: Hornblenda e minerais opacos com fina borda de titanita. Lado maior da foto $1,63 \mathrm{~mm}$

Fotomicrografia 28: Associação de minerais opacos com magnetita martitizada e ilmenohematita s.s. vistos à luz refletida. Lado maior da foto $1,04 \mathrm{~mm}$

Fotomicrografia 29: Associação típica de cumulato máfico em SLS com diopsídio, biotita, minerais opacos e feldspato alcalino. Lado maior da foto $8,32 \mathrm{~mm}$.

Fotomicrografia 30: Associação magnetita e ilmenita-hematita s.s. vistos à luz refletida. Lado maior da foto $0,260 \mathrm{~mm}$ 
Fotomicrografia 31: Aspecto geral da SSI com diopsídio, enstatita, feldspato alcalino e apatita. Hornblenda verde escura substui parcialmente o diopsídio. Lado maior da foto $3,25 \mathrm{~mm}$. .72

Fotomicrografia 32: Megacristais de diopsídio associados a feldspato alcalino e minerais opacos. Lado maior da foto $3,25 \mathrm{~mm}$ .72

Fotomicrografia 33: Feição tardia de intercrescimento entre quartzo e biotita e quartzo e albita (mimerquita). Lado maior da foto $1,30 \mathrm{~mm}$. .72

Fotomicrografia 34: Cristais euédricos de apatita associados a diopsídio, feldspato alcalino e minerais opacos. Lado maior da foto $3,25 \mathrm{~mm}$.

Fotomicrografia 35: Cristal de diopsídio com bordas de egirina devido a alteração por fluidos alcalinos. Lado maior da foto $3,25 \mathrm{~mm}$

Fotomicrografia 36: Alteração hidrotermal localizada por percolação de fluidos alcalinos. Lado maior da foto $8,32 \mathrm{~mm}$

Fotomicrografia 37: Aspecto geral dos sienitos SSE com feldspato alcalino zonado, diopsídio, biotita e apatita. Lado maior da foto $10,4 \mathrm{~mm}$. .73

Fotomicrografia 38: Núcleo reliquiar de diopsídio em hornblenda anédrica, associada a apatita, biotita, titanita e opacos. Lado maior da foto $1,3 \mathrm{~mm}$. . .73

Fotomicrografia 39: Zoneamento composicional em cristal de diopsídio. Lado maior da foto 5,2 $\mathrm{mm}$

Fotomicrografia 40: Zoneamento oscilatório em feldspato alcalino pertítico. Lado maior da foto $10,4 \mathrm{~mm}$.

Fotomicrografia 41: Cristal de hematita rico em lamelas de ilmenita, vistos à luz refletida. Lado maior da foto $1,3 \mathrm{~mm}$. .73

Fotomicrografia 42: Micro-sienito inequigranular porfirítico, com fenocristais de clinopiroxênio e matriz com feldspato alcalino, biotita, apatita e opacos. Lado maior da foto $2,60 \mathrm{~mm}$ .74

Fotomicrografia 43: Micro-sienito equigranular com feldspato alcalino, diopsídio, hornblenda, biotita, apatita, opacos e titanita. Lado maior da foto $3,25 \mathrm{~mm}$. 74

Fotomicrografia 44: Monzonito com feldspato alcalino pertítico, plagioclásio, hornblenda, biotita, apatita e opacos. Lado maior da foto $2,60 \mathrm{~mm}$.....

Fotomicrografia 45: Megacristal de plagioclásio com nucleo fortemente alterado em monzonito equigranular. Lado maior da foto $2,60 \mathrm{~mm}$

Fotomicrografia 46: Enclave diorítico fino com textura granoblástica, e intensa alteração sericítica no núcleo. Lado maior da foto $10,4 \mathrm{~mm}$

Fotomicrografia 47: Enclave diorítico fino com textura granoblástica e borda muito fina devido ao resfriamento rápido. Lado maior da foto $8,32 \mathrm{~mm}$.

Fotomicrografia 48: Enclave diorítico médio, com plagioclásio zonado, com núcleos intensamente modificados. Lado maior da foto $8,32 \mathrm{~mm}$.

Fotomicrografia 49: Enclave diorítico milimétrico, composto por plagioclásio, biotita marrom e magnetita. Lado maior da foto $1,63 \mathrm{~mm}$.

Fotomicrografia 50: Enclave diorítico com clinopiroxênio, hornblenda, plagioclásio, biotita, opacos e titanita. Lado maior da foto $3,25 \mathrm{~mm}$. 
Fotomicrografia 51: Enclave diorítico (mesma amostra da foto anterior) rico em hornblenda e plagioclásio com núcleos alterados. Lado maior da foto $1,3 \mathrm{~mm}$.

Fotomicrografia 52: Enclave bandado intercalando níveis ora com clinopiroxênio ora hornblenda, juntamente com plagioclásio, bornita e carbonato. Lado maior da foto $5,20 \mathrm{~mm}$.

Fotomicrografia 53: Porção rica em plagioclásio e magnetita do enclave bandado. Destaque para alteração sericítica do plagioclásio similar ao observados nos enclaves com biotita. Lado maior da foto $8,32 \mathrm{~mm}$.

Fotomicrografia 54: Nível rico em hornblenda do enclave bandado. Presença de plagioclásio (intercrescido com hornblenda e opacos), carbonato e minerais opacos. Lado maior da foto 8,32 $\mathrm{mm}$.

Fotomicrografia 55: Enclave bandado visto sob luz refletida. Presença de cristais bem desenvolvidos de bornita, com núcleos de calcosina e magnetita. Lado maior da foto $8,32 \mathrm{~mm} . . .76$

Fotomicrografia 56: Enclave cumulático ultramáfico com clinopiroxênio, apatita, titanita, biotita e opacos. Lado maior da foto $10,4 \mathrm{~mm}$.

Fotomicrografia 57: Anfibólio azul e carbonato tardios associados à alteração do clinopiroxênio. Lado maior da foto $3,25 \mathrm{~mm}$.

Fotomicrografia 58: Destaque da paragênesse tardia com carbonato e anfibólio azul. Lado maior da foto $3,25 \mathrm{~mm}$

Fotomicrografia 59: Cristal de bornita (rósea) com bordas de calcosina (tom de azul) e galena (fina borda cinza) vistos à luz refletida. Lado maior da foto $1,3 \mathrm{~mm}$. .76 


\section{CAPÍTULO I}

\section{I.1. INTRODUÇÃO}

Situado na porção sul do Estado de Minas Gerais, próximo às cidades de Caldas e Santa Rita de Caldas, o Sienito Pedra Branca tem idade neoproterozóica ( $610 \mathrm{Ma}$ ) e forma semi-circular, truncada pelo Maciço Alcalino de Poços de Caldas, de idade cretácea.

Embora localizado em uma região mapeada por diversos autores (e.g. Derby, 1883; 1887; Ellert, 1959; Wernik \& Penalva, 1980; Ulbrich, 1984; Campos Neto \& Figueiredo, 1985), poucos realizaram trabalhos exclusivamente no Sienito Pedra Branca (Winters, 1981; Janasi, 1992; Janasi, 1996) visando à compreensão das variações mineralógicas e origem de rochas tão peculiares.

Assim, o Sienito Pedra Branca permaneceu conhecido como gnaisses do embasamento fenitizados por fluidos alcalinos da intrusão de Poços de Caldas (Ellert, 1959) até o ano de 1981, quando Winters demonstrou o caráter magmático e a idade pré-Cambriana da ocorrência. Mais tarde estudos em escala de semi-detalhe realizados por Janasi (1996) demonstraram a existência de quatro pulsos magmáticos principais que geraram as diferentes variedades sieníticas do plúton.

Em estudos mais recentes, Carvalho (2008) mostrou, além do zoneamento mineralógico do plúton, a existência de contrastes na fugacidade de oxigênio das fácies sieníticas, e a presença de enclaves microgranulares máficos e cristais reliquiares de plagioclásio associados aos sienitos supersaturados, que tiveram um papel importante na evolução magmática do Sienito Pedra Branca.

O Sienito Pedra Branca é formado essencialmente por sienitos potássicos (razão $\mathrm{K}_{2} \mathrm{O} / \mathrm{Na}_{2} \mathrm{O}>1$; Foley et al., 1987) e tem caráter tardi- a pós- orogênico. Embora se trate de um tipo de rocha relativamente incomum, algumas outras ocorrências similares são conhecidas em diferentes províncias do leste do Brasil, entre elas: o Sienito Capituva, vizinho a Pedra Branca em Minas Gerais (Janasi, 1992; 1993); o Sienito Piquiri no Rio Grande do Sul (Stabel et al., 2001; Nardi et al, 2008), o Plúton Serra do Man (Ferreira et al., 2002) e os complexos Bom Jardim e Toritama (Guimarães \& Silva Filho, 1998), na Província Borborema em Pernambuco, todos de idade neoproterozóica, além dos sienitos Itiúba, São Felix, Santanápolis e Anuri no Cráton de São Francisco, na Bahia, de idade paleoproterozóica (Conceição et al., 1991; Rosa et al., 2001; Conceição et al., 2007). Todos estes sienitos compartilham assinaturas geoquímicas peculiares caracterizadas pelo enriquecimento em elementos litófilos e terras raras leves e evidências de cristalização sob condições oxidantes. 
Entre os processos admitidos para a geração destes sienitos, que explicam o enriquecimento em elementos incompatíveis, estão a cristalização fracionada, assimilação de material crustal, imiscibilidade líquida e a fusão parcial de fontes mantélicas metassomatizadas. Assim, o estudo destas rochas tem grande potencial de contribuição para entendimento da evolução de magmas potássicos e de heterogeneidades do manto terrestre.

O Sienito Pedra Branca é alvo de estudo da presente dissertação de mestrado, que propõe uma investigação através do mapeamento faciológico, acompanhada de petrografia de detalhe e química mineral e de rocha, visando à caracterização dos diferentes litotipos e a compreensão da sua petrogênese.

\section{I.2 OBJETIVOS}

Ocorrências de sienitos e traquitos em ambientes tardi- a pós-colisionais vêm sendo consideradas como produto de fusão de fontes mantélicas previamente afetadas por subducção. Assim, o estudo de sienitos e rochas relacionadas tem sido uma ferramenta importante para o entendimento do manto terrestre.

O Sienito Pedra Branca apresenta características petrológicas peculiares, que incluem não só a assinatura geoquímica do plúton como um todo, mas também os contrastes mineralógicos (coexistência de sienitos insaturados e supersaturados em sílica) e as condições de cristalização das diferentes fácies sieníticas. A carência de estudos detalhados no Siento Pedra Branca incentivou o desenvolvimento desta dissertação, visto que ele permanece muito pouco conhecido para a comunidade científica. O entendimento da petrogênese do Sienito Pedra Branca poderá trazer contribuição para a compreensão dos processos de evolução do manto na região de estudo.

\section{I.3. MATERIAIS E MÉTODOS}

\section{I.3.1. Levantamento Bibliográfico}

O levantamento bibliográfico realizado neste trabalho teve como base a biblioteca do Instituto de Geociências da Universidade de São Paulo, além do site de periódicos da Capes. 


\section{I.3.2. Trabalhos de Campo}

Três etapas de trabalho de campo nas áreas norte e sul do plúton foram realizadas com o objetivo de mapear em detalhe a distribuição das diferentes fácies sieníticas, buscando identificar as relações de contato e relações estruturais entre elas, além de coletar amostras dos diversos litotipos encontrados (incluindo sienitos, enclaves, cumulatos, veios, etc) para estudos em laboratório.

\section{I.3.3. Compilação e Digitalização de Mapas Geológicos}

As informações geológicas iniciais para a cartografia geológica da região de Caldas e arredores no sul de Minas Gerais foram compiladas do mapa geológico simplificado do plúton apresentado por Winters (1981) na escala 1: 50.000 e de dados inéditos obtidos em trabalhos de campo por Janasi (1996).

A base topográfica utilizada foram as cartas em 1:50.000 de Caldas (SF-23-VD-IV-3) e Santa Rita de Caldas (SF-23-Y-B-I-1), em sua versão vetorial disponibilizada pelo IBGE.

Imagens de satélite LANDSAT (ETM+) e SRTM (Shuttle Radar Topografic Mission) também foram utilizadas como bases topográficas. A composição colorida da imagem LANDSAT (ETM+) foi a 421 (banda 4 no canal $R$, banda 2 no canal $G$ e banda 1 no canal B) com fusão da imagem pancromática e filtro de realce de bordas do tipo Laplace.

O mapa geológico do plúton foi gerado através do software ArcGis 9.2; as informações obtidas em campo e laboratório nos diferentes sítios de observação foram agrupadas em bancos de dados associados ao mapa.

\section{I.3.4. Susceptibilidade Magnética}

Tendo em vista as diferentes paragêneses máficas encontradas nos sienitos a susceptibilidade magnética, em alguns casos, pode ser uma ferramenta importante na distinção das diversas fácies sieníticas nos trabalhos de campo.

Nos trabalhos de campo foram feitas medidas de susceptibilidade magnética (K), utilizando um medidor portátil Exploranium Kappameter KT-9 que fornece leituras em unidades de SI (Sistema Internacional). A susceptibilidade magnética $\mathrm{K}$ mede a razão entre $\mathrm{J}$ (momento magnético dipolar por volume unitário) e $\mathrm{H}$ (intensidade do campo magnético aplicado) tal que $\mathrm{K}=\mathrm{J} / \mathrm{H}$. 
Durante os trabalhos de campo realizou-se cerca de 10 medidas por amostra/variedade litológica em superfícies frescas, e a média dos valores foi então utilizada.

\section{l.3.5. Petrografia}

Análises petrográficas foram realizadas no laboratório de Óptica do IGc-USP, utilizando microscópio petrográfico tipo Olympus modelo BXP-50 para análises de seções delgadas sob luz transmitida, e em microscópio Zeiss Axioplan, sob luz transmitida e refletida.

Cerca de 70 seções delgadas convencionais foram analisadas sob luz transmitida visando à investigação de texturas, mineralogia e evolução das paragêneses máficas em sienitos, enclaves e cumulatos. Além disso, aproximadamente 35 seções delgadas polidas foram investigadas através de luz refletida, para determinação da mineralogia e evolução textural de minerais opacos, especialmente os óxidos de Fe-Ti e sulfetos em sienitos, enclaves e cumulatos.

Uma documentação fotográfica das principais texturas encontradas nas seções delgadas foi realizada utilizando uma câmera fotográfica Olympus C5050Z acoplada ao microscópio Olympus BXP-50.

\section{I.3.6. Química Mineral}

As análises químicas em minerais foram obtidas em seções delgadas polidas utilizando os seguintes métodos:

\section{Microssonda Eletrônica}

Análises químicas de minerais máficos (piroxênio, anfibólio e biotita), óxidos de Fe-Ti e feldspatos de 10 lâminas delgadas foram obtidas em Microssonda Eletrônica JEOL modelo JXA-8600S, provida de cinco espectrômetros de dispersão de comprimento de onda (WDS) com Rowland Circle de 140 mm. Cada espectrômetro possui dois cristais analisadores permutáveis tipo Johann: espectrômetro $1 \mathrm{com}$ cristais STE/TAP, espectrômetro 2 com TAP/PET e espectrômetros 3-5 com cristais tipo PET/LiF. O sistema é acoplado a um espectrômetro de dispersão de energia 
(EDS) NORAN Voyager (v. 4.3) e os efeitos de matriz foram corrigidos pelo sistema PROZA. As condições analíticas encontram-se resumidas na Tabela 1.

Nas tabelas 2 e 3 estão os padrões utilizados para calibração dos diferentes elementos e o tempo das contagens durante as análises. O tempo total da integração de contagens igualmente dividido entre pico e radiação de fundo e o símbolo (S) significa padrão sintético e (s) refere-se ao tempo em segundos.

\begin{tabular}{|l|c|c|c|}
\hline \multicolumn{1}{|c|}{ Mineral } & $\begin{array}{c}\text { Voltagem de } \\
\text { Aceleração }\end{array}$ & $\begin{array}{c}\text { Corrente do feixe } \\
\text { eletrônico }\end{array}$ & $\begin{array}{c}\text { Diâmetro do feixe } \\
\text { eletrônico }\end{array}$ \\
\hline Piroxênio & $15 \mathrm{kV}$ & $20 \mathrm{n} \dot{A}$ & $5 \mu \mathrm{m}$ \\
\hline Anfibólio & $15 \mathrm{kV}$ & $20 \mathrm{n} \AA$ & $5 \mu \mathrm{m}$ \\
\hline Biotita & $15 \mathrm{kV}$ & $20 \mathrm{n} \dot{A}$ & $5 \mu \mathrm{m}$ \\
\hline Magnetita & $15 \mathrm{kV}$ & $20 \mathrm{n} \dot{A}$ & $5 \mu \mathrm{m}$ \\
\hline Ilmeno-hematita & $15 \mathrm{kV}$ & $20 \mathrm{n} \AA$ & $20 \mu \mathrm{m}$ \\
\hline Feldspato Alcalino & $15 \mathrm{kV}$ & $20 \mathrm{n} \AA$ & $20 \mu \mathrm{m}$ \\
\hline Plagioclásio & $15 \mathrm{kV}$ & $20 \mathrm{n} \dot{A}$ & $5 \mu \mathrm{m}$ \\
\hline
\end{tabular}

Tabela 1: Condições analíticas utilizadas para as análises WDS em microssonda eletrônica.

\begin{tabular}{|c|c|c|c|c|c|}
\hline Linha & Cristal & $\begin{array}{c}\text { Padrões } \\
\text { Feldspato }\end{array}$ & $\begin{array}{c}\text { Padrões } \\
\text { Piroxênio }\end{array}$ & $\begin{array}{c}\text { Padrões } \\
\text { Anfibólio }\end{array}$ & T (s) \\
\hline Si Ka & TAP & Microclínio & Wollastonita & Wollastonita & $10-20$ \\
\hline Ti Ka & LiF & Rutilo (S) & Rutilo (S) & Rutilo (S) & $20-40$ \\
\hline Al Ka & TAP & Anortita (S) & Hornblenda & Hornblenda & $10-40$ \\
\hline Fe Ka & LiF & Olivina & Olivina & Olivina & $20-30$ \\
\hline Mn Ka & LiF & Olivina & Olivina & Olivina & $20-40$ \\
\hline Mg Ka & TAP & Diopsídio & Diopsídio & Diopsídio & $20-40$ \\
\hline Ca Ka & PET & Anortita (S) & Wollastonita & Wollastonita & $10-30$ \\
\hline Na Ka & TAP & Albita & Albita & Albita & $10-20$ \\
\hline K Ka & PET & Microclínio & Microclínio & Microclínio & $20-40$ \\
\hline CI Ka & PET & - & - & Apatita & 10 \\
\hline F Ka & PET & - & - & Apatita & 10 \\
\hline
\end{tabular}

Tabela 2: Padrões e tempo de integração durante análises WDS.

\begin{tabular}{|c|c|c|c|c|}
\hline Linha & Cristal & Padrão IImenita & Padrão Magnetita & T (s) \\
\hline Si Ka & TAP & Diopsídio & Diopsídio & 20 \\
\hline Ti Ka & LiF & Ilmenita 128 & Rutilo (S) & 10 \\
\hline Al Ka & TAP & Anortita & - & 20 \\
\hline Fe Ka & LiF & Ilmenita & Hematita & 10 \\
\hline Mn Ka & LiF & Olivina & Olivina & 20 \\
\hline Mg Ka & TAP & Diopsídio & Diopsídio & 20 \\
\hline Ca Ka & PET & Anortita & - & 20 \\
\hline Cr Ka & LiF & $\mathrm{Cr}_{2} \mathrm{O}_{3}(\mathrm{~S})$ & $\mathrm{Cr}_{2} \mathrm{O}_{3}(\mathrm{~S})$ & 40 \\
\hline Zn Ka & LiF & $\mathrm{ZnO}(\mathrm{S})_{2 n}$ & $\mathrm{ZnO}(\mathrm{S})_{50}$ \\
\hline Nb La & PET & $\mathrm{Nb}$ metálico & $\mathrm{Nb}$ metálico & 50 \\
\hline
\end{tabular}

Tabela 3: Padrões e tempo de integração durante análises WDS. 


\section{Microscópio Eletrônico de Varredura (MEV)}

Imagens de elétrons retro-espalhados (Backscatered Electrons) e algumas análises EDS foram obtidas no Laboratório de Caracterização Tecnológica da Escola Politécnica da Universidade de São Paulo (LCT-EPUSP), utilizando um Microscópio Eletrônico de Varredura (MEV), marca LEO, modelo Stereoscan 440 com sistema acoplado EDS (Energy Dispersive Spectroscopy: detector de Si, marca Oxford, modelo INCAx-act com tecnologia SDD (Silicon Drift Detector).

\section{I.3.7. Geoquímica de rocha total}

\section{Procedimentos Analíticos e Tratamento de Amostras}

Para análise química de rocha, foram selecionadas 39 amostras, que foram preparadas no Laboratório de Tratamento de Amostras do IGc-USP. A preparação envolveu as etapas de fragmentação de amostras representativas livres de alteração em britador de mandíbulas de aço ou prensa hidráulica até a fração grânulo, seguida de quarteamento e moagem em moinho de ágata do tipo planetário, até granulação $<200$ mesh.

As análises foram obtidas no Laboratório de Fluorescência de raios $X$ do IGcUSP a partir de pastilhas prensadas $(7,5 \mathrm{~g}$ de amostras para $20 \%$ de parafina) para análise dos elementos traço e fundidas (aprox. $1 \mathrm{~g}$ de amostra e $9 \mathrm{~g}$ de fundente) para os elementos maiores, segundo a metodologia descrita em Mori et al. (1999). Elementos traço adicionais, incluindo os elementos terras-raras, $\mathrm{Th}, \mathrm{U}, \mathrm{Hf}$ e $\mathrm{Nb}$, foram analisados por ICPMS no Laboratório de Química e ICP do IGc-USP, segundo o procedimento analítico descrito em Navarro et al. (2008), que envolve dissolução por ataque ácido $\left(\mathrm{HF}+\mathrm{HNO}_{3}\right)$ em bombas tipo Parr por 5 dias, permitindo alcançar limites de detecção típicos da ordem de 0,01 ppm.

Além disso, foram realizadas análises adicionais de elementos maiores e traço (V, Sr, Y, Zr, Ba e La) em 9 amostras por ICP-OES no Laboratório de Química e ICP do IGc-USP. 


\section{Controle de Qualidade Analítico}

Em razão do baixo fechamento nos elementos maiores de algumas amostras analisadas por fluorescência de raios X, optou-se por análises adicionais em 9 amostras por ICP-OES, com objetivo de comparar os resultados obtidos.

A Figura 1 é um gráfico de barras construído com as diferenças $D$ entre alguns elementos maiores. Os valores absolutos mostram que principalmente $\mathrm{SiO}_{2}$ e $\mathrm{K}_{2} \mathrm{O}$ (aproximadamente de 0.2 a $1.5 \%$ ) apresentam contrastes significativos nos dois métodos estudados e influenciam no valor total dos elementos maiores (que varia de 0.75 a $4.1 \%$ ), assim o baixo fechamento nas análises por fluorescência de raios $X$ pode estar relacionado à subestimação destes elementos. No entanto, ao comparar os valores em porcentagem no caso de $\mathrm{SiO}_{2}$ a diferença na maioria das amostras encontra-se dentro do erro analítico (1-4\%), já o $\mathrm{K}_{2} \mathrm{O}$ em muitas amostras a diferença é cerca de $1 \%$, mas pode chegar a $9 \%$ (PB-8B).

Embora a diferença entre os valores absolutos seja significativa os dois métodos apresentam bons resultados, pois em porcentagem as diferenças estão dentro do erro analítico. O elemento mais problemático é o $\mathrm{K}_{2} \mathrm{O}$, que em alguns casos a porcentagem ultrapassa o erro. Assim, serão utilizados dados de ICP-OES disponíveis (9 amostras) pois estas possuem melhor fechamento, no entanto o restante de amostras que possuem apenas análises por FRX não serão descartados já que os dados também estão bons.

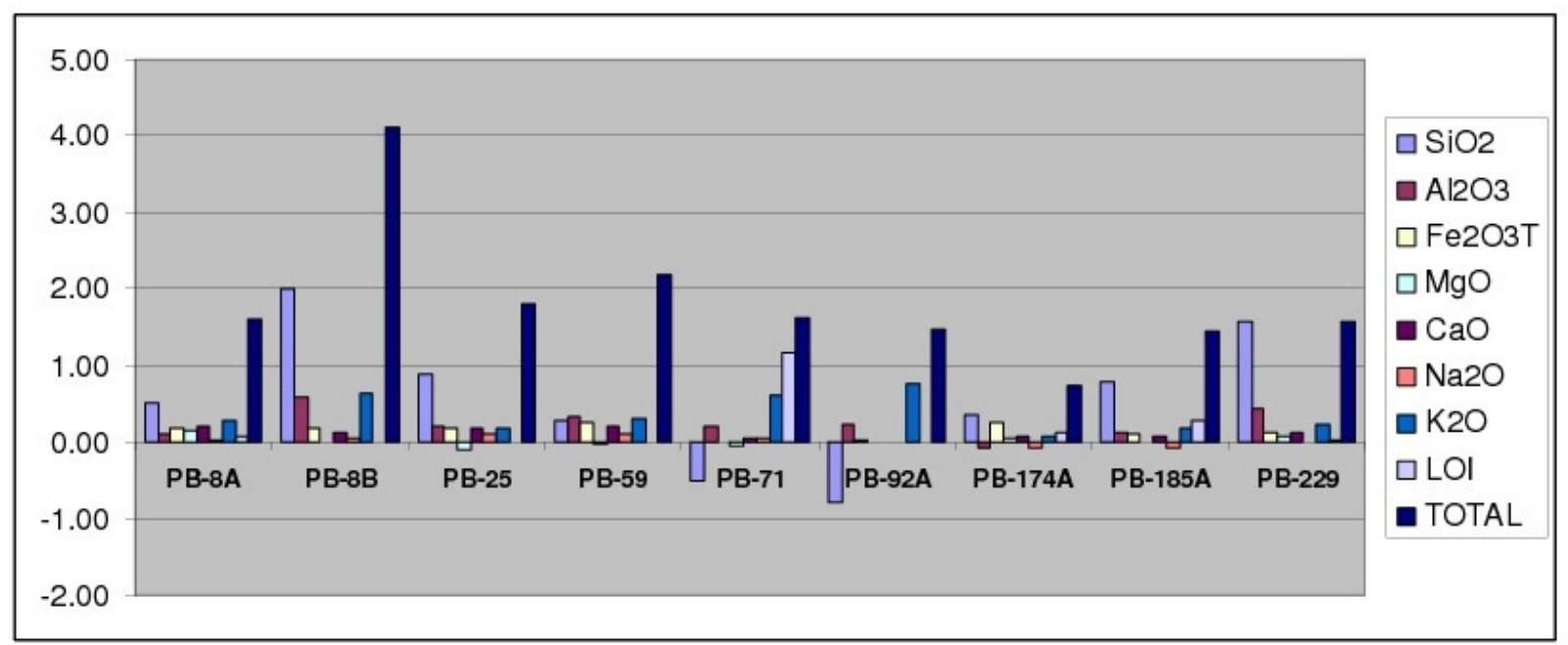

Figura 1: Gráfico de barras com a diferença obtida entre os valores obtidos por ICP-OES e FRX em alguns elementos maiores. Valores em porcentagem em peso.

Analogamente à Figura 1, a Figura 2 é um gráfico de barras construído com as diferenças $\mathrm{D}$ entre alguns elementos traço $(\mathrm{V}, \mathrm{Sr}, \mathrm{Y}, \mathrm{Zr}, \mathrm{Ba}$ e $\mathrm{La})$. Os valores 
absolutos mostram que principalmente $\mathrm{Sr}$ e $\mathrm{Ba}$ apresentam contrastes significativos (de 50 a 500 ppm) nos dois métodos estudados em geral, os conteúdos obtidos por ICP-OES são superiores na maioria das amostras (PB-8B, PB-25, PB-59, PB-71, PB92A, PB-174A e PB-185A), exceto para PB-8A e PB-229. Já os conteúdos de Zr são maiores quando obtidos por $\mathrm{FRX}$, fator que pode estar relacionado com a dissolução incompleta de cristais durante o ataque ácido.

Já os valores em porcentagem mostram que para elementos como V, Y e La os valores estão muito além do admitido pelo erro analítico (varia de 1 a 2 ppm no ICP-OES). Para Y e La, certamente análises ICP-MS são mais precisas, enquanto para $\mathrm{V}$ o método $\mathrm{FRX}$ é o mais indicado.

Desta forma, no item geoquímica (Capítulo IV) serão utilizados valores de FRX para $\mathrm{Zr}$, Ba, Sr e V, e valores de ICP-MS para Y e La.

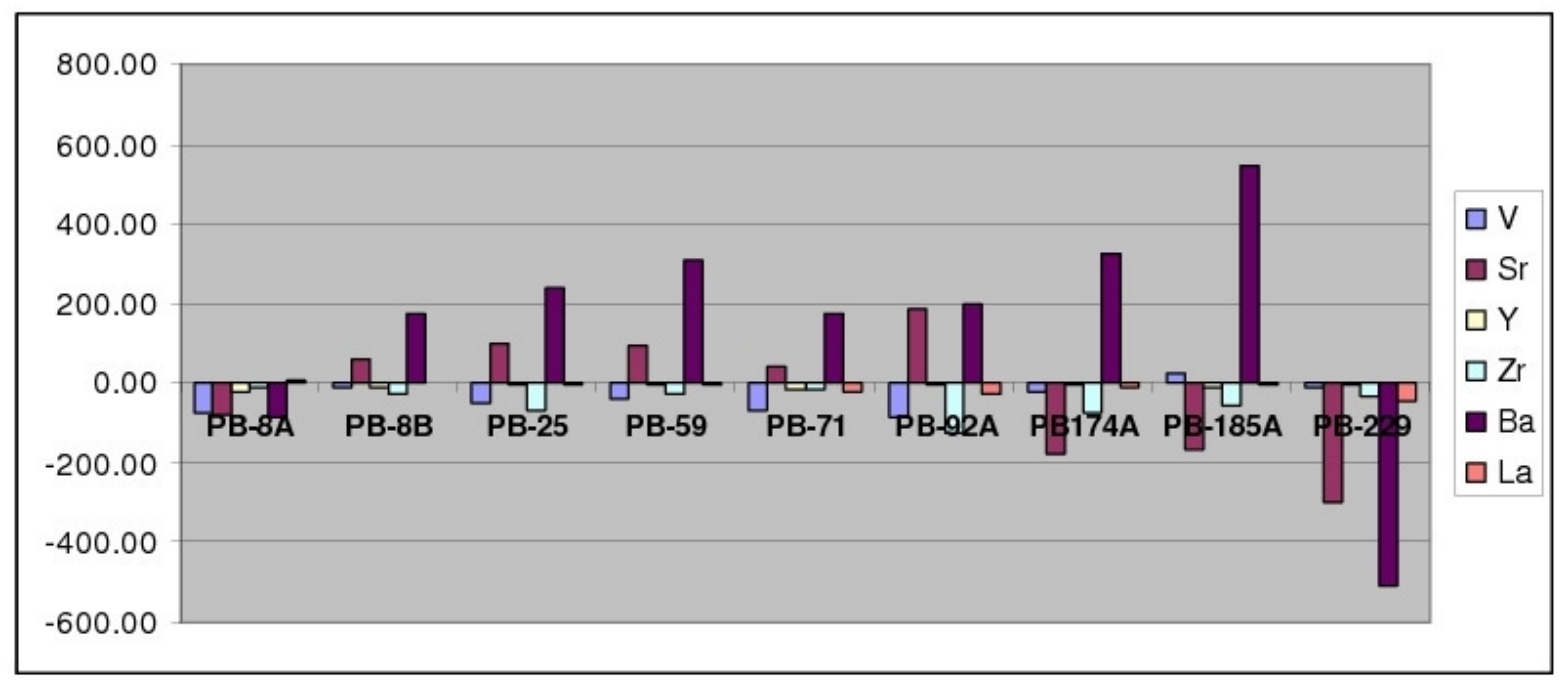

Figura 2: Gráfico de barras com a diferença obtida entre os valores obtidos por ICP-OES e FRX em alguns elementos traço. Valores em partes por milhão (ppm).

\section{I.3.8. Geoquímica Isotópica}

Análises isotópicas $\mathrm{Sm}-\mathrm{Nd}$ e $\mathrm{Rb}-\mathrm{Sr}$ de 3 amostras de diferentes unidades do Sienito Pedra Branca foram feitas pelo orientador desta Dissertação ao longo dos anos de 1997-1998, durante visita ao "Isotope Geochemistry Laboratory" (IGL) da Universidade do Kansas, EUA, sob supervisão do Prof. William R. van Schmus. Os procedimentos de análise são descritos em Janasi (2002). 


\section{CAPITULO II - OCORRÊNCIAS DE SIENITOS RICOS EM POTÁSSIO NO BRASIL: UMA REVISÃO}

Nas últimas décadas, a ocorrência de sienitos e traquitos em ambientes tardi- a pós-colisionais vem sendo considerada como produto de fusão de fontes mantélicas previamente afetadas por subducção. Desta forma, o estudo de sienitos e rochas relacionadas tem sido uma ferramenta importante para $\circ$ entendimento da heterogeneidade do manto terrestre.

Sienitos potássicos $\left(\mathrm{K}_{2} \mathrm{O} / \mathrm{Na}_{2} \mathrm{O}>1\right.$; Foley et al., 1987), ocorrem em muitas províncias graníticas tardi- a pós-orogênicas do Leste do Brasil. Entre os sienitos de idade neoproterozóica, no Brasil, estão Piquiri (Nardi et al., 2008) no Rio Grande do Sul, Serra do Man (Ferreira et al., 2002) e Bom Jardim (Guimarães \& Silva Filho, 1998) em Pernambuco, Capituva (Janasi, 1993) e Pedra Branca (Winters, 1981; Janasi, 1996) em Minas Gerais. O Batólito Sienítico Itiúba, o Maciço São Felix e o Dique Sienítico Anuri na Bahia representam manifestações de sienitos potássicos de idade paleoproterozóica (Conceição et al., 1991; Rosa et al., 2001; Conceição et al., 2007).

As ocorrências de rochas plutônicas básicas a intermediárias do brasiliano tardio no leste do Brasil (620-580 Ma) são caracterizadas pelo alto conteúdo em elementos litófilos, como $\mathrm{K}, \mathrm{Ba}$ e elementos terras-raras leves (ETRL). Em alguns casos, a presença de pequenos corpos de dioritos ricos em LILE, sob a forma de enclaves e diques, sugere que o caráter enriquecido destas rochas pode também estar relacionado com contaminação por magmas graníticos; entretanto, estudos petrológicos detalhados em algumas ocorrências isoladas de rochas básicas a intermediárias sugerem que estas características geoquímicas geralmente são primárias (Janasi et al., 1993).

Entre os processos admitidos para geração desses sienitos, que explicam o seu enriquecimento em elementos incompatíveis, estão: a cristalização fracionada de líquidos basálticos, assimilação de material crustal rico em elementos incompatíveis e a fusão parcial de uma fonte mantélica metassomatizada. Desta forma, o estudo dessas rochas pode trazer informações importantes dos processos que envolvem a geração de magmas tão particulares e raros.

\section{II.1. Sienitos potássicos paleoproterozóicos da Bahia}

O Cinturão Móvel Salvador-Curaçá foi interpretado por Padilhae Melo (1991) como sendo a parte profunda de um orógeno estabilizado há 1.9 Ga (dados Rb-Sr). A 
porção mediana do cinturão é marcada pela colocação de intrusões de magmas sieníticos e graníticos potássicos (apud. Rosa et al., 2001) como os sienitos Itiúba, São Felix, Anuri e Santanápolis.

O Batólito Sienítico Itiúba é um exemplo importante de sienito alcalino Paleoproterozóico, e apresenta forma alongada N-S, com cerca de $150 \mathrm{~km}$ de comprimento e $12 \mathrm{~km}$ de largura (1800 km² em área). Localiza-se na porção norte do Cráton do São Francisco, intrudindo gnaisses e granulitos paleoproterozóicos do Cinturão Salvador-Curaça (>2.1 Ga), e representa o plutonismo potássico tardi- a pósorogênico na região (Conceição et al., 1991).

Mais de $98 \%$ do maciço constitui-se de álcali-feldspato sienitos leucocráticos e hipersolvus, com sienitos mesocráticos e hololeucocráticos subordinados. O restante, cerca de $2 \%$ é composto por cumulatos máficos (apatita-diopsídio cumulatos) que ocorrem como níveis ou camadas e enclaves, além de diques tabulares (holo) leucocráticos de sienitos e granitos alcalinos que podem ou não apresentar bordas de resfriamento (Conceição et al., 1991; Conceição et al., 2003). A Figura 3 é um mapa geológico simplificado do maciço.

Os sienitos apresentam granulação média a grossa, na qual o feldspato alcalino é a fase mineral principal, e os outros minerais ocupam os interstícios entre os cristais de feldspato. Essa textura foi interpretada como produto de processos como acumulação e compactação (Conceição et al., 1991). Sua paragênese é composta por feldspato alcalino, diopsídio, edenita a Mg-hornblenda, quartzo e óxidos de Fe-Ti (ilmenita e Ti-magnetita), com minerais acessórios apatita, zircão, titanita, mica (flogopita a biotita) e allanita.

Três tipos de enclaves foram distinguidos com base na mineralogia e forma:

- xenólitos de rochas do embasamento (granulitos e gnaisses): apresentam forma angular e são encontrados principalmente nas zonas marginais do maciço;

- enclaves de quartzo-diorito a monzonito, centimétricos e tabulares;

- enclaves cumuláticos elipsoidais, constituídos por clinopiroxênio e apatita, além de anfibólio, óxidos de Fe-Ti e biotita como fases intercumulus;

Diversas gerações de diques intrusivos nos sienitos também foram hierarquizadas por Conceição et al. (1991):

- Diques granulares brancos com espessura centimétrica e contatos difusos, compostos por álcali-feldspato sienitos leucocráticos, semelhantes ao sienito hospedeiro. Podem representar líquidos residuais extraídos por filter-pressing.

- Diques róseos a avermelhados apresentam contatos retilíneos e margens resfriadas, formados por álcali-feldspato-quartzo sienito a álcali-feldspato granito.

- Diques pegmatíticos possuem contatos retilíneos e são composicionalmente 
zonados, com núcleos ricos em quartzo e margens ricas em álcali-feldspato, alternadas por zonas ricas em anfibólio e biotita.

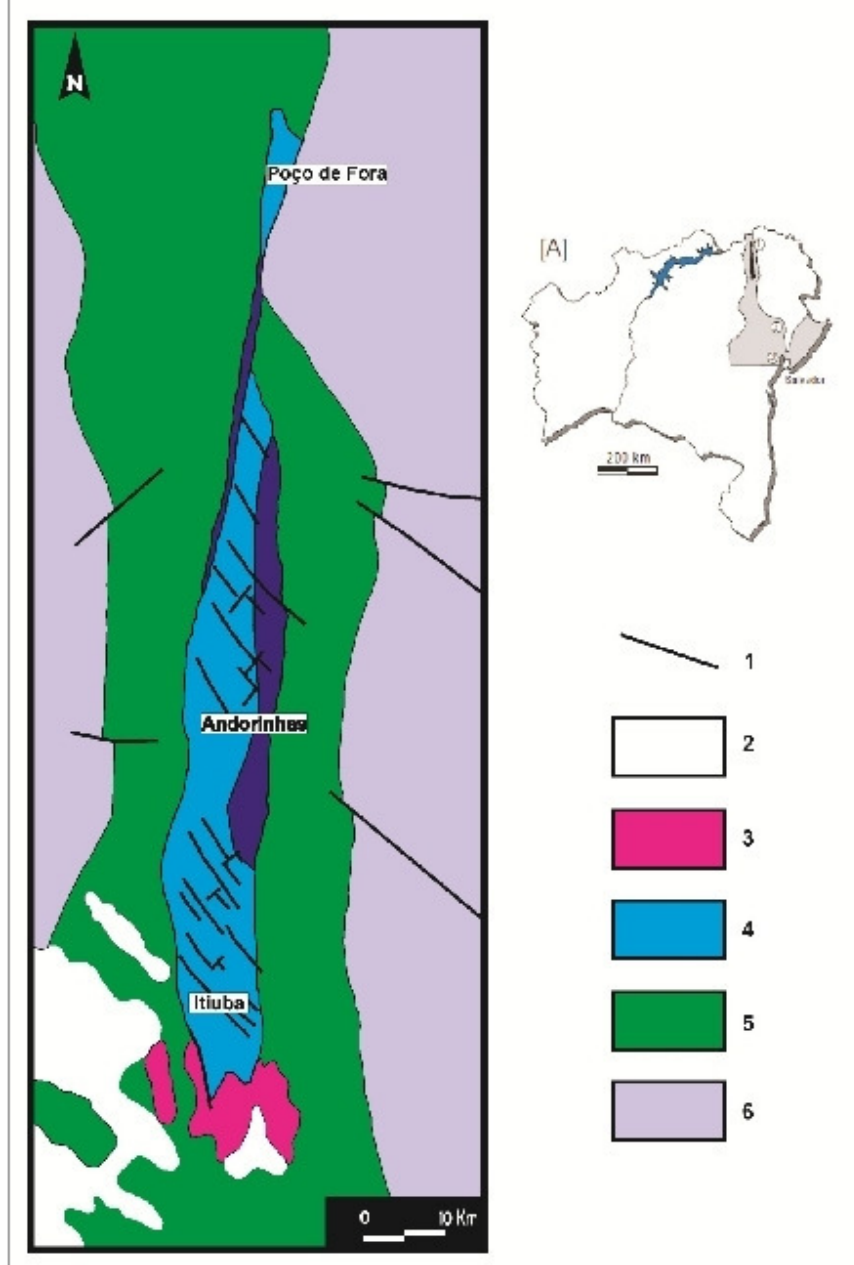

Figura 3: Mapa Geológico do Batólito Itiúba e rochas encaixantes (Conceição et al., 1991); $1=$ falhas; $2=$ sedimentos quaternários; $3=$ Granito Pedra Solta; $4=$ Sienito Itiúba; 5= Faixa Móvel Salvador Curaçá; $6=$ Diatexitos e Metatexitos. As bordas em azul escuro são destacadas por apresentar foliação no estado sólido.

Os sienitos possuem caráter metaluminoso, e enriquecimento nos elementos $\mathrm{K}$, Mg, P, Ti e Ba. Segundo Conceição et al. (1991), os dados geológicos, mineralógicos e geoquímicos indicam que as rochas que constituem o Batólito Itiúba não representam líquidos magmáticos. Os conteúdos de $\mathrm{P}$ e Ti são maiores que os esperados para líquidos sieníticos, e sugerem processos de acumulação de apatita e óxidos de $\mathrm{Fe}-\mathrm{Ti}$, seja por assentamento de cristais ou por remoção de líquidos residuais. Além disso, os conteúdos de elementos traço, juntamente com Ti e P, são controlados pelas fases minerais acessórias, e mostram padrões complexos e comportamento geral idêntico dos sienitos e cumulatos máficos, porém em pequena escala, com comportamento reverso, o que só poderia ser explicado pela "mistura" dos cumulatos continuamente com os líquidos residuais em evolução. 
Uma idade média de $2095 \pm 5$ Ma $(M S W D=2,2)$ foi obtida através da evaporação de $\mathrm{Pb}$ em monocristais de zircão (Conceição et al., 2003).

O Maciço Sienítico de São Félix (Figura 4) é uma intrusão alongada com cerca de $32 \mathrm{~km}^{2}$, encaixada em terrenos gnáissicos granulíticos, que representa a expressão mais a sul do alinhamento de corpos sieníticos na porção mediana do Cinturão Móvel Salvador-Curaçá (Rosa et al., 2001).

É constituído por rochas de grande homogeneidade composicional e textural, geralmente leucocráticas, de coloração cinza a rósea, granulação fina a média, ocasionalmente porfirítica, apresentando predominantemente estrutura gnáissica, localmente milonítica. Três fácies petrográficas foram identificadas por Rosa et al. (2001): gnáissica, porfirítica e máfica.

Cerca de $85 \%$ da área aflorante é constituída por sienitos com estrutura gnáissica e paragênese composta por feldspato alcalino pertítico, diopsídio pobre em Ti, Si-edenita, mica marrom, plagioclásio (com teor de anortita inferior a 15\%) e quartzo. Os minerais acessórios são fluor-apatita, zircão, titanita, monazita, óxidos de Fe e Ti e sulfetos.

Os sienitos porfiríticos constituem cerca de $9 \%$ das rochas aflorantes, possuindo a mesma paragênese dos sienitos gnáissicos, das quais diferem devido à ocorrência de megacristais de feldspato alcalino com 3-7 cm, que perfazem aproximadamente $7 \%$ do volume da rocha.

Os sienitos máficos ocorrem como níveis e apresentam texturas cumuláticas, onde os minerais cumulus são diopsídio pobre em $\mathrm{Ti}$, fluor-apatita e os minerais intercumulus são feldspato alcalino rico em $\mathrm{Ba}$ e biotita.

A geoquímica demonstra que os sienitos têm caráter metaluminoso e afinidade potássica, e cerca de $15 \%$ das amostras podem ser classificadas como ultrapotássicas (Rosa et al., 2001). Apresentam conteúdos elevados de Ba (1270-4320 ppm), Sr (6002200 ppm) e elementos terras raras (433-1189 ppm ETR total). Os padrões de ETR mostram forte enriquecimento nos leves, com fracas ou ausentes anomalias negativas em $\mathrm{Eu}$, enquanto que os diagramas multielementares mostram fortes anomalias negativas de $\mathrm{Nb}, \mathrm{P}$ e $\mathrm{Ti}$. Os autores consideram esta assinatura geoquímica do compatível com um ambiente pós-colisional.

A datação $\mathrm{Pb}-\mathrm{Pb}$ por evaporação de monocristais de zircão indica que o Sienito São Félix tem idade de $2098 \pm 1 \mathrm{Ma}$, similar às outras ocorrências no Cinturão, demonstrando que a sua colocação está relacionada com as etapas finais de estabilização do Cinturão Móvel Salvador-Curaçá.

As rochas do maciço caracterizam-se isotopicamente por valores $\varepsilon_{\mathrm{Nd}(t)}$ negativos $(-1,5$ a $-2,9)$, corroborando para a hipótese de fontes enriquecidas; as baixas 
razões ${ }^{87} \mathrm{Sr} /{ }^{86} \mathrm{Sr}(\mathrm{t})(0,701$ a 0,704$)$ são consistentes com fontes mantélicas. Essa assinatura isotópica é similar aos outros maciços sieníticos do cinturão e reflete provavelmente um manto metassomatizado (Rosa et al., 2001).

O Dique Sienítico Anuri abrange uma área de cerca de $72 \mathrm{~km}^{2}$ e é o representante meridional de um alinhamento $\mathrm{N}-\mathrm{S}$, de grandes diques de sienito que ocorrem no leste do Estado da Bahia, encaixados em terrenos polimetamórficos de alto grau.

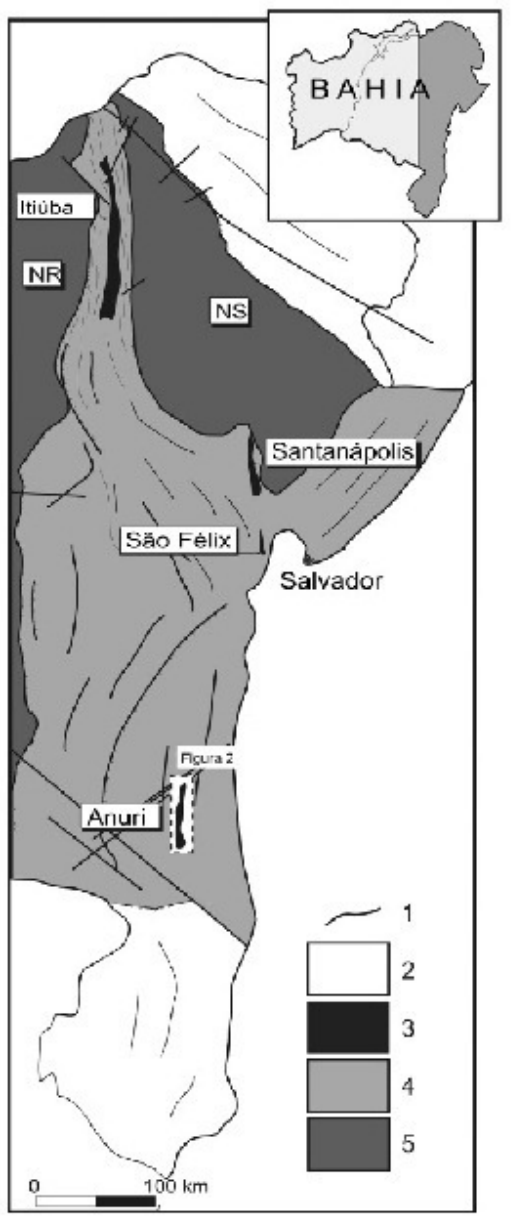

Figura 4: Localização dos diques de Sienito Itiúba, Santanápolis, São Felix e Anuri. Simbologia: $1=$ fraturas e falhas; $2=$ terrenos neoproterozóicos; $3=$ diques de sienito paleoproterozóicos; $4=$ terrenos granulíticos arqueanopaleoproterozóicos; $5=$ núcleos arqueanos; extraído de Conceição et al. (2007).

Cerca de $90 \%$ da ocorrência é constituída por sienitos de cor cinza, diques sieníticos brancos (com aproximadamente 1 metro de espessura) e autólitos e leitos máficos formados por diopsídio (em alta proporção modal), edenita, flogopita, apatita e feldspato alcalino. Foliação de fluxo magmático subvertical bem marcada é comum e localmente pode ser observada estrutura gnáissica. Os sienitos têm caráter hipersolvus de afinidade ultrapotássica, e são enriquecidos em $\mathrm{Ba}, \mathrm{Sr}, \mathrm{P}$ e elementos 
terras raras leves; os baixos conteúdos em Ti, Nb e Ta são indicativos de magmas mantélicos com assinatura de subducção (Conceição et al., 2007).

Datações U-Pb em zircão, em amostras de álcali-feldspato sienito forneceram idade de $2095 \pm 4$ Ma para a cristalização do dique (Conceição et al., 2007).

As razões isotópicas de $\mathrm{Sr}\left({ }^{87} \mathrm{Sr} /{ }^{86} \mathrm{Sr}(\mathrm{t})=0,703\right.$ a 0,707$)$ e $\mathrm{Nd}\left(\varepsilon_{\mathrm{Nd}(\mathrm{t})}-1,71\right.$ a $3,87)$ são compatíveis com fontes mantélicas enriquecidas.

As estruturas e as texturas ígneas do Batólito Itiúba observadas em campo indicam que sua colocação foi posterior ao metamorfismo de alto grau do Cinturão Salvador-Curaçá. A idade de $2095 \pm 5$ Ma obtida para estes sienitos é próxima daquelas encontradas para os outros dois corpos sieníticos presentes neste cinturão (Santanápolis - $2100 \pm 4 \mathrm{Ma}$ (U-Pb) e São Félix - $2098 \pm 1 \mathrm{Ma}$ (Pb-Pb), Rosa et al., 2001), indicando que a colocação deste magmatismo no cinturão ficou restrita ao intervalo entre 2090 e $2104 \mathrm{Ma}$ (Conceição et al., 2003).

Embora Conceição et al. (1991) tenham admitido que os sienitos do Batólito Itiúba não correspondem a composições de líquidos, trabalhos mais recentes dos mesmos autores (Conceição et al., 2003 e 2007; Rosa et al., 2001) modificaram esta interpretação, e consideram que estas rochas (assim como as ocorrências de mesmo contexto geológico: Sienito São Felix, Santanápolis e Anuri) são produtos de cristalização de magmas sieníticos resultantes da fusão do manto litosférico enriquecido.

\section{II.2. Complexos Bom Jardim e Toritama}

Os Complexos Bom Jardim e Toritama formam corpos alongados entre o maciço Pernambuco-Alagoas e o cinturão Pajeú-Paraíba, e compõem múltiplas intrusões dominadas por rochas de composição monzonítica e sienítica, que abrigam abundantes diques sin-plutônicos, enclaves de dioritos, monzodioritos e monzonitos, além de sienitos máficos e xenólitos de rochas metassedimentares (Guimarães, 1989). 


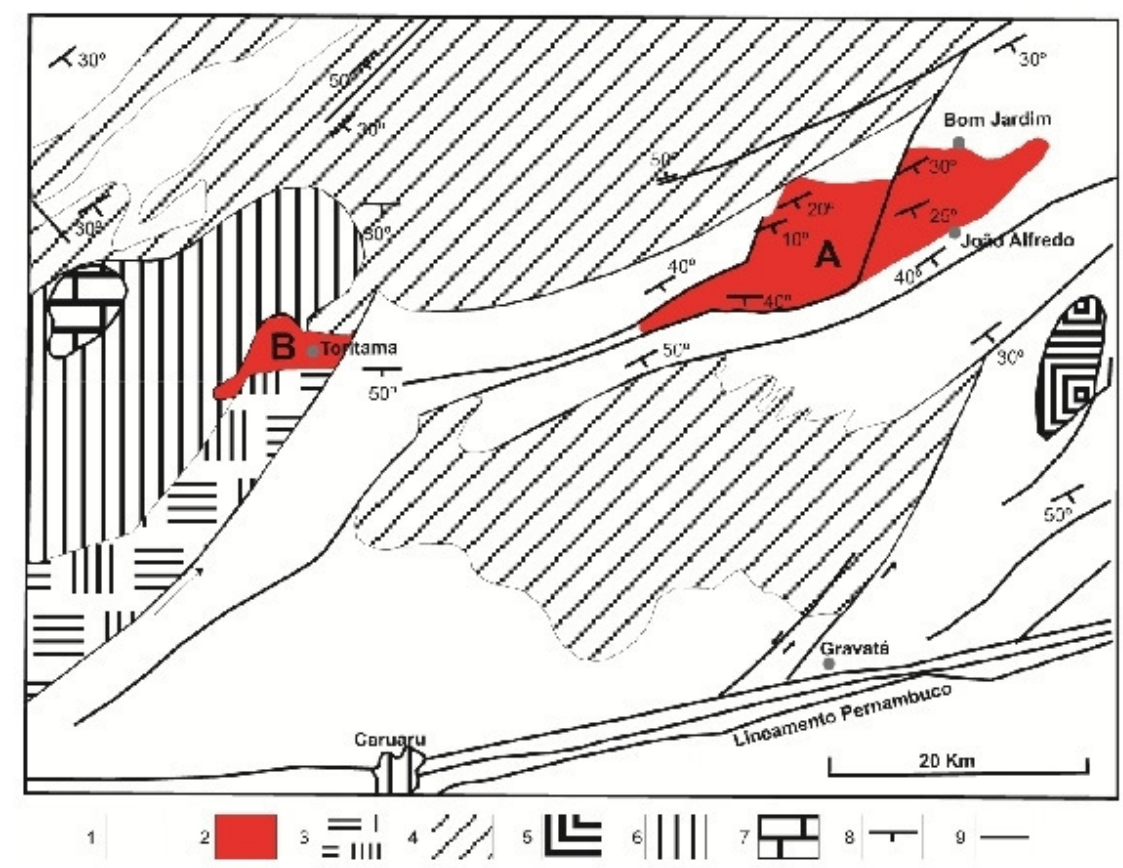

Figura 5: Mapa Geológico Regional do Complexo Bom Jardim (Guimarães \& Silva Filho, 1998). Legenda: 1 = gnaisses e migmatitos; $2=$ Complexo Bom Jardim (A) e Toritama (B); $3=$ Complexo Fazenda Nova (cálcio-alcalino de alto potássio); 4= Biotita Xistos com lentes de quartzito e mármore; 5= Anortisito Passira; $6=$ Augen-gnaisse; $7=$ Plúton Santa Cruz do Capibaribe; $8=$ foliação; 9 = falhas geológicas.

O Complexo Bom Jardim localiza-se cerca de $90 \mathrm{~km}$ a noroeste de Recife, e cobre uma área de cerca de $200 \mathrm{~km}^{2}$; o Complexo Toritama situa-se $30 \mathrm{~km} \mathrm{a}$ sudoeste, e tem área aproximada de $60 \mathrm{~km}^{2}$ (Figura 5).

Datados em $592 \pm 7.2 \mathrm{Ma}$ por U-Pb em zircão, os dois complexos representam o magmatismo associado ao final do regime compressivo no Neoproterozóico dentro do Cinturão Pajeú-Paraíba, e sua colocação parece estar relacionada a falhas de empurrão (Guimarães \& Silva Filho, 1998).

Quatro fácies principais foram identificadas nos dois complexos:

- Sienitos a monzonitos máficos com piroxênio, biotita e anfibólio (PBAMS): volumetricamente é a fácies mais abundante. A textura é porfirítica com fenocristais de microclínio pertítico zonado e plagioclásio; texturas rapakivi e anti-rapakivi ocorrem localmente. Piroxênio manteado por anfibólio também é comum, e quartzo está presente em pequenas proporções $(<5 \%)$. Minerais acessórios são apatita, titanita marrom, allanita, monazita arredondada e zircão. A ocorrência de monazita nessas rochas foi considerada por Guimarães (1989) como evidência de contaminação crustal. 
- Sienitos médios com piroxênio, biotita e anfibólio (MPBAS): correspondem a sienitos com granulação média, granulares a porfiríticos; comparados à fácies PBAMS, apresentam um aumento de feldspato alcalino modal (em média, 54\%), com diminuição das fases máficas. Os minerais acessórios são magnetita, apatita, zircão, titanita alaranjada, monazita, allanita e torita.

- Sienitos de granulação muito grossa e cor marrom (CS): caracterizam-se pela textura porfirítica com grandes fenocristais $(>5 \mathrm{~cm}$ ) de feldspato alcalino marrom (de 60-90\% em volume) com inclusões aciculares de minerais opacos, além de inclusões concêntricas de biotita, piroxênio e anfibólio. Albita pode circundar os fenocristais de feldspato alcalino, os minerais máficos são biotita, piroxênio e anfibólio, e os acessórios são apatita, zircão e titanita.

- Leuco-sienitos com piroxênio, biotita (PBLS): esta fácies apresenta textura equigranular média, porém variedades porfiríticas são encontradas localmente. Apresenta menos que $20 \%$ de minerais máficos e anfibólio magmático não foi observado; quartzo representa cerca de $10 \%$ da moda. Os minerais acessórios são apatita, titanita alaranjada e keilhauita, minerais ricos em Th incluindo torita e quantidades traço de allanita.

A geoquímica de elementos maiores e traço destes complexos definem afinidade shoshonítica para todo o conjunto de rochas. Características geoquímicas marcantes são o alto conteúdo em $\mathrm{MgO}, \mathrm{Cr}$ e $\mathrm{Ni}$, e altas razões LILE/HFSE, com enriquecimento em $\mathrm{K}, \mathrm{Rb}$ e ETR leves.

Análises de isótopos $\mathrm{Sm}-\mathrm{Nd}$ em rocha total foram realizadas em sete amostras. Os valores de $\varepsilon_{\mathrm{Nd}(\mathrm{t})}$ estão entre -10 e -14 , onde os valores mais negativos foram obtidos em amostras mais diferenciadas (PBLS). As idades modelo Sm-Nd ( $T_{D M}$ ) estão entre $1.8 \mathrm{Ga}$ e $2.0 \mathrm{Ga}$ (Guimarães \& Silva Filha, 1998).

O modelo admitido para formação do membro mais básico do Complexo Bom Jardim propõe fusão de horizontes metassomatizados do manto superior, enriquecidos em elementos incompatíveis assim com K, Rb e Terras Raras leves. Depois da geração dos magmas parentais no manto e antes da ascensão, ainda em crosta inferior, processos de fracionamento principalmente de anfibólio e biotita, além de pequenas quantidades de clinopiroxênio, podem ter tido papel importante na geração das demais fácies. O membro granítico, que intrude o complexo em seu estagio final, é considerado produto de fusão da crosta continental durante o processo de colisão, porém sua intrusão é tardia, visto a impossibilidade de ascensão durante o regime 
compressional (Guimarães, 1989).

\section{II.3. Pluton Serra do Man}

O Plúton Serra do Man (Figura 6), situado $450 \mathrm{~km}$ a oeste de Recife, ocupa área de cerca de $130 \mathrm{~km}^{2}$, e intrude ao norte os xistos e gnaisses supracrustais (Complexo Riacho da Barreira) e ao sul granitóides e metapelitos neoproterozóicos (Complexo São Caetano), ambos pertencentes ao Terreno Alto Pajeú, na Província Borborema, nordeste do Brasil (Ferreira et al., 2002).

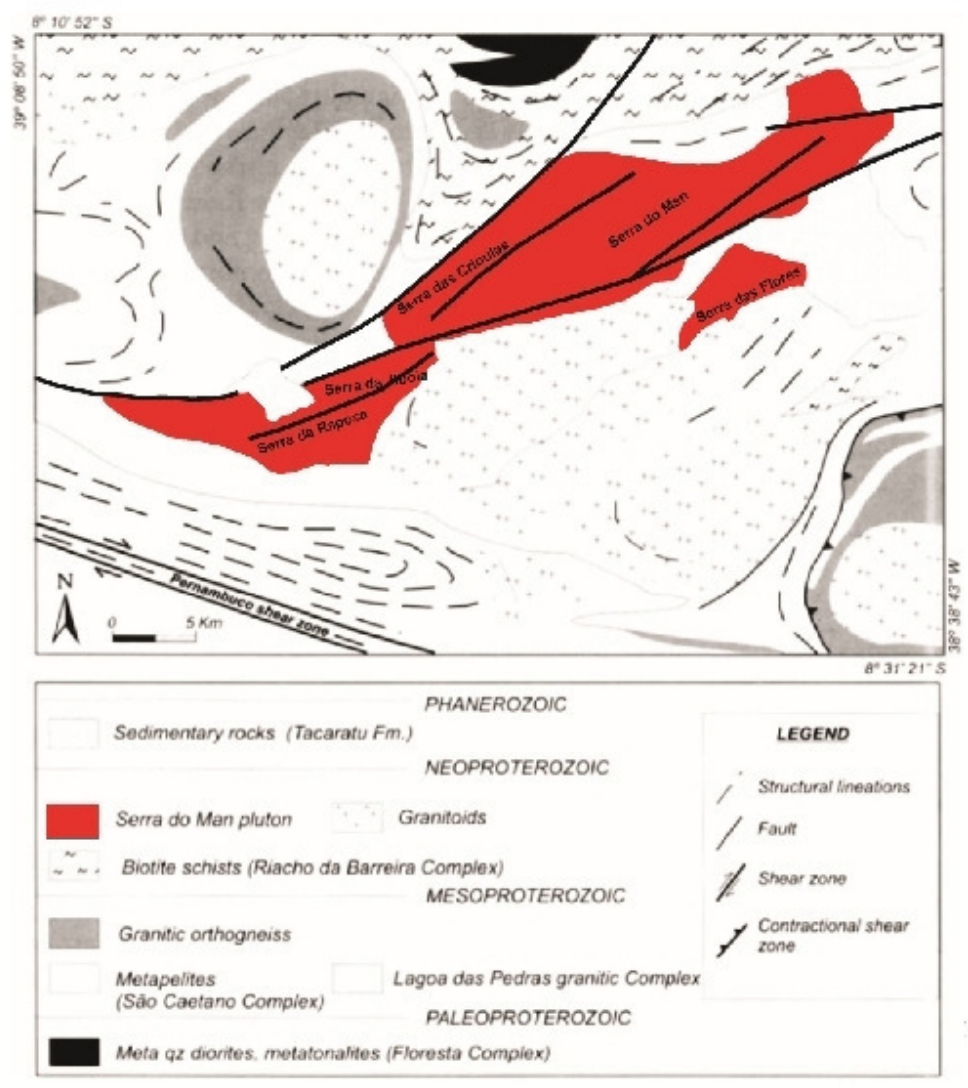

Figura 6: Mapa Geológico do Pluton Serra do Man (Ferreira et al., 2002).

Como os demais plútons ultrapotássicos da região, possui limites tangenciais a grandes zonas de cisalhamento, e a sua colocação está relacionada aos espaços gerados pelos movimentos ao longo das zonas de cisalhamento durante o evento tectonotermal brasiliano.

As rochas predominantes, classificadas como feldspato alcalino sienitos e quartzo-feldspato alcalino sienitos, apresentam granulação fina a média e exibem 
megacristais de feldspato e clinopiroxênio. Microclínio róseo é a fase mais abundante (cerca de $75 \%$ em volume), seguido por egirina-augita, quartzo, apatita, titanita e winchita.

Xenólitos de granitóides e gnaisses são comuns, enquanto os menos abundantes são os mica piroxenitos. Diques tardios leucocráticos de composição sienítica intrudem os sienitos hospedeiros, e são constituídos essencialmente por microclínio e quartzo; geralmente não ocorrem fases máficas.

Ferreira et al. (2002) consideram que todas as ocorrências de rochas ultrapotássicas na Província Borborema, incluindo o Plúton Serra do Man, tenham sua origem relacionada a processos de imiscibilidade de magmas, em um modelo análogo ao proposto por Ferreira et al. (1992) para o Batólito Triunfo, o que seria evidenciado, entre outros fatores, pela presença de diques sin-plutônicos de piroxenitos, que são comumente observados em todos esses plutons.

\section{II.4. Sienito Piquiri}

O Sienito Piquiri é um plúton de forma semi-circular e área aproximadamente $150 \mathrm{~km}^{2}$, situado na porção centro-norte do Escudo Sul-Rio-Grandense (Jost et al, 1985). A Figura 7 mostra que o plúton é circundado por rochas metamórficas e é invadido a SE pelo Complexo Granítico Encruzilhada. A NW o Sienito Piquiri faz contato tectônico com seqüências sedimentares neoproterozóicas da Bacia do Camaquã (Nardi et al., 2008). A idade do plúton foi estimada em $611 \pm 3 \mathrm{Ma}$ (Pb-Pb em zircões magmáticos; Phillip et al., 2002).

Os diferentes litotipos presentes no Sienito Piquiri permitiram o reconhecimento de 5 unidades principais:

- Álcali-feldspato sienitos grossos a médios, predominam no núcleo da intrusão;

- Sienitos a quartzo monzonitos finos a médios, principalmente nas bordas do plúton;

- Flogopita-álcali-feldspato sienitos, que mostram estruturas de interação com álcalifeldspato sienitos;

- Sienogranitos e álcali-feldspato sienitos;

- Enclaves, de diferentes tipos: microgranulares máficos dioríticos, autólitos cumuláticos (compostos por piroxênio e mica), fragmentos de margens resfriadas, xenólitos do embasamento metamórfico e enclaves microgranulares máficos lamprofíricos.

Foliação magmática é bem desenvolvida em todas as rochas do pluton, principalmente nos sienitos grossos, e é marcada pelo alinhamento dos cristais de 
feldspato potássico. Os contatos entre as quatro unidades sieníticas principais geralmente são gradacionais e sugerem uma cristalização aproximadamente simultânea. Os granitos representam líquidos finais, que cortam contatos internos e contêm autólitos sieníticos.

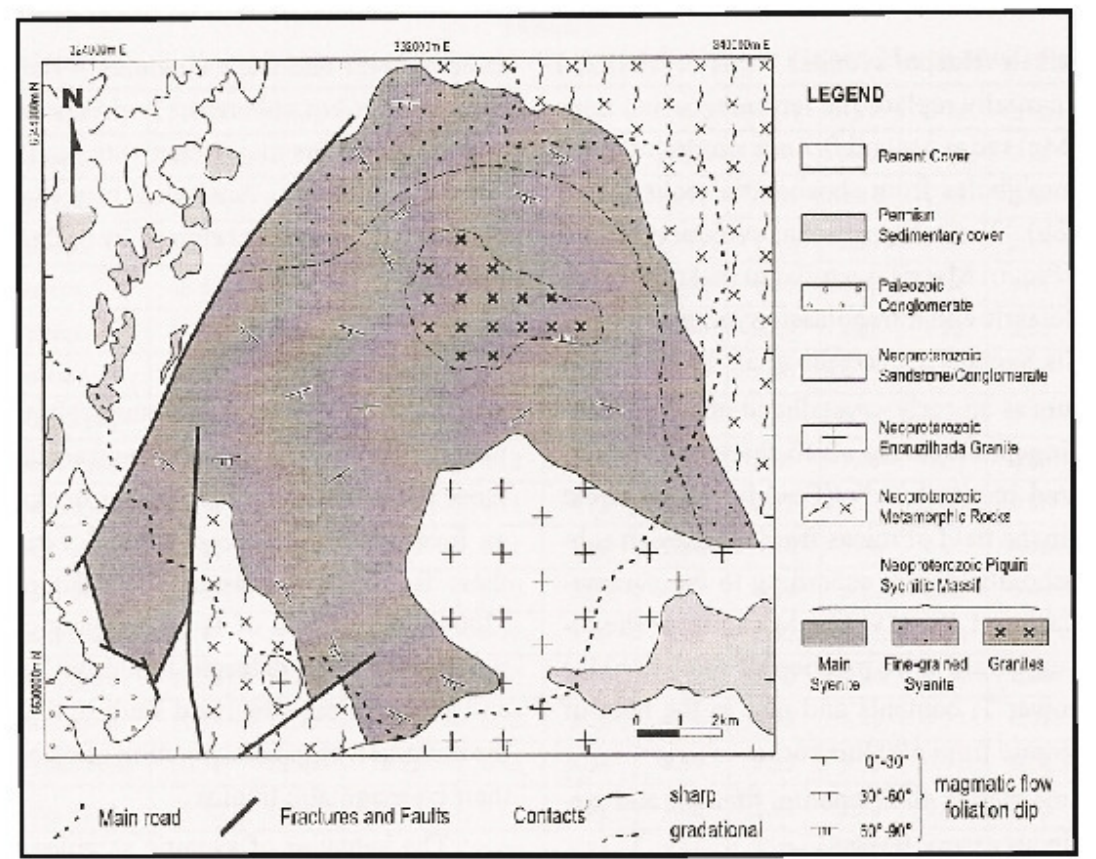

Figura 7: Mapa Geológico do Sienito Piquiri (Nardi et al., 2008).

Os sienitos finos a médios, interpretados como margens resfriadas, têm como minerais máficos o diopsídio, que pode ser substituído por Mg-hornblenda e edenita, além de biotita. O plagioclásio apresenta teores de anortita entre 20 e 51, é fase precoce na cristalização e pode ocorrer como inclusões em outros minerais. Feldspato alcalino apresenta quantidades variáveis de pertita (em geral $<20 \%$ em volume).

Já os álcali-feldspato sienitos médios a grossos apresentam augita como máfico principal, seguido por edenita e Mg-hornblenda. O feldspato é mais pertítico, podendo conter ate $25 \%$ de albita; localmente podem ser encontradas inclusões de plagioclásio parcialmente reabsorvidas (Stabel et al., 2001). As principais fases acessórias são ilmenita, magnetita, flúor-apatita, titanita e zircão.

O álcali-feldspato sienito apresenta textura inequigranular hipidiomórfica, e os minerais máficos são titanita, anfibólio e biotita. Os sienogranitos apresentam textura similar à dos sienitos, e apresentam como minerais máficos biotita, anfibólio, apatita e zircão. 
A presença de estruturas relacionadas a processos de segregação e acumulação pode sugerir que estes sienitos não correspondem a líquidos verdadeiros, mas o comportamento geoquímico dessas rochas é similar ao de magmas traquíticos ou traquiandesíticos. Os sienitos finos encontrados na borda do pluton, interpretados como líquidos resfriados rapidamente, são considerados como magmas parentais dos álcali-feldspato sienitos. Essas características foram admitidas por Nardi et al. (2008) como evidências para que esses sienitos representem líquidos e não cumulatos.

A ocorrência de enclaves microgranulares máficos (lamprófiros tipo minette) com clinopiroxênio rico em $\mathrm{K}$ foi interpretada como uma indicação de que estas rochas são produtos de fusão sob altíssimas pressões (> 5.0 GPa) (Plá Cid et al., 2003). A relação textural entre o sienito hospedeiro e os enclaves lamprofíricos, e a identificação de fases minerais ricas em $\mathrm{K}$ preservadas (inclusive como xenocristais no sienito hospedeiro) sugerem que a interação entre esses magmas deve ter se iniciado sob condições mantélicas (próximo às suas temperaturas liquidus). De acordo com Plá Cid et al. (2003), o contraste de temperatura entre os dois magmas teria acelerado o resfriamento do magma máfico, impedindo que houvesse difusão química e conseqüentemente a perda do $\mathrm{K}$ presente no clinopiroxênio.

As características composicionais dos dois magmas (sienito e lamprófiro) são similares, mas os conteúdos de Cs, Rb, U, LREE e Sr são maiores nos enclaves. Além disto, as razões $\mathrm{Nb} / \mathrm{Ta}$ variam em torno de 20 nos sienitos e são mais altas ( 30), enquanto $\mathrm{Th} / \mathrm{U}$ e $\mathrm{Zr} / \mathrm{H} f$ são mais baixos nos enclaves. Este comportamento não seria consistente com um modelo de geração dos sienitos por fracionamento do magma parental lamprofírico, já que a maioria destes elementos teria comportamento incompatível, concentrando-se nos líquidos mais evoluídos (sienítico). Assim, a geração dos dois magmas por processos cogenéticos seria mais plausível neste caso, envolvendo diferentes proporções de fusão parcial de uma fonte mantélica similar (Nardi et al., 2007).

\section{II.5. Sienito Capituva}

Os Sienitos Capituva e Pedra Branca, datados em 610 Ma (Topfner, 1996), ocorrem no SW de Minas Gerais, e são intrusivos em rochas metamórficas de alto grau e em granitos da Nappe Socorro-Guaxupé (NSG), marcando o final da evolução magmática neoproterozóica na região.

O Siento Pedra Branca é tema desta Dissertação de Mestrado, e será descrito em detalhe adiante. 
O Sienito Capituva tem forma elipsoidal, com cerca de $180 \mathrm{~km}^{2}$, resultou da intrusão seqüenciada de quatro pulsos magmáticos parcialmente superpostos. É composto de sienitos supersaturados com índice de cor entre 20 e 25 que mostram importantes variações texturais indicativas de cristalização progressivamente mais lenta nas fácies mais jovens (Janasi, 1993).

O plúton (Figura 8) é constituído por sienitos médios a grossos (MCS), que incluem a variedade de fácies porfirítica (nas margens) e laminada média a grossa (no centro do plúton), refletindo o aumento do tamanho dos grãos da matriz e diminuição da abundância dos megacristais de K-feldspato. Apesar da tendência à transição, os contatos entre essas fácies são localmente abruptos, e de caráter intrusivo.

O quarto pulso magmático é o mais complexo, e apresenta um núcleo de melasienitos (MS) porfiríticos, com índice de cor acima de 35, circundado por sienitos laminados grossos que hospedam também corpos anelares de quartzo sienito fino (FQS) e fino a médio (FMQS).

Xenólitos de gnaisses do embasamento são comuns e podem ser produto do colapso do teto e das margens da câmara magmática. Além disso, próximo aos xenólitos são encontradas lentes máficas-ultramáficas centimétricas e sienitos muito grossos, são interpretados como cumulatos (Janasi, 1992).

As rochas encaixantes formam um padrão aproximadamente concêntrico ao redor do maciço, e seus contatos são truncados pelos sienitos. A disposição da foliação tectônica das encaixantes e da foliação magmática dos sienitos sugere para o maciço uma forma de "funil" inclinado na direção SW, e sua estrutura deve ser resultado de uma intrusão forçada (Janasi, 1993).

Todas as fácies do Sienito Capituva, exceto os melasienitos (MS), são isentas plagioclásio magmático e por isso são descritos como hipersolvus. Muitas dessas rochas apresentam recristalização pós-magmática, que gerou oligoclásio secundário $(\mathrm{An}<20)$ pela exsolução do álcali-feldspato original. Já nos melasienitos, que têm composição mais cálcica, o plagioclásio $\left(\mathrm{An}_{22}\right)$ magmático pode ser observado na matriz em equilíbrio com o feldspato alcalino.

Cristais xenomórficos de plagioclásio parcialmente reabsorvidos, inclusos em feldspato alcalino, também são encontrados nas fácies mais finas, pois devido ao resfriamento rápido esses cristais não tiveram tempo suficiente para reagir com o magma.

Assim como nos casos descritos anteriormente, a possibilidade de que os sienitos do Maciço Capituva não representem líquidos, mas sim cumulatos também foi explorada por Janasi (1993). Para este autor, a composição da maioria das rochas do maciço é similar à de seus magmas originais. Na unidade FQS, os sienitos são finos, 
exibem texturas sub-vulcânicas típicas e têm pequenas proporções de fenocristais. Os magmas que deram origem a FQS não poderiam gerar os sienitos da unidade MCS por acumulação de feldspatos, pois apesar das diferenças texturais (porfirítica a fina) ambas as unidades apresentam composições semelhantes.

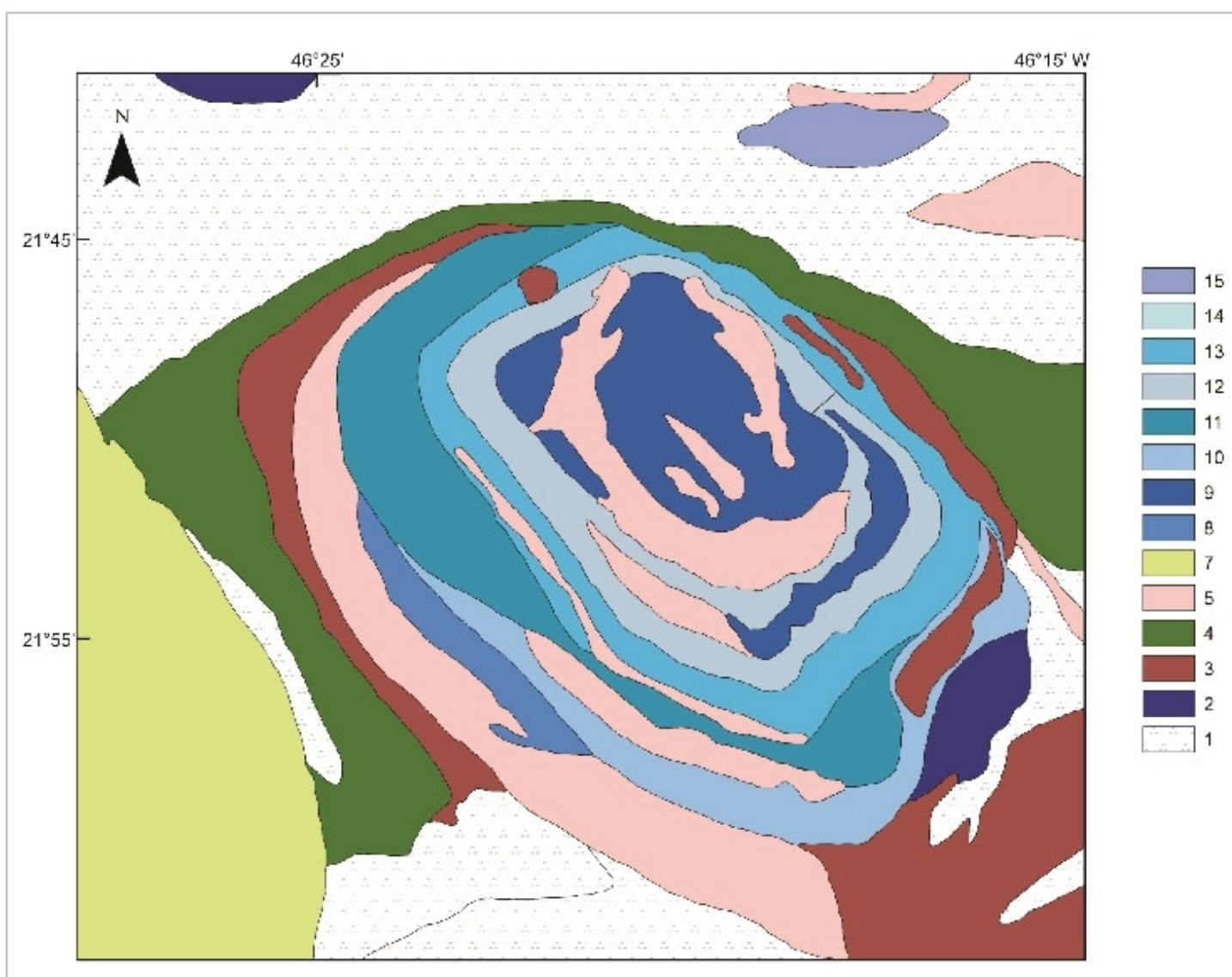

Figura 8: Mapa Geológico do Maciço Sienítico Capituva e rochas encaixantes (Janasi, 1993).

Simbologia: 1 = Gnaisses; 2= Granulitos; $\mathbf{3}=$ Granitos equigranulares róseos; $\mathbf{4}=$ Suíte composta por Mangeritos, Charnockitos e Granitos 5=Granitos cálcio-alcalinos porfiríticos; $\mathbf{7 =}$ Maciço Alcalino de Poços de Caldas; 8-15= Maciço Sienítico Capituva; 8, 9 e 11 fácies MCS; $\mathbf{8}=$ sienitos laminados grossos e sienitos porfiríticos com matriz fina; $\mathbf{9}=$ melasienitos $(\mathrm{MS}) ; \mathbf{1 0}=$ Sienitos Porfiríticos de matriz fina a média; 11 = Sienitos laminados médios; $12=$ Quartzo Sienitos finos (FQS); 13= Sienitos laminados grossos; 14=Quartzo Sienitofinos a médios (FMQS); 15= corpo satélite, composto principalmente por leucosienitos.

Dados isotópicos inétidos da ocorrência serão apresentados no Capítulo IV item IV.3. Geoquímica Isotópica Sr-Nd. 
O modelo genético proposto para o Sienito Capituva considera que os magmas sieníticos são derivados de parentais lamprofíricos (minettes), por sua vez gerados pela fusão de horizontes enriquecidos do manto litosférico continental (Janasi et al., 1993), modificados anteriormente durante eventos de subducção. 


\section{CAPÍTULO III- GEOLOGIA DO SIENITO PEDRA BRANCA}

\section{III.1. CONTEXTO GEOLÓGICO}

A Província Mantiqueira (PM) é um sistema orogênico neoproterozóico localizado no sul e sudeste do Brasil que inclui os orógenos Araçuaí, Ribeira, Dom Feliciano e São Gabriel e pela zona de Interferência entre os orógenos Brasília e Ribeira (Figura 9). Desenvolvida durante a Orogenia neoproterozóica Brasiliano-Pan Africana, a Província Mantiqueira resultou da amalgamação do paleocontinente Gondwana ocidental (Heilbron et al., 2004). Uma subdivisão estratigráfica simplificada foi aplicada à PM (e é adotada em todos segmentos geográficos: setentrional, central e meridional):

- Embasamento arqueano e/ou paleoproterozóico (mais velho que $1.7 \mathrm{Ga}$ );

- Sequências metassedimentares depositadas em bacias intracontinentais paleoproterozóicas a mesoproterozóicas;

- Seqüências metassedimentares e meta-vulcano-sedimentares neoproterozóicas que incluem seqüências de margem passiva, seqüências relacionadas a fechamentos de oceanos e ao estágio de colisão continental;

- Granitóides neoproterozóicos pré-colisionais, gerados em arco-magmático intraoceânico ou de margem continental ativa (contemporâneas a subducção);

- Granitóides neoproterozóicos sin-colisionais;

- Coberturas neoproterozóico-cambrianas associadas a bacias tardi-orogênicas e ao magmatismo pós-colisional;

O segmento central da PM inclui o Orógeno Ribeira, a zona de interferência (entre os Orógenos Brasília e Ribeira) e os terrenos Apiaí, São Roque e Embu.

O Orógeno Brasília Sul (OB) (Figura 10) consiste em uma pilha de nappes que registra episódios de subducção e colisão durante o neoproterozóico. Três ambientes tectônicos principais foram definidos (de WSW para ENE) (Campos Neto et al., 2004):

- domínio de arco magmático desenvolvido na margem continental ativa da Placa Paranapanema (Nappe Socorro-Guaxupé);

- domínio continental subductado (Terreno Andrelândia);

- domínios de margem passiva e/ou relacionados à Placa Sanfranciscana (Sistema de Nappes Lima Duarte); 


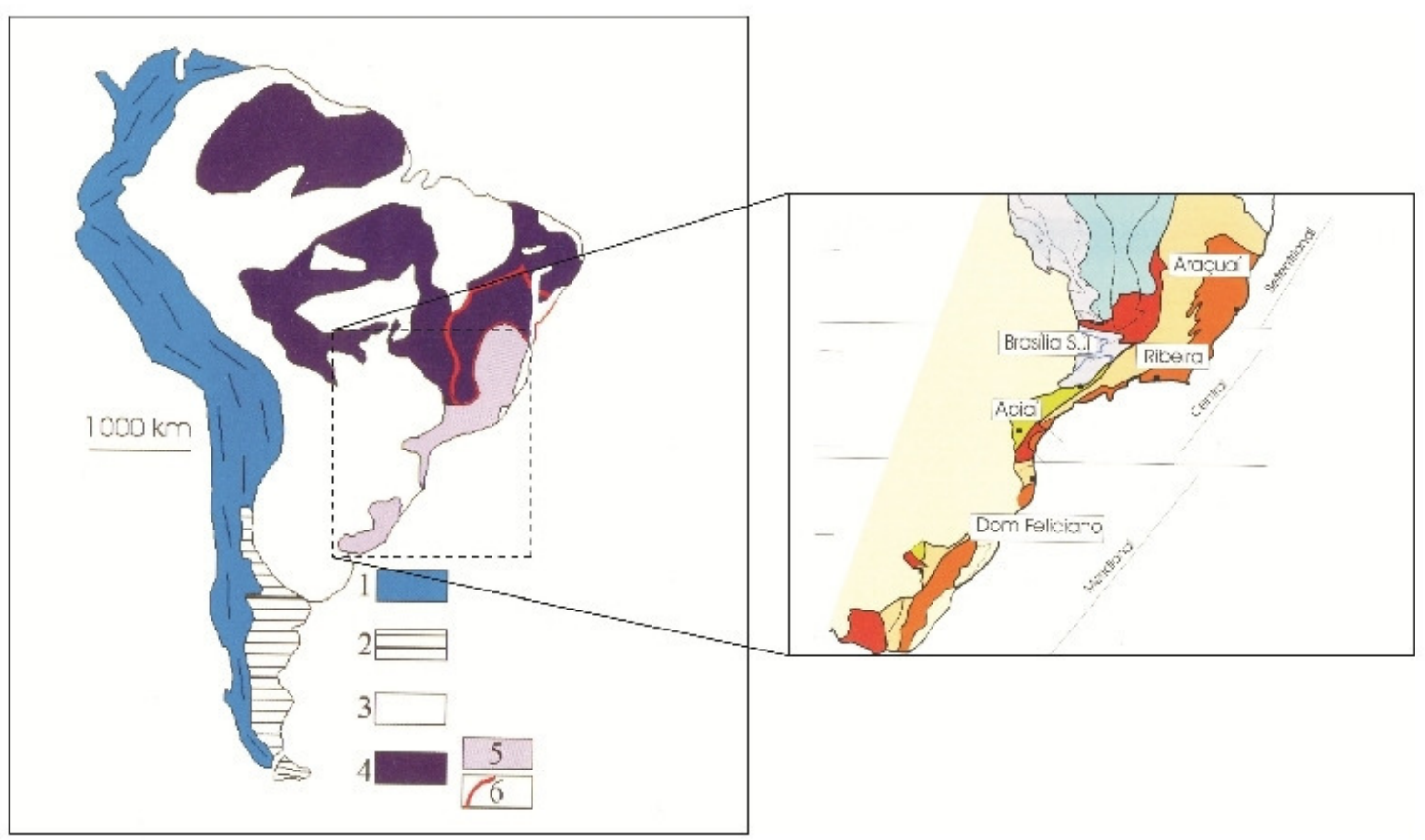

Figura 9: À esquerda: Mapa tectônico da América do Sul. 1= Sistema Orogênico Andino; $2=$ Terreno Patagônia; 3= Cobertura Fanerozóica da Plataforma Sul-America; 4=Escudos da

Plataforma Sul-Americana, destacando a Província Mantiqueira (5) e o Cráton São Francisco(6). À direita: Subdivisão da Província Mantiqueira. O segmento setentrional é o orógeno Araçuaí, já o segmento central compreende a porção sul do Orógeno Brasília e os Orógenos Ribeira e Apiaí. Já o segmento meridional inclui os orógenos Dom Feliciano e São Gabriel (extraído de Heilbron et al., 2004).

A parte sul do OB é subdivida em nappes com empilhamento vergente para EESE, rumo ao cráton do São Francisco ou tangente à sua borda meridional. As nappes da parte sul do $\mathrm{OB}$ foram agrupadas em inferiores e superiores. As inferiores atingiram metamorfismo em fácies granulito de pressão relativamente alta e incluem os seguintes domínios estruturais: Klippe Carrancas, Nappe Luminárias, Nappes São Tomé das Letras, Nappes Carmo da Cachoeira e Nappe Varginha. A Nappe SocorroGuaxupé representa as nappes superiores, e registra metamorfismo de pressões mais baixas e inúmeros corpos de granitóides cálcio-alcalinos (Heilbron et al., 2004). 


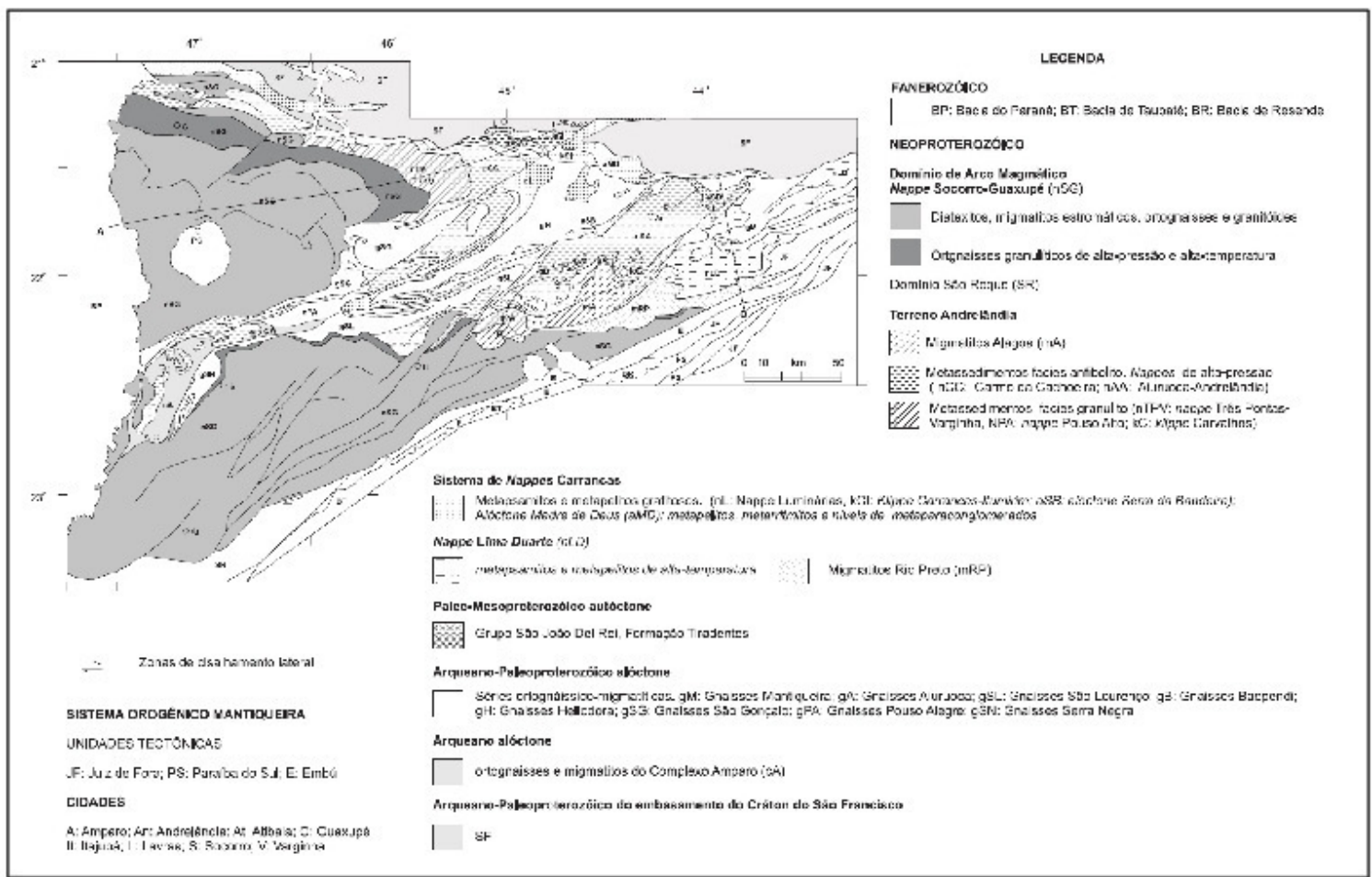

Figura 10: Mapa Geológico simplificado do Orógeno Brasília Sul (extraído de Campos Neto et al., 2004).

\section{Nappe Socorro-Guaxupé}

A Nappe Socorro Guaxupé (NSG) é parte de um sistema de nappes que resultou da convergência entre as placas São Francisco e Paranapanema no final do neoproterozóico (Campos Neto \& Caby, 1999) e corresponde a um domínio de arco magmático desenvolvido na margem continental ativa da Placa Paranapanema pouco antes da colisão continental (Campos Neto et al., 2004)

A estrutura alóctone está segmentada em dois domínios, Guaxupé a norte e Socorro a sul (Figura 10; Campos Neto et al., 2004), que estão separados por rampas laterais de alto ângulo. Em contraste com as nappes vizinhas, é caracterizada pela ocorrência de expressivos volumes de granito, e por metamorfismo de alta temperatura, que alcança a fácies granulito em suas porções basais. Campos Neto \& Caby (2000) dividiram a NSG em três unidades distintas: 
- Unidade Granulítica Basal: formada principalmente por granada-biotita-ortopiroxênio granulitos bandados de composição enderbítica a charno-enderbítica, com intercalação de gnaisses gabro-noríticos. Os membros intermediários são cálcioalcalinos e os máficos toleíticos (Heilbron et al., 2004).

- Unidade Diatexítica Intermediária: constituída por ortognaisses metaluminosos, representados por migmatitos estromáticos e gnaisses nebulíticos. Gnaisses kinzigíticos (com espinélio, sillimanita, cordierita e granada) ocorrem como faixas estreitas, enquanto granada-diopsídio-escapolita gnaisses calcio-silicáticos são encontrados como xenólitos. No Domínio Guaxupé essas ocorrências são denominados Complexo Pinhal (Wernik \& Penalva, 1980).

- Unidade Migmatítica Superior: consiste em uma seqüência metassedimentar anatética, composta principalmente por (cordierita)-granada-sillimanita-biotita gnaisses, que se intercalam com sillimanita-muscovita- quartzitos feldspáticos e gnaisses quartzosos, gnaisses cálcio-silicáticos, rochas metabásicas, hornblenda gnaisses e mármores.

A Figura 11 é uma compilação de mapas geológicos (Campos Neto \& Figueiredo, 1985; Oliveira et al., 1983; Janasi, 1992; Haddad,1995) do extremo sul do Domínio Guaxupé realizada por Janasi (1999), e mostra a grande variedade de rochas graníticas ali presente. Rochas encaixantes de caráter migmatítico são também dominantemente graníticas, e constituem os complexos metamórficos Pinhal (ortoderivado) e Caconde (seqüência supracrustal, dominada por paragnaisses quartzosos e metapelitos-metagrauvacas; Campos Neto \& Figueiredo, 1985); ambos os complexos passam a equivalentes granulíticos a N-NE. Quatro grupos principais de rochas graníticas podem ser reconhecidos:

(1) uma suíte de afinidade cálcio-alcalina potássica, que forma ○ Batólito Pinhal-Ipuiúna (Haddad, 1995) e várias ocorrências menores, datada em 620 Ma (U$\mathrm{Pb}$ em zircão) (Janasi et al., 2007).

(2) duas suítes "charnockíticas" datadas em 625 Ma, uma mais félsica e derivada de granulitos com idades-modelo $\mathrm{Sm}-\mathrm{Nd}$ da ordem de $1.5 \mathrm{Ga}$ (suíte mangerito-sienogranito São Pedro de Caldas) e outra mais máfica (com maior proporção de dioritos e menor volume de granitos associados), e derivada da fusão de granulitos com maior residência crustal (idades-modelo Sm-Nd mais antigas que 1.8 
Ga), a suíte Divinolândia (Janasi, 2002).

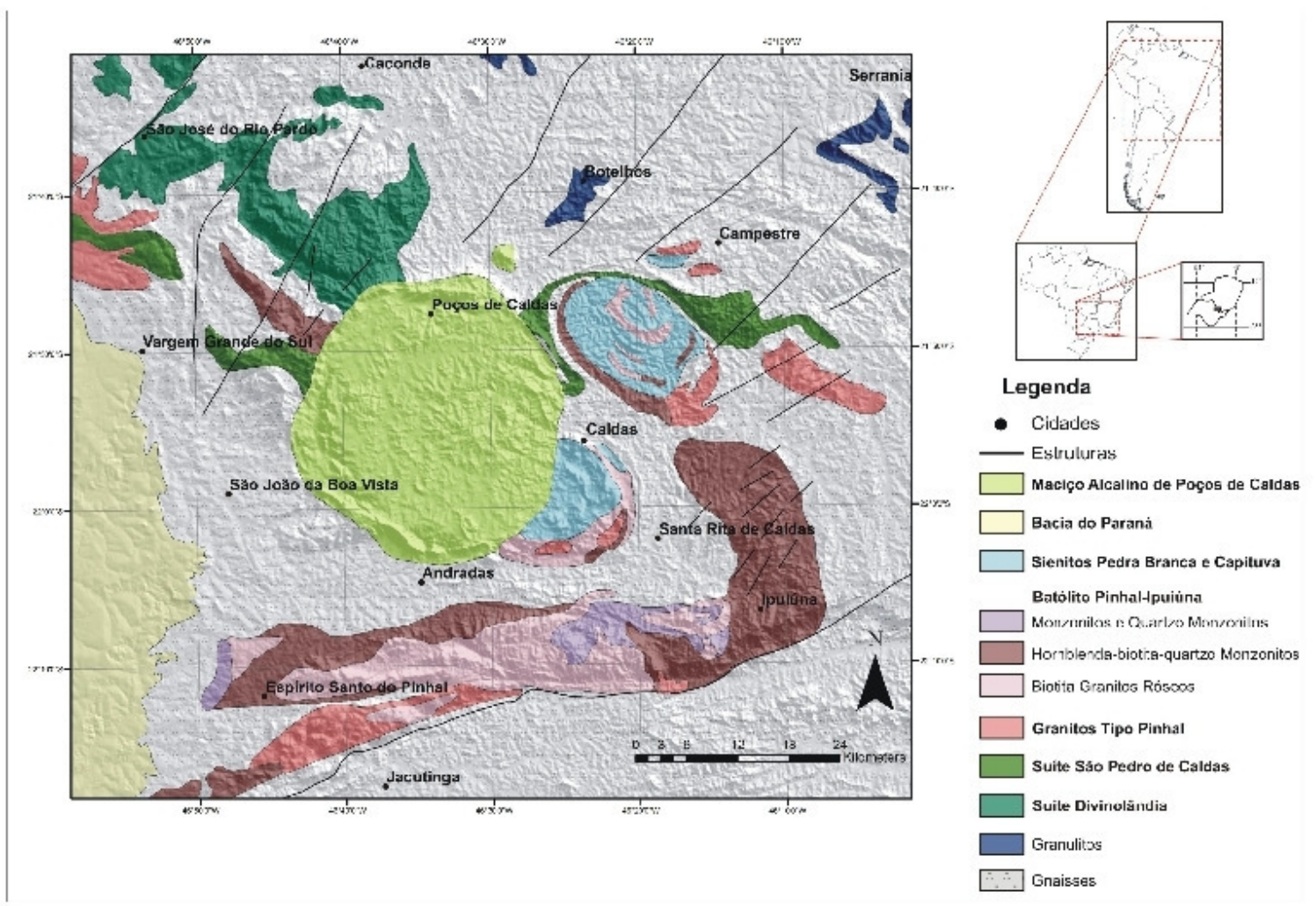

Figura 11: Mapa Geológico do extremo sul do Domínio Guaxupé, sudeste do Brasil (Janasi, 1999).

(3) os biotita-granitos anatéticos equi a inequigranulares "tipo Pinhal" (Wernick \& Penalva, 1980), derivados da fusão parcial de ortognaisses do Complexo Metamórfico Pinhal, também com idades da ordem de 625 Ma (Janasi, 1999);

(4) os sienitos Pedra Branca e Capituva, que marcam o final da evolução magmática na região, datados em $\sim 613 \pm 3 \mathrm{Ma}$ (Töpfner, 1996).

\section{III.2. GEOLOGIA LOCAL}

O Sienito Pedra Branca localiza-se na porção sul do Estado de Minas Gerais, próximo às cidades de Caldas e Santa Rita de Caldas, e abrange uma área de cerca 
de $90 \mathrm{~km}^{2}$, sendo truncado, em sua metade ocidental, pela intrusão do Maciço Alcalino Poços de Caldas, idade cretácea (Anexo I - Mapa Geológico e de Pontos).

Em trabalhos iniciais, essas rochas eram consideradas gnaisses do embasamento cristalino, metassomatizados por fluidos alcalinos provenientes da intrusão de Poços de Caldas (Ellert, 1959). Estudos em escala de semi-detalhe, no entanto, demonstraram o caráter magmático da ocorrência (Winters, 1981), que corresponde a um plúton de idade neoproterozóica seccionado pela intrusão alcalina.

As evidências mineralógicas e texturais para o caráter magmático do Sienito Pedra Branca foram demonstradas por Winters (1981). O zoneamento mineralógico apresentado pelo plúton, com rochas portadoras de quartzo no centro do corpo, em contato com as rochas do maciço alcalino, e de nefelina (em uma amostra) na borda, em contato com os migmatitos, seria indicativo de cristalização magmática, e não reflexo de um processo de fenitização, que deveria gerar zoneamento inverso, com rochas insaturadas mais próximas à intrusão alcalina.

O mapeamento geológico em escala de semi-detalhe do plúton mostra que ele apresenta zoneamento magmático evidenciado por variações mineralógicas importantes.

O corpo principal pode ser dividido em três unidades. Uma unidade isenta de quartzo (Sienito Laminado Saturado a Insaturado em Sílica; SLSI) constitui a maior parte das bordas externas do plúton, em contato com gnaisses migmatíticos do embasamento cristalino. Sienitos laminados médios a grossos com quartzo (Sienito Laminado Supersaturado em Sílica; SLS) compõem a maior parte da ocorrência, incluindo o Pico da Pedra Branca, situado a 1780 metros de altitude, e truncam localmente a unidade externa (Anexo I - Mapa Geológico). O núcleo do plúton é formado por sienitos equigranulares finos a médios supersaturados em sílica (Sienito Supersaturado em Sílica Interno; SSI), e é truncado pelas rochas do Maciço Alcalino de Poços de Caldas.

Uma quarta unidade é formada por corpos lenticulares de sienitos médios com quartzo (Sienito Supersaturado em Sílica Externo; SSE) que estão separados do resto do plúton por um septo de granitos.

Uma foliação magmática de alto ângulo (mergulho superior a $60^{\circ}$ ) é definida por cristais tabulares de álcali-feldspato nas variedades de sienitos grossos do plúton, e é paralela aos contatos externos com as rochas encaixantes migmatíticas e graníticas (Anexo I - Mapa de Geológico).

As fácies sieníticas mapeadas foram distinguidas a partir de seus contrastes petrográficos e geoquímicos. A Tabela 4 é um quadro explicativo que destaca as paragêneses diagnosticas em cada caso, juntamente com a nomenclatura utilizada 
para as unidades sieníticas dos mapas em anexo (Anexo I - Mapa geológico e de Pontos).

A nordeste do plúton Pedra Branca foi encontrado ainda um corpo de rocha ultramáfica rica em piroxênio, biotita e apatita (pontos PB-169 e PB-170). Este biotita piroxenito assemelha-se a enclaves de caráter cumulático encontrados nas unidades sieníticas UPC e UPPB, de modo que ele parece ter relação genética com o Sienito Pedra Branca.

\begin{tabular}{|l|c|c|c|c|}
\hline Unidade & $\begin{array}{c}\text { Sienito } \\
\text { Supersaturado } \\
\text { em Sílica } \\
\text { Interno }\end{array}$ & $\begin{array}{c}\text { Sienito Laminado } \\
\text { Supersaturado em } \\
\text { Sílica }\end{array}$ & $\begin{array}{c}\text { Sienito } \\
\text { Laminado } \\
\text { Saturado a } \\
\text { Insaturado em } \\
\text { Sílica }\end{array}$ & $\begin{array}{c}\text { Sienito } \\
\text { Supersaturado } \\
\text { em Sílica } \\
\text { Externo }\end{array}$ \\
\hline Abreviação & SSI & SLS & SLSI & SSE \\
\hline $\begin{array}{l}\text { Paragênese } \\
\text { Diagnostica }\end{array}$ & $\begin{array}{c}\mathrm{Di}+\mathrm{Qtz} \\
+I I m-\mathrm{Hem} \pm \mathrm{Opx}\end{array}$ & $\begin{array}{c}\mathrm{Di}+\mathrm{Qtz} \\
+I I m-\mathrm{Hem}\end{array}$ & $\begin{array}{c}\text { Na-Cpx }+\mathrm{Hem}+ \\
\mathrm{Mt}\end{array}$ & $\begin{array}{c}\mathrm{Di}+\mathrm{Qtz} \\
+I I m-\mathrm{Hem}\end{array}$ \\
\hline
\end{tabular}

Tabela 4: Nomenclatura utilizada nas unidades do Sienito Pedra Branca juntamente com as paragêneses diagnosticas de cada fácies.

O sienito Pedra Branca vem sendo amplamente utilizado como rocha ornamental, e como resultado da importância nesse setor, suas rochas foram estudadas e testadas por Meyer (2003), que as caracterizou como de boa qualidade para tal uso.

\section{III.2.1.Susceptibilidade Magnética}

A susceptibilidade magnética $(K)$ é uma característica importante em todas as unidades do Sienito Pedra Branca. Um contraste singular ocorre entre SLSI e as outras unidades sieníticas, a primeira atinge as maiores médias de K, entre 2.6 e $55 \mathrm{x}$ $10^{-3} \mathrm{SI}$ (média aproximadamente $19 \times 10^{-3} \mathrm{SI}$ ), já na unidade SLS os valores de $\mathrm{K}$ variam entre 0.5 a $76 \times 10^{-3} \mathrm{SI}$ (média aproximadamente $9 \times 10^{-3} \mathrm{SI}$ ), sendo portanto os máximo e mínimo atingido no plúton. 


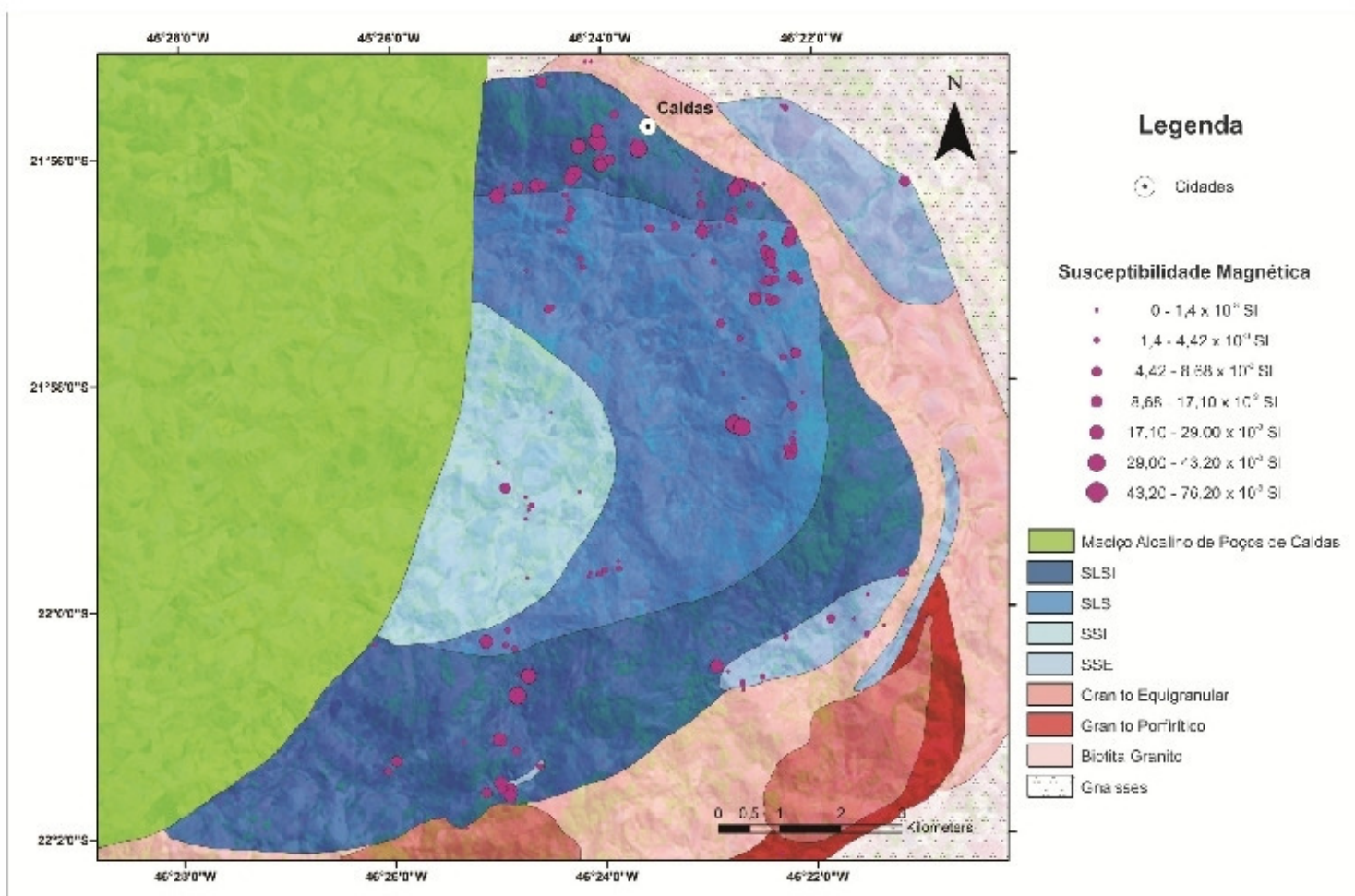

Figura 12: Mapa Geológico incluindo valores de susceptibilidade magnética do Sienito Pedra Branca.

A distribuição dos valores de susceptibilidade magnética no mapa geológico do plúton (Figura 12) é heterogênea, mas o padrão principal mostra que os valores mais elevados predominam em SLSI, especialmente na parte norte da ocorrência. Embora as unidades SSE e SSI tenham menor número de amostragem que SLS e SLSI, os seus valores de $\mathrm{K}$ são claramente inferiores; enquanto isto, SLS muitas vezes atinge valores similares a SLSI.

A Figura 13 contempla as freqüências relativas dos valores de susceptibilidade magnética obtidas em 129 amostras de sienitos nas unidades do plúton. Embora SLS apresente os maiores valores do conjunto, cerca de $40 \%$ dos valores amostrados estão entre 1 e $5 \times 10^{-3} \mathrm{SI}$, enquanto em SLSI cerca de $51 \%$ dos valores são superiores a $20 \times 10^{-3} \mathrm{SI}$. A unidade SSI apresenta média igual a $2,9 \times 10^{-3} \mathrm{SI}$ e em SSE a média é de $3,5 \times 10^{-3} \mathrm{SI}$; em ambas, cerca de $80 \%$ dos valores estão abaixo de $5 \times 10^{-3} \mathrm{SI}$.

As variações de susceptibilidade magnética estão diretamente ligadas às assembléias de minerais opacos, já que no SLSI magnetita e hematita são acessórios importantes, enquanto nas unidades supersaturadas a magnetita aparece mais raramente e a hematita é substituída por ilmeno-hematita (ver item Petrografia para maiores detalhes). 


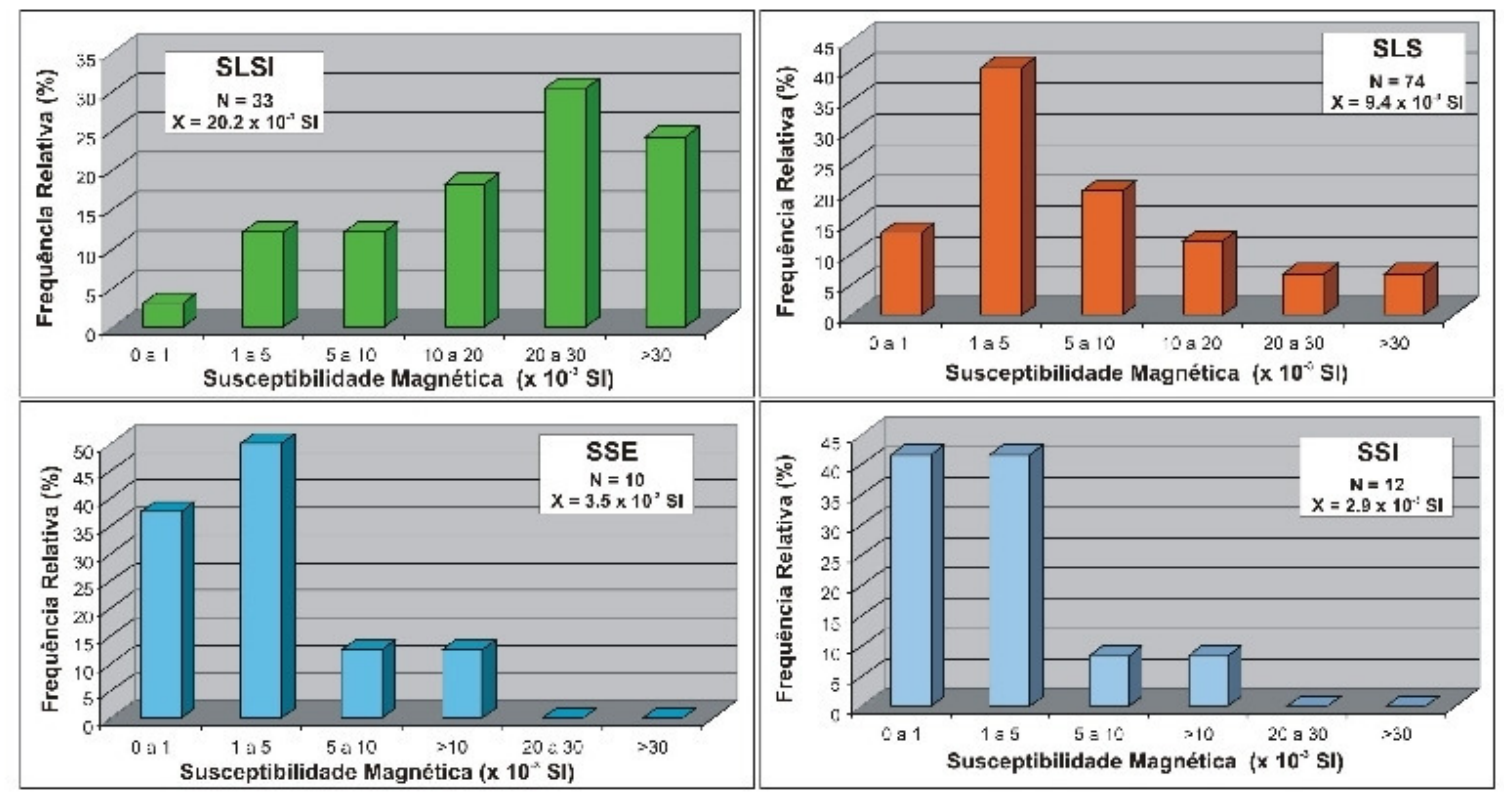

Figura 13: Histogramas de freqüência relativa dos valores de susceptibilidade magnética em amostras das diferentes unidades sieníticas do plúton ( $\mathrm{N}$ é o número de amostras e $\mathrm{X}$ é a média dos valores amostrados).

\section{III.2.2. Feições de Campo}

\section{Sienito Laminado Saturado a Insaturado em Sílica}

A unidade de Sienito Laminado Saturado a Insaturado em Sílica (SLSI) ocorre nas bordas norte, sul e sudeste do plúton, em contato com os migmatitos e granitos encaixantes, e sustenta parte das elevações da Serra da Pedra Branca. Constitui-se de álcali-feldspato sienitos de caráter saturado a localmente insaturado em sílica (ponto PB-92, com sienitos portadores de nefelina).

Os sienitos saturados são laminados, têm cor marrom-arroxeada e textura inequigranular média a grossa (Prancha I - Foto 2) a localmente porfirítica (Prancha I - Foto 1). O índice de cor (IC) é em média 25, porém sienitos grossos de mais alto índice de cor, ou mela-sienitos (IC>35) também são comuns, e muitas vezes associam-se a cumulatos feldspáticos com IC $\sim$.

Os sienitos desta unidade constituem-se de feldspato alcalino, piroxênio e biotita, além dos minerais acessórios titanita, óxidos de Fe-Ti e apatita (em algumas amostras atinge a proporção de 5\% - Prancha I - Foto 4). 
Uma característica marcante destas rochas é a forte foliação magmática evidenciada pelos cristais tabulares de feldspato alcalino que são bem alongados e possuem razão axial ( $\mathrm{Ra}$ ) aproximadamente igual a 4 (Prancha I - Foto 1). A alta razão axial do feldspato resulta em uma melhor orientação dos cristais, de modo que a foliação magmática fica bem marcada.

Em alguns locais, observa-se a existência de zonas de cisalhamento sinmagmáticas, demonstradas pela disposição de cristais de feldspato alcalino idiomórficos de hábito tabular ao longo de pares S/C (Prancha I - Foto 3). Em grande parte das exposições ocorre entelhamento de cristais de K-feldspato, e em geral mostram movimentação sinistral.

Cumulatos máfico-ultramáficos de dimensões variadas $(5$ a $40 \mathrm{~cm}$ de espessura) são facilmente encontrados na unidade SLSI, e constituem-se principalmente por piroxênio e apatita, com biotita e titanita subordinados. As estruturas cumuláticas típicas estão apresentadas na Prancha I, Fotos 11, 12 e 13.

Estes cumulatos podem ocorrem como faixas ou bandas intercaladas com sienitos grossos de IC superiores a 35 (Prancha I - Foto 12), ou até mesmo formando enclaves e schlierens (Prancha I - Fotos 11, 12 e 13) devido ao retrabalhamento e desagregação pelo fluxo magmático. Os enclaves cumuláticos mais comuns são os máfico-ultramáficos enquanto os félsicos ou feldspáticos (leucosienitos com $\mathrm{IC}<5$ ) são subordinados, com dimensões entre 3 e $25 \mathrm{~cm}$. Ambos podem ocorrer em associação, como no afloramento PB-174 onde enclaves cumuláticos félsicos apresentam aglomerações de minerais máfico-ultramáficos nas bordas (Prancha I - Foto 13).

Diques não são comuns nesta unidade, mas podem ser encontradas intrusões tabulares félsicas de sienito, com espessuras variáveis (de 2 até $50 \mathrm{~cm}$ ), que podem apresentar contatos retilíneos ou mesmo sinuosos (Prancha I - Foto 5). Alguns dos diques félsicos podem apresentar bandamentos composicionais (Prancha I - Foto 5), que evidenciam maior ou menor conteúdo de voláteis; localmente podem formar brechas magmáticas (Prancha I - Foto 6).

Pegmatitos são subordinados, e apresentam como minerais principais feldspato alcalino, quartzo, anfibólio e magnetita. Em alguns locais observa-se intensa alteração hidrotermal nestes veios com formação de carbonato, calcopirita e malaquita, além de cavidades miarolíticas (Prancha I - Fotos 8, 9 e 10).

Em um dos afloramentos (PB-174) foi observado dique com espessura de 40 $\mathrm{cm}$ e direção N30E/85SE de rocha ultramáfica de textura afanítica, coloração cinza escura e valores de susceptibilidade magnética $K=\sim 43,50 \times 10^{-3} \mathrm{SI}$ (Prancha I - Foto 7). 


\section{Sienito Laminado Supersaturado em Sílica}

Internamente a SLSI, em contato intrusivo, ocorrem os sienitos laminados supersaturados em sílica (SLS), que sustentam as partes mais elevadas da Serra da Pedra Branca. Em campo, esses sienitos são similares aos SLSI, já que o quartzo raramente é observado a olho nu, no entanto diferenciam-se pela geometria menos alongada dos cristais tabulares de feldspato alcalino, que possuem uma razão axial menor $(R a=2,5)$; assim, a foliação magmática torna-se um pouco menos marcada, porém é ainda muito evidente (Prancha I - Foto 14).

Esses sienitos apresentam textura inequigranular média a grossa, têm coloração marrom arroxeada, por vezes rosada e na maioria das exposições em campo apresentam baixos valores de susceptibilidade magnética $\left(K_{\text {médio }}=9,2 \times 10^{-3} \mathrm{~S}\right)$. Em alguns afloramentos (PB-185 e PB186), entretanto, a susceptibilidade pode atingir valores de $K=56 \times 10^{-3} \mathrm{SI}$.

As rochas desta unidade são álcali-feldspato sienitos supersaturados, portadores de quartzo em proporções inferiores a $5 \%$, e têm como minerais principais feldspato alcalino, piroxênio, anfibólio, biotita, titanita e apatita (esta última, com proporções de até $2 \%$ ). Em algumas amostras está presente pequena proporção de plagioclásio, que pode formar cristais corroídos inclusos feldspato alcalino (Prancha I Foto 16).

$\mathrm{Na}$ maioria dos casos os sienitos não apresentam deformação no estado sólido, entretanto foi encontrada no afloramento PB-213 uma zona de cisalhamento pós-magmática de direção $\mathrm{N62W} /$ subvertical que trunca a foliação magmática do sienito (indeformado) de direção N25W/85SW. Neste local o quartzo sienito apresenta textura milonítica devido à intensa deformação e cominuição na periferia dos cristais de anfibólio e quartzo, que podem ter formato ocelar (Prancha I - Foto 15).

As concentrações de minerais máficos e félsicos também são encontradas com freqüência nesta unidade, em especial os cumulatos máficos constituídos de piroxênio e/ ou anfibólio, biotita, apatita e titanita. Estas acumulações ocorrem em feições de retrabalhamento pelo fluxo magmático que provoca desagregação, formação de enclaves cumuláticos (Prancha I - Fotos 22 e 23), schlieren e dobras de camadas/leitos ultramáficos (Prancha I - Foto 32 e 33).

Além disso, em alguns casos, estes cumulatos podem conter em seu interior pequenos enclaves microgranulares.

Em algumas exposições são encontradas "nuvens de sólidos" (Prancha II Foto 33) que consistem em porções onde ocorrem concentrações de materiais sólidos como cargas de cristais, diversos tipos de enclaves microgranulares e cumuláticos, 
além de venulações de minerais máficos. Neste caso é possível observar um bandamento modal (devido à maior proporção de cristais máficos previamente formados) concordantes com a foliação de fluxo magmático dos sienitos, demonstrando que neste local o fluxo magmático mais intenso foi capaz de carregar uma pesada carga de material sólido.

Um dos enclaves da "nuvem" é microgranular máfico (Prancha II - Foto 24) e composto por biotita, piroxênio, titanita, apatita e K-feldspato. O valor de susceptibilidade magnética (K) é de $64,2 \times 10^{-3} \mathrm{SI}$ ).

Outro enclave da "nuvem" de sólidos apresenta cor arroxeada, formato triangular e contatos retilíneos, e trata-se de um sienito laminado grosso (Prancha I Foto 33). Neste enclave sienítico o feldspato alcalino apresenta alta Ra, além disso, a susceptibilidade magnética é igual a $8 \times 10^{-3} \mathrm{SI}$, semelhante ao encontrado na unidade saturada do plúton. Os contatos sugerem um grande contraste de viscosidade e possivelmente de temperatura, o que pode sugerir uma relação intrusiva entre os sienitos supersaturados e os sienitos saturados (que estariam previamente cristalizados). A SM do enclave é inferior à encontrada nos sienitos saturados (em geral, $\mathrm{SM} \sim 30 \times 10^{-3} \mathrm{SI}$ ).

Interações complexas de intrusão de sienitos finos em sienitos típicos também são encontradas e devem estar associadas ao repreenchimento da câmara magmática. Localmente foi observada presença de enclaves leucocráticos grossos com plagioclásio, além de cumulatos máficos e félsicos associados a intrusão de sienitos finos (Prancha I - Foto 30).

São encontrados veios graníticos e de quartzo tardios discordantes a subconcordantes com a foliação magmática. Em muitos pontos a susceptibilidade magnética aumenta nas proximidades desses veios, como resultado de atividade hidrotermal. Cavidades miarolíticas também são encontradas, e são sugestivas de colocação do plúton em crosta rasa (Prancha I - Foto 20).

Rochas félsicas (leuco-sienitos, quartzo sienitos grossos, granitos e pegmatíticos) são subordinadas, e ocorrem como diques retilíneos desde 2 até $40 \mathrm{~cm}$ de largura (Prancha I - Foto 17, 18, 19 e 21). Os pegmatitos constituem-se de feldspato alcalino e quartzo, raramente com plagioclásio; os minerais máficos em geral são anfibólio, magnetita e titanita. Em um dos afloramentos (PB-209) foi observado um dique pegmatítico de direção N30E/54SE e susceptibilidade magnética igual a 77,5 $\mathrm{x}$ $10^{-3} \mathrm{SI}$, com simplectitos formados por intercrescimento entre quartzo e feldspato alcalino (textura gráfica) (Prancha I - Foto 19). 
A ocorrência de enclaves no plúton foi previamente apresentada por Carvalho (2008) que descreveu a presença de enclaves dioriticos e monzoniticos em associação com os sienitos do plúton.

Os enclaves microgranulares félsicos são comuns nesta unidade e possuem dimensões muito variadas. Em geral, apresentam textura equigranular muito fina a fina e cor acinzentada. Devido à granulação fina, a sua mineralogia raramente é observada a olho nu, de modo que eles são melhor classificados através da petrografia.

Os enclaves mais abundantes têm aspecto sacaroidal, composição diorítica, índice de cor (IC) entre 10-15 e textura equigranular muito fina a fina. Constituem-se por plagioclásio, mineral mais abundante, biotita, e quartzo, que ocorre em pequena proporção. De dimensões variadas (desde milimétricos, caso em que são identificados apenas em seções delgadas, até centimétricos), esses enclaves podem apresentar formas tabulares com bordas de granulação muito fina (Prancha I - Foto 26), além bordas de reação, evidenciadas por altas concentrações de biotita (Prancha I - Foto 27).

Enclaves microgranulares de composição monzonítica a sienítica não são raros, mas ocorrem apenas nas unidades supersaturadas. $O$ tamanho destes enclaves varia desde 2 até $30 \mathrm{~cm}$, e eles têm textura inequigranular fina, IC entre 15 e 25 e são constituídos por feldspato alcalino, piroxênio e biotita. Em geral, os contatos com os sienitos hospedeiros são sinuosos, e não existem bordas mais finas (Prancha I - Foto 29).

Um enclave sienítico de forma tabular com cerca de $30 \mathrm{~cm}$ de comprimento foi encontrado no afloramento PB-250 (Prancha I - Foto 28). A estrutura deste microsienito é sutilmente bandada, textura é equigranular fina a média, IC $=15$ e constitui-se principalmente de feldspato alcalino e piroxênio. O grande contraste de viscosidade com o sienito hospedeiro, evidenciado pela sua forma tabular e contatos bruscos, abre a possibilidade que este seja um fragmento de margem resfriada.

Em uma das pedreiras visitadas (ponto PB-185) foi amostrado um enclave de rocha ultramáfica com textura inequigranular grossa, e susceptibilidade magnética igual a $64,2 \times 10^{-3} \mathrm{SI}$. Esta rocha constitui-se principalmente por biotita, piroxênio, titanita, apatita, tendo como minerais acessórios o feldspato alcalino, quartzo, além de alguns cristais submilimétricos de bornita e calcopirita (Prancha I - Foto 25). 


\section{Sienito Supersaturado em Sílica Interno}

Sienito Supersaturado em Sílica Interno (SSI) ocorre intrusivo na unidade SLS, e corresponde a uma área de relevo rebaixado no interior do plúton. Internamente, a unidade SSI é invadida pelas rochas do Maciço Alcalino de Poços de Caldas. A foliação de fluxo magmático é menos marcada se comparada às porções mais externas do maciço e em algumas exposições os sienitos têm estrutura maciça.

Os sienitos da unidade SSI possuem índice de cor entre 20 e 25, apresentam textura equigranular fina a média (Prancha I - Foto 34) a localmente inequigranular (Prancha I - Fotos 35 e 36) e coloração esverdeada. Os valores de susceptibilidade magnética são os mais baixos do plúton $\left(K_{\text {médio }}=2,9 \times 10^{-3} \mathrm{~S}\right)$.

Os minerais presentes são feldspato alcalino, piroxênio, anfibólio, biotita e apatita, podendo aparecer quartzo e plagioclásio. Em algumas amostras ocorrem aglomerados irregulares de biotita.

Assim como nas outras unidades supersaturadas, a presença de enclaves microgranulares félsicos é muito comum. Enclaves microgranulares, em média com 6 cm de comprimento, forma tabular (Prancha I - Foto 38) e composição diorítica são os mais abundantes, mas enclaves sieníticos com formas irregulares (Prancha I - Foto 39) também estão presentes nesta unidade.

Veios de quartzo, além de diques de quartzo sienito, granito (Prancha I - Foto 37) e pegmatito de dimensões variadas (desde 6 a $40 \mathrm{~cm}$ de espessura) são abundantes nesta unidade.

Alteração hidrotermal muito localizada pode ocorrer próximo a fraturas tardias, e está provavelmente ligada à intrusão alcalina de Poços de Caldas.

\section{Sienito Supersaturado em Sílica Externo}

A unidade de Sienito Supersaturado em Sílica Externo (SSE) corresponde a corpos lenticulares que ocorrem a E-NE da ocorrência e separam-se do restante do plúton por um septo de granitos. O aspecto macroscópico das rochas desta unidade é muito semelhante aos sienitos do plúton vizinho Capituva, que ocorre a nordeste do Sienito Pedra Branca.

Os sienitos da unidade SSE possuem IC 25, textura inequigranular fina a média, cor rósea (Prancha I - Foto 40) e susceptibilidade magnética baixa $\left(K_{\text {médio }}=3,5\right.$ $x 10^{-3} \mathrm{~S} /$ ). A foliação magmática é evidente, e em algumas exposições exibem sienitos 
laminados onde a foliação é marcada pelo feldspato alcalino de $R a=2.5$ (Prancha I Foto 41 e 42) similar ao SLS.

A mineralogia principal dos SSE é composta feldspato alcalino, piroxênio e/ou anfibólio, biotita, e quartzo e plagioclásio como minerais acessórios.

Uma zona de cisalhamento pós-magmática com cerca de $5 \mathrm{~cm}$ de espessura onde ocorre deformação no estado sólido foi encontrada no afloramento PB-264. A direção N50E/subvertical é paralela à foliação magmática, onde o sienito continua intacto (não sofreu deformação). Na zona de cisalhamento o sienito apresenta textura milonítica devido à intensa deformação e cominuição na periferia dos cristais de feldspato alcalino (Prancha I - Foto 43).

Dois tipos de enclaves foram encontrados nesta unidade: microgranulares (Prancha I - Foto 44) e cumuláticos máficos (Prancha I - Foto 45). Ambos possuem dimensões menores que $10 \mathrm{~cm}$.

Diques não foram observados, porém em algumas exposições o sienito parece alterado por eventos tardios, já que ocorre mudança busca na cor que de rósea passa a avermelhada (Prancha I - Foto 46), que se associa ao aparecimento de sulfetos (e.g. pirita; Prancha I - Foto 47). 
- PRANCHA I -

FOTOS DE CAMPO 


\section{Sienito Laminado Saturado a Insaturado - SLSI -}

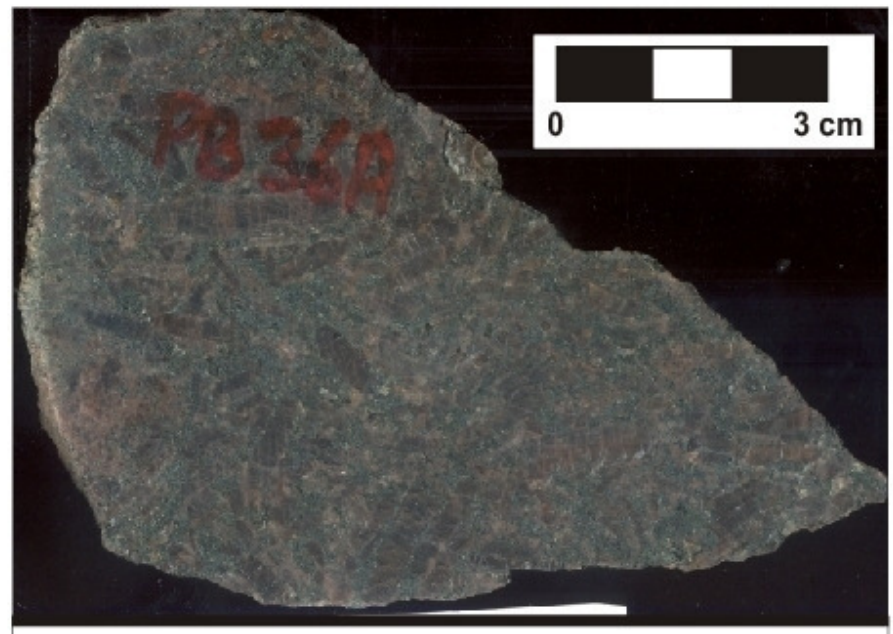

Foto 1 (PB-36A): Amostra de álcali sienito com textura inequigranular porfirítica grossa.

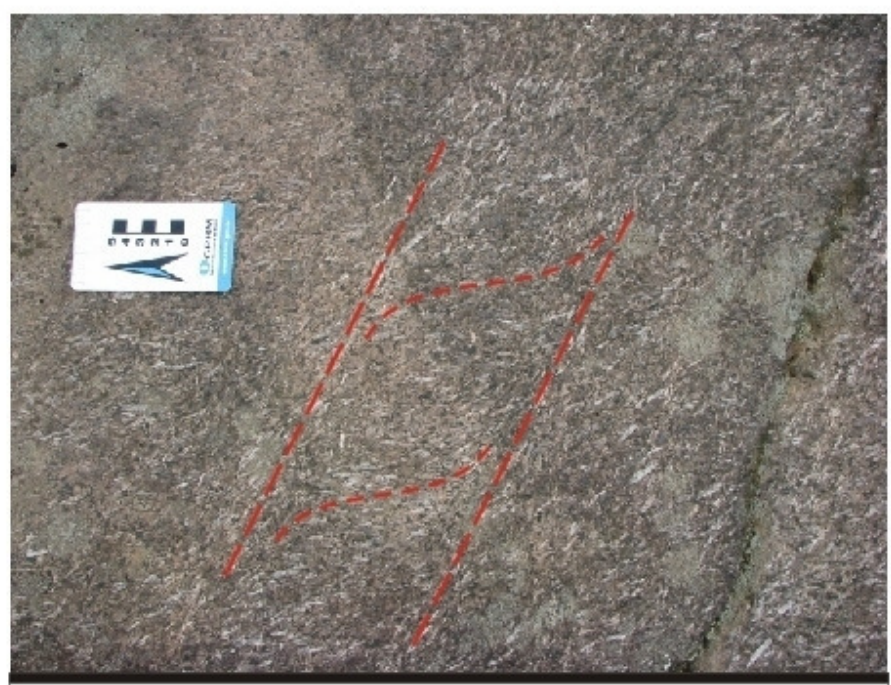

Foto 3 (PB-189): Intensa foliação magmática em álcali sienito e par $\mathrm{S} / \mathrm{C}$ formado em zona de cisalhamento sin-magmática.

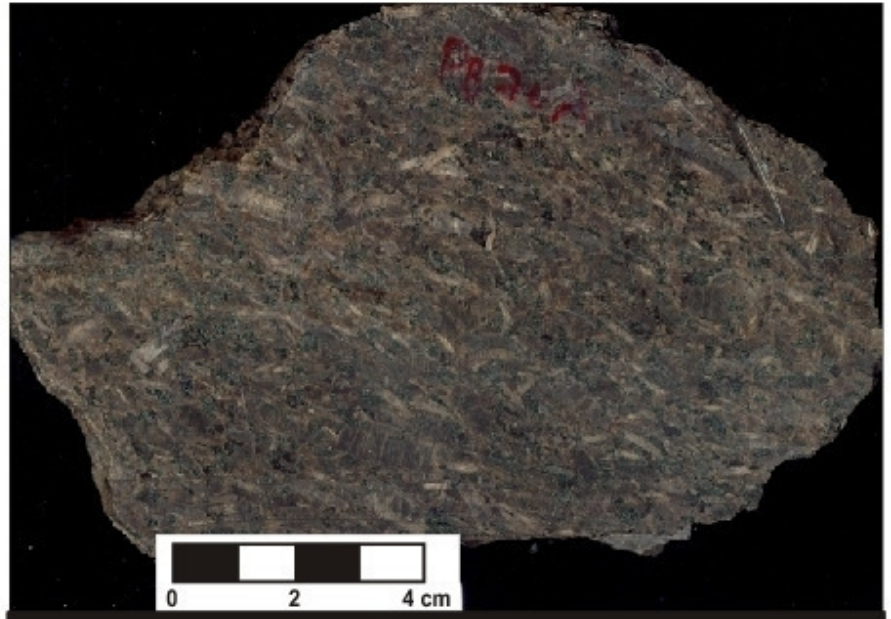

Foto 2 (PB-70A): Amostra de álcali sienito com textura inequigranular média, e intensa foliação magmática dada pelos cristais tabulares de feldspato alcalino com razão axial 4.

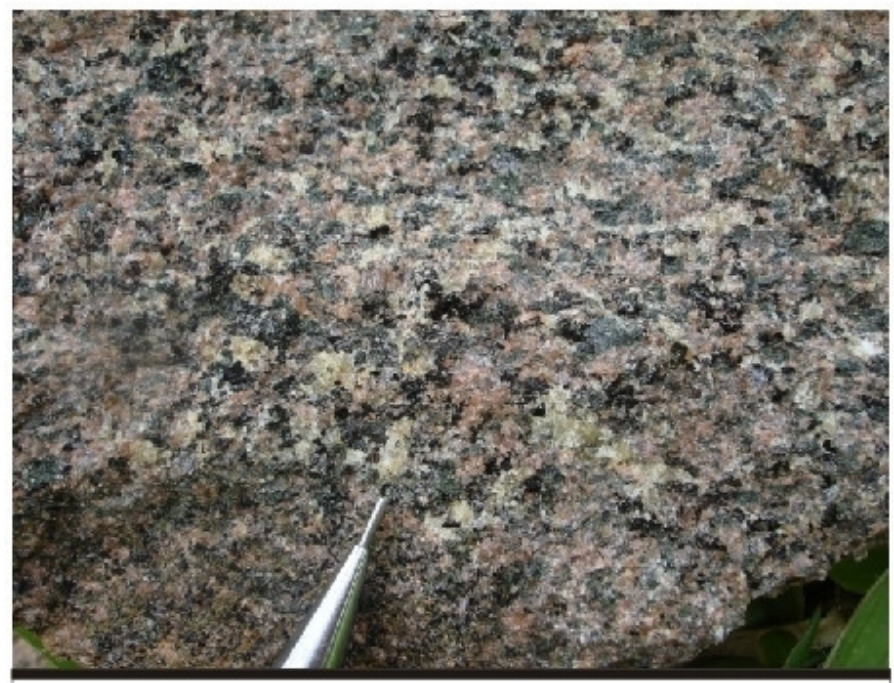

Foto 4 (PB-288): Álcali sienito com textura inequigranular média, rico em minerais máficos. Apatita atinge proporções modais de $5 \%$. 


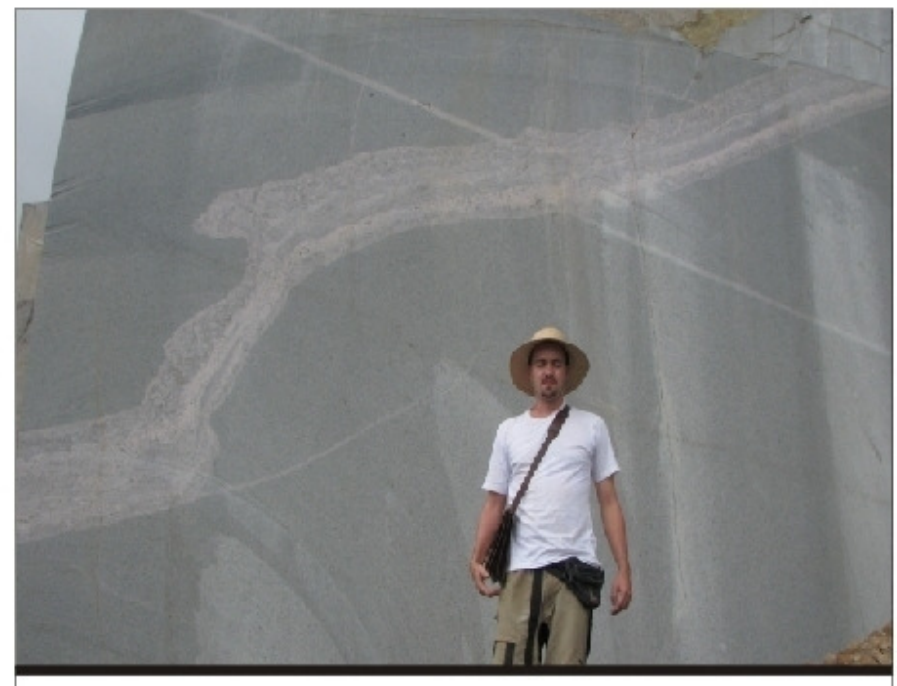

Foto 5 (PB-174): Dique sienítico com bandamento composicional evidenciado por diferentes conteúdos em voláteis.

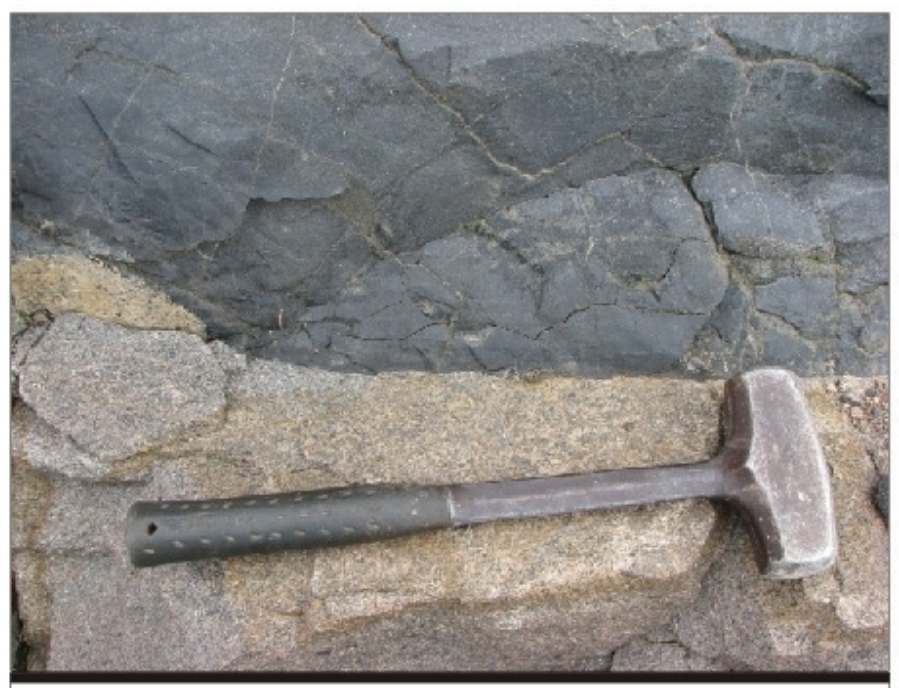

Foto 7(PB-176): Dique ultramáfico com textura afanítica intrusivo em alcali sienito.

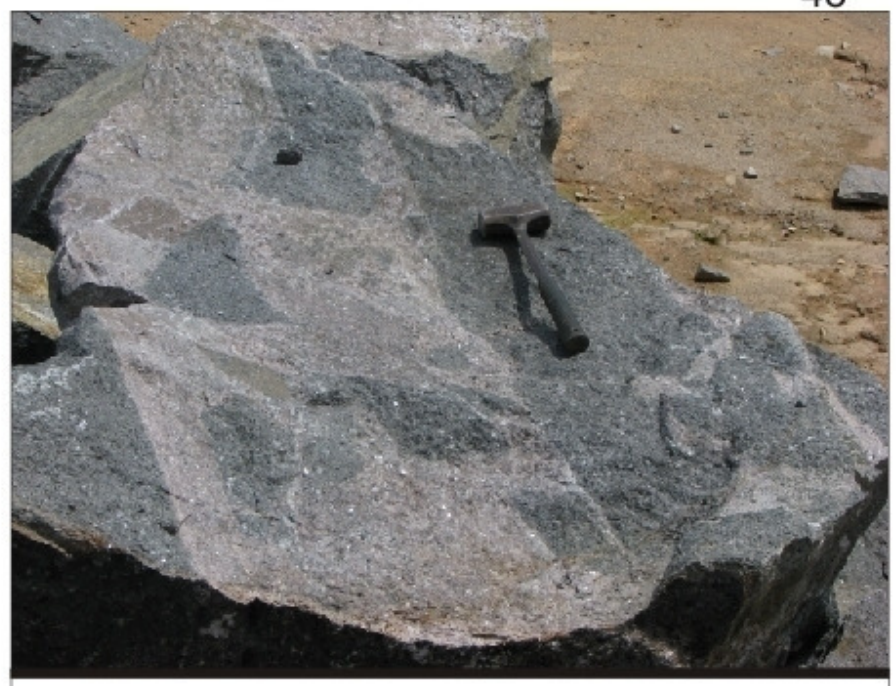

Foto 6(PB-188): Brecha magmática formada pela intrusão forçada de sienito róseo tardio em sienito cinza hospedeiro.

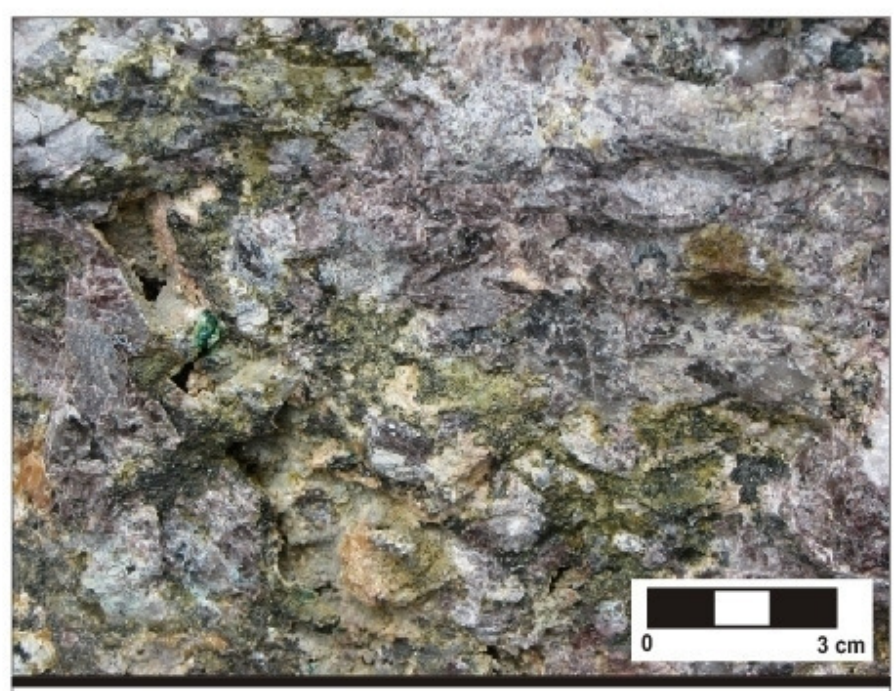

Foto 8 (PB-174): Intensa alteração hidrotermal em sienito grosso. Presença de cavidades miarolíticas e carbonato e malaquita tardios.

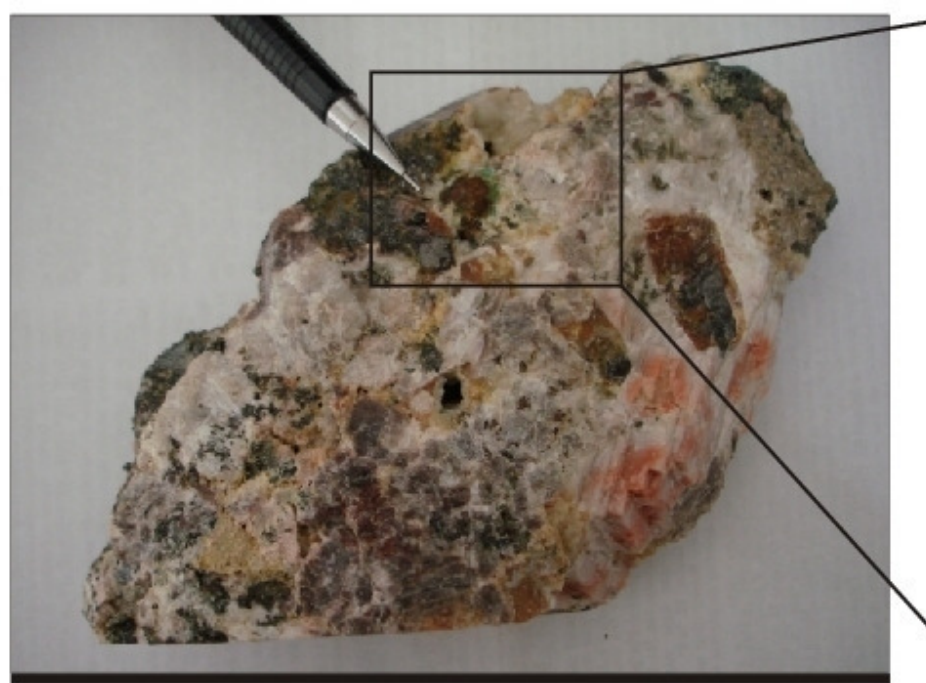

Foto 9: Veio pegmatítico tardio com intensa alteração hidrotermal. Paragênese exótica com K-feldspato, apatita, magnetita, carbonato, calcopirita e malaquita.

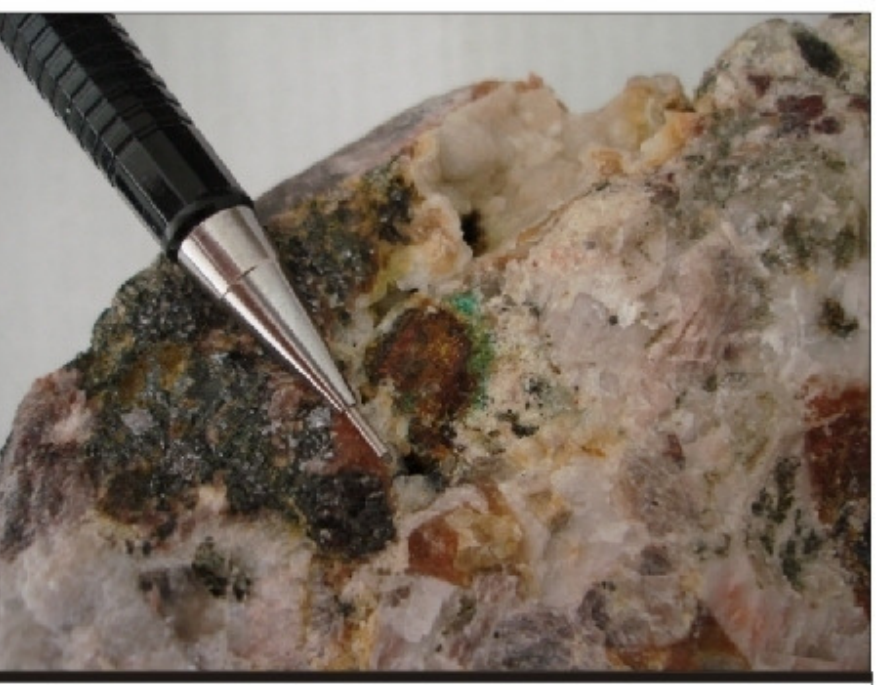

Foto 10(PB-174E): Destaque para presença de cavidades miarolíticas, além de magnetita, calcopirita com malquita nas bordas. 


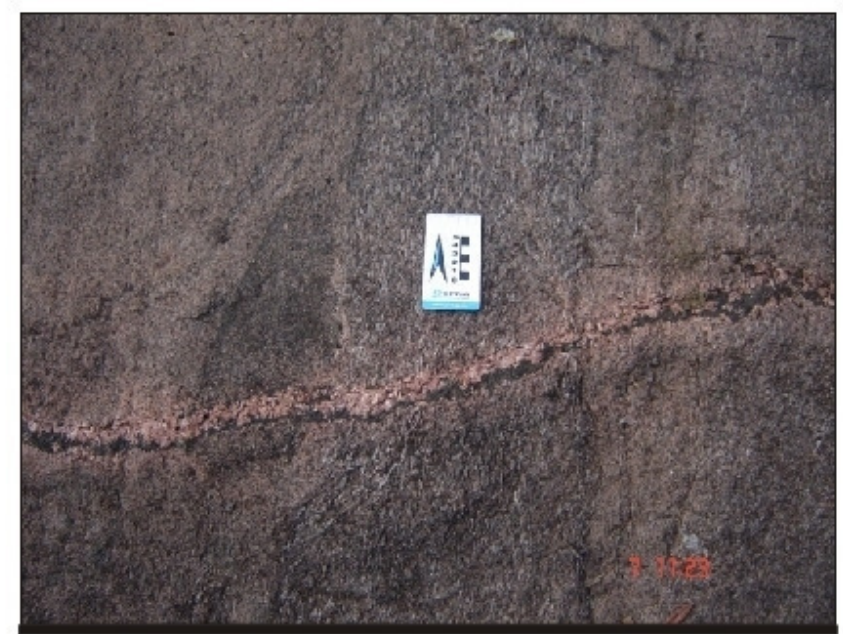

Foto 11 (PB-235): Interação entre sienitos laminados grosso e finos, e enclave de melasienito cortados por veio tardio com acumulação de máficos nas bordas.

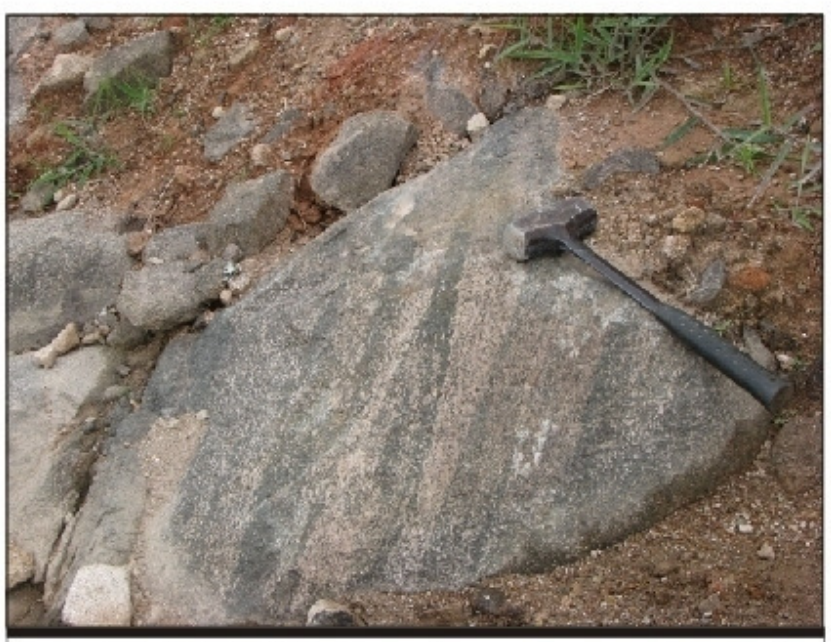

Foto 12 (PB-175): Bandamento modal dado pelo aumento na proporção de minerais máficos em álcali sienito. As porções mais escuras constiuem-se de piroxênio e apatita.

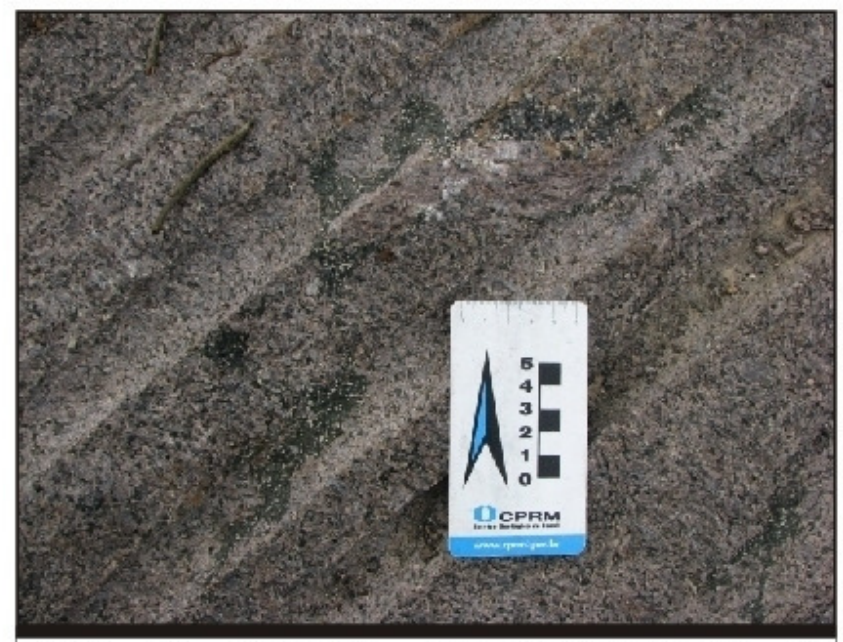

Foto 13 (PB-174): Retrabalhamento de cumulatos máficos e feldspáticos (leucosienito) ocasionando a formação de enclaves cumuláticos, muito comuns nesta unidade.

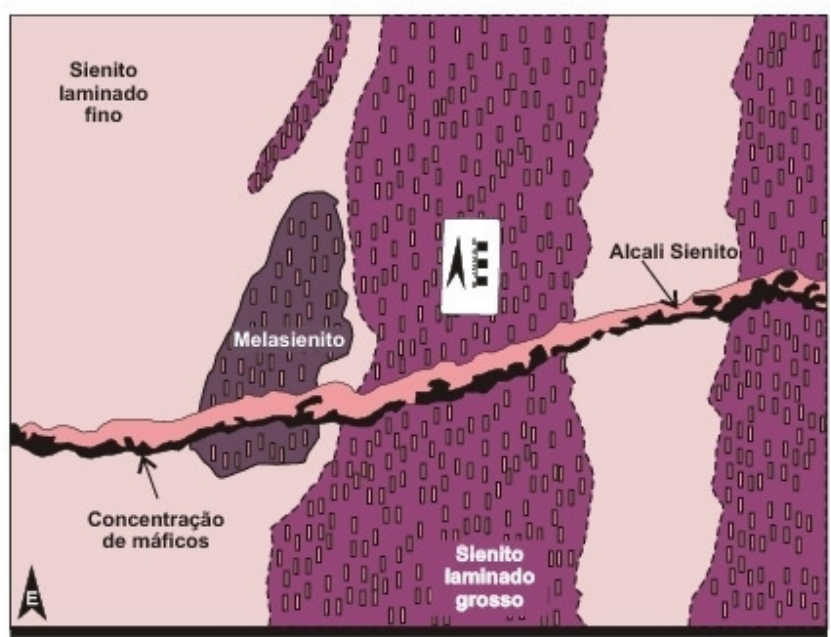

Croqui esquemático da foto 11 .

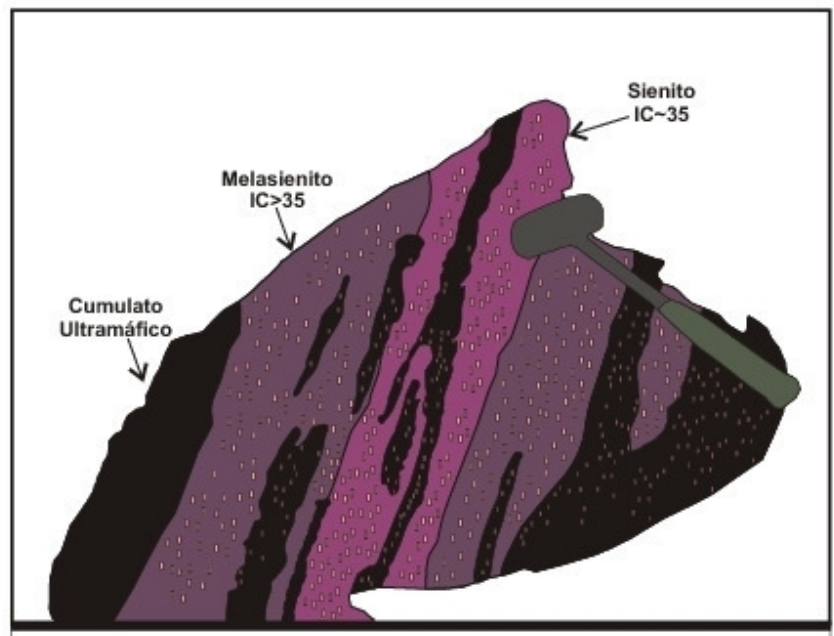

Croqui esquemático da foto 12.

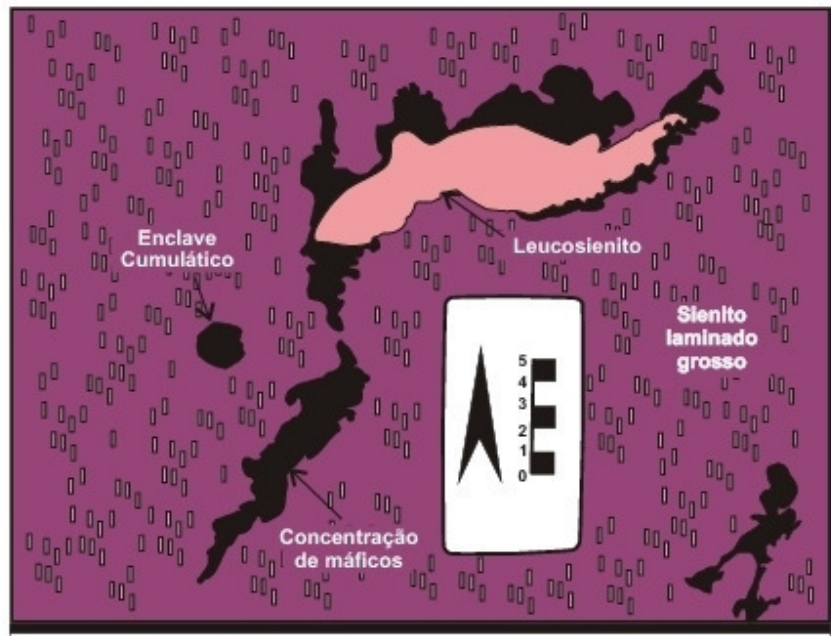

Croqui esquemático da foto 13. 


\section{Sienito Laminado Supersaturado em Sílica - SLS -}

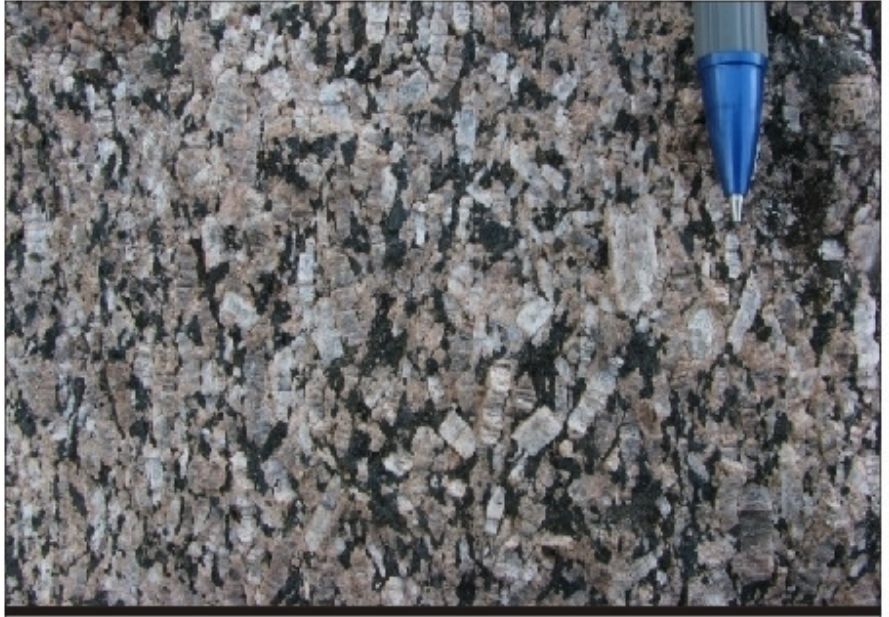

Foto 14 (PB-197): Sienito com quarzto, textura inequigranular grossa. Foliação magmática bem marcada pelos cristais de feldspato alcalino tabular com $\mathrm{Ra}=2,5$.

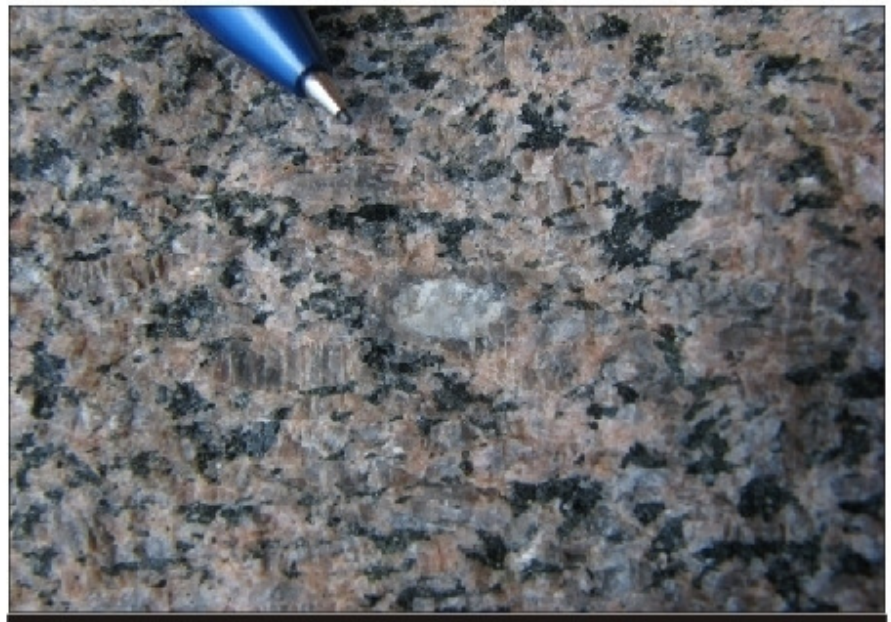

Foto 16 (PB-212): Sienito com cristal de plagioclásio incluso em feldspato alcalino.

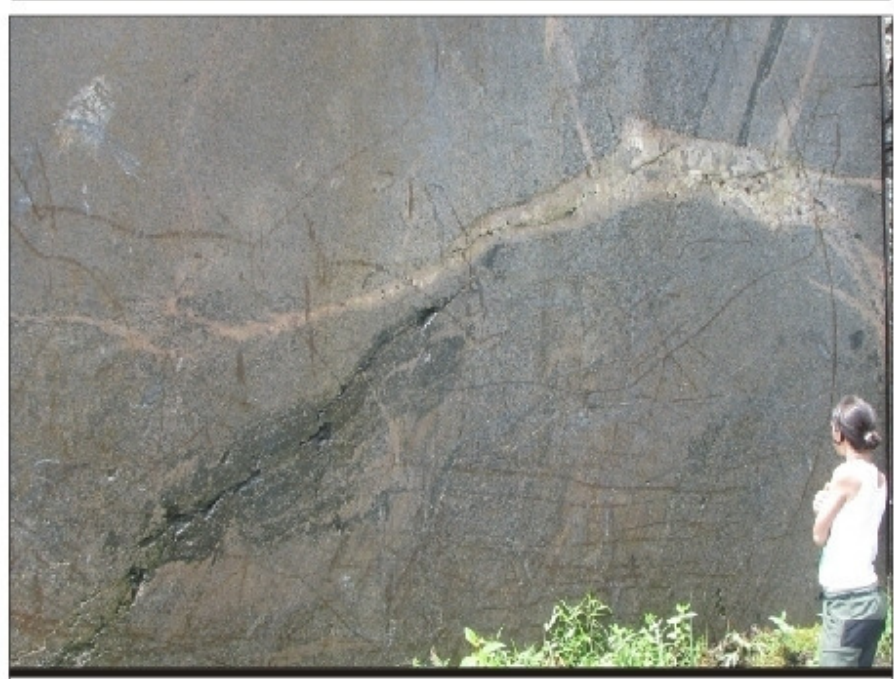

Foto 18(PB-209): Veio pegmatítico intrusivo em sienito com quartzo e $I C=25$. Presença de cumulatos máficos e sienito bandado.

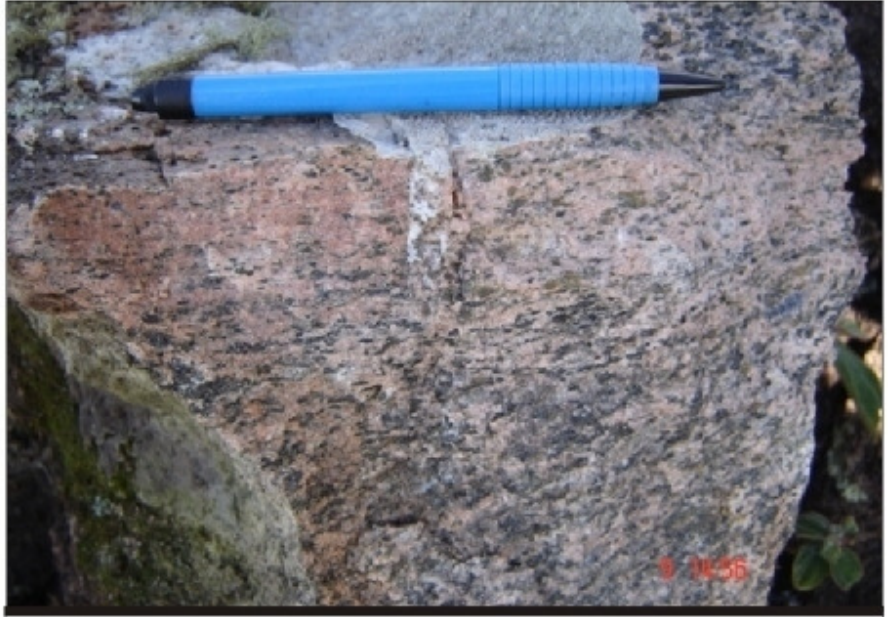

Foto 15 (PB-213): Sienito com quartzo intensamente deformado por zona de cisalhamento pós-mag-mática.

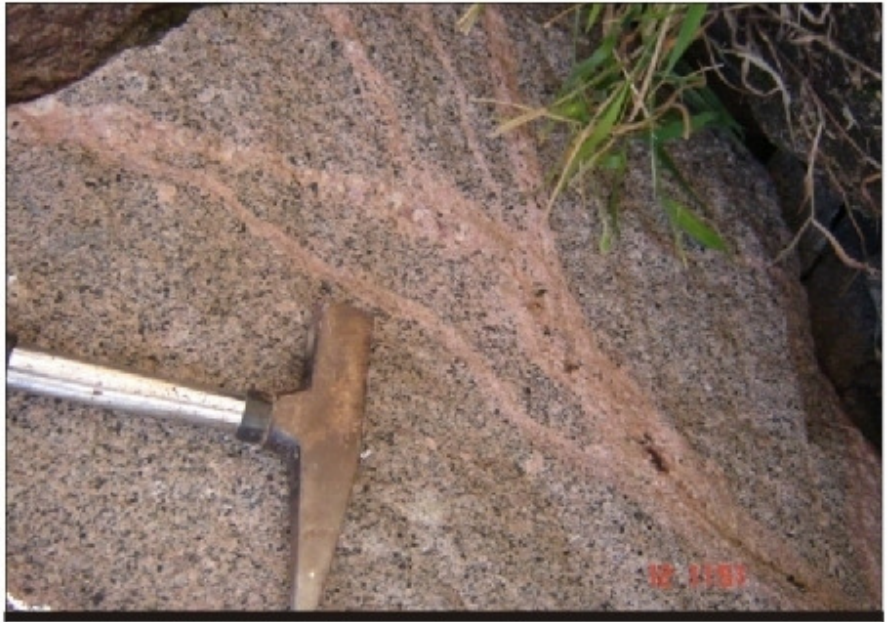

Foto 17 (PB-246): Veios tardios de quartzo sienito em sienito supersaturado.

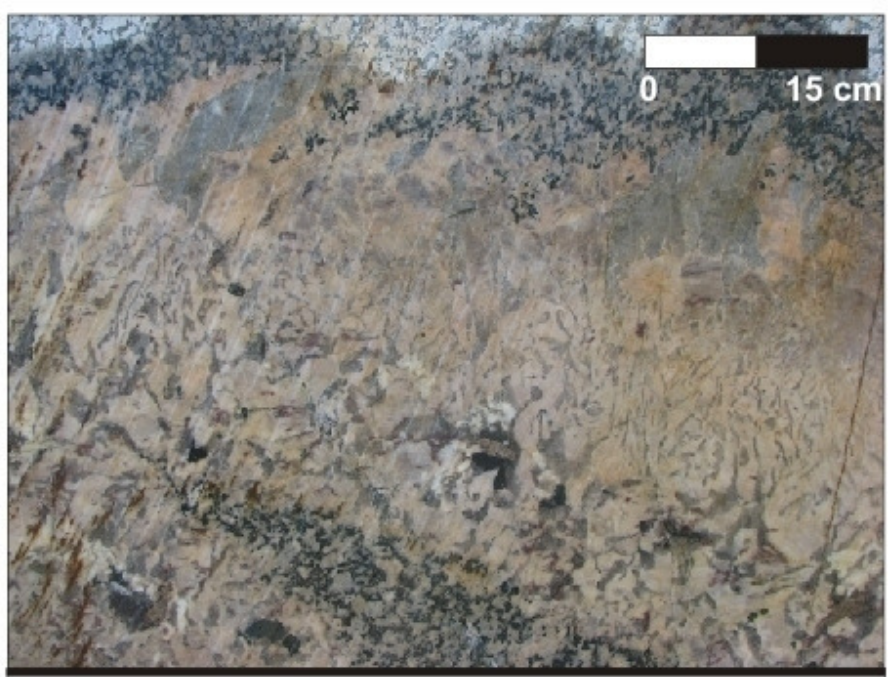

Foto 19 (PB-209): Detalhe da foto 5 mostrando veio pegmatítico com textura gráfica. 


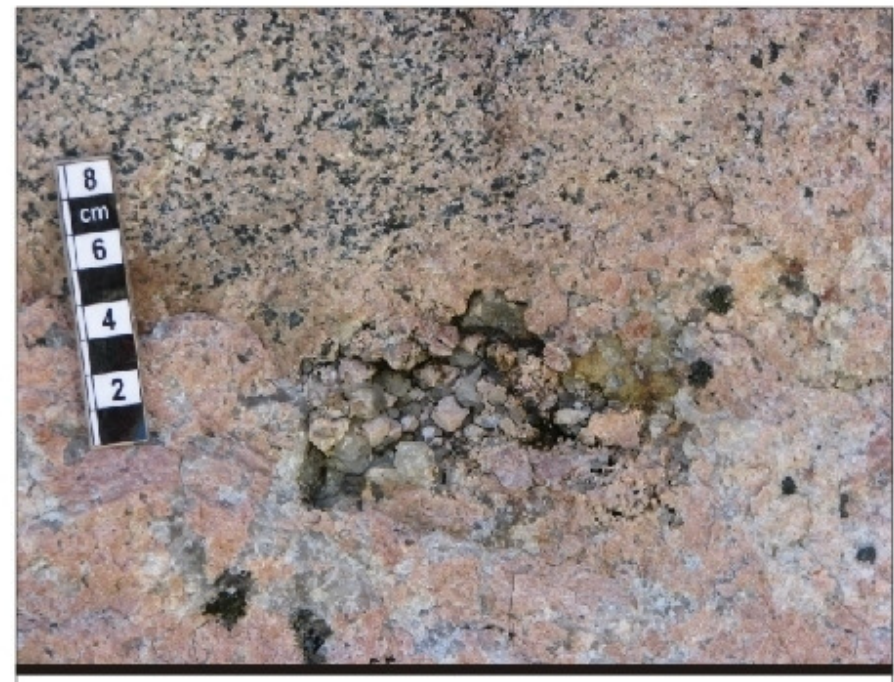

Foto 20(PB-210): Cavidade miarolítica com quartzo piramidado em sienito tardio.

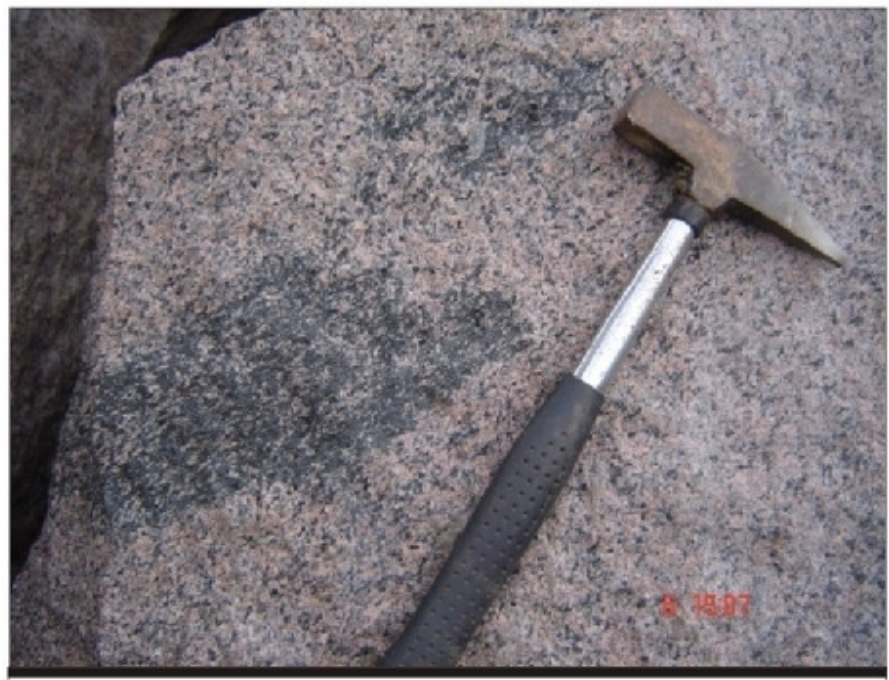

Foto 22(PB-231): Enclave cumulático ultramáfico em sienito com quartzo.

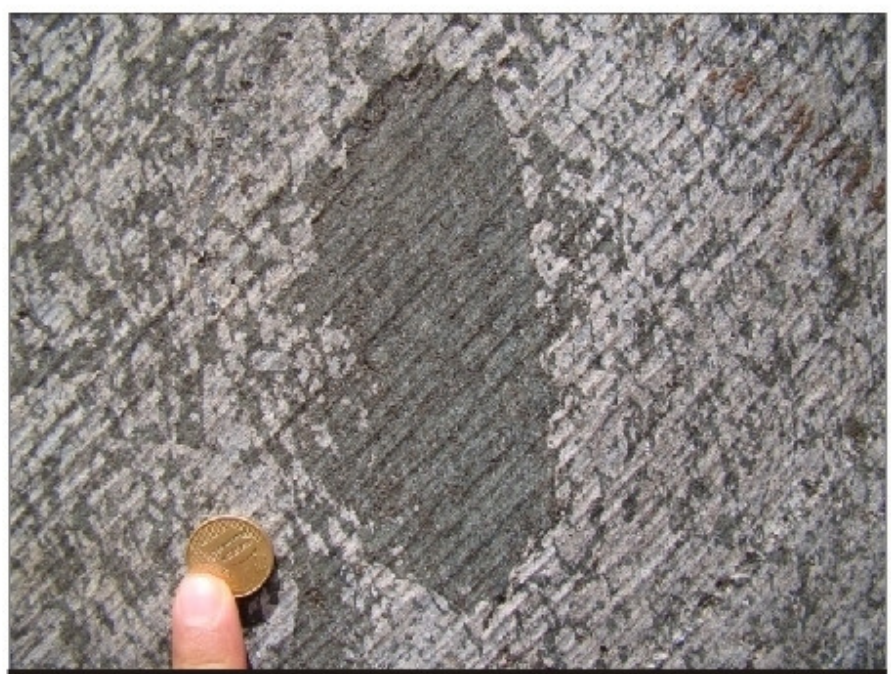

Foto 24(PB-209): Enclave microgranular ultramáfico em sienito. Destaque para captura de cristais de feldspato e concentração de máficos nos contatos com a rocha hospedeira.

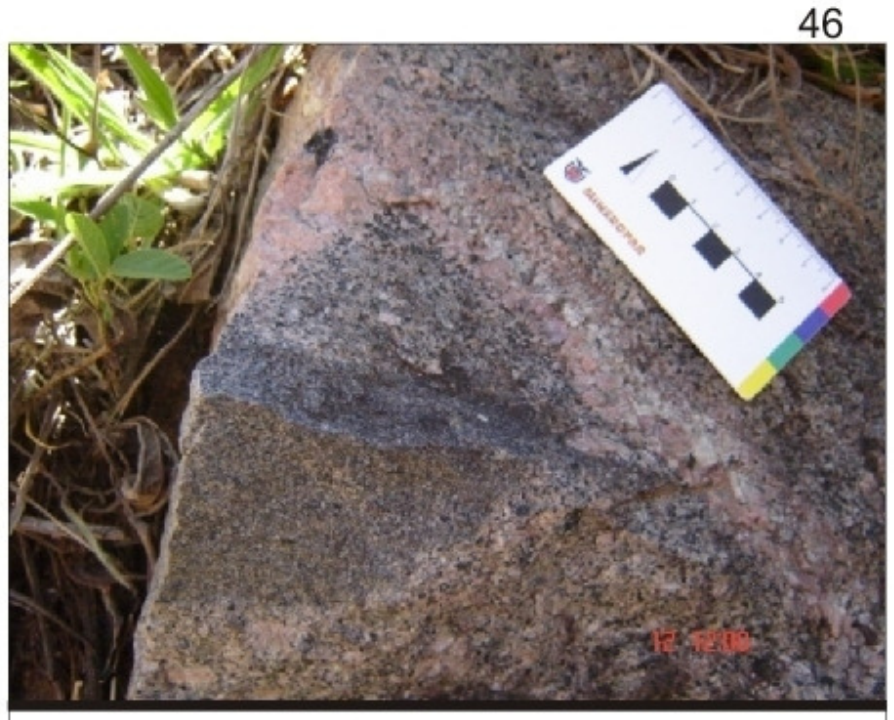

Foto 21 (PB-247): Enclave microgranular monzonítico em sienito com quartzo. Presença de veio granítico tardio.

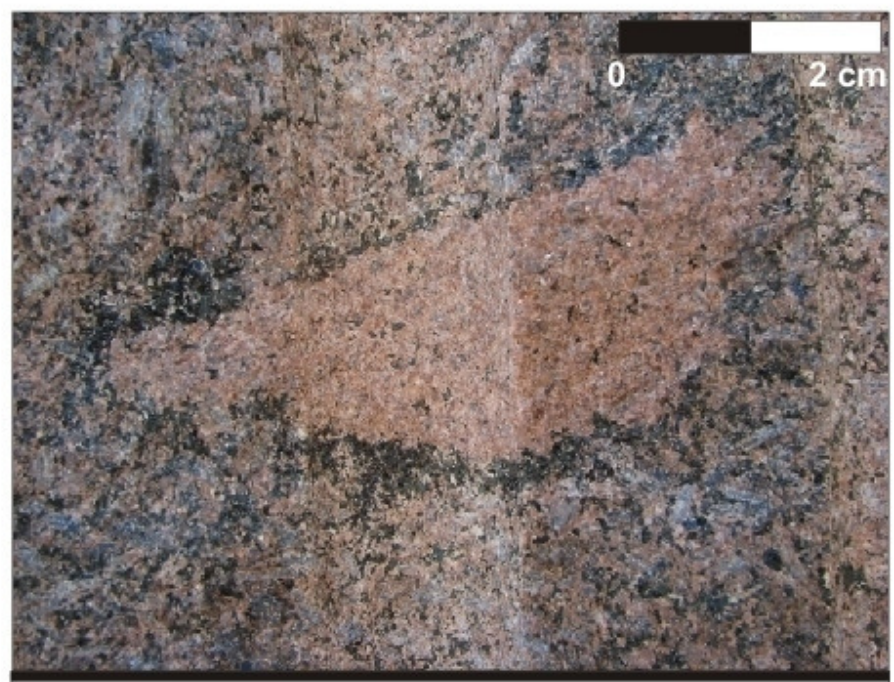

Foto 23(PB-185): Enclave cumulático félsico rico em feldspato em sienito com quartzo. $\mathrm{Na}$ bordas ocorre concentração de piroxênio e apatita.

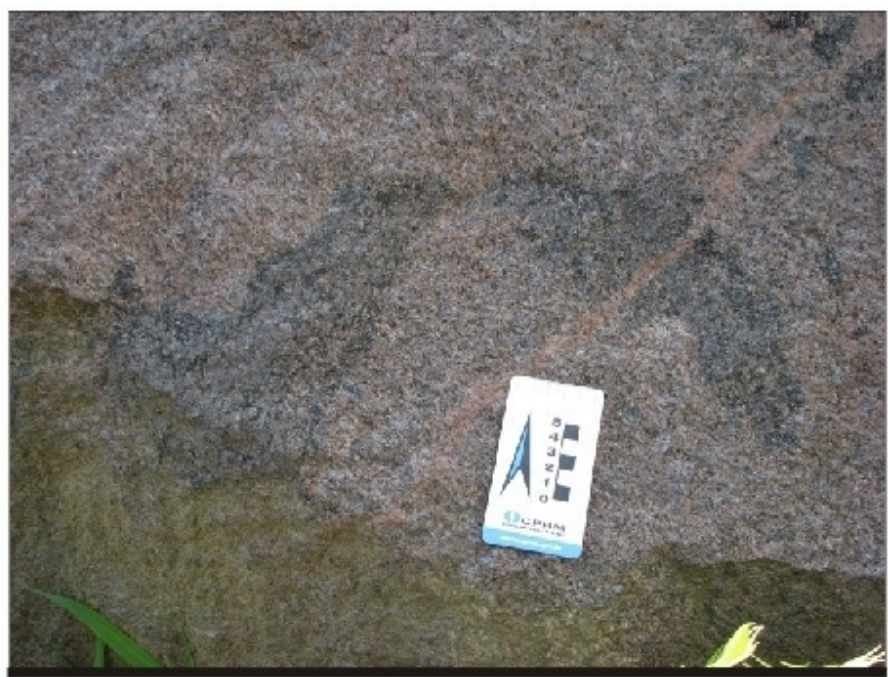

Foto 25 (PB-185): Enclave ultramáfico com piroxênio, flogopita, apatita, titanita, magnetita, calcopirita e bornita 


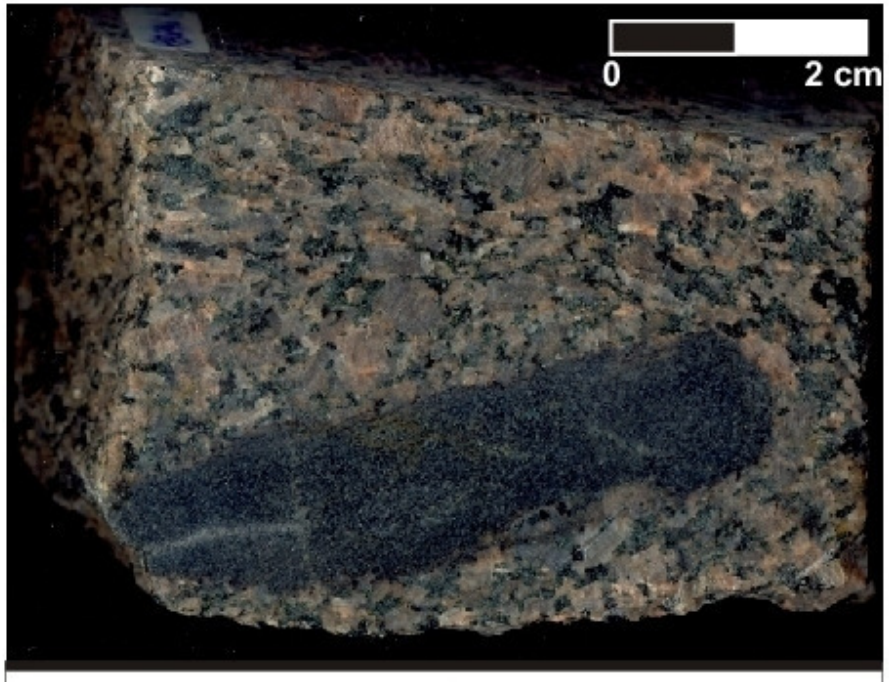

Foto 26 (PB-246): Enclave microgranular diorítico tabular com bordas resfriadas em sienito com quartzo.

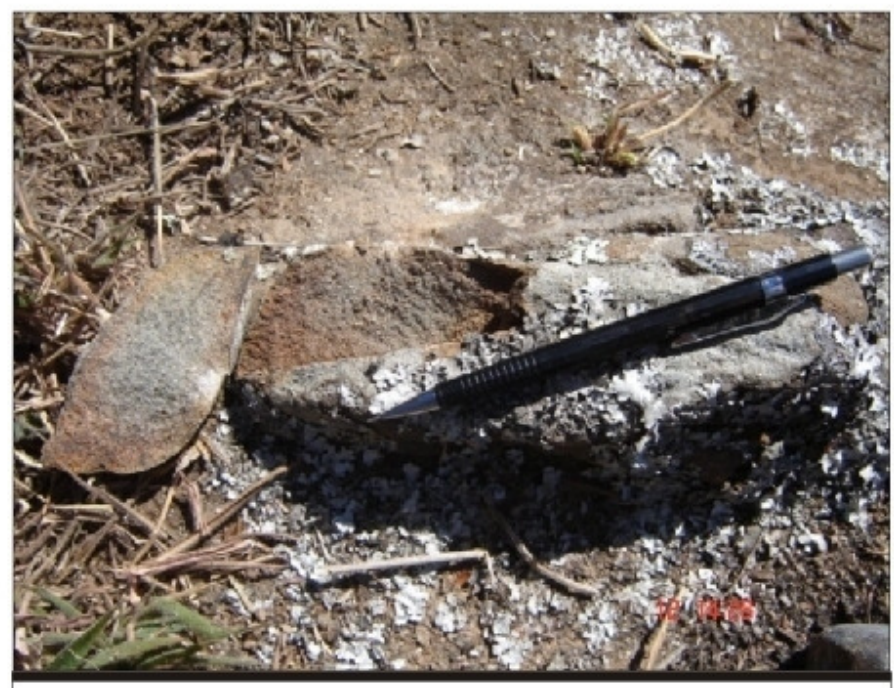

Foto 28 (PB-250): Enclave microgranular sienítico com sutil bandamento composicional e forma tabular.

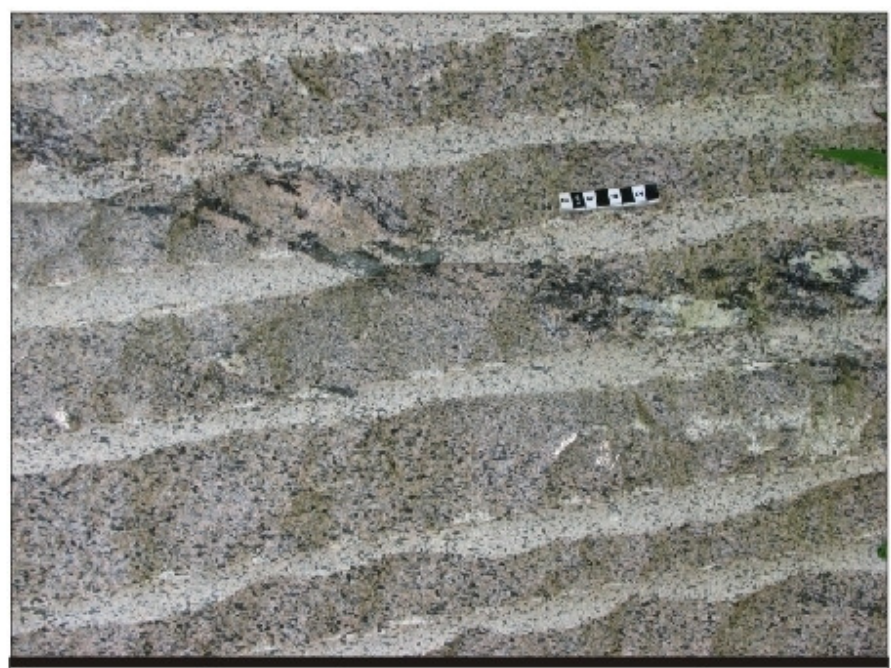

Foto 30 (PB-209): Interação complexa entre sienito $(I C=25)$ e sienito fino $(I C=20)$ com enclaves cumuláticos máficos, leucosienito fino e enclave leucocrático grosso rico em plagioclásio.

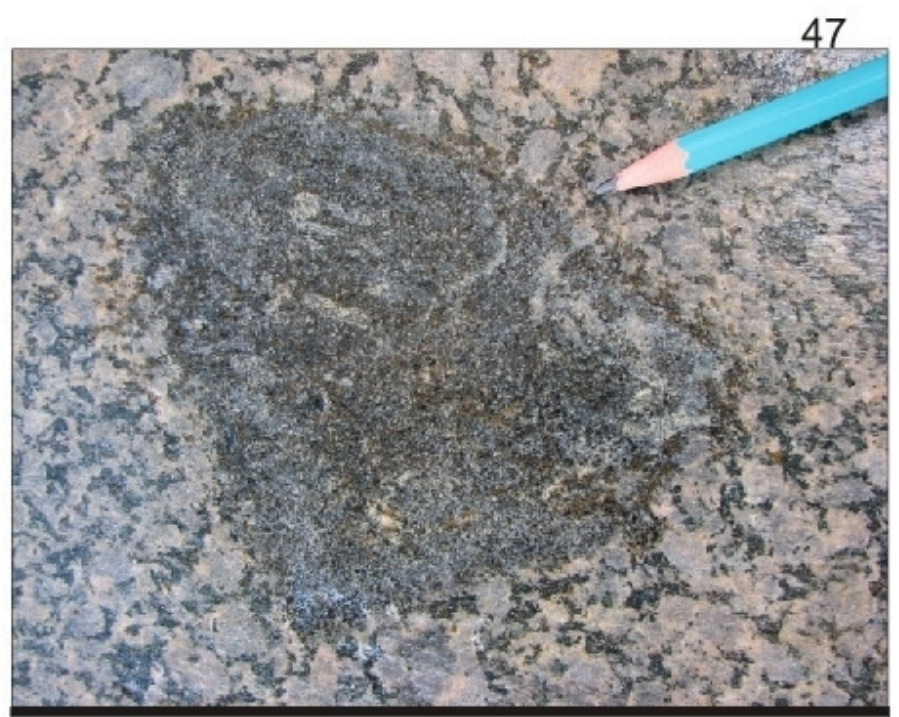

Foto 27(PB-209): Enclave microgranular diorítico com contatos difusos ricos em biotita em sienito com quartzo.

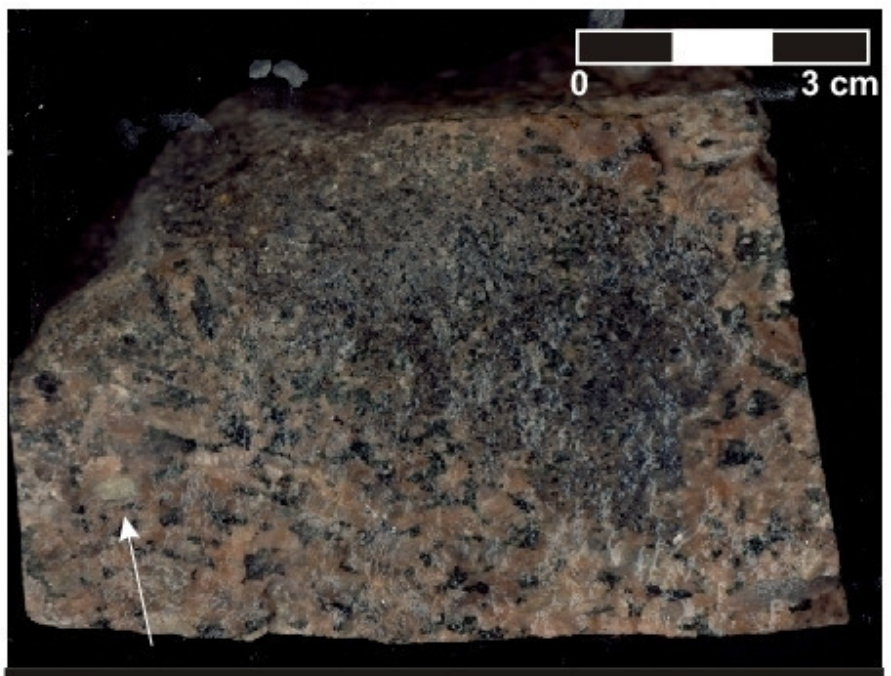

Foto 29 (PB-209): Enclave microgranular sienítico com contatos difusos em sienito com quartzo. Destaque para pequeno cristal de plagioclásio incluso em feldspato alcalino.

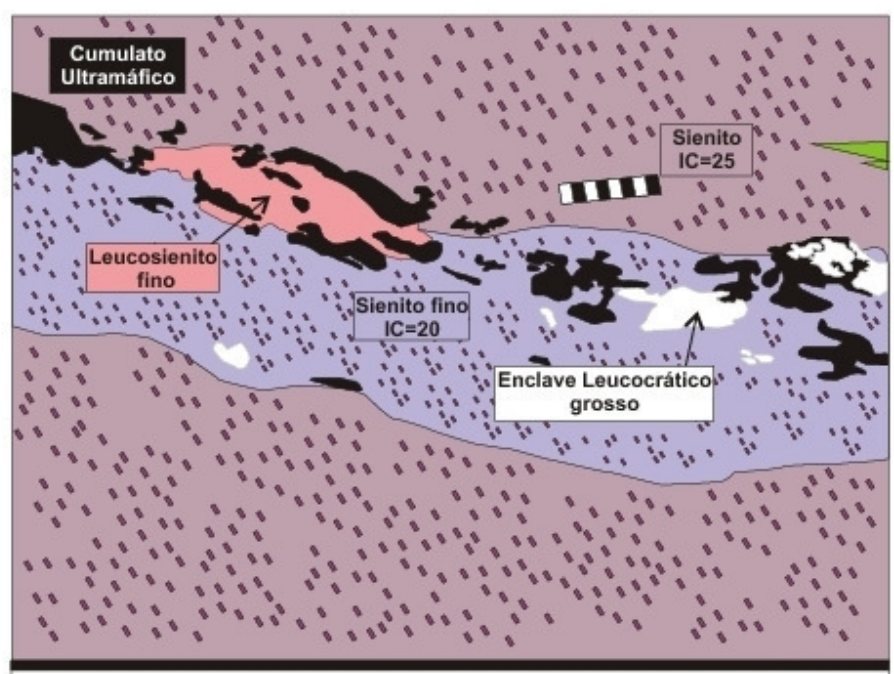

Croqui esquemático da foto 30 . 


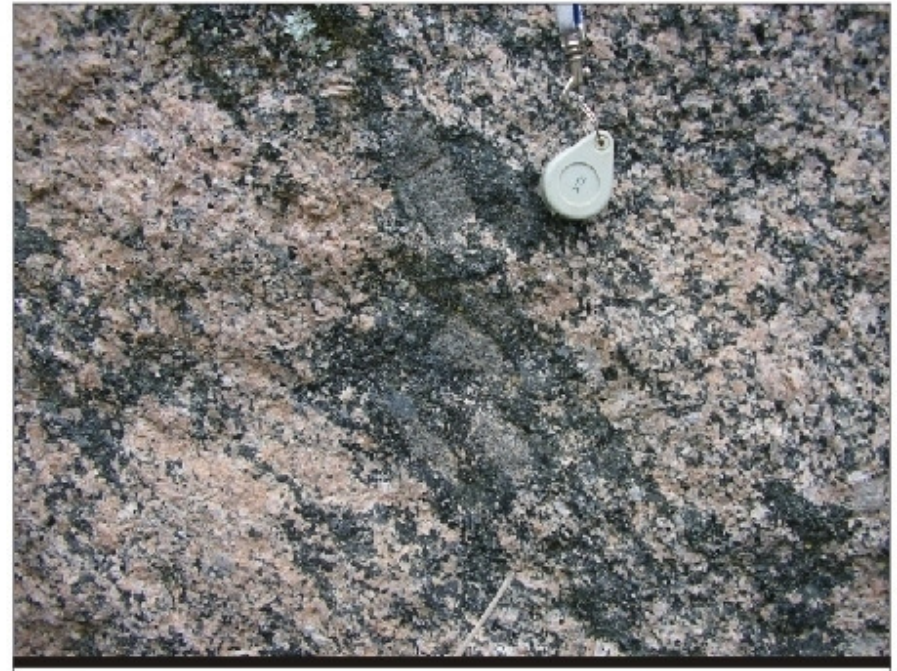

Foto 31 (PB-156): Sienito e cumulatos ultramáficos com enclaves microgranulares dioríticos em seu interior.

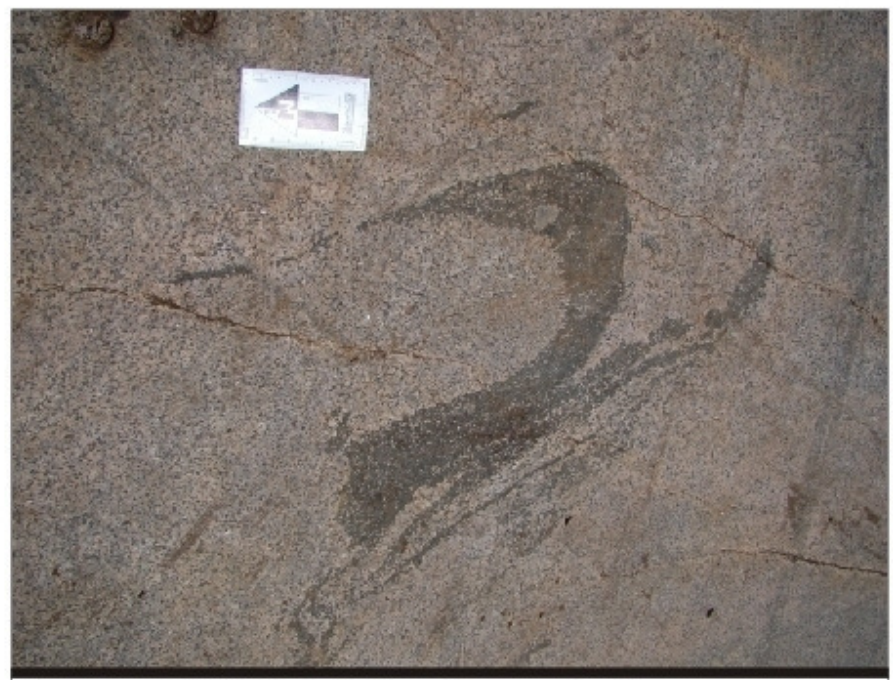

Foto 32(PB-209): Retrabalhamento e desagregação de banda cumulática ultramáfica e melasienitos (IC>35). Destaque para enclave microgranular félsico incluso no cumulato.

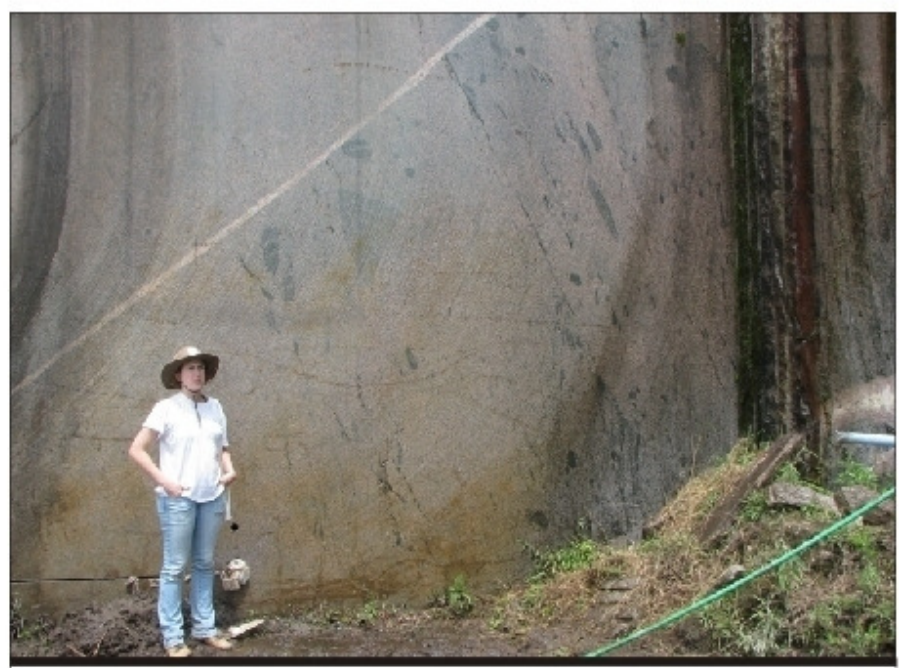

Foto 33 (PB-209): Nuvem de sólidos: xenólito, enclaves microgranulares e cumuáticos, vênulas máficas e minerais máficos. Destaque para xenólito de sienito laminado (SLSI) e enclave máfico (lamprofírico).

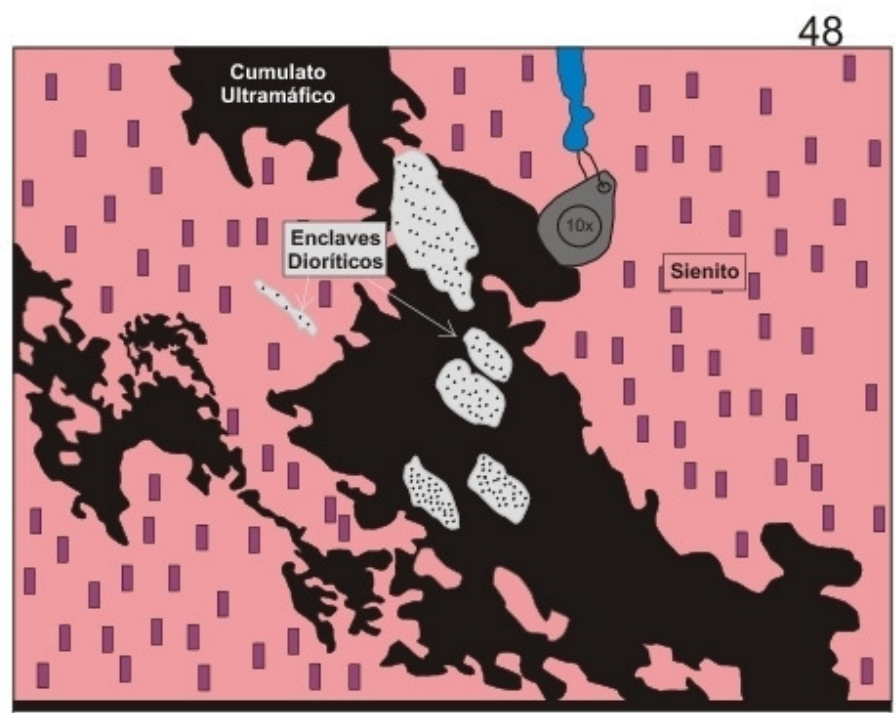

Croqui esquemático da foto 31 .

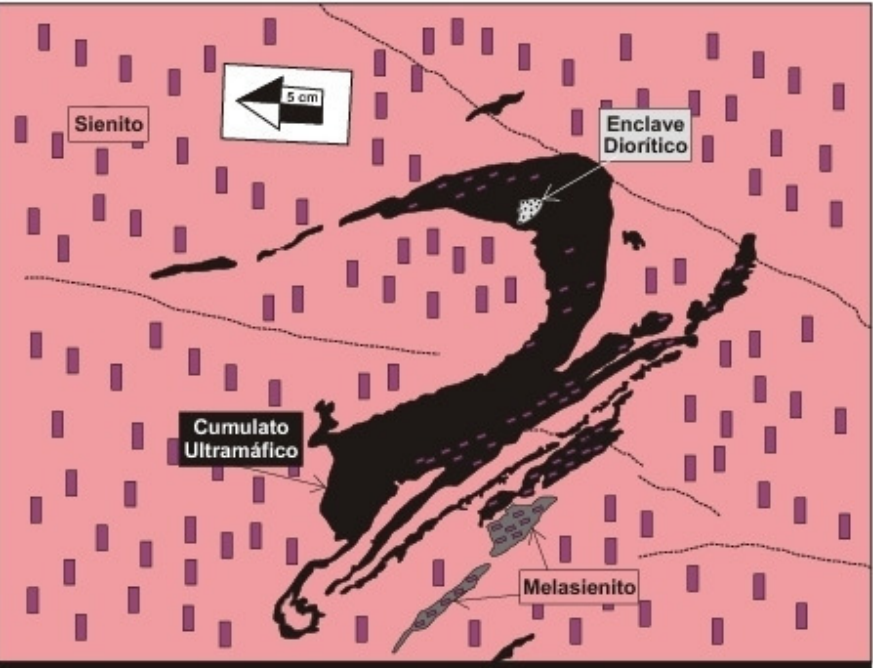

Croqui esquemático da foto 32 .

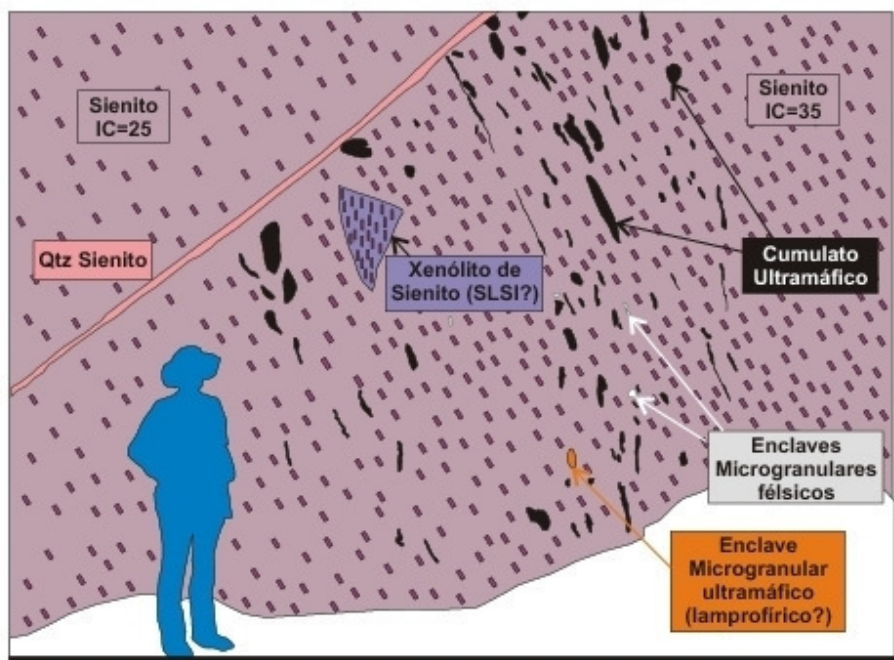

Croqui esquemático da foto 33 . 


\section{Sienito Supersaturado em Sílica Interno - SSI -}

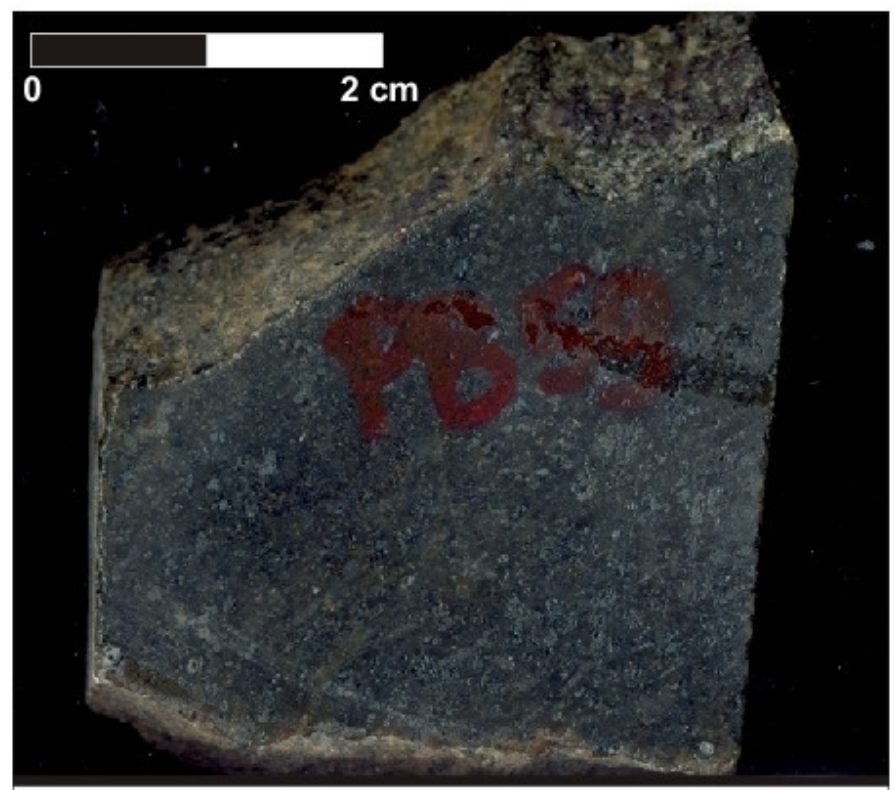

Foto 34 (PB-59): Sienito com quartzo textura equigranular fina, cor esverdeada.

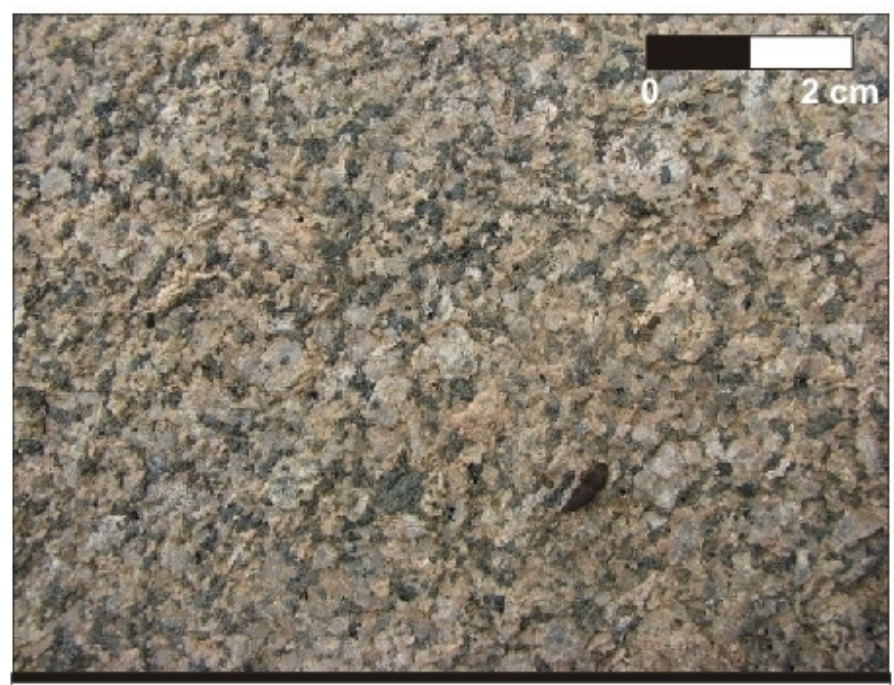

Foto 36(PB-58): Sienito supersaturado inequigranular médio.

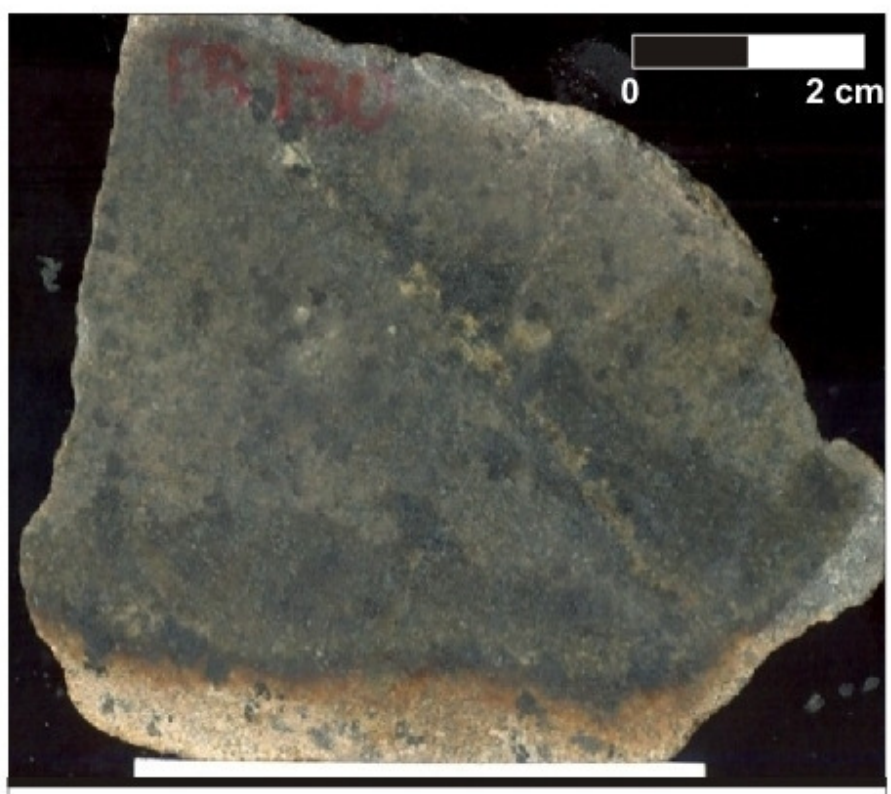

Foto 35 (PB-130): Sienito com quartzo, textura inequigranular fina com mega-cristais de piroxênio, cor esverdeada.

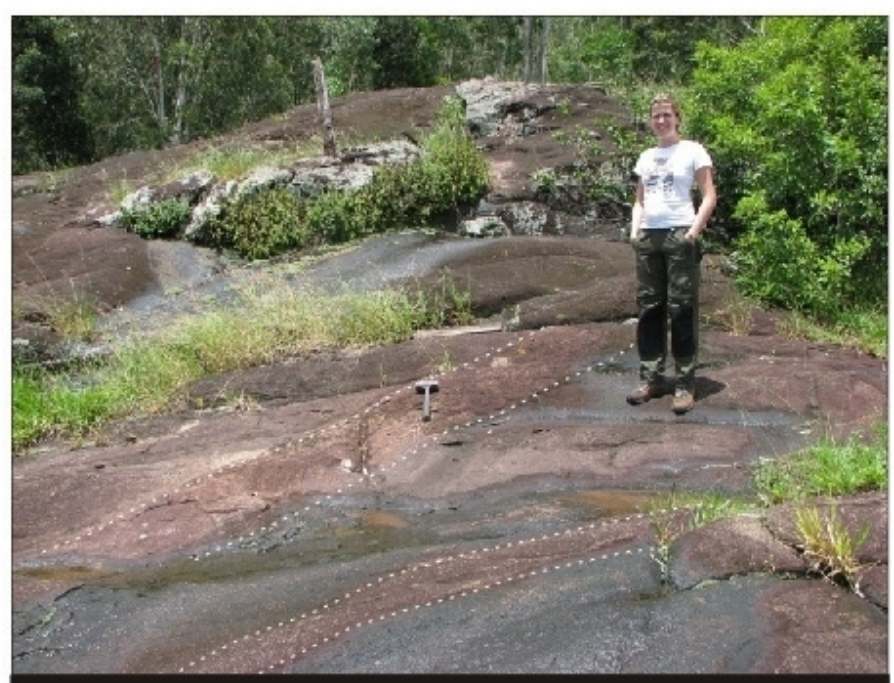

Foto 37 (PB-171): Diques graníticos tardios, intrusivos em sienito supersaturado. 


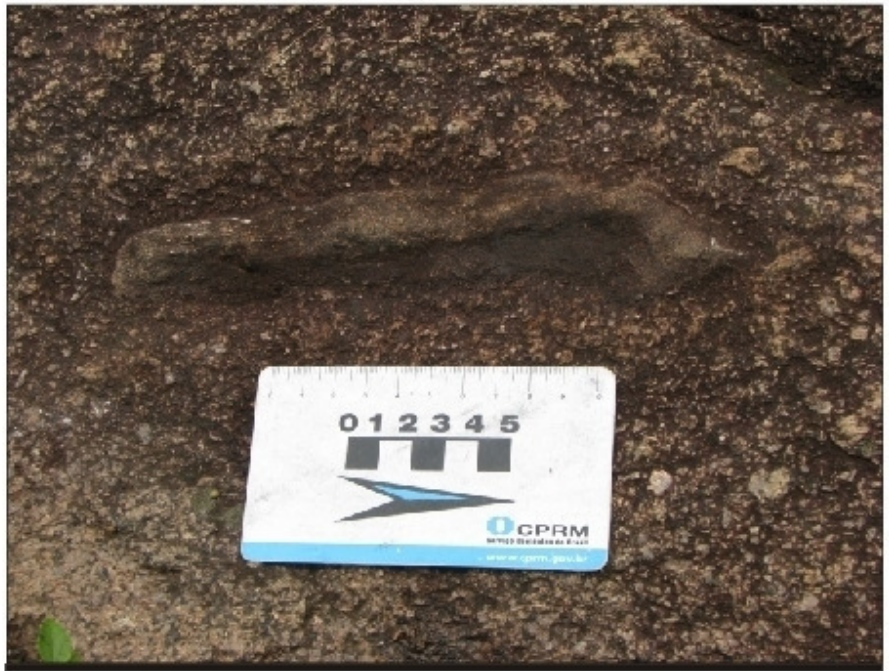

Foto 38(PB-58): Enclave microgranular incluso em sienito supersaturado. Destaque para a forma tabular e concentração de máficos nas bordas.

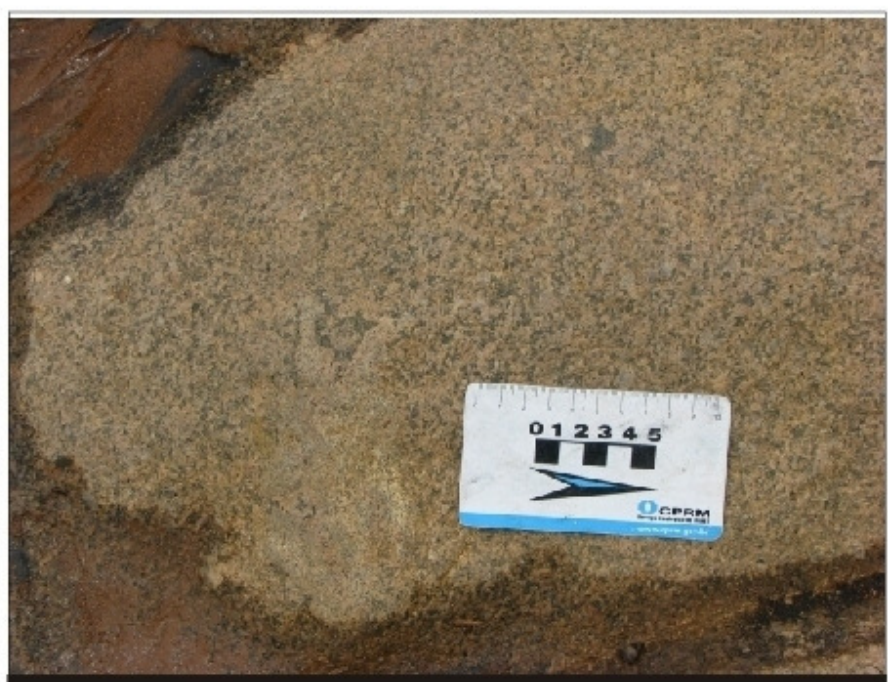

Foto 39 (PB-171): Enclave microgranular sienítico em sienito supersaturado. Destaque para limites irregulares do enclave mostrando baixo contrate de viscosidade com a rocha hospedeira. 


\section{Sienito Supersaturado em Sílica Externo - SSE -}

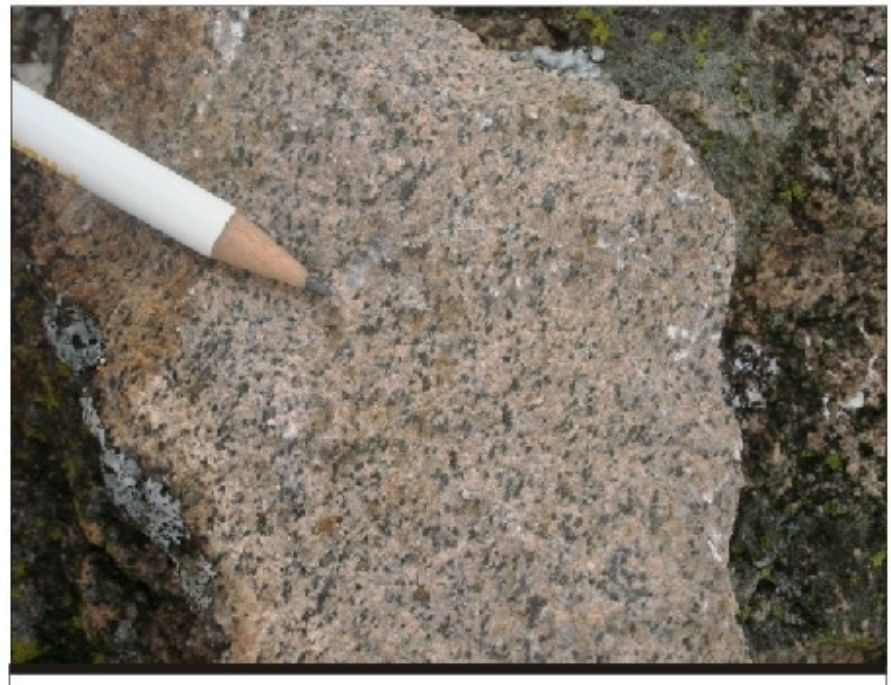

Foto 40 (PB-260): Sienito com quartzo, textura inequigranular fina e cor rósea, foliação magmática insipiente.

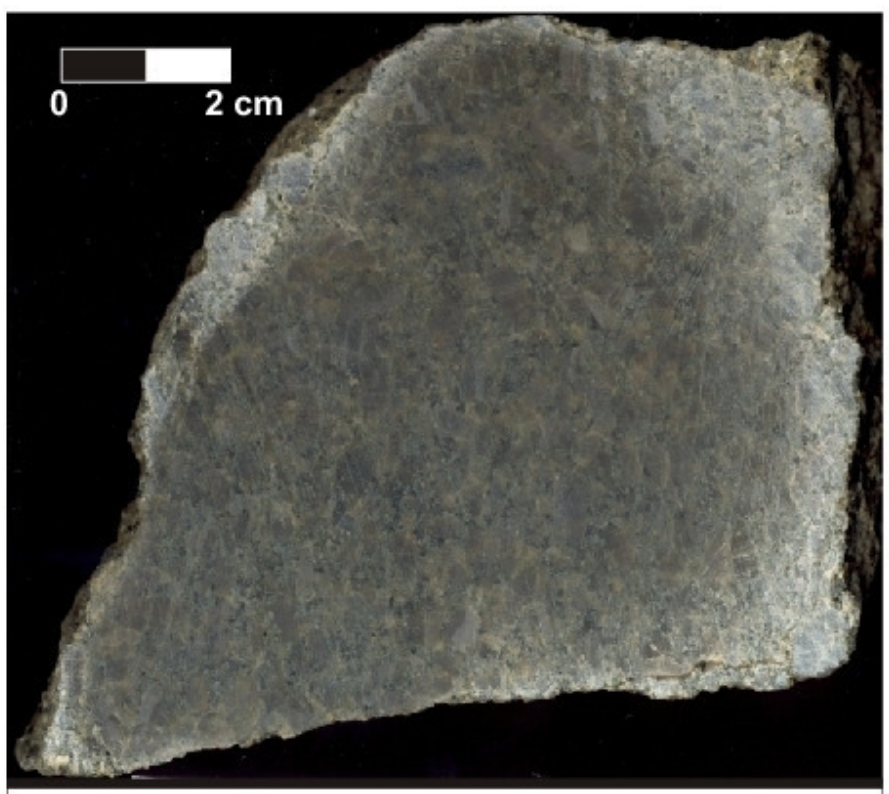

Foto 42(PB-265): Amostra de sienito com quartzo, textura inequigranular média e cor esverdeada.

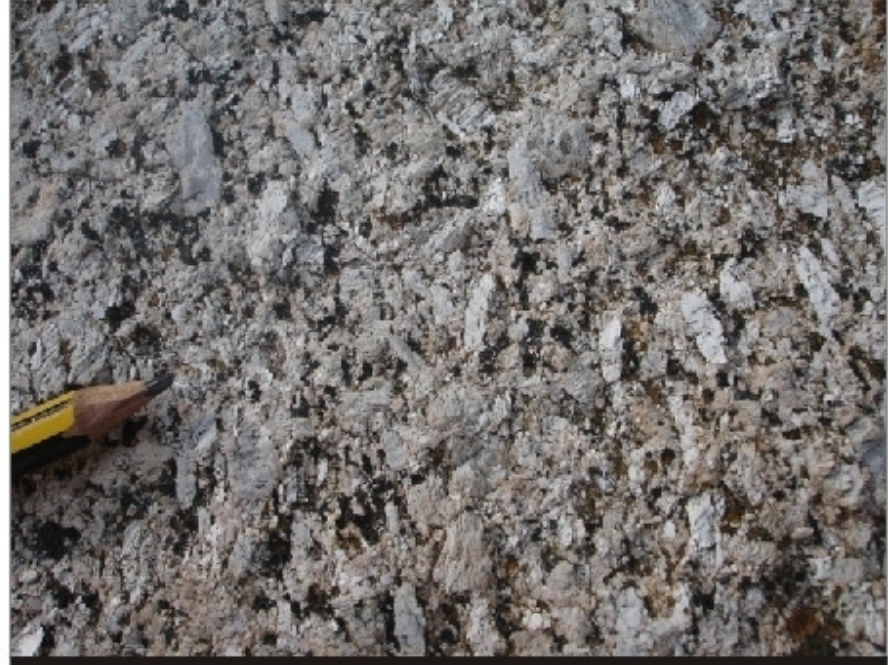

Foto 41 (PB-264): Sienito com quartzo, textura inequigranular média a grossa. Foliação Magmática marcada por felspato alcalino tabular $\mathrm{Ra}=2,5$.

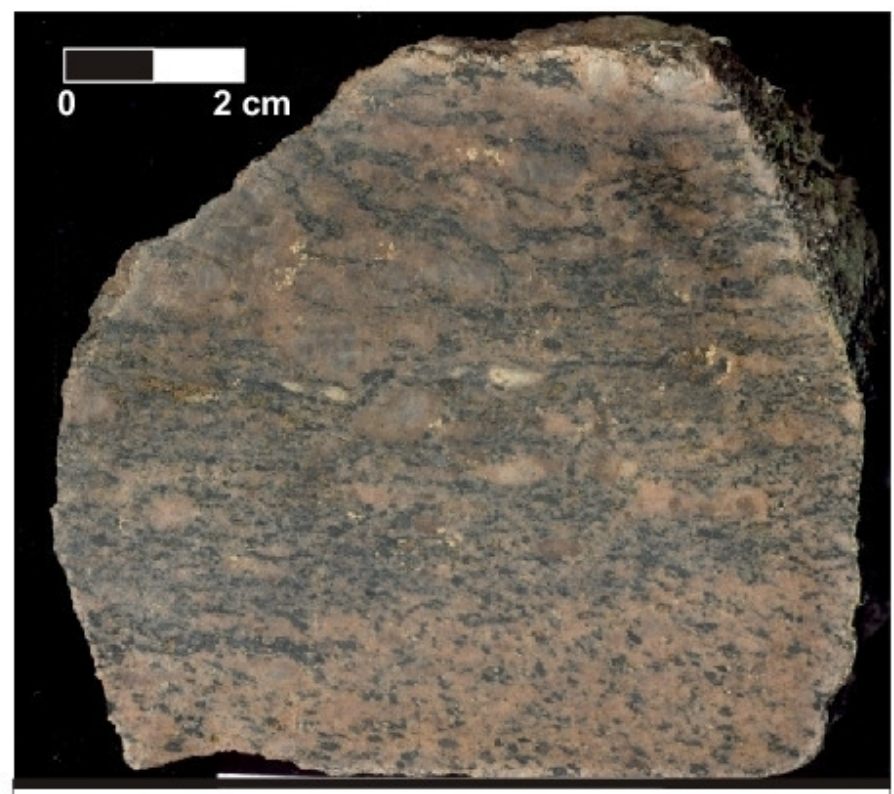

Foto 43(PB-264): Amostra de sienito milonitizado devido a presença de zona de cisalhamento pós-magmática. Destaque para forma sigmoidal do feldspato alcalino. 


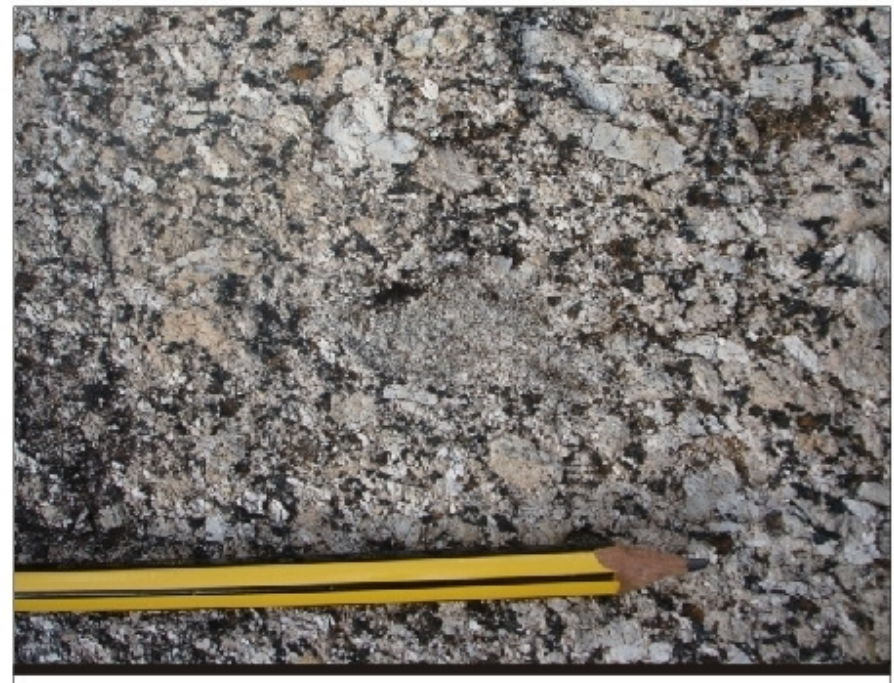

Foto 44(PB-264): Enclave microgranular diorítico em sienito com quartzo.

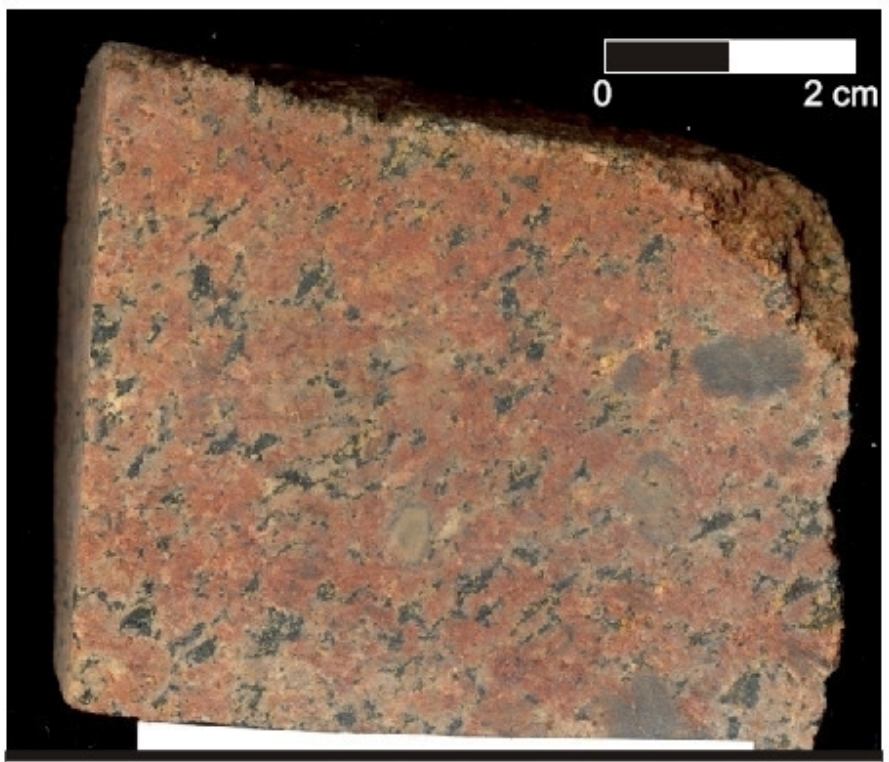

Foto 46 (PB-264): Alteração hidrotermal em sienito com quartzo. Destaque para cristais de feldspato marrom, provavelmente intactos.

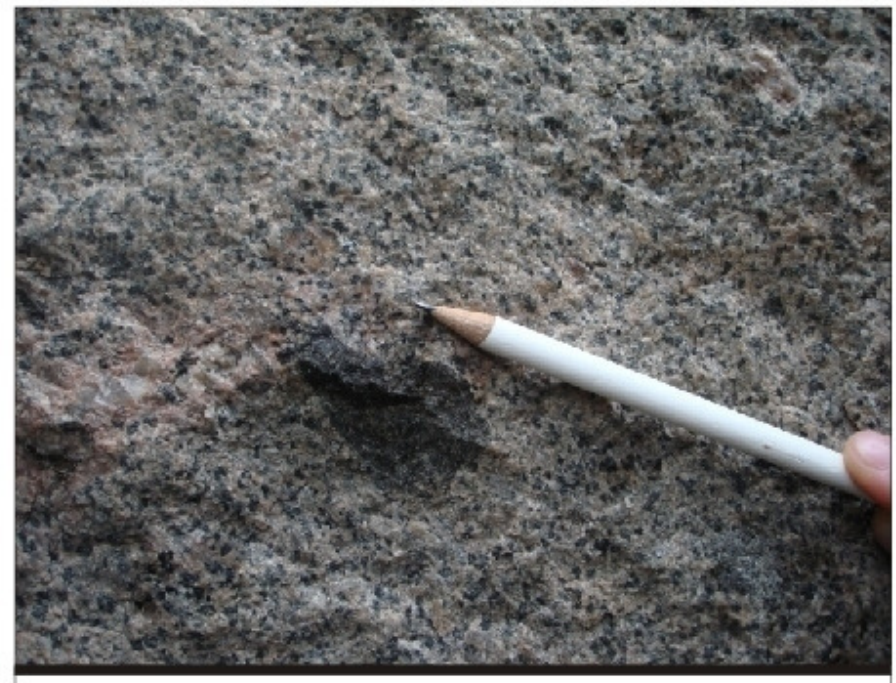

Foto 45(PB-259): Enclave cumulático máfico em sienito com quartzo.

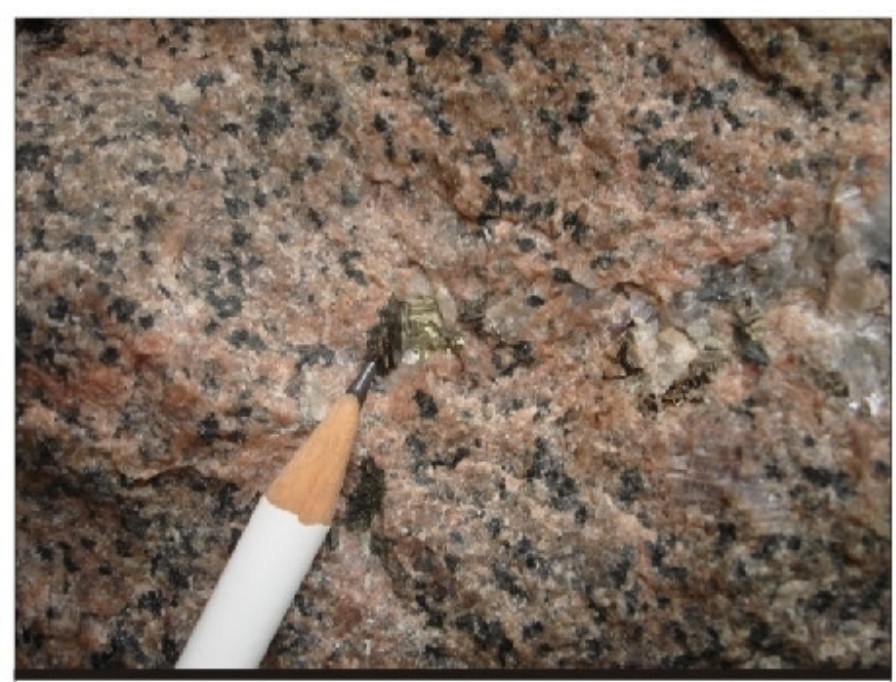

Foto 47(PB-259): Cristal de pirita e biotita em sienito com quartzo. 


\section{CAPITULO IV - PETROGRAFIA E QUIMICA MINERAL}

\section{IV.1. PETROGRAFIA}

Em todas as unidades sieníticas o feldspato alcalino compõe cerca de 65-75\% em volume da rocha, enquanto os minerais máficos são piroxênio (15-20\% modal), óxidos de $\mathrm{Fe}-\mathrm{Ti}(\sim 5 \%)$, biotita ( $<5 \%)$, que aparecem nos interstícios entre os cristais tabulares de feldspato alcalino. Em algumas amostras de sienito supersaturado, anfibólio pode ocorrer como mineral máfico principal.

Embora tenham características comuns, as quatro unidades sieníticas são petrograficamente distintas, por isso as particularidades de cada unidade do plúton serão descritas separadamente nos próximos itens.

\section{Sienito Laminado Saturado a Insaturado em Sílica}

Os sienitos desta unidade caracterizam-se pela ausência de quartzo e pela presença de clinopiroxênio cor verde intenso egirina-augita (Prancha II Fotomicrografia 1). Em uma amostra (PB-92A), foi encontrada nefelina intersticial anédrica, que ocorre em proporções inferiores a 1\% (Prancha II - Fotomicrografia 2).

A fase mineral mais abundante é o feldspato alcalino, que compõe entre 65$75 \%$ em volume da rocha. Seu hábito é tabular fortemente alongado (Prancha II Fotomicrografia 3) com uma razão axial em torno de 4; os cristais tendem a se orientar, definindo uma forte foliação magmática, característica macroscópica importante desta unidade.

O feldspato alcalino apresenta aspecto "sujo" devido à grande quantidade de finas inclusões aciculares de minerais máficos como hematita, diopsídio e apatita (Prancha II - Fotomicrografia 4). As inúmeras inclusões de hematita devem ser responsáveis pela cor marrom-arroxeada do feldspato, uma característica típica desta unidade. Os cristais podem ter zoneamentos composicionais discretos e raramente apresentam lamelas de exsolução. Geminação Carlsbad é comum.

Alguns cristais de albita podem ser encontrados nos interstícios entre cristais de feldspato alcalino. Em geral, suas proporções modais são inferiores a $1 \%$ e aparentemente estão relacionadas a lamelas de exsolução do feldspato alcalino (pertítico), que foram "drenadas" para os interstícios.

Nefelina foi primeiramente descrita em Pedra Branca por Winters (1981). Uma amostra do mesmo afloramento descrito pelo autor foi coletada e nela foram 
encontrados pequenos cristais de nefelina intersticial (Prancha II - Fotomicrografia 2).

A tendência alcalina dos sienitos desta unidade é caracterizada pela ocorrência de piroxênios ricos em $\mathrm{Na}$, com proporções mais altas de molécula acmita em sua composição. O clinopiroxênio de coloração verde escuro, descrito como egirina-augita (proporção modal 15-20\%), tem caráter euédrico a subédrico, indicando tratar-se de uma das fases precoces da cristalização magmática. Pode apresentar zoneamento composicional, definido pela presença de núcleos mais claros (Prancha II Fotomicrografias 1 e 5).

Anfibólio xenomórfico pode substituir o piroxênio nas fases mais tardias de cristalização da rocha, mas em geral a proporção de anfibólio nesta unidade é pequena, chegando no máximo a $5 \%$ modal. Ocorrem dois tipos: um deles é a hornblenda, com cor verde um pouco mais escura que aparece apenas como bordas ou lamelas no piroxênio (Prancha II - Fotomicrografia 6), já o outro é actinolita de coloração verde claro, que em geral ocorre como cristais independentes na matriz (Prancha II - Fotomicrografia 7).

A flogopita possui cor alaranjada, intenso pleocroísmo, e ocorre sempre em associação com clinopiroxênio e minerais opacos. A presença de flogopita é comum nesta unidade (5-7\% modal), e na grande maioria das amostras é a única fase hidratada presente.

A apatita é mineral acessório importante, e na maioria dos casos é euédrica a subédrica, com tamanho que varia desde pequenas agulhas inclusas em K-feldspato a cristais independentes bem distribuídos na rocha (Prancha II - Fotomicrografias 4, 5 e 6).

Outro mineral acessório importante é a titanita subédrica, que em geral ocorre nas fases tardias (Prancha II - Fotomicrografia 6). Pequenos cristais de zircão são esparsos nos sienitos desta unidade.

Os minerais opacos são magnetita e hematita e perfazem de $3-5 \%$ da moda da rocha (Prancha II - Fotomicrografia 8).

Nesta unidade a hematita exibe pequenas proporções de lamelas de ilmenita $\left(\mathrm{Hem}_{90-80} \mathrm{Ilm}_{10-20}\right)$. A hematita quase pura (Prancha II - Fotomicrografia 9) se associa com o clinopiroxênio verde, entretanto quando em paragênese com anfibólio a hematita se enriquece em ilmenita, e com isso as lamelas tornam-se mais abundantes (Prancha II - Fotomicrografia 8). A hematita pode aparecer com bordas finas de titanita.

Magnetita é abundante e pode ocorrer tanto em associação com clinopiroxênio (Prancha II - Fotomicrografia 8), sugerindo cristalização precoce, quanto em 
associação com anfibólio, que é fase tardia. Em alguns locais, a magnetita pode mostrar martitização (Prancha II - Fotomicrografia 10), o que deve estar associado à diminuição da susceptibilidade magnética em algumas amostras desta unidade.

Sulfetos como pirita e calcopirita são encontrados como acessórios em algumas amostras de sienitos desta unidade.

A Tabela 5 consiste em uma estimativa da ordem de cristalização dos sienitos desta unidade e foi baseada no estudo de diversas lâminas petrográficas.

\begin{tabular}{|c|c|c|c|}
\hline $\begin{array}{l}\text { Mineral/ Estágio } \\
\text { Magmático }\end{array}$ & Precoce & Principal & Tardio \\
\hline Feldspato Alcalino & 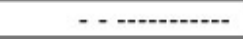 & - & 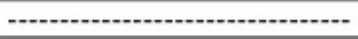 \\
\hline Egirina-Augita & - - - - & - & - \\
\hline Magnetita & 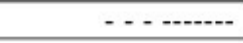 & & - \\
\hline Hematita & - . - - - & - & | \\
\hline Biotita & & - - - n & - \\
\hline Apatita & 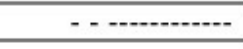 & - & pand \\
\hline Titanita & & - - - n-1-n & -1 \\
\hline
\end{tabular}

Tabela 5: Ordem de cristalização estimada para os sienitos da unidade SLSI.

\section{Cumulatos Máfico-Ultramáficos}

Os cumulatos máfico-ultramáficos mais comuns na unidade SLSI são apatita clinopiroxenitos de estrutura maciça e textura cumulática inequigranular grossa (Prancha II - Fotomicrografia 11).

O clinopiroxênio de cor verde intensa, opticamente identificado com egirinaaugita, é a principal fase cumulus, tem caráter subédrico, e pode apresentar zoneamentos composicionais evidenciados por núcleos ricos em inclusões de opacos e bordas homogêneas.

Já as fases intercumulus são representadas por apatita, biotita alaranjada, titanita e minerais opacos. Esses minerais ocorrem sempre nos interstícios entre cristais de clinopiroxênio.

Titanita pode ocorrer como cristais independentes, ou como bordas nos minerais opacos.

O mineral opaco mais comum é hematita com finas lamelas de ilmenita (Prancha II - Fotomicrografia 12), mas alguns cristais de magnetita também são encontrados.

Feldspato alcalino a única fase félsica encontrada nos cumulatos, é geralmente raro. 


\section{Sienitos Supersaturados}

Os sienitos supersaturados possuem similaridades petrográficas, como a presença de quartzo intersticial e clinopiroxênio diopsídio verde claro a incolor. Cada unidade apresenta particularidades texturais que serão destacadas nos itens a seguir.

\section{Sienito Laminado Supersaturado em Silica}

Assim como na SLSI, o feldspato alcalino tabular é a fase mineral principal destes sienitos e compõe cerca de $70-75 \%$ do volume da rocha. Em geral, os cristais são pertíticos e, em alguns casos, a proporção lamela/hospedeiro é cerca de $50 \%$ (mesopertitas). Exibem zoneamentos composicionais evidenciados por diferentes proporções de lamelas (Prancha II - Fotomicrografias 17 e 18). Cristais sem lamelas de exsolução podem exibir diferenças de birrefringência, com alternância de faixas mais clara e mais escura. Segundo Janasi (1993) os exemplos citados de feldspato alcalino ricos em lamelas enfatizam o potencial do processo de exsolução em cristais de feldspato alcalino formados sob altas temperaturas (e.g. com teor de $\mathrm{Ca}$ relativamente mais elevado) de gerar volumes de plagioclásio subsolidus com composições mais sódicas.

Inclusões finas de minerais opacos, piroxênio e apatita são muito comuns e muitas vezes podem formar trilhas marcando antigas faces dos cristais de feldspato alcalino (synneusis) (Prancha II - Fotomicrografias 18 e 19), e evidenciando zoneamentos composicionais.

Raros cristais de plagioclásio ocorrem como núcleos reliquiares corroídos no interior do feldspato alcalino em algumas amostras de sienito desta unidade, sempre em proporções de até $3 \%$. Alguns deles têm alterações sericíticas em seus núcleos (Prancha II - Fotomicrografias 19 e 20); outros cristais, mais preservados, apresentam geminação polissintética e teor de anortita entre 25 e 30.

Plagioclásio sódico formando lamelas em feldspato alcalino relacionadas a processos secundários de exsolução é comum, além disso pode aparecer como fase tardia da cristalização juntamente com quartzo, formando mimerquitas, e até mesmo delicadas bordas em feldspato alcalino (com mesma orientação óptica) ou cristais independentes (Prancha II - Fotomicrografia 22).

Quartzo constitui de 2 a $7 \%$ da moda dos sienitos desta unidade, e em todos os casos é intersticial e tardio na cristalização. Embora raras amostras apresentem pequenos cristais de quartzo que podem ser identificados a olho nu, na maioria das amostras o quartzo só é observado em lâminas petrográficas. 
O clinopiroxênio presente nas rochas desta unidade tem cor verde claro a incolor e foi descrito como diopsídio (Prancha II - Fotomicrografias 13 e 15). Assim como na unidade SLSI, o clinopiroxênio é o mineral máfico principal na maioria das amostras destes sienitos (10-15\% modal). Anfibólio verde-escuro (hornblenda) pode substituir total ou parcialmente o diopsídio (Prancha II - Fotomicrografias 13, 14, 15 e 16), alcançando em algumas amostras até $12 \%$ da moda da rocha. Pequenos traços de anfibólio azulado, possivelmente riebeckita, também são encontradas como delicadas bordas em anfibólio verde-escuro (Prancha II - Fotomicrografia 16).

A biotita marrom ocorre em proporções de 2 a $5 \%$ e ocorre associada ao clinopiroxênio e minerais opacos.

Os óxidos de $\mathrm{Fe}-\mathrm{Ti}$ são muito abundantes, e nesta unidade predominam membros intermediários da série ilmenita-hematita $\left(\mathrm{Hem}_{50-40} \| \mathrm{m}_{50-60}\right)$ formados por lamelas ou bandas alternadas com cor cinza acastanhado (ilmenita) ou branco acinzentado (hematita) (Prancha II - Fotomicrografias 23, 24 e 28). Dentro das bandas ocorrem lamelas ainda mais finas do outro membro-final.

Magnetita é menos abundante, e pode aparecer como cristais intersticiais tardios associados ao desenvolvimento do anfibólio, ou mesmo como cristais com bordas irregulares envolvidos por titanita (Prancha II - Fotomicrografia 25, 26, 27 e 28). Assim como na unidade SLSI, a magnetita pode registrar processos de martitização.

Apatita é um mineral acessório (2-3\% modal) comum que ocorre desde pequenas agulhas inclusas em feldspato alcalino a cristais grandes independentes bem distribuídos na rocha.

Allanita é rara, porém foi encontrada em algumas amostras como bordas irregulares, cor alaranjada, em cristais de apatita (Prancha II - Fotomicrografia 21).

Outro mineral acessório importante é titanita (Prancha II - Fotomicrografias 13, 25 e 27), que em geral ocorre como cristais independentes anédricos, ou como bordas em minerais opacos.

Alguns sulfetos como calcopirita (Prancha II - Fotomicrografia 23) e pirita podem ocorrer como pequenos cristais desenvolvidos em estágios tardios da cristalização.

Cristais intersticiais de carbonato também são encontrados em algumas amostras de sienitos desta unidade (Prancha II - Fotomicrografia 22). Em geral associam-se a fases tardias como albita e anfibólio.

A Tabela 6 apresenta uma estimativa da ordem de cristalização dos sienitos desta unidade e foi baseada no estudo de diversas lâminas petrográficas. 


\begin{tabular}{|c|r|r|r|}
\hline $\begin{array}{c}\text { Mineral/ Estágio } \\
\text { Magmático }\end{array}$ & Precoce & Principal \\
\hline Feldspato Alcalino & $-\ldots-1$ & \\
\hline Quartzo & & & \\
\hline Diopsídio & & & \\
\hline Hornblenda & & & \\
\hline Biotita & & & \\
\hline Apatita & & & \\
\hline Titanita & & & \\
\hline Albita & & & \\
\hline Allanita & & & \\
\hline Carbonato & & & \\
\hline
\end{tabular}

Tabela 6: Ordem de cristalização estimada para os sienitos da unidade SLS.

\section{Cumulatos Máfico-Ultramáficos}

Os cumulatos máfico-ultramáficos podem ser classificados como apatita clinopiroxenitos de estrutura maciça e textura cumulática inequigranular grossa.

São constituídos por diopsído, que pode ou não ser parcialmente substituído por hornblenda, apatita, biotita marrom, feldspato alcalino e minerais opacos (Prancha II - Fotomicrografia 29). O diopsídio e apatita compõem as fases cumulus, enquanto os outros minerais perfazem o intercumulus.

Os minerais opacos encontrados nos cumulatos são ilmeno-hematita, com proporções variáveis entre as fases, e magnetita (Prancha II - Fotomicrografia 30).

\section{Sienito Supersaturado em Sílica Interno}

Assim como nas outras unidades supersaturados estes sienitos possuem diopsídio, subédrico de cor marrom esverdeado a incolor (Prancha II Fotomicrografias 31 e 32), como mineral máfico principal ( 8-10\% modal). Uma característica singular desta unidade, no entanto, é a presença de ortopiroxênio (enstatita) em algumas amostras, que ocorre como pequenos cristais granulares de cor marrom (Prancha II - Fotomicrografias 31 e 33) perfazendo cerca de $5-7 \%$ da moda de algumas amostras. A granulação fina de muitas destas rochas revela que seu resfriamento deve ter sido mais rápido, o que provavelmente permitiu a preservação dos cristais de ortopiroxênio. $O$ ortopiroxênio pode apresentar bordas alteradas para massa de filossilicatos, sugerindo desequlíbrio.

O feldspato alcalino é a fase félsica mais abundante, compondo cerca de 55$60 \%$ do volume da rocha. Os cristais apresentam forma menos alongada, e em geral granular e pertítico. Albita ocorre com freqüência como lamelas de exsolução no 
feldspato alcalino ou como cristais independentes ( $10 \%$ modal) que podem ou não aparecer intercrescidos com quartzo, formando mimerquitas (Prancha II Fotomicrografia 33).

Plagioclásio $\left(\mathrm{An}_{15-20}\right)$ é observado como pequenos cristais na matriz.

Quartzo é um mineral comum, e compõe entre 3-6\% do volume da rocha. Os cristais são intersticiais, e também pode ocorrer em simplectitos com biotita (Prancha II - Fotomicrografia 33).

Hornblenda verde-escura (3-5\% modal) substitui o diopsídio nas bordas e raramente forma cristais independentes (Prancha II - Fotomicrografia 31). Outra fase máfica comum é a biotita marrom ( $<5 \%$ modal), que muitas vezes ocorre intercrescida com quartzo.

O mineral opaco mais comum é ilmeno-hematita, e em geral ocorre como cristais anédricos bem distribuídos por toda a rocha (5-7\% em proporções modais).

Apatita ( $2 \%$ modal) aparece como pequenos cristais euédricos a subédricos amplamente disseminados, muitas vezes incluso no feldspato alcalino ou até mesmo associados ao piroxênio (Prancha II - Fotomicrografia 34).

Uma das amostras coletadas (PB-57) apresenta aspecto muito alterado e oxidado, além disso, são observadas texturas de alteração, como piroxênio com núcleos verde-claro (diopsídio reliquiar) e bordas de cor verde intenso (egirina) (Prancha II - Fotomicrografia 35). Em alguns locais observa-se a formação de zeólitas, possivelmente alterando cristais pequenos de nefelina. Ainda assim, feições de alteração na maioria dos casos restringem-se a fraturas milimétricas (Prancha II Fotomicrografia 36). As características petrográficas destas feições sugerem que estas alterações podem estar associadas a fluidos alcalinos provenientes da intrusão de Poços de Caldas.

A Tabela 7 apresenta uma estimativa da ordem de cristalização dos sienitos desta unidade e foi baseada no estudo de diversas lâminas petrográficas. 


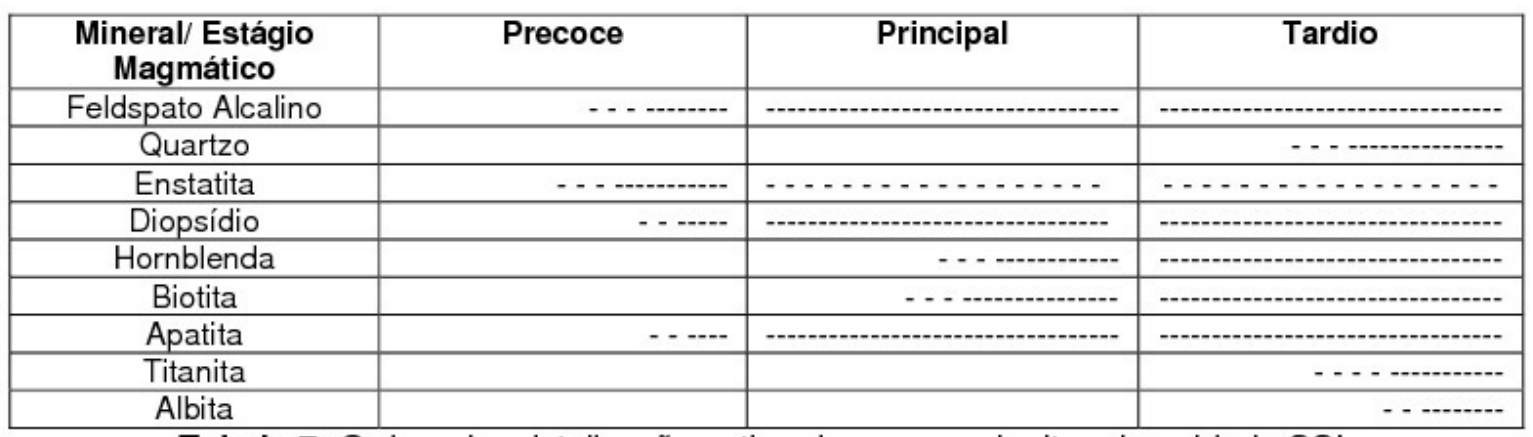

Tabela 7: Ordem de cristalização estimada para os sienitos da unidade SSI.

\section{Sienito Supersaturado em Sílica Externo}

O feldspato alcalino (55-65\% modal) é tabular euédrico, pertítico e muitas vezes pode apresentar zoneamentos composicionais oscilatórios (Prancha II Fotomicrografias 37 e 40). Albita ( 10\% modal) é outro mineral félsico importante e ocorre principalmente como lamelas no feldspato alcalino ou formando mimerquitas quando intercrescida com quartzo, mas também como pequenos cristais independentes na matriz destes sienitos.

Quartzo é pouco abundante ( $2 \%)$ e ocorre freqüentemente como pequenos cristais intersticiais na matriz.

O clinopiroxênio ( $8-12 \%$ modal), identificado opticamente como diopsídio, tem cor esverdeada a incolor (Prancha II - Fotomicrografia 37), e é o mineral máfico principal. Em alguns casos pode apresentar zoneamentos composicionais oscilatórios evidenciados por mudanças de cor e birrefringência (Prancha II - Fotomicrografia 39).

Hornblenda é comum e compõe cerca de $5 \%$ da moda da rocha na maioria das amostras; em alguns casos pode ser o mineral máfico principal, atingindo proporções de $10 \%$. Ocorre como cristais anédricos de cor verde-escuro, que substituem parcial ou totalmente o piroxênio (Prancha II - Fotomicrografia 38).

Outra fase importante é a biotita marrom-escura que, apesar de pouco abundante (<5\% modal) sempre aparece em associação com outros minerais máficos (e.g. piroxênio, anfibólio e apatita) (Prancha II - Fotomicrografia 38).

Os minerais acessórios (Prancha II - Fotomicrografia 38) são apatita idiomórfica ( $2 \%$ modal) com cristais de tamanho variado bem distribuída na rocha, e titanita ( $1 \%$ modal) que ocorre como delicadas bordas em minerais opacos e raramente forma cristais independentes. Zircão euédrico pode ocorrer em algumas amostras. 
Magnetita e hematita rica em lamelas de ilmenita (Prancha II Fotomicrografia 41) são os minerais opacos comuns. A magnetita não é comum, e quando presente associa-se ao anfibólio, é anédrica e pode ou não ter bordas de titanita. Já a ilmeno-hematita pode alternar-se para hemo-ilmenita, localmente ocorrem cristais de ilmenita quase pura associados ao anfibólio.

A Tabela 8 apresenta uma estimativa da ordem de cristalização dos sienitos desta unidade e foi baseada no estudo de diversas lâminas petrográficas.

\begin{tabular}{|c|c|c|c|}
\hline $\begin{array}{c}\text { Mineral/ Estágio } \\
\text { Magmático }\end{array}$ & Precoce & Principal & Tardio \\
\hline Feldspato Alcalino & - - - - - & - & - \\
\hline Diopsídio & - . - n & - & 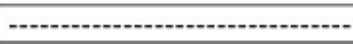 \\
\hline Hornblenda & & - - - - - & - \\
\hline Biotita & & - . - - - & - \\
\hline Titanita & & & - - - \\
\hline Albita & & & - - - - \\
\hline Magnetita & & & - - - - \\
\hline Ilmeno-hematita & & - - - - n- & - \\
\hline
\end{tabular}

Tabela 8: Ordem de cristalização dos sienitos da unidade SSE.

\section{Enclaves}

Este item será desenvolvido com base na descrição dos diversos tipos de enclaves encontrados nas unidades supersaturadas (SLS, SSI e SSE). Entre as diferentes variedades de enclaves os mais comuns são os microgranulares composição diorítica e sienítica, juntamente com os autólitos cumuláticos máficoultramáficos

\section{Micro-sienitos}

Enclaves microgranuleres sieníticos em geral têm textura equigranular muito fina a fina (Prancha II - Fotomicrografia 43), e raramente inequigranular porfirítica (Prancha II - Fotomicrografia 42) com fenocristais de clinopiroxênio incolor a verdeclaro (diopsídio) que compõem cerca de $7-10 \%$ do seu volume. O feldspato alcalino, assim com nas variedades grossas, é a principal fase mineral, compondo aproximadamente $75-80 \%$ destes enclaves. 
O quartzo raramente é observado, e quando presente a proporção modal nunca é maior que $1 \%$.

Hornblenda verde escura em alguns casos pode ocorrer como bordas em piroxênio ou formando cristais independentes na matriz, e não atinge proporções maiores que $3 \%$.

Biotita marrom $(<5 \%)$ é um mineral abundante na matriz, e ocorre entre os cristais de feldspato alcalino (Prancha II - Fotomicrograifas 42 e 43).

Os minerais acessórios principais são apatita (1-3\%), titanita (1\%) e zircão $(<1 \%)$, que ocorrem como pequenos cristais idiomórficos, que podem estar inclusos em feldspato alcalino. A titanita não está presente em todas as amostras, e pode ocorrer com finas bordas em minerais opacos ou como pequenos cristais independentes na matriz. Os minerais opacos (até 5\%) são hematita rica em lamelas de ilmenita e, em menor proporção, magnetita.

\section{Monzonitos}

A única amostra de composição monzonítica encontrada apresenta textura equigranular fina (Prancha II - Fotomicrografia 44) e é constituída por feldspato alcalino pertítico (40-45\% modal), plagioclásio (35\%) $\mathrm{An}_{20-25}$, que pode ser zonado e com núcleos parcialmente alterados. Em geral o plagioclásio apresenta mesmo tamanho que o feldspato alcalino, mas localmente observam-se cristais maiores ( 0,5 $\mathrm{cm}$ ) com núcleos totalmente alterados para sericita (Prancha II - Fotomicrografia 45), similar ao observado no SLS.

O clinopiroxênio ( $5 \%$ modal) é subidiomórfico, tem cor verde claro e ocorre como pequenos cristais independentes ou como núcleos preservados com bordas de hornblenda verde escura. Hornblenda xenomórfica é o mineral máfico principal e compõe cerca de $10-12 \%$ destes enclaves.

Biotita marrom é pouco abundante $(\sim 3 \%)$, e é mais abundante em porções onde o plagioclásio tem núcleos alterados, sugerindo que nestes locais há maior percolação de fluidos.

Os minerais acessórios são apatita acicular ( 3\%), titanita anédrica $(\sim 1 \%)$ e minerais opacos (magnetita ( 4\%) e ilmenita com lamelas de hematita ( 5\%). 


\section{Dioritos}

Em geral, os dioritos apresentam textura granoblástica e granulação fina, onde os contatos entre os minerais possuem contatos de $120^{\circ}$ formando mosaicos (Prancha II - Fotomicrografias 46, 47 e 48). As bordas podem apresentar granulação mais fina (Prancha II - Fotomicrografia 47) devido ao resfriamento rápido, enquanto os núcleos muitas vezes são alterados (Prancha II - Fotomicrografia 48).

O mineral principal é o plagioclásio $\mathrm{An}_{25-30}$ ( $80-85 \%$ modal), que pode apresentar geminação polissintética e zoneamento composicional. Característica marcante destes enclaves é a alteração sericítica que ocorre nos núcleos dos cristais de plagioclásio (Prancha II - Fotomicrografias 46, 48, 50 e 53).

Feldspato alcalino não aparece na maioria dos casos, mas quando presente pode compor cerca de $5 \%$ da moda. Quartzo é raro (até $2 \%$ ) e ocorre como cristais pouco desenvolvidos.

Biotita marrom é o mineral máfico principal na maioria das amostras (3-10\%), e em alguns casos é o único máfico presente (Prancha II - Fotomicrografias 46, 47, 48 e 49). Em algumas amostras pode se desenvolver nas bordas dos enclaves, demonstrando reação com a rocha hospedeira.

Apenas dois dos enclaves dioríticos amostrados (PB-247B e PB247D) apresentam IC 35-40; nesses casos, piroxênio e anfibólio são os máficos principais.

$\mathrm{Na}$ amostra PB-247B (Prancha II - Fotomicrografias 52 e 53), observa-se um bandamento modal evidenciado pela intercalação de níveis ora com clinopiroxênio e ora com hornblenda. Na porção rica em clinopiroxênio (15\% modal) também ocorre plagioclásio (55-60\%), magnetita, bornita e carbonato como acessório. $O$ clinopiroxênio de cor verde claro é subédrico e contém inúmeras inclusões de biotita fina em seu núcleo; a hornblenda verde escura aparece consumindo o clinopiroxênio pelas bordas e formando intercrescimentos com plagioclásio (Prancha II Fotomicrografia 52). Na porção rica em hornblenda, o clinopiroxênio é raro, porém pode aparecer como núcleos preservados no anfibólio. Nestes níveis a hornblenda ocorre formando simplectitos com plagioclásio e opacos; também ocorre biotita marrom, carbonato, magnetita, sulfetos e zircão (Prancha II - Fotomicrografia 54 e 55). Os minerais opacos são a magnetita (2\%) e os sulfetos como bornita, calcopirita e calcosina (Prancha II - Fotomicrografia 55). Os sulfetos em geral são os mais abundantes, bornita (cerca de $4 \%$ modal) é o mais comum. Assim como nas outras amostras de diorito, onde a biotita é o único mineral máfico, as porções ricas em plagioclásio apresentam intensa alteração sericítica (Prancha II - Fotomicrografia 53), sugerindo algum vinculo entre os dois tipos (de menor e maior índice de cor). 
$\mathrm{Na}$ amostra PB-247D hornblenda verde escura é o mineral máfico principal (15\% modal), enquanto o plagioclásio $A n_{30}(65 \%)$ é o mineral mais abundante. $O$ plagioclásio muitas vezes apresenta geminação polissintética e zoneamentos composicionais; também neste caso, os núcleos de alguns cristais estão fortemente sericitizados (Prancha II - Fotomicrografia 51).

Clinopiroxênio verde claro é pouco abundante (3\% modal) e raramente ocorre como cristais independentes, entretanto pode estar preservado nos núcleos da hornblenda verde escura (Prancha II - Fotomicrografia 50).

Os minerais acessórios são ilmenita com lamelas de hematita ( 25-40\%) e titanita, que ocorre apenas como finas bordas em opacos.

\section{Cumulatos Máfico-Ultramáficos}

Enclaves máfico-ultramáficos com textura cumulática são comuns nas unidades laminadas, e as características gerais destes cumulatos foram apresentadas anteriormente.

A assinatura geoquímica peralcalina e o Mg\# (ver Capítulo IV, item V.3. Geoquímica de Rocha Total) de um dos enclaves amostrados (PB-185C) sugerem que esta pode tratar-se de um enclave ultramáfico (representante de um magma parental), porém a assembléia mineral similar a dos sienitos (apenas em proporções distintas) e a textura cumulática inequigranular grossa sugerem que pode ser apenas um enclave cumulático.

Esta rocha peculiar é constituída por clinopiroxênio, biotita, apatita, titanita e magnetita, além disso, ocorrem sulfetos, carbonato e anfibólio azul (possivelmente riebeckita).

Na textura (Prancha II - Fotomicrografia 56) o cumulus é formado por clinopiroxênio verde claro (em proporções modais de $~ 50 \%$ ), apatita (10\% modal) e titanita ( $5 \%$ modal). Já o intercumulus é constituído por biotita alaranjada ( $25 \%$ modal) e minerais opacos.

Entre os minerais opacos estão magnetita (cerca de 3\%) e sulfetos como bornita e calcopirita (mais abundantes, $7 \%$ modal). A bornita ocorre como cristais independentes homogêneos, ainda assim pode ser substituída nas bordas por calcosina e galena (Prancha II - Fotomicrografia 59).

Anfibólio azul e carbonato são tardios (Prancha II - Fotomicrografias 57 e 58) e sempre ocorrem em interstícios próximos a cristais de clinopiroxênio, sugerindo que o aparecimento destes minerais pode estar associado à alteração do piroxênio. 
Feldspato alcalino pertítico pode ser encontrado no intercumulus, porém não atinge $1 \%$ em proporção modal. 


\section{- PRANCHA II - \\ PETROGRAFIA}




\section{Sienito Laminado Saturado a Insaturado - SLSI -}

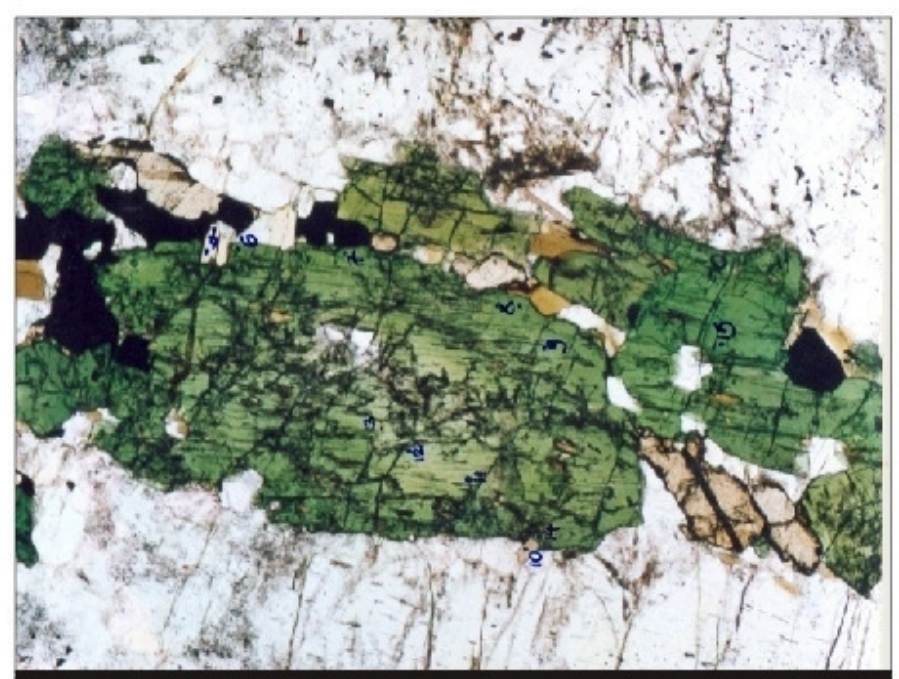

Fotomicrografia 1: Egirina-augita zonada, cor verde intenso, associada a titanita, biotita e magnetita. Lado maior da foto $3,25 \mathrm{~mm}$.

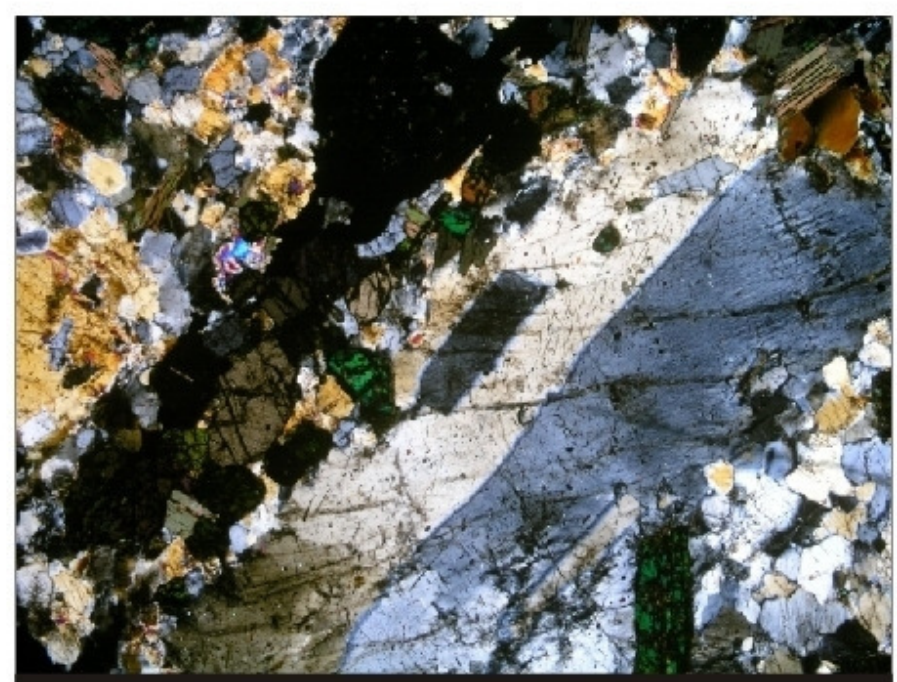

Fotomicrografia 3: Feldspato alcalino tabular zonado em sienito. Lado maior da foto $8,32 \mathrm{~mm}$.

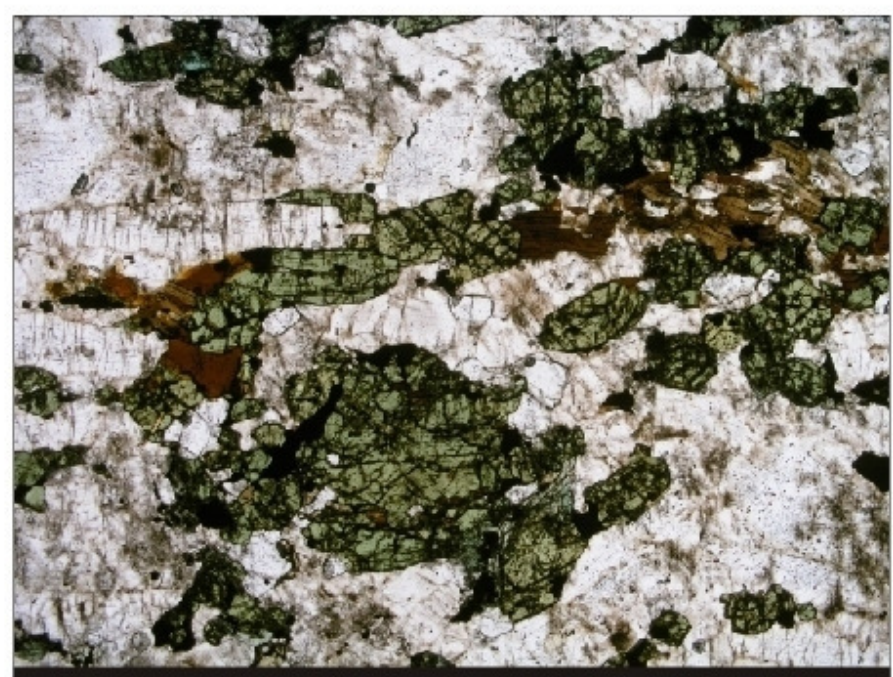

Fotomicrografia 5: Aspecto geral dos sienitos saturados, com piroxênio como mineral máfico principal, além biotita, apatita e magnetita. Lado maior da foto $10.4 \mathrm{~mm}$.

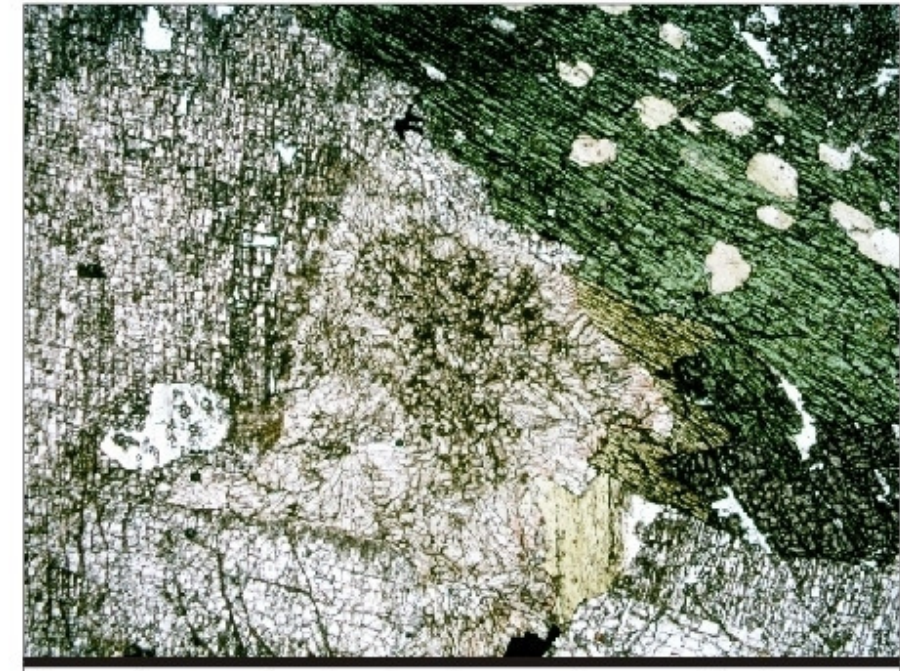

Fotomicrografia 2: Egerina-augita verde intenso, apatita incolor e nefelina, intersticial em sienito. Lado maior da foto $1,30 \mathrm{~mm}$.

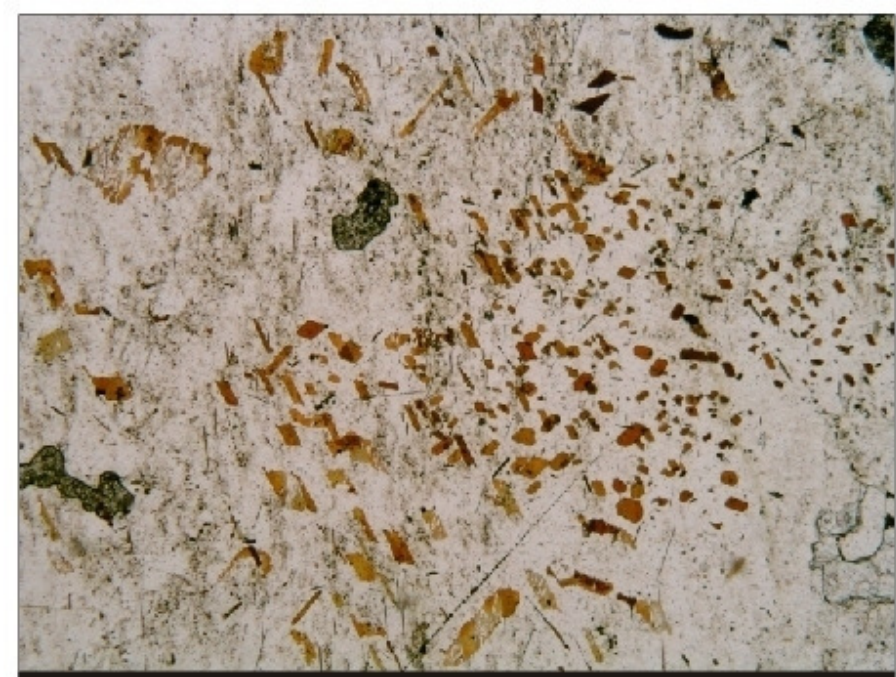

Fotomicrografia 4: Feldspato alcalino com finas inclusões de hematita. Lado maior da foto $0,26 \mathrm{~mm}$.

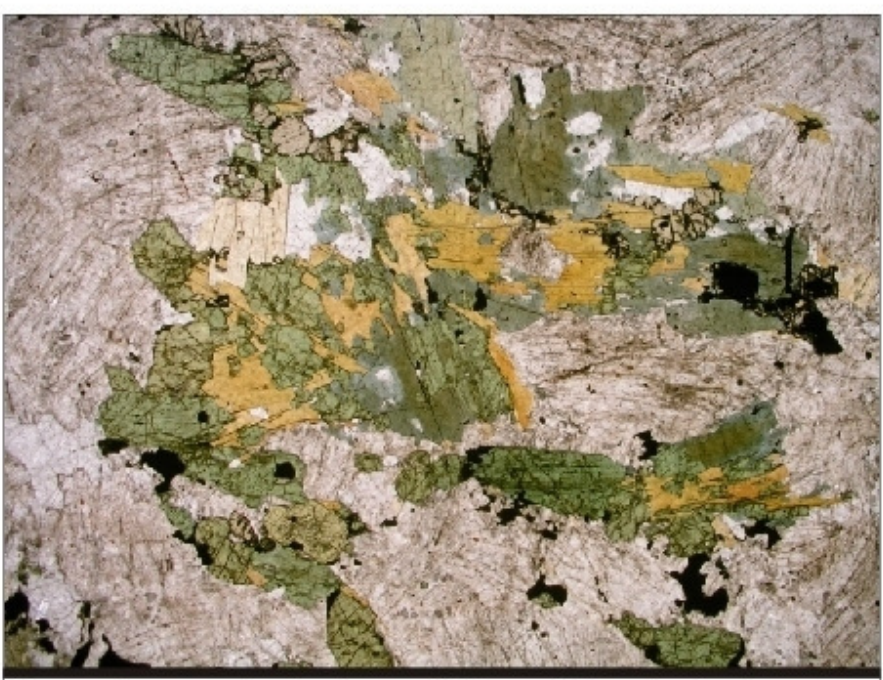

Fotomicrografia 6: Assembléia máfica de sienito com egirina-augita, hornblenda, biotita, apatita titanita, além de opacos hematita e magnetita. Lado maior da foto $10.4 \mathrm{~mm}$. 


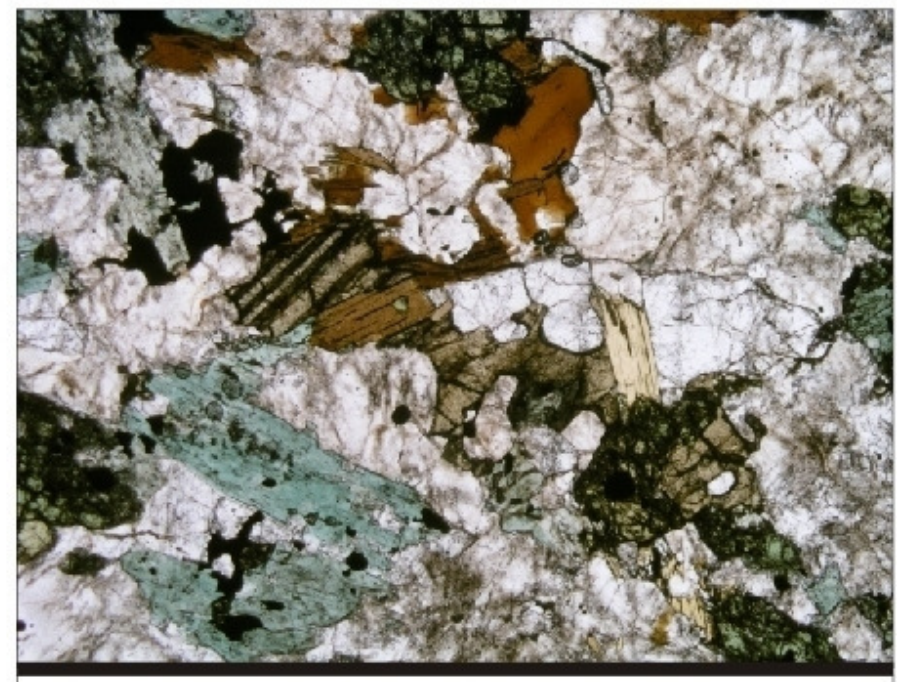

Fotomicrografia 7: Actinolita e titanita como minerais tardios em sienito saturado. Lado maior da foto $3,25 \mathrm{~mm}$.

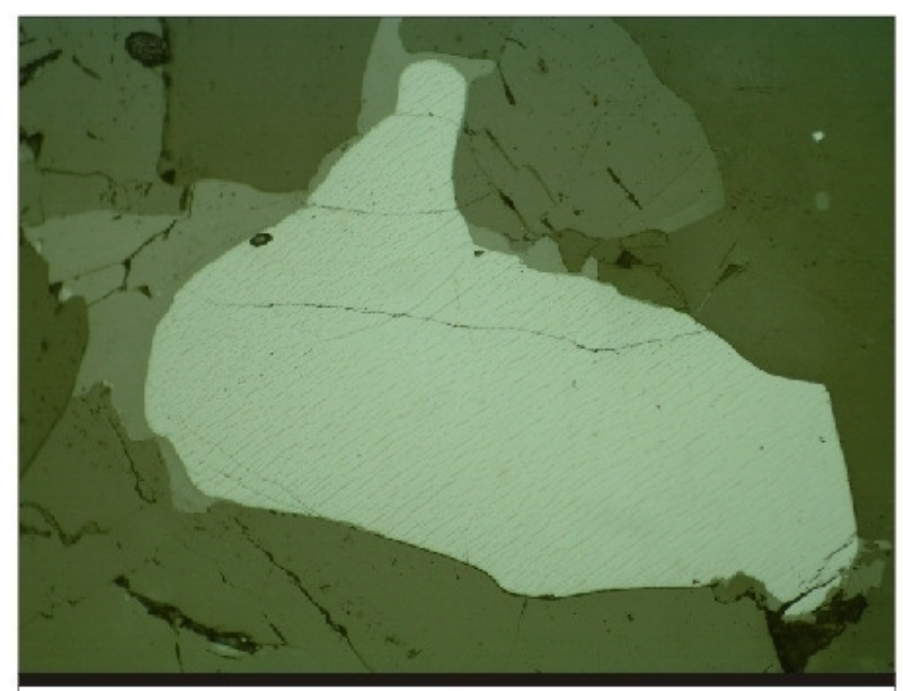

Fotomicrografia 9: Cristal de hematita quase pura, pobre em lamelas de ilmenita, vista à luz refletida. Lado maior da foto $0,260 \mathrm{~mm}$.

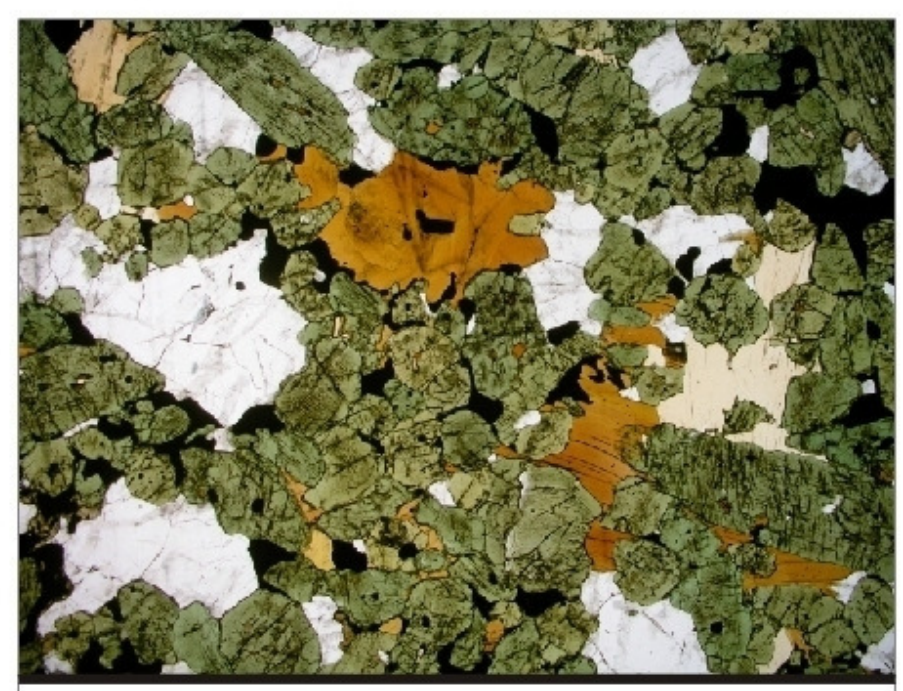

Fotomicrografia 11: Cumulato ultramáfico típico da SLSI, com egirina-augita, apatita, biotita, ilmenohematita e titanita. Lado maior da foto $8.32 \mathrm{~mm}$.

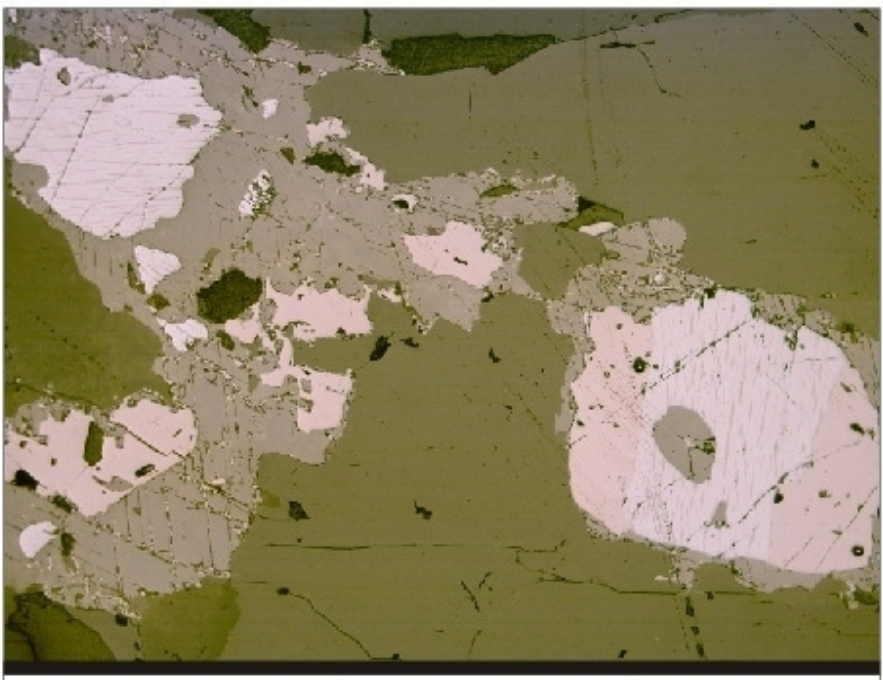

Fotomicrografia 8: Associação de minerais opacos típica do SLSI com hematita e magnetita, vistos à luz refletida. Lado maior da foto $1,30 \mathrm{~mm}$.

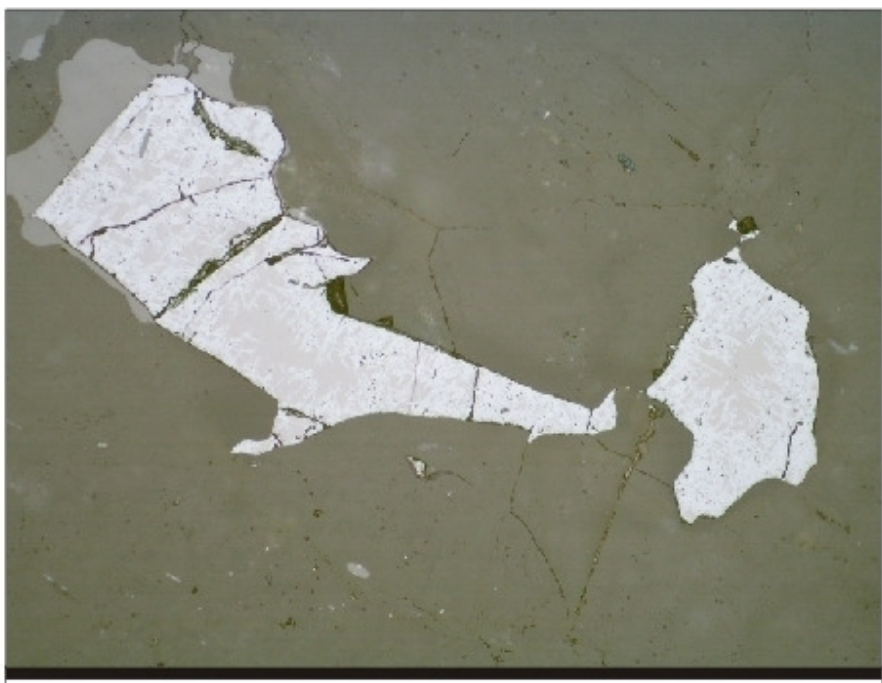

Fotomicrografia 10: Processo de martitização em cristais de magnetita, vistos à luz refletida. Lado maior da foto 0,260 .

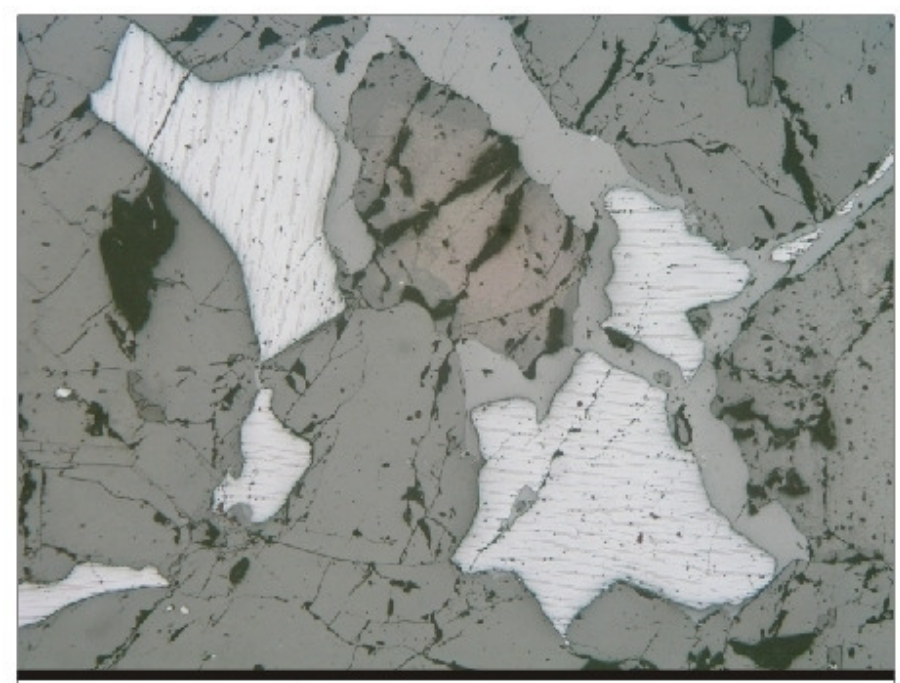

Fotomicrografia 12: Cristais de ilmeno-hematita em cumulato ultramáfico da SLSI, vistos à luz refletida. Lado maior da foto $1,30 \mathrm{~mm}$. 


\section{Sienito Laminado Supersaturado em Sílica - SLS -}

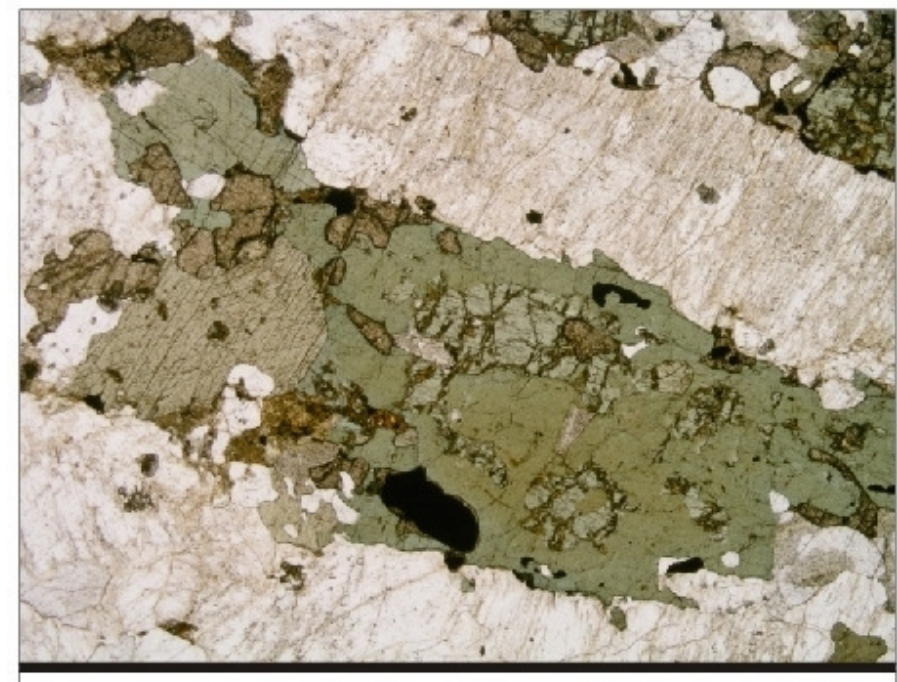

Fotomicrografia 13: Diopsídio reliquiar substituído por hornblenda, associado a titanita, apatita e opacos. Lado maior da foto $3,25 \mathrm{~mm}$.

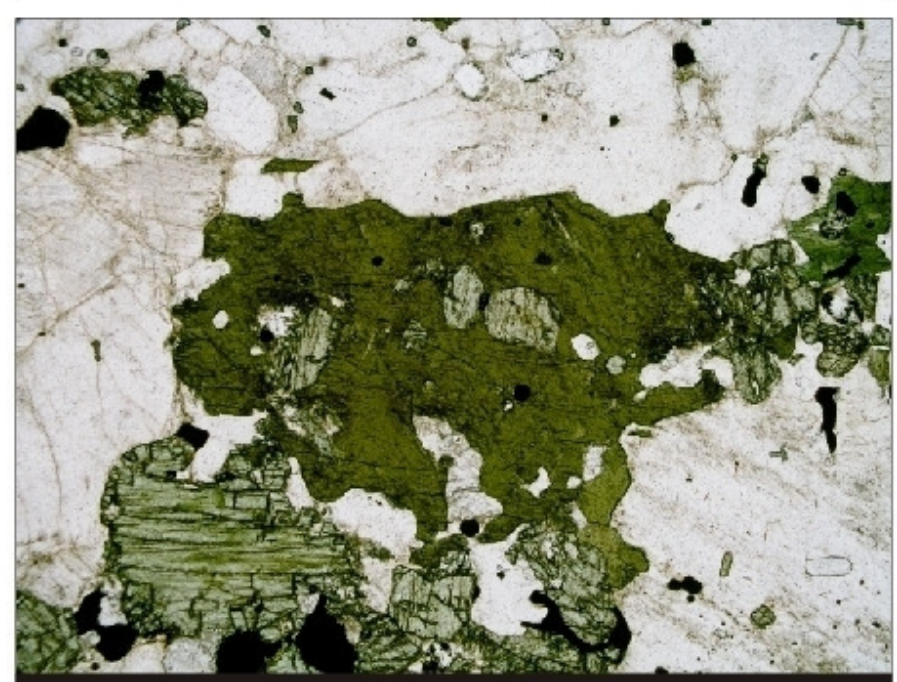

Fotomicrofrafia 15: Diopsídio reliquiar em núcleos de hornblenda. Lado maior da foto $10.4 \mathrm{~mm}$.

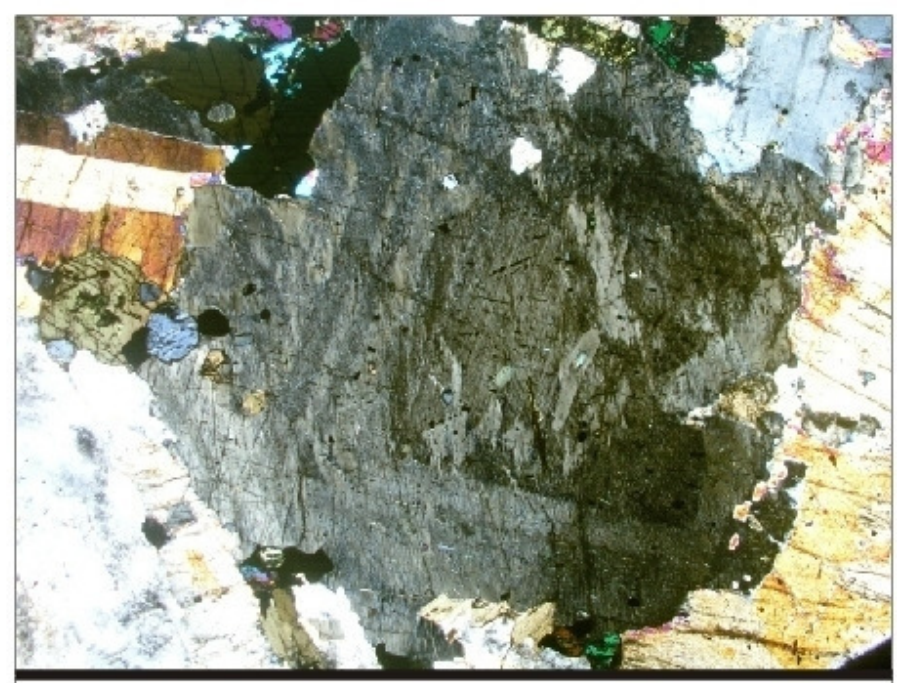

Fotomicrografia 17: Feldspato alcalino pertítico zonado. Destaque para lamelas espessas no núcleo do cristal. Lado maior da foto $10,4 \mathrm{~mm}$.

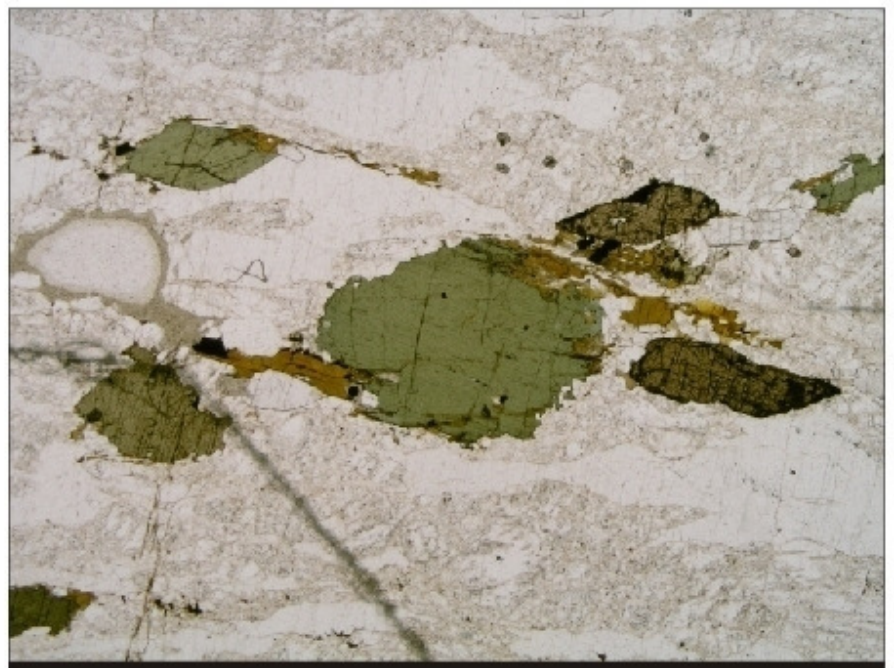

Fotomicrografia 14: Sienito supersaturado intensamente deformado com sigmóides de titanita e anfibólio com sombra de pressão. Lado maior da foto $3.25 \mathrm{~mm}$.

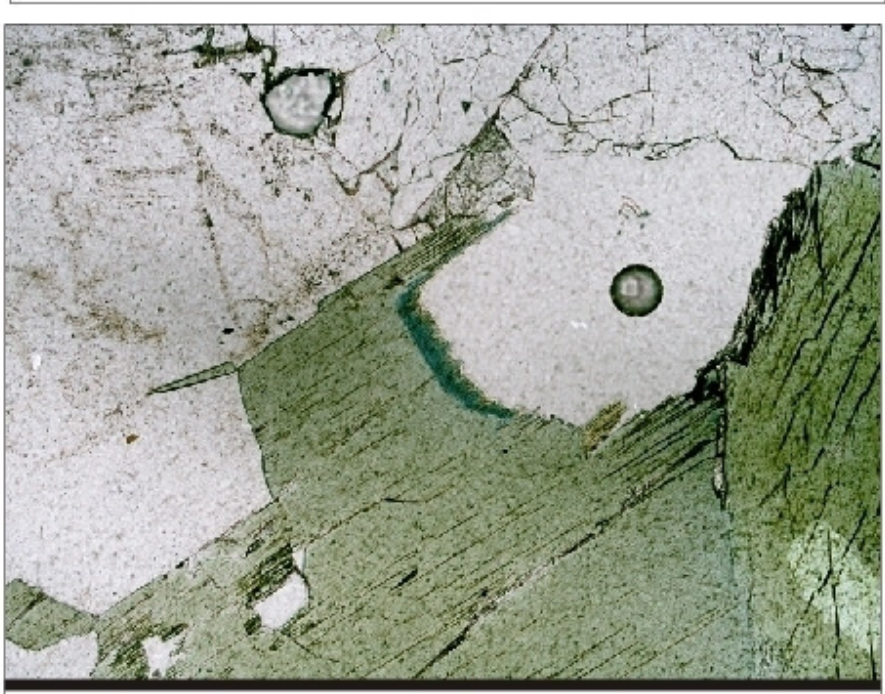

Fotomicrografia 16: Anfibólio azul (riebeckita) em borda de hornblenda. Lado maior da foto $1,3 \mathrm{~mm}$.

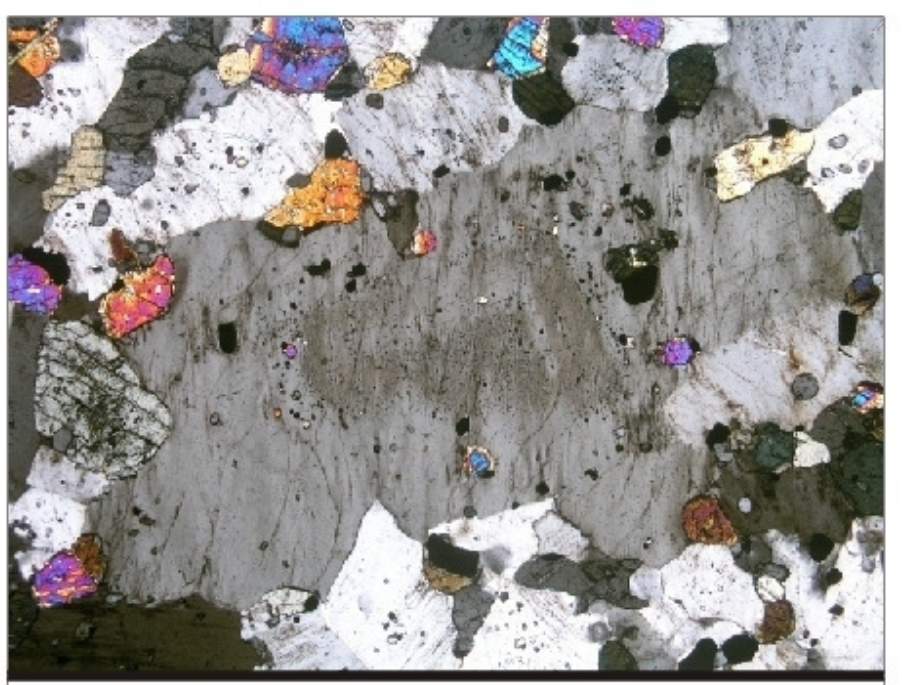

Fotomicrografia 18: Feldspato alcalino zonado com núcleo pertítico e bordas homogêneas, com trilha de máficos finos marcando o limite entre as duas zonas. Lado maior da foto $10,4 \mathrm{~mm}$. 


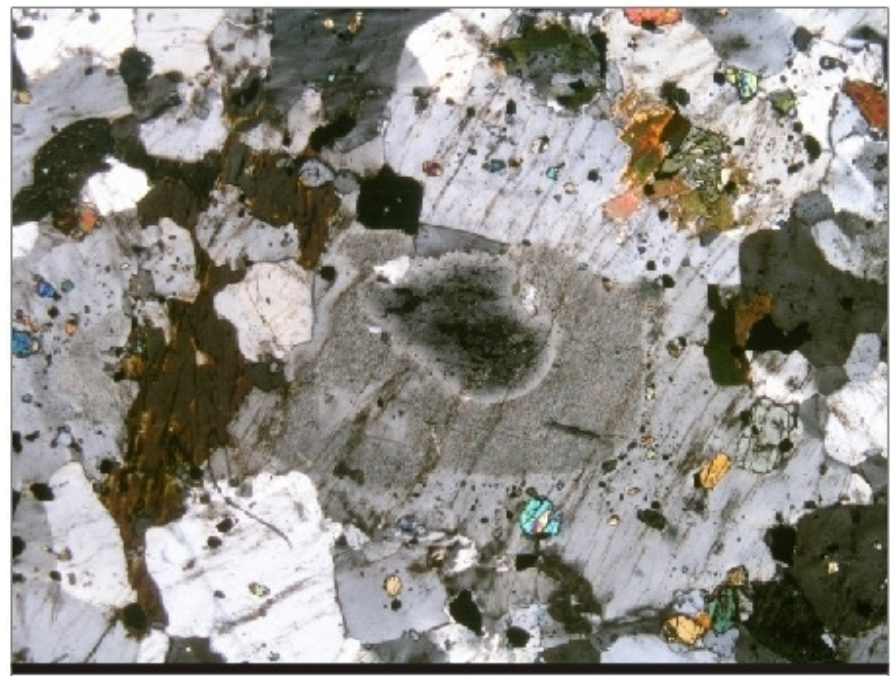

Fotomicrografia 19: Cristal de plagioclásio zonado com bordas irregulares, incluso em feldspato alcalino pertítico. Destaque para trilhas de máficos nas bordas do feldspato alcalino marcando antigas faces. Lado maior da foto $10,4 \mathrm{~mm}$.

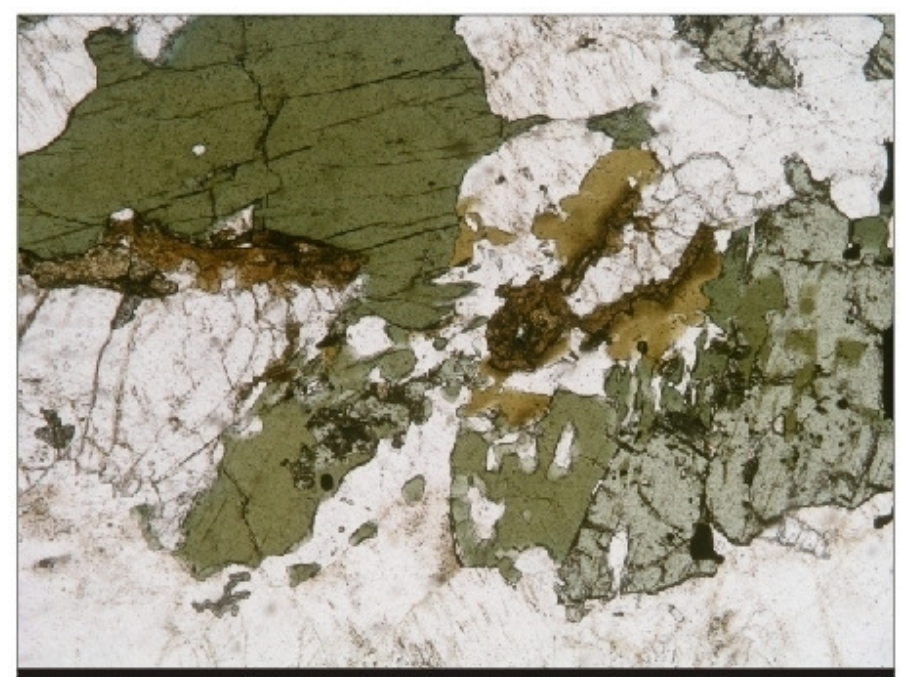

Fotomicrografia 21: Assembléia máfica com diopsídio substituído por hornblenda e apatita com allanita nas bordas. Lado maior da foto $3,25 \mathrm{~mm}$.

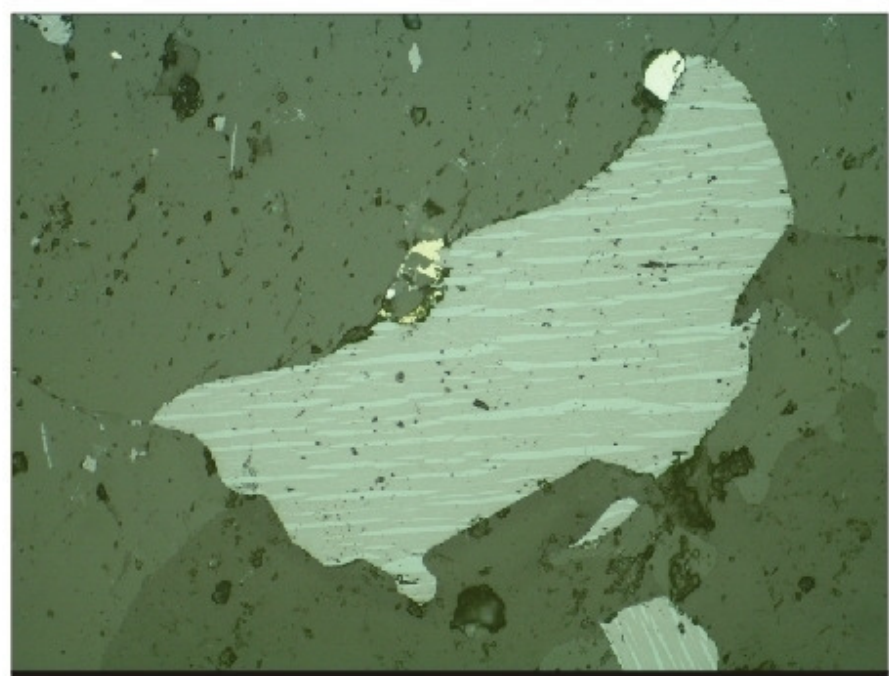

Fotomicrografia 23: Cristal de ilmeno-hematita s.s. e calcopirita vistos à luz refletida. Lado maior da foto $0,65 \mathrm{~mm}$.

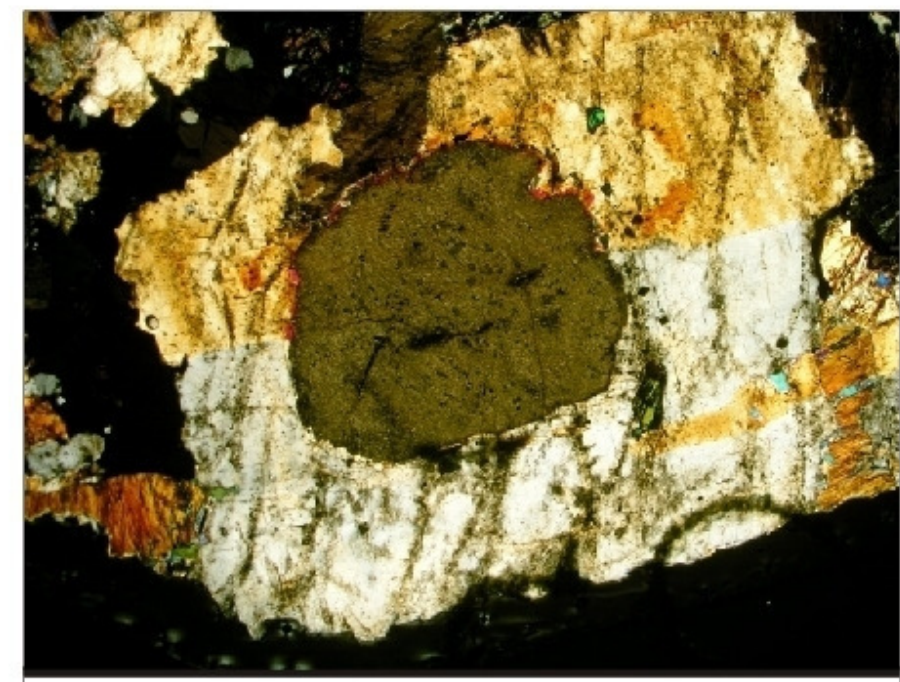

Fotomicrografia 20: Cristal de plagioclásio sericitizado com bordas irregulares incluso em feldspato alcalino. Lado maior da foto $10,4 \mathrm{~mm}$.

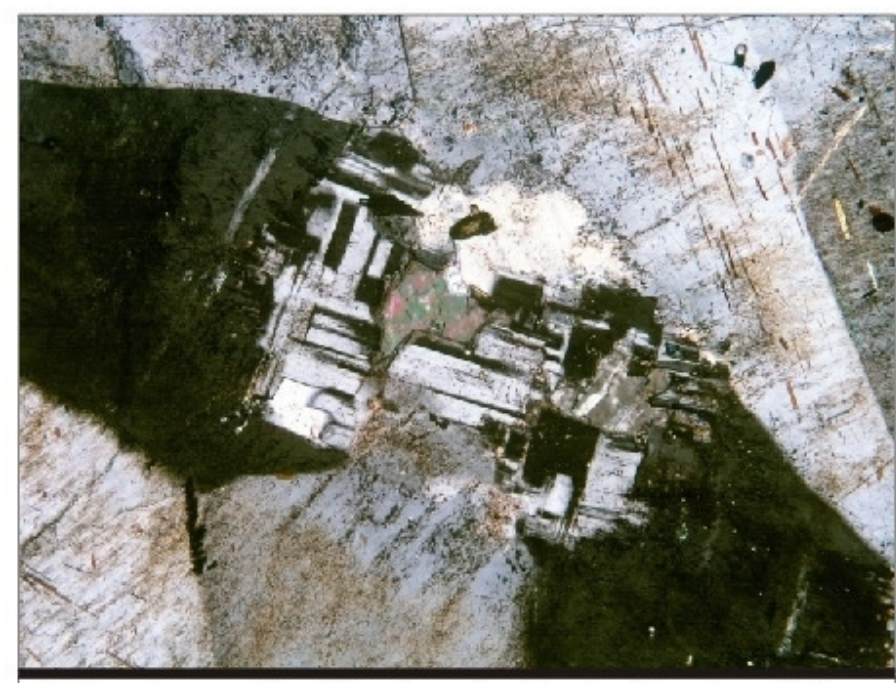

Fotomicrografia 22: Associação tardia de albita e carbonato entre cristais de feldspato alcalino. Lado maior da foto $1,30 \mathrm{~mm}$.

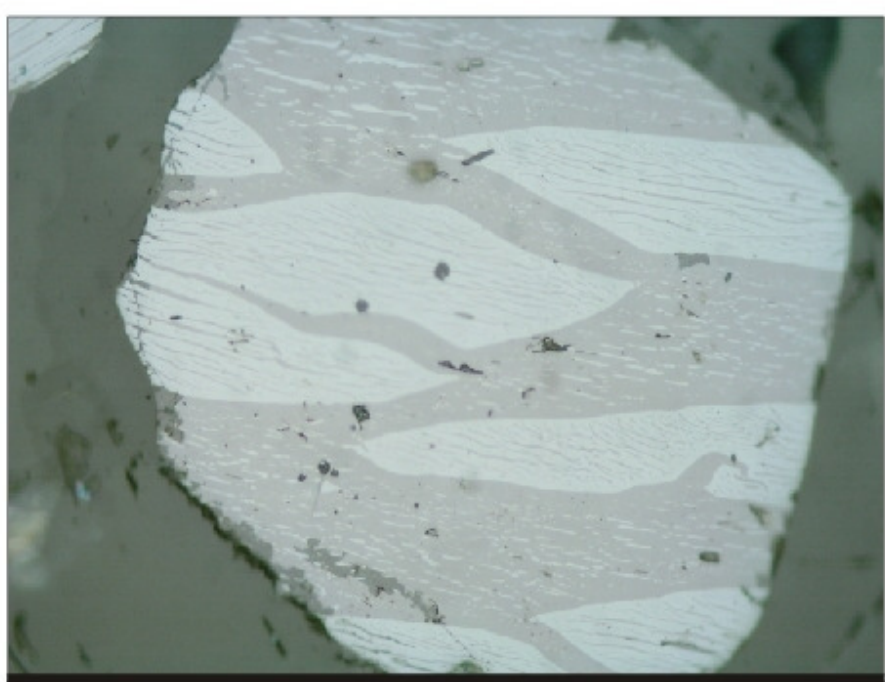

Fotomicrografia 24: Cristal de ilmeno-hematita s.s. Visto à luz refletida. Lado maior da foto $0,260 \mathrm{~mm}$. 


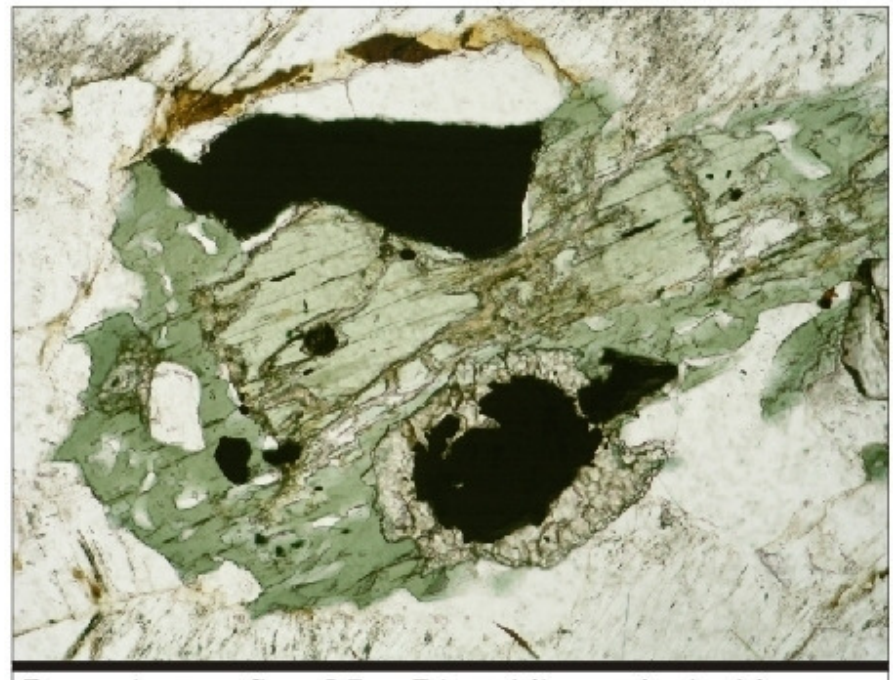

Fotomicrografia 25: Diopsídio substituído por hornblenda e mineral opaco com bordas de titanita. Lado maior da foto $3,25 \mathrm{~mm}$.

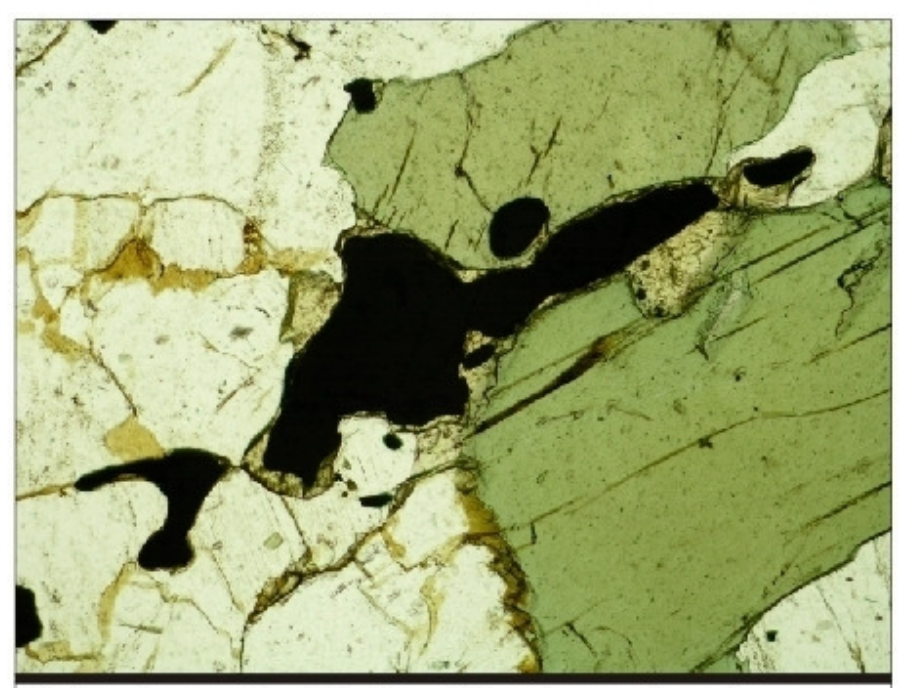

Fotomicrografia 27: Hornblenda e minerais opacos com fina borda de titanita. Lado maior da foto 1,63 $\mathrm{mm}$.

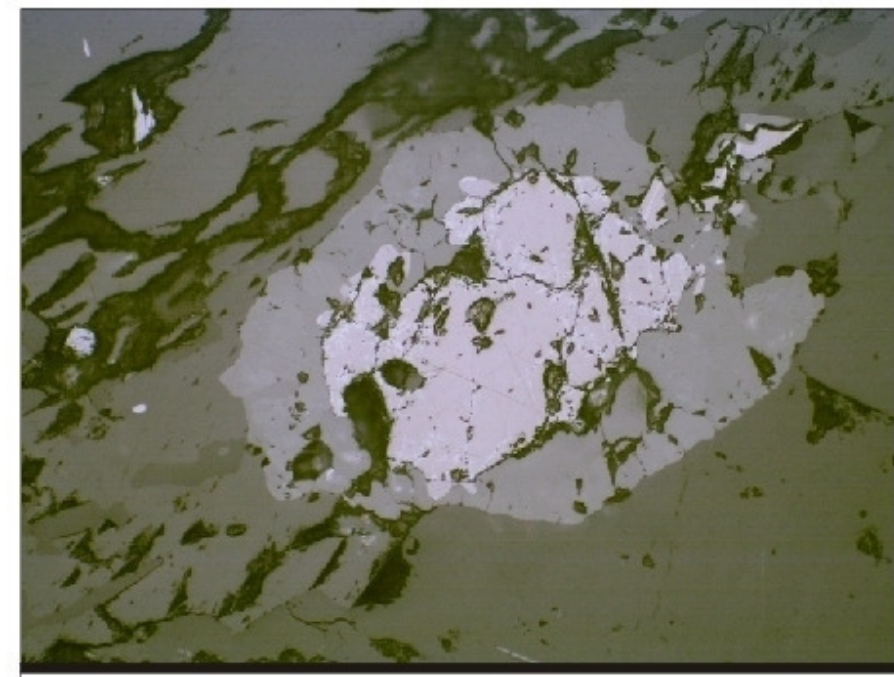

Fotomicrografia 26: Cristal de magnetita xenomórfico com titanita nas bordas. Lado maior da foto $1,04 \mathrm{~mm}$.

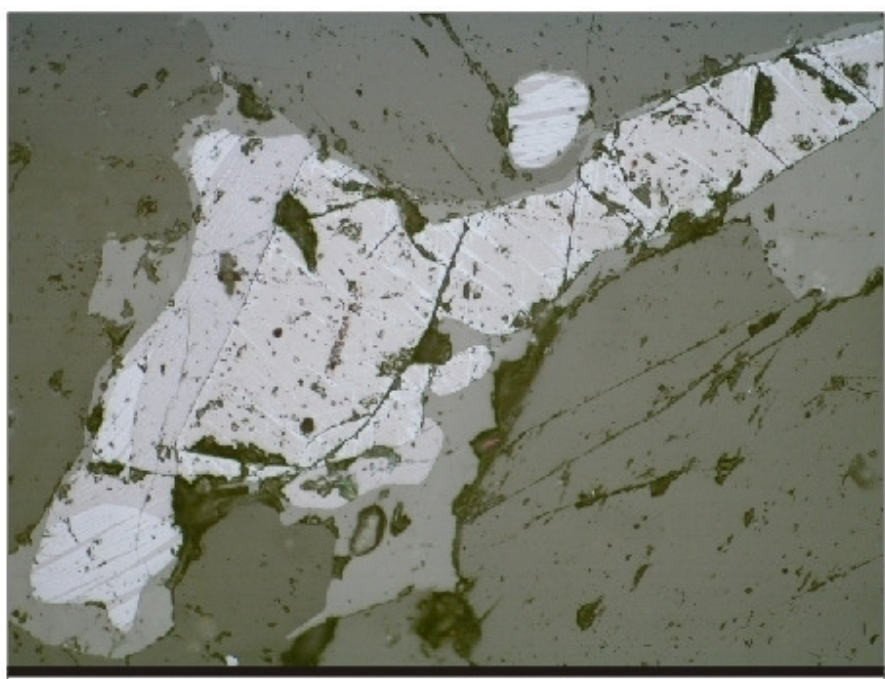

Fotomicrografia 28: Associação de minerais opacos com magnetita martitizada e ilmeno-hematita s.s. vistos à luz refletida. Lado maior da foto $1,04 \mathrm{~mm}$.

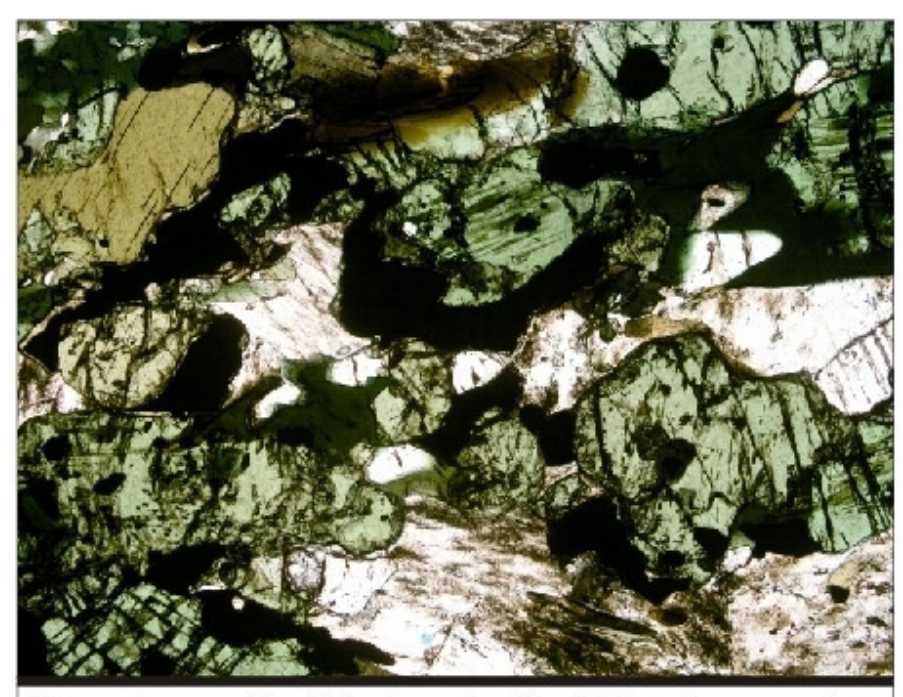

Fotomicrografia 29: Associação típica de cumulato máfico em SLS com diopsídio, biotita, minerais opacos e feldspato alcalino. Lado maior da foto 8,32 $\mathrm{mm}$.

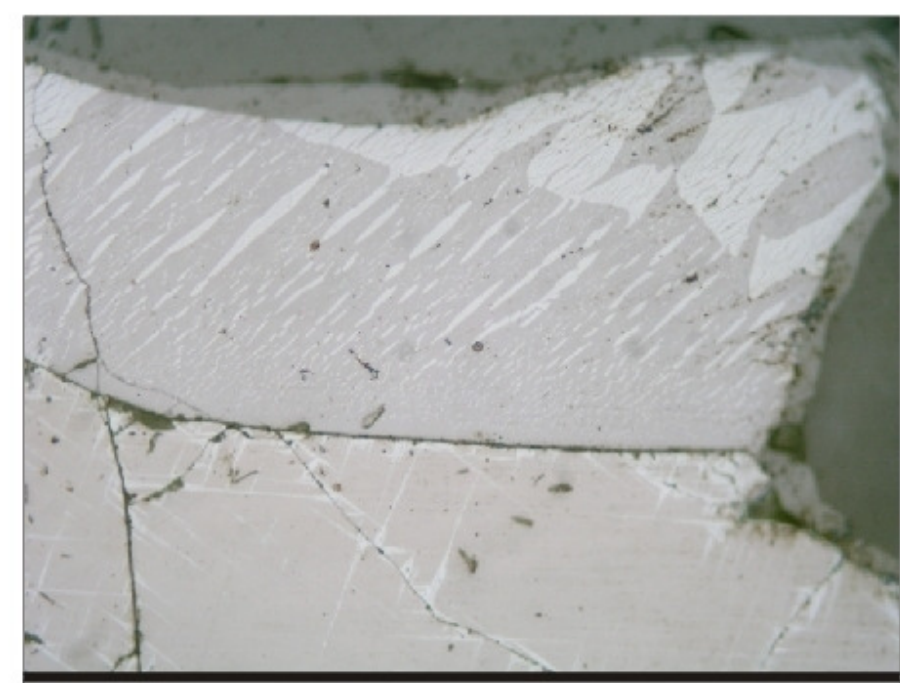

Fotomicrografia 30: Associação magnetita e ilmenita-hematita s.s. vistos à luz refletida. Lado maior da foto $0,260 \mathrm{~mm}$. 


\section{Sienito Supersaturado em Sílica Interno - SSI -}

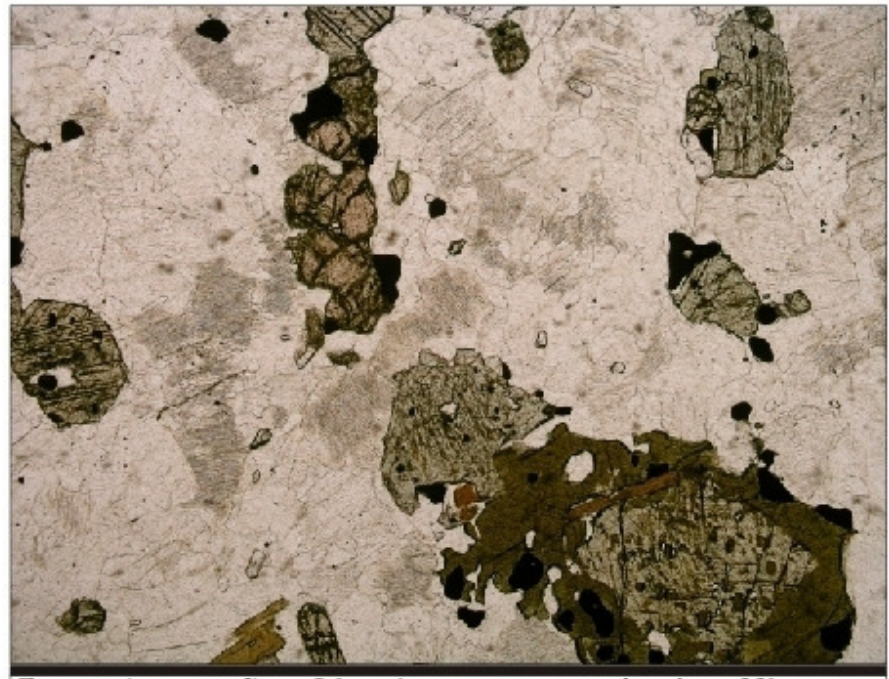

Fotomicrografia 31: Aspecto geral da SSI com diopsídio, enstatita, feldspato alcalino e apatita. Hornblenda verde escura substui parcialmente o diopsídio. Lado maior da foto $3,25 \mathrm{~mm}$.

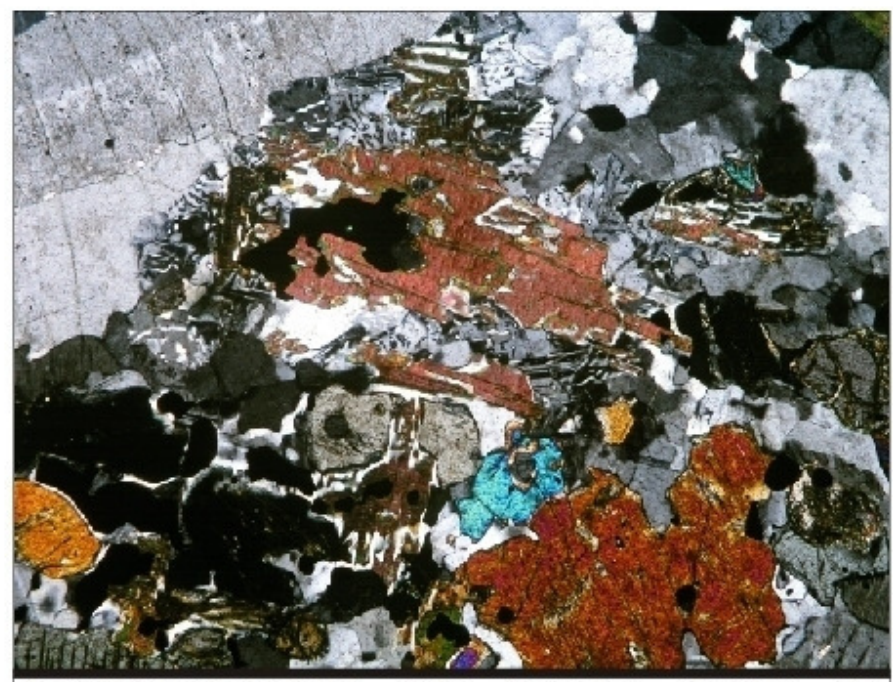

Fotomicrografia 33: Feição tardia de intercrescimento entre quartzo e biotita e quartzo e albita (mimerquita). Lado maior da foto $1,30 \mathrm{~mm}$.

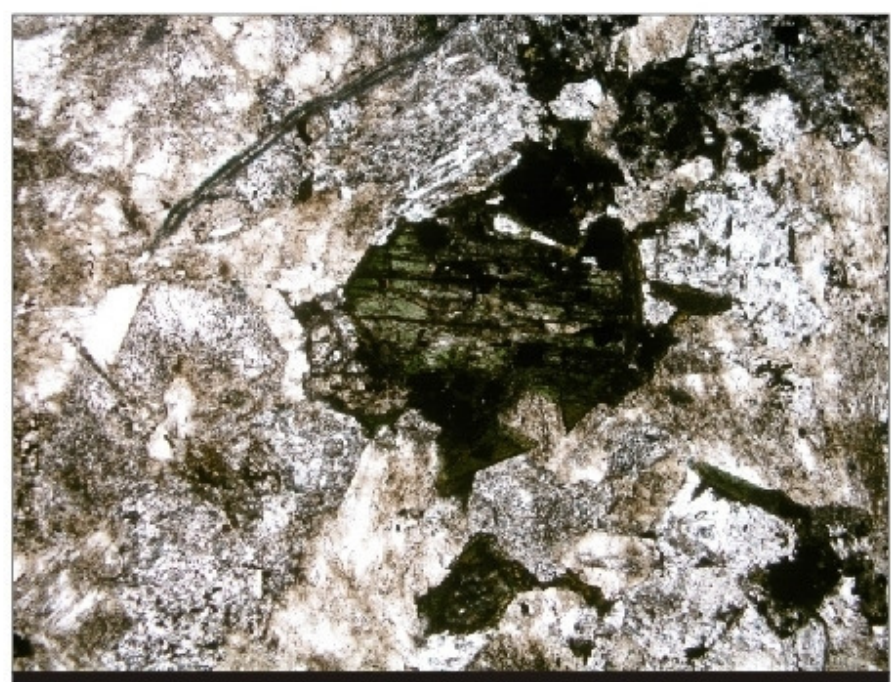

Fotomicrografia 35: Cristal de diopsídio com bordas de egirina devido a alteração por fluidos alcalinos. Lado maior da foto $3,25 \mathrm{~mm}$.

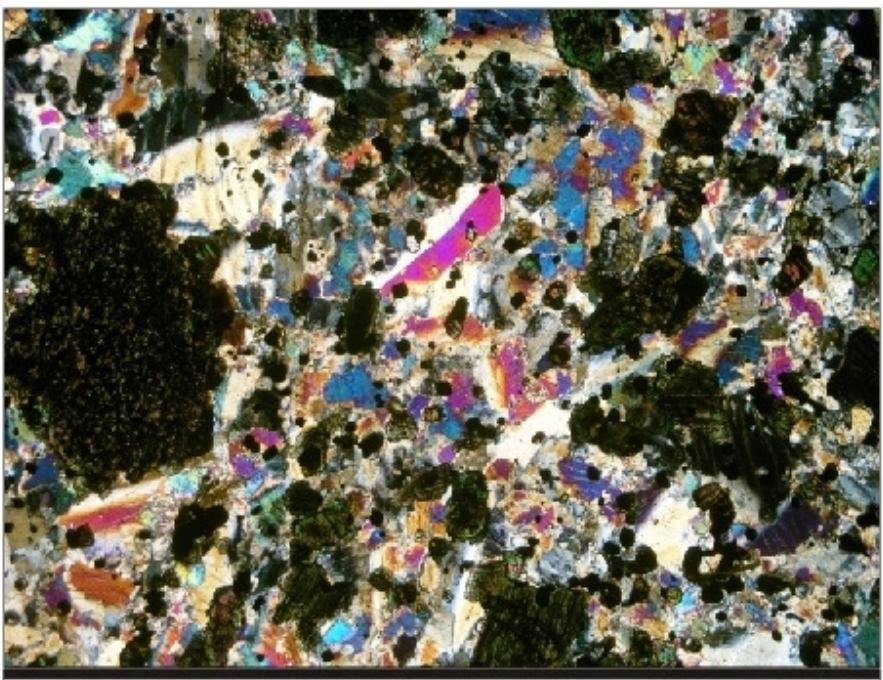

Fotomicrografia 32: Megacristais de diopsídio associados a feldspato alcalino e minerais opacos. Lado maior da foto $3,25 \mathrm{~mm}$.

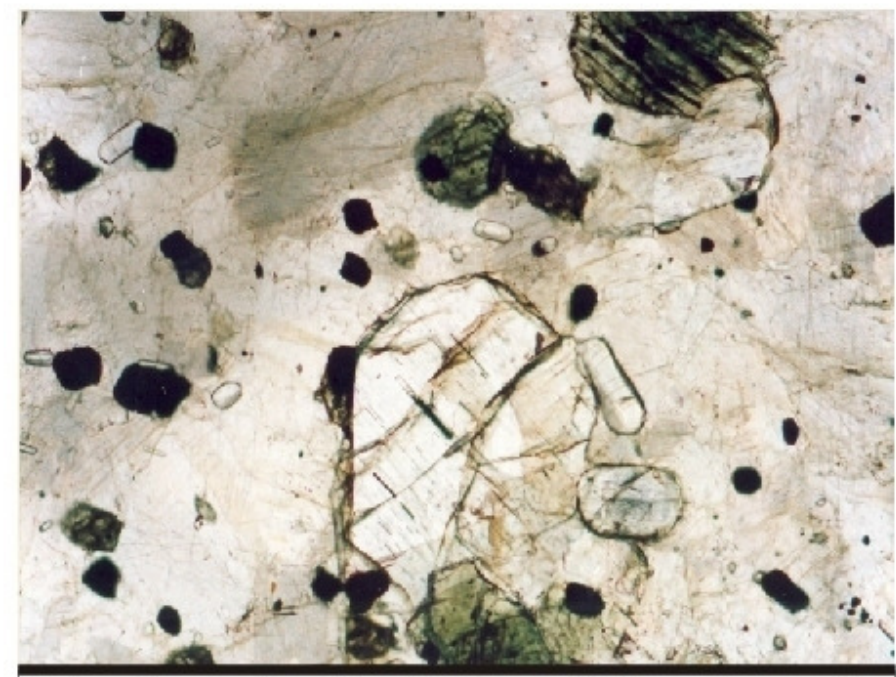

Fotomicrografia 34: Cristais euédricos de apatita associados a diopsídio, feldspato alcalino e minerais opacos. Lado maior da foto $3,25 \mathrm{~mm}$.

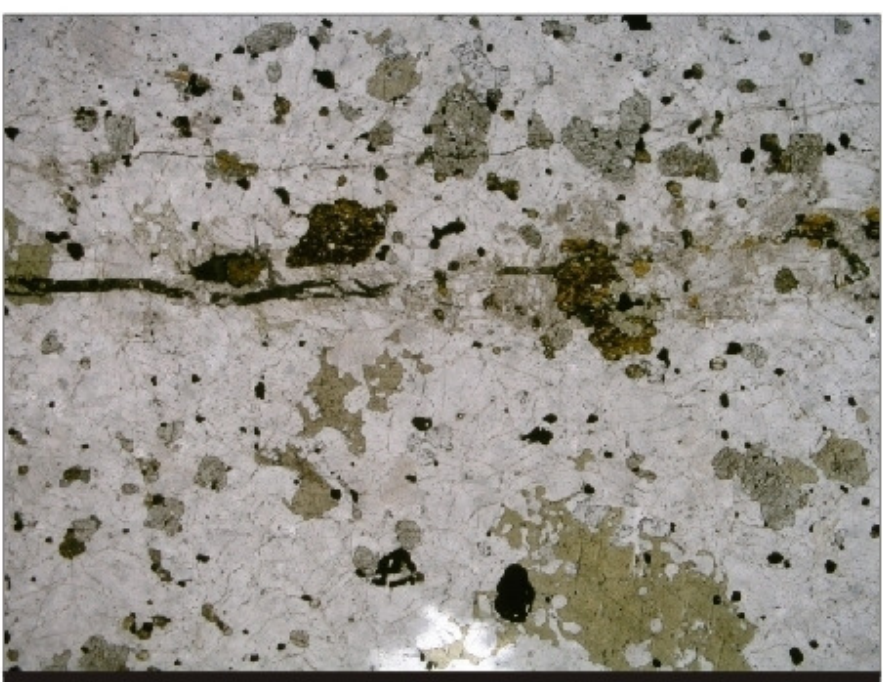

Fotomicrografia 36: Alteração hidrotermal localizada por percolação de fluidos alcalinos. Lado maior da foto $8,32 \mathrm{~mm}$. 


\section{Sienito Supersaturado em Sílica Externo - SSE -}

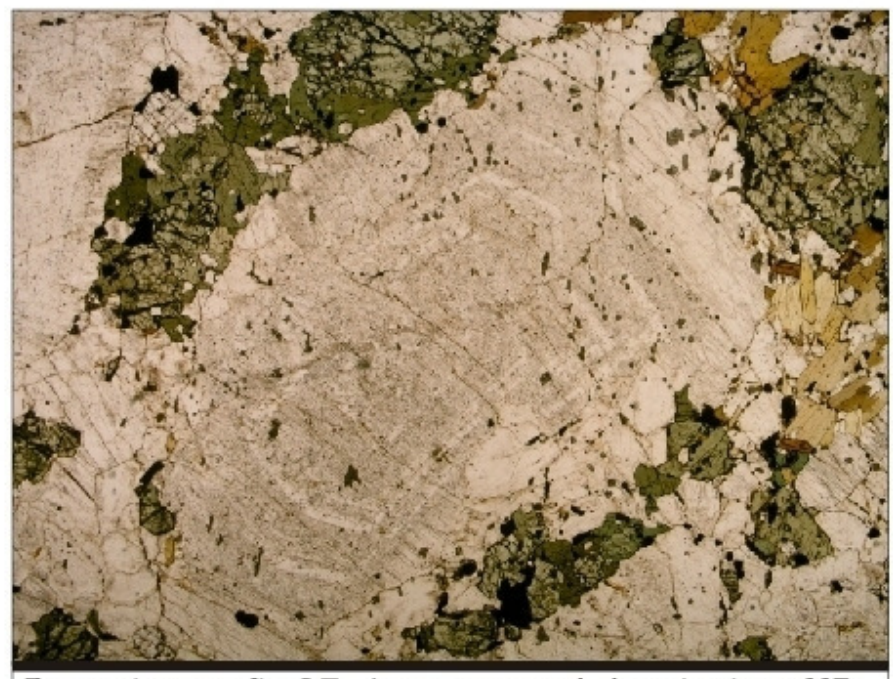

Fotomicrografia 37: Aspecto geral dos sienitos SSE com feldspato alcalino zonado, diopsídio, biotita e apatita. Lado maior da foto $10,4 \mathrm{~mm}$.

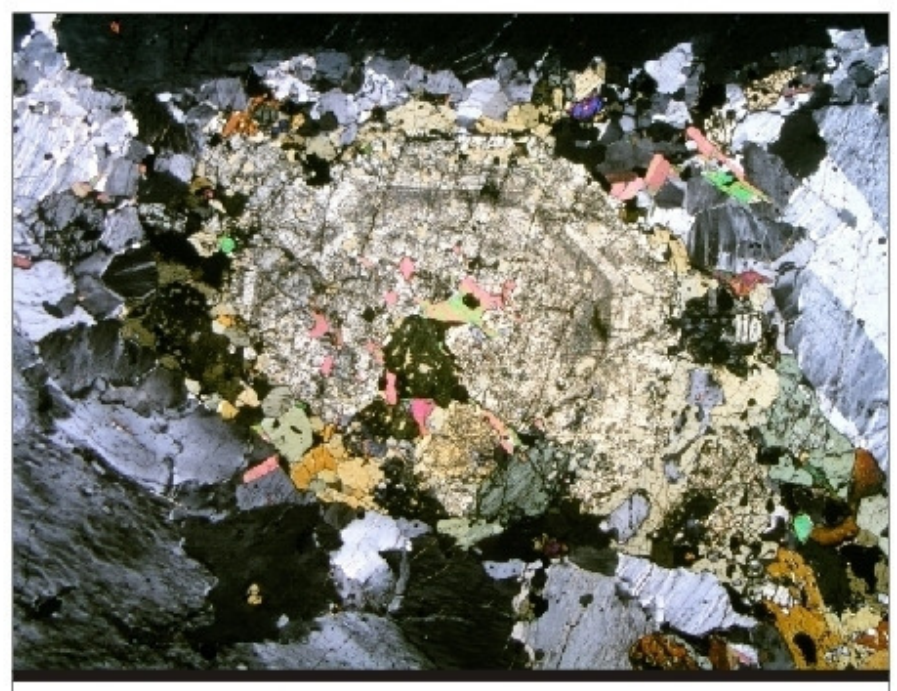

Fotomicrografia 39: Zoneamento composicional em cristal de diopsídio. Lado maior da foto $5,2 \mathrm{~mm}$.

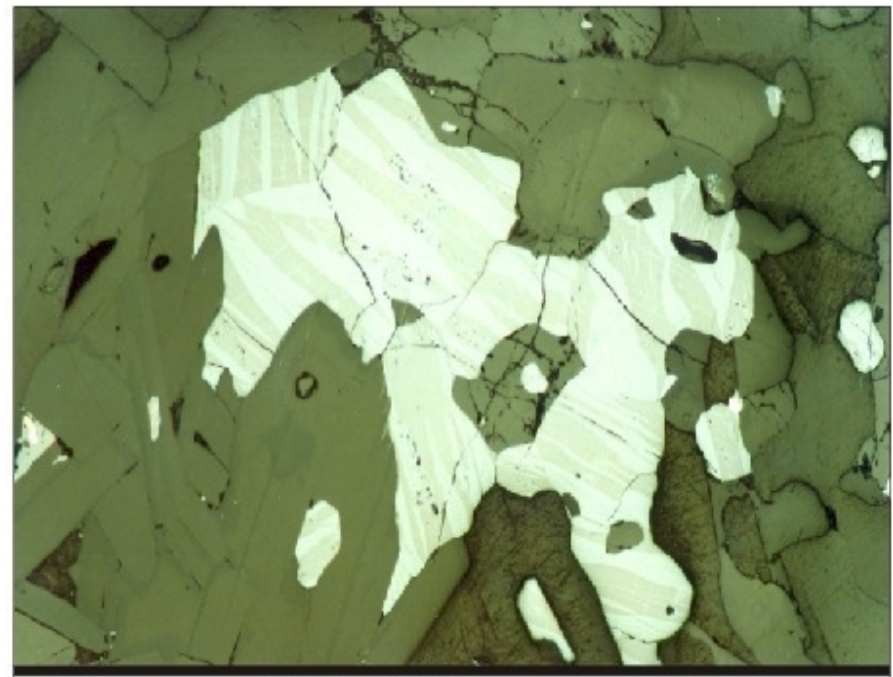

Fotomicrografia 41: Cristal de hematita rico em lamelas de ilmenita, vistos à luz refletida. Lado maior da foto $1,3 \mathrm{~mm}$.

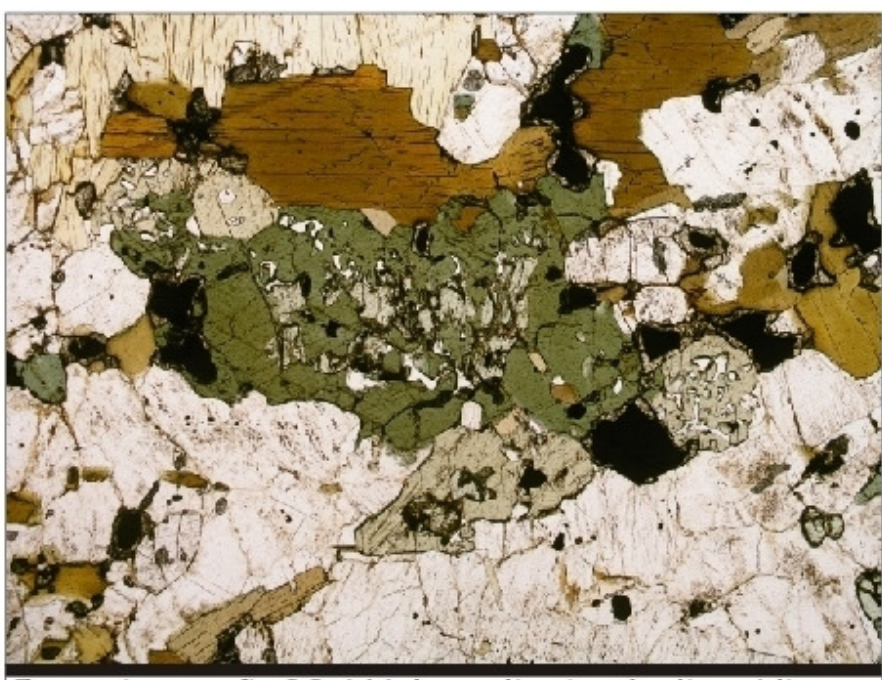

Fotomicrografia 38: Núcleo reliquiar de diopsídio em hornblenda anédrica, associada a apatita, biotita, titanita e opacos. Lado maior da foto $1,3 \mathrm{~mm}$.

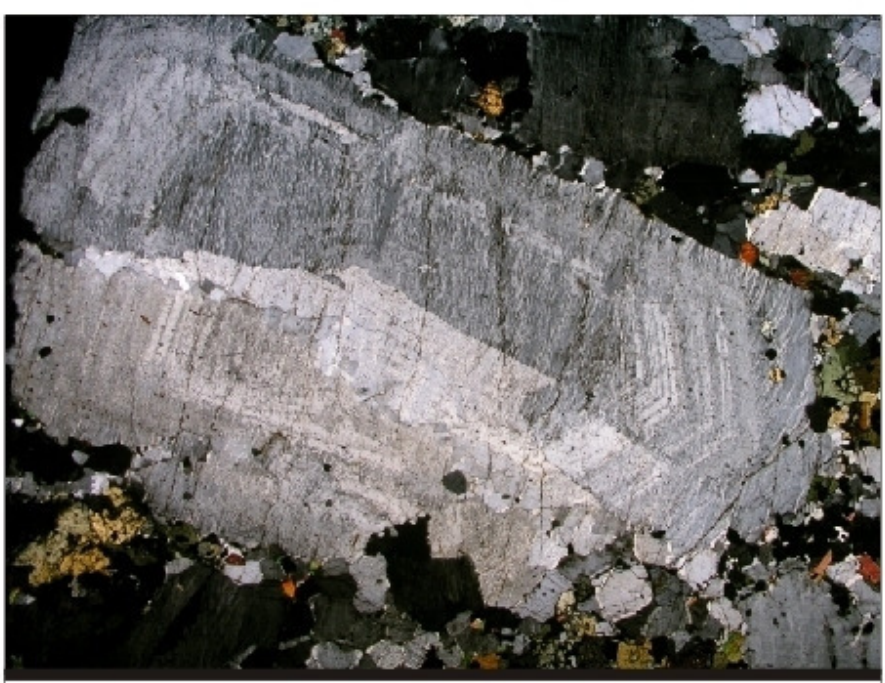

Fotomicrografia 40: Zoneamento oscilatório em feldspato alcalino pertítico. Lado maior da foto 10,4 $\mathrm{mm}$. 


\section{ENCLAVES}

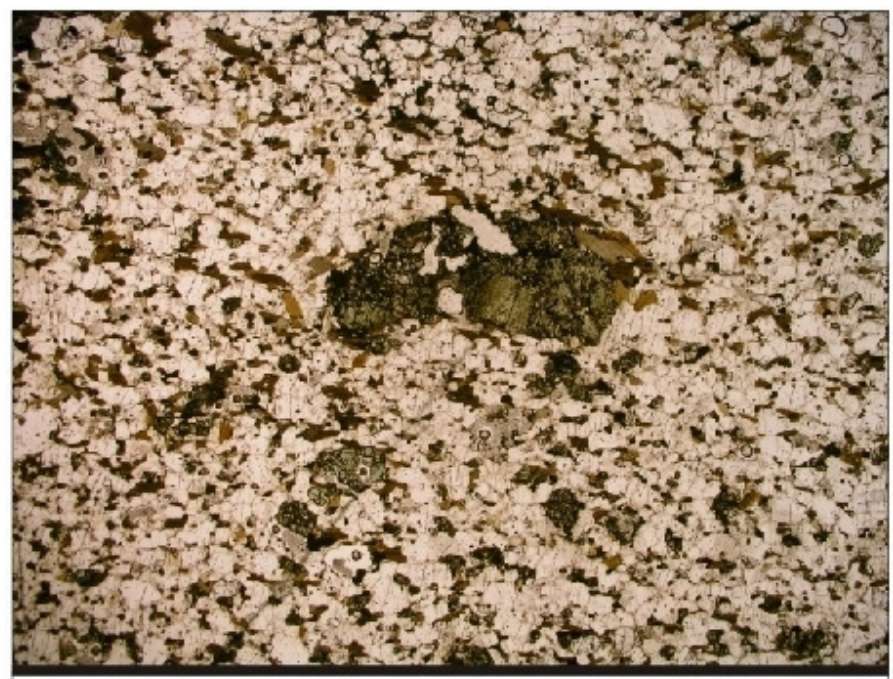

Fotomicrografia 42: Micro-sienito inequigranular porfirítico, com fenocristais de clinopiroxênio e matriz com feldspato alcalino, biotita, apatita e opacos. Lado maior da foto $2,60 \mathrm{~mm}$.

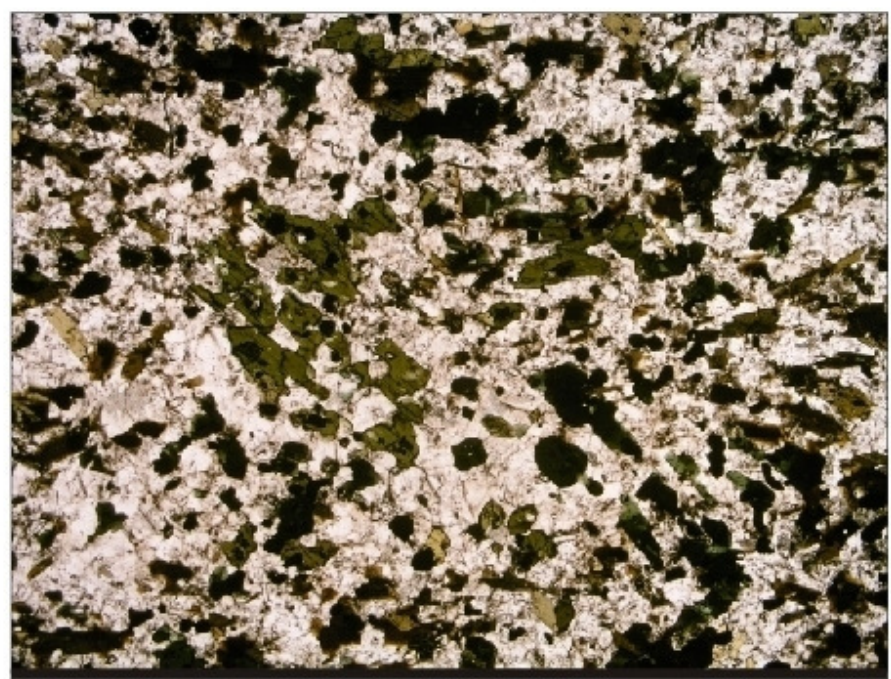

Fotomicrografia 44: Monzonito com feldspato alcalino pertítico, plagioclásio, hornblenda, biotita, apatita e opacos. Lado maior da foto $2,60 \mathrm{~mm}$.

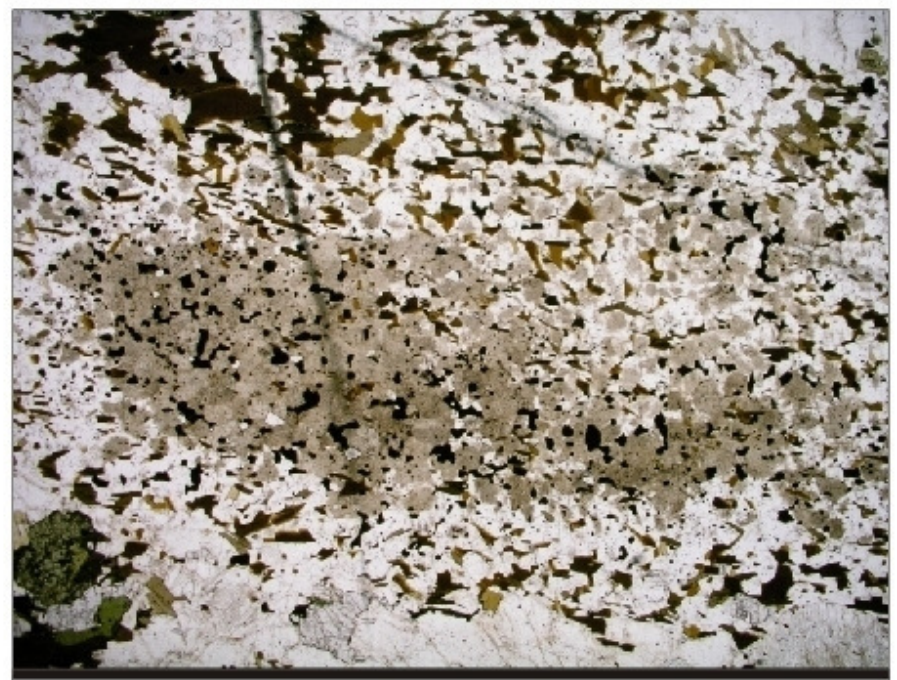

Fotomicrografia 46: Enclave diorítico fino com textura granoblástica, e intensa alteração sericítica no núcleo. Lado maior da foto $10,4 \mathrm{~mm}$.

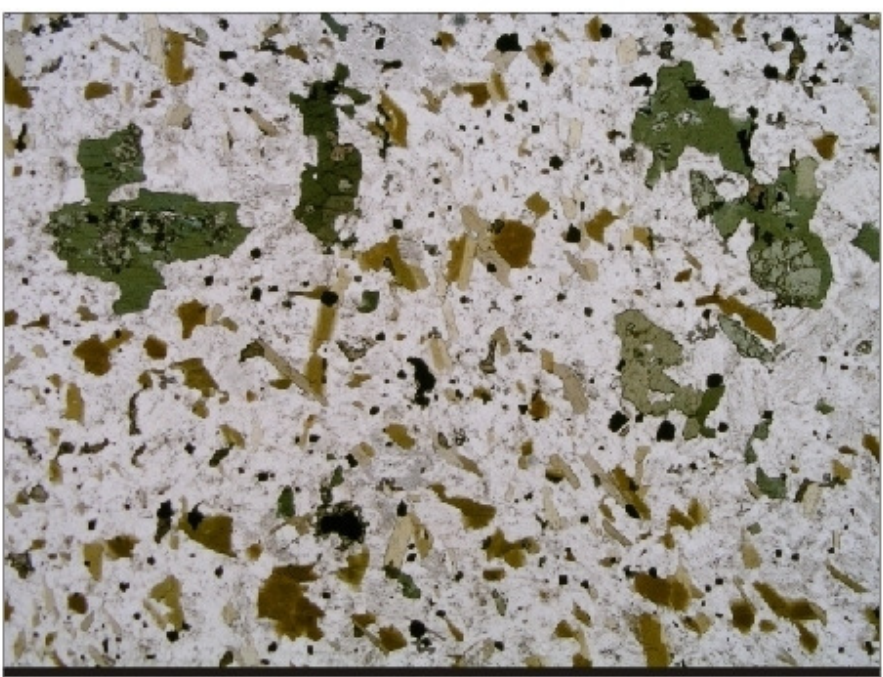

Fotomicrografia 43: Microsienito equigranular com feldspato alcalino, diopsídio, hornblenda, biotita, apatita, opacos e titanita. Lado maior da foto 3,25 $\mathrm{mm}$.

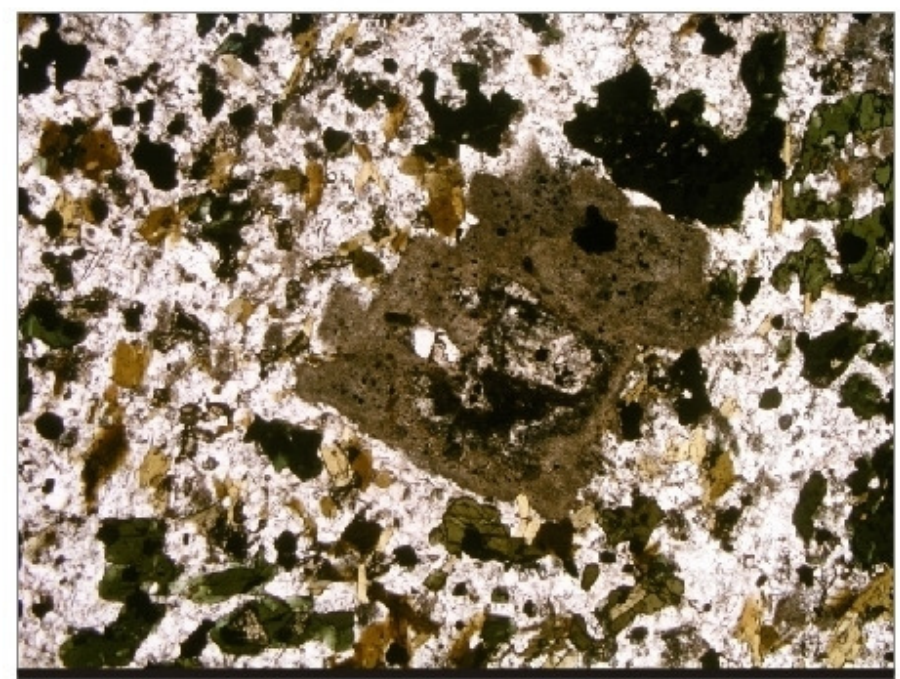

Fotomicrografia 45: Megacristal de plagioclásio com nucleo fortemente alterado em monzonito equigranular. Lado maior da foto $2,60 \mathrm{~mm}$.

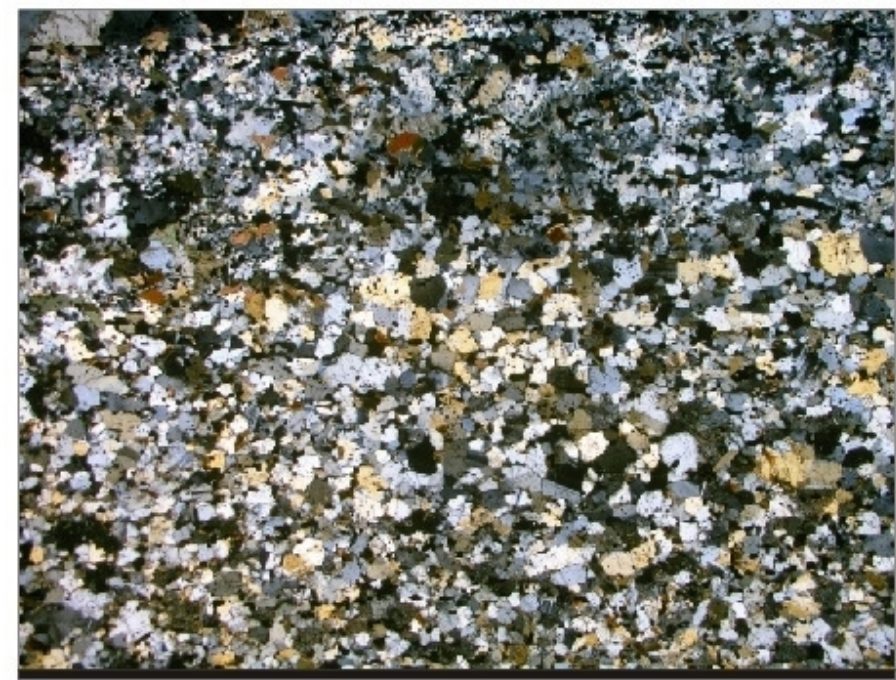

Fotomicrografia 47: Enclave diorítico fino com textura granoblástica e borda muito fina devido ao resfriamento rápido. Lado maior da foto $8,32 \mathrm{~mm}$. 


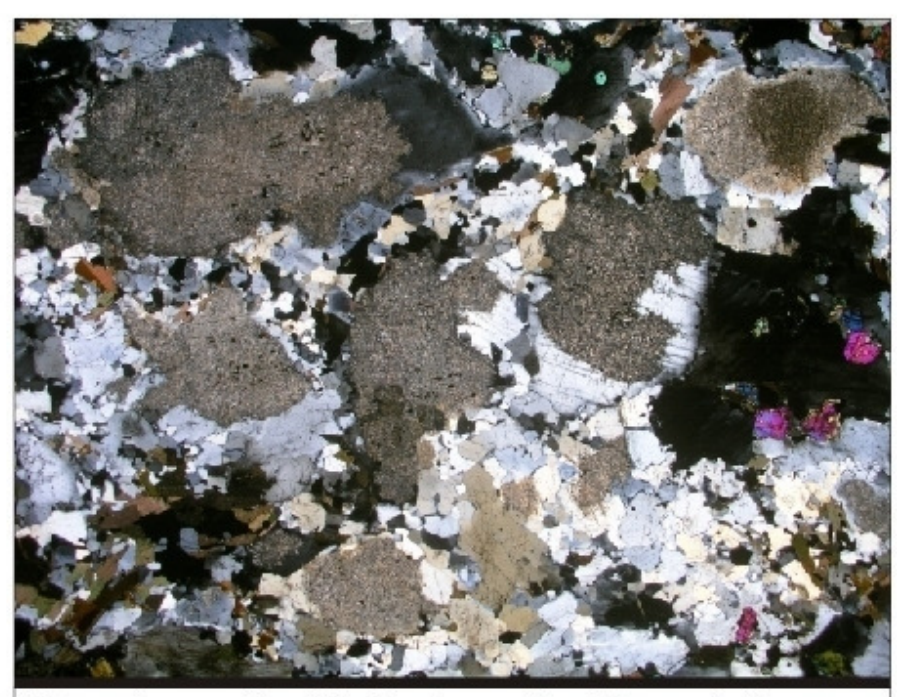

Fotomicrografia 48: Enclave diorítico médio, com plagioclásio zonado, com núcleos intensamente modificados. Lado maior da foto $8,32 \mathrm{~mm}$.

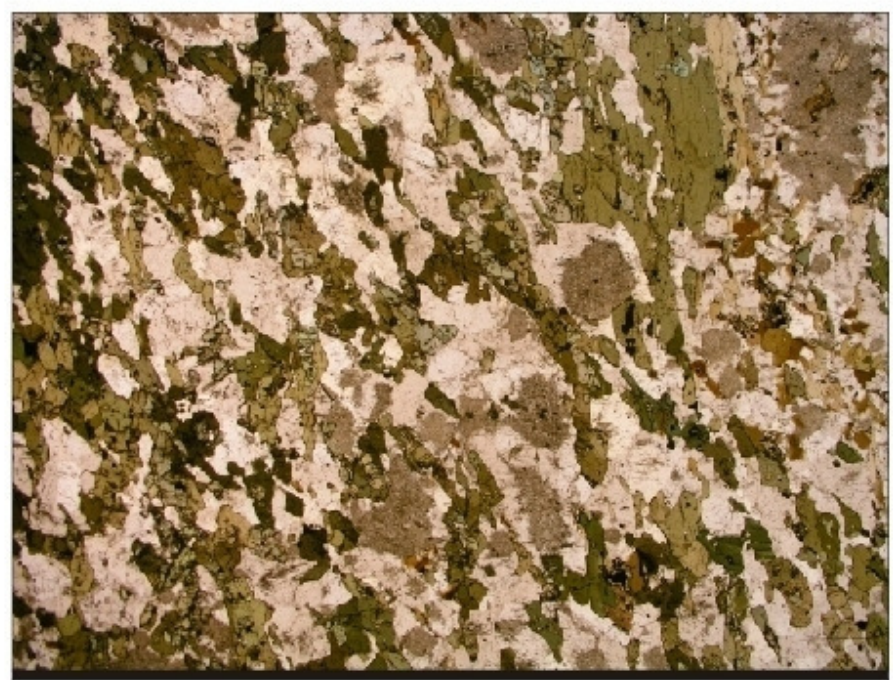

Fotomicrografia 50: Enclave diorítico com clinopiroxênio, hornblenda, plagioclásio, biotita, opacos e titanita. Lado maior da foto $3,25 \mathrm{~mm}$.

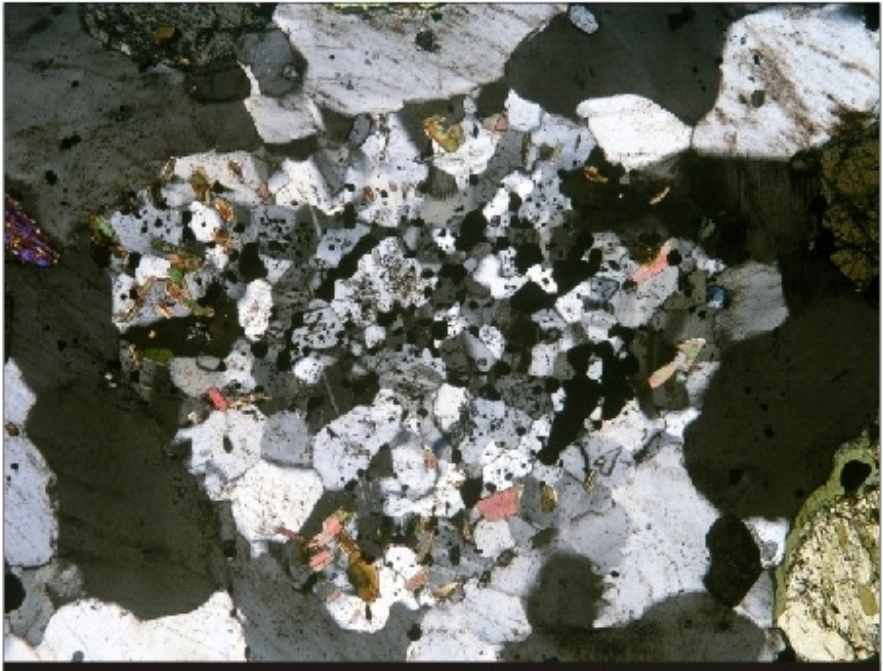

Fotomicrografia 49: Enclave diorítico milimétrico, composto por plagioclásio, biotita marrom e magnetita. Lado maior da foto $1,63 \mathrm{~mm}$.

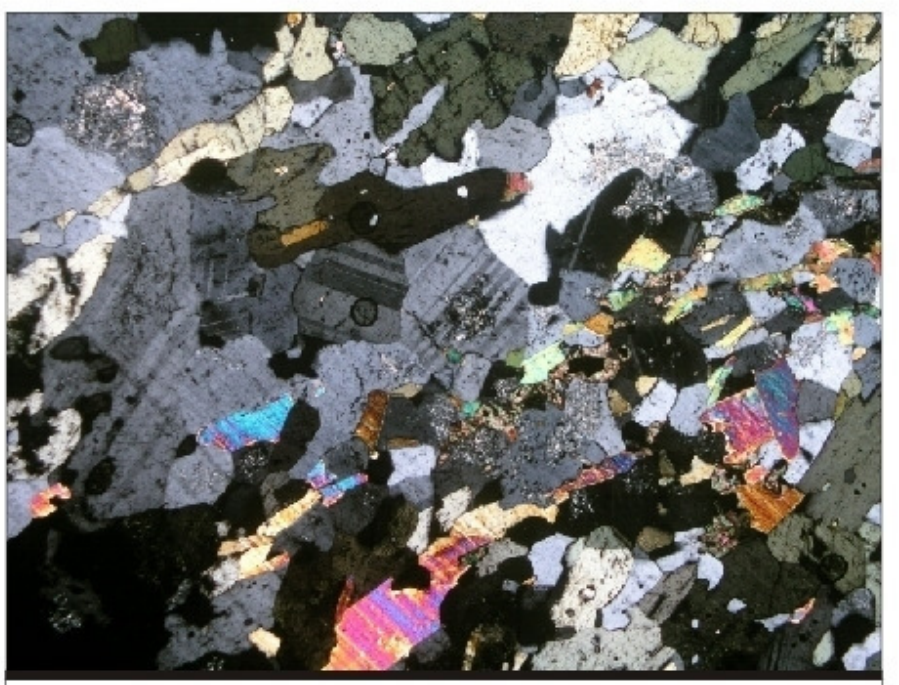

Fotomicrografia 51: Enclave diorítico (mesma amostra da foto anterior) rico em hornblenda e plagioclásio com núcleos alterados. Lado maior da foto $1,3 \mathrm{~mm}$.

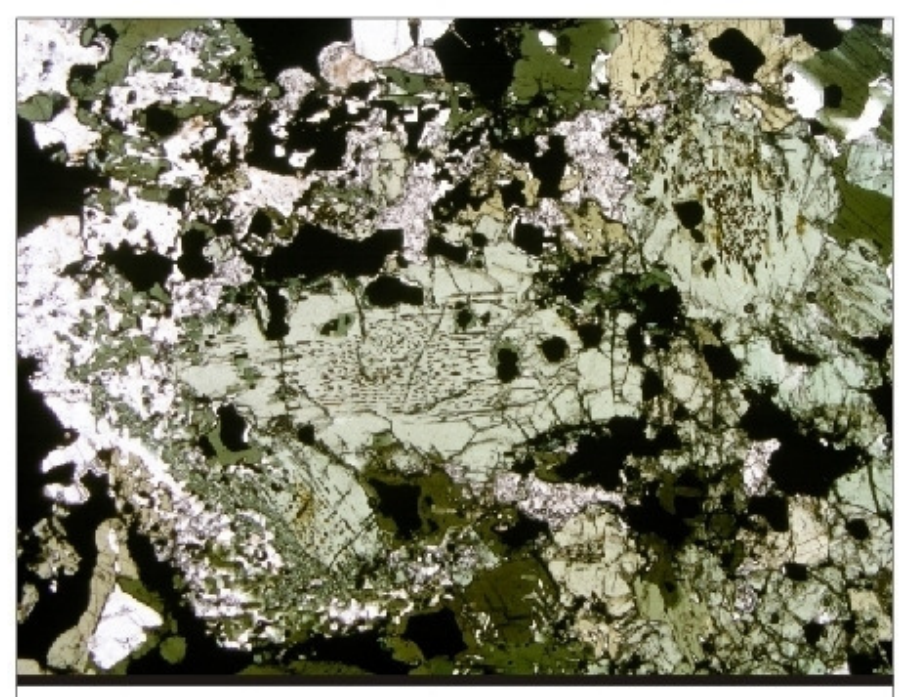

Fotomicrografia 52: Enclave bandado intercalando níveis ora com clinopiroxênio ora hornblenda, juntamente com plagioclásio, bornita e carbonato. Lado maior da foto $5,20 \mathrm{~mm}$.

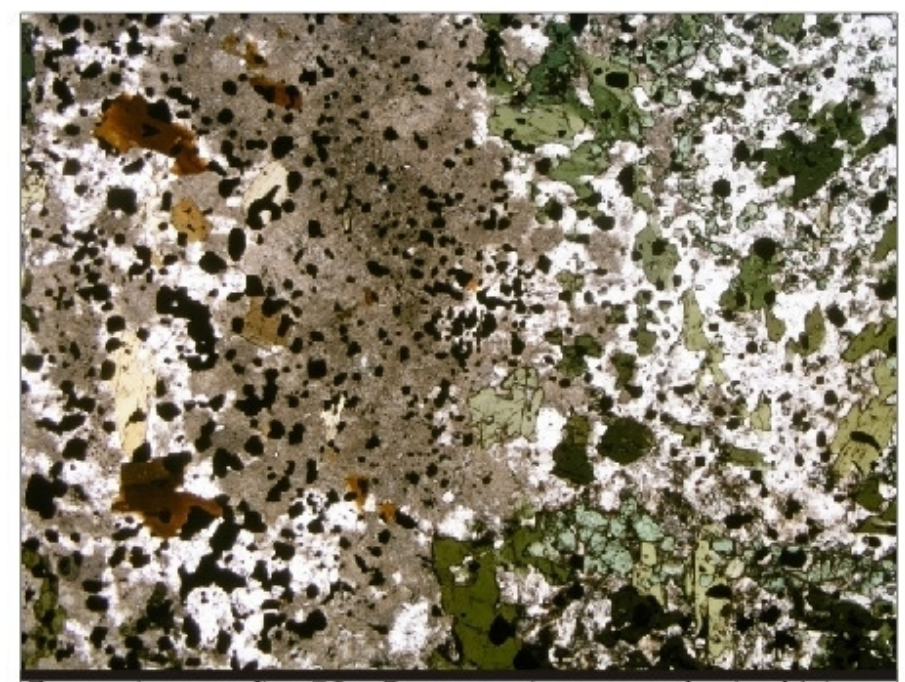

Fotomicrografia 53: Porção rica em plagioclásio e magnetita do enclave bandado. Destaque para alteração sericítica do plagioclásio similar ao observados nos enclaves com biotita. Lado maior da foto $8,32 \mathrm{~mm}$. 


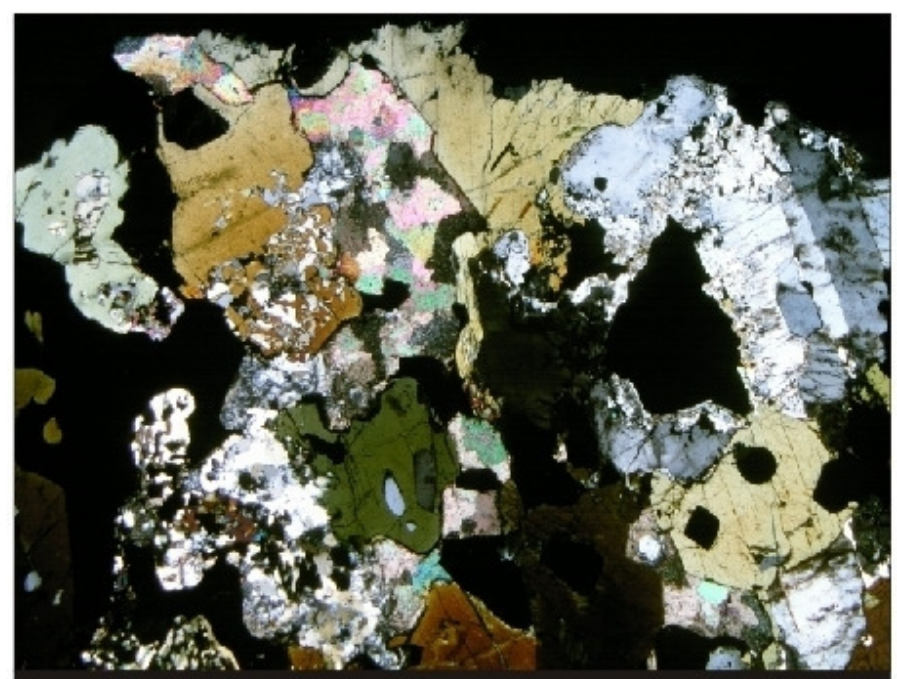

Fotomicrografia 54: Nível rico em hornblenda do enclave bandado. Presença de plagioclásio (intercrescido com hornblenda e opacos), carbonato e minerais opacos. Lado maior da foto $8,32 \mathrm{~mm}$.

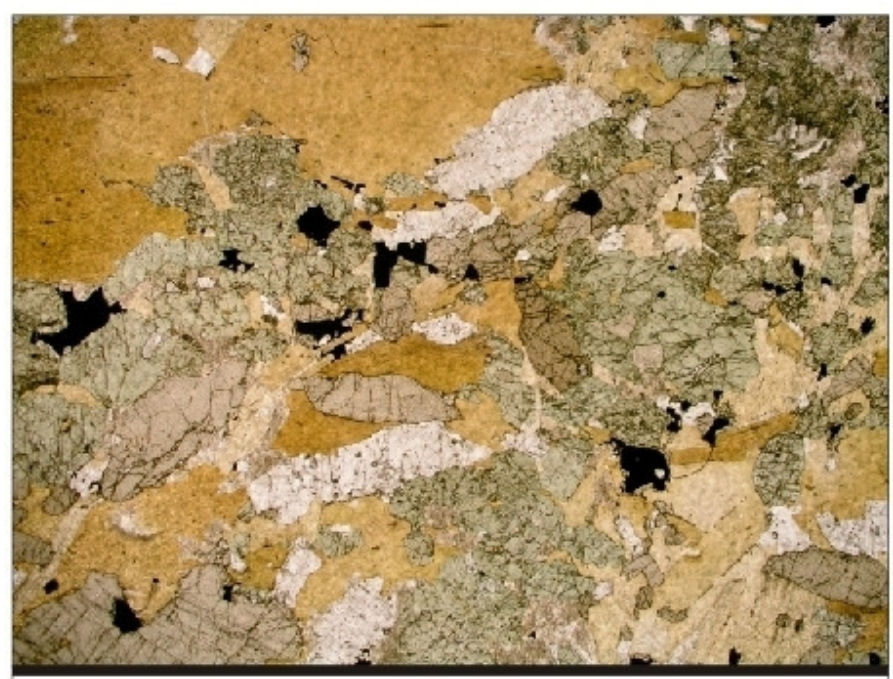

Fotomicrografia 56: Enclave cumulático ultramáfico com clinopiroxênio, apatita, titanita, biotita e opacos. Lado maior da foto $10,4 \mathrm{~mm}$.

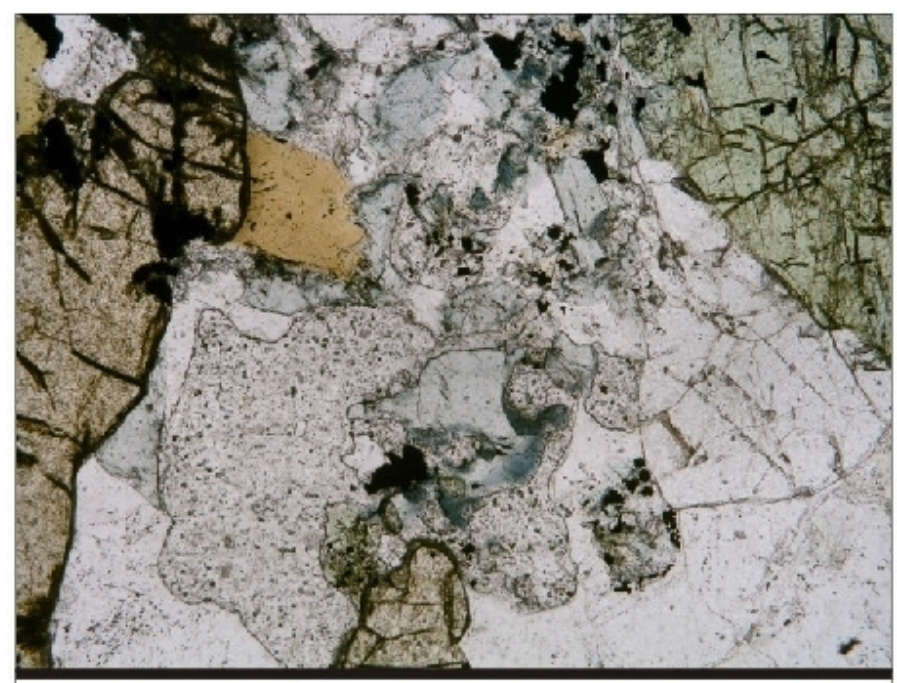

Fotomicrografia 58: Destaque da paragênesse tardia com carbonato e anfibólio azul. Lado maior da foto $3,25 \mathrm{~mm}$.

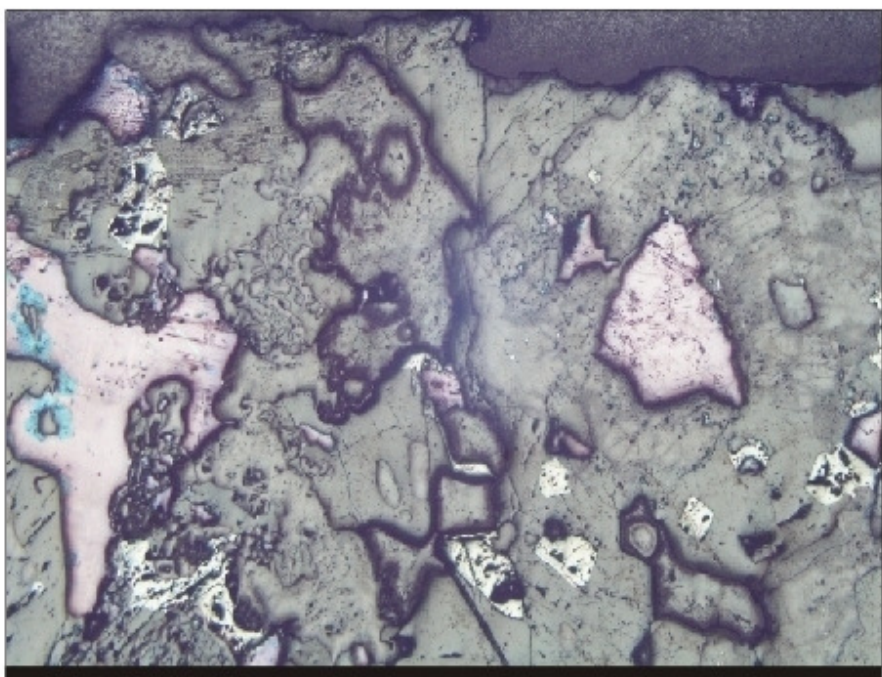

Fotomicrografia 55: Enclave bandado visto sob luz refletida. Presença de cristais bem desenvolvidos de bornita, com núcleos de calcosina e magnetita. Lado maior da foto $8,32 \mathrm{~mm}$.

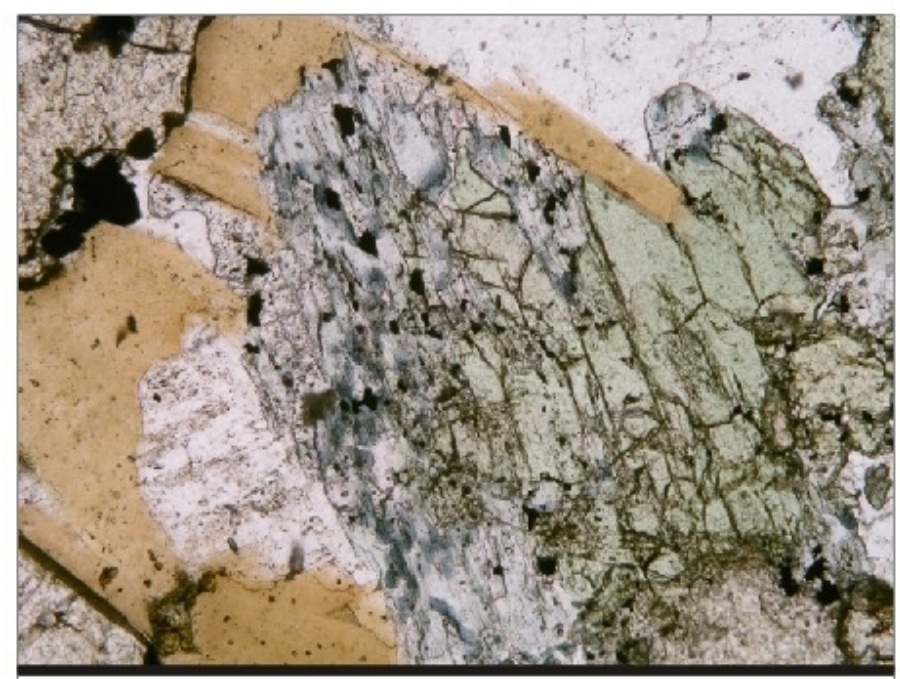

Fotomicrografia 57: Anfibólio azul e carbonato tardios associados à alteração do clinopiroxênio. Lado maior da foto $3,25 \mathrm{~mm}$.

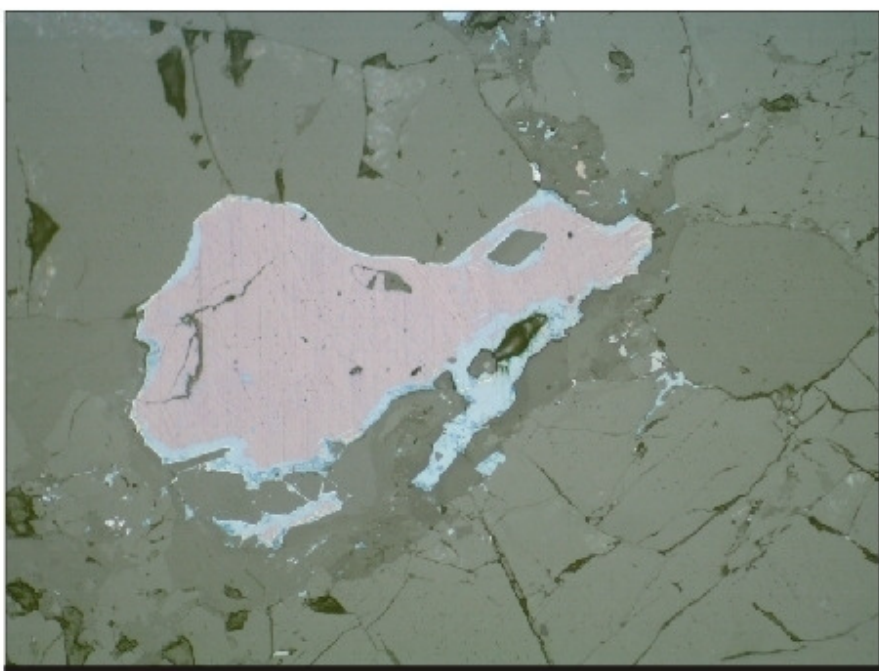

Fotomicrografia 59: Cristal de bornita (rósea) com bordas de calcosina (tom de azul) e galena (fina borda cinza) vistos à luz refletida. Lado maior da foto $1,3 \mathrm{~mm}$. 


\section{IV.2. QUÍMICA MINERAL}

Análises químicas de feldspato alcalino, piroxênio, anfibólio, biotita e minerais opacos dos sienitos do plúton, e de plagioclásio encontrados em sienitos e enclaves foram obtidas através de microssonda eletrônica. Os resultados obtidos estão descritos nos itens a seguir.

Os resultados analíticos $\mathrm{e}$ as respectivas fórmulas estruturais encontram-se no anexo II (Tabela 1: Feldspatos; Tabela 2: Piroxênio; Tabela 3: Anfibólio; Tabela 4: Biotita; Tabela 5: Óxidos de Fe-Ti).

\section{IV.2.1. Feldspato Alcalino e Plagioclásio}

O feldspato alcalino é mineral mais abundante em todas as variedades sieníticas do plúton, e suas características químicas refletem diretamente a assinatura geoquímica do Sienito Pedra Branca. O plagioclásio ocorre apenas como cristais corroídos nas unidades supersaturadas ou em enclaves microgranulares (também exclusivos das unidades supersaturadas).

Os cristais em todas as amostras analisadas são heterogêneos e possuem grande quantidade de inclusões e, em geral, são pertíticos; todas estas características dificultam o processo analítico. Parte das variações encontradas nos cristais são secundárias, devido a exsolução, já que são comuns diferentes proporções de lamelas em núcleos e bordas dos cristais, no entanto esses contrastes evidenciam também diferenças composicionais primárias (como maior e menor conteúdo de $\mathrm{CaO}$, por exemplo).

As análises WDS em feldspato alcalino foram realizadas em áreas mais homogêneas possíveis, com feixes de $20 \mu \mathrm{m}$ visando obter a composição geral do cristal (hospedeiro + lamela). Além disso, também foram feitas médias e desvio padrão dos valores obtidos em diversas análises em áreas opticamente semelhantes com objetivo de estimar a composição inicial dos cristais.

Os cristais de plagioclásio são mais homogêneos, assim as análises em foram realizadas com feixes de $5 \mu \mathrm{m}$ em áreas mais límpidas possíveis e não houve necessidade de médias. 


\begin{tabular}{|ccc|}
\hline \multicolumn{3}{|c|}{ Plagioclásio } \\
PB-5A e PB-229 & PB-247A e PB-229 \\
$\circ \quad$ Borda & $\Delta$ & Borda \\
$-\quad$ Núcleo & $\Delta$ & Núcleo \\
\hline
\end{tabular}

\begin{tabular}{|c|c|c|c|c|c|}
\hline \multicolumn{6}{|c|}{ Feldspato Alcalino } \\
\hline \multicolumn{2}{|r|}{ SLSI } & \multicolumn{4}{|c|}{ SLS } \\
\hline \multirow{3}{*}{$\begin{array}{l}+ \\
0\end{array}$} & \multirow{2}{*}{ PB-38 } & \multicolumn{2}{|r|}{$\square$} & \multicolumn{2}{|c|}{ PB-123 } \\
\hline & & \multicolumn{2}{|c|}{ PB-5A } & \multicolumn{2}{|c|}{ PB-185A } \\
\hline & PB-8D & 4 & Borda & $\nabla$ & Borda \\
\hline$\Delta$ & PB-92A & 4 & Núcleo & $\nabla$ & Núcleo \\
\hline \multicolumn{2}{|c|}{ PB-47B } & \multicolumn{2}{|c|}{ PB-190A } & \multicolumn{2}{|c|}{ PB-229 } \\
\hline o & $\begin{array}{l}\text { Borda } \\
\text { Núcleo }\end{array}$ & $D$ & $\begin{array}{l}-190 A \\
\text { Borda } \\
\text { Núcleo }\end{array}$ & $\diamond$ & $\begin{array}{l}\text { Borda } \\
\text { Núcleo }\end{array}$ \\
\hline
\end{tabular}

Figura 14: Simbologia utilizada para feldspato alcalino e plagioclásio analisados em amostras do Sienito Pedra Branca.

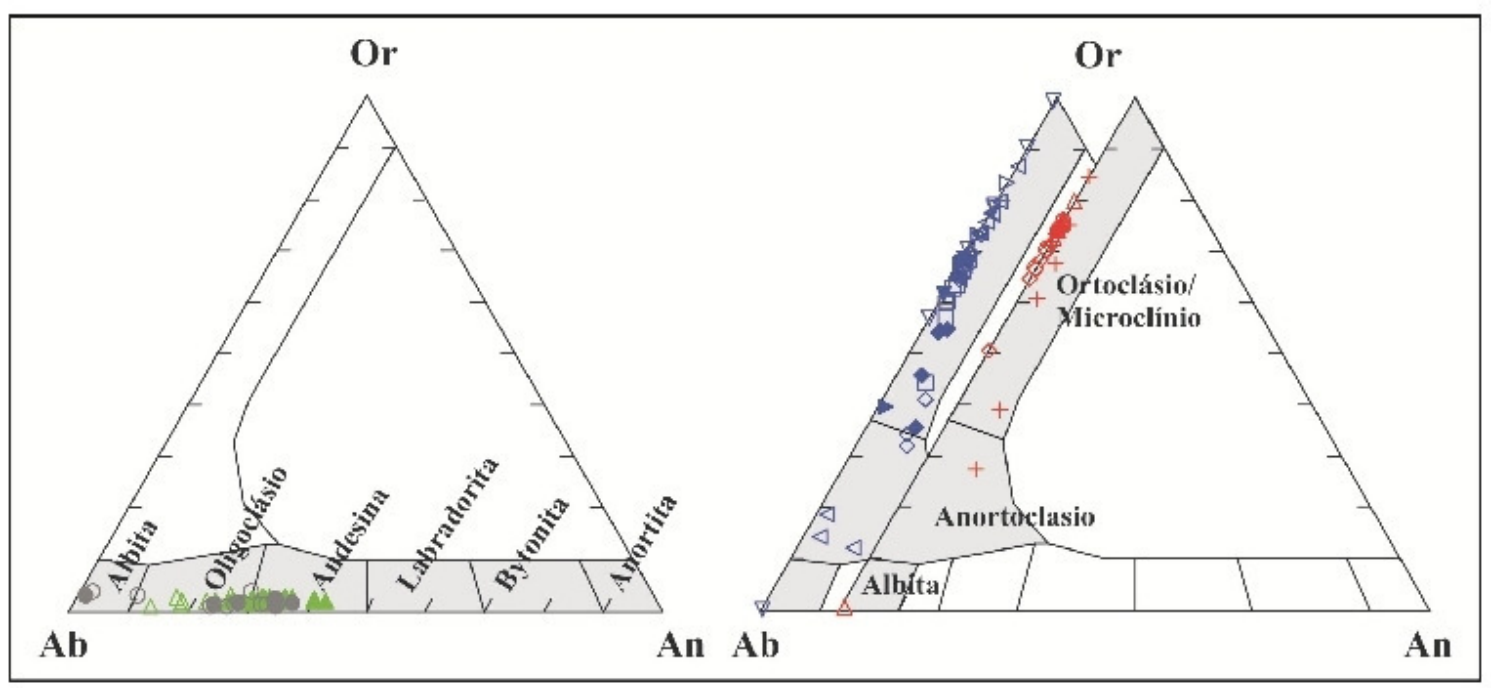

Figura 15: Diagrama classificatório dos Feldspatos do Sienito Pedra Branca. À esquerda (com símbolos em cinza e verde) estão as amostras de plagioclásio de enclaves e cristais corroídos encontrados na SLS. À direita (com símbolos em azul - SLS - e vermelho - SLSI) estão as amostras de feldspato alcalino.A simbologia utilizada encontra-se na figura 14.

O feldspato alcalino do SLSI em geral pode ser descrito apenas pelas moléculas de $\mathrm{K}(\mathrm{Or})$ e $\mathrm{Na}(\mathrm{Ab})$ (Figura 15), já que na maioria das amostras o membrofinal cálcico An é igual a zero; a composição dos cristais varia entre $A b_{15-70} A n_{0-9} \mathrm{Or}_{85-30}$. Uma das análises demonstrou a presença de albita intersticial $\mathrm{Ab}_{99} \mathrm{Or}_{1}$.

Zoneamentos composicionais raramente são observados na petrografia, e estão ligados à presença de maiores proporções do membro sódico (albita) nas bordas, enquanto os núcleos apresentam maiores proporções de $\mathrm{K}$ que se refletem em um aumento no conteúdo da molécula Or. As variações composicionais em cristais 
de feldspato alcalino da Figura 16 são muito sutis e podem estar dentro do erro gerado nas médias.

No feldspato alcalino desta unidade $\mathrm{CaO}$ é pouco abundante, na maioria dos pontos analisados é igual a zero, podendo atingir no máximo 1,84.\%. O $\mathrm{BaO}$ varia de 0 a $2,26 \%$, enquanto o SrO tem valor mínimo de $0,35 \%$ e máximo de $0,6 . \%$.
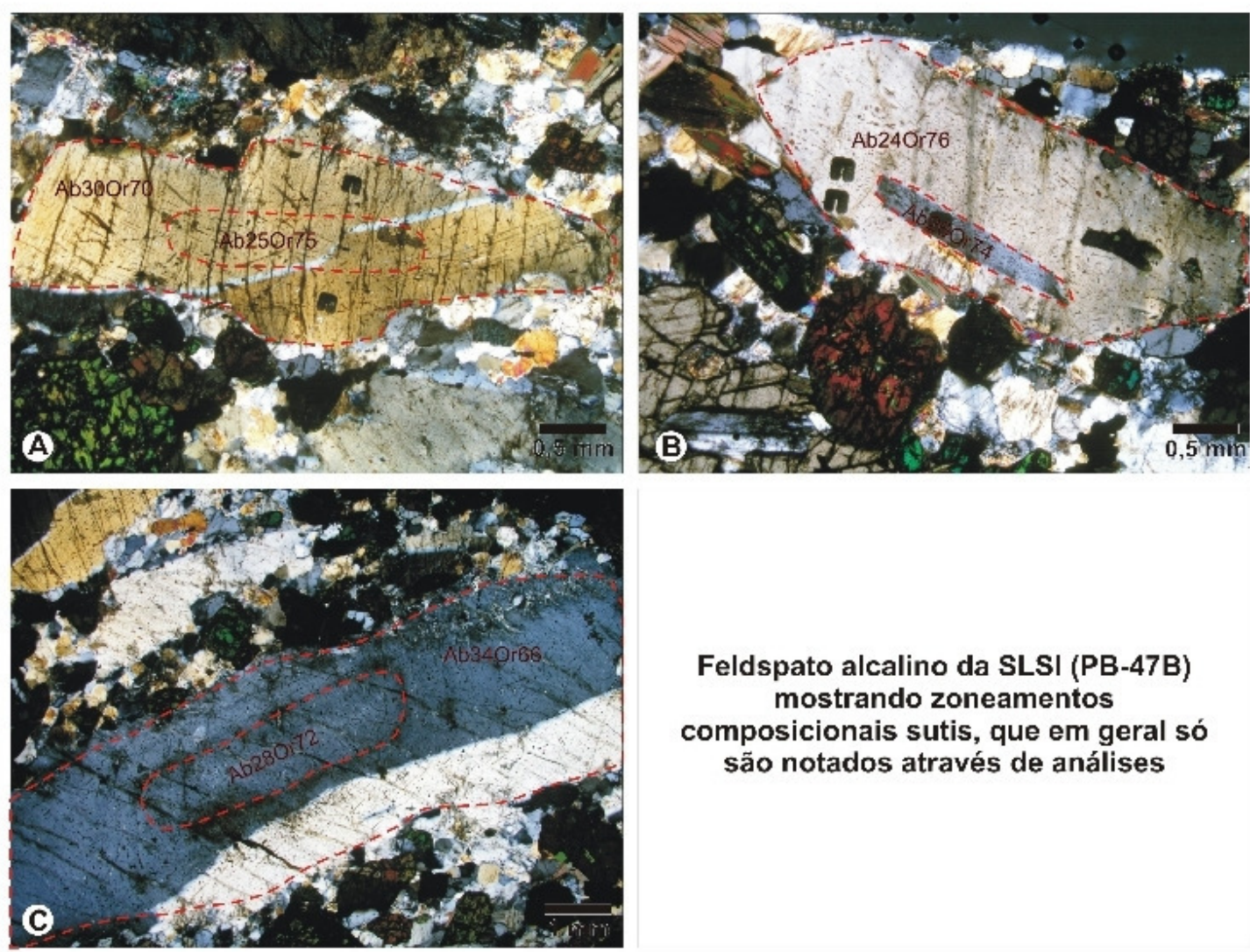

Feldspato alcalino da SLSI (PB-47B) mostrando zoneamentos composicionais sutis, que em geral só são notados através de análises

Figura 16: Fotomicrografias de feldspato alcalino, sob polarizadores cruzados, da unidade SLSI com indicação das proporções das moléculas Or e Ab, obtidas por microssonda eletrônica.

Embora, opticamente os cristais de feldspato alcalino da unidade SLS sejam intensamente pertíticos se comparados aos da SLSI (Figura 17), eles também possuem An igual a zero na maioria das amostras e sua composição varia no intervalo $A b_{15-99} A_{n_{0-9}} \mathrm{Or}_{1-99}$, ou seja muito similar a SLSI (Figura 16). Alguns cristais intersticiais analisados apresentam composições mais sódicas com $A b_{82-99} A_{n_{0-9}} \mathrm{Or}_{1-14}$.

$\mathrm{O}$ conteúdo de $\mathrm{CaO}$ varia de $\mathrm{O}$ a $2,01 \%$, enquanto valores de $\mathrm{Sr}$ e $\mathrm{Ba}$ são surpreendentemente altos, com $\mathrm{SrO}$ entre 0,05 a 0,79\% e de $\mathrm{BaO}$ de 0 a 3,5\%. 
Os zoneamentos composicionais evidenciados por variações na proporção de lamelas de exsolução observados nas seções delgadas devem-se a diferenças no conteúdo das moléculas de albita e anortita. No caso de porções mais pertíticas ocorre um aumento no teor de $\mathrm{Ab}$ e An, enquanto as porções mais homogêneas apresentam composições mais potássicas (maiores proporções da molécula Or). Na figura 17 (C), o feldspato alcalino apresenta um núcleo pertítico $\left(\mathrm{Ab}_{49} \mathrm{Or}_{45}\right)$ e bordas homogêneas mais ricas no membro ortoclásio $\left(\mathrm{Ab}_{34} \mathrm{Or}_{65}\right)$.

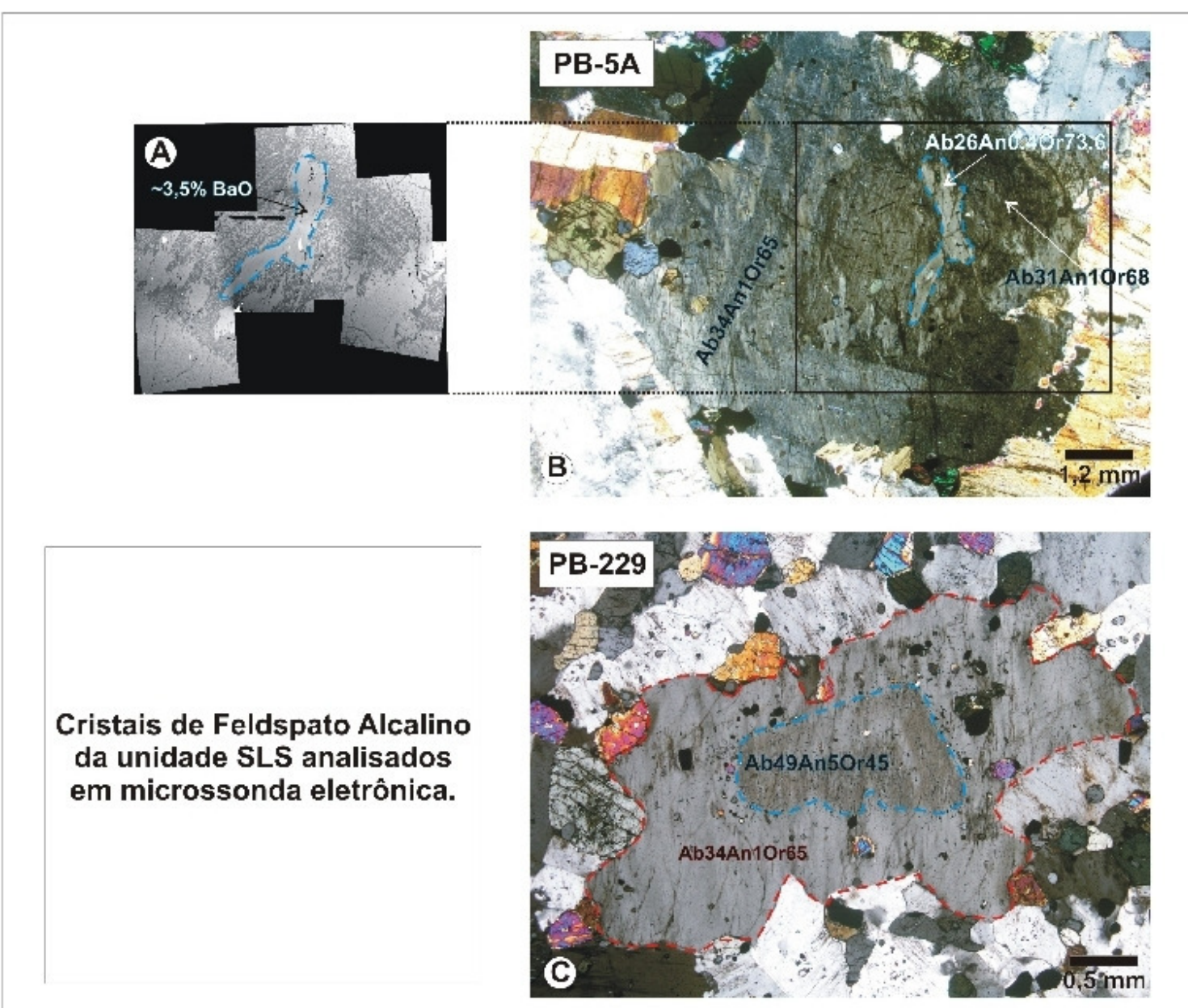

Figura 17: A) Imagem de elétrons retro-espalhados em feldspato alcalino; áreas em tons de cinza claro são ricas em $\mathrm{Ba}$. B, C) Fotomicrografias de feldspato alcalino, sob polarizadores cruzados, da unidade SLS com indicação das proporções das moléculas Or e Ab, obtidas por microssonda eletrônica.

Nos feldspatos alcalinos das duas unidades sieníticas (SLSI e SLS), a troca catiônica simples $\mathrm{K}^{+} \leftrightarrow \mathrm{Na}^{+}$e acoplada $\mathrm{Ca}^{2+}+\mathrm{Al}^{3+} \leftrightarrow \mathrm{K}^{+}+\mathrm{Si}^{4+}$ são responsáveis pelas variações composicionais. A maioria das amostras apresenta baixos conteúdos de 
$\mathrm{CaO}$ e valores consideráveis de $\mathrm{BaO}$ e $\mathrm{SrO}$, com isso o $\mathrm{Ca}^{2+}$ da troca acoplada deve dar lugar ao $\mathrm{Ba}^{2+}$ e/ou $\mathrm{Sr}^{2+}$.

Algumas análises (amostras PB-5A e PB-190A) evidenciaram que o feldspato alcalino dos SLS pode apresentar conteúdos de Ba muito altos ( $3.5 \%)$, o que evidencia a presença de hialofano (membro intermediário da série Ortoclásio-Celsiana - $\mathrm{BaAl}_{2} \mathrm{Si}_{2} \mathrm{O}_{8}$ ) em alguns cristais. $\mathrm{Na}$ Figura $17 \mathrm{~A}$, imagem de elétrons retroespalhados, os locais do cristal em tons de cinza claro apresentam entre 2.5 e $3.5 \%$. de $\mathrm{BaO}$. Nesta amostra alguns cristais de feldspato alcalino possuem zoneamentos marcados por diferenças no conteúdo de Ba.

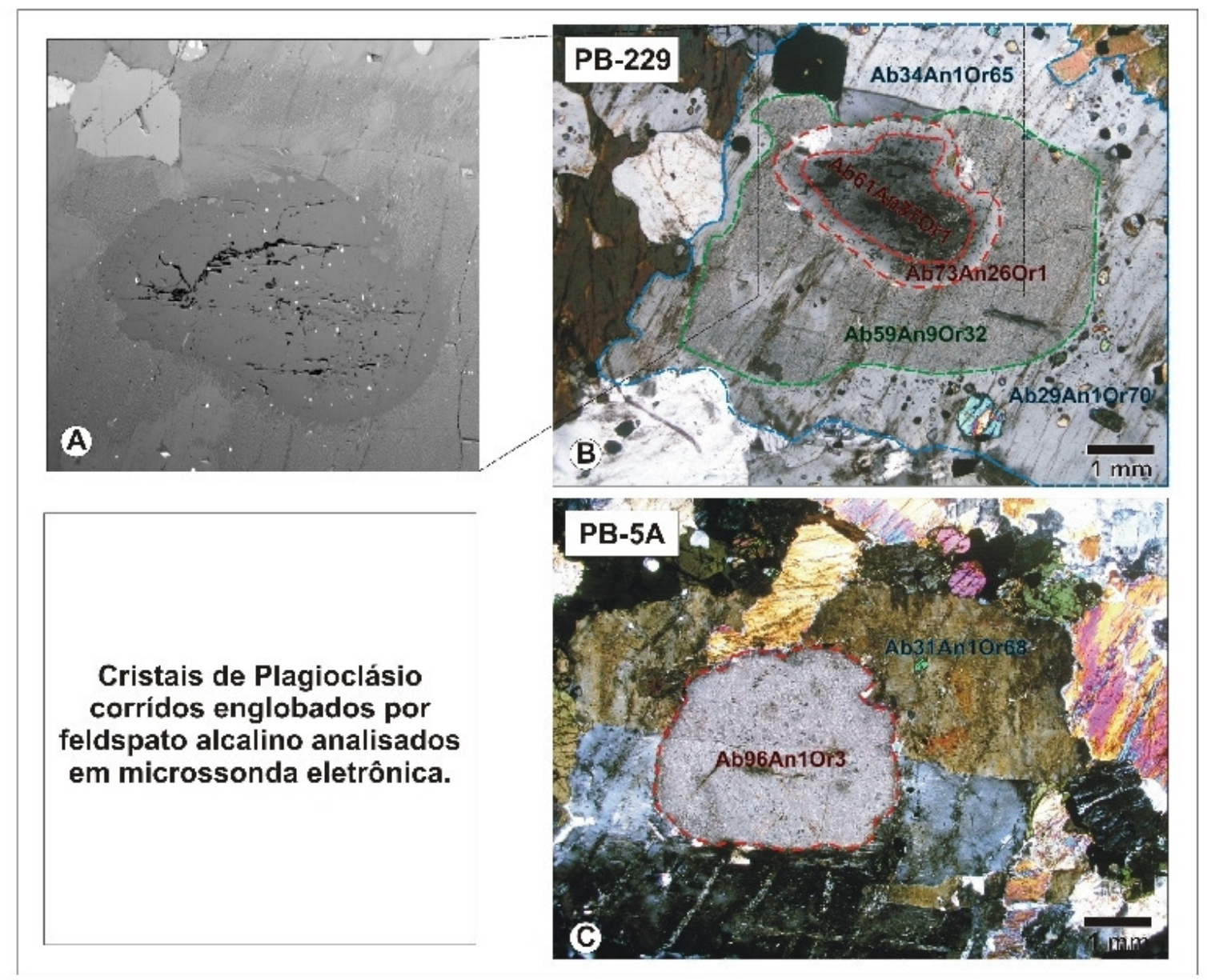

Figura 18: A) Imagem de elétrons retro-espalhados de cristais de plagioclásio $B$ )

Fotomicrografias de plagioclásio inclusos feldspato alcalino, sob polarizadores cruzados, da unidade SLS com indicação das proporções das moléculas An, Or e Ab, obtidas por microssonda eletrônica.

Dados composicionais de cristais corroídos de plagioclásio (Figura 18) encontrados em amostras de sienito da unidade SLS, além de cristais de plagioclásio 
presente em enclaves também mostraram características composicionais similares entre si.

Os cristais de plagioclásio apresentam núcleos mais cálcicos e bordas mais sódicas, e as composições variam no intervalo $A b_{61-90} A n_{1-37} \mathrm{Or}_{1-5}$. Dois dos cristais corroídos analisados apresentam composição essencialmente sódica, e foram classificados como $\mathrm{Ab}_{98} \mathrm{An}_{1} \mathrm{Or}_{1}$.

Os valores de $\mathrm{K}_{2} \mathrm{O}$ nestes cristais restringem-se ao intervalo 0,17 a $0,68 \%$, enquanto $\mathrm{BaO}$ varia de 0 a $0,22 \%$ e $\mathrm{SrO} 0,46$ a $0,69 \%$.

Nos cristais de plagioclásio presentes nos enclaves a composição dos cristais varia no intervalo $A b_{55-86} A_{n_{13-24}} \mathrm{Or}_{1-3}$. O conteúdo de $\mathrm{SrO}$ variam de 0,64 a 1,27\%, já os teores de $\mathrm{BaO}$ e $\mathrm{K}_{2} \mathrm{O}$ são restritos, respectivamente, 0 a 0,2.\% e 0,2 a 0,57.\%.

\section{IV.2.2. Piroxênio}

Análises químicas pontuais obtidas por microssonda eletrônica em amostras das diferentes unidades do plúton evidenciam contrastes composicionais entre os piroxênios dos sienitos. Os dados estão representados no Anexo II, Tabela 2.

Como já mencionado, os clinopiroxênios apresentam cores distintas (Figura 19), onde nos SLSI apresentam cor ver intenso enquanto nas unidades supersaturados variam de incolor a verde claro. O ortopiroxênio dos SSI ocorre como cristais granulares, cor marrom claro.

Zoneamentos composicionais são raros, mas nos SLSI heterogeneidades entre borda e núcleo são observadas e estão associadas a maiores proporções da molécula acmita nas bordas (Figura 19 - amostra PB-47B).

A tendência alcalina da unidade SLSI é claramente evidenciada pelo piroxênio, que tem composições mais sódicas, diferentemente das outras unidades do plúton onde as composições são mais cálcicas (Figura 21). Os conteúdos de $\mathrm{Na}_{2} \mathrm{O}$ variam de 1,2 a $4,2 \%$ (cerca de 0,33 de $\mathrm{Na}$ p.f.u.) nos SLSI, enquanto nas outras unidades supersaturadas os teores situam-se no intervalo entre de 0-2,3\% (cerca de 0,16 p.f.u).

O diagrama Wo-En-Fs (Morimoto, 1988) mostra que nos sienitos supersaturados o piroxênio tem composições mais cálcicas e situa-se no campo do diopsídio, enquanto os de SLSI são mais sódicos, e contêm maiores proporções do de acmita em sua composição.

O piroxênio dos SLSI classifica-se como augita a egirina augita, e compreende um intervalo composicional $\mathrm{Eg}_{0-31} \mathrm{Jd}_{0-7} \mathrm{WEF}_{68-91} \quad(\mathrm{WEF}=$ somatória das moléculas 
wollastonita, enstatita e ferrosilita), enquanto os piroxênios das unidades SLS e SSE são classificados como diopsídio com intervalo composicional de $\mathrm{Wo}_{44-47} \mathrm{En}_{33-38} \mathrm{Fs}_{15-20}$. A amostra PB-59 apresenta dois piroxênios, um deles classificado como diopsídio $\left(\mathrm{Wo}_{45} \mathrm{En}_{37} \mathrm{Fs}_{16}\right)$ e o outro enstatita $\left(\mathrm{Wo}_{1} \mathrm{En}_{60} \mathrm{Fs}_{30}\right)$.

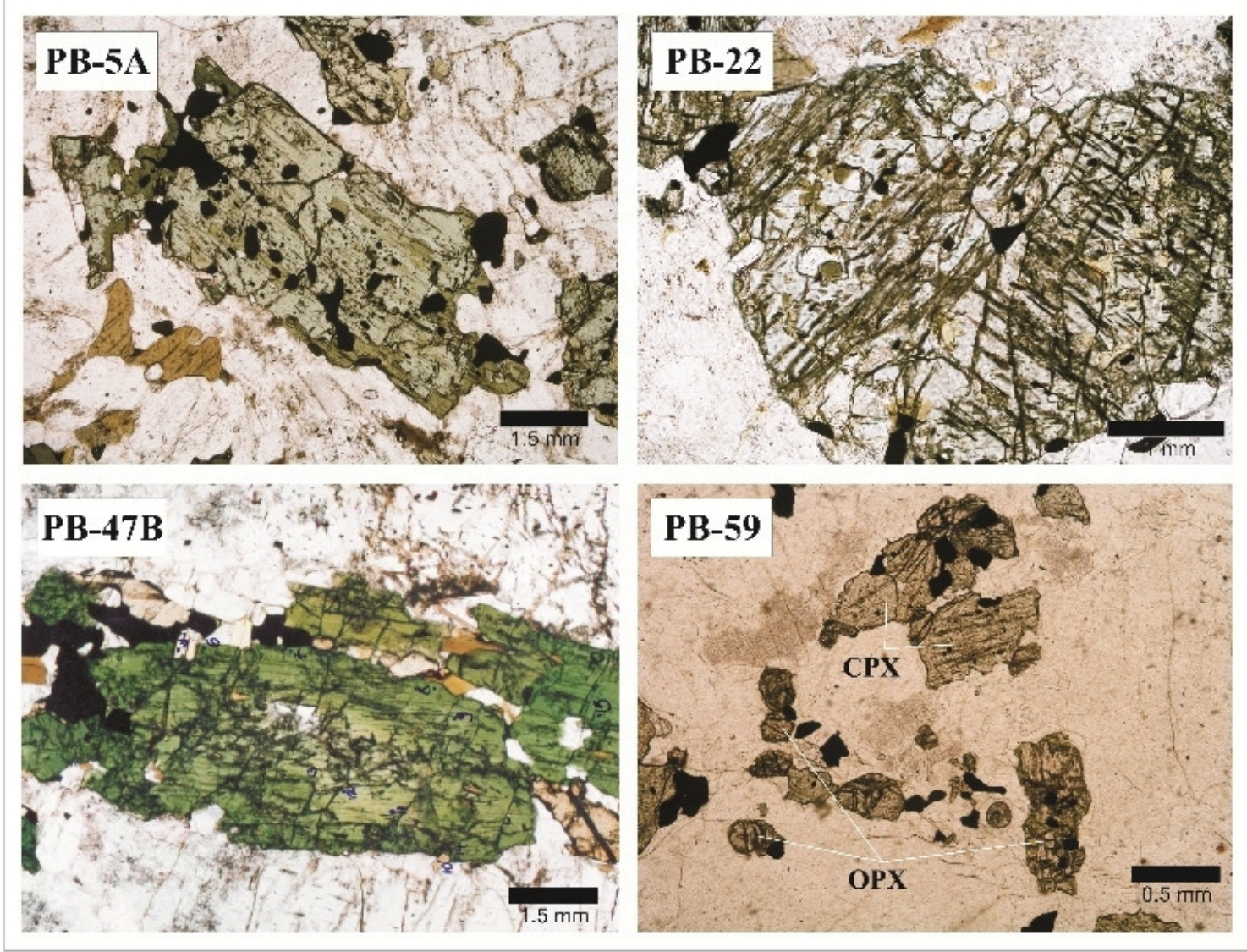

Figura 19: Cristais de piroxênio das diferentes unidades sieníticas.

\begin{tabular}{|c|c|c|c|c|c|c|c|}
\hline & \multicolumn{7}{|c|}{ Piroxênio } \\
\hline & SLSI & & SLS & & SSI & & SE \\
\hline$\theta$ & PB-2 & & & & & & \\
\hline$\triangleright$ & PB-36C & & & & & & \\
\hline+ & PB-38 & $\triangleleft$ & PB-5A & & & & \\
\hline$\diamond$ & PB-42A & $\nabla$ & PB-185A & घ & PB-59 & $\bullet$ & PB-22 \\
\hline o & PB-47B & $\triangle$ & PB-185C & & & & \\
\hline$\Delta$ & PB-48 & & & & & & \\
\hline • & PB-52 & & & & & & \\
\hline
\end{tabular}

Figura 20: Simbologia utilizada para cristais de piroxênio das amostras do Sienito Pedra Branca. 
Os conteúdos de Ti são baixos, cerca de 0,004 a 0,021 p.f.u.; os teores de $\mathrm{Ni}$, $\mathrm{Cr}$ e $\mathrm{Zr}$ raramente ocorrem acima do limite de detecção.
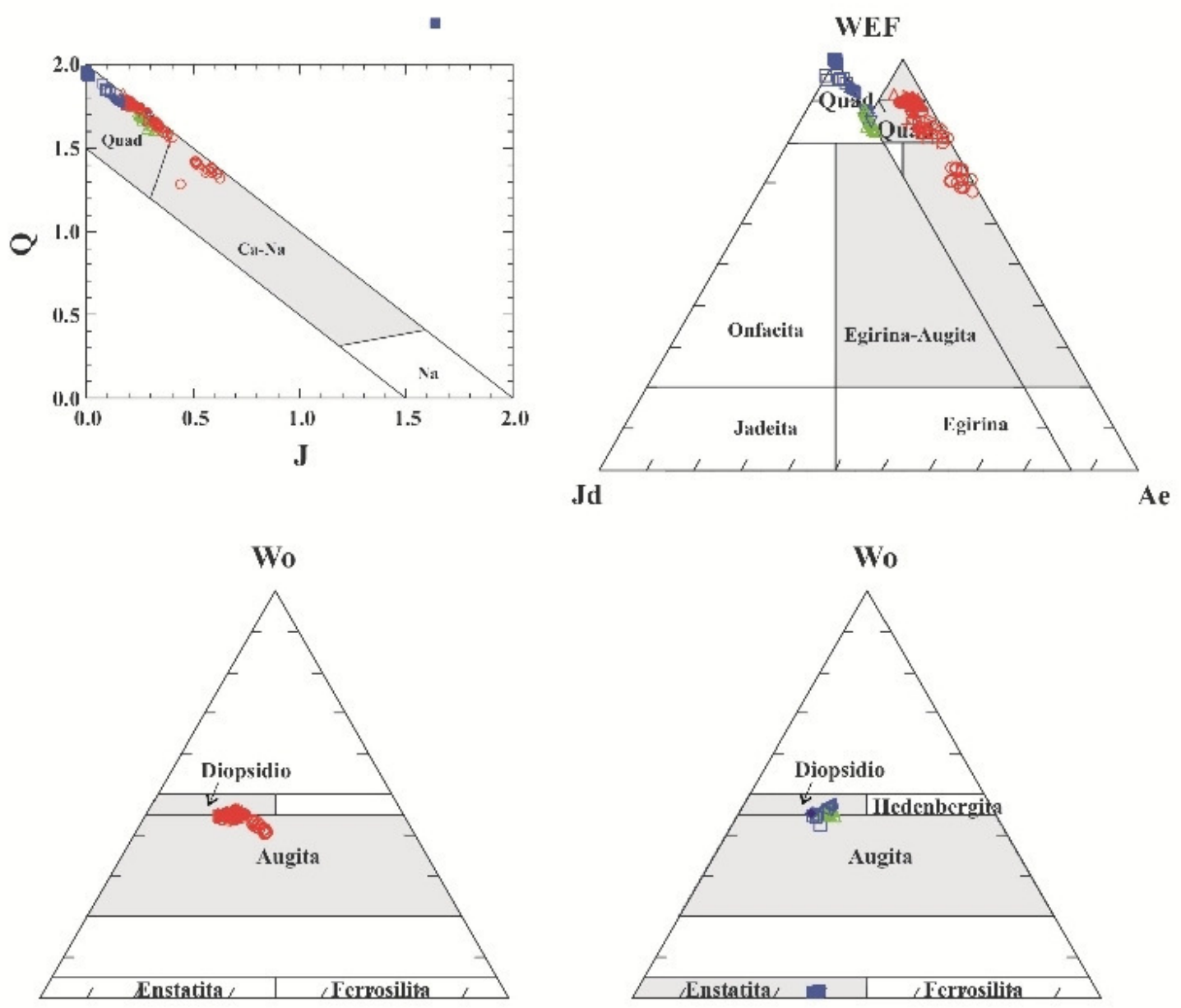

En

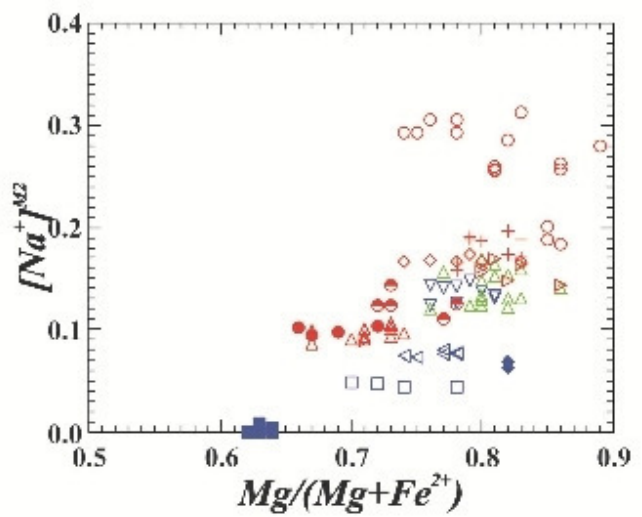

Fs
Fs

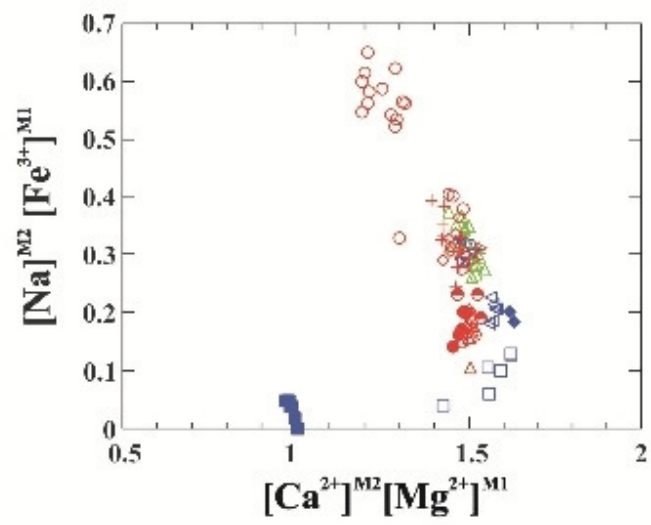

Figura 21: Diagramas de variação química dos piroxênios do Sienito Pedra Branca; diagramas classificatórios segundo Morimoto (1988). Simbologia como na figura 20.

O diagrama $\left[\mathrm{Na}^{+}\right]^{\mathrm{M} 2}$ vs. $\mathrm{Mg \#}\left(\mathrm{Mg} /\left(\mathrm{Mg}+\mathrm{Fe}_{\text {total }}\right)\right)$ (Figura 21) demonstra que os piroxênios mais sódicos possuem mesmo intervalo de $\mathrm{Mg} \#$ que os piroxênios das 
unidades supersaturadas. Os diversos cristais analisados possuem $\mathrm{Mg} \#=65-88$, exceto ortopiroxênio enstatita da amostra PB-59 na qual o Mg\# é inferior e varia de 61 a 65. O piroxênio do enclave ultramáfico (PB-185C) tem Mg\# similar ao do piroxênio do sienito hospedeiro (SLS) ( 75-85), indicando que esta amostra pode tratar-se de um cumulato ultramáfico.

A seguinte troca catiônica acoplada parece ser a mais adequada para representar as variações composicionais dos piroxênios estudados:

$$
\left[\mathrm{Na}^{+}\right]^{\mathrm{M} 2}\left[\mathrm{Fe}^{3+} ; \mathrm{Al}^{3+}\right]^{\mathrm{M} 1} \leftrightarrow\left[\mathrm{Ca}^{2+}\right]^{\mathrm{M} 2}\left[\mathrm{Mg}^{2+} ; \mathrm{Fe}^{2+}\right]^{\mathrm{M} 1}
$$

A correlação negativa entre os termos desta equação na Figura 21 mostra que ela é responsável pelo amplo intervalo composicional observado entre as diferentes unidades sieníticas. É notável que os piroxênios da unidade SLSI admitem maior proporção desta troca, resultando então na presença de egirina-augita.

\section{IV.2.3. Anfibólio}

Análises químicas de anfibólio foram obtidas em apenas quatro amostras representativas das unidades de sienitos laminados, entre elas duas dos SLSI (PB-30 e PB-181A) e duas dos SLS (PB-5A e PB-148). Os resultados das análises estão apresentados no Anexo II, Tabela 3.

$\mathrm{Na}$ unidade SLSI, o anfibólio é verde claro (Figura 22), enquanto nos SLS a cor é verde escuro. Embora na unidade SLSI seja rara a presença de anfibólio, ele pode ocorrer substituindo o piroxênio (e.g. na amostra PB-181A) ou até mesmo aparecer como cristais tardios na matriz (e.g. na amostra PB-30). Já nos SLS o anfibólio substitui o piroxênio parcial (e.g. PB-5A) e em alguns casos totalmente (e.g. PB-148).

Entre os anfibólios analisados observa-se o predomínio do caráter cálcico nas amostras PB-5A, PB-30 e PB-148, enquanto na amostra PB-181A o anfibólio é sódicocálcico (Figura 20; Leake et al., 1997).

$\mathrm{Na}$ amostra PB-181, devido às composições sódico-cálcicas o anfibólio foi classificado como magnésio-katophorita (Figura 23) que possui fórmula estrutural: $\mathrm{Na}(\mathrm{CaNa}) \mathrm{Mg}_{4}\left(\mathrm{Al}, \mathrm{Fe}^{3+}\right) \mathrm{Si}_{7} \mathrm{AlO}_{22}(\mathrm{OH})_{2}$. Já os anfibólios cálcicos foram classificados (Figura 23) como actinolita na amostra PB-30, e nos SLS as composições variam de edenita (PB-5A) a Mg-Hastingsita (PB-148).

As composições do anfibólio da amostra PB-181A são sutilmente mais sódicas se comparadas a SLS, o que fica claro pela diferença no conteúdo de $\mathrm{Na}_{2} \mathrm{O}$, na 
primeira o intervalo entre 2,5 a $4,0 \%$, enquanto nos SLS varia 1,9 a $2,2 \%$. A amostra PB-30 tem o menor conteúdo de $\mathrm{Na}_{2} \mathrm{O}(0,3$ a 2,5 \%).
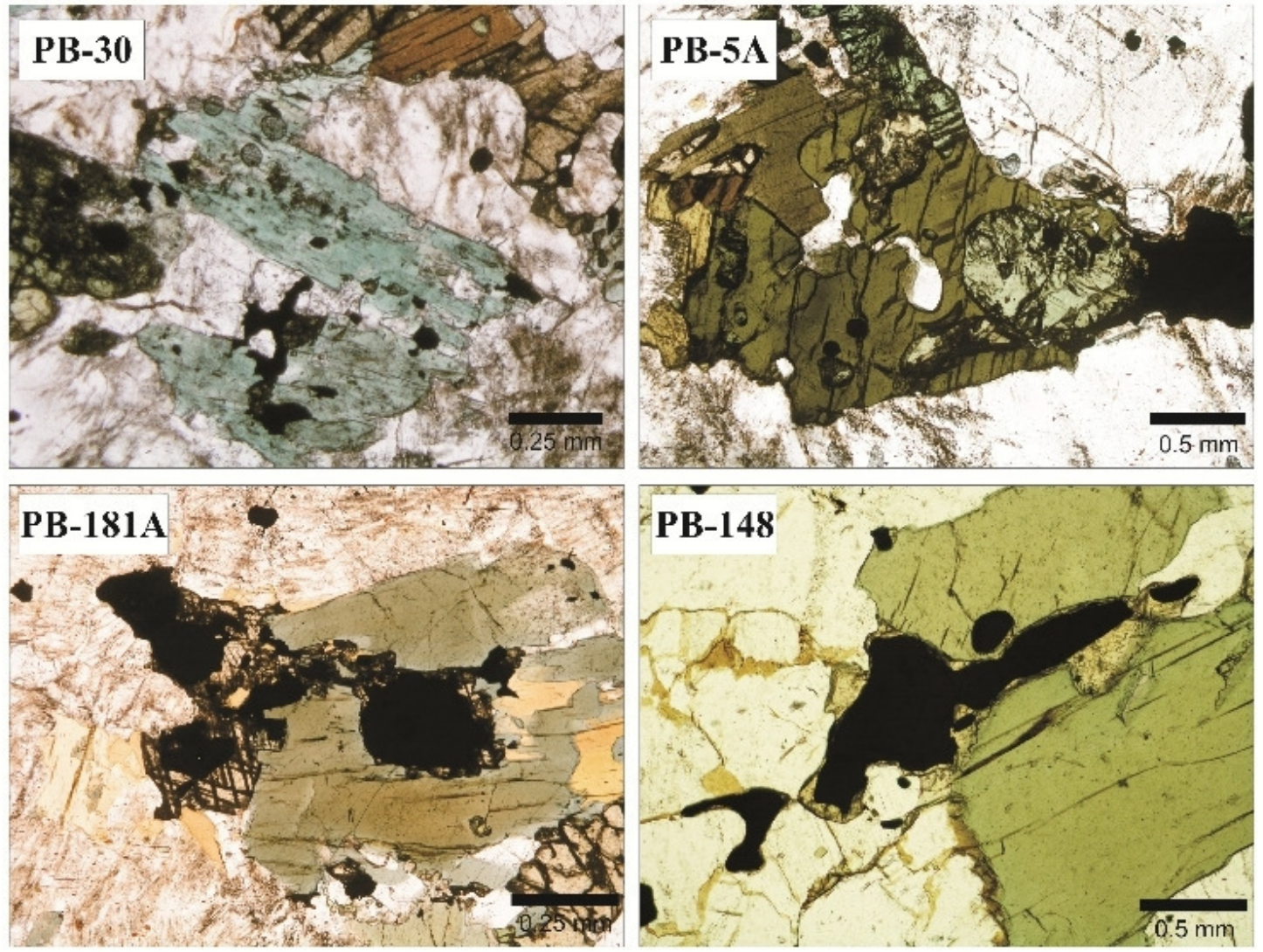

Figura 22: Cristais de anfibólio das unidades SLSI e SLS.

Outra característica química que difere o anfibólio das duas unidades sieníticas é o conteúdo de alumínio, que é maior nas amostras supersaturadas (SLSI: 0,16- 4,51 \% na PB-30 e 4,68-7,7.\% na PB-181A; SLS: 7,65 - 9,22 \%).

As principais variações composicionais dos anfibólios podem ser explicadas pela troca tschermakítica:

\section{$[\mathrm{Si}]^{\top}[\mathrm{AI}]^{\mathrm{C}} \leftrightarrow[\mathrm{AII}]^{\top}[\mathrm{Al}]^{\mathrm{C}}$}

A excelente correlação negativa (Figura 23 , diagrama $\left[\mathrm{Si}^{\top}[\mathrm{Al}]^{\mathrm{C}}\right.$ versus $[\mathrm{Al}]^{\top}[\mathrm{Al}]^{\mathrm{C}}$ ) evidenciada pelos dados obtidos mostra que as variações composicionais dos anfibólios dos SLSI e SLS está associada à saída progressiva do Si do sítio tetraédrico e Mg do sítio octaédrico implica na ocupação de ambos os sítios por Al. Por outro lado nos anfibólios dos SLSI, além da troca tschermakítica, a troca edenítica ([Si] $]^{\top}[]^{A} \leftrightarrow$ 
$\left.[\mathrm{Al}]^{\top}[\mathrm{Na}]^{A}\right)$ também é importante, pois as maiores proporções de Si na estrutura estão associadas aos menores conteúdos de $[\mathrm{Na}]^{\mathrm{A}}$, como na amostra PB-30.
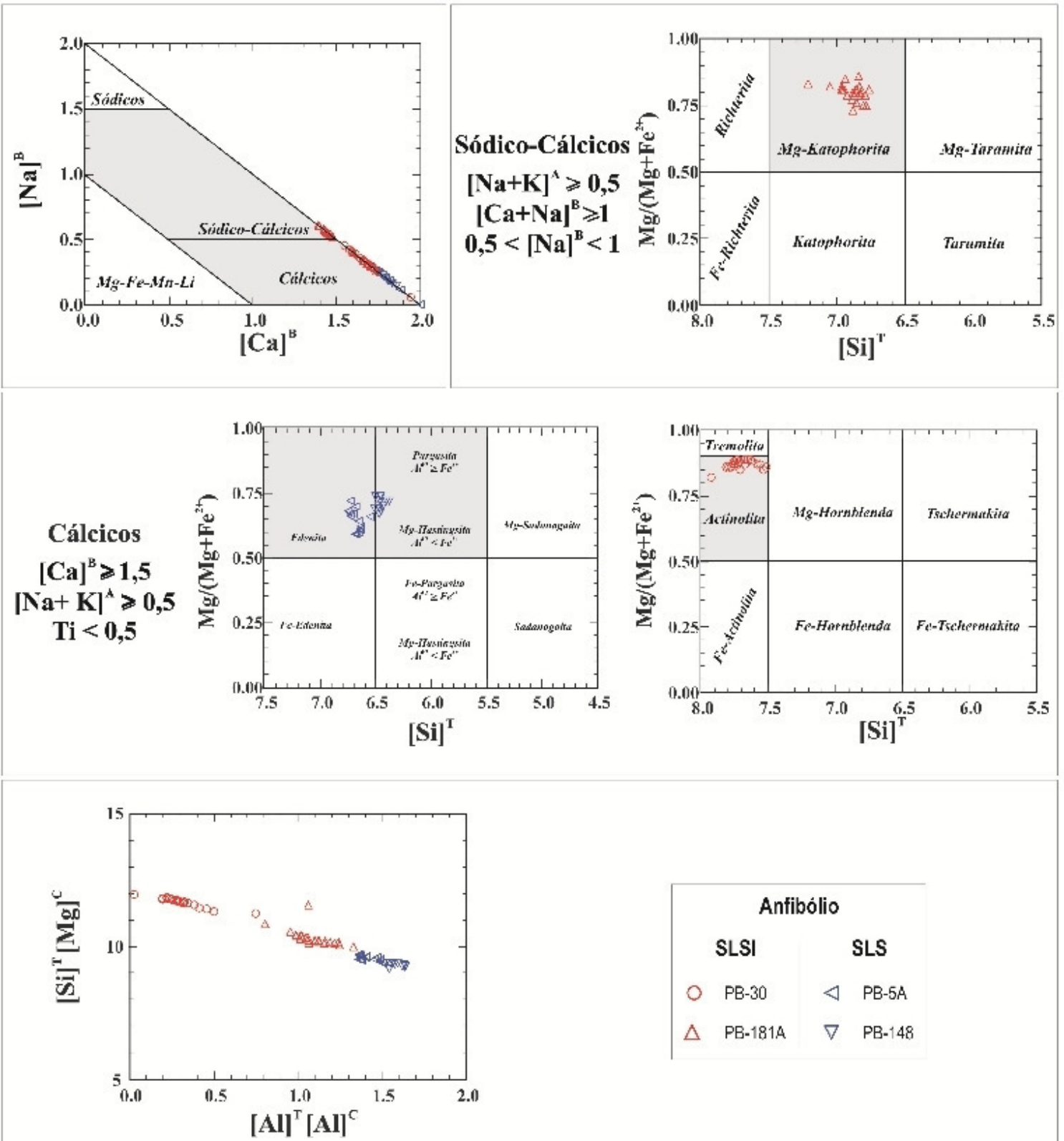

Figura 23: Classificação dos anfibólios do Sienito Pedra Branca, segundo Leake et al., 1997.

\section{IV.2.4. Biotita}

Análises de cristais de biotita das unidades SLSI (Pb-36C, PB-47B e PB-92A), SLS (PB-5A e PB123) e SSE (PB-22) mostraram algumas diferenças composicionais 
entre as variedades sieníticas. Os resultados das análises estão apresentados no anexo II, tabela 4.

Os cristais analisados são ricos em Mg e foram classificados como flogopita (Figura 24; $\mathrm{Al}^{\mathrm{IV}}$ vs. $\mathrm{Fe} /(\mathrm{Fe}+\mathrm{Mg})$ segundo Deer et al., 1992). As unidades supersaturadas apresentam menor Mg\#, porém maior conteúdo de $\mathrm{Al}^{\mathrm{lV}}$.

Além do maior $\mathrm{Al}_{\text {total }}$, as flogopitas das unidades supersaturadas possuem maior conteúdo em $\mathrm{Ti}$ (cerca de 0.3 a 0.45 p.f.u.), enquanto as dos SLSI possuem baixos teores deste elemento (0.10-0.16 p.f.u.), exceto pela amostra PB-36C, cujos teores de Ti se superpõem aos das amostras supersaturadas.

$\mathrm{O}$ diagrama de $\mathrm{Fe}^{2+}$ versus $\mathrm{Mg} /(\mathrm{Mg}+\mathrm{Fe})$ mostra claramente que as amostras dos sienitos supersaturados possuem mais $\mathrm{Fe}^{2+}$ (cerca de 1.25-1.75 p.f.u) que nos SLSI (1.00-1.25 p.f.u), essa característica deve-se às diferente condições de $\mathrm{fO}_{2}$ nas unidades sieníticas. Embora as rochas de todo o plúton tenham cristalizado sob condições oxidantes, os SLSI são relativamente mais oxidados que as outras unidades estudadas, por isso a flogopita é mais magnesiana e admite menor conteúdo de $\mathrm{Fe}^{2+}$ p.f.u.

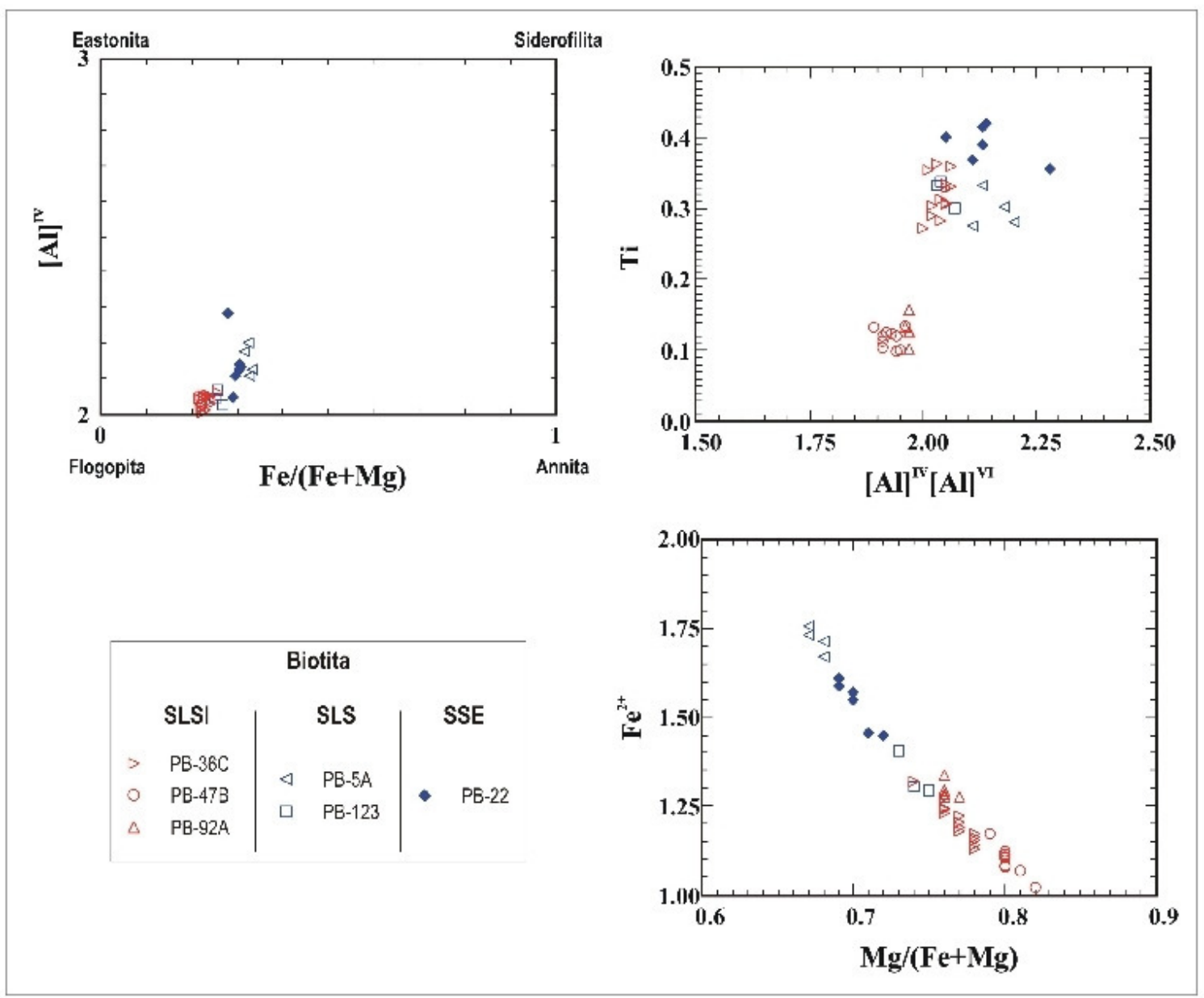

Figura 24: Diagramas de variação química das biotitas do Sienito Pedra Branca. 


\section{IV.2.5. Minerais Opacos}

Os minerais opacos mais abundantes nos sienitos e rochas associadas são os óxidos de $\mathrm{Fe}-\mathrm{Ti}$ (em proporções modais variadas, na maioria dos casos superior a $5 \%$ ) seguidos pelos sulfetos (acessório em grande parte das amostras, inferior a $1 \%$ modal).

\section{Óxidos Fe-Ti}

Os óxidos de $\mathrm{Fe}$ e $\mathrm{Ti}$ são constituintes importantes em todas as variedades sieníticas do plúton, e assim como outros minerais máficos, demonstram as condições de alta fugacidade de oxigênio destas rochas.

Como descrito na petrografia, ocorrem hematita, com proporções variáveis de ilmenita em solução sólida, e magnetita. Na unidade saturada magnetita é abundante e a hematita possui finas lamelas de ilmenita (Figura 25, A), enquanto nas unidades supersaturadas a magnetita raramente ocorre e a hematita possui quantidades significativas de ilmenita (Figura 25, B).
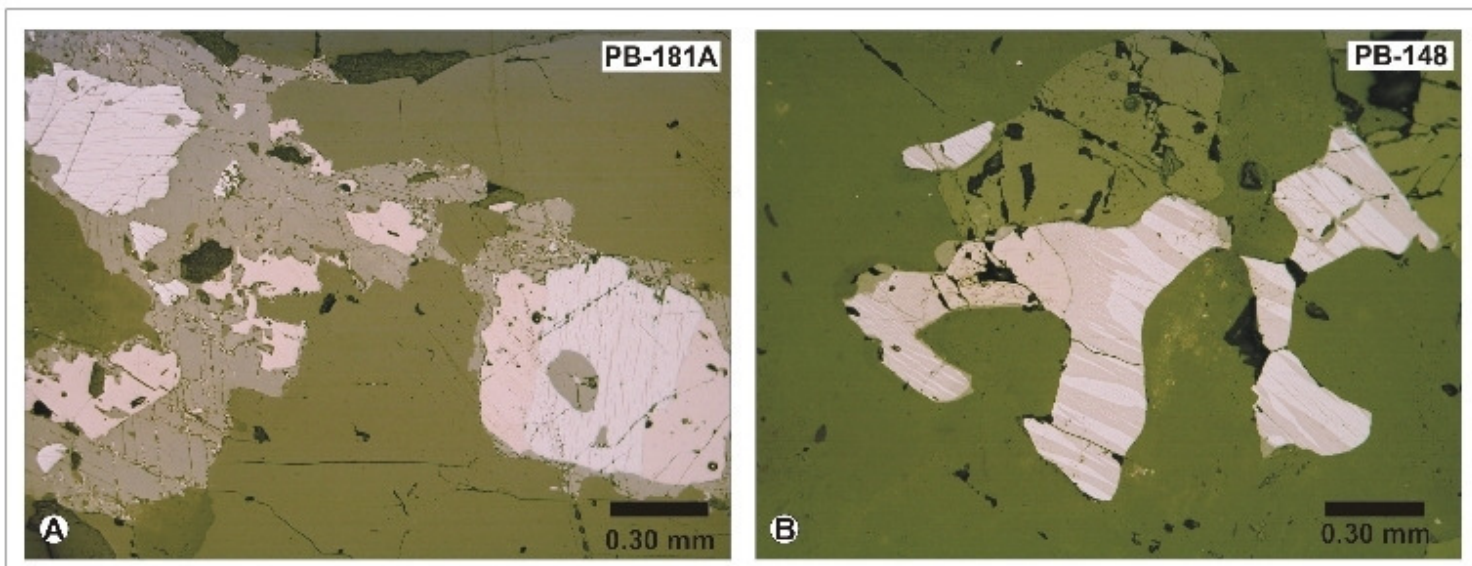

Figura 25: Minerais opacos das unidades SLSI (A) e SLS (B) vistos sob luz refletida.

As inúmeras micro-inclusões aciculares de minerais opacos no feldspato alcalino raramente são identificadas. Análises de EDS demonstraram que grande maioria trata-se de hematita, que deve ser responsável pela cor marrom-arroxeada dos feldspatos (Figura 26).

Segundo a classificação de Buddington \& Lindsley (1964) (Figura 27), a magnetita nas duas unidades estudadas é pobre em $\mathrm{TiO}_{2}$ (0.1 a $\left.0.3 \%\right)$, e nos SLSI é quase pura $\left(\mathrm{Mt}_{99} \mathrm{Usp}_{1}\right)$ enquanto nos SLS as composições abrangem um intervalo um 
pouco maior $\left(\mathrm{Mt}_{93-99} \mathrm{Usp}_{7-1}\right)$; esses baixos conteúdos de Ti são característicos de alta fugacidade de oxigênio.

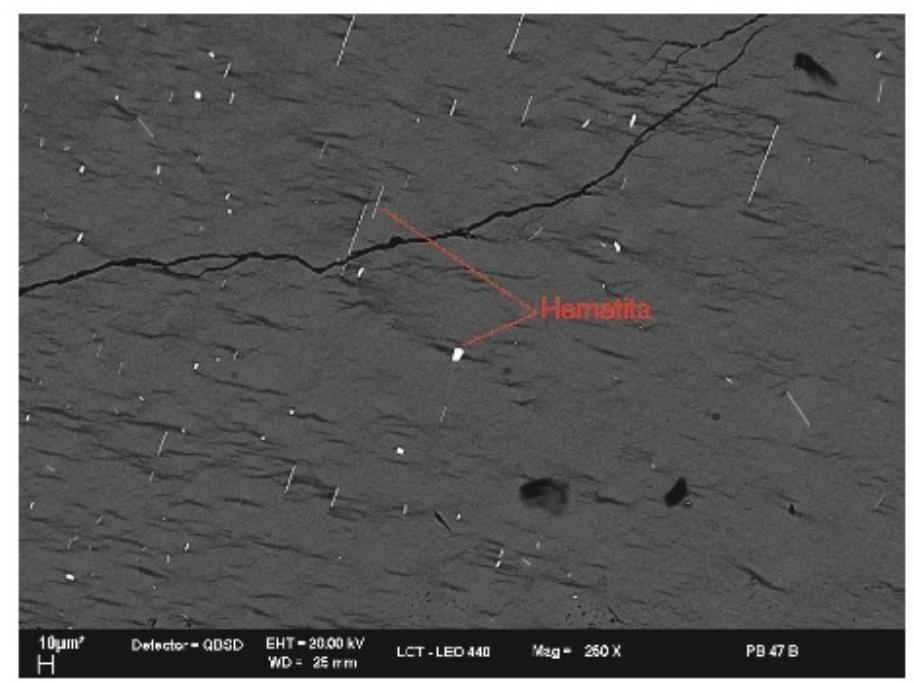

Figura 26: Imagem de elétrons retroespalhados mostrando inclusões aciculares em feldspato alcalino (amostra PB-47B).

A hematita é opticamente distinta nas duas unidades (com lamelas de ilmenita mais abundantes nas supersaturadas), no entanto composicionalmente abrangem um mesmo intervalo $\mathrm{Hem}_{45-55} \mathrm{Im}_{55-45}$ (Figura 27).

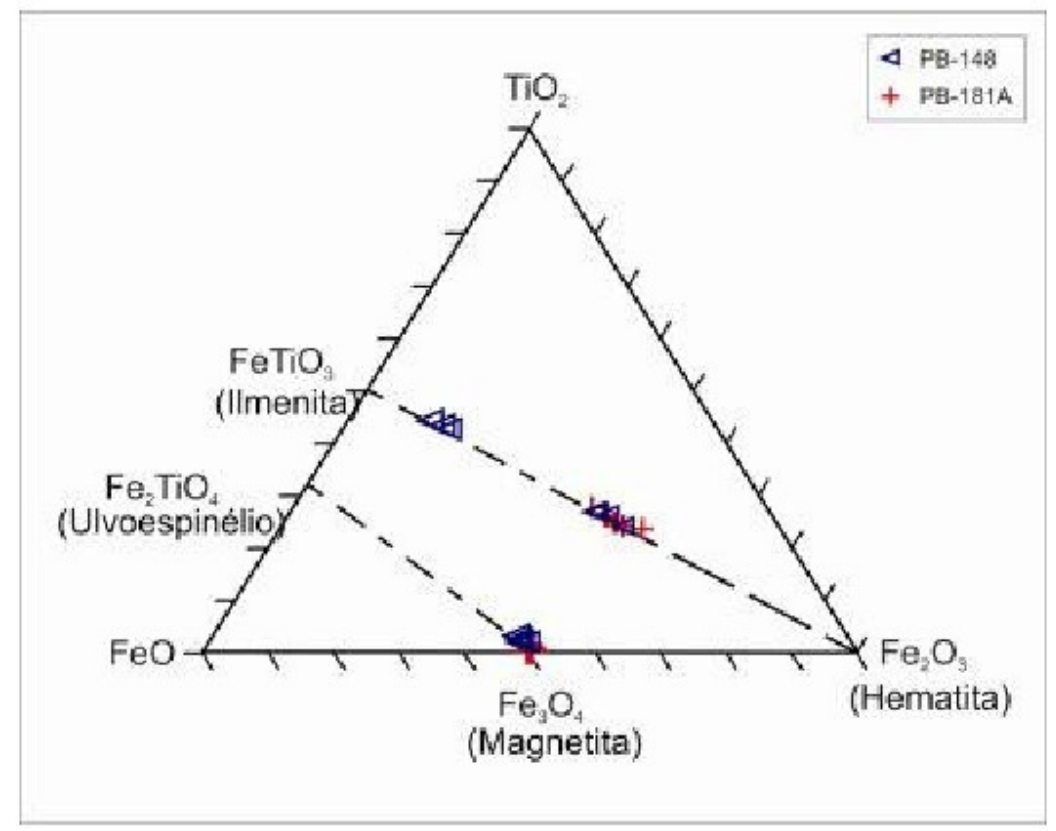

Figura 27: Diagrama ternário de classificação da série magnetita-ülvoespinélio e hematitailmenita (Buddington \& Lindsley, 1964). 
$\mathrm{Na}$ unidade SLS cristais mais ricos no membro ilmenita não são comuns, mas algumas análises sugerem composições originais mais ricas em $\mathrm{Ti}$, como é o caso de um dos cristais na Figura 25 (B) onde a composição é Hem He-18 $_{18} \operatorname{lm}_{87-82}$ (Figura 27). A existência de cristais com maior e menor conteúdo de lamelas esta relacionada com processo de exsolução subsolidus, no entanto também mostram que a composição original destes cristais era algo intermediário entre os dois extremos ( $\left.\mathrm{Hem}_{31} 1 \mathrm{~lm}_{69}\right)$, ou seja, mais pobre no componente hematita se comparada ao SLSI.

\section{Sulfetos}

Alguns sulfetos foram identificados através do estudo de seções polidas, imagens de elétrons retroespalhados e análises químicas semi-quantitativas.

Sulfetos como calcopirita e pirita são comuns na matriz dos sienitos e podem facilmente ser identificados ao microscópio.

Sulfetos são mais comuns em enclaves e podem ocorrer em todos os tipos: sieníticos, dioríticos e ultramáficos.

Um dos enclaves ultramáficos em especial (PB-185C, que possui 8600 ppm de $\mathrm{Cu}$ e $1600 \mathrm{ppm}$ de $\mathrm{Pb}$ ) apresenta grande quantidade de sulfetos, principalmente bornita, com fina bordas de calcosina e galena (Figura 28), e calcopirita.
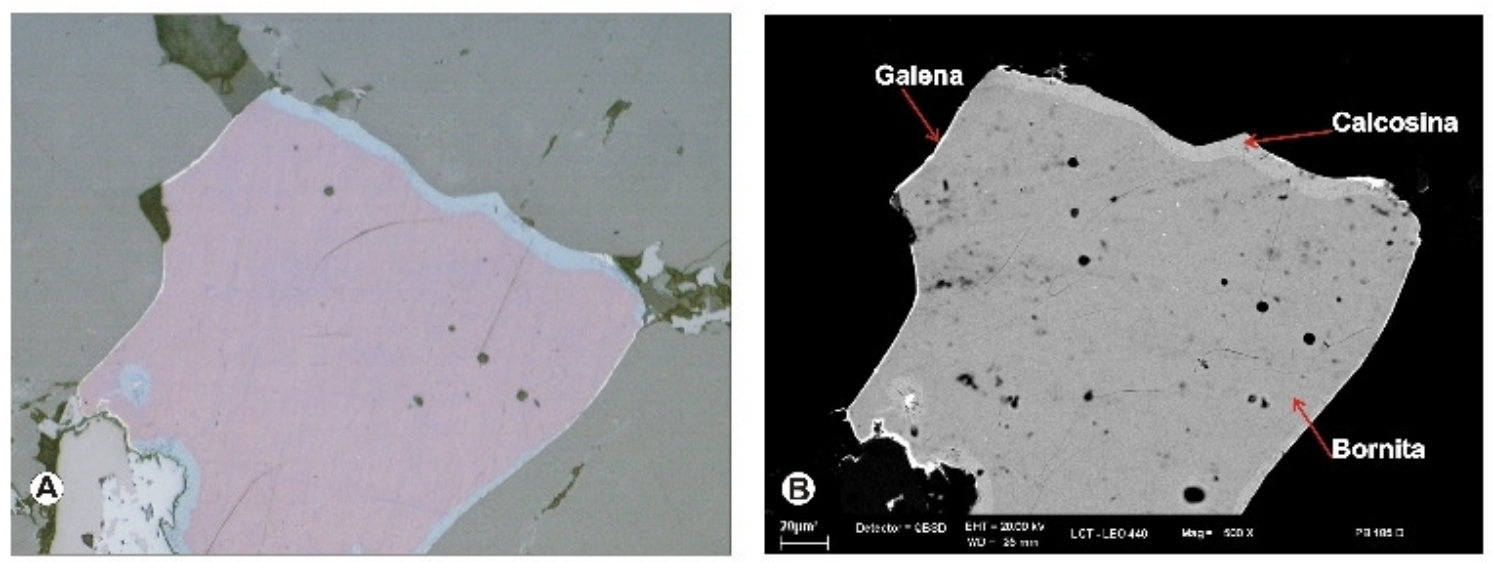

Figura 28: Cristal de bornita com finas bordas de calcosina e galena, vistos em fotomicrografia sob luz refletida $(A)$ e imagem de elétrons retroespalhados (B); amostra PB-185C.

Enclaves dioríticos também podem conter sulfetos, em especial nas amostras PB246B ( 1700 ppm de Cu) onde a calcopirita comumente é encontrada na matriz, e 
na amostra PB-247B, onde ocorrem grandes cristais de bornita com finas bordas de calcosina (Figura 29).
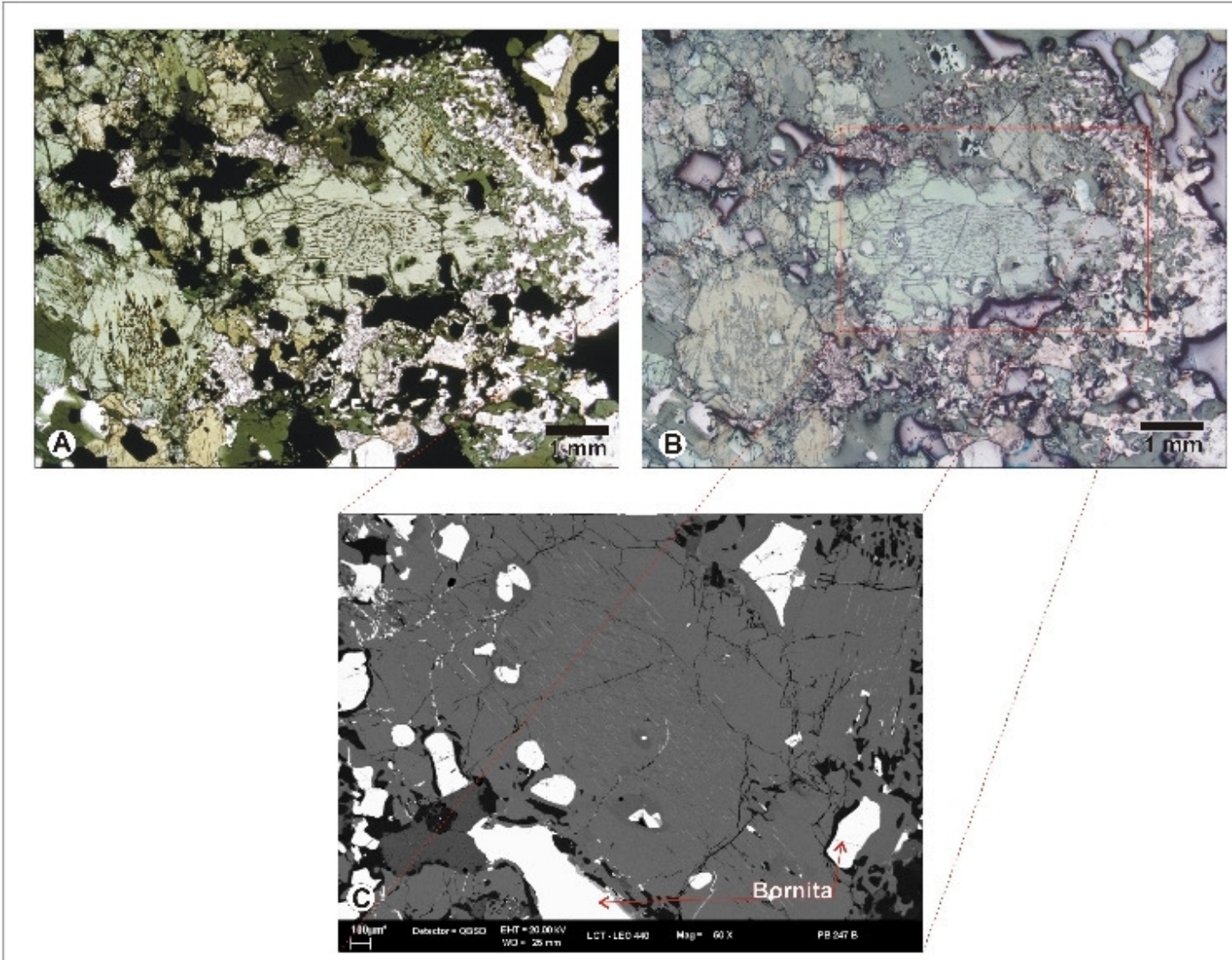

Figura 29: Cristais de bornita em enclave, vistos sob luz transmitida $(A)$, refletida $(B)$ e em imagem de elétrons retroespalhados (C); amostra PB-246B. 


\section{CAPITULO V - GEOQUÍMICA DE ROCHA TOTAL E ISOTÓPICA}

\section{V.1. GEOQUÍMICA DE ROCHA TOTAL}

\section{V.1.1. Mineralogia normativa CIPW}

A partir dos dados geoquímicos de rocha total, obteve-se a norma CIPW de cada uma das amostras analisadas, e algumas diferenças entre as unidades sieníticas foram observadas; dados disponíveis no Anexo III - Tabela 1. Sabendo que as rochas estudadas são oxidadas, a estimativa $\mathrm{Fe}^{2+}$ e $\mathrm{Fe}^{3+}$ foi feita admitindo-se como $70 \%$ de $\mathrm{FeO}$ e $30 \%$ de $\mathrm{Fe}_{2} \mathrm{O}_{3}$.

As unidades supersaturadas em geral possuem quartzo normativo (Figura 30) em proporções que variam de 0,2 a 6\%, mas duas amostras (PB-185A e PB-185B), da unidade SLS que contêm pequenas proporções de quartzo modal mostraram nefelina normativa $(0,5-1,1 \%)$.

Outra característica comum das unidades supersaturadas é a presença de ortopiroxênio (hiperstênio) normativo (Figura 30) em proporções que variam de 0,6 a 7,5\%; as maiores proporções ocorrem em SSI onde há enstatita modal. Além disso, seis amostras de SLSI compartilham tal característica, porém atingem no máximo $3,63 \%$.
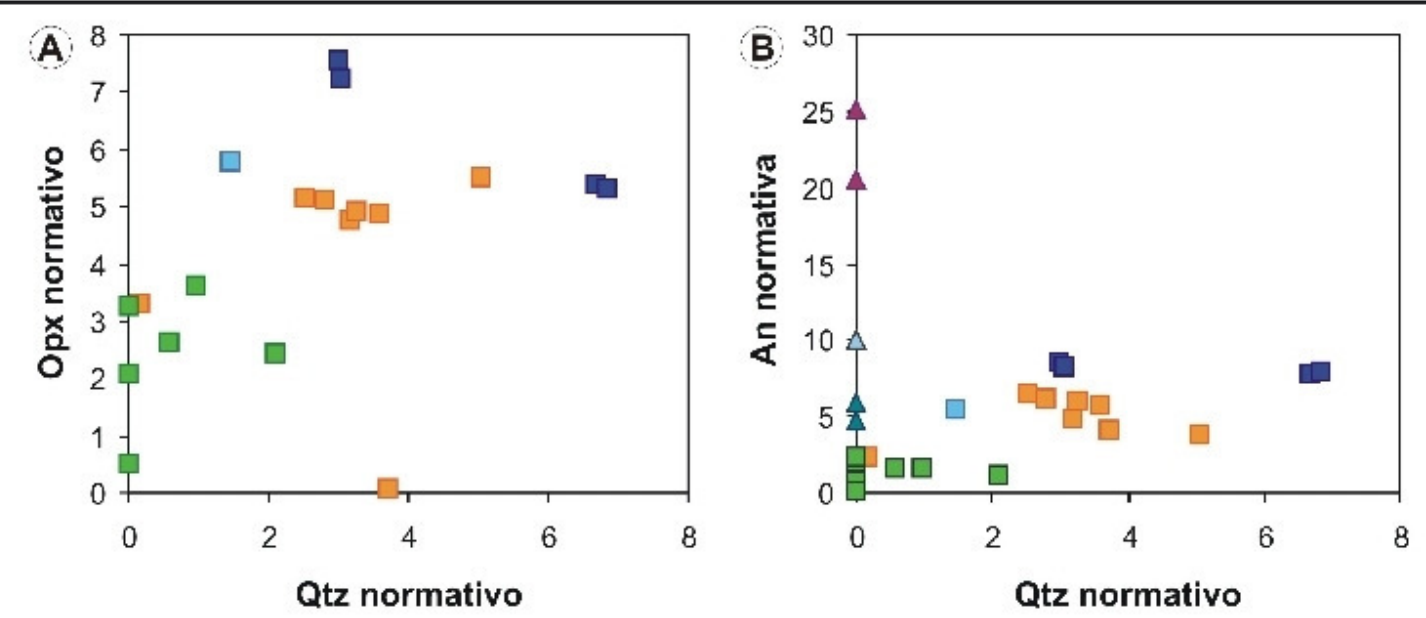

$\square S L S I \square S L S \square S S I \square S S E \Delta E$. Sienito $\triangle E$. Monzonito $\Delta$ E. Diorito

Figura 30: Diagrama Ortopiroxênio versus Quartzo normativo (A) e Anortita versus Quartzo normativo (B) para amostras de sienitos e enclaves do Sienito Pedra Branca.

Algumas amostras da unidade SLSI apresentam nefelina normativa em proporções que variam de 0,08 a $1,8 \%$. 
As proporções de An normativa (Figura 30) diferenciam as unidades supersaturadas $(>2,3 \%)$ da SLSI $(0-2,3)$. Os enclaves dioríticos apresentam os maiores teores do conjunto (20-25\%); eles são progressivamente menores nos enclaves monzonítico (10\%) e sieníticos (4-6\%), em consonância com a diminuição na proporção de plagioclásio modal nessa ordem.

Os enclaves microgranulares (dioríticos, sieniticos e monzoníticos) têm como característica comum a presença de nefelina normativa (enclaves sieníticos: 0,04 a 2,1\%; enclaves dioríticos: 2 a 4\%; enclave monzonítico: 5,3\%). Essa característica provavelmente está relacionada com as grandes proporções de biotita modal destas amostras, pois este mineral, que não entra na norma CIPW, apresenta deficiência em $\mathrm{SiO}_{2}$ quando comparado a outros minerais máficos

Os enclaves dioríticos apresentam algum coríndon normativo (0,7-4\%), mostrando afinidade peraluminosa, estranho ao contexto do Sienito Pedra Branca, e refletindo a ausência de minerais máficos ricos em $\mathrm{Ca}$, como anfibólio e piroxênio; tal característica possivelmente tem caráter secundário, relacionado a alterações da mineralogia primária, e geração de elevados conteúdos de biotita e/ou transformações.

As amostras de enclaves ultramáficos cumuláticos apresentam nefelina e olivina normativas; duas delas (PB-8D e, de SLSI, e PB-185C, de SLS) mostram acmita na norma, indicando afinidades peralcalinas.

\section{V.1.2. Índices de diferenciação e diagramas de classificação}

Os dados químicos obtidos para amostras representativas de sienitos e enclaves do Sienito Pedra Branca estão apresentados no Anexo 3, Tabelas 2 (FRX), 3 (ICP-OES) e 4 (ICP-MS). As amostras selecionadas para análise incluem 29 sienitos (SLSI, SLS, SSI e SSE), além de quatro amostras de rochas ultramáficas (UM), dois enclaves sieníticos (E. Sienito), um monzonítico (E. Monzonito) e dois dioríticos (E. Diorito) encontrados em amostragens na unidade SLS.

Os sienitos das diferentes unidades do plúton mostram uma variação restrita de $\mathrm{SiO}_{2}$ (Figura 31), entre 53 e $60 \%$, assim como as amostras de enclaves ultramáficos (entre 38 e $45 \%$ ) e os enclaves microgranulares sieníticos (52-55\%). Os enclaves monzonítico e dioríticos apresentam valores de $\mathrm{SiO}_{2}$ respectivamente $49 \%$ e $44-53 \%$. A amostra mais diferenciada do conjunto (com aproximadamente $65 \%$ de $\mathrm{SiO}_{2}$ ) é um leucosienito proveniente de um dique intrusivo na unidade SLS (PB-186).

Os índices Mg\# dos sienitos (Figura 32) variam de 43 a 53; os dos enclaves sieníticos e monzoníticos encontram-se dentro do mesmo intervalo (46-50), enquanto 
os das rochas ultramáficas se estendem para valores mais altos (50 a 63). Embora tenham caráter básico, os enclaves microgranulares dioríticos têm Mg\# mais baixo (32); a amostra de leucosienito tem o Mg\# mais baixo de todo o conjunto (23).

Segundo a classificação de Frost \& Frost (2008) (Figura 31), as amostras de sienito das diferentes unidades e os enclaves sieníticos e monzonítico são classificados como "magnesian". Observa-se entre essas rochas um aumento discreto nos valores de $\mathrm{FeO}^{*}\left(\mathrm{FeO} / \mathrm{FeO}+\mathrm{MgO}\right.$ ) juntamente com o aumento de $\mathrm{SiO}_{2}$. Já a amostra de leucosienito tardio e de um dos enclaves dioríticos (PB-246B) situam-se no campo "ferroan" do mesmo diagrama.
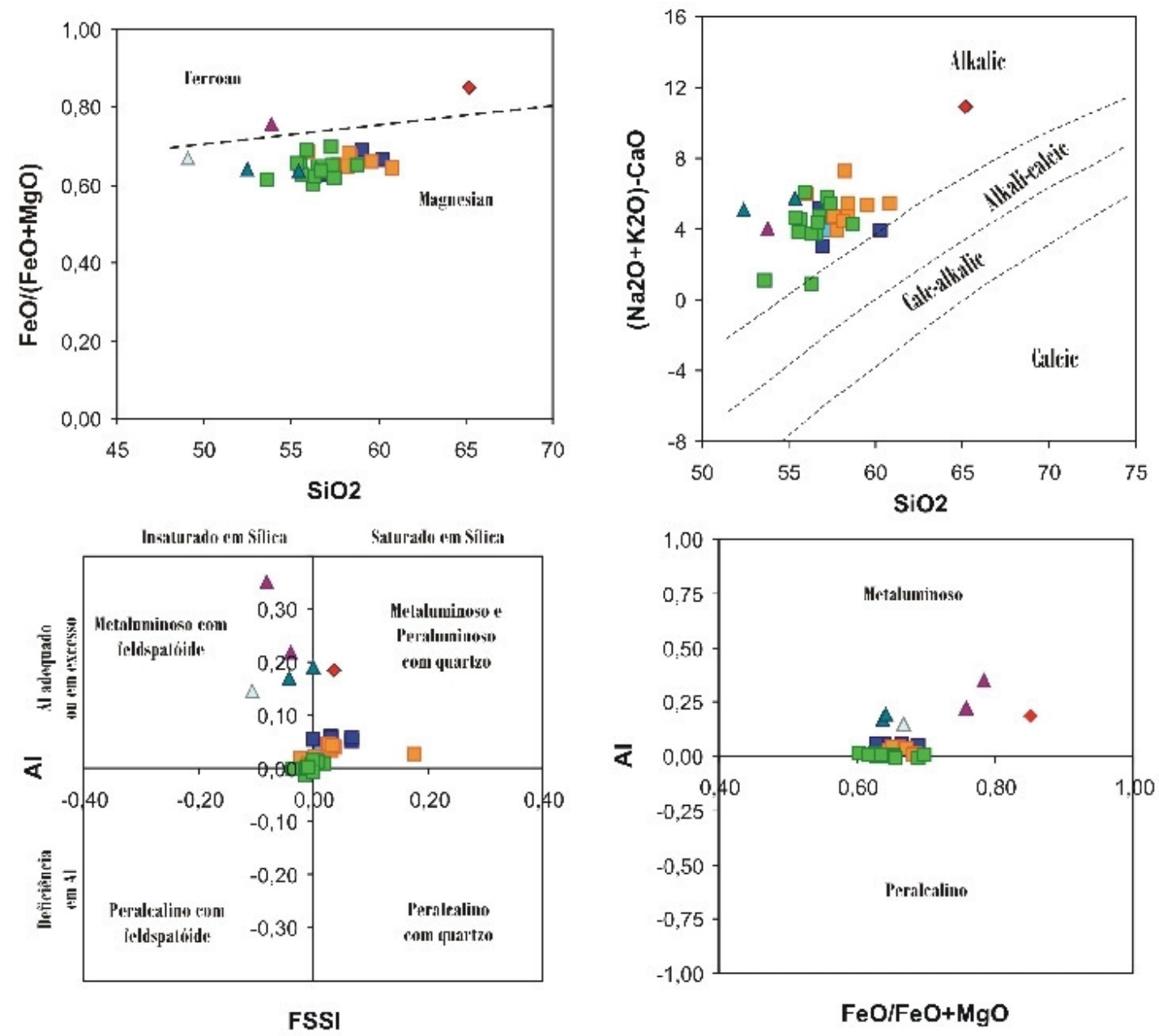

$\square$ SLSI $\square$ SLS $\square$ SSI $\square$ SSE OUM $\diamond$ Qtz Sienito $\Delta$ E. Sienito $\Delta E$. Diorito $\triangle E$. Monzonito

Figura 31: Diagramas de classificação composicional de rochas feldspáticas segundo Frost \& Frost (2008) para rochas do Sienito Pedra Branca.

No diagrama $\left(\mathrm{Na}_{2} \mathrm{O}+\mathrm{K}_{2} \mathrm{O}-\mathrm{CaO}\right)$ vs. $\mathrm{SiO}_{2}$ (Figura 31) observa-se o predomínio do caráter alcalic para todas as amostras estudadas, incluindo sienitos e enclaves 
microgranulares (sieníticos, monzoníticos e dioríticos), ou seja todas apresentam alto $\mathrm{Na}_{2} \mathrm{O}+\mathrm{K}_{2} \mathrm{O}$ relativo ao $\mathrm{CaO}$. O diagrama $\mathrm{Al}$ [Índice de Alcalinidade $=\mathrm{Al}-(\mathrm{K}+\mathrm{Na})$ ] vs. $\mathrm{FeO}^{*}$ mostra que todos os sienitos e enclaves possuem caráter metaluminoso, mas os SLSI têm Al no intervalo entre -0,01 a 0,02, no limite com o campo peralcalino.

Ainda na Figura 31, no diagrama de $\mathrm{Al}$ (índice de alcalinidade) vs. FSSI \{índice de saturação em sílica $=Q-([\mathrm{Lc}+2(\mathrm{Ne}+\mathrm{Kp})] / 100)\}$ as amostras de sienitos saturado SLSI situam-se no limite entre os campos Metaluminoso com feldspatóide $(A \mid<0$; $F S S I>0)$ e Peralcalino com feldspatóide $(A \mid<0 ; F S S I<0)$, enquanto as outras unidades supersaturadas situam-se no campo das rochas metaluminosas e peraluminosas com quartzo. Já os enclaves microgranulares situam-se no campo metaluminoso com feldspatóide.

\section{V.1.3. Elementos Maiores: diagramas de variação}

A Figura 32 mostra diagramas de variação usando $\mathrm{SiO}_{2}$ como discriminante (diagrama de Harker). Como esperado por sua mineralogia, os enclaves cumuláticos máficos-ultramáficos distinguem-se pelos teores elevados de $\mathrm{CaO}$ (10-16\%), MgO $(7,1-10,7 \%)$ e $\mathrm{Fe}_{2} \mathrm{O}_{3}(12-16 \%)$, e alcançam teores notavelmente elevados de $\mathrm{TiO}_{2}$ (até $5,5 \%$ ) e $\mathrm{P}_{2} \mathrm{O}_{5}$ (até $4 \%$ ), e baixos de $\mathrm{K}, \mathrm{Al}$ e $\mathrm{Na}$.

$\mathrm{O}$ diagrama $\mathrm{Al}_{2} \mathrm{O}_{3} \times \mathrm{SiO} 2$ (Figura 32) mostra que os sienitos supersaturados e enclaves sieníticos e monzoníticos têm teores sutilmente maiores nas unidades supersaturadas $(>14 \%$ ) quando comparados a SLSI , o que deve estar relacionado com a maior proporção de Anortita normativa ( $2-9 \%$ nos sienitos supersaturados vs. 0 $2 \%$ de An em SLSI; Figura 33). Os enclaves dioríticos têm teores bem mais elevados de $\mathrm{Al}_{2} \mathrm{O}_{3},(20-23 \%)$, que refletem conteúdos de $\mathrm{An}$ normativa bem mais elevados (cerca de 25\%).

Característica comum a todas as amostras de sienitos são os altos teores de $\mathrm{K}_{2} \mathrm{O}$, que variam entre 5,5 e $8,7 \%$. Existe uma tendência de variação progressiva dos teores, que aumentam na sequência sienitos supersaturados SSI+SSE $\rightarrow$ SLS $\rightarrow$ sienitos insaturados SLSI (Figura 32); a exceção são as duas amostras de SLS provenientes do ponto PB-185, que exibem os teores mais elevados. Os enclaves dioríticos, monzoníticos e ultramáficos que possuem os menores valores do conjunto (menor que $4 \%$ ).

$\mathrm{CaO}$ e $\mathrm{MgO}$ apresentam correlação negativa com $\mathrm{SiO}_{2}$, dentro do conjunto de sienitos; as rochas cumuláticas e o leucosienito diferenciado se situam ao longo da 
mesma tendência (Figura 32). Os enclaves microgranulares sieníticos e monzoníticos se alinham na mesma tendência para $\circ \mathrm{MgO}$, mas tanto eles como os enclaves dioríticos se deslocam da tendência geral para o $\mathrm{CaO}$, mostrando teores mais baixos a um mesmo teor de $\mathrm{SiO}_{2}$ (Figura 32).

Os altos valores de $\mathrm{Ti}$ e $\mathrm{P}$ nos cumulatos máficos-ultramáficos devem-se à presença dos minerais titanita, óxidos de $\mathrm{Fe}-\mathrm{Ti}$ e apatita, que devem portanto ser fases precoces, e podem constituir bons indicadores de evolução magmática.

Os teores de $\mathrm{TiO}_{2}$ são muito semelhantes entre os sienitos saturados e supersaturados, e apenas estes últimos mostram alguma correlação negativa com $\mathrm{SiO}_{2}$ (Figura 32).
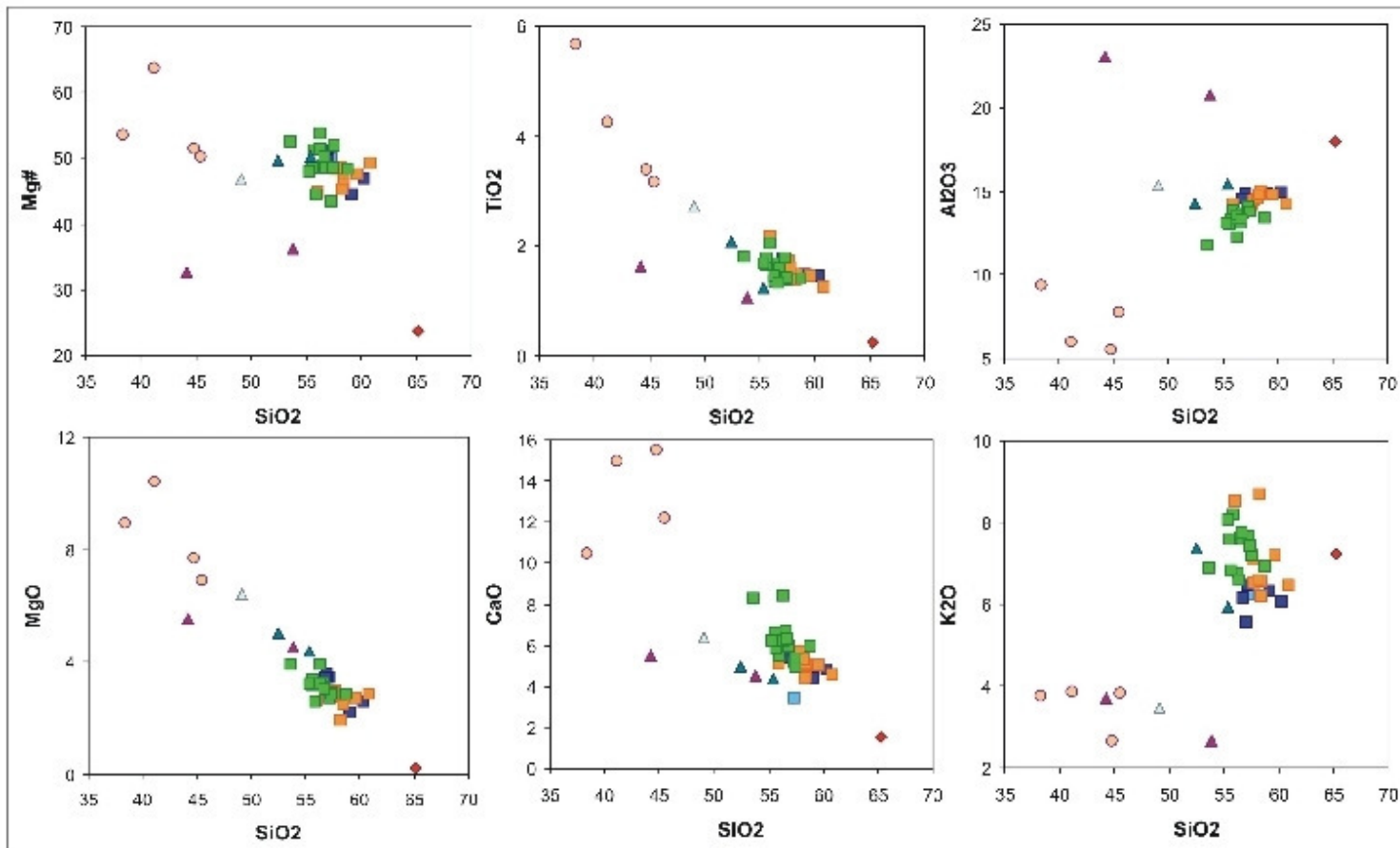

$\square S L S I \quad \square S L S \quad \square S S I \quad \square S S E$

OUM

$\bullet$ Leucosienito

$\Delta$ E. Sienito

$\Delta$ E. Diorito

$\triangle \mathrm{E}$. Monzonito

Figura 32: Diagrama de variação para elementos maiores utilizando sílica como índice de diferenciação para rochas do Sienito Pedra Branca.

$\mathrm{O} \mathrm{P}_{2} \mathrm{O}_{5}$ mostra correlação negativa com $\mathrm{SiO}_{2}$, mais evidente para os sienitos saturados SLSI, que mostram variação entre 1 e $2 \%$ de $\mathrm{P}_{2} \mathrm{O}_{5}$; os sienitos supersaturados apresentam teores em geral mais baixos e pouco variados $(0,9-1,1 \%)$; as amostras do afloramento 185 têm teores ainda mais baixos $(\sim 0,7 \%)$. Os enclaves dioríticos, um enclave sienítico (PB-209C) e o leucosienito tardio apresentam os menores valores do conjunto, cerca de $0,2 \%, 0,5 \%$ e $0,03 \%$ respectivamente.

Como $\mathrm{Al}_{2} \mathrm{O}_{3}$ constitui um bom discriminante entre sienitos saturados e supersaturados em sílica, foram também gerados diagramas de variação que utilizam 
este óxido. A Figura 33 mostra uma correlação negativa entre $\mathrm{Al}_{2} \mathrm{O}_{3}$ e $\mathrm{MgO}$ para a unidade SLSI e SLS, ainda assim a primeira, juntamente com SSI, SSE e os enclaves sieníticos possuem os valores superiores a $3 \%$, enquanto SLS e os enclaves dioríticos apresentam conteúdos similares (2-3\%).

A Figura 33, diagrama de $\mathrm{P}_{2} \mathrm{O}_{5}$ vs. $\mathrm{Al}_{2} \mathrm{O}_{3}$, mostra tendência paralela dos sienitos supersaturados com SLSI, aindo assim o valor máximo atingido por esses é de 1,2\%.

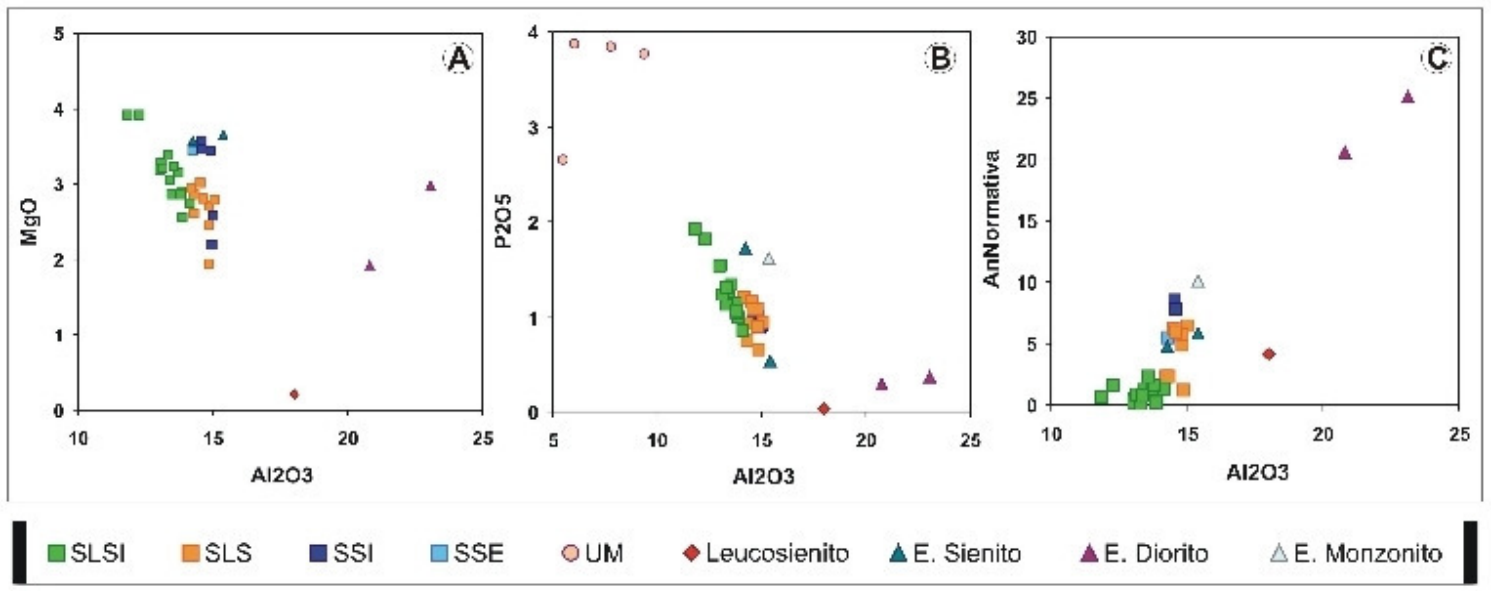

Figura 33: Diagramas de variação para MgO, P2O5 e An normativa em relação a $\mathrm{Al}_{2} \mathrm{O}_{3}$ para as rochas do Sienito Pedra Branca. As rochas ultramáficas não foram incluídas nos diagramas $(A)$ e $(C)$.

\section{V.1.4. Elementos Menores e Traço}

O enriquecimento em elementos menores e traço incompatíveis (em especial os litófilos (LILE), como K, Ba e Sr, além dos elementos terras raras leves, como La e Ce) é a característica geoquímica mais marcante do Sienito Pedra Branca.

Nas diferentes unidades sieníticas e nos enclaves microgranulares $\mathrm{Ba}$ apresenta uma correlação positiva bem marcada com $\mathrm{Sr}$, refletindo o fato de que ambos residem principalmente em um mesmo mineral (feldspato alcalino) (Figura 34). Deste modo, as razões $\mathrm{Ba} / \mathrm{Sr}$ são semelhantes nos sienitos e no enclave sienítico PB250 (variando de 1,5-2). Dentro desta tendência, nota-se que as unidades SLS e SLSI apresentam os maiores teores de $\mathrm{Ba}$ e Sr (até 10000 ppm e 4500 ppm respectivamente, enquanto SSI e SSE têm Ba 4000 ppm e $\mathrm{Sr}=2000-2500$ ppm). Os enclaves dioríticos e dois enclaves ultramáficos se deslocam da tendência, apresentando menor razão $\mathrm{Ba} / \mathrm{Sr}$, refletindo sua mineralogia pobre em feldspato alcalino. Em contrapartida o alto teor de $\mathrm{Sr}(\sim 3800$ ppm) de um enclave diorítico deve 
refletir residência no plagioclásio. É notável que o enclave microgranular sienítico PB209C também se desloca da tendência para razão $\mathrm{Ba} / \mathrm{Sr}$ mais baixa

Os teores de $\mathrm{Rb}$ variam amplamente entre os sienitos e enclaves microgranulares (100-250 ppm); considerando todo o conjunto de sienitos (exceto os enclaves), existe uma leve correlação positiva com o Sr (Figura 34), que reflete a tendência a menores teores de em SSI e os maiores em algumas amostras de SLSI.

A soma dos elementos Terras Raras Leves (LREE= elementos terras raras leves; soma de La até Sm, Figura 34) mostra os altos teores destes elementos em todas as amostras estudadas; é particularmente notável o enriquecimento observado nos enclaves ultramáficos (LREE $=1500-3000$ ppm). A correlação positiva dos teores de ETRL de todo o conjunto com $\mathrm{P}_{2} \mathrm{O}_{5}$ e TiO2 indica residência nos minerais acessórios apatita e titanita, confirmada por análises preliminares por LA-ICPMS (dados inéditos da autora). A amostra de SLS (PB-148) com os maiores teores de LREE ( 1400 ppm) é portadora de allanita como mineral acessório; a sua maior razão ETR/P2O5 deve ser responsável pelo surgimento de uma fase mineral que tem os ETR como componente estrutural essencial. Os menores teores de LREE são encontrados nos enclaves microgranulares dioríticos e no leucosienito (200 e 80 ppm, respectivamente).

Existe uma grande dispersão no conteúdo de $\mathrm{Zr}$, que varia entre 100 e 650 ppm, sem correlação com variações no conteúdo de $\mathrm{SiO}_{2}$ (Figura 34). A dispersão é observada também para os enclaves cumuláticos e para os enclaves microgranulares, embora seja nítido que os enclaves dioríticos e monzoníticos tenham teores relativamente baixos (200-250 ppm). Os menores teores de $\mathrm{Zr}$ são encontrados no leucosienito, com apenas $24 \mathrm{ppm}$.

Em todas as variedades de sienitos Th e $U$ exibem correlações negativas com $\mathrm{SiO}_{2}$, os maiores conteúdos encontram-se nas unidades laminadas SLS e SLSI (Th= 5-20 ppm e $U=1-3 \mathrm{ppm}$ ), enquanto nos SSI e SSE os teores são muito baixos (< 1 $\mathrm{ppm}$ ). As razões $\mathrm{Th} / \mathrm{U}$ variam entre 5 e 10 nos sienitos; é notável que elas são sensivelmente mais altas nos enclaves máficos-ultramáficos (10) quando comparados aos enclaves microgranulares ( 5). 


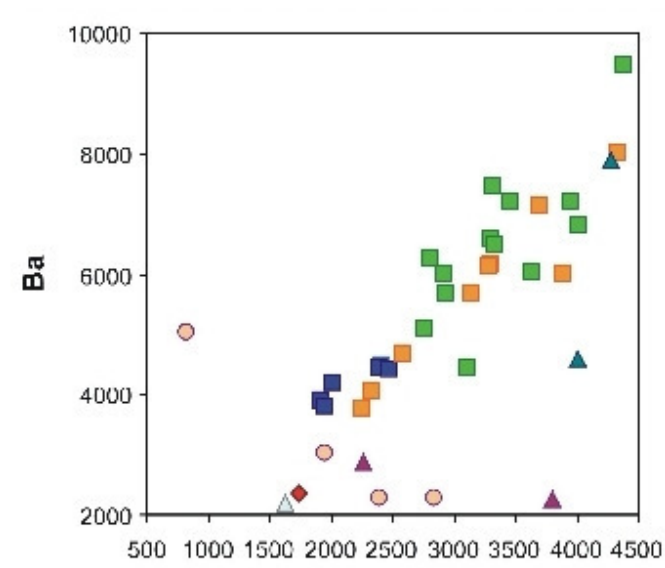

$\mathrm{Sr}$
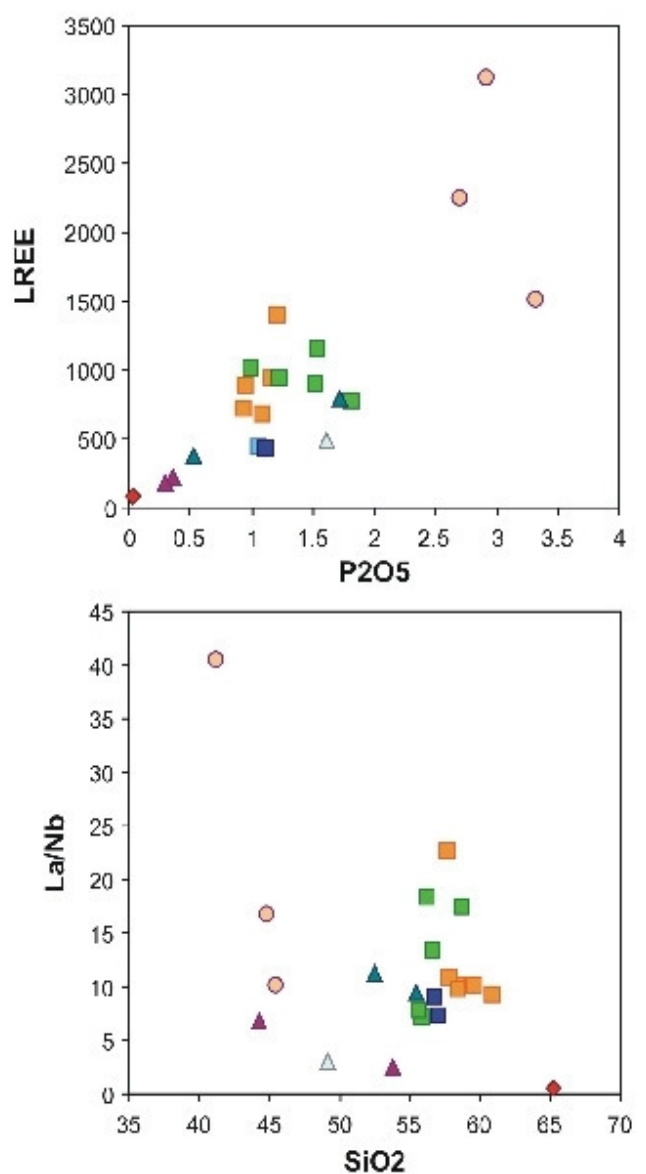

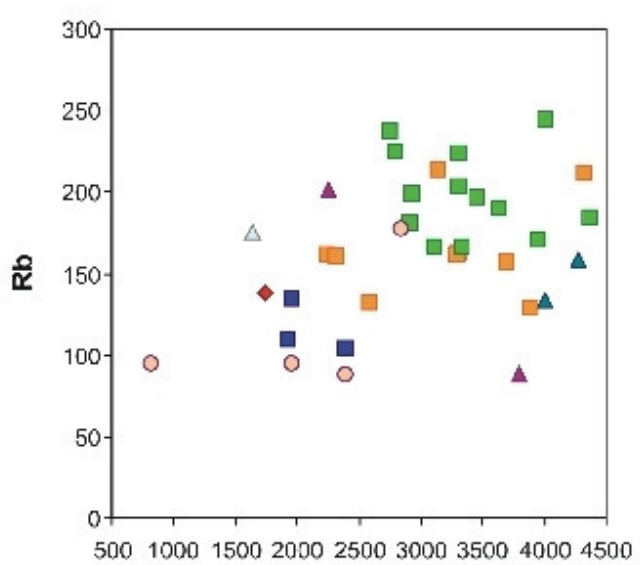

$\mathrm{Sr}$
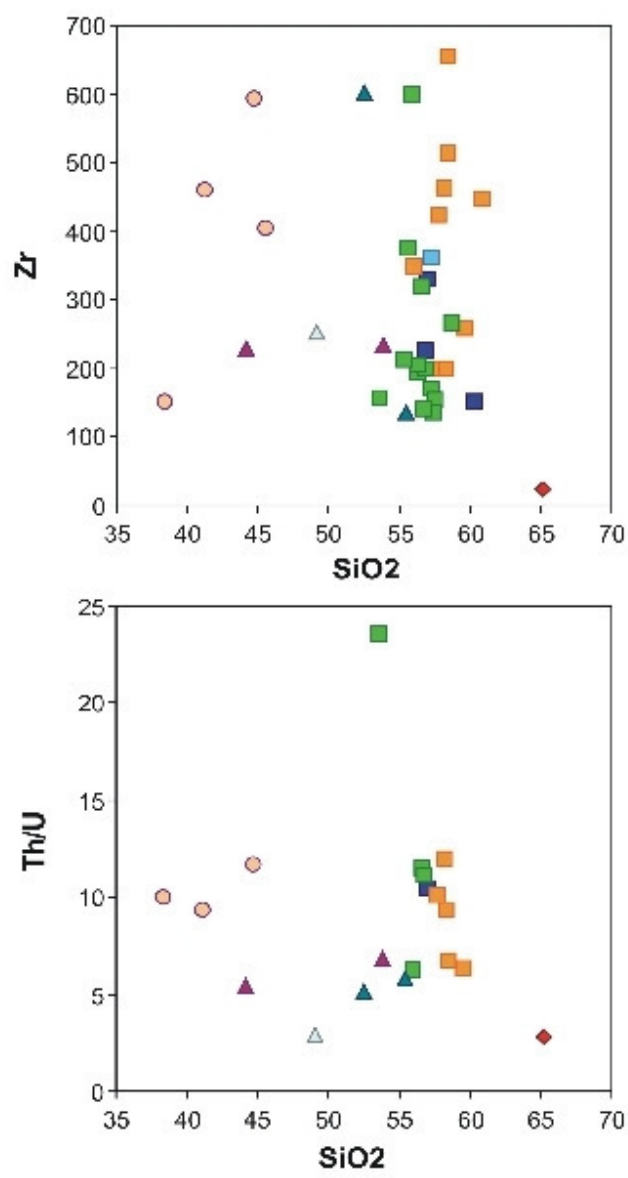

$\square S L S I \quad \square S L S \square S S I \quad \square S S E$ OUM Leucosienito $\triangle E$. Sienito $\Delta E$. Diorito $\triangle E$. Monzonito

Figura 34: Diagramas de variação de elementos traço do Sienito Pedra Branca.

As razões $\mathrm{La} / \mathrm{Nb}$ (Figura 34) encontram-se no intervalo entre 5 e 25 para sienitos e enclaves microgranulares sieníticos, e são similares nos cumulatos, exceto no caso da amostra PB-185C $(\mathrm{La} / \mathrm{Nb}=40)$. Essas razões tendem a ser ligeiramente mais baixas $(<5)$, nos enclaves dioríticos e monzoníticos e no leucosienito. 


\section{Elementos Terras Raras}

$\mathrm{Na}$ Figura 35 diagramas de elementos terras raras dos sienitos normalizados pelo condrito C1 (McDonough \& Sun, 1995) mostram um padrão fortemente fracionado sem anomalias significativas de Eu. Os diferentes enclaves também mostram padrões enriquecidos, mostrando ser esta uma característica comum a todas as rochas do plúton.

As elevadas razões $(\mathrm{La} / \mathrm{Yb})_{\mathrm{N}}$ medem o forte fracionamento dos elementos terras raras leves. SLSI e SLS têm padrões paralelos, com dispersão um pouco maior dos ETR leves em SLS, resultando em variação maior de $(\mathrm{La} / \mathrm{Yb})_{\mathrm{N}}$ (55-131 em SLS contra 63-109 em SLSI). SSE e SSI têm menor conteúdo de ETR e menores razões $(\mathrm{La} / \mathrm{Yb})_{\mathrm{N}}(46 \mathrm{e}$ 41, respectivamente).

Os enclaves ultramáficos exibem os maiores teores de ETR de todo o conjunto, porém as razões $(\mathrm{La} / \mathrm{Yb})_{N}$ são similares as dos sienitos (62-101). Em contrapartida, o leucosienito tem os menores teores, e padrão pouco fracionado [(La/Yb $\left.)_{N}=5\right]$, com leve anomalia negativa de Eu.

Os enclaves microgranulares sieníticos apresentam comportamento semelhante aos das unidades sieníticas; a amostra PB-209C tem teores ligeiramente mais baixos que os das unidades menos enriquecidas (SSE e SSI), e razão $(\mathrm{La} / \mathrm{Yb})_{\mathrm{N}}=$ 50 , similar ao dessas unidades.

Os enclaves dioríticos têm menores teores de ETR, em especial os ETR pesados, cuja variação condiciona os valores contrastados da razão (La/Yb) $)_{N}(42-120)$. O enclave monzonítico tem padrão similar ao dos enclaves sieníticos, porém levemente menos fracionado, $\operatorname{com}(\mathrm{La} / \mathrm{Yb})_{N}=43$.

No diagrama de $(\mathrm{La} / \mathrm{Yb})_{\mathrm{N}}$ versus $(\mathrm{La} / \mathrm{Sm})_{\mathrm{N}}$ (Figura 35$)$ observa-se uma correlação positiva, ou seja em todo o conjunto o aumento de $(\mathrm{La} / \mathrm{Yb})_{\mathrm{N}}$ está diretamente associado ao aumento no conteúdo das ETR leves, já que o conteúdo das ETR pesadas é praticamente constante em todos os sienitos (cerca de 10 vezes o do condrito). 

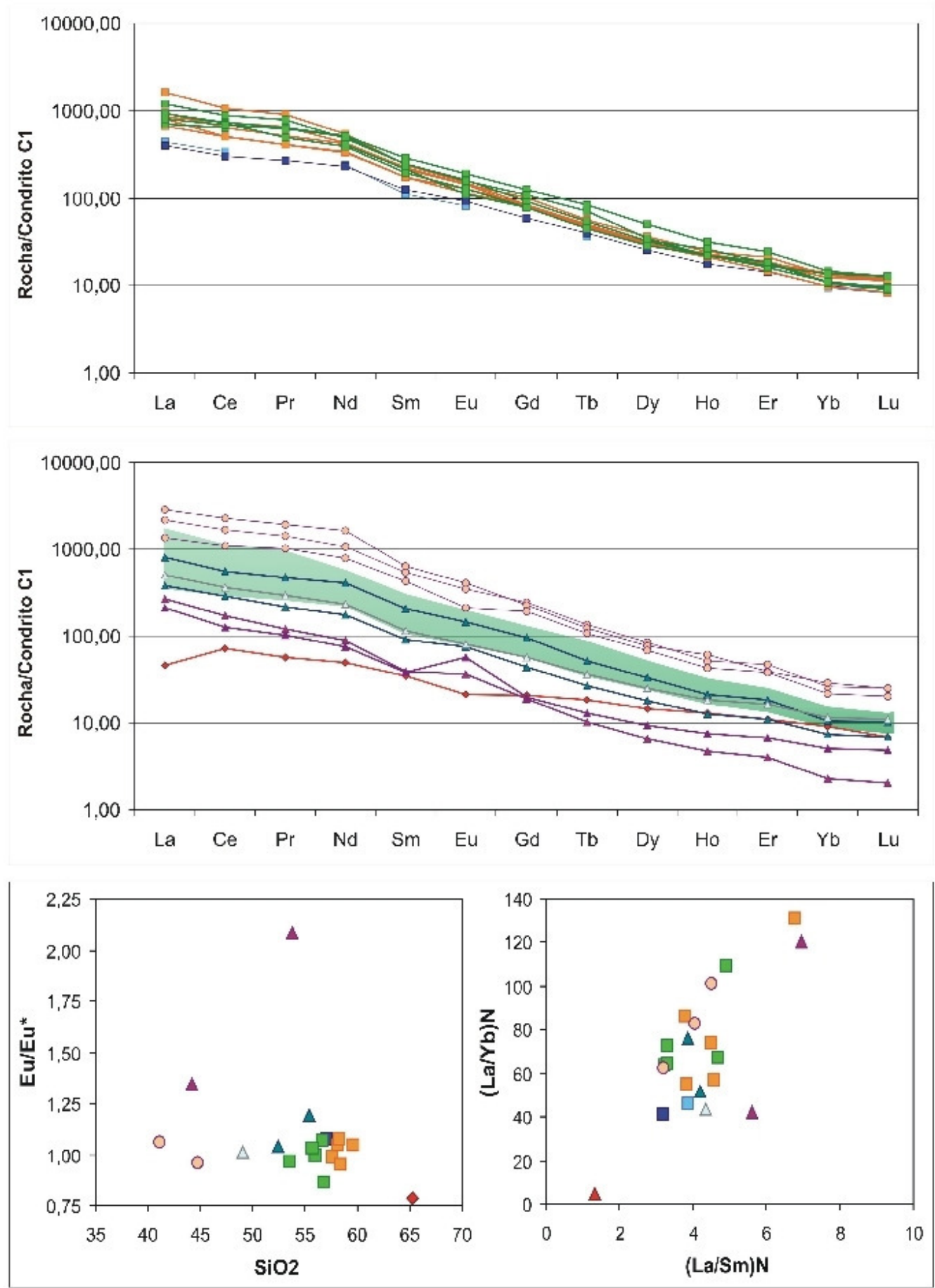

$\square$ GLSI $\square S L S \quad \square S S I \quad \square S S E \quad O U M \quad$ Leucosienito $\Delta$ E. Sienito $\Delta$ E. Diorito $\triangle E$. Monzonito

Figura 35: Padrões de elementos terras raras para amostras do Sienito Pedra Branca. No diagrama dos enclaves a área hachurada representa os padrões das diferentes unidades sieníticas.

Os valores de $\mathrm{Eu} / \mathrm{Eu}^{*}\left(\mathrm{Eu}_{\mathrm{N}} / \sqrt{ }\left(\mathrm{Sm}_{\mathrm{N}}{ }^{*} \mathrm{Gd} \mathrm{d}_{\mathrm{N}}\right)\right)$ nas diferentes unidades sieníticas variam de 0,86 a 1,07 (Figura 35). Os valores mais baixos (anomalias negativas melhor definidas) são encontrados no quartzo sienito $\left(E u / E u^{*}=0,76\right)$ e em uma amostra de rocha ultramáfica $(0,73)$. Anomalias positivas são encontradas nos 
enclaves dioríticos $\left(E u / \mathrm{Eu}^{*}=1,34\right.$ a 2,08) e em um dos enclaves sieníticos (PB-209C; $\left.\mathrm{Eu} / \mathrm{Eu}^{*}=1,19\right)$.

\section{Diagramas multielementares normalizados}

O diagrama da Figura 36 mostra padrões de elementos incompatíveis em sienitos e enclaves do Sienito Pedra Branca normalizados pelo Manto Primitivo de Sun \& McDonough (1989).

Os padrões das diferentes unidades sieníticas e dos enclaves microgranulares sieníticos, são muito semelhantes, com notáveis enriquecimentos em elementos fortemente incompatíveis como $\mathrm{Ba}, \mathrm{K}, \mathrm{La}, \mathrm{Ce}$ e $\mathrm{Pb}$. Desenvolvem-se notáveis anomalias negativas dos elementos HFSE ( $\mathrm{Ta}, \mathrm{Nb}, \mathrm{Hf}, \mathrm{Zr}$ e Ti). Uma exceção é o sienito PB-181a da unidade SLSI, que tem teores anomalamente elevados de $\mathrm{Zr}$ e $\mathrm{Hf}$. Entre todas as amostras estudadas, as unidades SSE e SSI e o enclave sienítico PB209C, apresentam os padrões menos enriquecidos do conjunto.

O leucosienito tem padrão similar ao das unidades supersaturadas, mas apresenta anomalias negativas em $\mathrm{Zr}-\mathrm{Hf}$ e $\mathrm{Ti}$ ainda mais pronunciadas.

Os padrões dos enclaves microgranulares dioríticos, embora apresentem algumas semelhanças com os dos sienitos hospedeiros, se distinguem claramente pelas anomalias positivas de $\mathrm{Sr}$ e $\mathrm{Eu}$, e pelas menores razões $\mathrm{Ba} / \mathrm{Rb}$ e, especialmente, pela ausência de anomalias negativas de $\mathrm{Ti}, \mathrm{Zr}$ e Hf; entre os HFSE, apenas as anomalias negativas de $\mathrm{Nb}$ e Ta se mantêm.

O padrão do enclave monzonítico distingue-se dos demais enclaves microgranulares por teores mais altos de Cs e $U$ e menores razões Th/ $\mathrm{U}$ e $\mathrm{Ba} / \mathrm{Rb}$ (Figura 34) e pela ausência de anomalia positiva de Sr. O restante do padrão assemelha-se mais aos enclaves sieníticos, seja pelos teores mais elevados de elementos incompatíveis, seja pela presença de anomalia negativa de $\mathrm{Zr}$ e $\mathrm{Hf}$ bem definida.

Os enclaves ultramáficos se destacam pelo notável enriquecimento nos elementos terras-raras, $\mathrm{Ti}, \mathrm{P}$, e mesmo Th e $\mathrm{U}$, apresentando em geral teores mais altos que os dos sienitos nesses elementos. Em contrapartida, são mais pobres nos elementos litófilos residentes nos feldspatos ( $\mathrm{K}, \mathrm{Ba}, \mathrm{Sr})$, e mostram anomalias negativas de $\mathrm{Zr}$-Hf. O pronunciado pico em $\mathrm{Pb}$, observado na amostra $\mathrm{PB}-185 \mathrm{C}$ pode estar relacionado com a presença de sulfetos (e.g. calcopirita, bornita e galena) (ver Capítulo IV - Petrografia e Química Mineral). As anomalias negativas de $\mathrm{Sr}$ dos 
enclaves ultramáficos devem-se à pequena abundância de feldspato alcalino nestas rochas, reforçando a idéia que o Sr reside não apenas na apatita, mas principalmente no feldspato alcalino.
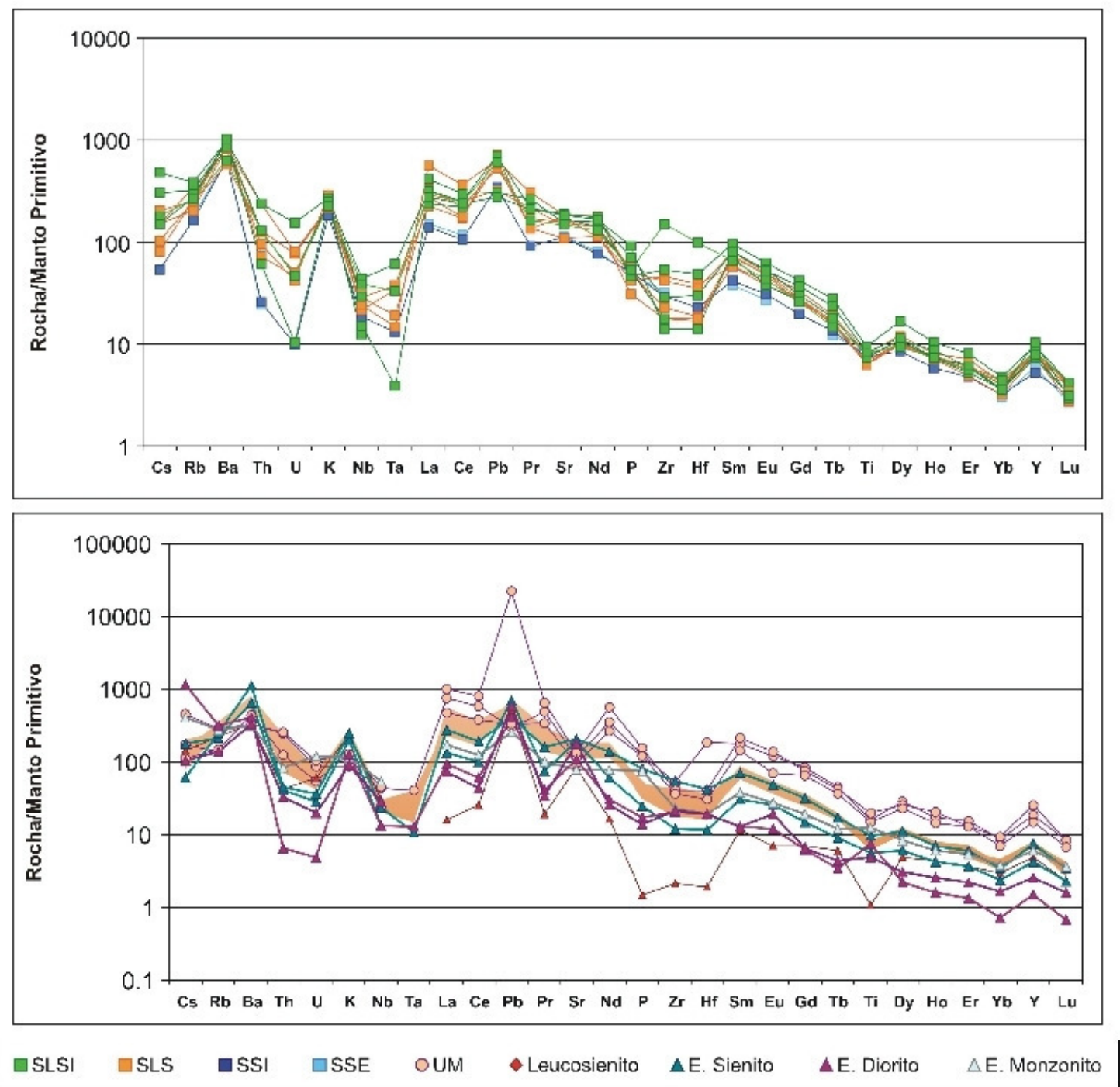

Figura 36: Diagramas multi-elementares para sienitos e enclaves do Sienito Pedra Branca, normalizados pelo manto primitivo (Sun \& McDonough, 1989). No diagrama dos enclaves a área hachurada representa os padrões do sienito hospeiro destes enclaves (SLS).

\section{V.2. COMPARAÇÃO GEOQUÍMICA COM OUTROS SIENITOS POTÁSSICOS PRÉ-CAMBRIANOS DO BRASIL}

Devido às similaridades petrológicas entre as ocorrências sieníticas descritas anteriormente (Capítulo II - II.1 Ocorrência de Sienitos Ricos em Potássio no Brasil: uma revisão), neste item será realizada uma comparação geoquímica utilizando dados disponíveis dos seguintes plútons: Itiúba (Conceição et al., 1991), Bom Jardim 
(Guimarães \& Silva Filho, 1998), Piquiri (Nardi et al., 2008), Capituva (Janasi, 1993) e Pedra Branca (dados da presente dissertação de mestrado). Os campos hachurados em tom de cinza foram construídos utilizando os valores máximos e mínimos atingidos pelo Sienito Pedra Branca.

\section{Elementos Maiores}

A Figura 37 contempla os diagramas de elementos maiores obtidos pela compilação de dados da literatura onde se utilizou $\mathrm{SiO}_{2}$ como índice de diferenciação. Nesta figura encontra-se a legenda para dos demais diagramas (Figuras 38, 39 e 40).

Os elementos maiores (Figura 37), em geral, mostram um comportamento similar entre os sienitos; o conteúdo de $\mathrm{SiO}_{2}$ restringe-se ao intervalo entre $52-65 \%$, das rochas intermediárias, onde os sienitos Capituva e Bom Jardim apresentam os menores teores, e os maiores são atingidos por Itiúba e Piquiri. As amostras mais primitivas, ou seja, com menor $\mathrm{SiO}_{2}$ e maior Mg\#, pertencem ao Sienito Bom Jardim

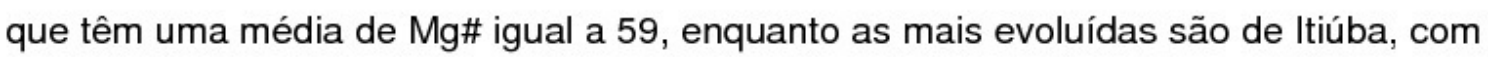
média de Mg\# em torno de 42.

$\mathrm{O}$ diagrama de afinidade geoquímica que de $\mathrm{A} / \mathrm{NK}$ versus $\mathrm{A} / \mathrm{CNK}$ (Maniar \& Piccoli, 1989) mostra o caráter metaluminoso para a maioria das amostras; nota-se que os sienitos de Itiúba, Bom Jardim e Pedra Branca (unidade saturada) apresentam A/NK 1, aproximando-se do campo peralcalino.

Segundo Foley et al. (1987), rochas ultrapotássicas podem ser definidas geoquimicamente por apresentarem $\mathrm{K}_{2} \mathrm{O}>3 \%, \mathrm{~K}_{2} \mathrm{O} / \mathrm{Na}_{2} \mathrm{O}>2 \%$ e $\mathrm{MgO}>3 \%$. Embora em todos os casos os conteúdos de $\mathrm{K}_{2} \mathrm{O}$ sejam superiores aos estipulados por Foley et al. (1987), variando entre $~ 7 \%$ em Pedra Branca e Piquiri e 4,5-5\% em Bom Jardim ( $4.5 \%)$ e Itiúba ( 5\%), quando se considera as razões $\mathrm{K}_{2} \mathrm{O} / \mathrm{Na}_{2} \mathrm{O}$ e os teores de $\mathrm{MgO}$ (Figura 37), apenas algumas amostras poderiam ser classificadas como ultrapotássicas. Essas amostras são os sienitos finos de Piquiri, algumas amostras de sienito saturado e as duas de sienito supersaturado do ponto PB-185 em Pedra Branca; e duas amostras mais primitivas de Capituva. A maior parte das demais amostras tem $\mathrm{MgO}<3 \%$, e poderia corresponder a termos mais diferenciados (por exemplo, Itiúba), mas em alguns casos as razões $\mathrm{K}_{2} \mathrm{O} / \mathrm{Na}_{2} \mathrm{O}$ são sistematicamente inferiores a 2 (e.g., Bom Jardim e Capituva). 

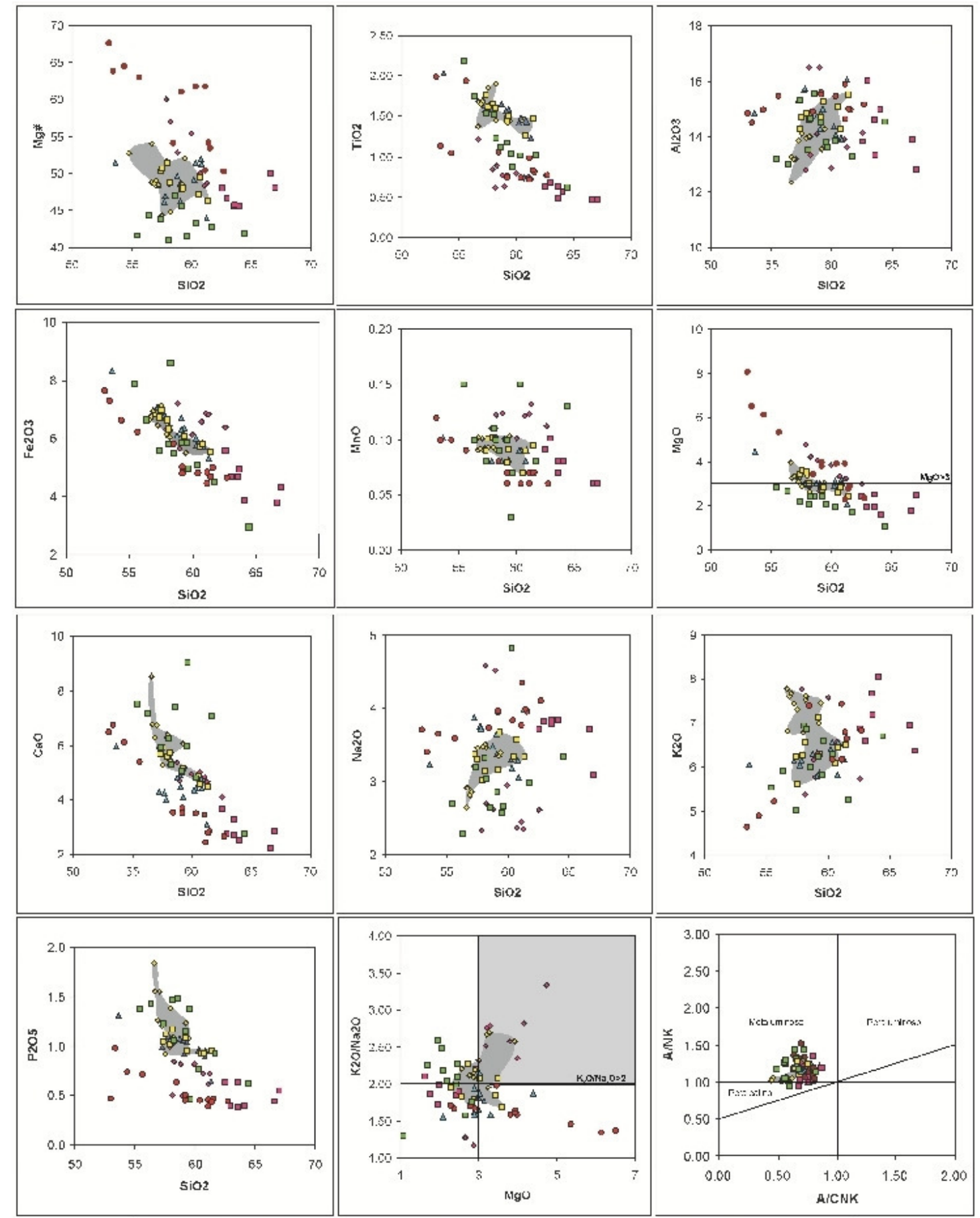

$\diamond$ Piqueri (fino) $\square$ Piqueri (grosso) $\diamond$ Pedra Branca (sat) $\square$ Pedra Branca (super) - Bom Jardim $\triangle$ Capituva $\square$ Itiuba

Figura 37: Diagramas de elementos maiores utilizando $\mathrm{SiO}_{2}$ como índice de diferenciação. $\mathrm{O}$ diagrama de afinidade geoquímica foi extraído de Maniar \& Piccoli (1989).

De acordo com Foley et al. (1987) suítes ígneas com rochas que possuem razão molar $\mathrm{K}_{2} \mathrm{O} / \mathrm{Na}_{2} \mathrm{O}>1$ são potássicas, e neste caso todas as amostras podem ser consideradas potássicas, tratando-se então de sienitos potássicos. 
Os diagramas de variação para $\mathrm{MgO}$ e $\mathrm{CaO}$ revelam a existência diferentes tendências de evolução, destacando-se o caso de Bom Jardim, que segue tendências com mais alto $\mathrm{Mg}$ e mais baixo $\mathrm{Ca}$, enquanto Itiúba se distingue pelos teores mais baixos de Mg. É notável que as amostras de Capituva seguem uma tendência mais pobre em Ca, se comparadas a Pedra Branca, Piquiri e Itiúba, e se aproxima de Bom Jardim.

Os conteúdos de $\mathrm{Al}_{2} \mathrm{O}_{3}$ mostram variação restrita, entre 12.4 e $16.4 \%$, e não mostram correlação com a sílica, o mesmo acontece com $\circ \mathrm{Na}_{2} \mathrm{O}$, cujos valores máximos e mínimos são observados nas amostras de Itiúba e Piquiri fino (respectivamente $4.5 \%$ e $2.3 \%$ )

Os óxidos $\mathrm{TiO}_{2}$ e $\mathrm{P}_{2} \mathrm{O}_{5}$ possuem conteúdos consideráveis (respectivamente, 0.5-2.18\% e 0.5-1.97\%), refletindo abundância de titatita, óxidos de Fe-Ti e apatita, em todos esses sienitos. Observa-se em todos os casos uma, correlação negativa com $\mathrm{SiO}_{2}$ demonstrando assim o seu comportamento compatível (apatita e óxidos de $\mathrm{Fe}-\mathrm{Ti}$ são fases precoces nessas rochas). Os maiores teores de $\mathrm{TiO}_{2}$, em torno de $2 \%$, são observados em uma amostra de Itiúba, seguida por amostras de Capituva, Bom Jardim e Pedra Branca; os menores valores são observados em amostras de Piquiri ( 0.5\%). Para $\mathrm{P}_{2} \mathrm{O}_{5}$, os maiores teores são atingidos pela unidade saturada de Pedra Branca, seguida por Itiúba ( 1.4\%); analogamente ao $\mathrm{TiO}_{2}$, amostras do Sienito Piquiri apresentam os menores teores ( 0.5\%).

\section{Elementos Menores e Traço}

Na figura 38 estão apresentados alguns elementos menores e traço utilizando como índices de diferenciação $\mathrm{SiO}_{2}$ e $\mathrm{Mg \#}$.

Os altos teores de $\mathrm{Sr}$ (1000-4500 ppm) e Ba (1750-9500 ppm) são características marcantes de todas as unidades de sienitos. Para ambos os elementos os maiores teores são atingidos por Pedra Branca saturado, enquanto os menores são os das amostras de Bom Jardim. O comportamento destes elementos é compatível já que os maiores teores de $\mathrm{Ba}$ e $\mathrm{Sr}$ são atingidos por amostras com menor conteúdo de $\mathrm{SiO}_{2}$; ainda assim, os teores destes elementos são altos mesmo nas amostras mais evoluídas.

Já o Rb é claramente incompatível, pois apresenta correlação positiva com $\mathrm{SiO}_{2}$. Os maiores teores são atingidos pelas amostras do Piquiri fino (364 ppm), enquanto os menores são de Itiúba e Pedra Branca supersaturado. 
Entre os critérios utilizados para distinguir a composição de magmas primários, (obtidos experimentalmente em condições de equilíbrio entre o líquido gerado e um peridotito com Mg\# em torno de 90, sob pressões mantélicas), são o conteúdo de Mg\# superior a $70, \mathrm{SiO}_{2}$ abaixo de $50 \%$, altos valores de $\mathrm{Ni}$ (> 500 ppm) e $\mathrm{Cr}$ (>1000ppm). No entanto, a cristalização fracionada de minerais ferro-magnesianos pode resultar em uma queda considerável na abundancia de $\mathrm{Ni}$ e $\mathrm{Cr}$ (Thompson \& Fowler, 1986). Além disso, o metassomatismo no manto permitirá a formação de minerais como clinopiroxênio + flogopita + granada \pm espinélio na rocha fonte, desta forma terá um Mg\# diferente do admitido para um manto "normal" (Foley et al., 1987).

Alguns autores admitem que os sienitos estudados sejam magmas primários, ou seja, fusão parcial direta do manto metassomatizado (Rosa et al., 2003; Ferreira, et al., 2002; Plá Cid et al., 2003; Nardi et al., 2007 e 2008), outros consideram que estas rochas tratem-se do produto de fracionamento de magmas máficos lamprofíricos (Janasi, 1993; Janasi et al., 1993).

Em geral os baixos conteúdos em $\mathrm{Cr}$ ( $<100$ ppm) e Ni (<70 ppm), além do Mg\# ( 50) destas rochas são avaliados como fortes evidências para a segunda hipótese, pois espera-se que o produto da fusão parcial do manto seja mais "enriquecido" nestes elementos. Além disso, o fracionamento de minerais máficos pode contribuir para a diminuição dos teores destes elementos, reforçando ainda mais a segunda hipótese.

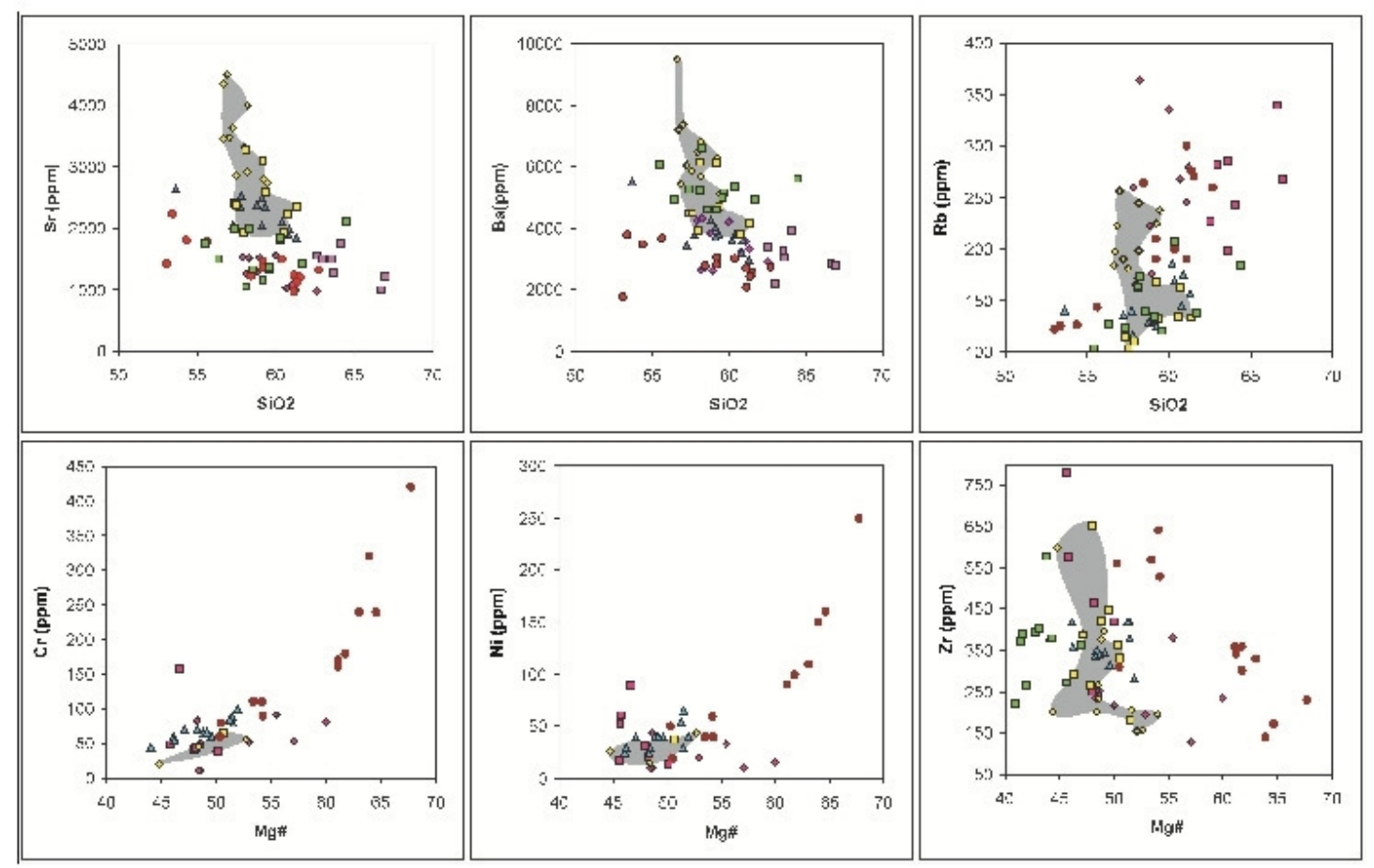

Figura 38: Diagramas de elementos menores. Legenda como na figura 37. 
A maioria das amostras apresentam teores de $\mathrm{Cr}$ de até 100 ppm e Ni em torno de 50 ppm, a exceção é o sienito Bom Jardim que apresenta os maiores teores em ambos elementos (respectivamente médias de 180 e 100 ppm). Além disso, as amostras com maior conteúdo destes elementos são também as mais primitivas ( $\mathrm{Mg \#}$ $>60)$.

Os valores de $\mathrm{Zr}$ variam amplamente em todas as unidades estudadas (desde 128-750 ppm). Os maiores teores ocorrem no Piquiri grosso, enquanto os menores ocorrem no Piquiri fino. Em todos os casos, observa-se uma grande variação no

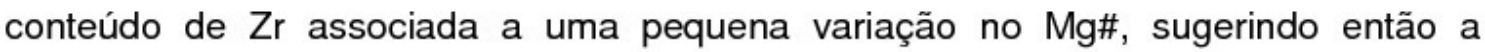
ocorrência de processos de acumulação de minerais (e.g. zircão).

\section{Elementos Terras Raras}

Todas as ocorrências sieníticas usadas na comparação apresentam alto conteúdo em elementos litófilos e terras raras leves, particularidade esta que vem sendo considerada por diversos autores como assinatura geoquímica de magmas gerados por fusão parcial de um manto metassomatizado. Nas figuras 39 e 40 estas características se destacam, e embora as unidades tenham similaridades, ao compará-las é possível observar algumas diferenças.

No diagrama de elementos terras raras na figura 39 (valores normalizados pelo condrito C1, Sun \& McDonough, 1989) é notável que todos os sienitos apresentam enriquecimento em terras raras leves em relação aos pesados, contribuindo assim para altas razões $(\mathrm{La} / \mathrm{Yb})_{\mathrm{N}}$. As menores razões são mostradas pela variedade fina do Sienito Piquiri fino, que tem uma média igual a 30 (valores máximo e mínimo, respectivamente 50 e 22). As demais outras ocorrências apresentam razões $(\mathrm{La} / \mathrm{Yb})_{\mathrm{N}}$ intermediárias: Piquiri grosso com média 49 (entre 45 e 59), Bom Jardim com média 45 (27-72), Capituva com média 44 (33-55) e Itiúba com 42 (apenas um valor disponível).

Na Figura 39, observa-se a ausência de anomalias de Eu, entretanto os valores de $\mathrm{Eu} / \mathrm{Eu}^{*}$ mostram anomalias sutilmente positivas em Pedra Branca $\left(E u / E u^{*}=1.07\right)$, Itiúba $\left(\mathrm{Eu} / \mathrm{Eu}^{*}=1.03\right)$, três amostras de Bom Jardim $\left(\mathrm{Eu} \mathrm{Eu}^{*}=1.05\right)$ e uma de Piquiri fino $\left(E u / E u^{*}=1.05\right)$. Já Capituva $\left(E u / E u^{*}=0.9\right)$, Piquiri fino $\left(E u / E u^{*}=0.82\right)$ e grosso $\left(E u / \mathrm{Eu}^{*}=0.93\right)$, Bom Jardim (entre 0.85 e 0.95) e apenas uma amostra de Pedra Branca $\left(E u / \mathrm{Eu}^{*}=0.86\right)$ mostram leves anomalias negativas. Embora pequenas variações nos padrões de Eu possam estar ligados a processos de segregação de minerais, observa-se que, sendo compostos dominantemente por feldspato alcalino, 
caso os sienitos correspondessem a cumulatos, deveriam exibir anomalias fortemente positivas já que, ao menos no caso de Pedra Branca, essas anomalias estão presentes no feldspato alcalino (dados de LA-ICPMS inéditos da autora).

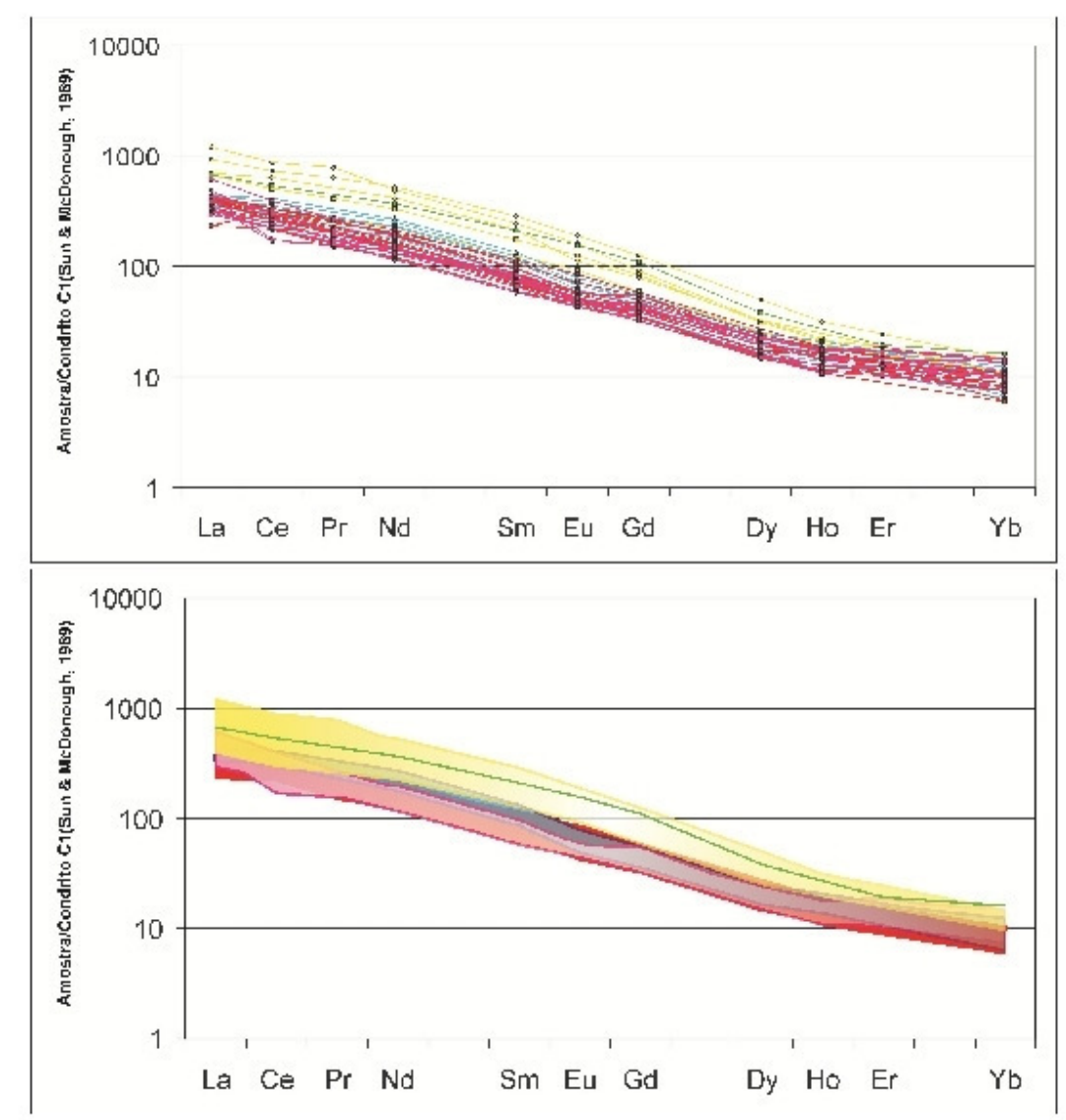

Figura 39: Diagrama de elementos Terras Raras. Valores normalizados pelo condrito $\mathrm{C}_{1}$ (McDonough\& Sun, 1995). Legenda como na figura 37.

\section{Elementos Incompatíveis}

O diagrama de elementos incompatíveis (Figura 40), mostra assinaturas geoquímicas das ocorrêncis sieníticas que são enriquecidas em elementos com $\mathrm{Ba}$, $\mathrm{Sr}, \mathrm{P}$ e ETR leves ( $\mathrm{La}, \mathrm{Ce}$ ), e empobrecidos em $\mathrm{Ti}, \mathrm{Nb}$ e Ta se comparados ao manto primitivo (Sun \& McDonough, 1989).

O Sienito Pedra Branca mostra-se mais enriquecido que as outras ocorrências nos elementos $\mathrm{Ba}, \mathrm{La}, \mathrm{Ce}, \mathrm{Sr}, \mathrm{Nd}, \mathrm{P}, \mathrm{Sm}, \mathrm{Eu}, \mathrm{Gd}$ e Dy. Entretanto, apresenta pronunciados vales principalmente em $\mathrm{Cs}$, Th, U, Hf, Zr, além de Ta-Nb e Ti. 


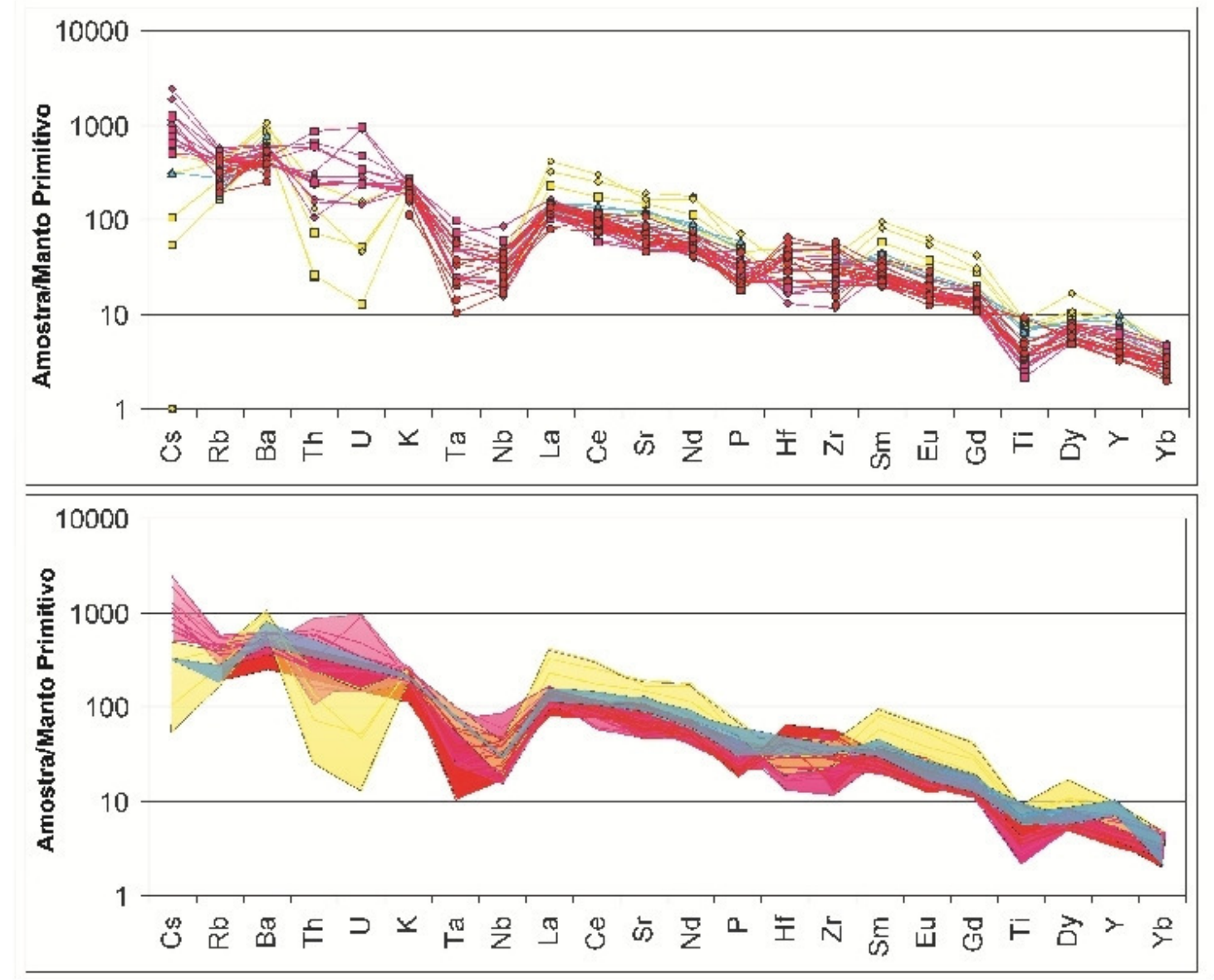

$\overline{\text { Figura 40: Diagrama de elementos incompatíveis. Valores normalizados pelo manto primitivo }}$

(Sun \& McDonough, 1989). Legenda como na figura 34.

Já o Sienito Piquiri apresenta anomalias positivas e maiores valores do conjunto nos elementos $\mathrm{Cs}$, Th, $\mathrm{U}, \mathrm{Hf}$ e $\mathrm{Zr}$, diferentemente do observado em Pedra Branca. Os valores extremamente altos nos LILE, além de Rb e Cs foram considerados como produto da fusão completa de flogopita na fonte mantélica (Nardi et al., 2007).

As amostras do sienito Bom Jardim também apresentam altas razões La/ $\mathrm{Nb}$ mostrando assim o enriquecimento desses magmas em LILE e empobrecimento em HFSE. Um comportamento similar é observado nas amostras de Capituva, que apresentam, em geral, valores intermediários em relação às outras ocorrências.

Apesar da assinatura geral comum entre as ocorrências sieníticas, diferenças observadas em alguns elementos (e.g. Cs, U, Th) podem sugerir diferentes proporções de fusão parcial, ou até mesmo diferenças composicionais nas fontes geradoras dos magmas. 


\section{V.3. GEOQUÍMICA ISOTÓPICA Sr-Nd}

Três amostras representativas de diferentes unidades do Sienito Pedra Branca foram analisadas para os sistemas isotópicos $\mathrm{Sm}-\mathrm{Nd}$ e $\mathrm{Rb}-\mathrm{Sr}$; os resultados dessas análises encontram-se abaixo na Tabela 9. Com o objetivo de comparar as assinaturas do plúton com outras ocorrências regionais utilizou-se dados do Sienito Capituva (dados inéditos de V.A. Janasi) e do Batólito Granítico Pinhal-Ipuiúna (sinorogênico de afinidade cálcio-alcalina de alto potássio; Janasi et al., 2009).

\begin{tabular}{|c|c|c|c|c|c|c|c|c|}
\hline Amostra & Unidade & Sm & Nd & 147Sm/144Nd & 143Nd/144Nd & $\varepsilon N d(t)$ & $\varepsilon N d(t)$ & TDM(Ga) \\
\hline PB-8a & SLSI & 33.4 & 207.2 & 0.098 & 0.511854 & -7.6 & -15.3 & 1.56 \\
\hline PB-09 & SSI & 16.4 & 96.4 & 0.103 & 0.511868 & -7.7 & -15.0 & 1.60 \\
\hline PB-92a & SLSI & 49.1 & 292.9 & 0.101 & 0.511841 & -8.1 & -15.5 & 1.62 \\
\hline & & & & & & & & \\
\hline Amostra & Unidade & Rb & Sr & $\mathbf{8 7 R b / 8 6 S r}$ & $\mathbf{8 7 S r / 8 6 S r}$ & $\mathbf{8 7 S r / 8 6 S r}(t)$ & & \\
\hline PB-8a & SLSI & 189.9 & 3798 & 0.145 & 0.70894 & 0.70767 & & \\
\hline PB-09 & SSI & 103.3 & 2572 & 0.116 & 0.70852 & 0.70751 & & \\
\hline PB-92a & SLSI & 239.9 & 4407 & 0.158 & 0.70917 & 0.70779 & & \\
\hline
\end{tabular}

Tabela 9: Dados isotópicos em amostras do Sienito Pedra Branca; as razões foram calculadas para idade de cristalização do plúton ( $\mathrm{t}=610 \mathrm{Ma}) . \mathrm{TDM}=$ idade-modelo $\mathrm{Sm}-\mathrm{Nd}$ segundo o método de DePaolo (1981).

Os valores de $\varepsilon \operatorname{Nd}_{(t)}$ foram calculados para as idades de cristalização estimadas para os Sienitos Pedra Branca e Capituva (610 Ma; Töpfner, 1996; V.A. Janasi, dados inéditos), e são muito similares (Pedra Branca: $-8.1<\varepsilon \mathrm{Nd}_{(\mathrm{t})}<-7.6$; Capituva $-9.7<\varepsilon N d_{(t)}<-7.1$ ), embora o intervalo para primeiro seja mais restrito. Os granitos do Batólito Pinhal-Ipuiúna (com idade de cristalização de $620 \mathrm{Ma}$; Janasi et al., 2009), abrangem um intervalo semelhante de $\varepsilon \mathrm{Nd}_{(t)}$, alcançando valores um pouco menos negativos $\left(-10<\varepsilon \mathrm{Nd}_{(\mathrm{t})}<-6\right)$, (Figura 41, B). As idades modelo $\mathrm{T}_{\mathrm{DM}}$ calculadas pelo método de DePaolo (1981), variam de 1.56 a 1.62 Ga para Pedra Branca, e de 1.51 a 1.73 Ga para Capituva (Figura 41, A).

As razões ${ }^{87} \mathrm{Sr}^{86} \mathrm{Sr}_{(t)}$ diferenciam os plútons sieníticos dos granitos do Batólito Pinhal-Ipuiúna. Nas amostras do Sienito Capituva a razão ${ }^{87} \mathrm{Sr}^{86} \mathrm{Sr}_{(\mathrm{t})}$ situa-se no intervalo 0,7071-0,7077, e nas de Pedra Branca a variação é ainda menor (0,70750,7078 ). Nos granitos sin-orogênicos as razões ${ }^{87} \mathrm{Sr}^{86} \mathrm{Sr}_{(t)}$ (também calculadas para $620 \mathrm{Ma})$ são sempre mais elevadas $(0,708-0.712)$. 


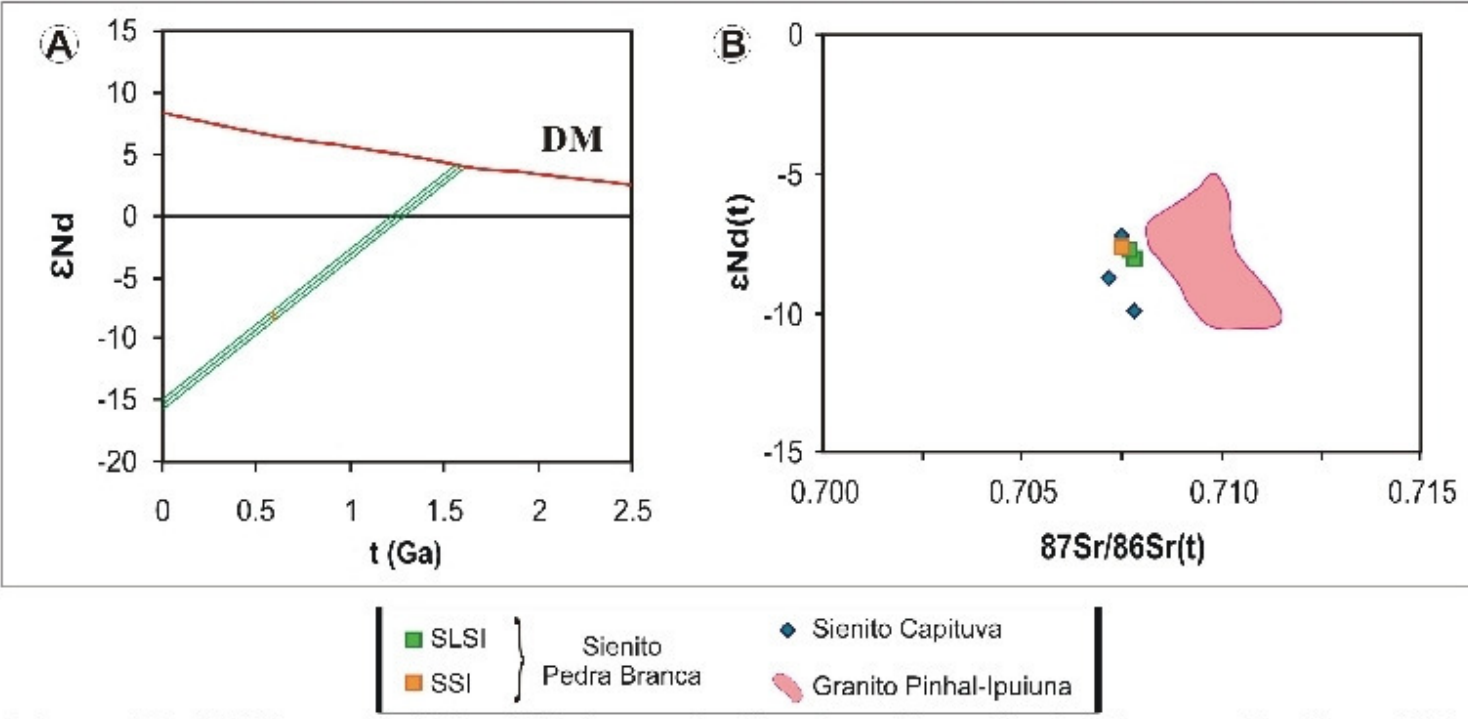

Figura 41: (A) Diagrama $\varepsilon N d$ x t (Ga) para sienitos dos plútons Pedra Branca e Capituva; DM: linha de evolução do manto empobrecido (DePaolo, 1981); (B) Diagrama $\varepsilon N d(t) x$ $87 \mathrm{Sr} / 86 \mathrm{Sr}(\mathrm{t})$; para comparação, é indicado o campo ocupado pelos granitos do Batólito Pinhal-Ipuiúna. 


\section{CAPITULO VI - PETROGÊNESE DO SIENITO PEDRA BRANCA}

\section{VI.1 CONSIDERAÇÕES SOBRE A GEOLOGIA DO PLUTON}

O plúton é constituído por três pulsos principais onde o primeiro é representado pelos SLSI de afinidade peralcalina. Os demais pulsos possuem afinidades metaluminosas: o segundo é representado por SLS que intrudem o SLSI e o terceiro e último representado por SSI que trunca o SLS. SSE pode estar relacionado ao segundo ou terceiro pulso. As variações texturais entre as unidades sugerem uma cristalização sucessivamente mais rápida dos SSE e SSI. Na unidade SSI a granulação fina das rochas permite inclusive a preservação de ortopiroxênio.

- Pulso 1: intrusão do SLSI nas encaixantes graníticas. Nos granitos encaixantes não são observados vestígios de metamorfismo devido à intrusão do magma sienítico. Além disso, a granulação média a grossa destes sienitos laminados podem indicar que não havia contraste extremo de temperatura. A idade obtida para granitos do Batólito Pinhal-Ipuiúna considerados equivalentes aos granitos encaixantes são da ordem de $620 \mathrm{Ma}$ (U-Pb em zircão; Janasi et al., 2007) enquanto o Pedra Branca foi datado em $\sim 610 \mathrm{Ma}$ (Töpfner, 1996), assim os granitos podem ter permanecido em temperaturas relativamente altas durante a colocação do SLSI. A forma dos granitos regionalmente acompanha os contatos do Sienito Pedra Branca, isso mostra que no momento da intrusão essas rochas deviam estar em estado plástico, possibilitando "deformação" e não a ruptura das encaixantes, pois não são encontrados xenólitos.

- Pulso 2: intrusão dos SLS. Se as unidades supersaturadas foram geradas a partir da interação entre o magma de tendência peralcalina (SLSI) e um "componente basáltico", então a modificação da composição não deve ter ocorrido in situ, mas sim em níveis mais profundos da crosta, pois não são encontradas estruturas indicativas da injeção dos magmas básicos (e.g., diques), mas apenas enclaves, em boa parte recristalizados, que parecem ter sido incorporados como sólidos. SLS intrude a parte interna da unidade SLSI, que está em estágio mais avançado de cristalização, permitindo a retirada de "pedaços" já cristalizados (PB-209, ver PRANCHA I, foto 33: xenólito).

- Pulso 3: intrusão da unidade SSI, truncando internamente aos SLS. Esta unidade, que representa o último pulso de magma do plúton, muitas vezes possui granulação 
mais fina indicativa de cristalização mais rápida, e garantindo a preservação de ortopiroxênio entre os minerais máficos. No presente trabalho o SSI não foi mapeado em detalhe, assim, as relações entre os sienitos com e sem ortopiroxênio ainda carecem de estudos, pois pode se tratar de unidades distintas, ou mesmo de diferentes pulsos de magma.

Até o momento não foram encontrados argumentos para inferir se a intrusão da unidade SSE está associada ao pulso 2 ou 3, ou se trata de um pulso independente. SSE intrude a parte externa da SLSI, aproveitando descontinuidades das rochas encaixantes. Além disto, em muitos afloramentos é texturalmente similar ao SLS, o que permitiria agrupá-la ao pulso 2. Por outro lado, as semelhanças químicas entre SSI e SSE e a ocorrência de sienitos com granulação mais fina sugerindo cristalização mais rápida torna possível que estas duas unidades sejam contemporâneas ao pulso 3.

\section{VI.2. PARÂMETROS INTENSIVOS E CONDIÇÕES DE CRISTALIZAÇÃO}

A composição mineralógica peculiar do Sienito Pedra Branca tem como resultado a ausência de algumas paragêneses minerais que geralmente são usadas em estimativas das condições de cristalização em rochas granitóides. De qualquer modo, apresentam-se abaixos algumas estimativas dos parâmetros com $\mathrm{P}, \mathrm{T}$ e $\mathrm{fO}_{2}$ baseadas em paragêneses minerais dos sienitos do plúton.

\section{VI.2.1. Temperatura}

As diferentes variedades litológicas do Sienito Pedra Branca cristalizaram sob temperaturas relativamente elevadas, o que é demonstrado pela sua composição mineral e paragênese, que se situam próximas da barreira térmica do sistema Qtz-Ab$\mathrm{Ne}$.

Para uma estimativa das temperaturas utilizou-se em paralelo equação de Harrison \& Watson (1984) que se baseia em teores de $\mathrm{SiO}_{2}$ e $\mathrm{P}_{2} \mathrm{O}_{5}$ para obtenção de temperaturas de saturação em apatita. Os altos conteúdos de $\mathrm{P}_{2} \mathrm{O}_{5}$ desses magmas sugerem temperaturas mínimas de $1000^{\circ} \mathrm{C}$ para solubilização de todo fósforo em magmas com teores de $\mathrm{SiO}_{2}$ similares aos destes sienitos. 
A ocorrência de apatita como um mineral de cristalização precoce permite tratar as temperaturas de saturação deste mineral como de liquidus nas diferentes variedades sieníticas do plúton.

As temperaturas obtidas apresentadas no diagrama de barras da figura $42(A)$ mostram que os SLSI possuem as temperaturas mais elevadas do conjunto (valor máximo de $1160^{\circ} \mathrm{C}$, e em média $1091^{\circ} \mathrm{C}$ ), seguido pelos SLS (valor máximo $1103^{\circ} \mathrm{C}$, em média $1065^{\circ} \mathrm{C}$ ) que na maioria dos casos situam-se acima da isoterma $1080^{\circ} \mathrm{C}$ (Watson \& Harrison, 1984) (Figura 42, B). As unidades SSI e SSE possuem valores similares (valor máximo $1082^{\circ} \mathrm{C}$, em média $1066^{\circ} \mathrm{C}$ ), similares (Figura 42, B) ao campo composicional do vizinho Sienito Capituva $\left(1015-1080^{\circ} \mathrm{C}\right)$. A temperatura de saturação do leuco-quartzo sienito é a menor do conjunto, da ordem de $750^{\circ} \mathrm{C}$.

Uma das amostras de enclave sienítico (PB-250) tem temperatura dentro do intervalo dos sienitos laminados $\left(1097^{\circ} \mathrm{C}\right)$, e a outra (PB-209C) apresenta temperatura significativamente mais baixa $\left(932^{\circ} \mathrm{C}\right)$. $\mathrm{O}$ enclave monzonítico tem temperatura de saturação em apatita de $1033^{\circ} \mathrm{C}$.

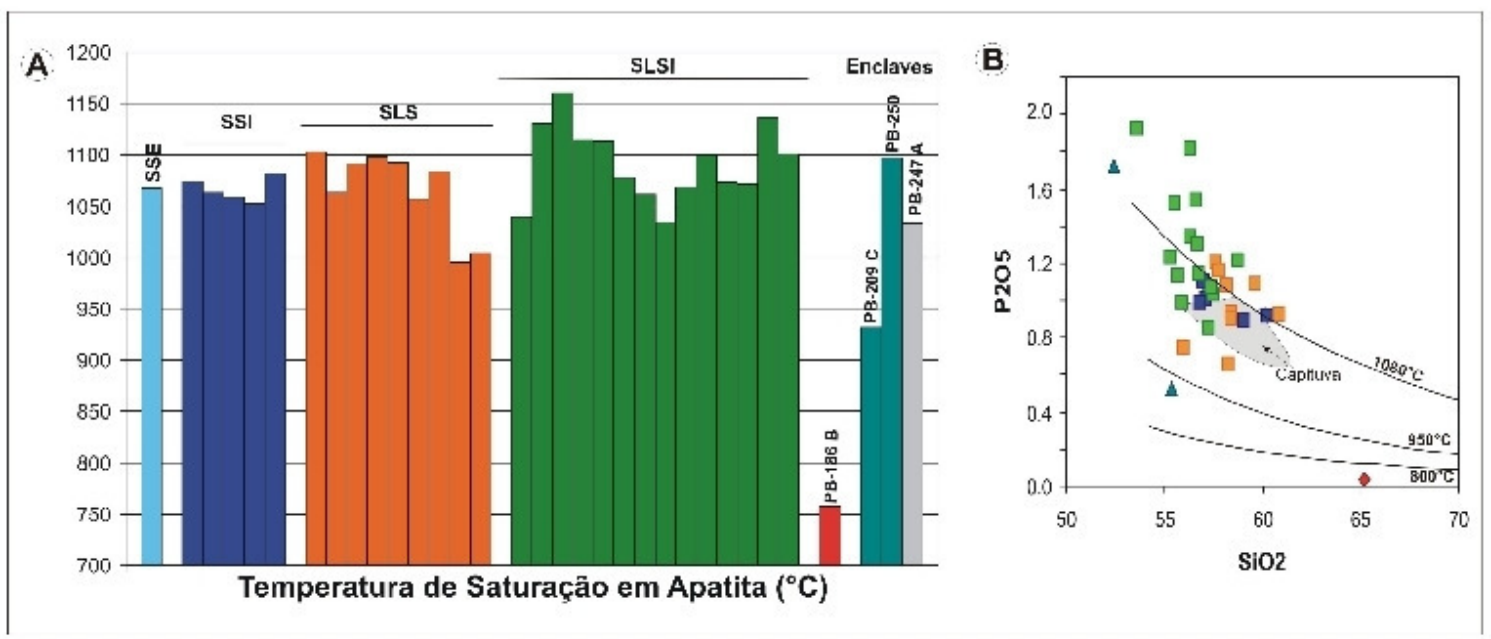

Figura 42: (A) Diagrama de barras com as temperaturas obtidas pelo termômetro de Harrison \& e Watson (1984); (B) Diagrama $\mathrm{P}_{2} \mathrm{O}_{5}$ versus $\mathrm{SiO}_{2}$ para rochas do Sienito Pedra Branca (simbologia como na figura $\mathrm{x}$ ) e Capituva (campo hachurado em cinza), com isotermas de Watson \& Harrison (1984).

Ao contrário do observado no Sienito Capituva, onde as rochas são localmente afetadas por recristalização subsolidus (formação de actinolita + epidoto; Janasi, 1992), os sienitos do plúton Pedra Branca não apresentam substituições das paragêneses originais por associações de baixa temperatura. Análises texturais sugerem que a substituição do piroxênio por anfibólio observada em algumas amostras ocorreu ainda no estágio magmático, sob temperaturas elevadas. Lamelas 
de exsolução em feldspatos e ilmeno-hematita provavelmente se formaram em temperaturas inferiores a $700^{\circ} \mathrm{C}$ ou subsolidus.

A coexistência de orto e clinopiroxênio (enstatita e diopsídio) nos SSI torna possível a estimativa de temperatura utilizando um termômetro de piroxênios de Lindsley (1983). No entanto, na Figura 43, observa-se que ambos não se encontram em equilíbrio, pois situam-se em diferentes isotermas (enstatita na isoterma de $\sim 1000^{\circ} \mathrm{C}$ e diopsídio na isoterma de $\sim 800^{\circ} \mathrm{C}$ ).

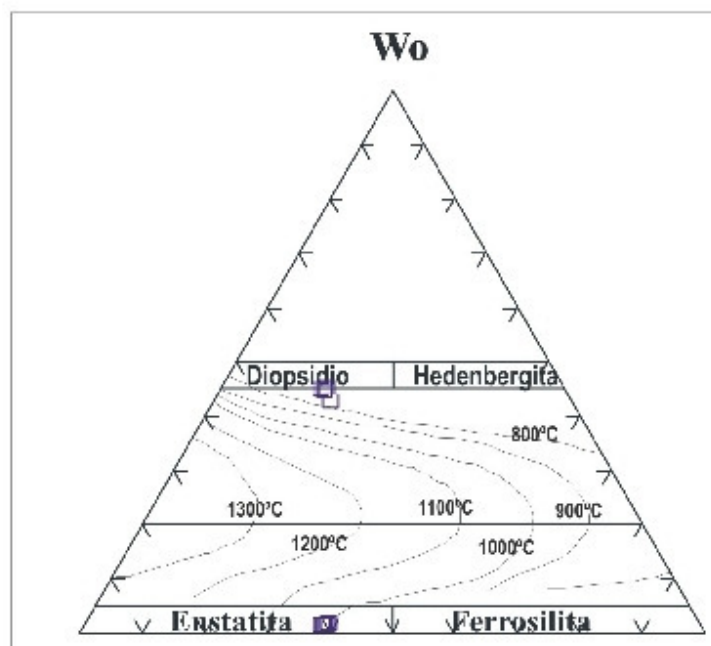

En

Fs

Figura 43: Termometria de Piroxênios (Lindsley, 1983) para amostra PB-59 (SSI) do Sienito Pedra Branca.

\section{VI.2.2. Pressão}

As pressões de cristalização de plútons graníticos podem ser estimadas a partir do teor de Al da hornblenda (Anderson \& Smith, 1995). No entanto, é requerida a paragênese quartzo, titanita, plagioclásio. O Sienito Pedra Branca possui paragêneses inadequadas para aplicação destes geobarômetros, pois a maioria das amostras estudadas não possui plagioclásio.

Anderson \& Smith (1995) propuseram uma fórmula para o uso do geobarômetro de Al hornblenda levando em conta as temperaturas do par hornblendaplagioclásio coexistentes; no entanto, a ausência de plagioclásio nos SLSI impede a obtenção das temperaturas. 
Parte dos sienitos supersaturados apresenta plagioclásio, porém na grande maioria dos casos ele se mostra em desequilíbrio com a rocha hospedeira, o que torna os resultados obtidos de significado incerto. De qualquer modo, estimativas foram feitas para os SLS (Figura 44), e mostraram pressões da ordem de 3,3 a 4,8 kbar, similares aos estimados por Janasi (1992) no Sienito Capituva (4,1 $\pm 0,5$ kbar). Os valores encontrados, se estiverem corretos, indicam uma colocação destes sienitos a cerca de $12 \mathrm{~km}$ de profundidade, em crosta média a superior.

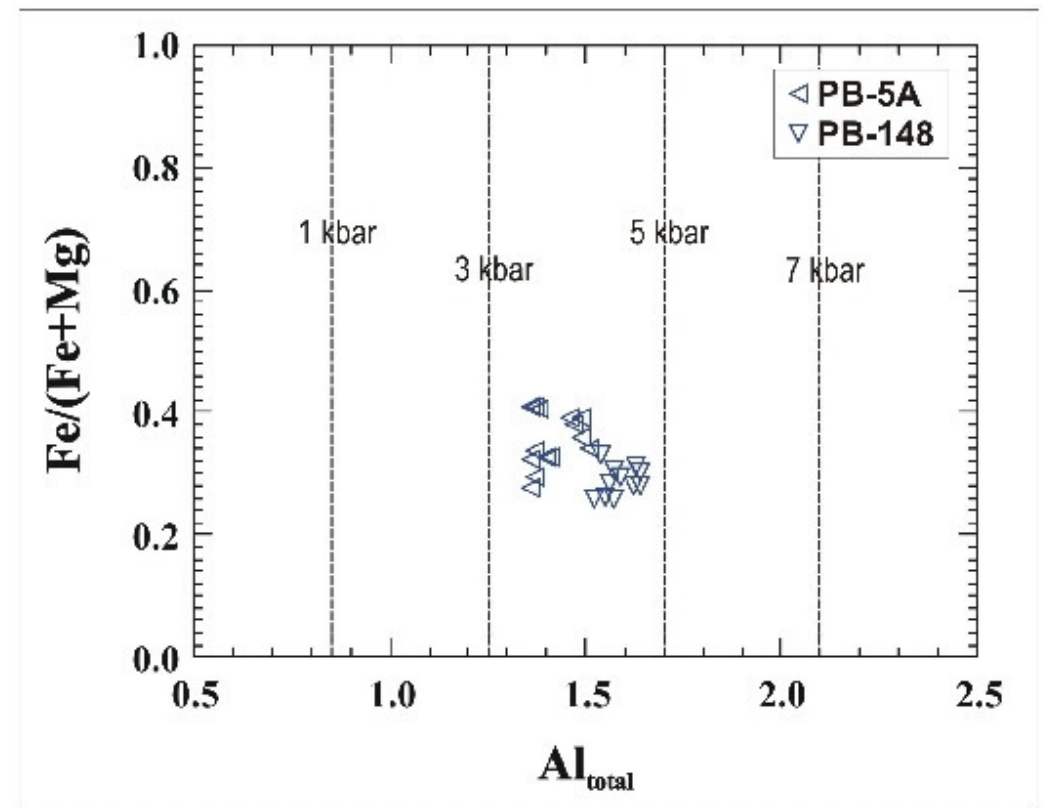

Figura 44: Estimativa de pressão do Sienito Pedra Branca em amostras do SLS, utilizando a metodologia de Anderson \& Smith (1995).

Evidências geológicas observadas em campo, como por exemplo, a presença local de cavidades miarolíticas em veios pegmatíticos e de texturas gráficas sugerem a possibilidade de cristalização em crosta mais rasa; entretanto, o comportamento relativamente dúctil das rochas encaixantes, que parecem se amoldar à forma do plúton é mais consistente com as pressões estimadas pelo teor de Al em hornblenda.

\section{VI.2.3. Fugacidade de Oxigênio}

Estimativas indiretas da fugacidade de oxigênio nas diferentes variedades faciológicas do plúton podem ser feitas devido à presença de minerais máficos com $\mathrm{Mg} \#$ relativamente alto e pela associação de óxidos de Fe-Ti (magnetita e ilmeno- 
hematita) que evidenciam cristalização sob condições fortemente oxidantes. As composições dos anfibólios das unidades SLS e SLSI situam-se no campo de alta fugacidade de oxigênio (Figura 45) no diagrama de Anderson \& Smith (1995).

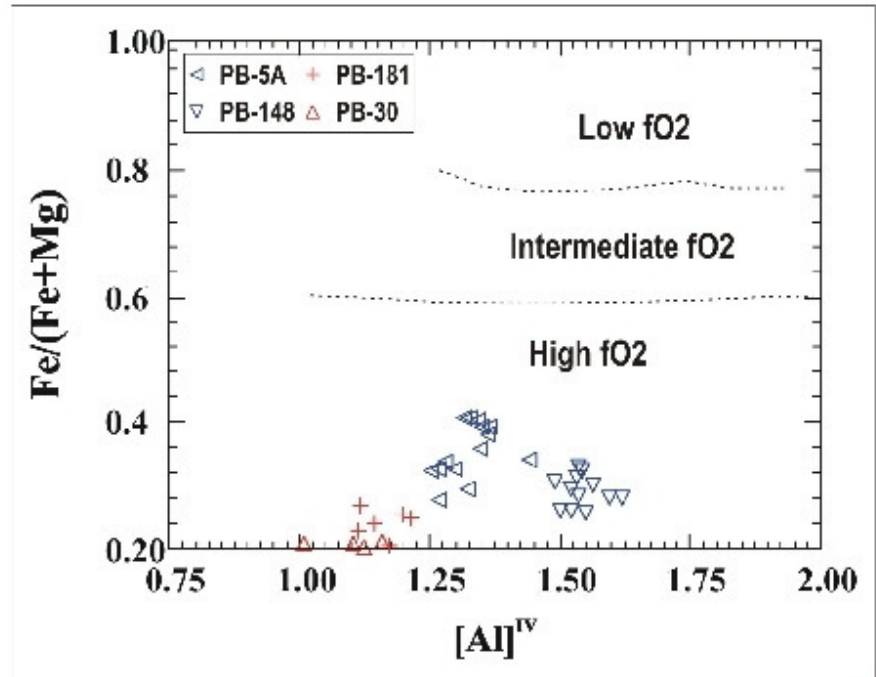

Figura 45: Diagrama de Fugacidade conforme a composição de cristais de anfibólio das unidades do Sienito Pedra Branca (Anderson \& Smith, 1995).

Embora a associação hematita-magnetita seja ideal para obtenção quantitativa da fugacidade de oxigênio, as estimativas utilizando dados químicos dos óxidos realizadas neste trabalho não deram resultados significativos, pois as temperaturas encontradas são da ordem de $600^{\circ} \mathrm{C}$ e $\mathrm{fO}_{2}$ acima do buffer $\mathrm{HM}$. As avaliações das condições de $\mathrm{fO}_{2}$ tornaram-se difíceis, pois, embora aparentemente haja um equilíbrio entre as fases minerais (hematita-magnetita e ilmeno-hematita-magnetita), como mostrado no item de petrografia, ocorre mais de uma geração de magnetita o que pode ter inviabilizado as estimativas.

\section{VI.3. PROCESSOS DE EVOLUÇÃo MAGMÁTICA}

\section{VI.3.1. Revisão da Literatura}

Entre os processos admitidos para geração de magmas como os de Pedra Branca, que explicam o seu enriquecimento em elementos incompatíveis, estão: cristalização fracionada, assimilação de material crustal rico em elementos incompatíveis, imiscibilidade líquida e fusão parcial de uma fonte mantélica metassomatizada. 


\section{Cristalização Fracionada}

Desde os estudos experimentais realizados por Bowen (1928), a cristalização fracionada tem sido considerada um processo importante na diferenciação de magmas. Além disso, seu papel na geração dos magmas ultrapotássicos foi admitido pela primeira vez em 1967 por O'Hara \& Yoder (apud Foley et al. 1987) quando sugeriram que o fracionamento de clinopiroxênio e granada de um magma picrítico resultaria não somente no enriquecimento em elementos incompatíveis, como também no aumento da razão $\mathrm{K}_{2} \mathrm{O} / \mathrm{Na}_{2} \mathrm{O}$ do líquido residual.

A cristalização fracionada reflete a diferenciação do líquido por meio do resfriamento, cristalização e segregação de cristais. A segregação de cristais pode ocorrer por processos gravitacionais, caso haja diferenças de viscosidade e densidade, por correntes magmáticas, ou ainda por "filter pressing", quando cumulatos se formam por cristalização in situ, e o líquido é expelido (por tensões externas ou não).

Embora este modelo seja possível em certos casos, algumas ressalvas importantes existem, entre elas (1) o enriquecimento em elementos incompatíveis das rochas ultrapotássicas demandaria um alto grau de fracionamento (cerca de 95\%); (2) o extremo fracionamento também diminuiria os $\mathrm{Mg} \#$, que seriam muito inferiores aos dos magmas primários (Foley et al., 1987);

Alguns autores sugerem uma relação genética entre magmas lamprofíricos e sienitos, admitindo que a cristalização fracionada dos primeiros possa gerar líquidos mais evoluídos de composição sienítica (Janasi et al., 1993). Esses mesmos autores admitem que os Sienitos Pedra Branca e Capituva possuam origem comum de magmas parentais tipo minette, e foram gerados por fracionamento de minerais máficos.

O comportamento de alguns elementos ( $\mathrm{Cr}$, Ni e $\mathrm{Mg \# )}$ é compatível com o modelo por cristalização fracionada a partir de magmas básicos por extração de olivina e piroxênio, no entanto a identificação do tipo de magma básico que gerou esses sienitos é dificultada, pois em Pedra Branca, assim como no Sienito Capituva, não são encontrados enclaves máficos associados aos sienitos. Para Janasi (1993) isto pode estar relacionado às altas densidades dos magmas máficos, que poderia impedir que estes atingissem níveis crustais mais rasos.

No sul da Groenlândia, a Província Alcalina Gardar, tem como importante ocorrência o Complexo Klokken, que apresenta como associação típica gabros e sienitos cristalizados sob condições de alta fugacidade de oxigênio. De geometria anelar, a intrusão Klokken (1159 $\pm 11 \mathrm{Ma}$ ) constitui-se externamente por gabros que 
passam a sieno-gabros e sienitos não laminados, e internamente por sienitos laminados com intensa foliação de fluxo magmático e biotita sienodioritos. A presença comum de texturas cumuláticas permitiu a interpretação da passagem de gabros a sienitos como produto do fracionamento de minerais máficos (Parsons, 1978).

\section{Assimilação de Material Crustal}

O modelo petrogenético de combinação entre materiais de origem mantélica e crustal também foi admitido por alguns autores, pois de certa forma explicaria as características composicionais peculiares das rochas ultrapotássicas: alto $\mathrm{Mg} \#, \mathrm{Ni}$ e $\mathrm{Cr}$ (características mantélicas), além de $\mathrm{Rb}, \mathrm{Zr}$ e Ba (características crustais). No entanto, a existência de rochas ricas em potássio com baixos conteúdos de sílica e a necessidade de magmas parentais básicos superaquecidos, uma vez que grandes quantidades de assimilação podem acelerar a cristalização, contrariam o modelo de assimilação de material crustal (Foley et al.,1987).

\section{Imiscibilidade Líquida}

A separação de um líquido inicialmente homogêneo em dois magmas silicáticos de composições contrastantes é um processo reconhecido em muitas localidades para explicar a ocorrência simultânea de basaltos e riolitos, ou de carbonatitos e piroxenitos, entre outras associações. Estudos experimentais também mostram que este processo pode ocorrer em estágios iniciais da diferenciação magmática.

O Batólito Triunfo, na Província Borborema, é uma intrusão peralcalina ultrapotássica composta por álcali-feldspato sienitos leucocráticos que carregam piroxenitos como inclusões co-magmáticas (diques sin-plutônicos e tardios). Ambos possuem mesmas fases minerais (egirina-augita, microclínio, titanita, apatita, anfibólio azul e magnetita), diferenciando-se apenas nas proporções modais (Ferreira et al., 1992). Raros enclaves de uma rocha mista $(60 \%$ sienito $+40 \%$ piroxenito) também estão preservados e segundo os autores, em todos os casos de interação, os dois magmas mantiveram suas características, não havendo mistura mecânica. A rocha mista é considerada como representativa do magma antes da separação dos dois líquidos (sienítico e piroxenítico). 
As características químicas da associação sienito-piroxenito descartam a cristalização fracionada como mecanismo gerador dos dois magmas. Padrões de elementos terras raras paralelos para os ambos, segundo os autores, são melhor explicados por processos de imiscibilidade. O comportamento de isótopos estáveis (valores de $\delta^{18} \mathrm{O}$ ), além de isótopos de $\mathrm{Sr}\left({ }^{87} \mathrm{Sr} /{ }^{86} \mathrm{Sr} \sim 0.710\right)$ e $\mathrm{Nd}\left({ }^{143} \mathrm{Nd} /{ }^{144} \mathrm{Nd} \sim 0.51104\right)$ é similar nos dois casos, reforçando o modelo de imiscibilidade líquida.

Ferreira et al. (1992) atribuem a formação da intrusão peralcalina ultrapotássica ao processo de imiscibilidade líquida e separação em dois magmas (sienitopiroxenito); o magma inicial teria como fonte os horizontes do manto afetados por subducção.

\section{Fusão Parcial de uma fonte mantélica previamente enriquecida}

Determinações experimentais das composições de magmas gerados no manto superior têm sido tema de intensa pesquisa, com ênfase em composições anidras ou nos efeitos de pequenas quantidades de água ou fluidos com $\mathrm{C}-\mathrm{H}-\mathrm{O}$. Evidências oriundas da petrologia experimental e da geoquímica isotópica e de elementos menores e traço em rochas magmáticas e xenólitos do manto têm demonstrado que a composição do manto é bastante variável. Além disso, um manto homogêneo não seria capaz de fornecer a diversidade geoquímica dos magmas primitivos apenas com alterações na pressão, temperatura e conteúdo de voláteis (Conceição \& Green, 2004).

A partir dos modelos de origem de basaltos por fusão parcial de um granada peridotito mantélico, surgiram as primeiras idéias de que líquidos altamente enriquecidos em elementos incompatíveis poderiam ser gerados no manto por volumes extremamente pequenos de fusão parcial $(<<1 \%)$. O estudo de xenólitos mantélicos com minerais hidratados primários (e.g. flogopita), evidências de processos de enriquecimento prévios e a petrologia experimental contribuem para a aceitação deste modelo (Foley et al.,1987).

Assim, os magmas potássicos podem ser considerados as mais acessíveis manifestações das fontes mantélicas enriquecidas em elementos traços, e por isso são importantes no entendimento dos processos de concentração de elementos incompatíveis no manto superior (Roger, 1992).

A origem de magmas potássicos por fusão composta do manto peridotítico em uma "litosfera vênulada" foi proposta por Foley (1992b). A associação mineral dessas vênulas é composta principalmente por anfibólio, mica, apatita, óxidos e clinopiroxênio, 
portanto mais enriquecidas em voláteis e elementos incompatíveis, com temperaturas solidus mais baixas.

A fusão se inicia nas vênulas, já que estas possuem altas concentrações de fases hidratadas e elementos incompatíveis, porém se propaga e ocorre fusão das paredes peridotíticas, e dessa forma o magma gerado será um híbrido da vênula e da parede. A dissolução de olivina das paredes peridotíticas contribuirá para características primárias (como Mg\# e conteúdo de $\mathrm{Ni}$ ), encontradas na maioria dos magmas parentais das rochas potássicas. Nos casos dos magmas derivarem apenas da fusão parcial das vênulas, essas características primárias seriam menos acentuadas (Foley, 1992b).

No caso de Pedra Branca, o Mg\# mais baixo do que o admitido para magmas gerados em equilíbrio com o manto (Foley et al., 1987) associado aos teores muito baixos de $\mathrm{Ni}$ e $\mathrm{Cr}$ podem sugerir que esses magmas correspondam a fracionados a partir de parentais mais primitivos. Alternativamente, eles poderiam ser resultado da fusão parcial de horizontes (ou vênulas) enriquecidos, nos quais a olivina seria rara a ausente.

No Sienito Piquiri, a ocorrência de enclaves microgranulares máficos (tipo minette) com clinopiroxênio rico em $\mathrm{K}$ mostrou que esses lamprófiros são produtos de fusão sob altíssimas pressões (>5.0 GPa). A relação textural entre o sienito hospedeiro e os enclaves lamprofíricos, e a identificação de fases minerais ricas em $\mathrm{K}$ preservadas, sugerem que a interação entre esses magmas deve ter se iniciado sob condições mantélicas (próximo às temperaturas liquidus). O contraste de temperatura entre os dois magmas acelerou o resfriamento do magma máfico, impedindo que houvesse difusão química e conseqüentemente a perda do $\mathrm{K}$ presente no clinopiroxênio (Plá Cid et al., 2003).

As características composicionais dos dois magmas (sienítico e lamprofírico) são similares, entretanto os conteúdos de Cs, Rb, U, LREE e Sr são maiores nos enclaves, além disso, razões $\mathrm{Nb} / \mathrm{Ta}$ variam em torno de 20 nos sienitos e aproximadamente 30 nos enclaves, enquanto as razões $\mathrm{Th} / \mathrm{U}$ e $\mathrm{Zr} / \mathrm{Hf}$ são inferiores nos enclaves. Este comportamento não é consistente com um modelo de geração dos sienitos por fracionamento do magma parental lamprofírico, já que a maioria destes elementos teria comportamento incompatível, concentrando-se nos líquidos mais evoluídos (sieníticos). Assim, a geração dos dois magmas por processos semelhantes seria mais plausível neste caso, envolvendo diferentes proporções de fusão parcial de uma fonte mantélica similar, contudo mais rasa para os sienitos (cerca de $3 \mathrm{GPa}$ ) (Nardi et al., 2007). 
No nordeste do Brasil pequenos enclaves de mica piroxenitos em sienitos potássicos a ultrapotássicos foram apontados como possíveis xenólitos mantélicos por terem composição similar à de enclaves encontrados em lavas ultrapotássicas de Uganda. Os xenólitos são constituídos por diopsídio (alto Mg\# 77-93), flogopita (baixo $\mathrm{Ti}$ e $\mathrm{SiO}_{2}$ ), carbonato, titanita, apatita e feldspato intersticial. As assinaturas geoquímicas destes enclaves são caracterizadas por alto conteúdo em elementos terras raras leves, discretas anomalias negativas de Eu e altas concentrações de $\mathrm{Ba}$, $\mathrm{La}, \mathrm{K}, \mathrm{Ce}, \mathrm{Nd}, \mathrm{Sm}, \mathrm{Sr}, \mathrm{Ti}, \mathrm{Al}, \mathrm{Mn}, \mathrm{Ca}, \mathrm{Na}$ e Y, diferente do observado em um manto "normal". Esses xenólitos foram considerados por Ferreira \& Sial (1993) como evidência para existência de uma fonte mantélica metassomatizada geradora do extenso magmatismo ultrapotássico da Província Borborema (e.g. Batólito Triunfo, Complexos Bom Jardim e Toritama e Plúton Serra do Man).

Derivação de magmas potássicos por descompressão e fusão de flogopitapargasita Iherzolito foi abordada experimentalmente por Conceição \& Green (2004). A estabilidade de pargasita e flogopita foi observada com objetivo de avaliar quando magmas supersaturados em sílica (com quartzo normativo) ricos em potássio (alta razão $\mathrm{K} / \mathrm{Na}$ ) poderiam derivar diretamente do manto metassomatizado por desidratação e fusão de um flogopita Iherzolito a $1 \mathrm{GPa}$ de pressão. Nestes experimentos, foram explorados campos de baixa pressão, na qual um afinamento da litosfera e diapirismo do manto são esperados, gerando assim fusão por descompressão de uma litosfera previamente metassomatizada. O magma produzido por fusão por descompressão é um shoshonito magnesiano supersaturado em sílica com $\mathrm{K}_{2} \mathrm{O}>\mathrm{Na}_{2} \mathrm{O}$, deixando um Iherzolito residual (olivina+ ortopiroxênio+ clinopiroxênio + espinélio).

\section{Fluidos e o Enriquecimento do Manto}

O estudo de xenólitos mantélicos e a composição dos magmas mostra que a fugacidade de oxigênio no manto pode ser heterogênea, desta forma a ocorrência de ambientes reduzidos ou oxidados no manto são de grande importância na gênese de magmas, além disso a estabilidade de diferentes elementos voláteis terá grande influência na composição do líquido produzido.

Experimentos de equilíbrio entre fases demonstram o papel essencial da abundância e tipo dos voláteis nas temperaturas de fusão e na composição dos líquidos gerados. Os elementos $\mathrm{F}$ e $\mathrm{Cl}$ são importantes constituintes nas micas e na apatita, que em geral estão envolvidas na gênese dos magmas alcalinos. 
Voláteis como $\mathrm{H}_{2} \mathrm{O}, \mathrm{CO}_{2}, \mathrm{CH}_{4}$ e $\mathrm{HF}$ podem ter papeis decisivos na fusão parcial geradora das rochas ultrapotássicas. Os diferentes conteúdos de $\mathrm{SiO}_{2}$ encontrados nestas rochas podem ser produtos de diferentes profundidades de fusão parcial, porém Foley et al. (1986), através da petrologia experimental, observaram que a formação de líquidos ricos em $\mathrm{SiO}_{2}$, por fusão parcial de um flogopita harzburgito está ligada à presença de $\mathrm{CH}_{4}$ e $\mathrm{HF}$ na fonte. Já líquidos pobres em $\mathrm{SiO}_{2}$ podem ser produzidos sob altas pressões, em ambientes mais reduzidos, ou até mesmo em ambientes oxidados com alta razão $\left(\mathrm{CO}_{2} / \mathrm{CO}_{2}+\mathrm{H}_{2} \mathrm{O}\right)$.

$\mathrm{O}$ elevado conteúdo de $\mathrm{K}_{2} \mathrm{O}$ na fonte é indispensável para produzir magmas potássicos por fusão parcial, e pode ser resultado de processos de desidratação ou fusão parcial de uma placa subductada. As fontes possíveis para o potássio seriam os sedimentos subductados ou crosta oceânica basáltica modificada, de modo que a entrada de fluidos aquosos carregando $\mathrm{K}_{2} \mathrm{O}$ em solução resultaria em reações na cunha mantélica e consequente formação de mica. A contaminação da cunha mantélica pelo material subductado sob altas pressões pode ainda enriquecer o manto em elementos incompatíveis, principalmente LILE (Foley et al., 1987; Rogers, 1992). Como conseqüência deste influxo de fluidos ricos em $\mathrm{K}$, desenvolve-se uma distribuição heterogênea de flogopita em pequena escala, o que torna relevante a idéia de uma fonte não-Iherzolítica para os modelos de fusão parcial heterogênea das rochas ultrapotássicas (Foley, 1992a).

Um modelo à parte dos fluidos de subducção para o enriquecimento do manto foi proposto por Mackenzie (1989) que demonstra que frações de fusão extremamente pequenas ( $<10^{-3} \%$ de fusão parcial), altamente enriquecidas em $\mathrm{K}_{2} \mathrm{O}$ e outros elementos incompatíveis, podem gerar metassomatismo em regiões do manto inferior.

\section{VI.3.2. Processos de Cristalização Fracionada}

Processos de cristalização fracionada ocorrem em todas as unidades do Sienito Pedra Branca, por isso cumulatos máfico-ultramáficos e fracionados (e.g. leuco-sienitos tardios) são freqüentemente encontrados em associação com sienitos. As variações litológicas das diferentes unidades não podem ser explicadas por extração de minerais máficos, já dentro das mesmas algumas diferenças composicionais podem ser explicadas por fracionamento.

Bandas ou níveis cumuláticos são comuns em Pedra Branca, localmente podem estar associadas a sienitos com baixo índice de cor. Essa feição pode sugerir que estes também são gerados por segregação in situ, onde o agrupamento de 
cristais, seguido de tensão permitiria a expulsão do líquido, formando então os pares máficos-félsicos.

A correlação negativa de elementos como $\mathrm{TiO}_{2}, \mathrm{P}_{2} \mathrm{O}_{5}, \mathrm{Sr}$ e Ba com $\mathrm{SiO}_{2}$ mostra o comportamento compatível destes elementos que resultam na cristalização precoce não só de feldspato alcalino (principal residência de Ba e Sr), mas também de apatita e óxidos de Fe-Ti (ilmeno-hematita; magnetita).

Alguns autores consideram rochas sieníticas como as de Pedra Branca como produto da acumulação de feldspato alcalino; a comum existência de estruturas cumuláticas nestas rochas contribui para possibilidade deste modelo. No entanto, os padrões de Eu podem trazer informações importantes que contradizem tais idéias. A ausência de anomalias de Eu, observada na maioria das amostras do plúton, ser explicadas por evidências como:

- o fracionamento plagioclásio e minerais máficos em proporções adequadas pelo magma parental;

- presença de Eu trivalente no magma devido às condições fortemente oxidantes;

O fracionamento de plagioclásio, juntamente com proporções adequadas de minerais máficos (e.g. clinopiroxênio e apatita) poderia gerar padrões isentos de anomalias de Eu. Embora os sienitos não possuam anomalias negativas de Eu, o forte enriquecimento em Sr sugere que estes magmas não devem ter derivado de parentais básicos por fracionamento de plagioclásio.

A ocorrência de fortes anomalias positivas de Eu nos feldspatos alcalinos (dados inéditos obtidos por LA-ICPMS) demonstra que o Eu é dominantemente bivalente nesses magmas, embora estes magmas tenham se cristalizado sob alta fugacidade de oxigênio. Além disso, a ausência de expressivas anomalias positivas de Eu nas rochas demonstra que, embora haja evidências de campo de processos de acumulação, esses sienitos podem em parte corresponder a composições de líquidos e não à de cumulatos feldspáticos, como sugerido por alguns autores (Conceição et al., 1991). Por tratarem-se de rochas essencialmente compostas por feldspato alcalino ( $75 \%$ modal), as anomalias de Eu deveriam ser positivas caso representassem cumulatos feldspáticos. Adicionalmente, composição de um dos enclaves sieníticos (PB-250) é muito similar à dos sienitos hospedeiros (SLS e SLSI), o que reforça a ideia de que realmente esses sienitos podem ser considerados representativos do magma que os originou.

Os enclaves microgranulares sieníticos são encontrados ora com formas tabulares e contatos abruptos, ora com contatos sinuosos com o sienito hospedeiro, sugerindo situações, respectivamente, de alto e baixo contraste de viscosidade com o 
magma sienítico. Em ambos os casos a paragênese máfica desses enclaves é similar à dos sienitos supersaturados.

A geoquímica de dois destes enclaves, um deles tabular (PB-250) e o outro elipsoidal com contatos sinuosos (PB-209C), mostra discrepâncias composicionais nos dois tipos: PB-250 tem menores teores de $\mathrm{SiO}_{2}, \mathrm{Na}_{2} \mathrm{O}, \mathrm{Al}_{2} \mathrm{O}_{3}$ e maiores conteúdos de $\mathrm{TiO}_{2}, \mathrm{~K}_{2} \mathrm{O}, \mathrm{P}_{2} \mathrm{O}_{5}$, padrão de elementos terras raras e incompatíveis similar aos de SLS e SLSI, e temperatura de saturação em apatita $\sim 1097^{\circ} \mathrm{C}$, enquanto PB-209C tem pequenas proporções de plagioclásio $\left(A n_{20}\right)$, padrão de elementos terras raras e incompatíveis similar aos de SSI e SSE, é menos enriquecido que PB-250, e tem temperatura de saturação em apatita $\sim 932^{\circ} \mathrm{C}$.

Esses dados indicam que suas origens podem ser distintas. A amostra de forma tabular, com mais altas temperaturas liquidus e composicionalmente similar a SLS e SLSI pode representar um fragmento de magem resfriada. Enquanto isto, a amostra PB-209C, com menor contraste de viscosidade com o sienito hospedeiro, temperaturas mais baixas e composição semelhante a SSE e SSI, poderia representar novas injeções de líquido na câmara magmática.

Os enclaves máficos-ultramáficos em geral apresentam granulação grossa, e são comuns em todas as unidades. Em geral exibem textura cumulática, e são compostos por piroxênio, flogopita, apatita e titanita, os mesmos minerais máficos que compõem os sienitos hospedeiros.

A geoquímica de rocha total mostra que o Mg\# desses enclaves é similar ao da rocha hospedeira (50-55), o que é consistente com uma origem por acumulação. Uma exceção é a amostra PB-185C, que tem Mg\# mais alto (65), sugestivo de derivação a partir de um magma mais primitivo. Observa-se, no entanto, que a composição do clinopiroxênio do enclave e rocha hospedeira é idêntica, e o Mg\# situa-se no mesmo intervalo $(\sim 75-80)$.

A hipótese mais atraente para origem dos enclaves cumuláticos seria a formação por retrabalhamento e desagregação de bandas ou lentes cumuláticas pelo intenso fluxo magmático do sienito. A ocorrência comum de schlieren mostra que a foliação magmática muitas vezes pode desagregar totalmente corpos cumuláticos maiores.

O enriquecimento em elementos terras raras e incompatíveis reflete a presença de apatita e titanita como minerais essenciais. As anomalias negativas de Eu $\left(E u / \mathrm{Eu}^{*}=0,73\right)$ encontradas nestes enclaves devem-se seguramente à ausência de feldspato alcalino e à abundância de minerais como clinopiroxênio, apatita e titanita, que possuem tais anomalias nos seus padrões de terras raras (análises inéditas de LA-ICPMS). 
A única amostra de sienito tardio analisada foi a PB-186B; este leuco-sienito, que garantiu informações importantes sobre a evolução do SLS.

O conteúdo mais alto de $\mathrm{SiO}_{2}(\sim 65 \%), \mathrm{Mg \#}=23$ e teores mais baixos de $\mathrm{P}, \mathrm{Ti}$, $\mathrm{Zr}$, indicam tratar-se de líquidos mais diferenciados. Além disso, o seu padrão de elementos terras raras é o mais empobrecido do conjunto e também o menos fracionado, com razão $(\mathrm{La} / \mathrm{Yb})_{N}=5$ e anomalias negativas de $\mathrm{Eu}\left(\mathrm{Eu} / \mathrm{Eu}^{*}=0,76\right)$.

O empobrecimento nestes elementos sugere o comportamento compatível dos mesmos nos magma sienítico devido á cristalização de minerais como apatita, ilmenohematita e zircão, que em geral são abundantes no SLS. A existência de anomalias negativas de Eu deve estar ligada à extração de feldspato alcalino do magma.

Temperatura de saturação em apatita para esta amostra de leuco-sienito é $750^{\circ} \mathrm{C}$, significativamente mais baixa do que as temperaturas dos sienitos hospedeiros.

\section{VI.3.3. Processos de Mistura e Significado dos Enclaves Microgranulares Dioríticos}

Os processos ligados à formação de rochas cogenéticas portadoras ora de quartzo ora de nefelina são questões petrológicas importantes devido à existência da barreira termal do sistema de fases $\mathrm{Ne}-\mathrm{Ks}-\mathrm{Qtz}-\mathrm{H}_{2} \mathrm{O}$. Em geral, os líquidos evoluem em direção ao mínimo granítico, dando origem a rochas supersaturadas em sílica ou, em direção ao mínimo dos nefelina sienitos gerando rochas insaturadas em sílica. A coexistência de sienitos saturados a insaturados com sienitos supersaturados em sílica no Sienito Pedra Branca, certamente chama atenção e demonstra que estes magmas violaram a barreira térmica.

A violação da barreira térmica pode ocorrer por diversos processos, sob sistema fechado (e.g. aumento da pressão de voláteis ou água; cristalização fracionada) e sistema aberto (e.g. assimilação de material) (Riihuus et al., 2008).

No Sienito Pedra Branca a ocorrência de enclaves microgranulares exclusivamente nas unidades supersaturadas sugere que a geração destas variedades sieníticas deve estar ligada a processos sob sistema aberto, devido à interação entre dois tipos contrastantes de magmas (sienítico de tendência alcalina versus diorítico).

Os enclaves monzoníticos e dioríticos em geral apresentam formas tabulares, e podem ou não desenvolver biotita nas bordas, evidenciando reação com o magma hospedeiro sienítico. Em geral, suas composições não estão totalmente preservadas, 
pois o plagioclásio por vezes encontra-se alterado para sericita e muitas vezes a biotita é o único mineral máfico presente, demonstrando que os outros minerais máficos foram substituídos. Tais transformações dificultam a inferência sobre a origem destes enclaves.

Apenas um dos enclaves dioríticos possui anfibólio como mineral principal, que pode conter clinopiroxênio reliquiar em alguns núcleos; biotita é mineral acessório. Plagioclásio muitas vezes está preservado, porém pode estar sericitizado no núcleo. Esta amostra (PB-246A) deve representar as composições iniciais dos enclaves dioríticos.

$\mathrm{O}$ conteúdo de $\mathrm{Al}_{2} \mathrm{O}_{3}$ varia de 20 a $23 \%$ nestes enclaves e reflete o alto conteúdo de An normativa (entre 20 e $25 \%$ ).

Os padrões de elementos incompatíveis dos enclaves microgranulares dioríticos, embora apresentem algumas semelhanças com os dos sienitos hospedeiros, se distinguem claramente pelas anomalias positivas de $\mathrm{Sr}$ e Eu, e pelas menores razões $\mathrm{Ba} / \mathrm{Rb}$ e, especialmente, pela ausência de anomalias negativas de $\mathrm{Ti}$, $\mathrm{Zr}$ e Hf; entre os HFSE, apenas as anomalias negativas de $\mathrm{Nb}$ e Ta se mantêm. As similaridades no comportamento desses enclaves com as variedades sienitícas podem ser efeito da interação entre eles, embora não se possa descartar a possibilidade dessas características serem primárias.

As anomalias claramente positivas de $\mathrm{Eu}\left(\mathrm{Eu} / \mathrm{Eu}^{*}=1,34 ; 2,08\right)$ dos enclaves dioríticos evidenciam a presença de plagioclásio como mineral essencial.

Assinatura geoquímica dos elementos maiores e menores das rochas do plúton é similar em todas as unidades estudadas, exceto no conteúdo de $\mathrm{Al}_{2} \mathrm{O}_{3}$ que é superior nos sienitos supersaturados (> 14\%), refletindo no aumento de anortita normativa destas rochas ( $2-9 \%$ de $A n$ normativa). Além disso, os dados químicos dos enclaves dioríticos analisados mostram que estes são as rochas mais ricas em $A n$ normativa do conjunto ( $25 \%$ ), com teores de $\mathrm{Al}_{2} \mathrm{O}_{3}$ da ordem de $23 \%$.

Análises pontuais em cristais de plagioclásio corroídos inclusos em feldspato alcalino dos SLS mostraram composições semelhantes às dos cristais de plagioclásio de enclaves dioríticos $\left(\mathrm{An}_{27-37}\right)$, indicando que eles devem corresponder a xenocristais incorporados a partir desses enclaves ou seus precursores magmáticos. Tal evidência, ao lado das relações químicas entre sienitos e enclaves sugerem que a coexistência de sienitos saturados a insaturados e supersaturados em sílica no Sienito Pedra Branca pode estar diretamente ligada a processos de interação com outros magmas. Um modelo petrogenético possível seria de um magma inicial de tendência alcalina (formador dos SLSI) que adquire caráter metaluminoso ao incorporar um "componente basáltico", dando origem aos sienitos supersaturados. 
A Intrusão Kangerlussuaq no leste da Groenlândia (Riihuus et al., 2008) também apresenta sienitos supersaturados e insaturados em sílica, porém neste caso os autores atribuem a violação da barreira térmica à assimilação de rochas crustais, uma vez que a assinatura isotópica de $\mathrm{Sr}, \mathrm{Pb}, \mathrm{Nd}$ e $\mathrm{Hf}$ indica um aumento do componente crustal nos sienitos supersaturados. No caso do sienito Pedra Branca, análises isotópicas de $\mathrm{Sr}$ e $\mathrm{Nd}$ foram obtidas em apenas três amostras, que não mostram diferenças significativas. No entanto, não se pode excluir a possibilidade de que haja contrastes entre as unidades do plúton, sendo necessárias análises isotópicas adicionais.

Já as variações composicionais evidenciadas pelas paragêneses máficas das unidades sieníticas (SLSI: egirina-augita + flogopita + hematita + magnetita; SLS e SSE: diopsídio + flogopita +ilmeno-hematita \pm magnetita; SSI: diopsídio + enstatita + flogopita +ilmeno-hematita \pm magnetita) e texturais (sienito fino versus sienito médio a grosso) devem-se principalmente às diferentes condições de cristalização destes sienitos.

$\mathrm{Na}$ unidade saturada a paragênese máfica sugere condições de mais alta fugacidade de oxigênio, se comparada às demais unidades do plúton. A interação entre o magma sienítico percalino e o magma dioritico, responsável pela geração dos sienitos supersaturados, pode, portanto, ter afetado também nas condições de cristalização. A razão $\mathrm{Fe}^{3+} / \mathrm{Fe}^{2+}$ nos dois magmas certamente é contrastante, as condições mais redutoras nos enclaves (ilmenita como opaco principal com magnetita rara) torna plausível admitir que diminuição da fugacidade de oxigênio nos sienitos supersaturados também está associada à mistura.

Nas unidades supersaturadas os enclaves microgranulares dioríticos podem ocorrer no interior de acumulações máficas; tendo em vista que esses cumulatos são formados por minerais de cristalização precoce do magma sienítico (e.g. piroxênio, apatita), a interação com os magmas básicos deve ter ocorrido no estágio inicial da evolução magmática do Sienito Pedra Branca.

Embora a composição da maioria destes enclaves esteja tranformada, eles, de fato, mostram que houve uma interação entre magmas básicos e o sienito hospedeiro. Os maiores conteúdos de $\mathrm{Al}_{2} \mathrm{O}_{3}$ nos sienitos supersaturados parecer estar relacionados à presença destes enclaves. A forma dos mesmos e a ausência de diques ou corpos básicos associados aos sienitos indicam que a interação entre o magma sienítico e básico não deve ter ocorrido ao nível da câmara atualmente exposto, mas em maiores profundidades, sob condições que permitiram uma interação efetiva, sob altas temperaturas favorecendo os processos de interação e difusão entre ambos. 
A Figura 46 é um diagrama triangular de feldspatos normativos (Ab-An-Or) gerado a partir de dados geoquímicos; foi lançada para referência a curva de solvus para feldspatos ternários (LKS) e a linha "cotética" (PAL= plagioclase- alkaline feldspar line) para os sistemas dos feldspatos saturado (sem quartzo) a 2 kbar e a $\left(\mathrm{H}_{2} \mathrm{O}\right)=0,1$ (Nekvasil, 1990).

SLSI e um dos enclaves sieníticos (PB-250) situam-se no campo "feldspato alcalino + líquido". Assim, devido ao conteúdo muito baixo de An dessas rochas não se forma plagioclásio magmático e o feldspato alcalino formado em condições de equilíbrio, terá a mesma composição do componente "feldspato" do magma.

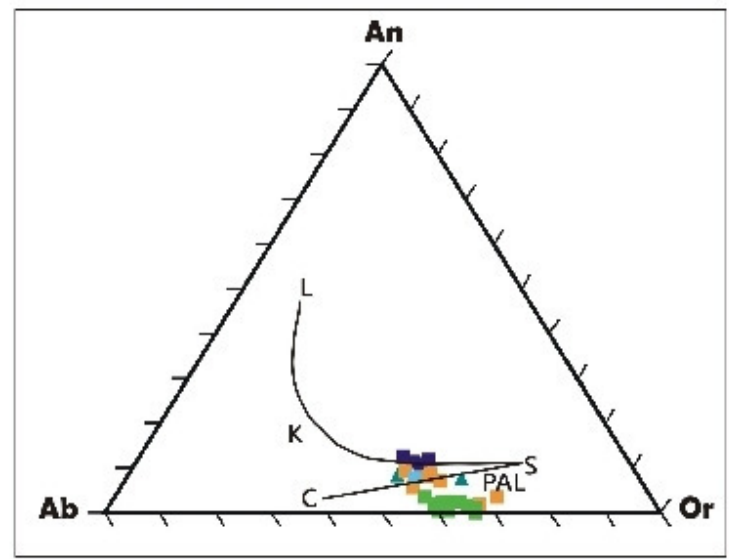

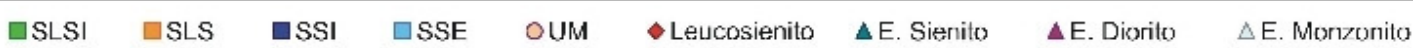

Figura 46: Diagrama de composições normativas dos feldspatos em amostras de sienito e enclaves.

SLSI, SLS e SSE, e um dos enclaves sieníticos (PB-209C), situam-se entre a curva de solvus e a curva cotética. Para composições situadas nesta área o primeiro feldspato a se formar é o plagioclásio $\left(A n_{10-20}\right)$ que, no entanto, é reabsorvido ao final da cristalização do magma.

Analogamente, amostras do Sienito Capituva também situam-se nesta área do diagrama, o que levou Janasi (1993) a atribuir a ocorrência de núcleos de plagioclásio parcialmente reabsorvidos à preservação desses primeiros cristais que se formariam em um magma com estas composições. No caso de Pedra Branca, acredita-se que a presença de cristais reabsorvidos deve estar relacionada à interação com outros magmas ou rochas previamente cristalizadas; como discutido anteriormente, se tratando então de xenocristais, uma vez que teor de An é idêntico ao do plagioclásio presente nos enclaves. 
As composições da unidade SSI situam-se pouco acima da curva de solvus, de modo que poderá ocorrer a formação de dois feldspatos, consistente com a ocorrência de feldspato alcalino e plagioclásio na matriz $\left(A n_{15-20}\right)$ destes sienitos.

\section{VI.3.4. Considerações sobre as Áreas Fontes}

Apesar dos contrastes existentes entre as unidades do Sienito Pedra Branca, todas elas apresentam assinaturas geoquímicas semelhantes, como os elevados teores em elementos litófilos $(\mathrm{Ba}, \mathrm{Sr}, \mathrm{K})$ além de outros elementos incompatíveis como $\mathrm{P}$ e terras raras leves. Até o momento não foram encontrados possíveis testemunhos dos magmas parentais dos quais resultaram a geração destes sienitos, no entanto os dados geoquímicos destas rochas permitem algumas inferências importantes sobre as áreas fonte destes magmas.

Os altos conteúdos de $\mathrm{K}$ e $\mathrm{Ba}$ são importantes indícios da presença de flogopita nas áreas fontes. Já elementos terras raras exibem padrões com forte fracionamento dos leves (altas razões $L_{N} / Y b_{N}$ ) e podem estar relacionados com baixas proporções de fusão, com a presença de granada residual, ou refletir uma característica da própria fonte (rica em elementos terras raras leves).

O notável enriquecimento em LILE e empobrecimento em HFSE demonstrado pelas pronunciadas anomalias negativas em $\mathrm{Nb}-\mathrm{Ta}, \mathrm{Ti}$ e $\mathrm{Hf}-\mathrm{Zr}$ é caracteristico de áreas ativas onde a injeção de fluidos ricos em REE e LILE durante a subducção gera metassomatismo no manto superior (Rogers, 1992).

As assinaturas isotópicas dos Sienitos Pedra Branca e Capituva de $\varepsilon \mathrm{Nd}_{(\mathrm{t})}$ pouco negativo além de razões moderadas ${ }^{87} \mathrm{Sr}^{86} \mathrm{Sr}_{(t)}$ associadas ao elevado conteúdo de elementos traço $(\mathrm{Ba}, \mathrm{Sr}$ e ETR), reforçam que estas rochas estão associadas à fusão parcial de horizontes enriquecidos do manto litosférico (EMI). Assim como estes sienitos neoproterozóicos, outras ocorrências paleoproterozóicas (e.g. Sienito Itiúba, São Felix e Anuri) e neoproterozóicas (Batólito Triunfo, Bom Jardim) no nordeste do Brasil possuem características isotópicas similares que também são interpretadas como produto de fusão de manto metassomatizado (Conceição et al., 2007; Ferreira et al., 1997; Guimarães \& Silva Filho, 1998; Rosa et al., 2001).

\section{VI.3.5. Considerações sobre Ambiente Tectônico}


A origem de magmas ricos em elementos incompatíveis tem sido relacionada por diversos autores (Thompson \& Fowler, 1986; Foley et al. (1986), Foley, 1992a, 1992b; Rogers, 1992) a eventos de subducção responsáveis pela introdução no manto de sedimentos ou de crosta oceânica basáltica modificada (por interação com água do mar), o que levaria à percolação de fluidos e a ocorrência de reações na cunha mantélica para a formação de mica. A contaminação pelo material subductado pode ainda enriquecer o manto em elementos incompatíveis (LILE) além de alterar a sua composição isotópica, gerando baixas razões ${ }^{147} \mathrm{Sm} /{ }^{146} \mathrm{Nd} \mathrm{e}{ }^{143} \mathrm{Nd} /{ }^{144} \mathrm{Nd}$, e altas razões ${ }^{87} \mathrm{Sr} /{ }^{86} \mathrm{Sr}$ e ${ }^{87} \mathrm{Rb} /{ }^{86} \mathrm{Sr}$ (Foley et al., 1987; Roger, 1992).

Em diagramas discriminantes (Figura 47) os sienitos de Pedra Branca situamse em campos de arco-vulcânico e margem continental ativa (Figura 47, A) que podem transicionar ao campo de rochas intraplaca (Figura 47, B). Roger (1992) mostrou que, comparando amostras de rochas potássicas provenientes de rifts (e.g. Karisimbi médias de Virunga e Eifel) e de áreas de subducção ativas (e.g. Indonésia e Itália), a diferença entre os dois grupos é enfatizada pelos elementos traço. Em especial, as rochas de áreas de subducção ativa apresentam anomalias muito negativas em $\mathrm{Nb}$ Ta, Ti e Zr-Hf, assim como o Sienito Pedra Branca.
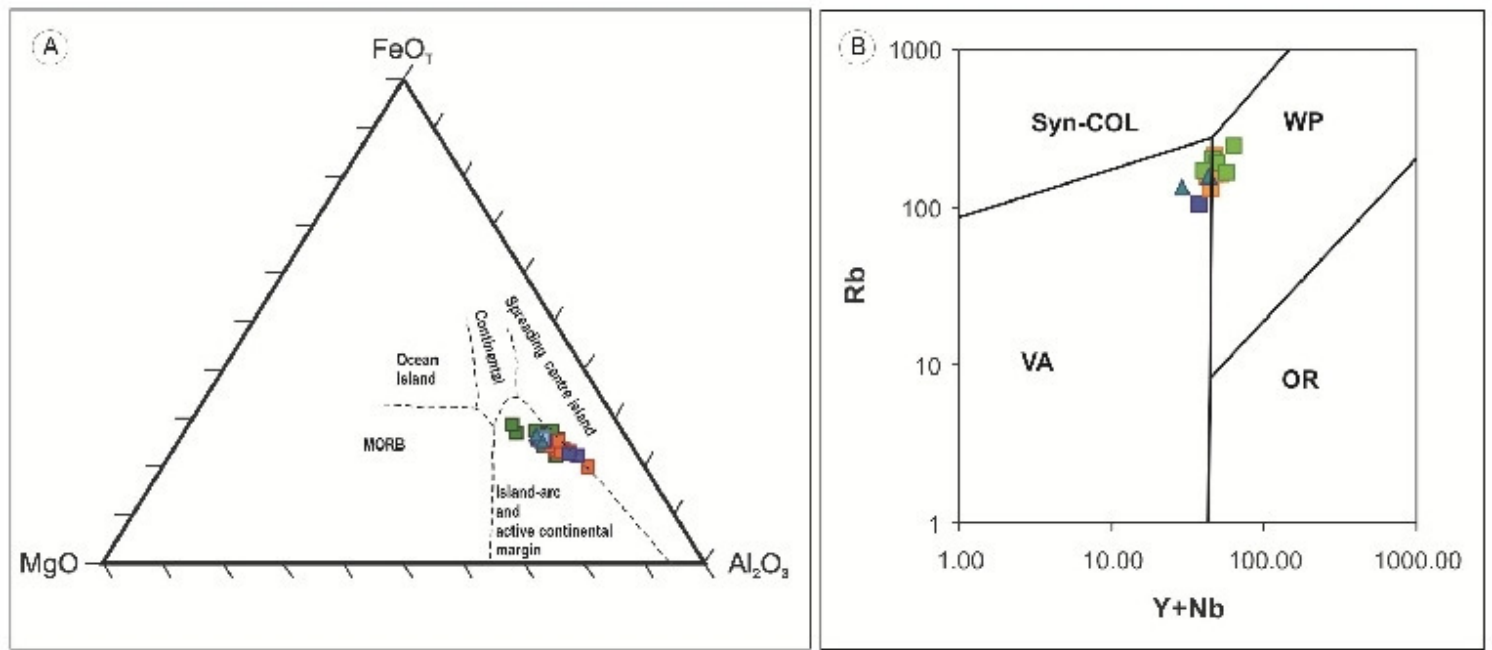

Figura 47: Diagramas de discriminação tectônica para o Sienito Pedra Branca; simbologia como na figura $\mathrm{Y}$. (A) Diagrama ternário $\mathrm{FeO}_{\mathrm{T}}-\mathrm{MgO}-\mathrm{Al}_{2} \mathrm{O}_{3}$, campos segundo Pearce et al. (1977). (B) Diagrama binário $\mathrm{Nb}+\mathrm{Y}$ versus $\mathrm{Rb}$, campos segundo Pearce et al. (1984): Syn-COL - sin-colisional, WP- intra-placa, VA-arco vulcânico, ORG- orogênico.

$\mathrm{O}$ diagrama de $\mathrm{Nb}$ versus $\mathrm{Zr}$ (Figura 48; Thopson \& Fowler, 1986), distingue rochas de ambientes pos-colisionais ou relacionadas a subducção (campo B) de 
rochas associadas a extensão continental, longe da subducção no espaço ou tempo (campo A). Todas as mostras do Sienito Pedra Branca situam-se no campo B, mostrando que a geração destes magmas provavelmente está relacionada à subducção anterior à colocação destes magmas (630-610 Ma).

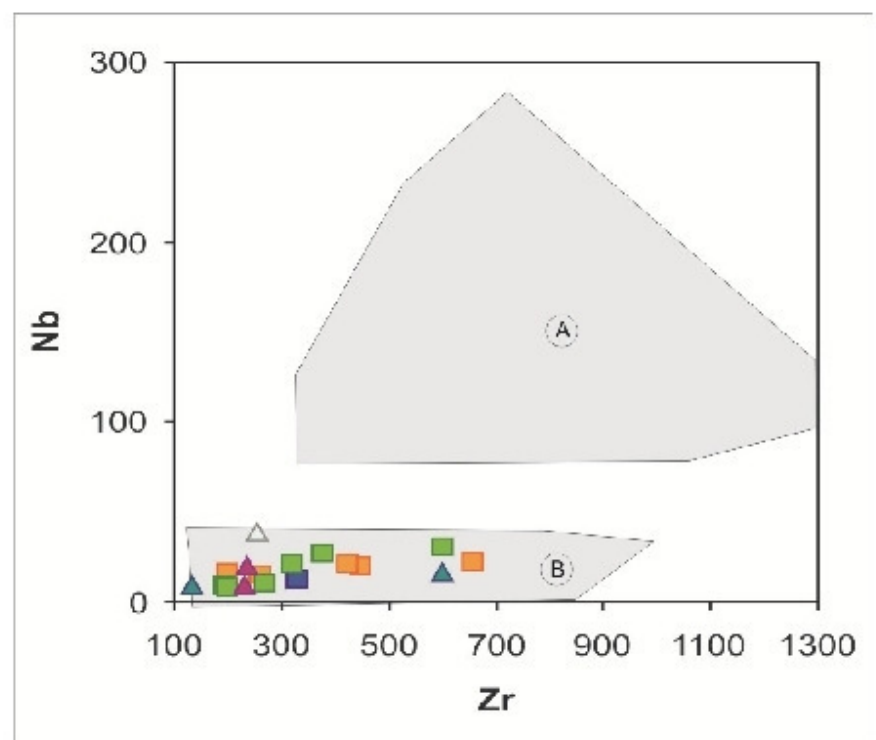

Figura 48: Diagrama $\mathrm{Nb}$ versus $\mathrm{Zr}$, para rochas potássicas com teores de $\mathrm{SiO}_{2}$ inferiores a $60 \%$ (Thompson \& Fowler, 1986). O campo hachurado em (A) representa rochas separadas de processos de subducção no espaço e/ou tempo; (B) corresponde a rochas próximas a subducção no espaço e/ou tempo.

As idades modelo estimadas com base em teores e razões isotópicas $\mathrm{Sm}$ e $\mathrm{Nd}$, revelam a idade da fonte dos magmas sieníticos de Pedra Branca, que varia de 1.56 a $1.62 \mathrm{Ga}$, e Capituva, que possui um intervalo ainda maior 1.51-1.73 Ga. Tais plútons sieníticos marcam o final da evolução do arco magmático desenvolvido na margem continental ativa da Placa Paranapanema (Campos Neto et al., 2004) e são datados em $610 \mathrm{Ma}$. Por tratarem-se de magmas gerados em horizontes enriquecidos do manto, seria consistente admitir que durante a subducção, a entrada de material na cunha mantélica seria responsável pela modificação composicional, ainda assim idades modelo mais antigas sugerem que outros eventos tectônicos podem ter influenciado o manto regional.

Estas idades modelo (cerca de $1.6 \mathrm{Ga}$ ), semelhantes nos Sienitos Pedra Branca e Capituva, são comuns em toda a região, como por exemplo nas suítes charnokíticas ( $T_{D M}$ 1.5-1.8 Ga; Janasi, 2002) e no Granito Pinhal-Ipuiúna (dados inéditos de V.A. Janasi). No entanto, idades similares de cristalização são desconhecidas no local, isso sugere que o significado das idades $T_{D M}$ ainda merece 
investigação, podendo ser reflexo de eventos paleoproterozóicos ou até mesmo subducção de material mais antigo durante a colisão do Paranapanema com o cráton do São Francisco. 


\section{CAPITULO VII - CONSIDERAÇÕES FINAIS}

\section{VII.1 CONSIDERAÇÕES FINAIS}

A disposição das diferentes fácies do plúton Pedra Branca indica que este se estruturou a partir da intrusão de três pulsos magmáticos principais: um deles com tendência peralcalina e os outros dois de afinidade metaluminosa.

O primeiro pulso é representado pela intrusão do SLSI de tendência peralcalina no embasamento granítico, e o segundo pulso consiste na intrusão do SLS, que trunca o interior do SLSI. Já o terceiro e último pulso trunca internamente SLS, e constitui o centro do plúton (SSI). SSE intrude a parte externa da SLSI, aproveitando descontinuidades entre sienito encaixantes e granito-gnaisse, e pode estar associado ao segundo ou terceiro pulso, no entanto, até o momento não há argumentos consistentes que permitam assegurar com precisão a qual dos pulsos eles são contemporâneos ou ainda se trata-se de um pulso independente.

Tal zoneamento mineralógico do Sienito Pedra Branca, caracterizado pela presença de sienitos saturados na borda e supersaturados no interior do pluton, associado à presença de enclaves dioríticos sugerem que a mudança de caráter e conseqüente violação da barreira térmica ocorreram devido à interação com magmas básicos. Devido à interação do magma de tendência peralcalina e o componente basáltico, houve a mudança do caráter saturado-insaturado para supersaturado em sílica. A ausência de diques e a presença apenas de enclaves básicos, indica que a interação entre os dois magmas e a conseqüente modificação da composição não deve ter ocorrido in situ, mas sim em níveis mais profundos da crosta

O Sienito Pedra Branca é dominado por sienitos hipersolvus com alto índice de cor (entre 20-25), onde as variações mineralógicas mostram diferentes condições de cristalização. O SLSI atingiu condições relativamente mais oxidantes que os sienitos supersaturados (SLS, SSI e SSE), registradas pelas paragêneses máficas egirinaaugita + flogopita + hematita + magnetita versus diopsídio + flogopita \pm hornblenda + ilmeno-hematita \pm magnetita nas outras unidades. Embora em todos os sienitos a cristalização ocorra sob condições oxidantes, o Mg\# dos máficos relativamente maior na unidade saturada e as maiores proporções do componente hematita nos óxidos de Fe reforçam que no SLSI a fugacidade de oxigênio foi ainda mais elevada.

Processos cumuláticos são comuns em todas as unidades e são registrados pela presença de bandas e/ou níveis de sienitos com índice cor acima de 35, que podem ou não estar associados a cumulatos dominantemente feldspáticos. Em geral esses cumulatos máfico-ultramáficos são constituídos principalmente por piroxênio, 
flogopita, apatita, titanita e óxidos de $\mathrm{Fe}-\mathrm{Ti}$, com feldspato alcalino como mineral acessório principal. Os minerais que compõem esses cumulatos evidenciam a cristalização precoce de apatita e ilmeno-hematita nestes magmas. Enclaves cumuláticos também são encontrados nestes sienitos e sua formação deve-se ao retrabalhamento destas bandas pelo intenso fluxo magmático nestas rochas.

Textura e mineralogia das diferentes fácies do Sienito Pedra Branca estão intactas, demonstrando que processos de hidratação pós-magmáticos foram restritos ou nulos. No SLSI o piroxênio é mineral máfico principal e raramente é substituído por anfibólio, já nos sienitos supersaturados a hornblenda muitas vezes aparece substituindo o piroxênio, indicando que houve diferenças não só nas condições redox, mas também contrastes na $\mathrm{a}_{\mathrm{H} 2 \mathrm{O}}$ destes magmas.

A intrusão do Maciço Alcalino de Poços de Caldas, de idade cretácea, não provoca alterações pervasivas, algumas modificações restritas à fraturas do Sienito Pedra Branca ocorrem apenas nas proximidades com o contato deste maciço.

Estimativas de temperatura utilizando a saturação em apatita mostraram altas temperaturas de liquidus destes magmas entre de $1040-1160^{\circ} \mathrm{C}$, superiores às obtidas para o vizinho Sienito Capituva $\left(1015-1080^{\circ} \mathrm{C}\right)$. Já as tentativas de quantificar a pressão utilizando o conteúdo de Al na hornblenda foram frustradas, visto que a ausência de plagioclásio nestas rochas limita o uso do barômetro, assim as pressões obtidas provavelmente estão super estimadas (3,3-4,8 Kbar).

O contraste na fugacidade de oxigênio é evidenciado pelas paragêneses máficas das unidades sieníticas, no entanto as estimativas quantitativas foram malsucedidas já que os cristais analisados (par hematita-magnetita) não estão em equilíbrio.

Enclaves microgranulares são exclusivos dos sienitos supersaturados e os encontrados foram sieníticos, monzoníticos e dioríticos. Os enclaves sieníticos possuem duas origens possíveis: um deles foi interpretado como uma margem resfriada, devido às semelhanças petrográficas e composicionais com SLSI e SLS, enquanto o outro, devido a presença de plagioclásio e do empobrecimento em elementos como $\mathrm{P}, \mathrm{Ti}, \mathrm{Ba}$ e $\mathrm{Sr}$, foi interpretado como nova injeção de magma repreenchendo a câmara magmática.

Já os enclaves monzoníticos e dioritítico são representativos de magmas básicos que interagiram com o magma sienítico em porções mais profundas da crosta e foram trazidos durante a ascensão. A composição destes enclaves, muitas vezes está modificada (e.g. plagioclásio alterado para sericita e biotita como máfico principal) o que traz dificuldades na inferência sobre suas fontes. A presença destes enclaves no interior de cumulatos indica que a interação ocorreu no início da cristalização. 
Os dados químicos das fácies do Sienito Pedra Branca mostram uma pequena variação composicional e diferem-se apenas no conteúdo de $\mathrm{Al}_{2} \mathrm{O}_{3}$, e compartilham elevados teores em LILE como Ba (4000-10000 ppm) e Sr (2000-4500 ppm), além de outros elementos como $\mathrm{P}_{2} \mathrm{O}_{5}(1,0-2 \%)$ e terras raras leves ( $\left.\mathrm{La}=100-300 \mathrm{ppm}\right)$. Contrastes como menor ou maior enriquecimento são observados entre os sienitos laminados (SLSI e SLS: maiores razões $\mathrm{La}_{N} / \mathrm{Yb}_{\mathrm{N}}$ ) e os SSI e SSE (menores razões $\mathrm{La}_{N} / \mathrm{Yb}_{\mathrm{N}}$ e menores conteúdos em $\mathrm{Ba}, \mathrm{Sr}$ e $\mathrm{P}$ ) podem estar relacionados a cristalização e extração de fases precoces (e.g. apatita) durante a injeção dos primeiros pulsos.

Os padrões de elementos terras raras destes sienitos não apresentam anomalias significativas de $\mathrm{Eu}$, no entanto a ocorrência de fortes anomalias positivas de Eu nos feldspatos alcalinos (dados inéditos) demonstra disponibilidade de Eu bivalente, embora estes magmas tenham se cristalizado sob alta fugacidade de oxigênio. Além disso, ausência de expressivas anomalias positivas do mesmo elemento, demonstra que embora haja processos de acumulação esses sienitos podem representar líquidos verdadeiros e não cumulatos feldspáticos, como sugerido em ocorrências similares por alguns autores (Conceição et al., 1991). Por tratarem-se de rochas essencialmente compostas por feldspato alcalino ( $75 \%$ modal), as anomalias de Eu deveriam ser positivas caso não representassem líquidos, mas sim cumulatos feldspáticos.

A similaridade composicional de um dos enclaves sieníticos (PB-250) com sienitos laminados sugerem que suas assinaturas geoquímicas devem representar 0 magma que os originou.

As semelhanças geoquímicas existentes entre as unidades sugerem que, apesar de suas diferenças, eles têm origem comum. Os modelos de gênese de magmas potássicos da literatura sugerem como área fonte mais provável dessas rochas, o manto enriquecido. As altas razões LILE/HFSE demonstradas pelas pronunciadas anomalias negativas em $\mathrm{Nb}-\mathrm{Ta}, \mathrm{Ti}$ e $\mathrm{Hf}-\mathrm{Zr}$, demonstram vinculo com áreas ativas onde a injeção de fluidos ricos em REE e LILE durante a subducção gera metassomatismo no manto superior (Rogers, 1992).

As assinaturas isotópicas dos Sienitos Pedra Branca e Capituva de $\varepsilon \mathrm{Nd}_{(\mathrm{t})}$ pouco negativo além de razões moderadas ${ }^{87} \mathrm{Sr}^{86} \mathrm{Sr}_{(t)}$ associadas ao elevado conteúdo de elementos traço (Ba, Sr e ETR), reforçam que estas rochas estão associadas a fusão parcial de horizontes enriquecidos do manto litosférico. Analogamente outras ocorrências de sienitos potássicos paleoproterozóicos como Sienito Itiúba, São Felix e Anuri, e neoproterozóicas como Batólito Triunfo e Sienito Bom Jardim possuem características isotópicas similares, que também são interpretadas como produto de 
fusão de manto metassomatizado (Conceição et al., 2007; Ferreira et al., 1997; Guimarães e Silva Filho, 1998; Rosa et al., 2001). 


\section{REFERÊNCIAS BIBLIOGRÁFICAS}

Anderson, J.L \& Smith, D.R. 1995. The effect of temperatures and oxygens fugacity on Al-in-hornblende barometry. American Mineralogist, 87: 125-138.

Bowen, N.L. 1928. The evolution of the igneous rocks. Princeton University Press, Pinceton, 322pp.

Buddington, A.F.; Lindsley, D.H. 1964. Iron- Titanium Oxide Minerals And Synthetic Equivalents. Journal of Petrology, 5 (2): 310-357.

Campos Neto, M. C.; Basei, M. A. S.; Vlach, S. R. F.; Caby, R., Szabó, G. A. J.; Vasconcelos, P. 2004. Migração de orógenos e superposição de orogêneses: um esboço da colagem brasiliana no sul do Cráton do São Francisco, SE Brasil. Revista do Instituto de Geociências - USP, São Paulo, 4 (1): $13-40$.

Campos Neto, M.C.; Caby, R. 1999. Neoproterozoic high-pressure metamorphism and tectonic constraint from nappe system south of the São Francisco craton, southeast Brazil. Precambrian Research, 97: 3-26.

Campos Neto, M.C.; Caby, R. 2000. Terrane accretion and upward extrusion of highpressure granulites in the Neoproterozoic nappes of southeast Brazil: Petrologic and structural constraints. Tectonics, 19 (4): 669-687.

Campos Neto, M. C.; Figueiredo, M. C. H. 1985. Geologia das folhas São José do Rio Pardo e Guaranésia (porção paulista) 1:50.000. Relatório Instituto de Geociências, USP/PRÓ-MINÉRIO, v. 1, 124p.

Carmichael, I.S.E. 1967. The iron-titanium oxides od salic volcanic rocks and their associated ferromagnesian silicates. Contributions to Mineralogy and Petrology, 14: $36-64$.

Carvalho, B.B. 2008. Geologia e Evolução Magmática dos Sienitos Saturados a Supersaturados do Plúton Pedra Branca (MG). Monografia de Trabalho de 
Formatura, Instituto de Geociências, Universidade de São Paulo, São Paulo, SP, 50p.

Conceição, H., Sabaté, P., Bonin, B., 1991. The Itiúba alkaline syenite massif, Bahia State (Brazil): mineralogical, geochemical and petrological constraints-relation to the genesis of rapakivi magmatism. Precambrian Research, 51 (14): 283-314.

Conceição, H., Rosa, M.L.S., Macambira, M.J.B, Scheller, T., Marinho, M.M., Rios, D.C. 2003. 2.09 Ga Idade Mínima Da Cristalização Do Batólito Sienítico Itiúba: Um Problema Para O Posicionamento Do Clímax Do Metamorfismo Granulítico (2,05-2,08 Ga) No Cinturão Móvel Salvador-Curaçá, Bahia? Revista Brasileira de Geociências, 33 (3): 391-394.

Conceição, H., Rosa, M.L.S., Oberli, F., Rios, D.C. 2007. Idade U-Pb do dique sienítico Anurí, sul da Bahia: magmatismo alcalino-potássico paloeoproterozóico e sua implicação para a orogenia transamazônica no Cráton do São Francisco. Revista Brasileira de Geociências, 37: 61-69.

Conceição, R.V. \& Green, D.H. 2004. Derivation of potassic (shoshonitic) magmas by decompression melting of phlogopite+pargasite Iherzolite. Lithos, 72: 209-229.

Deer, A., Howie, R. A. \& Zussman, J., 1992. An Introduction to the Rock-Forming Minerals. Second Edition. Longman Scientific \& Tecnical, London, 696 pp.

DePaolo, D.J. 1981. Crustal growth and mantle evolution: inferences from models of element transport and $\mathrm{Nd}$ and $\mathrm{Sr}$ isotopes. Geochimica et Cosmochimica Acta, 44: 1185-1196.

Derby, O.A. 1883. A study in consanguity of eruptive rocks. The Journal of Geology, 1 (6): 597-605.

Derby, O.A. 1887. On Nepheline-Rocks in Brazil, with Special Reference to the association of Phonolite and Foyaite. Quartely Jounal of Geological Society, 43: 457-473. 
Ellert, R. 1959. Contribuição à geologia do maciço alcalino de Poços de Caldas. Boletim FFCL/USP, 237: 5-63.

Ferreira, V.P., Sial, A.N., Whitney, J.A. 1992. Imiscibilidade de Líquidos como Principal Processo Magmático na Formação dos Sienitos Peralcalinos Ultrapotássicos e Piroxenitos Associados, no Precambriano do Nordeste do Brasil. Anais da Academia Brasileira de Ciências, 64 (4): 367-382.

Ferreira, V.P. and Sial, A.N. (1993) Mica-pyroxenite as a probable source for ultrapotassic and potassic magmas in Northeast Brazil. Anais da Academia Brasileira de Ciencias, 65: 51-62.

Ferreira, M.A.F., Ferreira, V.P., Sial, A.N., Pimentel, M.M., 2002. Origin and Intensive Parameters in the Crystallization of Ultrapotassic Syenites: The Serra Do Man Pluton, Northeastern Brazil. Gondwana Research, 5(2): 275-285.

Foley, S.F.; Taylor, W.R.; Green, D.H. 1986. The role of fluorine and oxygen fugacity in the genesis of ultrapotassic rocks. Contributions to Mineralogy and Petrology, 94: 183-192.

Foley, S., Venturelli, G., Green, D.H., Toscani, L. 1987. The Ultrapotassic Rocks: characteristics, classification, and Constraints for Petrogenetic models. Earth Science Reviews, 24: 81-134.

Foley, S. 1992a. Petrological characterization of the source components of potassic magmas: geochemical and experimental constraints. Lithos, 28: 187-204.

Foley, S., 1992b. Vein-plus-wall-rock melting mechanisms in the lithosphere and the origin of potassic alkaline magmas. Lithos, 28 (3-6): 435-453.

Frost, B.R. \& Frost, C.D. 2008. A Geochemical Classification for Feldspatic Igneous Rocks. Journal of Petrology, 49 (11): 1955-1969. 
Guimarães, I. de P. 1989. The Petrological Evolution and Tectonic Associations of the Bom Jardim Complex, Pernambuco State, NE Brazil. Tese de Doutoramento, Department of Geology, Royal School of Mines, Imperial College, London SW7 2BP, 423pp.

Guimarães, I.P., Silva Filho, A.F. 1998. Nd- and Sr- isotopic and U-BP geochrologic constraints for the evolution of the shoshonitic brasiliano Bom Jardim and Toritama Complexes: evidence for a Transamazonian enriched mantle under Borborema Tectonic Province, Brazil. International Geology Reviews 40, 500527.

Haddad, R.C. 1995. O batólito granitóide Pinhal-Ipuiúna (SP-MG): um exemplo do magmatismo cálcio-alcalino potássico Neoproterozóico no sudeste brasileiro. Tese de Doutoramento, Instituto de Geociências, Universidade de São Paulo, $\mathrm{SP}, 270 \mathrm{p}$.

Harrison, T.M. \& Watson, E.B. 1984. The behavior of apatite during crustal anatexis: Equilibrium and kinetic considerations. Geochimica et Cosmochimica Acta, 48: 1468-1477.

Heilbron, M., Pedrosa-Soares, A.C., Campos Neto, M.C., Silva, L.C., Trouw, R.A.J., Janasi, V.A. 2004. Provincia Mantiqueira. In: Mantesso-Neto, V., Bartorelli, A., Carneiro, C.D.R. \& Brito Neves, B.B. (organizadores): Geologia do Continente Sulamericano: evolução da obra de Fernando Flávio Marques de Almeida. Primeira Edição. São Paulo, Beca Prod. Culturais, pp. 203-235.

Janasi, V.A. 1992. Rochas sieníticas e mangerítico-charnoquíticas da região entre Caldas e Campestre, MG: aspectos petrológicos, Tese de Doutoramento, Instituto de Geociências, Universidade de São Paulo, São Paulo, SP, 281 p.

Janasi, V.A. 1993. Petrogenesis and tectonic setting of the neoproterozoic Capituva Ksyenite, SW Minas Gerais. Revista Brasileira de Geociências, São Paulo, 23 (2): 129-138. 
Janasi, V.A. 1996. Os sienitos potássicos neoproterozóicos do maciço Pedra Branca, SW de Minas Gerais: geologia, petrografia e geoquímica. In: Congresso Brasileiro de Geologia 39. Salvador, Anais do Congresso Brasileiro de Geologia, Salvador, 6: 453-455.

Janasi, V. A. 1999. A idade dos granitos Nazaré Paulista e Pinhal, e implicações para o metamorfismo da Nappe Socorro-Guaxupé (SP-MG). In: VI Simpósio de Geologia do Sudeste, 1999, São Pedro, SP. Boletim de Resumos, p. 7-7.

Janasi, V.A. 2002. Elemental and Sr-Nd isotope geochemistry of two Neoproterozoic mangerite suites in SE Brazil: implications for the origin of the mangeritecharnockite-granite series. Precambrian Research, 119: 301-327.

Janasi, V.A., Haddad, R.C., Ulbrich, H.H.G.J. 2007. Geoquímica e isotopia Sr-Nd do Batólito Pinhal-Ipuiúna, Nappe Socorro-Guaxupé, SP-MG, XI Congresso Brasileiro de Geoquímica. Anais. Sociedade Brasileira de Geoquímica, Atibaia, SP, p. CD-ROM.

Janasi, V.A.; Vlach, S.R.F.; Ulbrich, H.G.J. 1993. Enriched mantle contribution to the Itu Granitoid Belt, southeastern Brazil: evidences from K-rich diorites and syenites. Anais da Academia Brasielira de Ciências, 65: 107-118.

Janasi, V.A., Vlach, S.R.F., Campos Neto, M.C., Ulbrich, H.H.G.J. 2009. Associated AType Subalkaline and High-K Calc-Alkaline Granites in the Itu Granite Province, Southeastern Brazil: Petrological and Tectonic Significance. The Canadian Mineralogist, 47: 1505-1526.

Jost, H.; Brod, J.A.; Holz, M.; Kuhn, A.; Flor, M.A.D.; Kronbauer, A.; Dielemburg, S. 1985. Geologia estrutural, petrografia e petrologia do Sienilo Piquiri (Proterozóico Superior), Rio Grande do Sul. In: SBG - Simpósio Sul-Brasileiro de Geologia 2, Florianópolis. Anais: 63-81. 
Leake, B.E., Woolley, A.R., Arps, C.E.S., Birch, W.D., Gilbert, M.C., Grice, J.D., Hawthorne, F.C., Kato, A., Kisch, H.J., Krivovichev, V.G., Linthout, K. et al. 1997. Nomeclature of amphiboles: Report of the Subcomittee on Amphiboles of the International Mineralogical Association Commission on New Minearls and Mineral Names. Canadian Mineralogist, 35: 219-246.

Lindsley, D. Pyroxene thermometry. American Mineralogist, 68: 673-678.

McDonough, W.F. \& Sun, S.S. 1995. The composition of the Earth, Chemical Geology, 120: 228.

McKenzie, D. 1989. Some remarks on the movement of small melt fractions in the mantle. Earth and Planetary Science Letters, 95: 53-72.

Meyer, A. P. 2003. A influência da petrografia no comportamento tecnológico de rochas ornamentais do Complexo Socorro (SP) e Maciço Pedra Branca (MG). Dissertação (Mestrado em Geociências (Geologia Regional) [Rio Claro]) Universidade Estadual Paulista Júlio de Mesquita Filho.

Maniar, P.D. \& Piccoli, P.M. 1989. Tectonic discrimination of granitoids. Geol Soc Am Bull, 101(5): 635-643.

Mori, P. E; Reeves, S; Correia, C.T; Haukka, M. 1999. Development of a fused glass disc XRF facility and comparison with the pressed powder pellet technique at Instituto de Geociências, Universidade de São Paulo. Revista Brasileira de Geociências, 29: 441-446.

Morimoto, N.J., Fabries, J., Ferguson, A.K., Ginzburg, I.V., Ross, M., Seifert, F.A., Aoki, J.Z.K. \& Gottardi, G. 1988. Nomenclature of pyroxenes. American Mineralogist, 73: 9-10.

Nardi, L.V.S.; Plá Cid, J.; Bitencourt, M.F. 2007 Minette mafic microgranular enclaves and their relationship to host syenites in systems formed at mantle pressures: major and trace element evidence from the Piquiri Syenite Massif, southernmost Brazil. Mineralogy and Petrology, 91: 101-116. 
Nardi, L.V.S.; Plá-Cid, J.; Bitencourt, M.F; Stabel, L.Z 2008. Geochemistry and petrogenesis of post-collisional ultrapotassic syenites and granites from southernmost Brazil: the Piquiri Syenite Massif. Anais da Academia Brasileira de Ciências, 80 (2): 353-371.

Navarro, M.S.; Andrade, S.; Ulbrich, H.; Gomes, C.B.; Girardi, V.A.V., 2008. The Direct Determination of Rare Earth Elements in Basaltic and Related Rocks using ICP-MS: Testing the Efficiency of Microwave Oven Sample Decomposition Procedures. Geostandards and Geoanalytical Research, 32 (2): 167-180.

Nekvasil, H. 1990. Reaction relations in hte granite system: implications for trachytic and syenitic magmas. American Mineralogist, 77: 592-604.

Oliveira, M.A.F.; Francesconi, O.; Cordeiro, C.M.; Inglez, A.G.; Oliveira, E.G.; Sena, C.A.S. 1983. Geologia da porção paulista das quadrículas de Caconde e Guaxupé. In: 1a Jornada sobre a Carta Geológica do Estado de São Paulo em 1:50.000, PRÓ-MINÉRIO, São Paulo, p. 171-191.

Parsons, I. 1979. The Klokken Gabro-Syenite Complex, South Greenland: Cryptic Variation and Origin of Inversely Graded Layering. Journal of Petrology, 20 (4): 653-694.

Pearce, T.H., Gorman, B.E., Birkett, T.C. 1977. The relationship between major element chemistry and tectonic environment of basic and intermediate volcanic rocks. Earth Planetary Science Letters, 36: 121-132.

Pearce, J.A.; Harris, N.B.W.; Tindle, A.G. 1984. Trace Element discrimination diagrams for tectonic interpretation of granitic rocks. Journal of Petrology, 25 (4): 956983.

Phillip, R.P.; Machado, R.; Nardi, L.V.S.; Lafon, J.M. 2002. O magmatismo granítico neoproterozóico do Batólito Pelotas no sul do Brasil: novos dados e revisão da geocronologia regional. Revista Brasileira de Geociências, 32: 277-290. 
Plá Cid, J.; Nardi, L.V.S.; Stabel, L.Z; Conceição, R. V.; Balzaretti, N.M. 2003. High Pressure minerals in mafic microgranular enclaves: evidences for co-mingling between lamprophiric and syenitic magmas at mantle conditions. Contributions to Mineralogy and Petrology, 145: 444-459.

Riishuus, M.S, Peate, D.W.; Tegner, C.; Wilson, J.R.; Brooks, C.K. 2008. Petrogenesis of Cogenetic Silica-Oversaturated and -Undersaturated Syenites by periodic recharge in crustally contaminated magma chamber: the Kangerlussuaq Intrusion, East Greenland. Journal of Petrology, 49 (3): 493-522.

Roger, N.W. 1992. Potassic magmatism as a key to trace-element enrichment processes in the upper mantle. Journal of Volcanology ang Geothermal Research, 50: 85-99.

Rosa, M.L.S, Conceição, H., Macambira, M.J.B, Scheller, T., Martin, H., Leal, L.R.B. 2001. Idade $\mathrm{Pb}-\mathrm{Pb}$ e assinatura isotópica $\mathrm{Rb}-\mathrm{Sr}$ e $\mathrm{SM}-\mathrm{Nd}$ do Magmatismo Sienítico Paleoproterozóico no sul do Cinturão Móvel Salvador-Curaçá: Maciço Sienítico São Felix, Bahia. Revista Brasileira de Geociências, 31 (3): 397-400.

Tompson, R.N. \& Fowler, M.B. 1986. Subduction-related shoshonitic and ultrapotassic magmatism: a study of Siluro-Ordovician syenites from Scottish Caledinides. Contributions to Mineralogy and Petrology, 94: 507-522.

Töpfner, C. 1996. Brasiliano-granitoide in den Bundesstaaten São Paulo und Minas Gerais, Brasilien- eiene Vergleichende studie. Münchner Geol. Hefte A17.

Stabel, L.Z., Nardi, L.V.S., Pla Cid, J. 2001. Química Mineral e Evolução Petrológica do Sienito Piquiri, Magmatismo Shoshonítico, neoproterozóico, Pós-Colisional no sul do Brasil, Revista Brasileira de Geociências, 31: 211-222.

Sun, S \& McDonough, W.F. 1989. Chemical and Isotopic systematics of ocean basalts: implications for mantle composition and processes. In: Saunders, A.D., Norry, M.J. Eds: Magmatism in ocean Basins. Geol. Soc. Spec. Publ., London: 313345. 
Ulbrich, M.N.C. 1984. Aspectos mineralógicos e petrológicos de nefelina sienitos do maciço alcalino de Poços de Caldas, MG-SP, Tese de Doutoramenteo, Instituto de Geociências, Universidade de São Paulo, São Paulo-SP, 369pp.

Watson, E.B. \& Harrison, T.M. 1984. Acessory Minerals and the heochemical evolution of crustal magmatica systems: a summary and prospectus of experimental approaches. Physics of the Earth Planetary Interiors, 35: 19-30.

Wernick, E. \& Penalva, F. 1980. Contribuição à geologia do Grupo Pinhal (SP e MG). Revista Brasileira de Geociências, 10 (1): 43-62.

Winters, A.A.M. 1981. A Geologia do Maciço Sienítico da Pedra Branca, Caldas-MG. Dissertacão de Mestrado - Instituto de Geociências, Universidade de São Paulo, São Paulo, 92 pp. 


\section{ANEXO I \\ MAPA GEOLÓGICO E DE PONTOS \\ DO SIENITO PEDRA BRANCA}




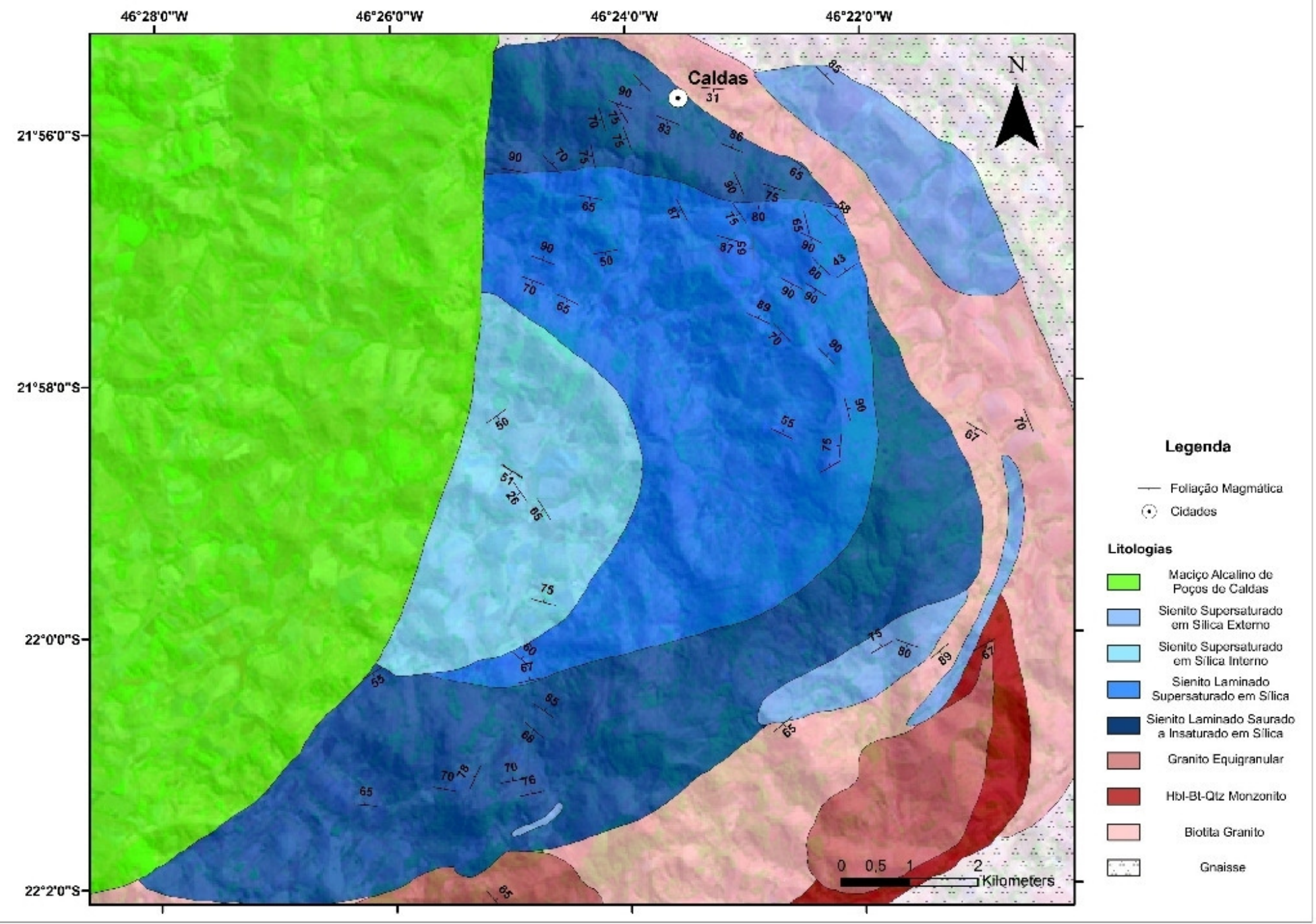




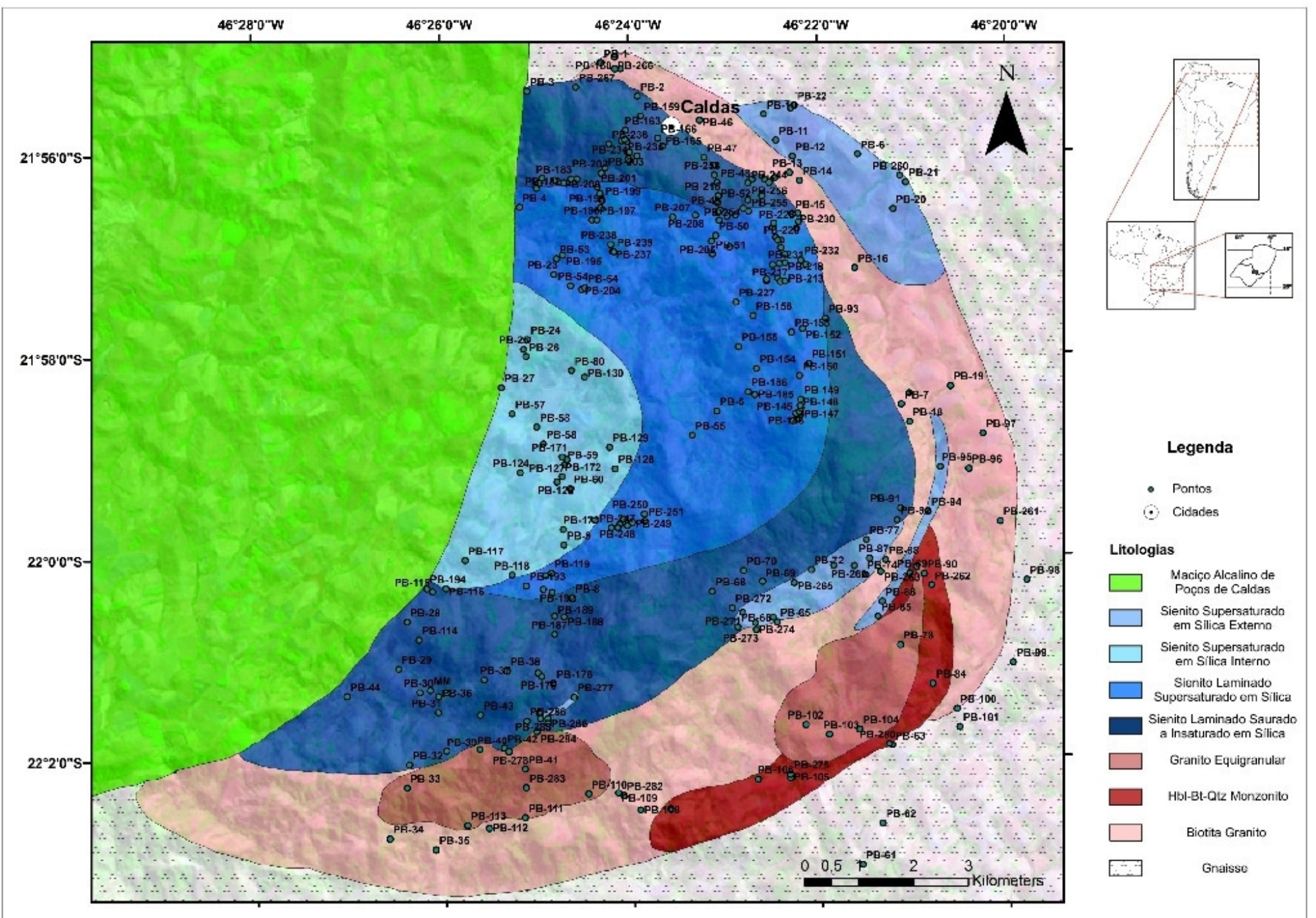


ANEXO II

TABELAS DE QUÍMICA MINERAL 
Tabela 1: Análises WDS em cristais de feldspato do Sienito Pedra Branca. 


\begin{tabular}{|c|c|c|c|c|c|c|c|c|c|c|c|c|}
\hline $\begin{array}{l}\text { Amostra } \\
\text { Análise }\end{array}$ & $\begin{array}{c}\text { PB-123A } \\
\text { p } 28\end{array}$ & $\begin{array}{c}\text { PB-123A } \\
\text { p32 }\end{array}$ & $\begin{array}{c}\text { PB-123A } \\
\text { p33 }\end{array}$ & $\begin{array}{c}\text { PB-123A } \\
\text { p34 }\end{array}$ & $\begin{array}{c}\text { PB-123A } \\
\text { P36 }\end{array}$ & $\begin{array}{c}\text { PB-123A } \\
\text { p37 }\end{array}$ & $\begin{array}{c}\text { P日-1B5A } \\
\text { p0-1-2 } \\
\text { Eorda }\end{array}$ & $\begin{array}{l}\text { Desvio } \\
\text { Padräo }\end{array}$ & $\begin{array}{l}\text { PB-185A } \\
\text { p0-6.7 } \\
\text { Nucico }\end{array}$ & $\begin{array}{l}\text { Desvio } \\
\text { Padrä́c }\end{array}$ & $\begin{array}{c}\text { PB-185A } \\
\text { p1-4-5-6 } \\
\text { Nudec }\end{array}$ & $\begin{array}{l}\text { Desvio } \\
\text { Padrăo }\end{array}$ \\
\hline SHO2 & 64.85 & 64.75 & 64.71 & 6475 & 64.94 & 34.66 & 6437 & 021 & 54.21 & 083 & 53.58 & $0.4 \mathrm{~s}$ \\
\hline $\mathrm{Al} / 2 \mathrm{O}_{3}$ & 18.72 & 20.00 & 20.56 & 1863 & 19.02 & 19.91 & 18 15 & 0.13 & 19.23 & 008 & 19.03 & 0.19 \\
\hline $\mathrm{Fe} 2 \mathrm{O}_{3}$ & 0.10 & 0.12 & 0.13 & 0.10 & 0.10 & 0.07 & 0.42 & 0.03 & 0.40 & 0.01 & 0.34 & 0.09 \\
\hline $\mathrm{CaO}$ & 0.28 & 0.56 & 1.10 & 0.21 & 0.26 & 0.29 & 0.02 & 002 & 0.02 & 0.01 & 0.02 & 0.00 \\
\hline $\mathrm{SrO}$ & 0.65 & 0.54 & 0.48 & 0.55 & 0.56 & 0.57 & 0.45 & 0.04 & 0.54 & 0.02 & 0.04 & 0.29 \\
\hline $\mathrm{BaO}$ & $10 \mathrm{~s}$ & 111 & 0.71 & 0.85 & 9.95 & 1.03 & 1.20 & 003 & 1.37 & 0.07 & 1.24 & 0.24 \\
\hline $\mathrm{Na} 20$ & 393 & 4.18 & 5.17 & 3.42 & 3.52 & 3.58 & 4.81 & 015 & 4.26 & 124 & 3.56 & D. 10 \\
\hline $\mathrm{K}_{20}$ & $\$ 20$ & $\varsigma 00$ & 7.04 & 1047 & 9.02 & 9.87 & 9.65 & 020 & 0.55 & 1.37 & 11.75 & 0.03 \\
\hline Total & $9 \notin .84$ & 100.26 & $99.8 \subseteq$ & $100.0^{1}$ & 99.07 & 99.98 & 100.10 & & 100.58 & & 99.55 & \\
\hline $\mathrm{Si}$ & 11825 & 11.763 & 11.690 & 11.823 & 11.926 & 11.795 & 11.793 & & 11.768 & & 11.784 & \\
\hline Al & 4.285 & 4279 & 4.372 & 4.221 & 4114 & 4.271 & 4.132 & & 4.150 & & 4.154 & \\
\hline $\mathrm{Fe} 3$ & 0.010 & 0 & 0.020 & 0.013 & 0510 & 0.010 & C. .060 & & 0.060 & & 0.050 & \\
\hline $\mathrm{Ba}$ & 0.074 & 0.079 & 0.050 & 0.061 & 0.058 & 0.074 & 0.086 & & 0.098 & & 0.090 & \\
\hline $\mathrm{Ca}$ & 0.055 & 0.109 & 0.213 & 0.041 & 0.051 & 0.057 & 0.004 & & 0.004 & & 0.024 & \\
\hline $\mathrm{Na}$ & 1.390 & 1.472 & 1.811 & 1.211 & 1289 & 1.266 & 1.709 & & 1.514 & & 1.275 & \\
\hline$K$ & 2.169 & 2.086 & 1.622 & 2.439 & 2.254 & 2.297 & 2.262 & & 2.467 & & 2.777 & \\
\hline $\mathrm{Sr}$ & 0.073 & 0 & O.CEEC.C. & 0.63 & 0 ग60 & .060 & C. 050 & & 5.060 & & בx & \\
\hline Soma $\mathbf{T}$ & 16.070 & 16.062 & 15.082 & 16.059 & 15.050 & 16.082 & 15.955 & & 75.978 & & 15.988 & \\
\hline Soma M & 3.683 & 3.766 & 3.716 & 3.762 & 3.672 & 3.704 & 4.121 & & 4.743 & & 4.196 & \\
\hline Albila(Ab) & 360 & 40.10 & 49.70 & 3283 & 35.90 & 35.00 & 4500 & & 38.00 & & $31.4 \mathrm{C}$ & \\
\hline Anortita (An) & 1.50 & 300 & 5.00 & 1.10 & 1.40 & 1.60 & 0.10 & & 0.10 & & 0.10 & \\
\hline Ortoclásio (Or) & 5.80 & 56.90 & 44.50 & 66.10 & 62.70 & 53.50 & $5 \in 90$ & & 51.80 & & 58.50 & \\
\hline
\end{tabular}

Fórmula Estrutural com base em 32 oxigênios.

Análises Químicas WDS de cristais de Feldspato obtidos por Microssonda Eletrônica. 


\begin{tabular}{|c|c|c|c|c|c|c|c|c|c|c|c|c|}
\hline $\begin{array}{l}\text { Amostra } \\
\text { Análise }\end{array}$ & $\begin{array}{c}\text { PB-1B5A } \\
\text { p1-7-10 } \\
\text { Altita }\end{array}$ & $\begin{array}{l}\text { Desvio } \\
\text { Padräo } \\
\text { sticiel }\end{array}$ & $\begin{array}{l}\text { PB-185A } \\
\text { p1-9-11 } \\
\text { Nüclec }\end{array}$ & & $\begin{array}{l}\text { PB-185A } \\
\text { p3-5.6 } \\
\text { Bxda }\end{array}$ & $\begin{array}{l}\text { Desvio } \\
\text { Padráo }\end{array}$ & $\begin{array}{c}\text { P日-1B5A } \\
\text { p3-7-8 } \\
\text { Eorda }\end{array}$ & $\begin{array}{l}\text { Desvio } \\
\text { Padrä́o }\end{array}$ & $\begin{array}{c}\text { PB-180A } \\
\text { p2-1.2 } \\
F\end{array}$ & $\begin{array}{c}\text { PB-190A } \\
\text { P2-3-4 } \\
P\end{array}$ & $\begin{array}{l}\text { PB-190A } \\
\text { p2-5-6 } \\
\text { Nuidec }\end{array}$ & $\begin{array}{l}\text { Desvio } \\
\text { Padrăo }\end{array}$ \\
\hline SiO2 & $\approx 00$ & 076 & 63.11 & 0.76 & 63.20 & 0.43 & 6374 & 075 & 57.31 & $6 \$ 79$ & 84.18 & 0.29 \\
\hline $\mathrm{Al} / 2 \mathrm{O}_{3}$ & 20.09 & C 27 & 19.37 & 0.25 & 13.93 & 0.06 & 18.84 & $0 \mathrm{Jn}^{2}$ & 20.74 & 2172 & $18.4 i$ & 0.49 \\
\hline $\mathrm{Fe} 2 \mathrm{O}_{3}$ & 0.08 & 0.02 & 0.32 & 0.06 & 0.36 & 0.04 & 0.51 & 0.10 & $0.0 \Omega$ & 0.10 & 0.55 & 0.54 \\
\hline $\mathrm{C} \times$ & 0.00 & 0.00 & 0.03 & 0.01 & 0.01 & 0.01 & 0.00 & 000 & 0.25 & 201 & 0.04 & 0.02 \\
\hline Sro & 0.35 & 0.29 & 0.65 & 0.03 & 0.58 & 0.04 & 0.40 & $0.1 \mathrm{~B}$ & 0.16 & 2.19 & 0.50 & 0.28 \\
\hline $\mathrm{Ba} 0$ & C. 12 & 0.02 & 1.60 & 0.17 & 1.32 & 0.04 & 1.13 & 029 & $0 . C C$ & Q 22 & 1.04 & 0.48 \\
\hline $\mathrm{Na} 20$ & C 06 & C 06 & 3.42 & 0.34 & 1.05 & 0.11 & 2.27 & 1 हD & 10.97 & С 69 & 3.52 & D.30 \\
\hline 120 & 11.89 & 0.11 & 11.08 & 0.30 & 14.84 & 0.28 & 1323 & 197 & $0.5 \epsilon$ & 0.52 & 11.21 & 0.52 \\
\hline Total & 700.59 & & 99.58 & & 100.39 & & 100.12 & & 100.08 & 10024 & 99.51 & \\
\hline $\mathrm{Si}$ & 12.122 & & 11.724 & & 11.750 & & 11.812 & & 11.786 & $11 . \$ 32$ & 11.875 & \\
\hline Al & 4.215 & & 4.738 & & 4155 & & 4.111 & & 4277 & 4.564 & 4.025 & \\
\hline $\mathrm{Fa} 3$ & 0.013 & & 0.010 & & 0050 & & C. .070 & & 2010 & 0.010 & D.OBC & \\
\hline $\mathrm{Ba}$ & 0.005 & & 0.116 & & 0.096 & & 0.002 & & 0.000 & 0.015 & 0.075 & \\
\hline $\mathrm{Ca}$ & 0.000 & & $0.00 \epsilon$ & & 0.002 & & 0.000 & & 0.047 & 0.384 & 0.008 & \\
\hline $\mathrm{Na}$ & 0.021 & & 1.232 & & 0379 & & 0.816 & & 3.725 & 3.353 & 1.263 & \\
\hline K & 2.704 & & 2.626 & & 3.529 & & 3.128 & & 0.120 & 0.113 & 2.546 & \\
\hline $\mathrm{Sr}$ & 0.043 & & 0.070 & & 0570 & & C. 040 & & 0.020 & (c.23) & 3.250 & \\
\hline Soma $\mathbf{T}$ & ${ }^{\prime} 6.350$ & & 16.002 & & 15.935 & & 15.993 & & 16.073 & 15.956 & 15.980 & \\
\hline Soma M & 2.743 & & 4.020 & & 4056 & & 4.096 & & 3.907 & 3.880 & 4.072 & \\
\hline Albila(Ab) & 080 & & 31.50 & & 9.70 & & 2070 & & 95.60 & 870 & 32.20 & \\
\hline Anortita (An) & 0.00 & & 0.20 & & 0.10 & & 000 & & $1.2 \mathrm{C}$ & 1000 & 0.20 & \\
\hline Ortoclásio [Or) & 98.20 & & $\varpi .0 \mathrm{C}$ & & 95.30 & & 7830 & & 3.20 & 3.10 & 57.50 & \\
\hline
\end{tabular}

Fórmula Estrutural com base em 32 oxigênios.

Análises Químicas WDS de cristais de Feldspato obtidos por Microssonda Eletrônica. 


\begin{tabular}{|c|c|c|c|c|c|c|c|c|c|c|c|c|}
\hline $\begin{array}{l}\text { Amostra } \\
\text { Análise }\end{array}$ & $\begin{array}{c}\text { PB-190A } \\
\text { p2-7-8 } \\
\text { Borda }\end{array}$ & $\begin{array}{l}\text { Desvio } \\
\text { Padrä́o }\end{array}$ & $\begin{array}{c}\text { PB-190A } \\
\text { P4-2-3 } \\
\text { FI }\end{array}$ & $\begin{array}{c}\text { PB-190A } \\
\text { P4-3-4 } \\
\text { Bcrda }\end{array}$ & $\begin{array}{l}\text { Desvio } \\
\text { Padrä̊ }\end{array}$ & $\begin{array}{l}\text { PB-190A } \\
\text { p4-5.7 } \\
\text { R.udeo }\end{array}$ & $\begin{array}{l}\text { Desvio } \\
\text { Padrä́o }\end{array}$ & $\begin{array}{c}\text { PB-209e } \\
\text { P1-1 } \\
\text { I }\end{array}$ & $\begin{array}{c}\text { P日-209e } \\
\text { p1-1.2 } \\
\text { F }\end{array}$ & $\begin{array}{l}\text { PB-209e } \\
\text { p1-2-3 } \\
\text { P }\end{array}$ & $\begin{array}{c}\text { PB-209e } \\
\text { p1-2-4 } \\
\text { P }\end{array}$ & $\begin{array}{c}\text { PQ-209e } \\
p 2-1 \cdot 1 \\
P I\end{array}$ \\
\hline & & & & SLS & & & & \multicolumn{5}{|c|}{ Endave [eucaurail $x$ grcx:so } \\
\hline Sid2 & 63.72 & 023 & 6.88 & 6414 & 0.27 & 53.35 & 0.69 & 50.17 & 53.18 & 5853 & 58.90 & 62.26 \\
\hline $\mathrm{A} / 203$ & 18.60 & $\cos$ & $20.7 \mathrm{E}$ & 18.50 & 0.07 & 20.12 & 0.35 & 21.05 & 22.30 & 2474 & 24.34 & 22.51 \\
\hline $\mathrm{Fe} 2 \mathrm{O3}$ & 0.17 & 0.21 & 0.22 & 0.22 & 0.03 & 0.23 & 0.03 & 0.77 & 0.16 & 0.13 & 0.11 & 0.06 \\
\hline $\mathrm{C} \times$ & 0.01 & 0.01 & 0.47 & 0.05 & 0.07 & 0.31 & 0.15 & 551 & 3.43 & 6.35 & 0.16 & 3.75 \\
\hline Sro & 0.69 & 0.03 & 0.38 & 0.57 & 0.07 & 1.76 & 0.07 & 1.02 & 0.85 & 1.27 & 0.94 & 0.78 \\
\hline $\mathrm{Ba} 0$ & 117 & 0.02 & 0.03 & 1.15 & 0.03 & 1.71 & 0.15 & 013 & $0.0 C$ & Q 11 & 0.00 & 0.04 \\
\hline $\mathrm{Na} 20$ & 291 & 0.38 & 10.8: & 2.96 & 0.44 & 6.27 & 0.69 & 809 & 9.17 & 760 & $7.6 ?$ & 9.10 \\
\hline $\mathrm{K} 2 \mathrm{O}$ & 12.27 & 0.59 & 0.64 & 12.52 & 0.05 & 6.45 & 0.65 & 0.34 & $0.4 \varsigma$ & $0.2 B$ & 0.36 & 0.37 \\
\hline Total & $9 \Subset .44$ & & 700.24 & 100.11 & & 100.20 & & 99.54 & 99.57 & $\$ 905$ & 99.06 & 98.87 \\
\hline & & & & & & & & & & & & \\
\hline $\mathrm{Si}$ & 11864 & & 11.732 & 11.869 & & 11.600 & & 10.336 & 11.274 & 10.640 & 10.668 & 11.197 \\
\hline Al & 4.067 & & 4.285 & $4 \operatorname{cs} 2$ & & 4.339 & & 5.102 & 4.685 & 5.293 & 5.297 & 4.768 \\
\hline Fe3 & 0.020 & & 0.030 & 0.053 & & D.030 & & 0.000 & 0.020 & 0.020 & a.c & 0.010 \\
\hline $\mathrm{Ba}$ & 0.085 & & 0.002 & 0.063 & & 0.123 & & 0.073 & 0.000 & 0.003 & 0.006 & 0.000 \\
\hline $\mathrm{Ca}$ & 0.002 & & 0.088 & 0.012 & & 0.061 & & 1.263 & 0.656 & 1.235 & 1.195 & 0.722 \\
\hline $\mathrm{Na}$ & 1.081 & & 3.684 & 1.C62 & & 2.226 & & 2.326 & 3.171 & 2.675 & 2.5392 & 3.172 \\
\hline K & 2.915 & & 0.143 & 2.955 & & 1.507 & & 0.077 & 0.111 & 0.065 & 0.032 & 0.086 \\
\hline $\mathrm{Sr}$ & 0.070 & & 0.040 & 0.63 & & D. 190 & & 0.190 & 2.080 & (c.13\%) & 0. & $0 . \operatorname{cec} 0$ \\
\hline Sorma $\mathbf{T}$ & 75.941 & & 16.057 & $15 . .31$ & & $15.96 \subseteq$ & & 15957 & 15.979 & 15.953 & 15.975 & 75.975 \\
\hline Soma M & 4.073 & & 3.947 & 4.141 & & 3.947 & & 3.999 & 3.958 & 4.603 & 3.985 & 3.953 \\
\hline Albila(Ab) & 26.60 & & $54.1 \mathrm{C}$ & 2643 & & 58.70 & & 71.30 & 30.50 & 6732 & $57.3 \mathrm{C}$ & 79.70 \\
\hline Anortita (An) & C. 10 & & 2.20 & 0.20 & & $1.6 \mathrm{C}$ & & 25.50 & 16.70 & 5110 & 30.10 & 18.10 \\
\hline Ortoclásio [Ori] & 73.60 & & 3.70 & 73.43 & & 39.70 & & 190 & 2.80 & 160 & 2.10 & 220 \\
\hline
\end{tabular}

Fórmula Estrutural com base em 32 oxigênios.

Análises Químicas WDS de cristais de Feldspato obtidos por Microssonda Eletrônica. 


\begin{tabular}{|c|c|c|c|c|c|c|c|c|c|c|c|c|}
\hline $\begin{array}{l}\text { Amostra } \\
\text { Analise }\end{array}$ & $\begin{array}{c}\mathrm{PB-209e} \\
\mathrm{P} 2-1-2 \\
\mathrm{P}\end{array}$ & $\begin{array}{c}\text { PB-209e } \\
\text { p2-1-3 } \\
q 9\end{array}$ & $\begin{array}{c}\text { PB-209e } \\
\text { P2-1-4 } \\
\text { FI }\end{array}$ & $\begin{array}{c}\text { PB-209e } \\
\text { P2-1-5 } \\
\text { P }\end{array}$ & $\begin{array}{c}\text { PB-209e } \\
p 2-1-6 \\
P\end{array}$ & $\begin{array}{c}\text { PB-209e } \\
\text { p2-1-7 } \\
\text { FI }\end{array}$ & $\begin{array}{c}\text { PB-209e } \\
\text { p2.1-8 } \\
\text { P }\end{array}$ & $\begin{array}{l}\text { PB-209e } \\
\text { p2-1-9 } \\
\text { Fl }\end{array}$ & $\begin{array}{c}\text { PB-209e } \\
\text { p4-1-1 } \\
\text { F }\end{array}$ & $\begin{array}{c}\text { PB-209e } \\
\text { p4-1-2 } \\
\text { P }\end{array}$ & $\begin{array}{c}\text { PB-209e } \\
\text { p4-1-3 } \\
7\end{array}$ & $\begin{array}{c}\text { PB-209e } \\
\text { P4-1-4 } \\
\text { PI }\end{array}$ \\
\hline & \multicolumn{12}{|c|}{ Endive leuencrálicx grossa } \\
\hline $3 \mathrm{SO} 2$ & $5 x .85$ & 58.43 & 6265 & 6404 & 53.73 & 58.37 & 5C 78 & 50.04 & 50.95 & $5 C 8$. & 50.46 & 60.31 \\
\hline $\mathrm{A} / 2 \mathrm{O}_{3}$ & 24.79 & $25.2^{1}$ & 22.54 & 2163 & 25.28 & 25.35 & 2470 & 24.48 & 23.53 & 2427 & 23.36 & 24.30 \\
\hline $\mathrm{Fe} 2 \mathrm{O3}$ & 0.09 & 0.13 & 0.04 & 0.15 & 0.12 & 0.09 & 0.23 & 0.09 & 0.18 & 0.08 & 0.07 & 0.10 \\
\hline $\mathrm{C} \approx$ & 6.28 & 622 & 3.75 & 2.81 & 7.13 & 7.08 & 6.23 & 583 & 4.62 & 5.76 & 5.38 & 5.53 \\
\hline $\mathrm{SrO}$ & 1.03 & 105 & 0.98 & 0.84 & 1.02 & 1.11 & 0.97 & 1.14 & $1.0 \mathrm{~s}$ & 1.03 & 1.00 & 0.95 \\
\hline $\mathrm{BaO}$ & 020 & 000 & 0.00 & 0.01 & 9.23 & 0.12 & 0.15 & 020 & 0.14 & C 15 & 0.12 & 0.11 \\
\hline $\mathrm{Na} 20$ & 754 & 753 & $9.2 x$ & c. .95 & 7.15 & 737 & 7.61 & $7 \mathrm{~B}^{1}$ & $8.6 ?$ & 782 & 3.26 & B.15 \\
\hline $\mathrm{K} 20$ & 0.38 & 0.30 & 0.24 & 0.20 & 0.33 & 0.32 & 0.37 & 0.27 & 0.36 & 0.35 & 0.32 & 0.37 \\
\hline Total & $9 \notin .85$ & 98.36 & 99.90 & 9962 & 99.38 & 99.81 & 100.12 & 99.92 & 99.54 & 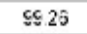 & 99.57 & 99.51 \\
\hline $\mathrm{Si}$ & 10.707 & 10.803 & 11.159 & 11.381 & 10.574 & 10.535 & 10.714 & 10778 & 10.959 & 10.797 & 10.878 & 10.812 \\
\hline Al & 5.245 & 5337 & 4.811 & 4.56 .3 & 5.351 & 5.3888 & 5.231 & 5.175 & 4.982 & 5.16: & 5.256 & 5.147 \\
\hline $\mathrm{Fe} 3$ & 0.010 & 0 & 0.010 & 0.023 & 0020 & 0.010 & c. 030 & 0.20 & 0.020 & 0.010 & 0.20 & 0.010 \\
\hline $\mathrm{Ba}$ & 0.014 & 0.000 & 0.000 & 0.001 & 0.006 & 0.008 & 0.010 & 0.074 & 0.010 & 0.010 & 0.009 & $0.0 c e$ \\
\hline $\mathrm{Ca}$ & 1.209 & 1.209 & 0.716 & 0.535 & 1375 & 1.369 & 1.196 & 1.132 & 0.890 & 1.115 & 1.038 & 1.061 \\
\hline $\mathrm{Na}$ & 2.627 & 2.551 & 3.209 & 3.429 & 2497 & 2.581 & 2.645 & 2.720 & 3.022 & 2.737 & 2.383 & 2.833 \\
\hline$K$ & 0.087 & 0.059 & 0.054 & 0.044 & 0.088 & 0.073 & 0.085 & 0.063 & 0.082 & 0.082 & 0.074 & 0.086 \\
\hline $\mathrm{Sr}$ & 0.110 & 0 ०१० & $0.1 \mathrm{cc}$ & 0.093 & 0110 & 0.120 & c. 100 & 0.120 & 0.110 & 0.110 & $0.11 \mathrm{C}$ & $0.1 \mathrm{cc}$ \\
\hline Soma $T$ & 15.965 & 16.010 & 15.980 & 15.564 & 15.955 & 15.933 & 15.975 & 15.953 & 15.961 & 15.967 & 15.943 & 75.969 \\
\hline Soma M & 3.947 & 3.949 & $3.9 e c$ & 4.029 & 3986 & 4.041 & 3.966 & 3.939 & 4.024 & 3.554 & 4.074 & 3.997 \\
\hline Albila $(A b)$ & 67.00 & 67.50 & $80.6 \mathrm{C}$ & 8563 & 63.10 & 54.20 & 6740 & 59.50 & 75.70 & (E) 6. & 72.20 & 71.20 \\
\hline Anortita (An) & $x .85$ & 30.30 & 18.00 & 1353 & 34.70 & 34.00 & 30.50 & 25.90 & 22.30 & 2830 & $25 . x$ & 26.70 \\
\hline Ortoclásio [Or] & 2.20 & 130 & 1.10 & 1.10 & 2.20 & 1.80 & 2.20 & 1.50 & 2.10 & 2.10 & 1.90 & 2.10 \\
\hline
\end{tabular}

Fórmula Estrutural com base em 32 oxigênios.

Análises Químicas WDS de cristais de Feldspato obtidos por Microssonda Eletrônica. 


\begin{tabular}{|c|c|c|c|c|c|c|c|c|c|c|c|c|}
\hline $\begin{array}{l}\text { Amostra } \\
\text { Análise }\end{array}$ & $\begin{array}{c}\mathrm{PB-209e} \\
\mathrm{P} 4-1-5 \\
\mathrm{P}\end{array}$ & $\begin{array}{c}\text { PB-209e } \\
p 9-1-1 \\
q\end{array}$ & $\begin{array}{c}\text { PQ-209e } \\
\text { p9-1-10 } \\
\text { FI }\end{array}$ & $\begin{array}{c}\text { PB-209e } \\
p 9-1 \cdot 11 \\
P\end{array}$ & $\begin{array}{c}\text { PB-209e } \\
p 9-1-12 \\
P\end{array}$ & $\begin{array}{c}\text { PB-209e } \\
\text { pg-1-14 } \\
\text { FI }\end{array}$ & $\begin{array}{c}\text { PB-209e } \\
\text { p9-1-15 } \\
\text { P }\end{array}$ & $\begin{array}{l}\text { PB-209e } \\
\text { p9-1-2 } \\
\text { नI }\end{array}$ & $\begin{array}{c}\text { PE-209e } \\
\text { p9-1.3 } \\
\text { F }\end{array}$ & $\begin{array}{c}\text { PB-209e } \\
\text { p9-1-4 } \\
\text { P }\end{array}$ & $\begin{array}{c}\text { PB-209e } \\
\text { p9-1-5 } \\
7\end{array}$ & $\begin{array}{c}\text { PB-209e } \\
p 9-1 \cdot 6 \\
P I\end{array}$ \\
\hline & \multicolumn{12}{|c|}{ Endive leuencrálicongrossa } \\
\hline 3102 & 61.57 & 57.27 & $586 C$ & 5812 & 53.47 & 57.20 & 5877 & 55.56 & 58.52 & $5 C 6$. & 31.23 & 50.78 \\
\hline $\mathrm{A} / 2 \mathrm{O}_{3}$ & 25.63 & 26.33 & $25.6 \mathrm{E}$ & 25.45 & 24.54 & 26.46 & 2E 14 & 25.87 & 25.74 & 2484 & 23.32 & 25.16 \\
\hline $\mathrm{Fe} 2 \mathrm{O3}$ & 0.10 & 0.06 & 0.06 & 0.08 & 0.04 & 0.12 & 0.11 & $0: 10$ & 0.11 & 0.08 & 0.10 & 0.09 \\
\hline $\mathrm{Ca}_{0}$ & 484 & 822 & 7.30 & 6.59 & 6.03 & 8.32 & 7.19 & 832 & 7.47 & 6.51 & 5.32 & 6.71 \\
\hline $\mathrm{SrO}$ & 0.81 & 0.92 & 1.06 & 0.89 & 0.33 & 0.84 & 0.99 & 0.37 & 0.79 & 0.64 & 0.67 & 0.97 \\
\hline $\mathrm{BaO}$ & C. 16 & 002 & 0.03 & 0.13 & 9.03 & 0.02 & 0.12 & 010 & $0 . c \varepsilon$ & 001 & 0.18 & $0.0 \AA$ \\
\hline $\mathrm{Na} 20$ & g.34 & 650 & 7.18 & 7.53 & 7.59 & 6.57 & 6.85 & 642 & 6.92 & 7.49 & 3.15 & 7.37 \\
\hline $\mathrm{K}_{20}$ & 0.33 & 0.34 & 0.48 & 0.36 & 0.43 & 0.39 & 0.43 & 0.33 & 0.50 & 0.48 & 0.57 & 0.44 \\
\hline Total & $9 \notin .75$ & 99.74 & 100.48 & 99.14 & 93.07 & 99.92 & 10072 & 100.06 & 100.13 & $\llbracket \subseteq 60$ & 99.34 & 700.57 \\
\hline $\mathrm{Si}$ & 11003 & 10.347 & 10516 & $10=33$ & $10: 2 x$ & 10321 & 10497 & 10216 & 10.509 & 10707 & 10008 & 17.698 \\
\hline Al & 4.973 & 553 & 5.472 & 5.455 & 5283 & 5.672 & 5.495 & 5.715 & 5.444 & 5.254 & 5.027 & 5.28 \\
\hline $\mathrm{Fe} 3$ & 0.010 & 0 & 0.010 & 0.013 & 0510 & 0.020 & C. 020 & 0.200 & 0.020 & 0.010 & 0.210 & 0.010 \\
\hline $\mathrm{Ba}$ & 0.011 & $0.0)^{n}$ & 0.002 & 0.010 & 0.002 & 0.001 & 0.000 & 0.007 & 0.006 & 0.001 & 0.013 & $0.0 C E$ \\
\hline $\mathrm{Ca}$ & 0.927 & 1.591 & 1.402 & 1.281 & 1.181 & 1.608 & 1.375 & 1.707 & 1.437 & 1.254 & 1.021 & 1.282 \\
\hline $\mathrm{Na}$ & $2.8 C 1$ & 2.311 & 2.494 & 2.645 & 2.724 & 2.299 & 2.417 & 2.250 & 2.409 & 2.610 & 2.830 & 2.549 \\
\hline$K$ & 0.075 & 0.077 & 0.109 & 0.082 & 0.100 & 0.090 & 0.099 & 0.077 & 0.114 & 0.110 & 0.129 & $0.0 \subseteq 0$ \\
\hline $\mathrm{Sr}$ & 0.080 & מכנר 0 & $0.11 \mathrm{C}$ & 0.093 & 0090 & 2.080 & c. 100 & $0.0 \times 0$ & 5.080 & (c.67) & $0.07 \mathrm{C}$ & $0.1 \mathrm{Cc}$ \\
\hline Soma $T$ & 15.986 & 15.959 & 15.948 & 15.983 & $15.98^{\circ}$ & 15.963 & 16.007 & 15.941 & 15.973 & 15.971 & 15.960 & 75.963 \\
\hline Sema M & 3.915 & 3990 & 4.017 & 4.029 & 4017 & 4.018 & 3.919 & 4.05 & 3.986 & 3.585 & 4.003 & 3.946 \\
\hline Albila $(A b)$ & 74.20 & 58.10 & 5230 & 6603 & 63.50 & 57.50 & 6210 & 55.80 & 50.80 & 6.570 & 71.10 & 64.50 \\
\hline Anortita (An) & 20.80 & 40.00 & 35.00 & 32.03 & 29.50 & 10.20 & 35.30 & 42.30 & 36.30 & 5160 & 25.70 & 32.60 \\
\hline Ortoclásio [Or] & 200 & 190 & 2.70 & 2.00 & 2.50 & 2.30 & 2.60 & 190 & 2.80 & 260 & 3.20 & 2.50 \\
\hline
\end{tabular}

Fórmula Estrutural com base em 32 oxigênios.

Análises Químicas WDS de cristais de Feldspato obtidos por Microssonda Eletrônica. 


\begin{tabular}{|c|c|c|c|c|c|c|c|c|c|c|c|c|}
\hline $\begin{array}{l}\text { Amostra } \\
\text { Análise }\end{array}$ & $\begin{array}{c}\text { PB-209e } \\
\text { P9-1-7 } \\
P \mid \\
\text { Enc }\end{array}$ & $\begin{array}{c}\text { PB-209e } \\
\text { p9-1-8 } \\
9 \\
\text { lexxicríl }\end{array}$ & $\begin{array}{c}\text { PB-209e } \\
\text { P9-1-9 } \\
\text { FI } \\
\text { axis }\end{array}$ & $\begin{array}{l}\text { PB-229 } \\
\text { p12-11 } \\
\text { Bcrda }\end{array}$ & $\begin{array}{l}\text { Desvio } \\
\text { Padrä̊ }\end{array}$ & $\begin{array}{c}\text { PB-229 } \\
\text { p4-5-8-13 } \\
\text { Nudeo }\end{array}$ & $\begin{array}{l}\text { Desvio } \\
\text { Padrä́o }\end{array}$ & $\begin{array}{c}\text { PB-229 } \\
\text { p5-9-10 } \\
\text { Borce } \\
\text { S1.8 }\end{array}$ & $\begin{array}{l}\text { Desvio } \\
\text { Padrắo }\end{array}$ & $\begin{array}{l}\text { PB-229 } \\
\text { p6-7-8 } \\
\text { Nucleo }\end{array}$ & $\begin{array}{l}\text { Desvio } \\
\text { Padrä́o }\end{array}$ & $\begin{array}{c}\text { PB-229 } \\
\text { p1-1-1 } \\
\text { PI }\end{array}$ \\
\hline 5102 & $6 \subset . C 9$ & 59.37 & 59.41 & 6402 & 1.12 & 34.56 & 0.23 & 53.88 & 0.44 & 6423 & 0.47 & 61.01 \\
\hline $\mathrm{A} / 2 \mathrm{O}_{3}$ & 24.73 & 25.15 & 25.26 & 1839 & 0.03 & 20.01 & 0.11 & 19.37 & 0.17 & 2085 & 0.15 & 23.44 \\
\hline $\mathrm{Fe} 2 \mathrm{O}_{3}$ & 0.06 & 0.07 & 0.04 & 0.10 & 0.00 & 0.16 & 0.04 & 0.07 & 0.07 & 0.13 & 0.02 & 0.12 \\
\hline $\mathrm{C} \approx 0$ & 6.01 & 670 & 5.49 & 0.23 & 0.15 & 0.91 & 0.12 & 021 & 0.07 & 1.78 & 0.18 & 5.03 \\
\hline $\mathrm{SrO}$ & 0.88 & 0.74 & 0.87 & 0.46 & 0.05 & 0.42 & 0.10 & 0.60 & 0.18 & 0.35 & 0.11 & 0.48 \\
\hline $\mathrm{B}=\mathrm{O}$ & C 12 & 009 & 0.12 & 1.09 & 9.21 & $0.8 \mathrm{C}$ & 0.11 & 113 & 0.26 & C 62 & 0.03 & 0.00 \\
\hline $\mathrm{Na} 20$ & 760 & 742 & 7.58 & 3.79 & 0.49 & 5.64 & 0.69 & 326 & 0.40 & 677 & 0.84 & B.77 \\
\hline $1 \times 20$ & 0.41 & 0.47 & 0.47 & 10.93 & 1.74 & 7.93 & 0.77 & 11.75 & 0.70 & 5.61 & 1.13 & 0.22 \\
\hline Total & $9 \notin .50$ & $100.0^{\circ}$ & 100.23 & 100.04 & & 100.43 & & 100.27 & & 100.39 & & 99.07 \\
\hline $\mathbf{S i}$ & 10.766 & 10.848 & 10.640 & 11.771 & & $11.68 \mathrm{G}$ & & 11.764 & & 11.551 & & 10.973 \\
\hline Al & 5.219 & 5312 & 5.328 & 4.195 & & 4.267 & & $4.20^{\circ}$ & & 4.413 & & 4. .6. 4 \\
\hline $\mathrm{Fe} 3$ & 0.010 & 0 & 0.010 & 0.013 & & 0.020 & & 0.000 & & 0.020 & & 0.020 \\
\hline $\mathrm{Ba}$ & 0.009 & 0.005 & 0.008 & 0.079 & & 0.057 & & 0.002 & & 0.044 & & 0.000 \\
\hline $\mathrm{Ca}$ & 1.153 & 1.283 & 1.244 & 0.045 & & 0.177 & & 0.04 & & 0.343 & & 0.970 \\
\hline $\mathrm{Na}$ & 2.641 & 2.579 & 2.632 & 1.351 & & 1.980 & & 1. 164 & & 2.359 & & 3.060 \\
\hline$K$ & 0.093 & 0.107 & 0.107 & 2.571 & & 1.832 & & 2.761 & & 1.285 & & 0.051 \\
\hline $\mathrm{Sr}$ & 0.085 & 0 & $0.0 E C$ & 0.053 & & 2.010 & & 0.060 & & 0.040 & & OCEC \\
\hline Soma $\mathbf{T}$ & 75.995 & 15.970 & 15.978 & 15.979 & & 15.976 & & 15975 & & 15.934 & & 75.957 \\
\hline Soma M & 3.905 & 3.990 & 4.001 & 4.055 & & 4.066 & & 4.058 & & 4.052 & & 4.101 \\
\hline Albita(Ab) & 67.50 & 64.90 & $\omega .1 \mathrm{C}$ & 3413 & & 49.60 & & 29.30 & & 5920 & & 75.60 \\
\hline Anortita (An) & x.70 & 32.10 & 31.20 & 1.10 & & 4.40 & & 100 & & 860 & & 23.80 \\
\hline Ortoclásio (Or) & 240 & 2.70 & 2.70 & 6463 & & 15.90 & & 59.60 & & 3220 & & 120 \\
\hline
\end{tabular}

Fórmula Estrutural com base em 32 oxigênios.

Análises Químicas WDS de cristais de Feldspato obtidos por Microssonda Eletrônica. 


\begin{tabular}{|c|c|c|c|c|c|c|c|c|c|c|c|c|}
\hline $\begin{array}{l}\text { Amostra } \\
\text { Análise }\end{array}$ & $\begin{array}{c}\text { PB-229 } \\
\text { p1-1-1b } \\
\text { P }\end{array}$ & $\begin{array}{c}\text { PB-229 } \\
p 1-1-1 b 1 \\
q\end{array}$ & $\begin{array}{c}\text { PB-229 } \\
\text { p1-1-1b2 } \\
\text { FI }\end{array}$ & $\begin{array}{c}\text { PB-229 } \\
\text { p1-1-1n } \\
\text { P }\end{array}$ & $\begin{array}{c}\text { PB-229 } \\
\text { p1-1-1n } 3 \\
P\end{array}$ & $\begin{array}{c}\text { PB-229 } \\
\text { p2-1-7 } \\
\text { FI }\end{array}$ & $\begin{array}{c}\text { PB-229 } \\
p 2 \cdot 2-8 \\
P\end{array}$ & $\begin{array}{l}\text { PB-229 } \\
\text { p2-2-8a }\end{array}$ & $\begin{array}{c}P B-229 \\
p 3-4-10 \\
F\end{array}$ & $\begin{array}{c}\text { PB-229 } \\
\text { p3-5-10a } \\
\text { PI }\end{array}$ & $\begin{array}{l}\text { PB-229 } \\
\text { p7-4-5 } \\
\text { Nudec }\end{array}$ & $\begin{array}{l}\text { Desvio } \\
\text { Padrä́o }\end{array}$ \\
\hline $3 \mathrm{SO} 2$ & 61.37 & 59.43 & 60.77 & 5809 & 57.32 & 59.76 & $6 C 96$ & 50.29 & 58.47 & EC 33 & 34.38 & 0.25 \\
\hline $\mathrm{A} / 2 \mathrm{O}_{3}$ & Z. .41 & 24.39 & 24.00 & 25.57 & 25.27 & 24.82 & 2427 & 23.89 & 25.34 & 2467 & 19.53 & 0.03 \\
\hline $\mathrm{Fe} 2 \mathrm{O}_{3}$ & 0.08 & 0.12 & 0.19 & 0.11 & 0.31 & 0.28 & 0.04 & 0.13 & 0.24 & 0.20 & 0.08 & 0.02 \\
\hline $\mathrm{C} \approx$ & 484 & 648 & 5.46 & 7.72 & 6.30 & 6.76 & 5.75 & 572 & 7.26 & 580 & 0.34 & 0.09 \\
\hline $\mathrm{SrO}$ & 0.69 & 0.51 & 0.63 & 0.62 & 0.55 & 0.53 & 0.60 & 0.50 & 0.65 & 0.57 & 0.54 & 0.02 \\
\hline $\mathrm{BaO}$ & C 12 & $C 01$ & 0.03 & $C .60$ & 9.05 & 0.02 & 0.12 & 0.03 & 0.13 & 005 & 1.20 & 0.07 \\
\hline $\mathrm{Na} 2 \mathrm{O}$ & 870 & 7 Б0 & B.X & 7.10 & 7.19 & 7.63 & 8.15 & 829 & 7.52 & 754 & 3.71 & D.11 \\
\hline $\mathrm{K}_{20}$ & C. 19 & 0.24 & 0.77 & 0.29 & 0.40 & 0.27 & 0.25 & 0.23 & 0.20 & 0.63 & 10.95 & 0.15 \\
\hline Total & $9 \notin .41$ & 99.37 & 99.65 & 99.50 & 93.19 & 100.07 & 100.13 & 99.18 & 99.79 & c\& 83 & 100.83 & \\
\hline $\mathrm{Si}$ & 11007 & 10.895 & 10.884 & 10.489 & 10.528 & 10.698 & 10.855 & $10 \mathrm{BSC}$ & 10.593 & 10.742 & 11.753 & \\
\hline Al & 4.844 & 5274 & 5.062 & 5.455 & 5439 & 5.229 & 5.094 & 5.068 & 5.375 & 5.254 & 4.220 & \\
\hline $\mathrm{Fe} 3$ & 0.010 & 0 & 0.030 & 0.013 & $0 x 0$ & 0.040 & c.010 & 0.000 & D.030 & (c.c3) & 0.20 & \\
\hline $\mathrm{Ba}$ & 0.005 & $0.00^{\prime}$ & 0.002 & 0.003 & 0.004 & 0.002 & 0.000 & 0.002 & 0.008 & 0.004 & 0.036 & \\
\hline $\mathrm{Ca}$ & 0.935 & 1.249 & 1.048 & 1.494 & 1332 & 1.296 & 1.099 & 1.105 & 1.402 & 1.124 & 0.057 & \\
\hline $\mathrm{Na}$ & 3.025 & 2.551 & 2.914 & 2.485 & $25<6$ & 2.648 & 2.818 & 2.395 & 2.627 & 2.645 & 1.313 & \\
\hline$K$ & 0.044 & 0.055 & 0.039 & 0.065 & 0.093 & 0.061 & 0.064 & 0.053 & 0.046 & $0.15 \hat{5}$ & 2.550 & \\
\hline $\mathrm{Sr}$ & 0.070 & 0 & $0.0 \% 0$ & 0.070 & 0050 & .050 & c. .060 & 0.060 & 2.070 & (..6.) & $0.05 \mathrm{CC}$ & \\
\hline Soma $T$ & 15.961 & 15.989 & 15.976 & $15 . \subseteq 37$ & 15.007 & 15.962 & $15 . \subseteq 70$ & 15.948 & 15.938 & 16.026 & 15.983 & \\
\hline Soma M & 4.015 & 3.975 & 4.093 & 4.055 & 4015 & 4.047 & 3.999 & 4.075 & 4.714 & 3.559 & 4.026 & \\
\hline Albila $(A b)$ & 76.60 & סD.J & 72.80 & 6143 & 64.10 & 56.10 & 70.80 & 71.40 & 5450 & 6740 & $33.4 \mathrm{C}$ & \\
\hline Anortita (An) & 20.30 & 31.50 & 26.20 & 36.93 & 33.50 & 32.40 & 27.60 & 27.30 & 34.40 & 2860 & 1.70 & \\
\hline Ortoclásio [Or) & 1.10 & 1.40 & 1.00 & 1.60 & 2.30 & 1.50 & 1.60 & 130 & 1.10 & 400 & 54.90 & \\
\hline
\end{tabular}

Fórmula Estrutural com base em 32 oxigênios.

Análises Químicas WDS de cristais de Feldspato obtidos por Microssonda Eletrônica. 


\begin{tabular}{|c|c|c|c|c|c|c|c|c|c|c|c|c|}
\hline $\begin{array}{l}\text { Amostra } \\
\text { Análise }\end{array}$ & $\begin{array}{l}\text { PE-229 } \\
\text { p7-6-7-8 } \\
\text { Nucieo }\end{array}$ & $\begin{array}{l}\text { Desvlo } \\
\text { Padrăo }\end{array}$ & $\begin{array}{c}\text { PB-229 } \\
\text { p7-9-10 } \\
\text { Borda }\end{array}$ & $\begin{array}{l}\text { Desvlo } \\
\text { Padráo }\end{array}$ & $\begin{array}{l}\text { PB-229 } \\
\text { p8-1-8 } \\
\text { Nuclec }\end{array}$ & $\begin{array}{l}\text { Desvlo } \\
\text { Padràn }\end{array}$ & $\begin{array}{c}\text { PE-229 } \\
\text { PB-6-7 } \\
\text { Eorda }\end{array}$ & $\begin{array}{l}\text { Desvlo } \\
\text { Padrăo }\end{array}$ & $\begin{array}{l}\mathrm{PB}-229 \\
\mathrm{p} 9-2-5-6 \\
\text { Nucleo }\end{array}$ & $\begin{array}{l}\text { Desvlo } \\
\text { Padráo }\end{array}$ & $\begin{array}{c}\text { PB-229 } \\
\text { pg-3-4-7 } \\
\text { Borca }\end{array}$ & $\begin{array}{l}\text { Desvlo } \\
\text { Padräo }\end{array}$ \\
\hline $\mathrm{SiO} 2$ & 64.70 & 0.58 & 63.98 & 0.22 & 64.09 & 0.31 & 6323 & 1.11 & 54.01 & 0.55 & 64.25 & 7.43 \\
\hline $\mathrm{A} \mid 203$ & 21.03 & 0.39 & 19.56 & 0.08 & 19.46 & 0.07 & $1 \subseteq 41$ & 0.04 & 20.05 & 0.09 & 19.29 & 0.11 \\
\hline $\mathbf{F c 2 O 3}$ & C 05 & C 06 & 0.11 & 0.01 & 0.23 & 0.04 & 0.69 & 005 & $0.0 ?$ & 005 & 0.08 & D.05 \\
\hline $\mathrm{CaO}$ & 174 & 0.52 & 0.20 & 0.02 & 0.13 & $0.0 C$ & 0.12 & 0.07 & 0.83 & 005 & 0.11 & 0.00 \\
\hline Sro & 0.05 & 0.05 & 0.57 & 0.01 & 0.55 & 0.03 & 0.65 & 0.09 & 0.44 & 0. 10 & 0.46 & 0.03 \\
\hline$B \times 0$ & C. 19 & 0.19 & 0.96 & 0.37 & 1.13 & 0.09 & 1.09 & 0.2 & 0.87 & 0.12 & 0.89 & 0.21 \\
\hline $\mathrm{Na} 2 \mathrm{O}$ & 6.36 & 0.99 & 3.55 & 0.28 & 3.41 & 0.00 & 3.27 & 070 & 4.52 & 0.30 & 3.26 & 0.14 \\
\hline $\mathrm{K} 20$ & 6.19 & 1.75 & $10.5 s$ & 0.33 & 11.41 & 0.10 & 11.61 & 127 & 9.26 & 0.40 & 11.74 & 0.14 \\
\hline Total & $100 \$ 1$ & & 99.52 & & 100.43 & & $\operatorname{sc} 40$ & & 100.05 & & 10506 & \\
\hline $\mathrm{Si}$ & 11.564 & & 11.763 & & $11.7 \cong 9$ & & 11740 & & 11.683 & & 11.810 & \\
\hline Al & 4.434 & & 4.235 & & 4208 & & 4.244 & & 4.309 & & 4.776 & \\
\hline $\mathrm{Fe}^{3}$ & 0.010 & & 0.020 & & 0.000 & & 0.010 & & 0.010 & & 0.010 & \\
\hline Ba & 0.013 & & $0.06 \mathrm{C}$ & & 0.085 & & 0.079 & & 0.062 & & 0.054 & \\
\hline $\mathrm{Ca}$ & 0.954 & & $0.0 \mathrm{ses}$ & & $0 \mathrm{D3} ?$ & & c.024 & & D. 169 & & 0. .272 & \\
\hline $\mathrm{Na}$ & $2 \% 5$ & & 1.266 & & 1214 & & 1.177 & & 1598 & & 1.152 & \\
\hline$K$ & 1.414 & & 2.578 & & 2.573 & & 2.750 & & 2.156 & & 2.753 & \\
\hline $\mathrm{Sr}$ & 0.010 & & $0.06 C$ & & 0.970 & & 0.060 & & 0.050 & & $0.05 \mathrm{C}$ & \\
\hline Soma $\mathbf{T}$ & 16028 & & 16.018 & & $15.9 \pi$ & & 15.994 & & $16 . \mathrm{CO}_{2}$ & & 15.906 & \\
\hline Soma M & 3.979 & & 3.972 & & 4009 & & 4.040 & & 3984 & & 4.211 & \\
\hline Al bita(Ab) & 55.80 & & 32.60 & & 30.90 & & $2 \subseteq 80$ & & 40.80 & & 29.50 & \\
\hline Anortita (An) & 840 & & 7.00 & & 0.90 & & 060 & & 4.20 & & 0.60 & \\
\hline Ortoclàslo [Or] & 35.70 & & $66.4 \mathrm{C}$ & & 63.10 & & $6 \subseteq 60$ & & 55.00 & & 69.90 & \\
\hline
\end{tabular}

Fórmula Estrutural com base em 32 oxigênios.

Análises Químicas WDS de cristais de Feldspato obtidos por Microssonda Eletrônica. 


\begin{tabular}{|c|c|c|c|c|c|c|c|c|c|c|c|c|}
\hline $\begin{array}{l}\text { Amostra } \\
\text { Análise }\end{array}$ & $\begin{array}{l}\text { PB-38 } \\
\text { p } 10\end{array}$ & $\begin{array}{c}\text { PB-38 } \\
\text { p12 }\end{array}$ & $\begin{array}{c}\text { P日-3B } \\
\text { P13 }\end{array}$ & $\begin{array}{l}\text { PB-38 } \\
\text { P14 }\end{array}$ & $\begin{array}{l}\text { PB-3B } \\
\text { p47 }\end{array}$ & $\begin{array}{c}\text { PB-38 } \\
\text { p49 }\end{array}$ & $\begin{array}{c}\text { PB-38 } \\
\text { p55 }\end{array}$ & $\begin{array}{c}\text { PB-38 } \\
\text { p56 }\end{array}$ & $\begin{array}{l}\text { PE-38 } \\
\text { borda/9 }\end{array}$ & $\begin{array}{l}\mathrm{PB}-38 \\
\mathrm{ne} 1 . / 1 / 2\end{array}$ & $\begin{array}{l}\text { PB-47B } \\
\text { p1-1-2 } \\
3 \alpha x c a\end{array}$ & $\begin{array}{l}\text { Desvio } \\
\text { Padrắo }\end{array}$ \\
\hline $\mathrm{SHO2}$ & 64.15 & 64.42 & 64.21 & 6383 & 65.17 & 25.34 & 6521 & 34.82 & 55.01 & 6425 & 53.51 & 0.31 \\
\hline $\mathrm{A} \mid 2 \mathrm{O}_{3}$ & 18.65 & 19.43 & 19.35 & 1850 & 20.07 & 19.71 & 20.99 & 20.96 & 19.13 & 18.33 & 29.04 & 0.06 \\
\hline $\mathrm{Fe} 2 \mathrm{O}_{3}$ & 0.36 & 0.35 & 0.30 & 0.35 & 0.13 & 0.10 & 0.10 & 0.71 & 0.38 & 0.44 & 0.29 & 0.03 \\
\hline $6 \times$ & 0.00 & 0.01 & 0.01 & 0.02 & 0.50 & 0.55 & 1.84 & 155 & 0.00 & 0.00 & 0.01 & 0.01 \\
\hline $\mathrm{SrO}$ & 0.57 & 0.49 & 0.64 & 0.62 & 0.50 & 0.42 & 0.41 & 0.36 & 0.51 & 0.57 & 0.36 & 0.14 \\
\hline $\mathrm{Ba} 0$ & 212 & 209 & 2.01 & 1.77 & 0.37 & 0.85 & 0.43 & 053 & 1.05 & 175 & $1 . \infty$ & 0.01 \\
\hline $\mathrm{Na} 20$ & 275 & $27 i$ & 2.88 & 2.57 & 3.77 & $2 \mathrm{cg}$ & 6.69 & 568 & 1.57 & 264 & 2.84 & D.56 \\
\hline $\mathrm{K} 20$ & 10.74 & 10.34 & 10.76 & 11.35 & $9.0^{1}$ & 0.45 & 4.34 & 629 & $\uparrow 3.21$ & 11.03 & 12.38 & 0.80 \\
\hline Total & 700.25 & 100.45 & 100.20 & 100.04 & 100.72 & 100.41 & s؟ 91 & 100.40 & 100.86 & 100.05 & 109.93 & \\
\hline $\mathrm{Si}$ & 11800 & 11.321 & 11.818 & 11.785 & $11.7 \circledast 0$ & 11.855 & 11.645 & 11.523 & $11.8 \subseteq 2$ & 11.828 & 10.681 & \\
\hline Al & 4.297 & 4209 & $4.2 \mathrm{cs}$ & 4.255 & 4272 & 4.211 & 4.415 & 4.426 & 4.121 & 4.191 & 5.751 & \\
\hline $\mathrm{Fe} 3$ & 0.060 & 0 & 0.010 & 0.053 & 0520 & 0.010 & C.010 & 0.00 & 0.050 & (c.6.) & 0.040 & \\
\hline $\mathrm{Ba}$ & 0.153 & 0.750 & 0.145 & 0.125 & 0.052 & 0.060 & 0.030 & 0.044 & 0.075 & 0.126 & 0.056 & \\
\hline $\mathrm{Ca}$ & 0.000 & 0.002 & 0.002 & 0.004 & 0.116 & 0.107 & 0.352 & 0.298 & 0.000 & $C .600$ & 0.002 & \\
\hline $\mathrm{Na}$ & 0.981 & 0.986 & 1.028 & 0.920 & 1321 & 1.052 & 2.282 & 1.975 & 0.557 & 0.542 & 0.926 & \\
\hline K & 2.520 & 2.538 & 2.526 & 2.672 & 2216 & 2.419 & 0.989 & 1.439 & 3.083 & 2.602 & 2.753 & \\
\hline $\mathrm{Sr}$ & 0.ces & 0 & $0.0 \% 0$ & 0.070 & 0050 & 0.010 & C. 040 & 0.210 & 0.050 & (. C6.) & 0.040 & \\
\hline Soma $\mathbf{T}$ & 76087 & 16.080 & 15.061 & 16.073 & 15.072 & 16.076 & $16.07^{\circ}$ & 16.059 & 16.063 & 16.079 & 15.472 & \\
\hline Soma M & 3.704 & 3.726 & 3.741 & 3.774 & 3.735 & 3.648 & 3.663 & 3.766 & 3.765 & 3.730 & 3.797 & \\
\hline Albila(Ab) & 2000 & 28.0 & 28.50 & 2563 & 35.20 & 2.40 & 6s 00 & 53.20 & 15.30 & $266)$ & 25.10 & \\
\hline Anortita (An) & 0.00 & 0.10 & 0.10 & C.10 & 3.20 & 3.00 & 9.70 & 800 & 0.00 & 000 & 0.10 & \\
\hline Ortoclásio (Or) & 72.00 & 72.00 & 77.00 & 7435 & 60.70 & 57.60 & 27.30 & 35.80 & 34.70 & 7340 & 74.90 & \\
\hline
\end{tabular}

Fórmula Estrutural com base em 32 oxigênios.

Análises Químicas WDS de cristais de Feldspato obtidos por Microssonda Eletrônica. 


\begin{tabular}{|c|c|c|c|c|c|c|c|c|c|c|c|c|}
\hline $\begin{array}{l}\text { Amostra } \\
\text { Análise }\end{array}$ & $\begin{array}{l}\text { PB-47B } \\
\text { p1-5-6 } \\
\text { Nucles }\end{array}$ & $\begin{array}{l}\text { Desvio } \\
\text { Padrắo }\end{array}$ & $\begin{array}{c}\text { PB-47日 } \\
\text { p2-5-6 } \\
\text { Borda }\end{array}$ & $\begin{array}{l}\text { Desvio } \\
\text { Padráo }\end{array}$ & $\begin{array}{c}\text { PB-47B } \\
p 2-7-8 \\
B x \cdot d a\end{array}$ & $\begin{array}{l}\text { Desvio } \\
\text { Padráo }\end{array}$ & $\begin{array}{c}\text { PB-47B } \\
\text { p4-12-13 } \\
\text { Eorda }\end{array}$ & $\begin{array}{l}\text { Desvio } \\
\text { Padráo }\end{array}$ & $\begin{array}{c}\text { PB-47B } \\
\text { P4-14-15 } \\
\text { Nuceo }\end{array}$ & $\begin{array}{l}\text { Desvio } \\
\text { Padrä̀ }\end{array}$ & $\begin{array}{l}\text { PB-5A } \\
\text { p1-2-4 } \\
\text { Borc } 8\end{array}$ & $\begin{array}{l}\text { Desvio } \\
\text { Padräo }\end{array}$ \\
\hline $\mathrm{SiO2}$ & 64.34 & 054 & 63.87 & 0.01 & 62.92 & 0.54 & 6413 & 031 & 54.04 & 043 & 53.34 & 0.00 \\
\hline $\mathrm{A} \mid 203$ & $1 c .64$ & 003 & 18.78 & C. 15 & 13.72 & 0.06 & $1 \leqslant 27$ & 03.5 & 18.92 & C 18 & 19.39 & 0.16 \\
\hline $\mathrm{Fe} 2 \mathrm{O3}$ & 0.40 & 0.09 & 0.47 & 0.02 & 0.55 & 0.17 & 0.62 & 009 & $0.5 \mathrm{E}$ & 0.13 & 0.05 & 0.07 \\
\hline $\mathrm{C} 20$ & 0.01 & 0.01 & 0.00 & 0.02 & 0.00 & 0.00 & 0.01 & 0.00 & 0.02 & 000 & 0.18 & 0.15 \\
\hline $\mathrm{SrO}$ & 0.49 & 0.03 & 0.44 & 0.02 & 0.43 & 0.07 & 0.35 & 0.02 & 0.30 & 0.09 & 0.61 & 0.03 \\
\hline$B \times 0$ & 100 & 0.00 & 1.02 & 0.14 & 1.05 & 0.25 & 1.05 & 0.10 & 1.36 & 0.27 & 1.34 & 0.19 \\
\hline $\mathrm{Na} 2 \mathrm{O}$ & 340 & 0.37 & 2.91 & 0.53 & $2.7 \AA$ & 0.88 & 3.80 & 0.99 & $3 . c c$ & Q 27 & 3.52 & 0.65 \\
\hline $\mathrm{K}_{20}$ & 12.30 & C.36 & 12.61 & 0.02 & 13.11 & 0.86 & 1159 & 152 & 12.33 & Q 53 & 11.34 & 1.39 \\
\hline Total & 100.98 & & 100.09 & & 99.54 & & 10073 & & 100.65 & & 99.77 & \\
\hline SI & 11.790 & & 11.815 & & 11.757 & & 11752 & & $11.7 \subseteq 2$ & & 11.734 & \\
\hline Al & 4.109 & & 4.081 & & 4119 & & 4.159 & & 4.109 & & 4.230 & \\
\hline Fea & 0.063 & & 0.080 & & 0 DBO & & c. .070 & & 2080 & & 0.20 & \\
\hline Ba & 0.072 & & 0.074 & & $057 ?$ & & C. .076 & & 2098 & & 5. 59 ? & \\
\hline $\mathrm{Ca}$ & 0.002 & & 0.000 & & 0.000 & & 0.002 & & 0.004 & & 0.036 & \\
\hline $\mathrm{Na}$ & $1.2 C 3$ & & 1.043 & & 1.000 & & 1.350 & & 1.103 & & 1.254 & \\
\hline K & 2.875 & & 2.976 & & 3.125 & & 2.709 & & 2896 & & 2. $.5 \mathrm{BC}$ & \\
\hline Sr & 0.050 & & 0.050 & & 0.050 & & 0.040 & & 0.030 & & 0.070 & \\
\hline Soma $\mathbf{T}$ & 75.959 & & 15.976 & & 15.956 & & 15857 & & 15.875 & & 15.974 & \\
\hline Soma M & 4.217 & & 4.163 & & 4282 & & 4.207 & & 4.781 & & 4.087 & \\
\hline Albtta(Ab) & $x 60$ & & 26.00 & & 24.20 & & 33.20 & & 27.60 & & $31 . B C$ & \\
\hline Anortita (An) & $\mathrm{C} 00$ & & D.00 & & 0.20 & & 000 & & 0.10 & & 0.50 & \\
\hline Ortoclásio [Ori] & 70.40 & & 74.00 & & 75.30 & & $\in \in 70$ & & 72.30 & & 57.30 & \\
\hline
\end{tabular}

Fórmula Estrutural com base em 32 oxigênios.

Análises Químicas WDS de cristais de Feldspato obtidos por Microssonda Eletrônica. 


\begin{tabular}{|c|c|c|c|c|c|c|c|c|c|c|c|c|}
\hline $\begin{array}{l}\text { Amostra } \\
\text { Análise }\end{array}$ & $\begin{array}{c}\text { PB-5A } \\
\text { p2-10-11 } \\
\text { Nucies }\end{array}$ & $\begin{array}{l}\text { Desvio } \\
\text { Padrä́o }\end{array}$ & $\begin{array}{c}\text { PB-5A } \\
\text { p2-15-16 } \\
\text { Nuclec }\end{array}$ & $\begin{array}{l}\text { Desvio } \\
\text { Padräo }\end{array}$ & $\begin{array}{l}\text { PB-5A } \\
\text { p2-2-3 } \\
\text { Brida }\end{array}$ & $\begin{array}{l}\text { Desvio } \\
\text { Padrào }\end{array}$ & $\begin{array}{c}\text { PB-5A } \\
\text { p2-21-22-23 } \\
\text { Eorda } \\
s\end{array}$ & $\begin{array}{l}\text { Desvio } \\
\text { Padräo }\end{array}$ & $\begin{array}{c}\text { PB-5A } \\
\text { p2-24-25 } \\
\text { Nuceo }\end{array}$ & $\begin{array}{l}\text { Desvio } \\
\text { Padrä́c }\end{array}$ & $\begin{array}{l}\text { PB-5A } \\
\text { p2-5-6 } \\
\text { 3orce }\end{array}$ & $\begin{array}{l}\text { Desvio } \\
\text { Padrä́o }\end{array}$ \\
\hline SHO2 & 61.35 & CB1 & 61.54 & 0.10 & 62.72 & 0.85 & 6308 & 037 & 53.94 & 044 & 82.92 & 0.29 \\
\hline $\mathrm{Al} / 2 \mathrm{O}_{3}$ & 18.75 & 0.12 & 19.76 & 0.09 & 19.55 & C. 67 & 18 39 & 0.53 & 19.44 & 0.39 & 19.36 & 0.26 \\
\hline $\mathrm{Fe} 2 \mathrm{O}_{3}$ & 0.09 & 0.12 & 0.08 & 0.01 & 0.11 & 0.02 & 0.11 & 0.04 & 0.07 & 0.05 & 0.13 & 0.01 \\
\hline $\mathrm{CaO}$ & 0.15 & 0.04 & 0.24 & 0.26 & 0.05 & 0.07 & 0.05 & 004 & 0.18 & 0.16 & 0.08 & 0.04 \\
\hline SrO & 0.69 & 0.29 & 0.63 & 0.21 & 0.55 & 0.12 & 0.71 & 0.15 & $0.4 \subseteq$ & 0.03 & 0.63 & 0.00 \\
\hline $\mathrm{BaO}$ & 348 & 039 & 3.38 & C.28 & 1.19 & C.05 & 1.25 & 041 & 1.12 & Q 15 & 1.51 & 0.45 \\
\hline $\mathrm{Na} 20$ & 324 & 0.51 & 3.13 & 6.39 & 2.33 & 6.02 & 2.14 & $05^{1}$ & $3 . \%$ & 1.20 & 2.63 & 0.07 \\
\hline 120 & 10.62 & 0.40 & 10.57 & 0.57 & 12.43 & 0.23 & 1320 & 0.56 & 11.03 & 205 & 12.53 & 0.09 \\
\hline Total & $9 \notin .40$ & & 99.32 & & 99.59 & & 10007 & & 100.05 & & 99.39 & \\
\hline $\mathrm{Si}$ & 11.574 & & 11.596 & & 11.377 & & 11728 & & 11.762 & & 11.715 & \\
\hline Al & 4.385 & & $4.38 \mathrm{~s}$ & & 4308 & & 4.246 & & 4211 & & 4.245 & \\
\hline Fa3 & 0.010 & & 0.010 & & 0020 & & c.020 & & 2010 & & 0.020 & \\
\hline $\mathrm{Ba}$ & 0.257 & & 0.250 & & 0.087 & & 0.093 & & 0.081 & & 0.710 & \\
\hline $\mathrm{Ca}$ & 0.030 & & 0.048 & & 0.012 & & 0.015 & & 0.036 & & 0.016 & \\
\hline $\mathrm{Na}$ & 1.185 & & 1.144 & & $10<0$ & & 0.771 & & 1350 & & 0.949 & \\
\hline$K$ & 2.655 & & 2.541 & & 2.952 & & 3.150 & & 2.588 & & 3.000 & \\
\hline $\mathrm{Sr}$ & 0.080 & & 0.080 & & 0050 & & c. 080 & & 20.50 & & a.tc & \\
\hline Soma $\mathbf{T}$ & 75.979 & & 75.989 & & 15.005 & & 15.994 & & $75 . \subseteq 83$ & & 15.980 & \\
\hline Soma M & 4.035 & & 3.983 & & 4111 & & 4.049 & & 4.065 & & 4.095 & \\
\hline Albila(Ab) & 31.43 & & 30.60 & & 25.50 & & $1 \mathrm{e} 60$ & & 34.00 & & 23.9C & \\
\hline Anortita (An) & 060 & & 1.30 & & 0.30 & & 0.40 & & 0.80 & & 0.40 & \\
\hline Ortoclásio (Or) & 67.80 & & $\varpi .10$ & & 73.70 & & 8000 & & 55.10 & & 75.70 & \\
\hline
\end{tabular}

Fórmula Estrutural com base em 32 oxigênios.

Análises Quimicas WDS de cristais de Feldspato obtidos por Microssonda Eletrônica. 


\begin{tabular}{|c|c|c|c|c|c|c|c|c|c|c|c|c|}
\hline $\begin{array}{l}\text { Am ostra } \\
\text { Análise }\end{array}$ & $\begin{array}{l}\text { PB-5A } \\
\text { p4-8-9-1 } \\
\text { Nucles }\end{array}$ & $\begin{array}{l}\text { Desvio } \\
\text { Padrắo }\end{array}$ & $\begin{array}{c}\text { PB-8D } \\
\text { p1 }\end{array}$ & $\begin{array}{c}\text { PB-BD } \\
\text { p2 }\end{array}$ & $\begin{array}{c}\text { PB-8D } \\
\text { p3 }\end{array}$ & $\begin{array}{c}\text { PB-9D } \\
\text { p4 }\end{array}$ & $\begin{array}{c}\text { PB-BD } \\
\text { p5 }\end{array}$ & $\begin{array}{c}\text { PB-8D } \\
\text { p6 }\end{array}$ & $\begin{array}{c}\text { PB-92A } \\
\text { p18 }\end{array}$ & $\begin{array}{c}\text { PB-92A } \\
\text { p19 }\end{array}$ & $\begin{array}{c}\text { PB-92A } \\
\text { p20 }\end{array}$ & $\begin{array}{c}\text { PB-92A } \\
\text { p21 }\end{array}$ \\
\hline $8 \mathrm{siO2}$ & 61.42 & C 10 & 52.06 & 6604 & 64.43 & 54.71 & 6496 & 55.39 & 58.45 & 6. 62 & 54.52 & 64.55 \\
\hline $\mathrm{A} \mid 2 \mathrm{O} 3$ & $x .10$ & 029 & 19.42 & 1925 & 13.90 & 19.11 & 1607 & 19.05 & 19.58 & 147. & 19.32 & $8 . c 2$ \\
\hline $\mathrm{Fe} 2 \mathrm{O3}$ & 0.06 & 0.00 & 0.37 & 0.38 & 0.33 & 0.35 & 0.33 & 0.35 & 0.11 & 0.33 & 0.37 & 0.55 \\
\hline $\mathrm{C}_{2} \mathrm{O}$ & 0.04 & 0.02 & 0.00 & 0.04 & 0.07 & 0.00 & 0.00 & 0.00 & 0.12 & 0.01 & 0.00 & 0.00 \\
\hline $\mathrm{SrO}$ & 0.79 & 0.20 & 0.56 & 0.50 & 0.47 & 0.67 & 0.65 & 0.51 & 0.43 & 0.66 & 0.52 & 0.42 \\
\hline B 20 & 3.15 & 021 & 0.90 & 0.76 & 0.38 & 0.50 & 0.89 & 0.37 & 0.00 & 202 & 1.19 & 0.81 \\
\hline $\mathrm{Na} 2 \mathrm{O}$ & 216 & 006 & 3.10 & 5.14 & 2.34 & 3.26 & 3.61 & 345 & 10.47 & 2.59 & 2.41 & 2.92 \\
\hline K2O & 12.37 & C 08 & 11.ce & 8.01 & 11.11 & 10.60 & 1C. 03 & 13.37 & $0 . \mathrm{cs}$ & 1120 & 11.6? & 11.70 \\
\hline Total & 700.11 & & 100.47 & 100.12 & 99.12 & 99.60 & $9 \subseteq 57$ & 100.10 & 99.65 & ss 81 & 100.00 & $99 . c 1$ \\
\hline SI & 11.548 & & 11.855 & 11.921 & 11.390 & 11.882 & $11 \subseteq 02$ & 11.921 & 11.973 & 11.756 & 11.854 & 11.871 \\
\hline Al & 4.451 & & 4.167 & $4 . C 92$ & 4111 & 4.132 & 4.115 & 4.090 & 4.116 & 4.295 & $4.1 B C$ & 4.055 \\
\hline $\mathrm{Fe} 3$ & 0.010 & & $0.0 X_{0}$ & 0.053 & 0050 & 0.050 & c.050 & $0.2 \times 00$ & D.010 & c. Co & 0.050 & 0.080 \\
\hline Ba & 0.232 & & 0.064 & 0.054 & 0.554 & 0.065 & C. 064 & 0.062 & 0.000 & 0.147 & D. 036 & o.ces \\
\hline $\mathrm{Ca}$ & 0.008 & & 0.000 & 0.005 & 0.002 & 0.000 & 0.000 & 0.000 & 0.022 & 0.002 & 0.000 & 0.000 \\
\hline $\mathrm{Na}$ & 0.787 & & 1.085 & 1.799 & 1.053 & 1.161 & 1.283 & 1.220 & 3.551 & C.853 & $0.35 s$ & 1.041 \\
\hline K & 2.967 & & 2.571 & 1.845 & 2.618 & 2.483 & 2.344 & 2.412 & 0.020 & 2.645 & 2.735 & 2.743 \\
\hline Sr & 0.050 & & $0.06 \mathrm{C}$ & $0 . C 50$ & 0.050 & 0.070 & $C .070$ & 0.060 & 0.040 & 0.070 & $0.05 \mathrm{C}$ & 0.040 \\
\hline Soma $\mathbf{T}$ & $7 \in 009$ & & 76.072 & 16.063 & 15.050 & 16.064 & 16057 & 16.061 & $76.0 \leqslant 8$ & 16.101 & 10.004 & 76.046 \\
\hline Soma M & 4.004 & & 3.780 & 3.755 & 3.787 & 3.759 & 3.741 & 3.744 & 3.603 & 3.702 & 3.730 & 3.922 \\
\hline Albhta(Ab) & 20.90 & & 29.50 & 49.30 & 23.70 & 31.90 & 35.40 & 33.60 & 98.80 & 24.50 & 23.90 & 27.50 \\
\hline Anortita (An) & C 20 & & D.00 & c. 20 & 0.10 & $0.0 \mathrm{C}$ & 003 & $0 \mathrm{Do}$ & $0.6 \mathrm{C}$ & C 10 & 0.00 & 0.00 \\
\hline Ortoclásio [0ri $]$ & त.\&D & & 70.10 & 50.50 & 71.30 & $\$ .10$ & 64.60 & 53.40 & 0.60 & 75.50 & 75.10 & 72.50 \\
\hline
\end{tabular}

Fórmula Estrutural com base em 32 oxigênios.

Análises Químicas WDS de cristais de Feldspato obtidos por Microssonda Eletrônica. 


\begin{tabular}{|c|c|c|c|c|}
\hline $\begin{array}{l}\text { Amostra } \\
\text { Análise }\end{array}$ & $\begin{array}{c}\text { PB-92A } \\
\text { p22 }\end{array}$ & $\begin{array}{c}\text { PE-92A } \\
\text { p23 }\end{array}$ & $\begin{array}{l}\text { PB-92A } \\
\text { p24 }\end{array}$ & $\begin{array}{c}\text { PE-92A } \\
\text { p25 }\end{array}$ \\
\hline 5102 & 62.77 & 64.30 & 64.32 & 6445 \\
\hline $\mathrm{A} \mid 2 \mathrm{O}_{3}$ & $1 \mathrm{E} .69$ & 19. J5 & 19.14 & 1899 \\
\hline $\mathrm{Fc} 203$ & 0.8 & 043 & 0.16 & 0.88 \\
\hline $\mathrm{CaO}$ & c 00 & $\cos$ & 0.00 & c.co \\
\hline Sro & 0.56 & 0.47 & 0.62 & 0.56 \\
\hline B $x 0$ & 2.26 & 121 & 1.00 & 1.02 \\
\hline $\mathrm{Na} 2 \mathrm{O}$ & 256 & 2.77 & 2.07 & 2.68 \\
\hline K2O & 11.17 & 11.22 & 12.54 & 11.65 \\
\hline Total & 10041 & 99.47 & 90.85 & 9077 \\
\hline $\mathrm{Si}$ & 71754 & 11.867 & 17.860 & 11.877 \\
\hline Al & 4.274 & 4143 & $4.15 \subseteq$ & 4.119 \\
\hline $\mathrm{Fe}^{3}$ & 0.000 & 0.050 & 0.020 & 0.050 \\
\hline Ba & 0.163 & $0: 033$ & 0.072 & 0.0 .74 \\
\hline $\mathrm{Ca}$ & 0.000 & 002 & 0.000 & 0.003 \\
\hline $\mathrm{Na}$ & 0.815 & 0.997 & 0.741 & $0 . \leqslant 57$ \\
\hline $\mathrm{K}$ & 2.627 & 2.542 & 2.962 & 2.740 \\
\hline Sr & 0.060 & 0.050 & $0.07 \mathrm{C}$ & 0.669 \\
\hline Soma $T$ & 16078 & 16.770 & 15.047 & 16. C45 \\
\hline Soma M & 3.755 & 3.783 & 3.785 & 3.821 \\
\hline Albita(Ab) & 25.80 & 27.30 & 20.10 & 25.93 \\
\hline Anortita (An) & 0.00 & 0.10 & 0.00 & 0.00 \\
\hline Ortoclásio (Or) & 74.20 & 72.70 & 79.50 & 7410 \\
\hline
\end{tabular}

Fórmula Estrutural com base em 32 oxigênios.

Análises Quimicas WDS de cristais de Feldspato obtidos por Microssonda Eletrônica. 
Tabela 2: Análises WDS em cristais de piroxênio do Sienito Pedra Branca. 


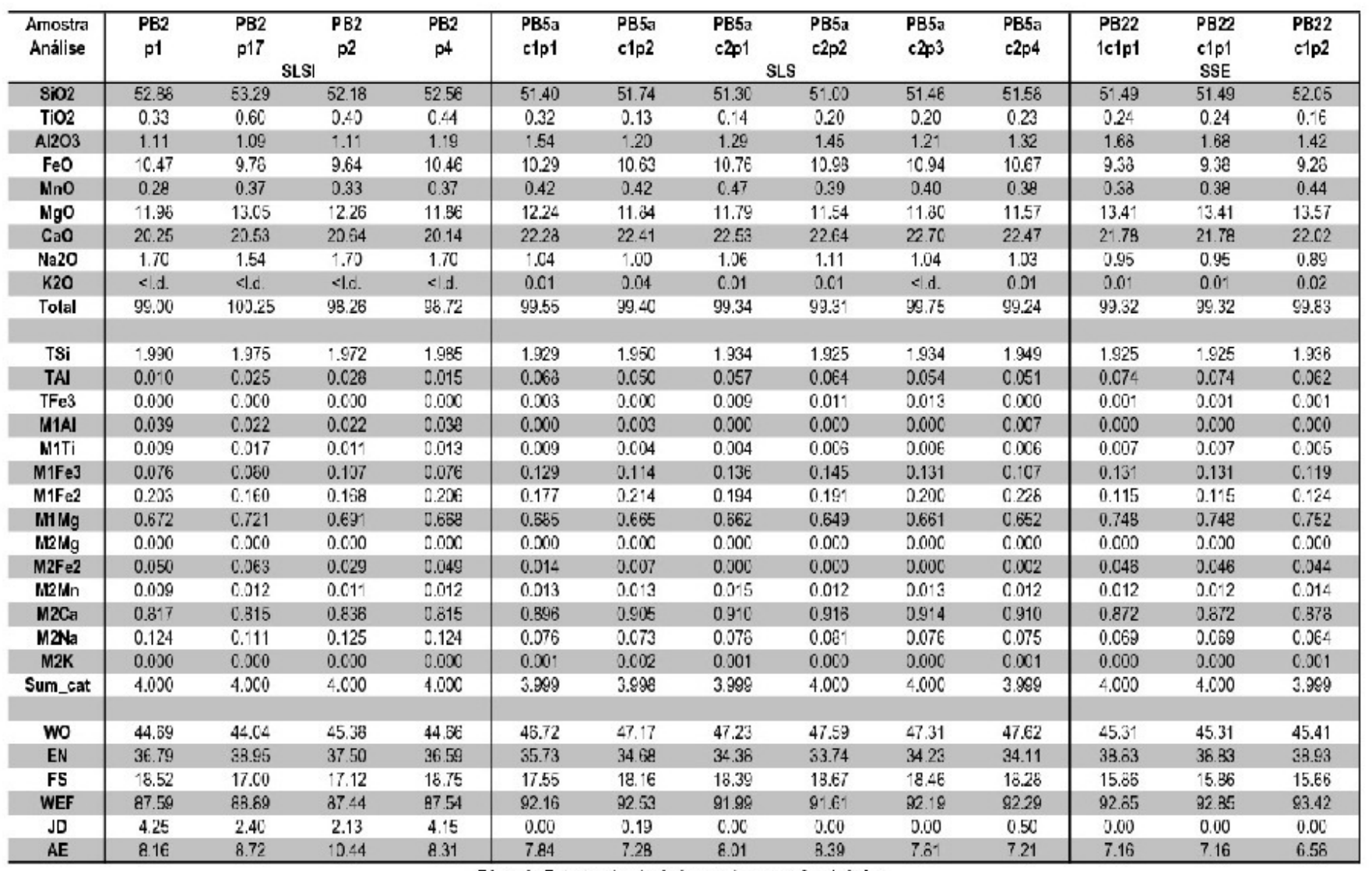

Fórmuka EsIrutural calcukada corn base ern 6 oxigênios. 


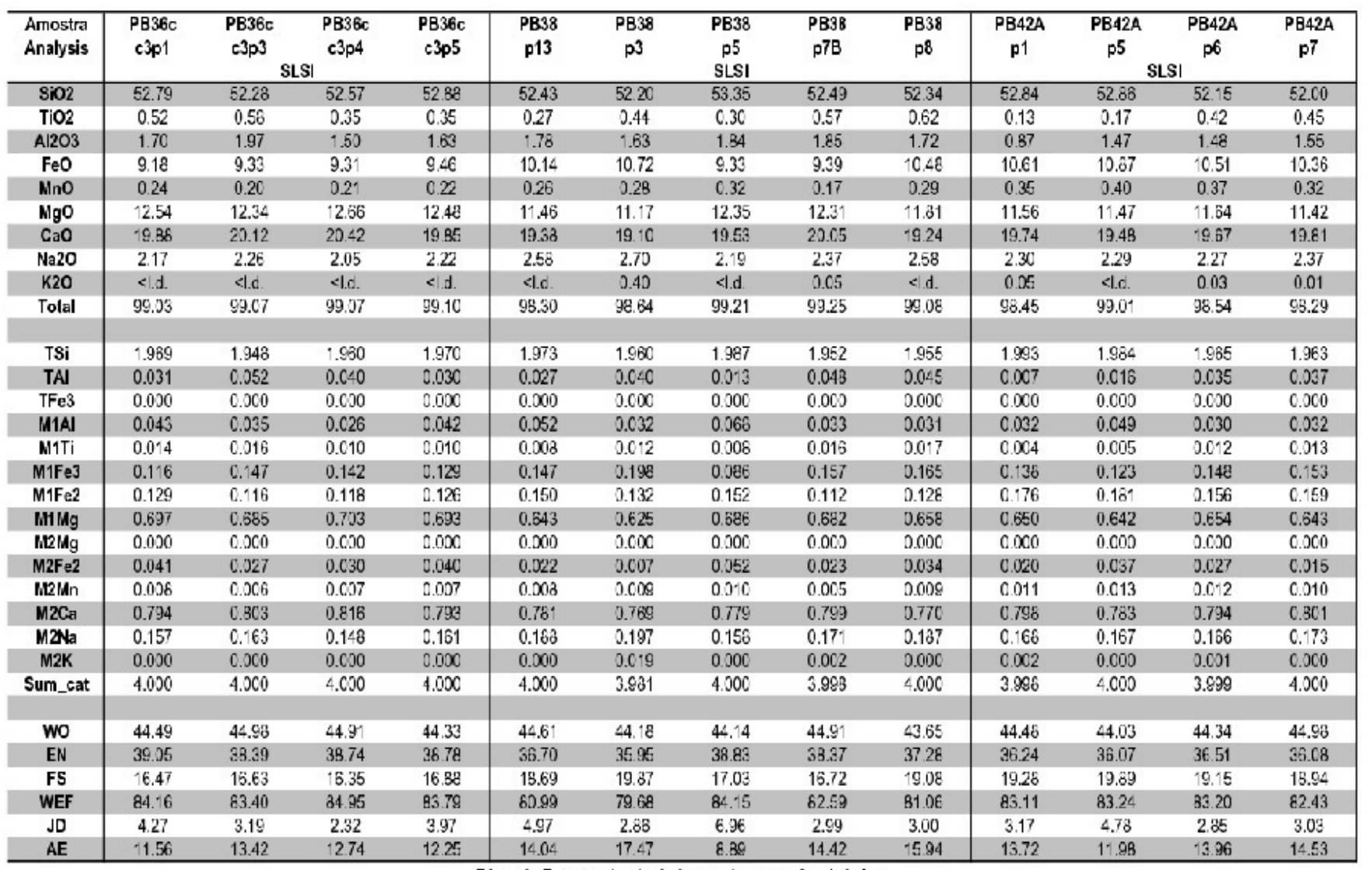

Fórmuka EsIrutural caleukada corn base ern 6 oxigênios. 


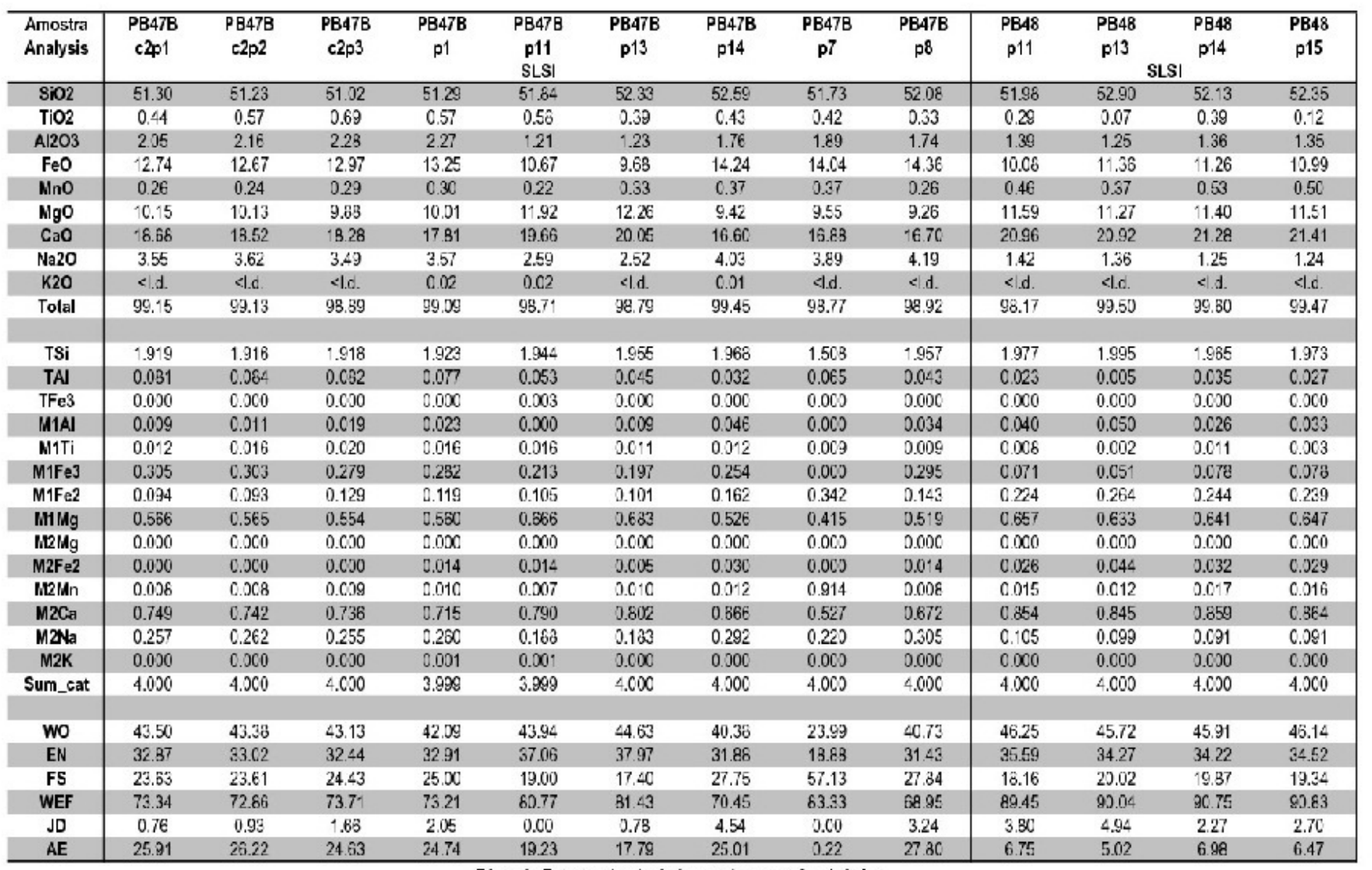

Fórmuka EsIrutural calcukada corn base ern 6 oxigênios. 


\begin{tabular}{|c|c|c|c|c|c|c|c|c|c|c|c|c|c|}
\hline $\begin{array}{l}\text { Amostra } \\
\text { Analysis }\end{array}$ & $\begin{array}{l}\text { PB48 } \\
\text { p20 }\end{array}$ & $\begin{array}{l}\text { PB48 } \\
\text { e2p3 }\end{array}$ & $\begin{array}{l}\text { PB48 } \\
\text { c2p4 } \\
\text { SLSI } \\
\end{array}$ & $\begin{array}{l}\text { PB48 } \\
\text { c2p5 }\end{array}$ & $\begin{array}{l}\text { PB48 } \\
\text { c3p1 }\end{array}$ & $\begin{array}{l}\text { PB52A } \\
\text { p14 }\end{array}$ & $\begin{array}{c}\text { PB52A } \\
\text { p15 } \\
\text { SLSI }\end{array}$ & $\begin{array}{c}\text { PB52A } \\
\text { p3 }\end{array}$ & $\begin{array}{l}\text { PB59 } \\
\text { p1 }\end{array}$ & $\begin{array}{l}\text { PB59 } \\
\text { p10-1 }\end{array}$ & $\begin{array}{c}\text { PB59 } \\
\text { p2-10 } \\
\text { SS1 }\end{array}$ & $\begin{array}{l}\text { PB59 } \\
\text { p2.1 }\end{array}$ & $\begin{array}{l}\text { PB59 } \\
\text { p2.2 }\end{array}$ \\
\hline S102 & 52.29 & 52.46 & 52.51 & 52.97 & 51.67 & 52.24 & 52.78 & 52.33 & 52.05 & 50.73 & 51.73 & 51.93 & 52.01 \\
\hline $\mathrm{TiO} 2$ & 0.46 & 0.16 & 0.1 & 0.23 & 0.43 & 0.28 & 0.35 & 0.07 & 0.11 & 0.41 & 0.54 & 0.00 & 0.10 \\
\hline $\mathrm{Al} 2 \mathrm{O} 3$ & 1.49 & 1.38 & 1.20 & 1.06 & 1.49 & 1.19 & 1.36 & 1.19 & 0.90 & 2.24 & 2.38 & 0.68 & 0.93 \\
\hline FeO & 11.11 & 11.13 & 11.05 & 10.72 & 10.61 & 11.56 & 11.57 & 11.85 & 23.64 & 10.81 & 9.65 & 23.50 & 23.55 \\
\hline $\mathrm{MnO}$ & 0.47 & 0.47 & 0.43 & 0.45 & 0.38 & 0.42 & 0.50 & 0.53 & 0.66 & 0.36 & 0.29 & 0.78 & 0.74 \\
\hline $\mathrm{MgO}$ & 11.50 & 11.86 & 11.76 & 11.72 & 11.91 & 11.43 & 11.19 & 11.14 & 21.26 & 13.01 & 12.70 & 21.44 & 21.08 \\
\hline $\mathrm{Na2O}$ & 1.38 & 1.37 & 1.45 & 1.17 & 1.37 & 1.34 & 1.40 & 1.29 & 0.12 & $0 . \overline{2}$ & 0.67 & 0.02 & 0.02 \\
\hline $\mathrm{K} 2 \mathrm{O}$ & $<. d$. & <.d. & 0.02 & $<d$. & 0.01 & eld. & <l.d & ad. & <.d. & $<d$ & <.c. & $<d$. & s.d. \\
\hline Tolal & 99.89 & 99.33 & 99.46 & 99.16 & 98.43 & 99.09 & 99.60 & 99.13 & 99.36 & 98.17 & 99.11 & 99.52 & 99.69 \\
\hline TSi & 1.965 & 1.976 & 1.974 & 2.003 & $1.96^{\circ}$ & 1.978 & 1.991 & 1.983 & 1.962 & 1.932 & 1.950 & 1.964 & 1.969 \\
\hline TAI & 0.035 & 0.024 & 0.026 & 0.000 & 0.039 & 0.022 & 0.008 & 0.014 & 0.038 & 0.068 & 0.050 & 0.030 & 0.031 \\
\hline TFe3 & 0.000 & 0.000 & 0.000 & 0.000 & 0.000 & 0.000 & 0.000 & 0.000 & 0.000 & 0.000 & 0.000 & 0.006 & 0.000 \\
\hline M1AI & 0.031 & 0.037 & 0.027 & 0.047 & 0.027 & 0.032 & 0.051 & 0.039 & 0.002 & 0.032 & 0.056 & 0.050 & C. .10 \\
\hline M1Ti & 0.013 & 0.005 & 0.003 & 0.007 & 0.012 & 0.008 & 0.010 & 0.002 & 0.003 & 0.012 & 0.015 & 0.000 & 0.003 \\
\hline $\mathrm{M} 1 \mathrm{Fe} 2$ & 0.229 & 0.215 & 0.212 & 0.266 & 0.198 & 0.243 & 0.269 & 0.264 & 0.000 & 0.159 & 0.203 & 0.0 .00 & C. .000 \\
\hline MilMg & 0.649 & C.566 & 0.659 & 0.680 & 0.574 & 0.645 & 0.529 & 0.632 & 0.957 & 0.739 & 0.714 & 0.963 & 0.970 \\
\hline $\mathrm{M} 2 \mathrm{Mg}$ & 0.0 .00 & C..$C_{0}$ & 0.050 & 0.000 & 0.000 & $9 . C O C$ & 0.000 & 0.000 & 0.238 & 0.000 & 0.000 & 0.246 & C. 219 \\
\hline M2Fe2 & 0.042 & 0.058 & 0.037 & 0.053 & 0.050 & 0.051 & 0.055 & 0.045 & 0.707 & 0.127 & 0.098 & 0.730 & 0.729 \\
\hline $\mathrm{M} 2 \mathrm{Mn}$ & 0.015 & C. .015 & 0.015 & 0.014 & 0.012 & 0.013 & 0.016 & 0.017 & 0.021 & 0.012 & 0.009 & 0.625 & 0.024 \\
\hline M2Ca & 0.842 & C. 328 & 0.841 & 0.844 & 0.837 & 0.837 & 0.526 & 0.843 & 0.025 & 0.815 & 0.846 & 0.027 & 0.027 \\
\hline M2Na & 0.101 & C. $1 \mathrm{CO}$ & 0.156 & 0.086 & 0.101 & 0.098 & 0.102 & 0.085 & 0.008 & 0.047 & 0.049 & 0.001 & 0.001 \\
\hline M2K & 0.000 & 0.000 & $0.00^{1}$ & 0.000 & 0.000 & 0.000 & 0.000 & 0.000 & 0.000 & 0.000 & 0.000 & 0.000 & 0.000 \\
\hline Sum_cat & 4.000 & $4 . x 0$ & 3.999 & 4.000 & 4.000 & 4.000 & 4.000 & 4.000 & 4.000 & 4.000 & 4.000 & 4.000 & 4.000 \\
\hline wo & 45.39 & 44.53 & 45.16 & 45.44 & 45.01 & 44.96 & 45.00 & 45.24 & 1.26 & 42.69 & 45.02 & 1.36 & 1.35 \\
\hline EN & 34.96 & 85.82 & 35.37 & 35.55 & 36.23 & 3466 & $34.2 E$ & 33.73 & $E D: A$ & 36.66 & 37.97 & $6 C .31$ & 59.91 \\
\hline FS & 19.53 & 19.65 & 19.47 & 19.01 & 18.76 & 20.39 & 20.74 & 20.93 & 38.59 & 18.64 & 17.01 & 38.33 & 35.74 \\
\hline WEF & $8 Q .3 \hat{3}$ & 89.81 & 29.31 & 81.46 & 69.76 & 90.08 & 89.77 & $9.46 \hat{~}$ & $\$ 8.11$ & 95.21 & 95.02 & 99.35 & $\$ 9.85$ \\
\hline$J D$ & 2.92 & 3.22 & 2.32 & 6.01 & 2.41 & 3.01 & 5.71 & 3.56 & 0.05 & 1.89 & 4.11 & 0.00 & 0.06 \\
\hline $\mathbf{A E}$ & 7.24 & 6.87 & B.33 & 2.52 & 7.83 & 6.90 & $4.5 \hat{2}$ & 5.88 & 0.65 & 3.09 & 0.68 & 0.15 & 0.08 \\
\hline
\end{tabular}

Fórmuka Esırutural calcukada corn base ern 6 oxigênios. 


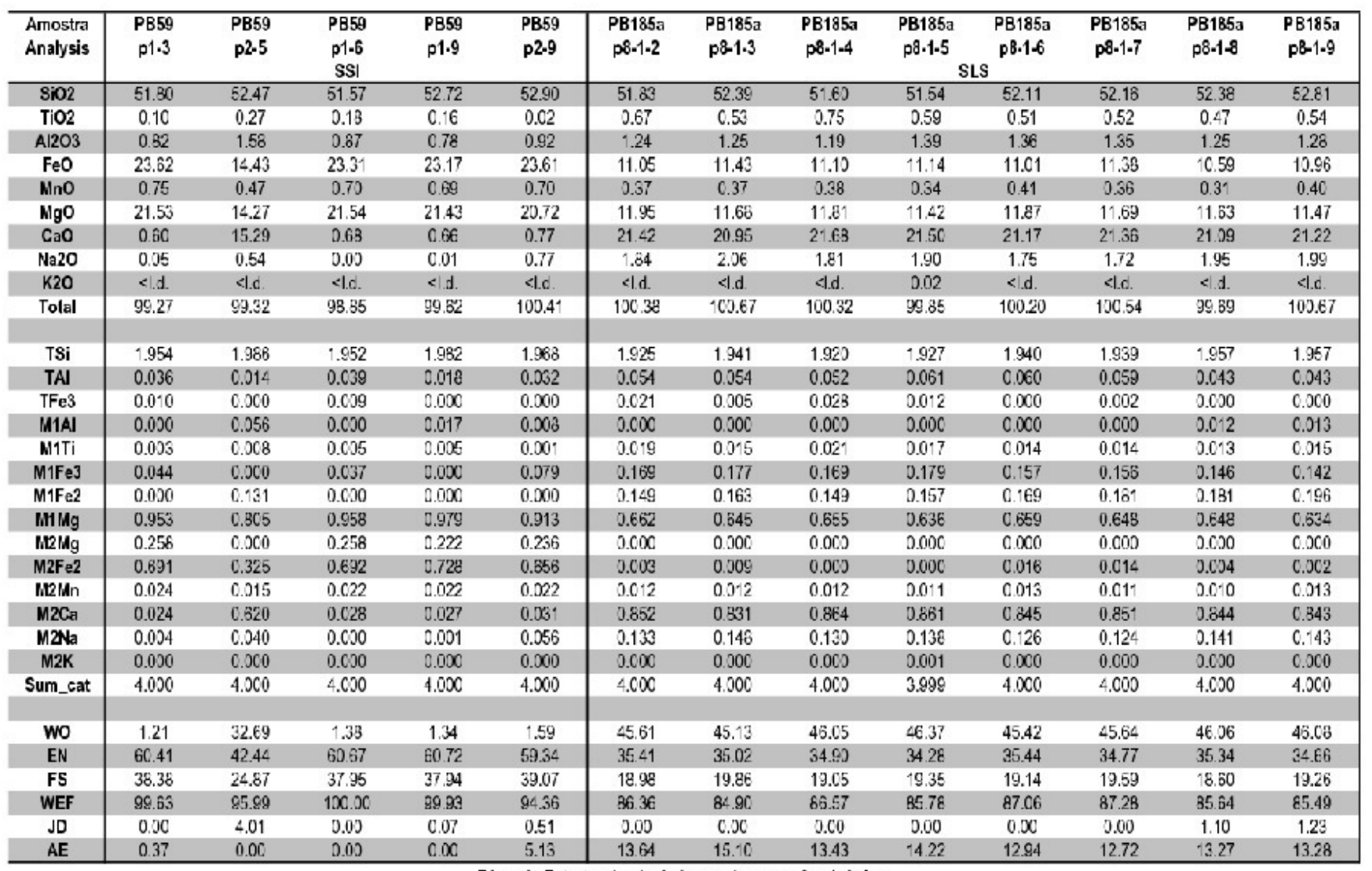

Fórmuka Esırutural calcukada corn base ern 6 oxigênios. 


\begin{tabular}{|c|c|c|c|c|c|c|c|c|c|c|c|c|c|}
\hline \multirow[t]{2}{*}{$\begin{array}{l}\text { Amostra } \\
\text { Analysis }\end{array}$} & $\begin{array}{l}\text { PB185d } \\
\text { p1.1-1 }\end{array}$ & $\begin{array}{l}\text { PB185d } \\
\text { p1-1.2 }\end{array}$ & $\begin{array}{l}\text { PB185d } \\
\text { p1-1-3 }\end{array}$ & $\begin{array}{l}\text { PB185d } \\
\text { p1-14 }\end{array}$ & $\begin{array}{l}\text { PB185d } \\
\text { p1-1.5 }\end{array}$ & $\begin{array}{l}\text { PB185d } \\
\text { p1-1-6 }\end{array}$ & $\begin{array}{l}\text { PB185d } \\
\text { p1.1.7 }\end{array}$ & $\begin{array}{l}\text { PB185d } \\
\text { p1-1-8 }\end{array}$ & $\begin{array}{c}\text { PB185d } \\
\text { p5.1-1 }\end{array}$ & $\begin{array}{l}\text { PB185d } \\
\text { p5:14 }\end{array}$ & $\begin{array}{l}\text { PB185d } \\
\text { p5-1.5 }\end{array}$ & $\begin{array}{l}\text { PB185d } \\
\text { p5-1-6 }\end{array}$ & $\begin{array}{l}\text { PB185d } \\
\text { p5-1-8 }\end{array}$ \\
\hline & & \multicolumn{12}{|c|}{ Enclave Ultramáfico } \\
\hline S102 & 52.05 & 51.67 & 52.25 & 51.90 & 52.00 & 52.06 & 52.14 & 52.04 & 51.94 & 51.39 & 51.27 & 51.69 & 52.01 \\
\hline $\mathrm{TiO} 2$ & 0.65 & 0.47 & 0.53 & 0.65 & 0.64 & 0.54 & 0.57 & 0.46 & 0.56 & 0.45 & 0.52 & 0.30 & 0.35 \\
\hline $\mathrm{Al} 2 \mathrm{O} 3$ & 0.91 & 1.22 & 1.12 & 1.09 & 1.16 & 1.25 & 1.22 & 1.34 & 1.25 & 1.27 & 1.25 & 1.25 & 1.30 \\
\hline $\mathrm{FeO}$ & 10.99 & 10.63 & 11.10 & 10.58 & 10.17 & 10.51 & 10.86 & 11.14 & 10.73 & 10.91 & 11.40 & 10.37 & 11.77 \\
\hline $\mathrm{MnO}$ & 0.36 & 0.32 & 0.32 & 0.42 & 0.32 & 0.27 & 0.30 & 0.29 & 0.39 & 0.31 & 0.33 & 0.38 & 0.35 \\
\hline MgO & 11.39 & 12.11 & 11.94 & 12.01 & 12.26 & 1122 & 11.50 & 11.02 & 11.92 & 11.60 & 11.57 & 11.32 & 11.24 \\
\hline $\mathrm{Na2O}$ & 1.78 & 1.82 & 1.67 & 1.70 & 1.70 & 1.84 & 2.05 & 2.16 & 1.72 & 2.11 & 2.19 & 2.08 & 2.33 \\
\hline $\mathrm{K} 2 \mathrm{O}$ & 0.02 & el.c. & <.o. & ed. & <L. & eld. & l.d. & 0.01 & $0.0^{-1}$ & $<d$ & <ا.c. & $<d$. & <l.c. \\
\hline Tolal & 100.01 & 99.91 & 100.14 & 99.23 & 100.04 & 99.28 & 100.01 & 99.23 & 100.13 & 98.78 & 99.29 & 99.52 & 99.76 \\
\hline TSi & 1.942 & 1.925 & 1.949 & 1.943 & 1.964 & 1.941 & 1.942 & 1.956 & 1.934 & 1.935 & 1.922 & 1.944 & 1.943 \\
\hline TAI & 0.040 & 0.054 & 0.049 & 0.048 & 0.051 & 0.055 & 0.054 & 0.044 & 0.055 & 0.056 & 0.055 & 0.655 & 0.057 \\
\hline TFe3 & $0.0^{\prime} 8$ & 0.021 & 0.002 & 0.000 & 0.015 & 0.005 & 0.004 & 0.000 & 0.011 & 0.008 & 0.023 & 0.001 & 0.000 \\
\hline IM1AI & 0.000 & 0.000 & 0.050 & 0.000 & 0.000 & 0.000 & 0.000 & 0.015 & 0.000 & 0.000 & 0.000 & 0.050 & $C . x 0$ \\
\hline M1Ti & $0.0^{\prime} 18$ & 0.013 & 0.016 & 0.018 & 0.013 & 0.015 & $0.0^{\prime} 6$ & 0.014 & $0.0^{\circ} \mathrm{E}$ & 0.013 & 0.015 & 0.009 & 0.010 \\
\hline M1Fe2 & 0.169 & 0.134 & $0.13^{\prime}$ & 0.168 & 0.149 & 0.161 & 0.160 & 0.190 & 0.164 & 0.143 & 0.127 & 0.151 & 0.158 \\
\hline $\mathrm{MH} M \mathrm{gg}$ & 0.651 & 0.573 & 0.654 & 0.670 & $0.2 \infty 0$ & 0.660 & 0.543 & 0.613 & 0.662 & 0.651 & 0.647 & 0.638 & 0.526 \\
\hline ML Mg & 0.000 & $0.0 C 0$ & 0.000 & 0.000 & 0.000 & 0.000 & 0.500 & 0.000 & 0.000 & 0.000 & 0.000 & 0.000 & $C . D C 0$ \\
\hline M2Fe2 & $0.0 J 5$ & 0.002 & 0.024 & 0.010 & 0.000 & 0.000 & 0.500 & 0.000 & 0.001 & 0.000 & 0.000 & 0.000 & 0.003 \\
\hline $\mathbf{M} / \mathrm{Mn}$ & $0.0+1$ & C. .010 & 0.010 & 0.013 & 0.010 & $0.00 \theta$ & $0.0^{2} 0$ & 0.009 & 0.012 & 0.010 & 0.010 & 0.012 & C.011 \\
\hline MZCa & 0.854 & 0.357 & 0.845 & 0.853 & 0.868 & 0.860 & 0.350 & 0.887 & 0.862 & 0.237 & 0.834 & 0.849 & 0.317 \\
\hline M2Na & 0.129 & 0.131 & 0.12 & 0.123 & 0.122 & 0.133 & 0.146 & 0.157 & 0.124 & 0.154 & 0.159 & 0.152 & 0.169 \\
\hline M2K & 0.001 & 0.000 & 0.000 & 0.000 & 0.000 & 0.000 & 0.000 & 0.000 & 0.000 & 0.000 & 0.000 & 0.000 & 0.000 \\
\hline Sum_cat & 3.999 & $4 . x 0$ & 4.000 & 4.000 & 4.000 & 4.000 & 4.000 & 4.000 & 4.000 & 4.000 & 4.000 & 4.000 & 4.000 \\
\hline wo & 45.69 & 45.64 & 45.32 & 45.69 & 46.31 & 46.31 & 46.17 & 45.13 & 46.11 & 45.46 & 45.13 & 46.12 & $4 \div .86$ \\
\hline EN & 35.37 & 35.84 & 35.59 & 35.87 & 36.27 & 35.57 & 34.98 & 34.66 & 35.37 & 35.36 & 34.98 & 34.65 & 34.36 \\
\hline FS & 18.95 & 15.52 & 19.10 & 18.45 & 17.42 & 18.12 & 18.90 & 19.81 & 18.52 & 19.18 & 19.89 & 19.23 & 20.79 \\
\hline WEF & 86.32 & 86.44 & 27.73 & 87.45 & 67.46 & 86.37 & 84.86 & 64.00 & B7.23 & 84.22 & 83.58 & 34.47 & 82.72 \\
\hline$J D$ & 0.00 & 0.00 & 0.00 & 0.00 & 0.00 & 0.00 & $0 . x$ & 1.37 & 0.00 & 0.00 & 0.00 & 0.00 & 0.00 \\
\hline $\mathbf{A E}$ & 13.16 & 13.56 & 12.27 & 12.55 & 12.54 & 13.63 & 15.12 & 14.63 & 12.77 & 15.76 & 16.42 & 15.53 & 17.28 \\
\hline
\end{tabular}

Fórmuka EsIrutural calcukada corn base ern 6 oxigênios. 
Tabela 3: Análises WDS em cristais de anfibólio do Sienito Pedra Branca. 


\begin{tabular}{|c|c|c|c|c|c|c|c|c|c|c|c|c|}
\hline $\begin{array}{l}\text { Amogtre } \\
\text { Anślke }\end{array}$ & $\begin{array}{l}\text { PBSA } \\
\text { C2P1 }\end{array}$ & $\begin{array}{l}\mathrm{PBSA} \\
\mathrm{C} 2 \mathrm{P} 2\end{array}$ & $\begin{array}{l}\text { PBSA } \\
\text { C2PA }\end{array}$ & $\begin{array}{l}\text { PBSA } \\
\text { C2P4 }\end{array}$ & $\begin{array}{l}\text { PBSA } \\
\text { CaP1 }\end{array}$ & $\begin{array}{l}\text { PESA } \\
\text { CaP4 }\end{array}$ & $\begin{array}{l}\text { PBSA } \\
\text { C3PS }\end{array}$ & $\begin{array}{l}\text { PBSA } \\
\text { CAPG }\end{array}$ & $\begin{array}{l}\text { PBSA } \\
\text { PA-1 }\end{array}$ & $\begin{array}{l}\text { PBSAA } \\
\text { PA-2 }\end{array}$ & $\begin{array}{l}\text { PE5A-A } \\
\text { PA:-3 }\end{array}$ & $\begin{array}{l}\text { PBSA } \\
\text { PA-4 }\end{array}$ \\
\hline$S 102$ & 4404 & 44.33 & $43.5 \%$ & 44 & $\angle<14$ & 4442 & 4325 & $4<27$ & $4 \sqrt{5} L_{i}$ & $\angle 5 . x$ & 45.17 & 4563 \\
\hline $\mathrm{THO}$ & 1.13 &..$t e$ & $1 . " \ddot{8}$ & 3.58 & J 35 & 1.8 & 111 & 1.21 & 1.53 & $1 / 2$ & .23 & 1.22 \\
\hline $\mathrm{Al} 203$ & 6.58 & 0.45 & $8: " 3$ & 0.28 & 357 & $7 . x$ & 771 & $7 . \pi$ & 793 & 763 & B.J & $B .01$ \\
\hline $\mathrm{F}_{\nexists \mathrm{O}}$ & 15.73 & $\Rightarrow 9$ & 14.57 & 14.76 & " & 15.10 & 5.16 & 5.43 & 14.65 & 1.45 & $1 \ldots 7$ & 14.75 \\
\hline Mno & (.25 & 0.35 & $02 E$ & $=.24$ & $33 \mathrm{C}$ & 0.31 & $=30$ & 0.25 & C 23 & 025 & 0.31 & 0.30 \\
\hline $\mathrm{Mg} \mathrm{O}$ & 12.65 & .256 & $12.5 \subseteq$ & 12." & -279 & 12.50 & 2.54 & 2.60 & $13<3$ & 13.2 & $13.1 \varepsilon$ & 13.01 \\
\hline $\mathrm{CaO}$ & 11.20 & $\therefore 73$ & $13.4 \mathrm{C}$ & 12.3 & $-3=3$ & 13.35 & 289 & 3.02 & 11.22 & $11.5^{\circ}$ & $1.5 ?$ & 1124 \\
\hline $\ln 20$ & 200 & 20.6 & 205 & 13 & $x$ & $2 x$ & 210 & $2 \pi 7$ & 200 & 211 & $21 ?$ & 209 \\
\hline$\kappa 20$ & 1.33 & 48 & $1<4$ & 1.20 & $\leq 2$ & 1.32 & 132 & 138 & $14 \hat{\imath}$ & 167 & 31 & 147 \\
\hline F & ᄃ. $\tilde{\hat{\sigma}}$ & $0.8 ?$ & $06 \mathrm{~A}$ & $\therefore 34$ & 284 & $0 \approx x$ & $\therefore 88$ & $1 \% 2$ & C. $5 \hat{\hat{\imath}}$ & $0 \mathrm{f8}$ & 0.14 & $08 \hat{5}$ \\
\hline CI & 6.17 & 0.13 & 0.5 & 2.21 & 218 & 0.5 & $\because 15$ & 0.18 & COI & 017 & 0.15 & $0.1^{\circ}$ \\
\hline Tofal & 88.33 & $97 \times 3$ & $80 . \pi$ & 98.0 & $95=9$ & $98.8^{\prime}$ & 483 & \$o. 22 & 8865 & 16.16 & 97.67 & 5857 \\
\hline $\mathrm{O}=\mathrm{F}, \mathrm{C}$ & 6.27 & 0.32 & $0 . x_{\bar{c}}$ & $=.19$ & $2 j 6$ & 0.30 & 240 & $0.4 ?$ & $(23)$ & $0: 3$ & $0.5 \Xi$ & 0.39 \\
\hline Tolal & $\Xi 8.06$ & 9755 & $9 \pi .38$ & $97.8^{\circ}$ & 9530 & 98.56 & 37.93 & 98.75 & $58<2$ & 36.13 & 97.58 & $\$ 8.5$ \\
\hline TSI & $\approx 558$ & $6 \div 53$ & 6634 & 6. 538 & 6.648 & 6696 & กิFES & 6.775 & $6 \cdot \overline{7}: R$ & 672 & 6703 & f.73L \\
\hline TAl & 1442 & 347 & 1.3ล̂. & 1.362 & $3=2$ & $13 \div$ & 342 & 325 & 1.322 & 1279 & 1.217 & 1265 \\
\hline TFe.3 & $\therefore 000$ & 0.70 & now & $\pi \cdot 00$ & $\operatorname{anc} 0$ & Don & 3000 & 0.000 & $\cos a$ & 3000 & $0 . x$ & $\therefore 003$ \\
\hline TII & $\approx \infty 0$ & 0.000 & $0.0 \mathrm{Jt}$ & $0.0 \%$ & 0.000 & 0.000 & 3000 & 0.100 & c.001 & 3000 & $0.2 x^{\circ}$ & Couj \\
\hline Scma T & $=\infty 0$ & 8.000 & $80 \pi$ & 0.000 & 8.000 & 8.000 & 3000 & $8 . \pi 0$ & 8.003 & 5000 & 8.20 & 8.000 \\
\hline CAl & $=060$ & 0.146 & 0.035 & 0.100 & 0.123 & 0.041 & $300 i$ & 0.743 & $(.00)$ & $3 \mathrm{COO}$ & 0.12 & C.132 \\
\hline CFe3 & 252 & 0.700 & $0.00 x$ & $0.6^{\circ}$ & 0.050 & 0.000 & 3000 & 0.500 & C.50 & 3204 & 0.309 & (.423 \\
\hline $\mathrm{CTI}$ & (13) & 0.119 & D13F & n.6.65 & a 1.8 & D. 33 & 316 & 0.36 & C. 65 & 3159 & 0.37 & ᄃ. 135 \\
\hline$C M_{g}$ & 2828 & 2:10 & 2884 & 254 & 2.772 & 2833 & 289 & 2832 & 295.1 & $2 \mathrm{f} 2 \mathrm{~s}$ & 2.216 & 2899 \\
\hline CFe 2 & 1445 & $=71$ & 1.859 & 1.797 & BEI & 1940 & .105 & 345 & 1243 & 149 & 1412 & 140.3 \\
\hline ClMn & 2033 & 0.015 & $0.03 \mathrm{~s}$ & $0.0 \%$ & 0.038 & D.WW & 3000 & 0.315 & c. 035 & 303 & 0.358 & 6035 \\
\hline${ }^{C C_{3}}$ & $\because \infty$ & 0.000 & $0.03 t$ & 0.00 & 0.000 & 0.000 & 3000 & 0.100 & C.001 & 3000 & 0.20 & c.000 \\
\hline Soma C & 500 & 5.100 & $500 \mathrm{H}$ & 5.00 & 5.000 & 5.000 & 5000 & 5.100 & 5.001 & 5000 & 5.20 & 5000 \\
\hline BMg & $=000$ & 0.500 & $0.03 \mathrm{C}$ & 0.000 & $0.0=0$ & 0.000 & 3000 & 0.300 & $C .003$ & $3 c 00$ & $0.00 \mathrm{C}$ & $C .003$ \\
\hline $\mathrm{BFe2}$ & $=000$ & 0.200 & $0.03 x$ & 0.000 & $0.0=0$ & 0.000 & 3000 & 0.300 & $C .003$ & 3000 & 0.000 & $\mathrm{C}, 003$ \\
\hline$B M n$ & $\therefore 000$ & 0.00 & 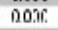 & 0.00 & 0000 & $00 \Omega$ & 3000 & 0.000 & cona & 3000 & 0.20 & i. 00.3 \\
\hline $\mathrm{BCa}$ & 1804 & $=87$ & $200 \%$ & 2500 & 2000 & $200 x$ & 2000 & 2300 & 1765 & 123 & 1933 & 1782 \\
\hline BNa & $\therefore 15$ & 0.113 & $003 \%$ & $0 . \alpha$ & 0.00 & 000 & 3000 & 0.000 & c.235 & .9108 & 0.67 & 0.25 \\
\hline Soma B & 200 & 2.000 & $20 \%$ & 2.00 & 2.000 & 20000 & 2000 & 2.100 & 2.001 & 2000 & 2.000 & 2000 \\
\hline$A C a$ & $=000$ & 0.500 & 0.198 & 0.146 & 0.153 & 0.72 & 3097 & 0.04 & $C .003$ & 9000 & $0.00 \mathrm{C}$ & $C 003$ \\
\hline ANa & $=45$ & 0.406 & $063 \mathrm{C}$ & $0.54<$ & $0.5 \overline{1} 1$ & 0.596 & 3617 & 0.544 & $c . x_{j}$ & 3440 & 0.426 & C.201 \\
\hline AK & 253 & 0.202 & $0.23 \mathrm{C}$ & 0.229 & 0.272 & $0255^{\circ}$ & 3250 & 0.266 & C.2iz & $529 i$ & 0.247 & $62 i 5$ \\
\hline Sorna A & 875 & 0.767 & $1.07 \%$ & $0 \leq x$ & $0.9=5$ & 0950 & 190 & 0.774 & $c .62^{\prime}$ & .7736 & 0.394 & C. ЕรA \\
\hline Soma Catisnica & 15.72 & $5 \pi$ & 16.79 & $1: 92$ & $5 \div 6$ & 15.25 & $\leq 97$ & $5 \leqslant 7$ & 1562 & 15.74 & $15.6 \mathrm{C}$ & 1565 \\
\hline
\end{tabular}

Fómula Estrutural calculada com base ern 23 oxigênios.

Análises Quimica WDS em Cristais de Anfibólio do Sienito Pedra Branca. 


\begin{tabular}{|c|c|c|c|c|c|c|c|c|c|c|c|c|}
\hline $\begin{array}{l}\text { Amogtre } \\
\text { Ansilke }\end{array}$ & $\begin{array}{l}\text { PBSA } \\
\text { PA-5 }\end{array}$ & $\begin{array}{l}\text { PBSA } \\
\text { PA- }\end{array}$ & $\begin{array}{l}\mathbf{P 3 3 0} \\
\mathbf{P 1} 1-1\end{array}$ & $\begin{array}{l}\mathrm{PBO0} \\
\mathrm{P} 1-11\end{array}$ & $\begin{array}{l}\text { PE30 } \\
\text { P1-12 }\end{array}$ & $\begin{array}{l}\mathrm{PB30} 0 \\
\mathbf{P 1 - 1 3}\end{array}$ & $\begin{array}{l}P_{\text {PB30 }} \\
P_{1-14}\end{array}$ & $\begin{array}{l}\text { PE30 } \\
\text { P1 } 1-2\end{array}$ & $\begin{array}{l}\text { PB30 } \\
\text { P1-3 }\end{array}$ & $\begin{array}{l}\text { PEO3 } \\
\text { P1-8 }\end{array}$ & 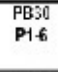 & $\begin{array}{l}\begin{array}{l}\mathrm{PB30} \\
\mathrm{P1-8}\end{array} \\
\end{array}$ \\
\hline 8102 & 4543 & 4573 & 54.77 & $56.0^{\prime}$ & $5<: \hat{\kappa}$ & 5445 & 5466 & $5<14$ & $648 \mathrm{~L}$ & $5<25$ & 55012 & 6409 \\
\hline $\mathrm{THO} 2$ & 1.45 & .87 & 0.07 & 3.06 & 324 & 0.0 & $\because 00$ & 0.26 & C.1. & 017 & 0.11 & 0.17 \\
\hline $\mathrm{Al} 203$ & 7.70 & $7.6 E$ & $1 \mathrm{~J}$ & 1.18 & $\cdot 51$ & 1.30 & 153 & 1.81 & 13 & 163 & $\because 1$ & 1.77 \\
\hline $\mathrm{F}_{\ominus} \mathrm{O}$ & 1398 & $\because 18$ & 756 & 0.00 & 77 & 7.21 & $\because 04$ & 8.54 & 7.77 & 619 & 7.05 & B.32 \\
\hline Mno & $C .3$ & 0.31 & 024 & 2.22 & 022 & 0.7 & $=23$ & 0.21 & C 22 & 019 & 0.22 & 0.25 \\
\hline $\mathrm{Mg} \mathrm{O}$ & 13.35 & .335 & 19.25 & 15.06 & $-5 \equiv 5$ & 18.37 & - $\subseteq .16$ & 8.56 & 1933 & 19.22 & 13.05 & 18.63 \\
\hline $\mathrm{CaO}$ & 11.40 & $\cdots 36$ & $1.3 E$ & $1 C .98$ & $-9 \Xi 8$ & 11.56 & $-10^{\prime}$ & 0.52 & 11.32 & 11.39 & 1.17 & 10.95 \\
\hline $\operatorname{Nin} 20$ & 215 & 28.6 & $1<?$ & 153 & $B 7$ & 159 & 174 & $1 \mathrm{A3}$ & 175 & 167 & 6? & 19 \\
\hline $\mathrm{k} 20$ & 1.37 & 0.14 & $0.3:$ & $\therefore 47$ & $\partial \leq f$ & 0.38 & $\therefore 46$ & 0.47 & c. 3? & 047 & $0<:$ & D. $5^{\prime}$ \\
\hline F & 105 & 12 & 084 & $\therefore 58$ & $2 \pi$ & 0.58 & $\therefore 96$ & $0 \cong 6$ & i.65 & 026 & $0 ? 3$ & 122 \\
\hline $\mathrm{Cl}$ & 6.13 & 0.68 & 0.05 & 3.04 & J 39 & 0.20 & 301 & $0 . \ldots \mathrm{s}$ & $60^{\circ}$ & $0 \div 1$ & 0.31 & 0.02 \\
\hline Tolal & 88.11 & 9785 & $9: 7$ & 97.7 & 9738 & 9.51 & 9793 & 98.26 & $87.8^{\circ}$ & 37.41 & 97,68 & 5782 \\
\hline $0=F, C$ & $C A i$ & $0.4 \subseteq$ & $0.3:$ & 2.25 & 032 & 0.25 & $=41$ & 0.41 & (2) & 011 & $0<1$ & 0.52 \\
\hline Todal & $\$ 7.97$ & 9736 & $9 \pi: 1$ & 97.49 & 9725 & 9.36 & 37.52 & $9 . .85$ & 57.53 & 37.33 & 97.27 & $\$ 733$ \\
\hline TSI & a 745 & 6734 & $775 \%$ & 7789 & 7.777 & $7 \pi 1$ & $i 718$ & 7.393 & $774^{\prime}$ & 7670 & 7703 & 7705 \\
\hline TAI & 1254 & $2 A B$ & 0221 & 0.19 & 0.223 & 0280 & 363 & 0.317 & $c .223$ & .927 & 0.218 & c. 212 \\
\hline TFe.3 & $\therefore 000$ & 0.700 & no2? & $\pi c 4<$ & $a 0^{2}=0$ & $\operatorname{Don} x$ & 3019 & 0.9100 & C. Q3. & .000 & $0 . x$ & $c 00,3$ \\
\hline$\pi$ & $\approx \infty 0$ & 0.000 & $0.0 \mathrm{Jl}$ & 0.00 & 0.000 & 0,000 & 3000 & $0 . \pi 0$ & C.OOJ & 300 & 0.20 & cooj \\
\hline Scmia T & $=000$ & 8.010 & $80 \pi$ & 0.000 & 8.000 & 8000 & 3000 & 8.70 & 8.003 & 5000 & 8.20 & 8.000 \\
\hline CAI & $=108$ & 0.897 & $0.03 \mathrm{C}$ & 0.000 & $0.0 z 9$ & $0.02 \mathrm{j}$ & 3000 & 0.360 & $C .003$ & $3 c 00$ & 0.232 & $\mathrm{C} 00 \mathrm{~L}$ \\
\hline CFe3 & $23^{\prime \prime}$ & 0.006 & 0.321 & 0.377 & 0.247 & $023 j$ & 3374 & 0.443 & C.253 & 3200 & $0.2<9$ & 1205 \\
\hline $\mathrm{CTI}$ & $\therefore 162$ & 0.151 & 0.917 & $n \pi \sigma_{\bar{t}}$ & ลก:ร & DOC 1 & .3010 & 0.221 & $0.0 \%$ & 3018 & 0.212 & 1.05 \\
\hline$C M_{g}$ & $295 \hat{~}$ & $2: 30$ & 41.98 & $\angle C .08$ & $39: 8$ & $40 x$ & $\angle 033$ & 3986 & $4 \sigma \pi R$ & $\angle C .5$ & 4.222 & 3957 \\
\hline$C F \subset 2$ & 1424 & 117 & 253? & 10.8 & (1) 672 & 0.7 .22 & 9565 & 0.514 & $C, Q \hat{\mathrm{S}}$ & TFIE & $0 \$ 3 ?$ & C. TOK \\
\hline ClAn & 2030 & $0.0 \%$ & $0.02 \%$ & 0.027 & $0.0 \angle 8$ & 0.021 & 3027 & $0.5 \$ 7$ & C.027 & 3023 & 0.528 & 6035 \\
\hline CCa & $\because \infty 0$ & 0.100 & $0.03 t$ & 0.000 & 0.000 & 0.000 & $j 000$ & 0.100 & c.001 & 3000 & $0 . x i$ & cooj \\
\hline Soma C & 5000 & 5. & $5.0 \mathrm{H}$ & 5.00 & 5.000 & 5000 & 5000 & 5.1100 & $5.00 \mathrm{~J}$ & 5000 & $5 . x$ & 5000 \\
\hline$B M g$ & $=000$ & 0.500 & $0.03 \mathrm{C}$ & 0.000 & $0.0=0$ & 0.000 & 3000 & 0.360 & $C .003$ & $3 c 00$ & $0.00 \mathrm{C}$ & $C 000$ \\
\hline $\mathrm{BFe} 2$ & $=000$ & 0.200 & 0.036 & 0.000 & $0.0 \leq 0$ & 0.000 & 3000 & 0.300 & C.003 & 3000 & $0.00 \mathrm{C}$ & $C 000$ \\
\hline$B M_{n}$ & $\therefore 000$ & 0.700 & Dow\% & $\pi .00$ & 0.000 & 003 & 3000 & 0.900 & $c 00$, & 3000 & $0.2 \pi$ & 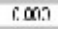 \\
\hline $\mathrm{BC}$ a & 184 & 793 & 1722 & $1 F 60$ & $h=0$ & 1751 & P65 & ง. 49 & 172 & 1724 & 139.5 & 1672 \\
\hline BNa & $\therefore 180$ & $0.20 T$ & 0278 & 0.340 & $0.3=0$ & 0240 & .1335 & 0.361 & c. $28 R$ & .9276 & 0.396 & c.305 \\
\hline Sorma B & 2000 & 2.000 & 200 & 2.00 & 2.000 & 2000 & 2000 & 2.00 & 2.001 & 2000 & 2.006 & 2000 \\
\hline $\mathrm{ACa}$ & $=000$ & 0.200 & $0.03 x$ & 0.000 & $0.0=0$ & 0.000 & 3000 & 0.300 & $C .003$ & 3000 & $0.00 \mathrm{C}$ & $C 003$ \\
\hline ANa & $=434$ & 0.701 & 0.122 & 0.105 & $0.1 \pm 2$ & $0.3 \bar{i}$ & 3140 & 0.49 & C. 92 & 3100 & 0.21 & $\mathrm{C} 200$ \\
\hline AK & $=250$ & 0.236 & $0.0 ; 1$ & 0.08 & 0.054 & 0.050 & 3003 & $0 . x \times 4$ & $(.07)$ & 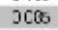 & $0.3 \%$ & C.093 \\
\hline Soma A & $\therefore 697$ & 0.407 & 0193 & 0.19 & 0.245 & 0255 & .2233 & 0.233 & c. $x_{2}$ & .9288 & 0.214 & 1.293 \\
\hline Soma Catibnica & 15.7 .2 & 541 & $15 \%$ & 1E: 9 & 525 & $15 \%$ & $\div 22$ & 5.23 & $152 \mathrm{~s}$ & 15.27 & 15.21 & 1527 \\
\hline
\end{tabular}

Fórmula Estrutural calculada com base em 23 oxigênios.

Análises Quimica WDS em Cristais de Anfibólio do Sienito Pedra Branca. 


\begin{tabular}{|c|c|c|c|c|c|c|c|c|c|c|c|c|}
\hline $\begin{array}{l}\text { Amogtrs } \\
\text { Ansilke }\end{array}$ & 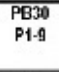 & $\begin{array}{l}\text { PB30 } \\
\text { P2-1 }\end{array}$ & $\begin{array}{l}8330 \\
\text { P2-2 }\end{array}$ & $\begin{array}{l}\mathrm{PB} \times 0 \\
\mathrm{P2} 2-3\end{array}$ & $\begin{array}{l}\mathrm{PB} 30 \\
\mathrm{P2}-4\end{array}$ & $\begin{array}{l}\mathrm{PB30} 0 \\
\text { P2-5 }\end{array}$ & 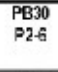 & 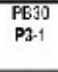 & $\begin{array}{l}\text { PB30 } \\
\text { P3-2 }\end{array}$ & $\begin{array}{l}\mathrm{PBO3} \\
\mathrm{Pa}-4\end{array}$ & $\begin{array}{l}\text { PB149 } \\
\text { afp1 } \\
\text { SLS }\end{array}$ & $\begin{array}{l}\text { PB148 } \\
\text { tisp1 } \\
\text { SLS }\end{array}$ \\
\hline$S 102$ & $545^{\prime}$ & $5<43$ & $54.1 \%$ & 52.58 & $5<: 8$ & ह2.3ิ & 5292 & 53.38 & $55<2$ & 53.75 & 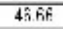 & 4665 \\
\hline TiO2 & 6.1 & 0.67 & 0.2 & $=.20$ & J1E & 0.6 & $\because 11$ & 0.28 & 6.05 & 014 & 0.25 & $1.1^{\circ}$ \\
\hline Al203 & 1.50 & .7 & $15 \%$ & 1.51 & $\pi i$ & 2.72 & $\angle \infty$ & 2.10: & 13 & 183 & G.5i & 7.13 \\
\hline $\mathrm{F}_{\theta} \mathrm{O}$ & $7 \% 3$ & 0.22 & 791 & ש. 6 & 78 & 9.57 & 31 & 9.88 & 7.62 & 667 & $1.0 t$ & 1100 \\
\hline Mno & 6.2 & 0.22 & 027 & 2.24 & $02 \epsilon$ & 0.28 & $=26$ & $0 . \bar{\varepsilon} \varepsilon$ & (.3) & 024 & $0.3=$ & 0.29 \\
\hline $\mathrm{Mlg} 0$ & 19.20 & $\cdot 313$ & 19.37 & $18.2 \mathrm{~s}$ & $\cdot 3: 8$ & $18.3 \mathrm{~K}$ & $\cdot \varepsilon .74$ & 8.45 & $19 \div$ & 19.2 & 15.07 & 1523 \\
\hline $\mathrm{CaO}$ & 11.29 & .389 & 10.54 & $16.8 i$ & .945 & 10.93 & ${ }^{\circ} \mathrm{CAT}$ & $0 . E 2$ & 11.03 & 11.19 & $13.6 \mathrm{E}$ & 10.55 \\
\hline $\operatorname{Nan} 20$ & 1 (x) & 82 & 197 & 105 & ? 16 & $2 \cdot 9$ & 208 & 2.11 & $17 R$ & $1 \subseteq 2$ & $25 \%$ & $25)$ \\
\hline $\mathrm{k} 20$ & C. 43 & 0.47 & 0.51 & 2.45 & $.2 \leq 7$ & 0.51 & $\therefore 45$ & $0=2$ & $c .37$ & 049 & $3 n$ & 1.35 \\
\hline F & ᄃ. & 0,4 & 1018 & $\therefore 83$ & .251 & $0 \approx$ & 102 & $0=1$ & c.0.7 & 071 & 2.99 & 189 \\
\hline $\mathrm{Cl}$ & 100 & 0.01 & 0.01 & 3.06 & $J \pi$ & 0.0 & 204 & 0.04 & CA5 & $0 \mathrm{t2}$ & 0.18 & 0.13 \\
\hline Tolal & 87.18 & 9705 & 9.35 & 98.02 & 9757 & 9.55 & 9750 & 97.70 & 87.53 & 57.05 & 93.32 & $58.7^{\prime}$ \\
\hline $0=F, C$ & $C .23$ & 0.27 & $0<\pi$ & 2.36 & $j z$ & 0.29 & $\therefore 44$ & 0.08 & C.13 & 030 & 0.91 & 0.82 \\
\hline Tolal & $\$ 7.20$ & 9739 & $97: 2$ & 97.66 & 9725 & 97.26 & 3706 & 97.48 & 57.23 & 37.36 & 97.61 & $\$ 792$ \\
\hline TSI & 7723 & $7 \approx 82$ & $775 !$ & 7.395 & 7.729 & 750 & $i$ F54 & $7.5 \mathrm{~F}^{\circ}$ & 785 & 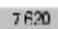 & 6835 & f82:? \\
\hline TAI & $\therefore 25$ & 0.283 & 0241 & OFFOS & 0.271 & $0<57$ & .9346 & $0 \leq 10$ & C. 85 & .922 & 1.11 & 1171 \\
\hline TFe.3 & $\therefore 0 x$ & 0.35 & nowe & acos & $a \pi^{2} n$ & 0033 & .9000 & 0.130 & $c .001$ & .96 .58 & $0 . x$ & $c 00.3$ \\
\hline$\pi$ & $\approx \infty$ & 0.010 & $0.0 \mathrm{Jl}$ & $0 . \omega$ & 0.000 & 0,000 & 3000 & 0.100 & c.oj & 300 & 0.20 & cooj \\
\hline Scmia T & $=000$ & 8.000 & $80 \pi$ & $\delta .00$ & 8.000 & 8000 & 3000 & $8 . \pi 0$ & 8.003 & 5000 & 8.20 & 8.000 \\
\hline Cal & $=000$ & 0.200 & $0.03 \subseteq$ & $0.14^{\circ}$ & 0.014 & 0.000 & 3002 & $0 . x 00$ & $C .003$ & $x_{0} 000$ & $0.5 x$ & $C .057$ \\
\hline CFe3 & $=200$ & $0.4 \Omega 6$ & 0.396 & $0 . E^{\circ} 3$ & $0.2=9$ & $0<32$ & 3400 & $0 \leq 42$ & C.2ki & 0334 & 0.499 & 0.515 \\
\hline $\mathrm{CTI}$ & 202 & $0.0 \%$ & 002 & 0.62 & anit & Dก T & 3012 & 0.225 & $c .015$ & 30.15 & 0 . तो & 1. 122 \\
\hline$C M_{g}$ & $405 \hat{~}$ & 4.25 & 403 & $3.8 \%$ & 3998 & $39 x$ & 3065 & $38 R 4$ & $400<$ & $\angle C .59$ & 3.317 & 3.03 \\
\hline CFo 2 & $\therefore 622$ & $0=19$ & 05.34 & 0.370 & $a \leq 20$ & $D K^{\prime} T$ & .9510 & 0.565 & C.ESE & $.9=65$ & 0.386 & 1.873 \\
\hline ClAn & 2025 & 0.533 & 0.032 & 0.028 & 0.031 & $0.03^{\prime}$ & $303^{\circ}$ & $0 . J S 3$ & C.033 & 3028 & $0.2 \%$ & 6035 \\
\hline CCa & $\because \infty 0$ & 0.00 & 0.00 & 0.00 & 0.000 & 0.0000 & $j 000$ & 0.1100 & C.0.j & 3000 & $0 . x i$ & 6000 \\
\hline Soma C & 5000 & 5. & $5.0 \mathrm{H}$ & $5 . c \omega$ & $5.0 \% 0$ & 5000 & 5000 & 5.100 & $5.00 \mathrm{~J}$ & 5000 & $5 . x$ & 5000 \\
\hline$B M g$ & $=000$ & 0.200 & $0.03 \mathrm{C}$ & 0.000 & 0.020 & 0.000 & 3000 & 0.300 & $c .00$ & $3 c 00$ & $0.00 \mathrm{C}$ & $C .003$ \\
\hline BFe2 & $=000$ & 0.200 & $0.03 \mathrm{C}$ & 0.000 & $0.0 \div 0$ & 0.000 & 3000 & 0.300 & $C .003$ & 3000 & $0.00 \mathrm{C}$ & $\mathrm{C} 000$ \\
\hline$B M_{n}$ & $\therefore 000$ & 0.00 & 20.\% & $\pi \cos$ & $a 0^{2} n$ & 000 & 3000 & 0.00 & cona & .600 & $0.2 \pi$ & 1.003 \\
\hline $\mathrm{BCa}$ & 173 & $\therefore 47$ & 1.594 & $1.73 \bar{T}$ & .574 & 1 6S3 & .593 & S12 & $1.6 \bar{t}^{\prime}$ & 1700 & $1 \mathrm{sinf}$ & $166 ?$ \\
\hline BNa & $\therefore 287$ & 0.53 & 24.7\% & 0.363 & $0 \leq 2 \hbar$ & $0.33 T$ & .9407 & 0.388 & c.329 & .2300 & 0.314 & 0.36 .9 \\
\hline Sorma B & 2000 & 2.000 & 200 & $2.0 \omega$ & 2000 & 2000 & 2000 & 2.00 & 2.003 & 2000 & 2.000 & 2.000 \\
\hline $\mathrm{ACa}$ & $=000$ & 0.200 & $0.03 \mathrm{C}$ & 0.000 & $0.0=0$ & 0.000 & 3000 & $0 . x 00$ & $C .003$ & 3000 & $0.00 \mathrm{C}$ & $C_{0003}$ \\
\hline ANa & 217 & $0.14 i$ & 0.121 & $0.9^{\circ}$ & 0.126 & 0250 & 3106 & 0.93 & $C \cdot 5 \hat{3}$ & 3229 & $0.42 C$ & {$[3 i]$} \\
\hline AK & $=073$ & 0.206 & 0.092 & $0.68^{\circ}$ & $0.0 \overline{4}$ & 0.092 & $300^{\circ}$ & 0.393 & $C .06 i$ & $x_{009}$ & 0.225 & $(2,252$ \\
\hline Sorma A & . 2555 & 0.231 & $02 \%$ & 0.172 & $0.1=0$ & 0.39 & .3247 & 0.286 & c.223 & .2318 & $0.57 ?$ & i. 622 \\
\hline Soma Catisnica & 15.5 & 523 & 15.21 & 1.5. 7 & 519 & $15 . \hat{\hbar}$ & 525 & 5.29 & 1522 & 15.32 & 15.67 & 1562 \\
\hline
\end{tabular}

Fómula Estrutural calculada com base ern 23 oxigênios.

Análises Quimica WDS em Cristais de Anfibólio do Sienito Pedra Branca. 


\begin{tabular}{|c|c|c|c|c|c|c|c|c|c|c|c|c|c|}
\hline $\begin{array}{l}\text { Anosirs } \\
\text { Ansillse }\end{array}$ & $\begin{array}{l}\text { PB145 } \\
\text { t:3p22 }\end{array}$ & $\begin{array}{l}\text { PE148 } \\
\text { e.3p3 }\end{array}$ & $\begin{array}{l}\text { PB148 } \\
\text { c3p44 }\end{array}$ & 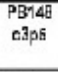 & $\begin{array}{l}\text { PE148 } \\
\text { q1p2 }^{2}\end{array}$ & $\begin{array}{l}\text { PB149 } \\
\text { c6510 }\end{array}$ & $\begin{array}{l}\text { PB146 } \\
\text { c5p11 } \\
\text { SLS }\end{array}$ & $\begin{array}{l}\text { PE148 } \\
\text { cspl2 }\end{array}$ & $\begin{array}{l}\text { PB144 } \\
\text { asip2 }\end{array}$ & $\begin{array}{l}\text { PB148 } \\
\text { e5p? }\end{array}$ & $\begin{array}{l}\text { PB148 } \\
\text { c5sp4 }\end{array}$ & $\begin{array}{l}\text { P3143 } \\
\text { c5:p6 }\end{array}$ & $\begin{array}{l}\text { PE148 } \\
\text { e5p7 }\end{array}$ \\
\hline s102 & 45.20 & 46.33 & 46.24 & $54 ?$ & 63.14 & 42.51 & $432 \hat{\mathrm{a}}$ & $\angle 248$ & $432 \mathrm{~F}$ & 42.91 & $\angle 231$ & $43 \div \leq$ & 4279 \\
\hline T102 & 1.27 & 112 & $\because 3$ & 1.12 & 152 & 1.13 & 1.12 & .10 & $\because \ddot{8}$ & 1.06 & DE & 1.5 & $=78$ \\
\hline $\mathrm{A} / 203$ & 7.73 & $\because 80$ & 70 & 6.0 & 572 & 9.17 & 6.65 & d. 22 & BDi & d. & 394 & 8.00 & в 16 \\
\hline $\mathrm{F} \otimes \mathrm{O}$ & 12.21 & $1 \approx \omega$ & 2.23 & 12.7 & 6.77 & $15.0 \mathrm{~d}$ & $15 \%$ & 15.45 & 11. It & 15.5 & 174 & $15 . \%$ & 1530 \\
\hline MnO & 0.30 & $=28$ & $0.3 C$ & C.2i & 320 & 0.33 & C23 & 0.24 & 027 & C.22 & $32 \epsilon$ & 0.30 & $=22$ \\
\hline $\mathrm{MgO}$ & 14.70 & 1462 & $\angle . \equiv 0$ & 14.93 & $-2 \mathrm{CO}$ & 12.67 & 13.03 & $12 \pi 0$ & 1234 & 12.99 & $2 \mathrm{SS}$ & 12.31 & $12 \mathrm{BS}$ \\
\hline $\mathrm{CrO}$ & 10.70 & 1693 & $0 . \pm 2$ & 10.83 & 0.26 & $1^{1} .0 E$ & 1095 & 1399 & 1.22 & $11.2 \mathrm{~L}$ & -129 & 10.31 & $11.4 \bar{z}$ \\
\hline $\mathrm{N}=20$ & $26 x^{\circ}$ & 257 & 271 & 256 & 217 & $2.1 \hat{\mathrm{A}}$ & 2.12 & 219 & 27 & 2.23 & 214 & $2 x$ & 215 \\
\hline $\mathrm{K} 2 \mathrm{O}$ & 139 & 124 & 32 & $1.3 \pi$ & 140 & 1.5. & 14.) & 44 & $\angle A$ & 1.36 & $\div 3$ & 141 & 140 \\
\hline F & 132 & 136 & $\pi 1$ & 182 & .979 & 1.23 & 15.) & 1.5 & 081 & 1.19 & . $6 \mathrm{f}$ & $1 \tilde{x} \mathfrak{9}$ & 105 \\
\hline Cl & 0.5 & $\because 12$ & $0 . \% 5$ & 6. 12 & 310 & 0.5 & 627 & 3.52 & 03 & C.28 & J99 & 0.25 & $\because 31$ \\
\hline Total & 98.39 & 3758 & $9 . .83$ & $58.5^{7}$ & 37.79 & 97.78 & 8823 & 9718 & 9.28 & 87.30 & 9756 & पT.11 & 9732 \\
\hline $\mathrm{O}=\mathrm{F}, \mathrm{Cl}$ & 0.59 & 200 & 0.74 & 6.79 & 396 & 0.53 & $C 69$ & 3.51 & $0<1$ & $0.5 t^{\prime}$ & $3 \pi$ & $0 . \pi 7$ & 252 \\
\hline Totel & 98.0 & 3699 & 98.29 & 57.75 & 37,43 & $9 . x$ & $\$ 75^{\circ}$ & 9367 & 9632 & $\varsigma \in .76$ & $9: 79$ & $9 \pi / 2$ & $\exists \in: 90$ \\
\hline$T S \mid$ & 6785 & ก 984 & 6 R?.5 & F. 857 & $\hat{3} \neq 6$ & $63 \%$. & F 4 46. & 6404 & 6511 & F. $A 6 \alpha$ & 6477 & ธร.าก & $\hat{3} 46 \bar{\gamma}$ \\
\hline$T A \mid$ & $12^{\prime} 5$ & 1116 & $1 \div 6$ & 1.43 & $=34$ & $1 \leqslant x$ & 1523 & $1=06$ & $1.48 \mathrm{C}$ & 1 . 33 & 6.23 & 1 ติก0 & 1533 \\
\hline$\pi e_{e} 3$ & Domo & 3000 & 0.20 & 5.00. & $30 x 0$ & 0.901 & .07 & $a: 00$ & now & $\cos \theta$ & arso & Domo & 3000 \\
\hline$\pi i$ & D.030 & 300 & $0 . J 00$ & C.003 & $3 x 0$ & 0.30 & {$[003$} & 0000 & $0.0 \%$ & cco & 0.000 & DQN30 & 300 \\
\hline Sana I & 8.030 & $3(0)$ & 8.300 & c.003 & 300 & $8 . \pi 0$ & 8003 & 8000 & $8.0 \pi$ & $8 . c \omega$ & $8.6 C 0$ & 8090 & 3000 \\
\hline CAI & $0.1=$ & 3102 & $0.5=0$ & C.043 & 3006 & 0.30 & $(00)$ & $0 \approx 41$ & $0.0 \pi t$ & $\mathrm{CCO} 2 \mathrm{O}$ & $0.0 \mathrm{C} 9$ & 0050 & 3097 \\
\hline $\mathrm{CFe} 3$ & 0.430 & 3506 & $0.5 \pm 4$ & C.44i & $3 \pi_{7}$ & $0.30 \bar{c}$ & $C_{903}$ & $0=35$ & $0.63 x$ & 6.761 & 0.649 & 0.922 & 3645 \\
\hline $\mathrm{CT}$ & $0.1 \leq 0$ & 3125 & $01=8$ & C. 22 & 3172 & 0.31 & f. 125 & a 125 & Q. $3 e$ & c. $12 x$ & 0.120 & D) 22 & 3029 \\
\hline $\mathrm{CMg}_{\mathrm{g}}$ & 32.2 & 3243 & 3248 & 3.293 & 2682 & 2835 & 29013 & 2.56 & 2882 & $2 S 6$ & $2: 12$ & $285 \bar{~}$ & 2849 \\
\hline $\mathrm{CFe}^{2}$ & $105 \AA$ & 1121 & 111 & 1.056 & $x .5$ & 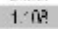 & 1003 & 1112 & 1.2ิ & $114 \overline{7}$ & 216 & 1095 & $1 \times 0$ \\
\hline $\mathrm{CMn}$ & 0.030 & 3130 & $0.7 \pm 8$ & c.os & 3639 & $0 . y^{\prime} 1$ & 6037 & 0.31 & 0.031 & $6 x$ & 0.639 & 0.030 & 3008 \\
\hline $\mathrm{CC}_{\mathbf{a}}$ & 0.030 & 300 & 0.300 & C.003 & $30 \times 0$ & 0.10 & 6003 & 0.000 & $0.0 \%$ & ecow & 0.600 & 00000 & 3000 \\
\hline Soma C & 5030 & $5 \mathrm{col}$ & 5.30 & 5.003 & $5 \cup 0$ & 5.30 & 5003 & 5000 & $50 \%$ & 5CW & 5.600 & 50030 & 5000 \\
\hline $\mathrm{BMg}$ & 0.030 & 300 & 0.520 & $C .003$ & 3000 & 0.30 & $(\infty)$ & $0=00$ & $0.0 x$ & $\mathrm{ccco}$ & $0.0 \mathrm{CO}$ & 0.030 & 3000 \\
\hline $\mathrm{BFe} 2$ & 0.030 & 3600 & $0.5=0$ & $C .003$ & 3000 & $0.30 \mathrm{C}$ & $(00)$ & $0=00$ & $0.0 x$ & $\mathrm{CCOO}$ & $0.0 C 0$ & 0.030 & 3000 \\
\hline EMn & Do90 & $\operatorname{arcos}$ & 0.750 & $c .00$ & $3 \times 00$ & $0.0 \%$ & 800 & 0.00 & $00 \%$ & $\cos 0$ & a.co & 0090 & 3000 \\
\hline $\mathrm{BCa}$ & 1630 & 1740 & 7.7 & $170 \mathrm{~s}$ & 745 & $1.77 \mathrm{~S}$ & 1752 & 1775 & 1895 & 1796 & 921 & $17.7 ?$ & $18=8$ \\
\hline BNa & 0.320 & .2260 & $02: 3$ & c.296 & 9265 & 0.221 & C. $2 \angle B$ & 02.25 & $0: 31$ & 1.200 & a.1F: & 0298 & 3142 \\
\hline Soma B & 2030 & 200 & $2 J 0$ & 2.009 & 2000 & 2.00 & 2003 & 2000 & $20 \pi$ & ¿CW & 2000 & 2090 & 2000 \\
\hline$A C a$ & 0.030 & 3000 & $0.5=0$ & $C .003$ & 3000 & 0.30 & $(00)$ & $0=00$ & $0.0 x$ & $\mathrm{ccco0}$ & $0.0 \mathrm{CO}$ & 0.030 & 3000 \\
\hline Alla & $0.4 \div 3$ & 3482 & $0 \leq \pm 0$ & C. 435 & 3275 & 0.200 & $\left(x_{3}\right.$ & 0417 & $0.4 \angle 6$ & C. .440 & $0.4=0$ & 0.395 & 3406 \\
\hline $\mathrm{AK}$ & 0231 & 3230 & 0.247 & 0.253 & $3 \times 8$ & 0.20 & $C 20 j i$ & $0 \overline{\bar{c}} \times 8$ & $0.2 i \xi$ & C.261 & 0.276 & 0230 & $32 i^{\circ}$ \\
\hline Soma A & $0.7 \%$ & .9718 & 0727 & ᄃ. & .943 & 0.994 & $\therefore \mathrm{E}^{2}$ & $a=94$ & $072 \mathrm{~F}$ & 0.70 & 0.724 & 0.573 & .975 \\
\hline Soms Catianica & 15.70 & $1 \leqslant 72$ & 5.73 & 1569 & $5 \in 4$ & 15.25 & 1563 & $15 \mathrm{FO}$ & $15 \pi^{2}$ & 15.71 & $=73$ & 15.57 & 16.76 \\
\hline
\end{tabular}

Fónu la Estrutural calculada com base em 23 oxigênios.

Análises Quimica WDS em Cristais de Anfibólio do Sienito Pedra Branca. 


\begin{tabular}{|c|c|c|c|c|c|c|c|c|c|c|c|c|}
\hline $\begin{array}{l}\text { Amogtrs } \\
\text { Ansilke }\end{array}$ & $\begin{array}{l}\text { PB148 } \\
\text { e5pa }\end{array}$ & $\begin{array}{c}\text { PE148 } \\
\text { CSp? }\end{array}$ & $\begin{array}{l}\text { PB181 } \\
\text { t1p-1 }\end{array}$ & $\begin{array}{l}\text { PE181 } \\
\text { e1p? }\end{array}$ & $\begin{array}{l}\text { PE191 } \\
\text { c'ps }\end{array}$ & 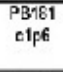 & $\begin{array}{l}\text { PQ181 } \\
\text { c1p7 }\end{array}$ & $\begin{array}{ll} & \begin{array}{c}\text { PB181 } \\
\text { ctp8 }\end{array} \\
\text { SLSI } & \\
\end{array}$ & $\begin{array}{l}\text { PB1B1 } \\
\text { a1p9 }\end{array}$ & $\begin{array}{l}\text { PE181 } \\
\text { c6p1 }\end{array}$ & $\begin{array}{l}\text { PB191 } \\
\text { cfpl0 }\end{array}$ & $\begin{array}{l}\text { PB181 } \\
\text { cEp11 }\end{array}$ \\
\hline 8102 & 4272 & 4315 & $46 \leq 6$ & $\triangle 6.26$ & $\angle 644$ & 45.23 & $57 \%$ & 46.76 & $4 \sqrt{625}$ & $\angle 7.5$ & $47 \pm ?$ & 4925 \\
\hline TiO2 & 12 & .12 & $10 \mathrm{z}$ & 3.80 & 337 & 0.36 & 871 & 0.75 & 6.87 & 0.46 & $0<7$ & 0.29 \\
\hline Al20? & $5.2)$ & 0.8.1 & $6 J_{i}$ & 0.91 & 5:1: & 6.7 & $\Sigma \oplus$ & 6.tit & EAD & 575 & Gid1 & 4.23 \\
\hline $\mathrm{F}_{\theta} \mathrm{O}$ & 15.56 & 5.12 & 12.6 & $12 . \pi \mathrm{V}$ & 203 & 13.20 & 193 & 2.67 & $12 \%$ & $11 . \%$ & 1.08 & 10.9 \\
\hline Mno & C.23 & 0.25 & 0.37 & 2.30 & 530 & 0.36 & $=37$ & $0 . . \bar{s}$ & C.33 & 036 & $0.3 E$ & 0.35 \\
\hline $\mathrm{Mlg} 0$ & 12.27 & .295 & 15.7 & 15.09 & 528 & 15.39 & -5.75 & 5.36 & 1534 & 16.17 & $15.7 \mathrm{E}$ & 16.67 \\
\hline $\mathrm{CaO}$ & 11.7 & .385 & 9.1 & $\Xi .30$ & 932 & 9.9 & $\lesssim 11$ & $9 . \pi$ & $(3)$ & $\delta \subseteq 1$ & 917 & 8.90 \\
\hline $\operatorname{Nan} 20$ & 214 & 20.6 & 372 & 375 & $3 \pi$ & 3.86 & 396 & 378 & $36 \hat{2}$ & $3: 8$ & 354 & 304 \\
\hline $\mathrm{k} 20$ & 145 & 41 & $17 \pi$ & 1.84 & in & 1.72 & 151 & 1 觙 & 175 & 167 & 54 & 1.35 \\
\hline F & C. 85 & 0.8 .6 & 281 & 200 & $2.3 ?$ & 158 & 237 & $2 \because 2$ & 202 & 231 & 2.79 & 248 \\
\hline $\mathrm{Cl}$ & 6.38 & 0.28 & OQDE & 2.04 & JjE & 0.77 & 204 & 0.04 & 6.05 & 063 & 0.35 & 0.01 \\
\hline Todal & 77.23 & $97 \$$ & 98.25 & 96.03 & $95 \geq 12$ & 80.19 & 458 & 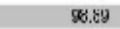 & 88.52 & 60.94 & 93.7 & 8837 \\
\hline $0=F, C$ & C.44 & 0.42 & 1.5 & 1.10 & $\partial x$ & 0.90 & 101 & $0 . \overline{C E}$ & $C B 3$ & $0 \subseteq 8$ & 0.57 & 100 \\
\hline Tolal & $\Xi 6.79$ & $93 \approx 8$ & $97.3 \mathrm{C}$ & 97.98 & 9746 & 97.91 & 3767 & 98.13 & $57.6 \hat{3}$ & 37.96 & $97.6 \mathrm{C}$ & $\$ 732$ \\
\hline TSI & 2457 & 6451 & $68 \div 7$ & 6.79 & $6.52 ?$ & ลริวิธ & $\hat{5} \mathbf{S}^{\circ}$ & 6REF & $6.80 \hat{~}$ & Sc:40 & $6: 56$ & 721 \\
\hline TAI & 1543 & 549 & 1.193 & $1.15 \%$ & 124 & 1021 & .9887 & 12 & 1. 22 & $9 \mathrm{c}: 9$ & $1.22 ?$ & c. 789 \\
\hline TFe.3 & $\therefore 000$ & 0.700 & $002 \%$ & nc.49 & ants & 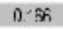 & .9052 & 0.42 & C. 052 & .967 & 0.211 & c. $00 a$ \\
\hline$\pi$ & $\approx \infty 0$ & 0.00 & $0.0 \%$ & 0.00 & $(0,0=0)$ & 0,000 & 3000 & 0.70 & c.oj & 300 & 0.20 & ¿003 \\
\hline Scmia T & $=000$ & 8.000 & $80 \pi$ & 0.000 & 8.000 & 8000 & 3000 & $8 . \pi 0$ & 8.003 & 5000 & 8.20 & 8003 \\
\hline Cal & $=090$ & 0.25 & $0.0 x c$ & 0.000 & $0.0=0$ & 0.000 & 3000 & $0 . x 00$ & $C .003$ & $x_{000}$ & $0.00 \mathrm{C}$ & $\mathrm{CO}^{\circ} \mathrm{O}$ \\
\hline CFe3 & 2644 & 0.531 & 0.596 & 0.643 & 0.614 & 0.996 & 3094 & 0.741 & C..$\oplus 3$ & 3753 & 0.308 & $c 5<9$ \\
\hline $\mathrm{CTI}$ & $\therefore 138$ & 0.126 & 0121 & n.c. & ans? & 0.29 & .3078 & $0.9 \% 2$ & C. CQA7 & 3050 & 0.251 & 1. 032 \\
\hline$C M_{g}$ & 2765 & $2=8$ & 3348 & 3.333 & 3.397 & 3370 & 3458 & 3367 & $3.3 \bar{z} \hat{i}$ & $3=2$ & 3451 & 3636 \\
\hline CFo 2 & 132 & $0 \cong x$ & D8RS & 0.89 & Q..$\leqslant 5$ & 0.777 & .9823 & 0,71 & 0.82 .1 & . TFB & 0.767 & c. 726 \\
\hline ClAn & 2038 & $0.5 \%$ & $0.0 \% 6$ & $0 . \mathrm{L}$ & 0.028 & 0.012 & 3046 & 0.419 & C. 07 & JC15 & $0 . x^{\prime}$ & cos \\
\hline CCa & $\because \infty 0$ & 0.200 & $0.03 t$ & 0.00 & 0.000 & 0.0000 & $j 000$ & 0.1100 & C..0.j & 3000 & $0.2 x$ & cooj \\
\hline Soma C & 500 & 5. & $5.0 \mathrm{H}$ & 5.60 & $5.0 \% 0$ & 5000 & 5000 & 5.100 & $5.00 \mathrm{~J}$ & 5000 & $5 . x$ & 5000 \\
\hline$B M g$ & $=000$ & 0.200 & $0.03 \mathrm{C}$ & 0.000 & 0.020 & 0.000 & 3000 & 0.300 & $c .00$ & $3 c 00$ & $0.00 \mathrm{C}$ & $C 000$ \\
\hline BFe2 & $=000$ & 0.200 & $0.03 \mathrm{C}$ & 0.000 & $0.0 \div 0$ & 0.000 & 3000 & 0.300 & $C .003$ & 3000 & $0.00 \mathrm{C}$ & $C 000$ \\
\hline$B M_{n}$ & $\therefore 000$ & 0.00 & Dow? & $0 \cos$ & $a 0^{2} n$ & 003 & 3000 & 0.300 & cona & 3000 & $0 . x i$ & 8.003 \\
\hline $\mathrm{BC}$ a & 1800 & 738 & $14 \leq E$ & 1.475 & 475 & $1<51$ & 438 & 428 & $14 \overline{7}^{\prime}$ & 1294 & $14 \angle 4$ & 1.295 \\
\hline BNa & $\therefore 19$ & 0.252 & 2556 & $0.62 \pi$ & $0 . .525$ & 0549 & $1 \neq 6 ?$ & 0.572 & C.529 & TFES & 0.566 & C. KOL \\
\hline Sorma B & 200 & 2.000 & 200 & 2.00 & 2000 & 2000 & 2000 & 2.00 & 2.003 & 2000 & 2.00 & 2003 \\
\hline $\mathrm{ACa}$ & $=000$ & 0.200 & $0.0 x c$ & 0.000 & $0.0=0$ & 0.000 & 3000 & $0 . x 00$ & $C .003$ & 3000 & $0.00 \mathrm{C}$ & $C_{000}$ \\
\hline ANa & $=438$ & 0.334 & $05 \%$ & $0.55^{\circ}$ & 0.035 & 0.551 & 3068 & $0.5 C 1$ & C. 59 & $3: 20$ & $0.53 t$ & $C 53$ \\
\hline AK & $=2 B$ & $0 . \overline{268}$ & $0.3 x$ & $0.34 i$ & 0.320 & 0.322 & 3204 & 0.369 & C. 303 & 5290 & 0.206 & $(252$ \\
\hline Soma A & $87 \%$ & $0=0103$ & 288? & 0.899 & $a . \dot{n}=5$ & 0873 & .185 & 0.311 & c. $8<7$ & .213 & 0.925 & 6.765 \\
\hline Soma Catibnica & 15.72 & 500 & 15.34 & $1 \leqslant 9$ & 506 & 15.97 & <85 & 5.81 & 1585 & 15.8 & $15 \hat{n}^{2}$ & 15.77 \\
\hline
\end{tabular}

Fómula Estrutural calculada com base ern 23 oxigênios.

Análises Quimica WDS em Cristais de Anfibólio do Sienito Pedra Branca. 


\begin{tabular}{|c|c|c|c|c|c|c|c|c|c|c|}
\hline $\begin{array}{l}\text { Amostras } \\
\text { Ansillse }\end{array}$ & $\begin{array}{l}\text { PB181 } \\
\text { cfp12 }\end{array}$ & $\begin{array}{l}\text { PB181 } \\
\text { a6p13 }\end{array}$ & $\begin{array}{l}\text { PB181 } \\
\text { e6p14 }\end{array}$ & $\begin{array}{l}\text { PE191 } \\
\text { c\&p22 }\end{array}$ & $\begin{array}{l}\text { PB181 } \\
\text { eAp3 }\end{array}$ & 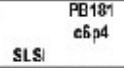 & $\begin{array}{c}\text { PB181 } \\
\text { C6ps }\end{array}$ & $\begin{array}{l}\text { PB1B1 } \\
\text { aEp6 }\end{array}$ & $\begin{array}{l}\text { PE181 } \\
\text { c6pī }\end{array}$ & $\begin{array}{l}\text { PB181 } \\
\text { ofp9 }\end{array}$ \\
\hline S102 & 4ลิ ผั & $46.8 \%$ & $25 \%$ & $\angle 6: 8$ & 47.53 & LF 94 & 48.12 & 47.65 & $\angle 5.85$ & $4 \pi \pm 7$ \\
\hline TI02 & 0.55 & 0.71 & 8.57 & 351 & 0.55 & $\because \infty$ & 0.17 & 6.13 & 056 & 0.7 \\
\hline $\mathrm{A} 2 \mathrm{O} 3$ & 6.48 & 6 İ & 5.00 & 516 & 6.0 & $\because 22$ & 5.54 & $6.7^{\prime}$ & 568 & 5.57 \\
\hline $\mathrm{FeO}$ & 219 & 12.32 & 12.50 & 256 & 12.31 & $\pi .08$ & $\cdots$ & 1207 & 15.26 & $1 . .41$ \\
\hline MnO & 0.35 & $0.3 \Xi$ & 2.33 & $\partial 3 \varepsilon$ & 0.30 & 239 & 0.44 & $c .3 i$ & 037 & 0.32 \\
\hline MgO & .557 & $15.3 \mathrm{G}$ & 15.43 & $5 \equiv 1$ & 15.55 & -580 & 5.58 & 15.83 & 15.70 & 15.65 \\
\hline $\mathrm{C}: 0$ & $9.4 ?$ & 921 & $\Xi .24$ & 932 & 9.3 & $\equiv 31$ & $9.2 E$ & $؟ 22$ & $\delta \varsigma_{0}$ & $95 \equiv$ \\
\hline $\mathrm{N}-20$ & 378 & 377 & 3.83 & 396 & $3 \pi$ & 373 & $3:$ : & 383 & 375 & $37 \hat{\pi}$ \\
\hline $\mathbf{k} 20$ & 61 & 16 ? & 1.68 & 54 & $1 \equiv 0$ & 157 & 1.52 & $14 R$ & 164 & $\pi \hat{n}$ \\
\hline F & $8 ?$ & 2.7 & 149 & 314 & 12 & 187 & 2.23 & 2.13 & 162 & 91 \\
\hline $\mathrm{Cl}$ & o.te & $00 \%$ & 8.06 & J4 & 0.25 & $\because 05$ & $0 . .56$ & 6.05 & 065 & 0.31 \\
\hline Iotal & $93 \%$ & 98.28 & 97.50 & 10022 & 18.35 & 35 & 96.64 & 8873 & 60.17 & 93.57 \\
\hline $\mathbf{0}=F, G \mid$ & $0.7 \varsigma$ & $0.9 \bar{c}$ & 2.64 & 32 & 0.86 & 280 & $0 . \overline{5}$ & $69^{\circ}$ & $0 \in 9$ & 0.54 \\
\hline Total & 9306 & 98.22 & 97.34 & $95 \equiv 9$ & 98.0 & 3656 & $9_{7.69}$ & 57.87 & 97.78 & $9 . \pi^{2}$ \\
\hline TSI & $6: 30$ & 68ถิ1 & $6 ! 23$ & 6.873 & $694<$ & 6837 & 7.961 & $6 \subseteq 9$ & 62.42 & $6 \% 3$ \\
\hline TAI & 121 & 1.193 & 1.09 & nat & 1040 & DE7 & 0.949 & $c .9$ & 10.12 & 1.214 \\
\hline$T F \in 3$ & 0.48 & Do3f & $0.6 \bar{\gamma}$ & $0 n=5$ & DOST & 3066 & 0.700 & $c .0<2$ & .9146 & 0.218 \\
\hline$\pi \mathrm{Ti}$ & 0.000 & $0.0 \%$ & $0.0 \%$ & 0.000 & 0.000 & 3000 & 0.100 & c. $\infty 0 \mathrm{~J}$ & 500 & 0.20 \\
\hline Soma T & 8.000 & $80 \pi$ & 0.000 & 8.000 & 8.000 & 3000 & 8.100 & 8.000 & 5000 & 8.206 \\
\hline CAI & 0.200 & $0.03 \mathrm{C}$ & 0.000 & $0.0=0$ & 0.000 & 3000 & 0.300 & C. .003 & 3000 & $0.00 \mathrm{C}$ \\
\hline $\mathrm{CFe}^{3}$ & 0.519 & $0.7 x$ & 0.58 & $0.0=8$ & $0 . \bar{z}^{\prime} \dot{\mathrm{u}}$ & 3780 & 0.514 & $C .00 \hat{3}$ & 9500 & 0.551 \\
\hline CTI & 0.105 & 10032 & 01675 & $a n=0$ & Do15 & 3065 & $0.9 \leq 1$ & C.053 & $.65^{2}$ & 0.378 \\
\hline $\mathrm{Clug}_{\mathrm{g}}$ & 3.405 & 333ล & 3.99 & $3 \div ? 9$ & $3<.38$ & 3387 & $3 \leq\{1$ & 2464 & 3418 & 3439 \\
\hline$C F: 2$ & 0.78 & $08 \% 1$ & $\pi \leq \infty$ & 0.126 & 0.79 & .1718 & 0.792 & c.T. & 9.974 & 0817 \\
\hline $\mathrm{Cl} / \mathrm{n}$ & $0 . .413$ & $0.0 \%$ & $0 . \mathrm{C}_{2}$ & 0.017 & 0.037 & J & 0.354 & $c .03$ & JCA6 & $0 . x^{\prime 2}$ \\
\hline $\mathrm{CC}_{\mathrm{a}}$ & 0.200 & 0.036 & 0.00 & 0.000 & 0.000 & 3000 & 0.000 & c.000 & 3000 & 0.20 \\
\hline SormaC & 5.000 & $50 \%$ & 5.00 & 5.000 & 5,000 & 5000 & 5.100 & $5.00 \mathrm{~J}$ & 5000 & 5.20 \\
\hline Blug & 0.200 & $0.03 \mathrm{C}$ & 0.000 & $0.0=0$ & 0.000 & 3000 & 0.560 & $C .003$ & $3 c 00$ & $0.00 \mathrm{C}$ \\
\hline BFe? & 0.000 & $003 x$ & 0.000 & $0.0=0$ & 0.000 & 3000 & 0.360 & $C .003$ & 3000 & $0.00 \mathrm{c}$ \\
\hline Blan & 0.70 & now & $\pi \cos$ & $\operatorname{anc} 0$ & $00 x$ & 3000 & 0.00 & $c 00$, & (c00 & 0.20 \\
\hline BCE & 482 & $14: 7$ & $145 ?$ & $\angle 34$ & $1<2 \pi$ & 453 & $\leq 22$ & $14<3$ & 1298 & $142 \%$ \\
\hline ENa & 0.518 & 1055? & $0.63 \bar{\gamma}$ & 0.576 & กร72 & 9547 & 0.578 & C.662 & TFi: & $0.57 \%$ \\
\hline Soma B & 2.000 & 2036 & 2.00 & 2.000 & 2000 & 2000 & 2.000 & 2.000 & 2000 & 2.006 \\
\hline $\mathrm{ACa}$ & 0.200 & 0.036 & 0.000 & $0.0 \div 0$ & 0000 & 3000 & $0 . x 60$ & $C .003$ & 3000 & 0.006 \\
\hline ANa & 0.556 & $0.5 \%$ & $0.56^{\circ}$ & $0.5 \pi$ & $0<90$ & 3506 & 0.517 & $C .50 i$ & 3450 & $0.50 ?$ \\
\hline AK & 0.002 & $0.3=1$ & 0.27 & $0.2 \pm 0$ & 0230 & 3292 & 0.204 & $C .2 i 3$ & $920 \%$ & $0.31 ?$ \\
\hline Soma A & 0.58 & 2825 & 0.879 & 0.776 & $0.7 x$ & .1790 & 0.801 & $c .82$ & .774 & 0.921 \\
\hline Scma Catisnica & 58 & $153^{2}$ & $1 \leqslant \approx$ & $5=8$ & 15.79 & $(8)$ & 5.01 & $158^{\prime}$ & 15.74 & 15.2 .2 \\
\hline
\end{tabular}

Fómula Estrutural calculada com base ern 23 oxigênios.

Análises Quimica WDS em Cristais de Anfibólio do Sienito Pedra Branca. 
Tabela 4: Análises WDS em cristais de biotita do Sienito Pedra Branca. 


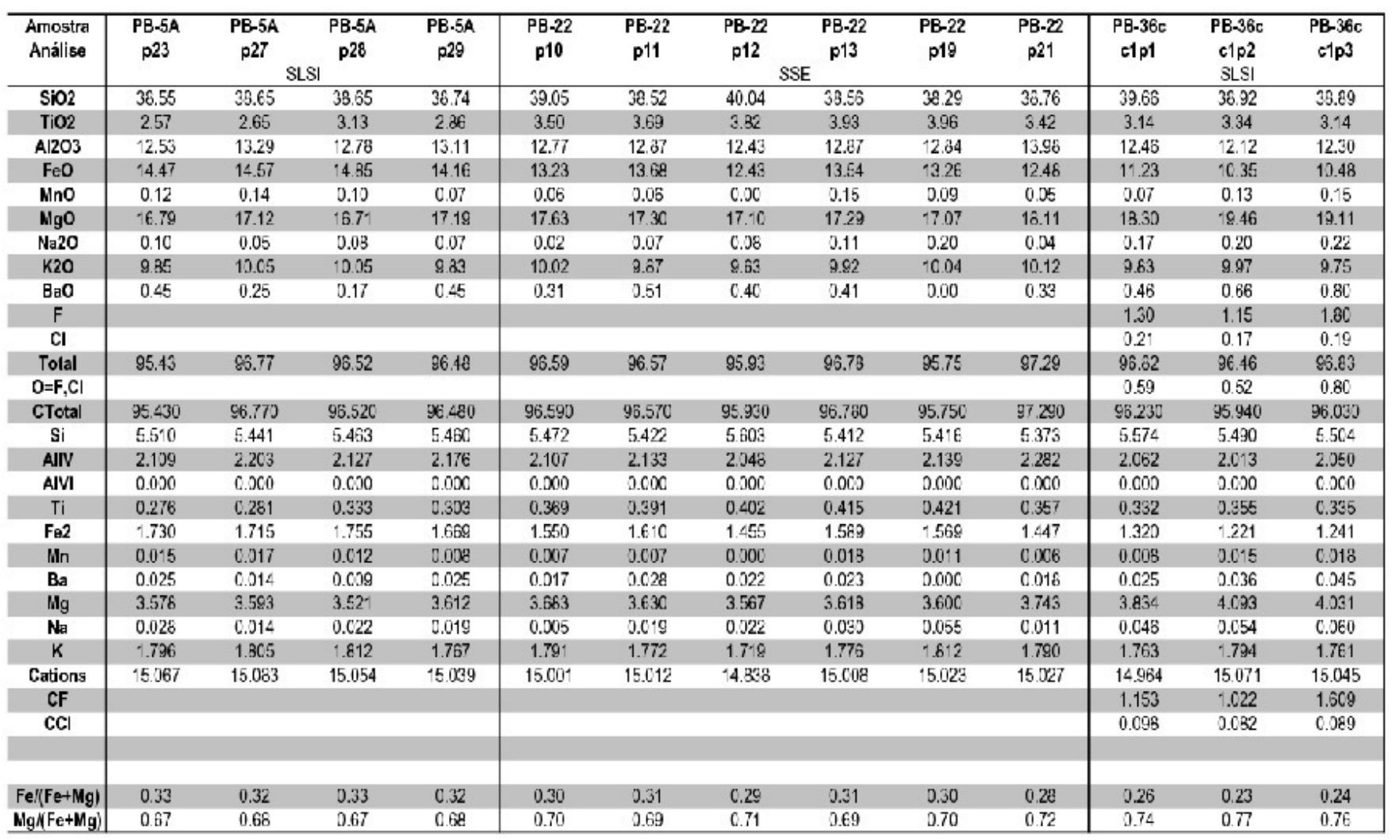

Fómu la Estrutural calculada com base em 22 oxigênios. 


\begin{tabular}{|c|c|c|c|c|c|c|c|c|c|c|c|c|c|}
\hline $\begin{array}{l}\text { Amostra } \\
\text { Análise }\end{array}$ & $\begin{array}{c}\text { PB-36c } \\
\text { c2\$1 }\end{array}$ & $\begin{array}{c}\text { PB-36c } \\
\text { e2p2 }\end{array}$ & $\begin{array}{c}\text { PB-36c } \\
\text { c2p3 }\end{array}$ & $\begin{array}{c}\text { PB-36c } \\
\text { c2p4 }\end{array}$ & $\begin{array}{c}\text { PB-36c } \\
\text { e2p5 }\end{array}$ & $\begin{array}{c}\text { PB-36c } \\
\text { c2p6 } \\
\text { SLS| }\end{array}$ & $\begin{array}{c}\text { PB-36c } \\
\text { c4p1 }\end{array}$ & $\begin{array}{c}\text { PB-36c } \\
\text { c4p2 }\end{array}$ & $\begin{array}{c}\text { PB·36c } \\
\text { c4p3 }\end{array}$ & $\begin{array}{c}\text { PB-36c } \\
\text { c4p4 }\end{array}$ & $\begin{array}{c}\text { PB-36c } \\
\text { c4p5 }\end{array}$ & $\begin{array}{c}\text { PB-47B } \\
c 1 p 1\end{array}$ & $\begin{array}{l}\text { PB-47B } \\
\text { c1p10 }\end{array}$ \\
\hline $\mathrm{SiO} 2$ & 39.59 & 39.32 & 39.93 & 39.52 & 40.23 & 39.34 & 39.83 & 40.42 & 39.77 & 39.60 & 39.20 & 40.33 & 40.94 \\
\hline $\mathrm{TiO} 2$ & 2.38 & 2.95 & 2.92 & 2.91 & 2.59 & 2.66 & 2.91 & 2.80 & 3.13 & 3.45 & 3.40 & 0.94 & 0.99 \\
\hline Al2O3 & 12.19 & 12.32 & 12.47 & 12.31 & 12.15 & 12.24 & 12.45 & 12.35 & 12.43 & 12.30 & 12.35 & 11,34 & 11.55 \\
\hline $\mathrm{FeO}$ & 995 & 9.59 & 10.52 & 10.11 & 9.93 & 10.75 & $9.3^{7}$ & 9.84 & 10.10 & 10.61 & 10.18 & 877 & 9.24 \\
\hline MnO & 0.13 & 0.14 & 0.15 & 0.15 & 0.11 & 0.09 & 0.13 & 0.17 & 0.09 & 0.11 & 0.12 & 0.43 & 0.34 \\
\hline $\mathrm{MgO}$ & 98.47 & 19.65 & 19.18 & 19.31 & 19.44 & 18.28 & 19.67 & 19.89 & $18.4 \mathrm{E}$ & 16.90 & 13.77 & 21.68 & 21.10 \\
\hline $\mathrm{K} 20$ & 9.78 & 9.87 & 9.49 & 9.54 & $9.70 \hat{~}$ & 9.95 & 8.36 & 9.73 & 9.61 & 9.76 & 9.66 & 9.92 & 15.66 \\
\hline $\mathrm{BaO}$ & 0.87 & 0.71 & 0.77 & 0.82 & 0.90 & 0.83 & 0.81 & 0.62 & 0.65 & 0.46 & 0.55 & 0.00 & 0.00 \\
\hline$F$ & 1.74 & 1.28 & 1.22 & 1.26 & 1.10 & 1.57 & 1.55 & 1.16 & 1.59 & 1.12 & 1.12 & 3.47 & 2.61 \\
\hline $\mathrm{Cl}$ & 0.08 & 0.04 & 0.03 & 0.07 & 0.08 & 0.07 & 0.09 & 0.07 & 0.11 & 0.09 & 0.09 & 0.05 & 0.03 \\
\hline Tolal & $96 . \hat{0} 3$ & 86.63 & $96.5^{-1}$ & 86.25 & 96.52 & 96.47 & 96.66 & 97.35 & 97.08 & 86.57 & 95.68 & 36.14 & 87.10 \\
\hline $\mathrm{D}=\mathrm{F}, \mathrm{Cl}$ & 0.75 & 0.55 & 0.52 & 0.54 & 0.48 & 0.68 & 0.67 & 0.50 & 0.70 & 0.49 & 0.49 & 1.47 & 1.10 \\
\hline CTotal & 95.380 & $95.46^{\prime \prime}$ & 96.290 & 95.710 & 96.040 & 95.790 & 95.990 & 96.850 & 96.350 & 96.020 & $\$ 5.190$ & 96.670 & 96.000 \\
\hline $\mathrm{Si}$ & 5.573 & 5.541 & 5.579 & $5.5 B \mathrm{~B}$ & 5.Eิ" & 5.571 & 5.570 & 5.594 & 5.557 & 5.550 & 5.541 & 5.695 & 5.735 \\
\hline AIV & 2.022 & 2.044 & 2.051 & 2.052 & 2.503 & 2.041 & 2.051 & 2.015 & 2.045 & 2.029 & 2.056 & 1.944 & 1.905 \\
\hline $\mathrm{Ti}$ & 0.335 & 0.313 & 0.357 & 0.302 & 0.272 & 0.224 & 0.306 & $0.29^{1}$ & 0.329 & 0.363 & 0.361 & 0.099 & 0.105 \\
\hline $\mathrm{F}_{\mathrm{Q} 2}$ & 1.171 & 1.131 & 1.229 & 1.190 & 1.162 & 1.273 & 1.155 & 1.139 & 7.181 & 1.244 & 1.204 & 1.023 & 1.DE3 \\
\hline Mn & $0.0^{1} 6$ & 0.017 & 0.018 & 0.018 & 0.013 & 0.010 & 0.015 & 0.020 & 0.010 & 0.013 & 0.015 & 0.051 & C. .040 \\
\hline $\mathrm{Ba}$ & 0.0 .37 & c. .039 & 0.042 & 0.045 & 0.249 & 0.046 & 0.033 & 0.023 & 0.036 & 0.025 & 0.030 & 0.000 & $0 . x 0$ \\
\hline $\mathrm{Mg}$ & 4.036 & 4.128 & 3.894 & 4.049 & 4.258 & 3.826 & 4.102 & 4.124 & 4.054 & 3.949 & 3.956 & 4.5.38 & $4.4 C 5$ \\
\hline $\mathrm{Na}$ & 0.039 & 0.342 & 0.038 & 0.049 & 0.057 & 0.020 & 0.052 & 0.055 & 0.041 & 0.050 & 0.062 & 0.056 & C.J67 \\
\hline $\mathrm{K}$ & 1.757 & 1.774 & 1692 & 1.712 & 1.746 & 1.797 & 1. 670 & 1.717 & 1.714 & 1.745 & 1.742 & 1.765 & 1.797 \\
\hline Cations & 15.006 & 15.029 & 14.950 & 14.983 & 14.991 & 15.037 & 14.954 & 14.988 & 14.987 & 14.968 & 14.967 & 15.141 & 15.197 \\
\hline CF & 1.519 & 1.750 & 1.079 & 1.118 & 0.975 & 1.410 & 1.368 & 1.012 & 7.407 & 0.889 & 0.997 & 3.665 & $2.3 c 9$ \\
\hline $\mathrm{CCl}$ & 0.040 & 0.021 & 0.013 & 0.032 & 0.038 & 0.034 & 0.043 & 0.034 & 0.053 & 0.043 & 0.043 & 0.025 & 0.016 \\
\hline $\mathrm{Fe} /(\mathrm{Fe}+\mathrm{Mg})$ & 0.22 & 0.22 & 0.24 & 0.23 & 0.22 & 0.24 & 0.22 & 0.22 & 0.23 & 0.24 & 0.23 & 0.18 & 0.20 \\
\hline $\mathrm{Mg}(\mathrm{Fe}+\mathrm{Mg})$ & 0.78 & 0.78 & 0.76 & 0.77 & 0.76 & 0.76 & 0.78 & 0.78 & 0.77 & 0.76 & 0.77 & 0.82 & 0.80 \\
\hline
\end{tabular}

Fómu la Estrutural calculada com base em 22 oxigênios.

Análises Quimicas WDS em Cristais de Biotita do Sienito Pedra Branca. 


\begin{tabular}{|c|c|c|c|c|c|c|c|c|c|c|c|c|c|}
\hline $\begin{array}{l}\text { Amostra } \\
\text { Análise }\end{array}$ & $\begin{array}{c}\mathrm{PB}-47 \mathrm{~B} \\
\mathrm{c} 1 \mathrm{p} 2\end{array}$ & $\begin{array}{c}\text { PB-47B } \\
\text { c-1p3 }\end{array}$ & $\begin{array}{l}\text { PB-47B } \\
\text { c1p4 }\end{array}$ & $\begin{array}{c}\text { PB-47B } \\
\text { c1p5 }\end{array}$ & $\begin{array}{c}\text { PB-47B } \\
\text { c1p6 }\end{array}$ & $\begin{array}{c}\text { PB-47B } \\
\text { c1p7 }\end{array}$ & $\begin{array}{c}\text { PBA7B } \\
\text { c1pB }\end{array}$ & $\begin{array}{c}\text { PB-47B } \\
\text { c1p9 }\end{array}$ & $\begin{array}{c}\text { PB-92A } \\
\text { p1 }\end{array}$ & $\begin{array}{c}\text { PB-92A } \\
\text { p12 }\end{array}$ & $\begin{array}{c}\text { PB-92A } \\
\text { p13 } \\
\text { SLSI }\end{array}$ & $\begin{array}{c}\text { PB-92A } \\
\text { P4 }\end{array}$ & $\begin{array}{c}\text { PB.92A } \\
\text { p6 }\end{array}$ \\
\hline $\mathrm{SiO}_{2}$ & 40.36 & 40.51 & 40.66 & 40.18 & 40.58 & 40.22 & 40.06 & 40.25 & 40.63 & 40.69 & 40.30 & 39.71 & 40.05 \\
\hline $\mathrm{TiO}_{2}$ & 0.95 & 1.19 & 1.15 & 1.27 & 1.17 & 1.14 & 1.06 & 1.24 & 1.20 & 1.19 & 1.47 & 1.24 & 0.96 \\
\hline Al2O3 & 11.73 & 11.60 & 11.72 & 11.81 & 11.63 & $11.4 \mathrm{~g}$ & 11.44 & 11.31 & 11.32 & 11.81 & 11.73 & 11.67 & 11.75 \\
\hline $\mathrm{FeO}$ & 9.96 & 9.55 & 9.19 & 9.45 & 9.42 & 3.36 & 9.36 & 9.39 & 10.84 & 10.79 & 10.87 & 11.24 & 10.74 \\
\hline Mno & 0.37 & 0.35 & 0.35 & 0.31 & 0.29 & 0.29 & 0.32 & 0.22 & 0.34 & 0.37 & 0.33 & 0.37 & 0.44 \\
\hline $\mathrm{MgO}$ & 21.31 & 21.02 & 20.32 & 20.72 & 20.77 & 2122 & $20.7 \mathrm{~s}$ & 2.5 .87 & 18.11 & 19.23 & 13. . $^{-1}$ & 78.55 & 19.71 \\
\hline $\mathrm{K} 20$ & 9.95 & 9.78 & 9.85 & 8.71 & 10.23 & อ. .0 อ & Q.BE & 9.47 & 9.67 & 9.79 & 9.70 & 9.79 & 9.88 \\
\hline $\mathrm{BaO}$ & 0.00 & 0.00 & $0.0^{\prime}$ & 0.00 & 0.00 & 0.00 & 0.00 & 0.00 & 0.58 & 0.30 & 0.52 & 0.49 & 0.44 \\
\hline$F$ & 2.61 & 2.84 & 2.09 & 2.31 & 3.17 & 3.26 & 2.30 & 3.20 & $3.7^{\circ}$ & 3.44 & 3.55 & 3.57 & 3.75 \\
\hline $\mathrm{Cl}$ & 0.03 & 0.02 & 0.02 & 0.00 & 0.06 & 0.02 & 0.03 & 0.02 & 0.00 & 0.00 & 0.01 & 0.00 & 0.00 \\
\hline Tolal & 96.65 & 87.10 & 97.04 & 86.11 & 97.59 & 97.10 & 96.46 & 95.27 & 38.32 & 87.87 & 97.54 & 97.35 & $87 . \& 9$ \\
\hline $\mathrm{O}=\mathrm{F}, \mathrm{Cl}$ & 1.11 & 1.20 & 1.22 & 0.97 & 1.35 & 1.38 & 1.19 & 1.35 & 1.56 & 1.45 & 1.50 & 1.50 & 1.58 \\
\hline CTotal & 95.540 & 95.900 & 95.820 & 95.140 & 96.240 & 95.720 & 95.200 & 94.920 & 96.760 & 96.420 & 96.040 & 96.350 & 96.410 \\
\hline $\mathrm{Si}$ & 5.631 & 5.693 & 5.714 & 5.672 & 5.705 & 5679 & 5686 & 5.716 & 5.744 & 5.747 & 5.734 & 5.656 & 5691 \\
\hline AIIV & 1.945 & 1.921 & 1.939 & 1.964 & 1.926 & 1.911 & 1.911 & 1.892 & 1.968 & 1.965 & 1.965 & 1.958 & 1.966 \\
\hline $\mathrm{Ti}$ & 0.101 & 0.125 & $0.12^{1}$ & 0.135 & 0.124 & 0.121 & 0.113 & 0.193 & 0.128 & 0.126 & 0.157 & 0.133 & 0.103 \\
\hline $\mathrm{F}_{\mathrm{Q} 2}$ & 1.067 & 1.122 & 1.CBO & 1.116 & 1.108 & 1.106 & 1.173 & 1.116 & $1.28 \hat{2}$ & 1.275 & 1.293 & 1.339 & 1.276 \\
\hline Mn & 0.044 & 0.042 & $0 . c 42$ & 0.037 & 0.035 & 0.035 & 0.038 & 0.027 & 0.041 & 0.044 & 0.040 & 0.045 & 0.053 \\
\hline $\mathrm{Ba}$ & 0.0 .00 & C.XCO & 0.000 & 0.000 & 0.000 & $5 . C O C$ & 0.000 & 0.000 & 0.032 & 0.017 & 0.029 & 0.027 & C. 024 \\
\hline $\mathrm{Mg}$ & 4.471 & $4.4 C 5$ & 4.369 & 4.361 & 4.354 & 4.468 & 4.386 & 4.42 .3 & 4.027 & 4.049 & 3.990 & 4.151 & 4.175 \\
\hline $\mathrm{Na}$ & 0.079 & 0.067 & 0.105 & 0.097 & 0.073 & 0.023 & 0.027 & 0.083 & 0.060 & 0.071 & 0.069 & 0.081 & 0.072 \\
\hline K & 1.737 & 1.753 & 1.766 & 1.749 & 1.835 & 1.766 & 1.786 & 1.715 & 1.730 & 1.764 & $1.76^{\prime}$ & 1.779 & $1.7 \mathrm{~g}$ \\
\hline Cations & 15.175 & 15.123 & 15.128 & 15.131 & 15.160 & 15.180 & 15.180 & 15.102 & 15.062 & 15.058 & 15.038 & 15.149 & 15.153 \\
\hline CF & 2.323 & 2.521 & $2.57^{\circ}$ & 2.058 & 2.819 & 2.815 & 2.515 & 2.874 & 3.317 & $3.07 \hat{3}$ & 3.195 & 3.216 & 3.370 \\
\hline $\mathrm{CCl}$ & $0.0^{1} 4$ & 0.008 & 0.011 & 0.000 & 0.027 & 0.009 & 0.015 & 0.010 & 0.000 & 0.000 & 0.005 & 0.000 & 0.000 \\
\hline $\mathrm{Fe} /(\mathrm{Fe}+\mathrm{Mg})$ & 0.19 & 0.20 & 0.20 & 0.20 & 0.20 & 0.20 & 0.21 & 0.20 & 0.24 & 0.24 & 0.24 & 0.24 & 0.23 \\
\hline $\mathrm{Mg} / \mathrm{Fe}+\mathrm{Mg})$ & 0.31 & 0.80 & 0.80 & 0.20 & 0.80 & 0.60 & 0.79 & 0.80 & 0.76 & 0.76 & 0.76 & 0.76 & 0.77 \\
\hline
\end{tabular}

Fómu la Estrutural calculada com base em 22 oxigênios. 


\begin{tabular}{|c|c|c|c|}
\hline $\begin{array}{l}\text { Amosira } \\
\text { Análise }\end{array}$ & $\begin{array}{c}\text { PB-123A } \\
\text { p20 }\end{array}$ & $\begin{array}{c}\text { PB-123A } \\
\text { P21 } \\
\text { SLS }\end{array}$ & $\begin{array}{c}\text { PB.123A } \\
\text { p24 }\end{array}$ \\
\hline $\mathrm{SiO} 2$ & 39.61 & 40.06 & 39.51 \\
\hline $\mathrm{TiO} 2$ & 3.15 & 2.35 & 3.18 \\
\hline $\mathrm{Al} 203$ & 12.25 & 12.47 & 12.25 \\
\hline $\mathrm{FeO}$ & 11.96 & $11.0 \mathrm{E}$ & 10.83 \\
\hline $\mathrm{MnO}$ & 0.11 & 0.06 & 0.06 \\
\hline $\mathrm{MgO}$ & 18.28 & 17.95 & 13.2.) \\
\hline $\mathrm{Na} 2 \mathrm{O}$ & 0.18 & 0.12 & 0.09 \\
\hline $\mathrm{K} 2 \mathrm{O}$ & 3.61 & S. .6 & 9.69 \\
\hline $\mathrm{BaO}$ & 0.69 & 0.54 & 0.67 \\
\hline$F$ & 3.23 & 2.78 & 3.31 \\
\hline $\mathrm{Cl}$ & 0.26 & $0.2^{7}$ & 0.29 \\
\hline Total & 99.30 & 97.76 & 93.13 \\
\hline $\mathrm{O}=\mathrm{F}, \mathrm{Cl}$ & 1.42 & 1.23 & 1.46 \\
\hline CTotal & 97.580 & $96.5^{2} 0$ & 96.720 \\
\hline $\mathrm{Si}$ & 5.562 & 5.647 & 5.584 \\
\hline AllV & 2.026 & 2.070 & 2.043 \\
\hline AlVI & 9.000 & 0.000 & 0.000 \\
\hline $\mathrm{Ti}$ & 0.333 & 0.302 & 0.399 \\
\hline $\mathrm{Fe} 2$ & 1.404 & 1.304 & 1.284 \\
\hline $\mathrm{Mn}$ & 0.013 & 0.007 & 0.007 \\
\hline $\mathrm{Ba}$ & 0.038 & 0.030 & 0.037 \\
\hline $\mathrm{Mg}$ & 3.628 & 3.772 & 3.842 \\
\hline $\mathrm{Na}$ & 0.044 & 0.039 & 0.025 \\
\hline K & 1.722 & 1.726 & 1.750 \\
\hline Cations & 14.971 & 14.381 & 14.931 \\
\hline CF & 2.868 & 2.478 & 2.964 \\
\hline $\mathrm{CCl}$ & 0.124 & 0.129 & 0.139 \\
\hline $\mathrm{Fe} /(\mathrm{Fe}+\mathrm{Mg})$ & 0.27 & 0.26 & 0.25 \\
\hline $\mathrm{Mg} /(\mathrm{Fe}+\mathrm{Mg})$ & 0.73 & 0.74 & 0.75 \\
\hline
\end{tabular}

Fómu la Estrutural calculada com base ern 22 oxigênios. 
Tabela 5: Análises WDS em cristais de óxidos de Fe-Ti do Sienito Pedra Branca. 


\begin{tabular}{|c|c|c|c|c|c|c|c|}
\hline & $\begin{array}{l}\text { Amostra } \\
\text { Análise }\end{array}$ & $\begin{array}{c}\text { Media do Grao } \\
\text { PB42A } \\
\text { SLSI } \\
\text { Hem }\end{array}$ & Desvio Padrao & $\begin{array}{c}\text { Media do Grao } \\
\text { PB47B } \\
\text { SLSI } \\
\text { Mt }\end{array}$ & Desvio Padrao & $\begin{array}{c}\text { Media do Grao } \\
\text { PB181 } \\
\text { SLSI } \\
\text { Hem }\end{array}$ & $\begin{array}{c}\text { Desvio Padrao } \\
\text { c1p1 }\end{array}$ \\
\hline & $\mathrm{SiO2}$ & 0.03 & 0.03 & 0.02 & 0.01 & 0.03 & 0.02 \\
\hline & $\mathrm{T} 102$ & 16.94 & 0.71 & 0.05 & 0.05 & 17.98 & 3.38 \\
\hline & Al203 & 0.06 & 0.02 & 0.02 & 0.01 & 0.18 & 0.15 \\
\hline \multicolumn{8}{|c|}{$\mathrm{Fe} 203(\mathrm{~T})$} \\
\hline & $\mathrm{Cr}_{2} \mathrm{O} 3$ & 0.06 & 0.02 & 0.12 & 0.00 & 0.09 & 0.02 \\
\hline & $\mathrm{FeO}(\mathrm{T})$ & 75.05 & 0.58 & 92.04 & 0.19 & 73.62 & 2.72 \\
\hline & $\mathrm{MnO}$ & 0.18 & 0.03 & 0.30 & 0.00 & 0.79 & 0.20 \\
\hline & $\mathrm{MgO}$ & 0.06 & 0.02 & 0.03 & 0.02 & 0.08 & 0.03 \\
\hline & $\mathrm{CaO}$ & 0.02 & 0.00 & 0.07 & 0.03 & 0.02 & 0.02 \\
\hline & Soma & 92.40 & 0.67 & 8266 & $0.1 \hat{3}$ & 92.78 & C.93 \\
\hline & Fe203 wt. $\%$ & 66.79 & 1.14 & 62.37 & 0.19 & 64.90 & 6.21 \\
\hline & $\mathrm{FeO}$ wit. " \%/ & 14.96 & 0.62 & 30.53 & 0.01 & 15.22 & 2.32 \\
\hline & total & 99.09 & 0.66 & $\$ 9.51$ & 0.15 & 99.29 & 0.45 \\
\hline \multirow{2}{*}{\multicolumn{8}{|c|}{ 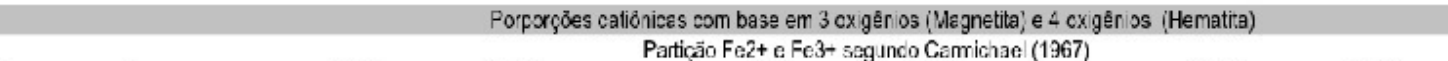 }} \\
\hline & & & & & & & \\
\hline 1 & Si & $0.00^{1}$ & 0.001 & 0.001 & 0.000 & 0.001 & 0.001 \\
\hline 1 & $T$ & 0.336 & 0.013 & 0.002 & 0.001 & 0.355 & 0.065 \\
\hline 2 & A & $0.0 \times 2$ & .0001 & $C . \times 1$ & $0 . \times 1$ & 0.005 & 0.0 .05 \\
\hline 2 & $F a-s$ & 1.324 & 0.025 & 1991 & 0.003 & 1.282 & $0.13 \mathrm{C}$ \\
\hline 1 & $F e-2$ & 0.329 & 0.012 & C.386̂ & 0.001 & 0.334 & $0.06 \mathrm{C}$ \\
\hline 1 & $\mathrm{Mn}$ & 0.004 & 0.001 & 0.010 & 0.500 & 0.018 & 0.034 \\
\hline 1 & $\mathrm{Mg}$ & 0.002 & 0.001 & 0.002 & 0.001 & 0.003 & 0.001 \\
\hline 1 & $\mathrm{Cz}$ & 0.001 & 0.001 & 0.003 & 0.001 & 0.001 & 0.001 \\
\hline \multirow[t]{2}{*}{2} & $\mathrm{Cr}$ & $0.00^{\prime}$ & 0.000 & C. .0.4 & 0.000 & 0.002 & 0.000 \\
\hline & Total: & 2.000 & & 3.000 & & 2.000 & \\
\hline
\end{tabular}

Análises quimicas WDS em óxidos de Fe.Ti do Sien ito Pedra Branca. 


\begin{tabular}{|c|c|c|c|c|c|c|c|}
\hline & $\begin{array}{l}\text { Amostra } \\
\text { Análise }\end{array}$ & $\begin{array}{c}\text { Media do Grao } \\
\text { PB1B1 } \\
\text { SLSI } \\
\text { Hem }\end{array}$ & $\begin{array}{c}\text { Desvio Padrao } \\
\text { c1p5 }\end{array}$ & $\begin{array}{c}\text { Me dia do Grao } \\
\text { PB181 } \\
\text { SLSI } \\
\text { Mt }\end{array}$ & $\begin{array}{c}\text { Desvio Padrao } \\
\text { c1p20-21 }\end{array}$ & $\begin{array}{c}\text { Media do Grao } \\
\text { PB181 } \\
\text { SLSI } \\
\text { Mt }\end{array}$ & $\begin{array}{c}\text { Desvio Padrao } \\
\text { c1-p8-p22 }\end{array}$ \\
\hline & $\mathrm{SiO}_{2}$ & 0.13 & 0.12 & 0.03 & 0.01 & 0.08 & 0.06 \\
\hline & T102 & 19.49 & 1.29 & 0.09 & 0.13 & 0.22 & 0.06 \\
\hline & $\mathrm{Al} 2 \mathrm{O} 3$ & 0.14 & 0.11 & 0.06 & 0.01 & 0.08 & 0.91 \\
\hline \multicolumn{8}{|c|}{$\mathrm{Fe} 203(\mathrm{~T})$} \\
\hline & $\mathrm{Cr}_{2} \mathrm{O}_{3}$ & 0.12 & 0.62 & C. 16 & 0.23 & 0.16 & 0.06 \\
\hline & $\mathrm{FeO}(\mathrm{T})$ & 73.00 & 1.62 & 93.16 & 0.21 & 92.92 & 0.44 \\
\hline & $\mathrm{MnO}$ & 0.53 & 0.11 & 0.06 & 0.00 & 0.04 & 0.01 \\
\hline & $\mathrm{MgO}$ & 0.05 & .0 .03 & 0.21 & 0.01 & 0.09 & 0.02 \\
\hline & $\mathrm{CaO}$ & 0.11 & 0.14 & 0.02 & 0.01 & 0.04 & 0.02 \\
\hline & Sorna & 93.6 .0 & $D .64$ & 91.60 & 0.00 & 91.60 & 0.00 \\
\hline & $\mathrm{Fe} 203$ wt. $\%$ & 62.34 & 2.30 & 68.83 & 0.29 & 68.42 & 0.18 \\
\hline & $\mathrm{FeO}$ wt. $\%$ & 16.9.) & 1.17 & 31.23 & 0.26 & 31.36 & 0.28 \\
\hline & total & 99.64 & 0.63 & 100.50 & 0.12 & 100.40 & 0.68 \\
\hline \multirow{2}{*}{\multicolumn{8}{|c|}{ 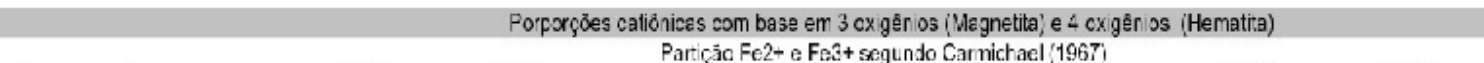 }} \\
\hline & & & & & & & \\
\hline 1 & S & 0.003 & 0.003 & 0.001 & 0.500 & 0.003 & 0.002 \\
\hline 1 & $\mathrm{~T}$ & 0.382 & 0.025 & 0.003 & 0.004 & 0.006 & 0.002 \\
\hline 2 & A & $0 . C 04$ & 0.004 & $0.00 \mathrm{~s}$ & $0 . x 1$ & 0.004 & $2.0 x$ \\
\hline 2 & $F a-s$ & 1.222 & 0.045 & 1.984 & 0.006 & 1.973 & 0.025 \\
\hline 1 & $\mathrm{Fe}-2$ & 0.363 & 0.025 & 1.900 & 0.003 & 1.005 & 0.001 \\
\hline 1 & $\mathrm{Nn}$ & 0.012 & 0.002 & 0.002 & 0.500 & 0.001 & 0.000 \\
\hline 1 & $\mathrm{Ng}$ & 0.002 & $0.00^{\circ}$ & 0.000 & 0.001 & 0.001 & 0.001 \\
\hline 1 & $\mathrm{Cr}$ & 0.003 & 0.004 & 0.001 & 0.000 & 0.002 & 0.001 \\
\hline \multirow[t]{2}{*}{2} & $\mathrm{Cr}_{\mathrm{r}}$ & $0 . .003$ & 0.000 & 0.005 & $0.0 \times 1$ & 0.005 & 0.0 .02 \\
\hline & Total: & 2.000 & & 3.000 & & 3.000 & \\
\hline
\end{tabular}

Análises quimicas WDS em óxidos de Fe-Ti do Sien ito Pedra Branca. 


\begin{tabular}{|c|c|c|c|c|c|c|c|}
\hline & $\begin{array}{l}\text { Amostra } \\
\text { Análise }\end{array}$ & $\begin{array}{c}\text { Media do Grao } \\
\text { PB181 } \\
\text { SLSI } \\
\text { Hem }\end{array}$ & $\begin{array}{c}\text { Desvio Padrao } \\
\text { c2p1-7 }\end{array}$ & $\begin{array}{c}\text { Media do Grao } \\
\text { PB181 } \\
\text { SLSI } \\
\text { Hem }\end{array}$ & $\begin{array}{c}\text { Desvio Padrao } \\
\text { C2p2-4-5-10 }\end{array}$ & $\begin{array}{c}\text { Media do Grao } \\
\text { PB181 } \\
\text { SLSI } \\
\text { Hem }\end{array}$ & $\begin{array}{c}\text { Desvio Padrao } \\
\text { c2-p6-9-11-12-12-14 }\end{array}$ \\
\hline & $\mathrm{SiO} 2$ & 0.01 & 0.01 & 0.01 & 0.01 & 0.03 & 0.01 \\
\hline & $\mathrm{TIOZ}$ & $20.4^{7}$ & 0.80 & 18.11 & 0.81 & 17.24 & 0.81 \\
\hline & Al203 & 0.03 & 0.01 & 0.04 & 0.09 & 0.08 & 0.04 \\
\hline \multicolumn{8}{|c|}{$\mathrm{Fe} 203(\mathrm{~T})$} \\
\hline & $\mathrm{Cr} 203$ & 0.09 & $C . x$ & 0.11 & 0.01 & 0.14 & 0.02 \\
\hline & $\mathrm{FeO}(\mathrm{T})$ & 72.41 & 0.17 & 75.10 & 1.50 & 74.80 & 0.31 \\
\hline & $\mathrm{MnO}$ & 0.34 & 0.02 & 0.27 & 0.03 & 0.31 & 0.08 \\
\hline & $\mathrm{MgO}$ & 0.08 & 0.01 & 0.07 & 0.01 & 0.06 & 0.02 \\
\hline & $\mathrm{GaO}$ & 0.02 & 0.02 & 0.03 & 0.02 & 0.04 & 0.05 \\
\hline & Soma & 93.46 & C.ES & 91.73 & 0.93 & 92.77 & 1.08 \\
\hline & $\mathrm{Fe} 203$ wt. $\%$ & $6 C .57$ & 1.01 & $67 . \hat{3}$ & 2.40 & 66.47 & 1.23 \\
\hline & $\mathrm{FeO}$ wt. \% & 17.91 & C. 74 & 14.06 & 0.72 & 15.07 & 0.78 \\
\hline & lotal & $99.5^{\circ}$ & 0.53 & 98.53 & 1.14 & 99.43 & 1.08 \\
\hline \multicolumn{8}{|c|}{ Popo'çరెes catićnizas com oase en 3 oxiçên 03 (Magnetia) e 4 oxiçên 03 iHematile) } \\
\hline & \multicolumn{7}{|c|}{ Partiçäo Fe2 + e Fêे- segundo Cam ichael (1967) } \\
\hline 1 & $\mathrm{Si}$ & $0.0 x$ & 0.000 & 0.000 & 0.000 & 0.001 & 0.000 \\
\hline 1 & 7 & 0.403 & 0.013 & 0.321 & 0.018 & 0.340 & 0.014 \\
\hline 2 & Al & 0.0 .51 & 0.020 & $0.00^{4}$ & 0.000 & 0.002 & 0.001 \\
\hline 2 & $\mathrm{Fe}+3$ & 1.192 & 0.027 & 1.353 & 0.036 & 1.313 & 0.028 \\
\hline 1 & $\mathrm{~F} \in+2$ & 0.391 & 0.014 & 0.312 & 0.018 & 0.331 & 0.015 \\
\hline 1 & P.n & 0.038 & 0.001 & 0.005 & 0.001 & 0.007 & 0.001 \\
\hline 1 & P.lg & 0.003 & 0.000 & 0.003 & 0.001 & 0.002 & 0.001 \\
\hline 1 & $\mathrm{C}_{9}$ & $0.0 x 0$ & 0.001 & 0.001 & 0.001 & 0.001 & 0.002 \\
\hline \multirow[t]{2}{*}{2} & $a$ & 0.002 & 0.000 & 0.002 & 0.000 & 0.003 & 0.000 \\
\hline & Total: & $2.0 x$ & & 2.000 & & 2.000 & \\
\hline
\end{tabular}

Análises quimicas WDS em óxidos de Fe.Ti do Sien ito Pedra Branca. 


\begin{tabular}{|c|c|c|c|c|c|c|c|}
\hline & $\begin{array}{l}\text { Amostra } \\
\text { Análise }\end{array}$ & $\begin{array}{c}\text { Media do Grao } \\
\text { PB181 } \\
\text { SLSI } \\
\text { Hem }\end{array}$ & $\begin{array}{c}\text { Desvio Padrao } \\
\text { c3-p1-2-3-5-9.10-11-12 }\end{array}$ & $\begin{array}{c}\text { Media do Grao } \\
\text { pb181 } \\
\text { SLSI } \\
\text { Hem }\end{array}$ & $\begin{array}{c}\text { Desvio Padrao } \\
\text { c1-91-2-4 }\end{array}$ & $\begin{array}{c}\text { Media do Grao } \\
\text { PB148 } \\
\text { SLS } \\
\text { IAt }\end{array}$ & $\begin{array}{l}\text { Desvio Padrao } \\
\text { c1-p5-6-10-11 }\end{array}$ \\
\hline & $\mathrm{SiO}_{2}$ & 0.03 & 0.02 & 0.02 & 0.03 & 0.05 & 0.01 \\
\hline & $\mathrm{T} 102$ & 17.30 & 0.41 & 19.40 & 2.50 & 0.11 & 0.12 \\
\hline & Al203 & 0.07 & 0.04 & 0.09 & 0.02 & 0.24 & 0.04 \\
\hline \multicolumn{8}{|c|}{$\mathrm{Fe} 203(\mathrm{~T})$} \\
\hline & $\mathrm{Cr} 203$ & 0.27 & 0.02 & 0.08 & 0.01 & 0.22 & 0.01 \\
\hline & $\mathrm{FeO}(\mathrm{T})$ & 75.06 & 0.66 & 72.68 & 2.56 & 91.72 & 0.47 \\
\hline & MnO & 0.27 & 0.02 & 0.32 & 0.07 & 0.01 & 0.01 \\
\hline & $\mathrm{MgO}$ & 0.12 & 0.15 & 0.25 & 0.05 & 0.04 & 0.02 \\
\hline & $\mathrm{CaO}$ & 0.04 & 0.03 & 0.04 & 0.03 & 0.01 & 0.01 \\
\hline & Sama & 92.36 & 0.69 & $\$ 2.68$ & 0.03 & $91.6 C$ & 0.02 \\
\hline & $\mathrm{Fe} 203$ int. \% & 66.60 & 1.16 & 62.26 & 5.19 & 67.49 & 0.43 \\
\hline & FeO wt. \% & 15.XE & 0.61 & 16.65 & 2.10 & 30.88 & 0.24 \\
\hline & total & 99.64 & 0.76 & 99.12 & 0.54 & 99.05 & 0.55 \\
\hline \multicolumn{8}{|c|}{ 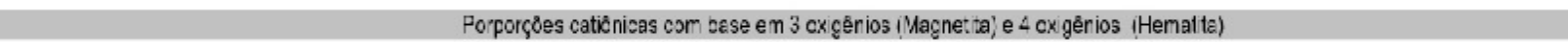 } \\
\hline \multicolumn{8}{|c|}{ Partigăc Fe2t e Feŝt segundo Carmichael (1967) } \\
\hline 1 & $\mathrm{Si}$ & 0.001 & 0.001 & 0.001 & $0.00^{\circ}$ & 0.002 & 0.001 \\
\hline 1 & $T$ & 0.341 & 0.008 & 0.383 & 0.050 & 0.003 & 0.004 \\
\hline 2 & Al & 0.092 & 0.001 & C.x.3 & C..001 & 2.011 & 0.002 \\
\hline 2 & $\mathrm{Fet}+3$ & 1.314 & 0.047 & 1.229 & C. .999 & 1.972 & 0.007 \\
\hline 1 & $\mathrm{Fe}+2$ & 0.330 & 0.074 & 0.365 & 0.047 & 1.002 & 0.004 \\
\hline 1 & IIn & $0.0 D E$ & 0.001 & 0.007 & 0.002 & 0.000 & 0.000 \\
\hline 1 & $\mathrm{ilg}$ & 0.005 & 0.006 & 0.010 & 0.002 & 0.002 & 0.001 \\
\hline 1 & $\mathrm{Ca}$ & 0.001 & 0.001 & 0.001 & $0.000^{\circ}$ & 0.001 & 0.001 \\
\hline \multirow[t]{2}{*}{2} & $\mathrm{Cr}$ & 0.002 & 0.000 & $0.0 \times 2$ & 0.000 & 0.027 & 0.001 \\
\hline & Total: & 2.000 & & 2.000 & 0.000 & 3.000 & \\
\hline
\end{tabular}

Análises quimicas WDS em óxidos de Fe-Ti do Sien ito Pedra Branca. 


\begin{tabular}{|c|c|c|c|c|c|c|c|}
\hline & $\begin{array}{l}\text { Amostra } \\
\text { Análise }\end{array}$ & $\begin{array}{c}\text { Media do Grao } \\
\text { PB148 } \\
\text { SLS } \\
\text { Hem }\end{array}$ & $\begin{array}{c}\text { Desvio Padrao } \\
\text { c2-p1-2-3-5-6 }\end{array}$ & $\begin{array}{c}\text { Me dia do Grao } \\
\text { PB148 } \\
\text { SLS } \\
\text { Hem }\end{array}$ & $\begin{array}{c}\text { Desvio Padrao } \\
\text { C2P7 }\end{array}$ & $\begin{array}{c}\text { Media do Grao } \\
\text { PB148 } \\
\text { SLS } \\
\text { Mt }\end{array}$ & $\begin{array}{c}\text { Desvio Padrao } \\
\text { c5-p5.6 }\end{array}$ \\
\hline & $\mathrm{SiO}_{2}$ & 0.25 & 0.50 & 0.015 & 0.015 & 0.05 & 0.50 \\
\hline & T102 & 17.83 & 1.80 & 38.570 & 38.57 & 0.11 & 0.15 \\
\hline & $\mathrm{Al} 2 \mathrm{O} 3$ & $0 . .53$ & $2 . C 6$ & 0.016 & 0.016 & 0.22 & 0.91 \\
\hline \multicolumn{8}{|c|}{$\mathrm{Fe} 203(\mathrm{~T})$} \\
\hline & $\mathrm{Cr}_{2} \mathrm{O}_{3}$ & 0.13 & 0.62 & 0.102 & 0.102 & 0.25 & 0.00 \\
\hline & $\mathrm{FeO}(\mathrm{T})$ & 73.82 & 1.65 & 56.052 & 56.062 & 92.11 & 0.43 \\
\hline & $\mathrm{MnO}$ & 0.15 & 0.04 & 0.43 & 0.43 & 0.00 & 0.01 \\
\hline & $\mathrm{MgO}$ & 0.12 & 2.64 & 0.343 & 0.343 & 0.02 & 0.03 \\
\hline & $\mathrm{CaO}$ & 0.17 & 0.32 & 0.036 & 0.006 & 0.09 & 0.01 \\
\hline & Sorna & 92.63 & 0.47 & 95.584 & 95.594 & 91.60 & 0.00 \\
\hline & $\mathrm{Fe} 203$ wt. $\%$ & 64.53 & 3.68 & $24.96186 .250 \hat{~}$ & & 67.25 & 0.16 \\
\hline & $\mathrm{FeO}$ wt. $\%$ & 15.76 & 1.55 & 33.62106764 & & 31.06 & 0.28 \\
\hline & total & 99.10 & 0.54 & $98.0 \leq \leq 96321$ & & 99.57 & 0.62 \\
\hline \multirow{2}{*}{\multicolumn{8}{|c|}{ 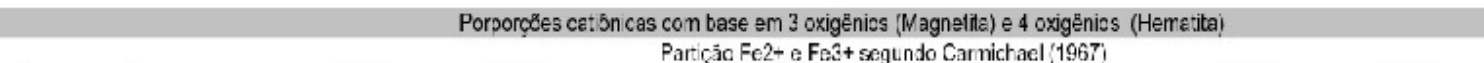 }} \\
\hline & & & & & & & \\
\hline 1 & S & 0.005 & 0.013 & 0.000389876 & & 0.002 & 0.000 \\
\hline 1 & $\mathrm{~T}$ & 0.353 & 0.036 & 0.754198231 & & 0.003 & 0.004 \\
\hline 2 & A & $0 . C 02$ & $0 . \mathrm{CO} 2$ & C. 00040013 & & 0.010 & $2.0 x$ \\
\hline 2 & $F a-s$ & 1.275 & 9.073 & 0.4882375661 & & 1.972 & 0.0 .28 \\
\hline 1 & $\mathrm{Fe}-2$ & 0.346 & 0.034 & $0.73 \cos 6631$ & & 1.003 & 0.003 \\
\hline 1 & $\mathrm{Nn}$ & 0.004 & 0.001 & 0.005466504 & & 0.000 & 0.000 \\
\hline 1 & $\mathrm{Ng}$ & 0.005 & 0.002 & 0.01329041 & & 0.001 & 0.001 \\
\hline 1 & $\mathrm{Cr}$ & 0.005 & 0.609 & 0.001002562 & & 0.000 & 0.001 \\
\hline \multirow[t]{2}{*}{2} & $\mathrm{Gr}$ & 0.603 & 0.002 & 0.002.99E:994 & & 0.008 & 0.0 .00 \\
\hline & Total: & 2.000 & & 2 & & 3.000 & \\
\hline
\end{tabular}

Análises quimicas WDS em óxidos de Fe-Ti do Sien ito Pedra Branca. 


\begin{tabular}{|c|c|c|c|c|c|c|c|c|}
\hline & $\begin{array}{l}\text { Amostra } \\
\text { Análise }\end{array}$ & $\begin{array}{c}\text { Media do Grao } \\
\text { PB148 } \\
\text { SLS } \\
\text { Mt }\end{array}$ & $\begin{array}{c}\text { Desvio Padrao } \\
\text { c5-p10.11-12 }\end{array}$ & $\begin{array}{c}\text { Media do Grao } \\
\text { PB148 } \\
\text { SLS } \\
\text { MI }\end{array}$ & $\begin{array}{c}\text { Desvio Padrao } \\
\text { c7-p1-2-3 }\end{array}$ & $\begin{array}{c}\text { PB148 } \\
\text { c7pd } \\
\text { Hem }\end{array}$ & $\begin{array}{c}\text { Media do Grao } \\
\text { PB148 } \\
\text { SLS }\end{array}$ & $\begin{array}{c}\text { Desvio Padrao } \\
\text { c5-p5-6.7-8 } \\
\text { Mit }\end{array}$ \\
\hline & $\mathrm{SiO} 2$ & 0.04 & 0.01 & 0.08 & 0.03 & 0.05 & 0.04 & 0.02 \\
\hline & $\mathrm{T} \mid 02$ & 0.08 & 0.08 & 0.03 & 0.03 & 19.59 & 0.09 & 0.10 \\
\hline & $\mathrm{Al} 203$ & 0.22 & 0.24 & 0.13 & 0.02 & 0.06 & 0.30 & $0.0 E$ \\
\hline \multicolumn{9}{|c|}{$\mathrm{Fe} 203(\mathrm{~T})$} \\
\hline & $\mathrm{C}_{2} \mathrm{OO}$ & 0.26 & 0.02 & 2.63 & 0.04 & 0.09 & 0.09 & $0 . x$ \\
\hline & $\mathrm{MnO}$ & 0.01 & 0.01 & 0.03 & 0.03 & 0.16 & 0.03 & 0.03 \\
\hline & $\mathrm{MgO}$ & 0.22 & 0.22 & 2.07 & 0.01 & 0.13 & 0.07 & 0.24 \\
\hline & $\mathrm{CaO}$ & 0.05 & 0.03 & 0.04 & 0.09 & 0.05 & 0.05 & 0.24 \\
\hline & Soma & 91.60 & C. $x$ & 97.60 & 0.00 & $\$ 2.51$ & $91.6 C$ & $0 . x$ \\
\hline & $\mathrm{Fe} 2 \mathrm{O} 3$ w. $\%$ & $67.8 \mathrm{E}$ & 0.72 & 68.31 & 0.46 & 61.30 & 67.61 & 0.37 \\
\hline & FeO wt. \% & 30.96 & 0.22 & 30.9 .3 & 0.16 & 17.23 & 30.72 & 0.25 \\
\hline \multicolumn{9}{|c|}{ Po'porçōes catiōnicas com base em 3 cx gên os (Magnet ta) e 4 cx gên os (Hematita) } \\
\hline & \multicolumn{8}{|c|}{ Pattiçäo Fe2+e Fe3+ seg ndo Carmichael (1967) } \\
\hline 1 & $\mathrm{Si}$ & 0.002 & 0.000 & 0.602 & 0.001 & 0.001 & 0.001 & 0.001 \\
\hline 1 & $\mathrm{Ti}$ & 0.002 & 0.002 & $0.00^{\circ}$ & 0.001 & 0.389 & 0.003 & 0.003 \\
\hline 2 & Al & $0.0^{\circ} 0$ & 0.002 & $9 . \mathrm{COB}$ & 0.001 & 0.002 & 0.014 & 0.002 \\
\hline 2 & $\mathrm{Fe}+3$ & 1.974 & 0.004 & 1.983 & 0.001 & 1.216 & 1.975 & 0.007 \\
\hline 1 & $\mathrm{Fe}+2$ & 1.001 & 0.003 & 0.897 & 0.001 & 0.360 & 0.897 & 0.003 \\
\hline 1 & $\mathrm{Mn}$ & 0.000 & 0.000 & $0.00^{1}$ & 0.001 & 0.003 & 0.001 & 0.001 \\
\hline 1 & $\mathrm{Mg}$ & 0.001 & 0.001 & 0.004 & 0.001 & 0.005 & 0.004 & 0.002 \\
\hline 1 & Ca & 0.002 & 0.001 & 0.002 & 0.001 & 0.001 & 0.002 & 0.001 \\
\hline \multirow[t]{2}{*}{2} & Er & 0.008 & 0.001 & 0.003 & 0.001 & 0.002 & $0 . \mathrm{cos}$ & 0.000 \\
\hline & Tolal: & 3.000 & & 3.600 & & 2.000 & 3.000 & \\
\hline
\end{tabular}

Análises quimicas WDS em óxidos de Fe-Ti do Sien ito Pedra Branca. 
ANEXO III

TABELAS DE QUÍMICA DE ROCHA TOTAL 
Tabela 1: Norma CIPW em rochas do Sienito Pedra Branca. 


\begin{tabular}{|c|c|c|c|c|c|c|c|c|c|c|c|c|c|}
\hline & $\begin{array}{l}\text { PB-2 } \\
\text { SLSI }\end{array}$ & $\begin{array}{c}\text { PB-5A } \\
\text { SLS }\end{array}$ & $\begin{array}{c}\text { PB-8A } \\
\text { SLSI }\end{array}$ & $\begin{array}{c}\text { PB-8B } \\
\text { SLSI }\end{array}$ & $\begin{array}{c}\text { PB-8D } \\
\text { Enclave } \\
\text { Ultramáfleo }\end{array}$ & $\begin{array}{l}\text { PB-g } \\
\text { SSI }\end{array}$ & $\begin{array}{c}\text { PB-22 } \\
\text { SSE }\end{array}$ & $\begin{array}{c}\text { PB-25 } \\
\text { SSI }\end{array}$ & $\begin{array}{c}\text { PB-30 } \\
\text { SLSI }\end{array}$ & $\begin{array}{c}\text { PB-36A } \\
\text { SLSI }\end{array}$ & $\begin{array}{l}\text { PB-47 } \\
\text { SLSI }\end{array}$ & $\begin{array}{c}\text { PB-38 } \\
\text { SLSI }\end{array}$ & $\begin{array}{c}\text { PQ-53 } \\
\text { SSI }\end{array}$ \\
\hline cuatec & & 3.17 & & & & 2.99 & 1.45 & 6.67 & & 0.57 & & & 2.52 \\
\hline atodasio & 43.35 & 42.48 & 4325 & 4143 & $15.6 E$ & 3265 & 35.76 & 36.40 & Ac: 34 & 40.07 & 45. 0.3 & 4497 & 36.59 \\
\hline albite & 26.34 & 26.91 & 26.50 & 27.72 & 5.16 & 27.75 & 23.52 & 26.74 & 2021 & 22.25 & 23.95 & 22.39 & 30.53 \\
\hline anotila & 0.24 & 4.93 & 1.30 & 1.37 & & 8.50 & 5.44 & 7.76 & 0.59 & 1.62 & 0.45 & 0.25 & 0.51 \\
\hline nefe ina & 0.51 & & 0.08 & 0.20 & 459 & & & & 0.51 & & & 0.94 & \\
\hline ciçsidic & 15.73 & 10.52 & 15.93 & 1459 & $48 . c s$ & 10.71 & 12.72 & 6.03 & 2242 & 22.95 & 18.32 & 1835 & 10.20 \\
\hline typerseleria & & 477 & & & & 7.67 & 5.31 & 5.38 & & $2.6 \%$ & 0.50 & & 5.16 \\
\hline olivinta & 200 & & 2.50 & 2.34 & 350 & & & & 155 & & 9.75 & 187 & \\
\hline nagnetila & 259 & 2.55 & 2.75 & 2.98 & 4.77 & 3.01 & 2.92 & 2.27 & 304 & 2.38 & 2.54 & 288 & 2.60 \\
\hline ilmenite & 272 & 2.77 & 2.91 & 3.38 & 5.46 & 3.65 & 3.35 & $2.6 \epsilon$ & 3.42 & 2.50 & 3.19 & 313 & 2.81 \\
\hline apetits & 248 & 2.53 & 2.74 & 2.04 & 523 & 2.87 & 2.43 & 2.09 & 4.47 & 4.22 & 3.57 & 3.52 & 2. 18 \\
\hline ecrits & & & & & 4.01 & & & & & & & & \\
\hline \multicolumn{14}{|l|}{ let:cila } \\
\hline Tokal & 96.50 & 100.65 & 97.54 & 9604 & 97.हย & 9808 & 89.41 & 95.98 & 8737 & 99.81 & 99.68 & $\$ 632$ & 99.18 \\
\hline
\end{tabular}

NORMA CIPW EM AMOSTRAS DO SIENITO PEDRA BRANCA. 


\begin{tabular}{|c|c|c|c|c|c|c|c|c|c|c|c|c|c|}
\hline & $\begin{array}{l}\text { PB-59 } \\
\text { SSI }\end{array}$ & $\begin{array}{c}\text { PB-68B } \\
\text { SLSI }\end{array}$ & $\begin{array}{c}\text { PB-70A } \\
\text { SLSI }\end{array}$ & $\begin{array}{l}\text { PB-71 } \\
\text { SLS| }\end{array}$ & $\begin{array}{c}\text { PB-92A } \\
\text { SLSI }\end{array}$ & $\begin{array}{c}\text { PB-92B } \\
\text { SLS }\end{array}$ & $\begin{array}{l}\text { PB-114 } \\
\text { SLSI }\end{array}$ & $\begin{array}{l}\text { PB-123A } \\
\text { SLS }\end{array}$ & $\begin{array}{l}\text { PB-130 } \\
\text { SS }\end{array}$ & $\begin{array}{l}\text { PB-142 } \\
\text { SLS }\end{array}$ & $\begin{array}{l}\text { PB-148 } \\
\text { SLS }\end{array}$ & $\begin{array}{c}\text { PB-169 } \\
\text { Enclave } \\
\text { Ultramaifleo }\end{array}$ & $\begin{array}{c}\text { PB-174,A } \\
\text { SLSI }\end{array}$ \\
\hline cuatzo & 3.04 & 2.10 & 0.96 & 0.00 & & 5.05 & & 2.79 & 6.33 & 3.58 & 3.25 & & \\
\hline \multicolumn{14}{|l|}{ corinden } \\
\hline otodasio & 36.40 & 41.01 & 4261 & 4405 & 43.85 & $3 \mathrm{a} 1 \mathrm{~B}$ & 33.91 & 38.53 & 25 93 & $3 B .89$ & 38.94 & 2223 & $45.3 \mathrm{~s}$ \\
\hline albita & 25.05 & 28.05 & 27.75 & 23.35 & 27.15 & 30.29 & 23.60 & 26.49 & 28.13 & 28.85 & 27.08 & 483 & 24.79 \\
\hline anvtila & 8. 25 & 1.22 & 1.64 & 0.38 & 023 & 3.87 & 2.34 & 6.26 & 8.05 & 5.70 & 6.01 & 5.32 & 0.79 \\
\hline nefe ina & & & & & 0.72 & & & & & & & 266 & 0.37 \\
\hline cicysidic & S97 & 16.66 & 13.15 & 1751 & 16.54 & $10 \$ 0$ & 15.89 & 11.67 & 821 & 8.75 & 10.76 & 1830 & 17.09 \\
\hline 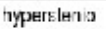 & 725 & 2.43 & 3.63 & 2.90 & & 5.62 & 3.29 & 5.14 & 533 & 4.39 & $4 . \mathrm{E} 1$ & & \\
\hline olvinira & & & & 0.92 & 0.87 & & 0.22 & & & & & 1294 & 1.67 \\
\hline magnetila & 2.82 & 2.62 & 2.31 & 2.97 & 2.72 & 2.53 & $2.6^{1}$ & 2.72 & 247 & 2.46 & 2.52 & 6.62 & 2.47 \\
\hline II menite & 3.10 & 2.68 & 2.64 & 3.28 & 3.53 & 2.41 & 2.79 & 3.04 & 277 & 2.57 & 2.67 & 1075 & 2.58 \\
\hline apatits & 229 & 2.83 & 2.41 & 2.85 & 2.32 & 2.15 & 3.11 & 2.69 & 2.13 & 2.09 & 2.49 & 6.78 & 3.13 \\
\hline \multicolumn{14}{|l|}{ acrits } \\
\hline \multicolumn{14}{|l|}{ letcila } \\
\hline Tokal & 96.17 & 99.63 & 97.13 & 9771 & 97.87 & 100.31 & 87.79 & 98.32 & $\varepsilon \& 8 \hat{0}$ & 97.86 & 98.64 & $\$ 5.00$ & 97.68 \\
\hline
\end{tabular}

NORMA CIPW EM AMOSTRAS DO SIENITO PEDRA BRANCA. 


\begin{tabular}{|c|c|c|c|c|c|c|c|c|c|c|c|c|}
\hline & $\begin{array}{c}\text { PB-181A } \\
\text { SLSI }\end{array}$ & $\begin{array}{c}\text { PB-1B5A } \\
\text { SLS }\end{array}$ & $\begin{array}{c}\text { PB-185B } \\
\text { SLS }\end{array}$ & $\begin{array}{c}\text { PB-185C } \\
\text { Enclave } \\
\text { Ultramáfleo }\end{array}$ & $\begin{array}{c}\text { PB-186B2 } \\
\text { Leucosienito }\end{array}$ & $\begin{array}{c}\text { PB-209B } \\
\text { Enclave } \\
\text { Ultramáfleo }\end{array}$ & $\begin{array}{c}\text { PB-209C } \\
\text { Enclave } \\
\text { Slenlto }\end{array}$ & $\begin{array}{l}\text { PB-210C } \\
\text { Enclave } \\
\text { Dlorlto }\end{array}$ & $\begin{array}{c}\text { PB-229 } \\
\text { SLS }\end{array}$ & $\begin{array}{c}\text { PB-247A } \\
\text { Enclave } \\
\text { Monzonlto }\end{array}$ & $\begin{array}{c}\text { P日-246B } \\
\text { Enclave } \\
\text { Dlorito }\end{array}$ & $\begin{array}{c}\text { PB-250 } \\
\text { Enclave } \\
\text { Slentlo }\end{array}$ \\
\hline quartzc & & & & & 3.71 & & & & 0.17 & & & \\
\hline Exinder & & & & & & & & 4.65 & & & 0.74 & \\
\hline artcclasic: & 4.363 & $4 \mathrm{~g} .55$ & 51.41 & 3.40 & $42.7 \overline{8}$ & 22.75 & 35.16 & $21 \mathrm{c} 2$ & 4056 & 20.57 & 1564 & 43.49 \\
\hline abite & 26.97 & $\uparrow .92$ & 24.50 & & 44.42 & 13.38 & 31.12 & 19.35 & 20.01 & 30.96 & 45.70 & 23.20 \\
\hline anortila & 0.08 & 2.30 & 1.25 & & 4.19 & 240 & 5.86 & 25.11 & 2.37 & 0.10 & 20.58 & 477 \\
\hline refel ng & 1.30 & 1.13 & 0.47 & 5.07 & & 0.45 & 2.11 & 4.03 & & 528 & 2.01 & 0.04 \\
\hline cicpsido & 17.27 & 13.94 & 13.45 & 41.92 & 277 & $\$ 5.49$ & 10.08 & & 1383 & 3.97 & & 7.11 \\
\hline bypers ternis & & & & & C 06 & & & & 3.30 & & & \\
\hline ai vira & 2.28 & 1.40 & 029 & 7.72 & & 618 & 5.41 & 1170 & & 8.08 & 6.73 & 625 \\
\hline magretila & $2.7 \epsilon$ & 2.70 & 2.01 & 3.79 & $0 \in 0$ & 588 & 3. 10 & 5.24 & 2.04 & 425 & 2.81 & 3.09 \\
\hline ilmenta & $3.4 \mathrm{C}$ & 4.24 & 255 & 3.10 & 0.45 & 6.03 & 2.37 & 3.09 & 3.33 & 520 & 2.03 & 3.95 \\
\hline epatta & 2.53 & 1.81 & 1.52 & 7.68 & 0.07 & 690 & 1.22 & 0.84 & 2.35 & 3.74 & 0.67 & 399 \\
\hline acmita & & & & 2.56 & & & & & & & & \\
\hline leucila & & & & $11.3 \mathrm{~g}$ & & & & & & & & \\
\hline Total & 97.54 & 96.62 & $\$ 7.03$ & 96.64 & $9 \notin .00$ & 96.45 & 97.44 & 95.95 & 97.15 & 97.14 & 97.22 & 85.90 \\
\hline
\end{tabular}

NORMA CIPW EM AMOSTRAS DO SIENITO PEDRA BRANCA. 
Tabela 2: Dados Geoquímicos do Sienito Pedra Branca Obtidos por FRX. 


\begin{tabular}{|c|c|c|c|c|c|c|c|c|c|c|c|c|}
\hline & $\begin{array}{l}\text { PB-2 } \\
\text { SLSI }\end{array}$ & $\begin{array}{l}\text { PB-5A } \\
\text { SLS }\end{array}$ & $\begin{array}{c}\text { PB-3D } \\
\text { Enclwes } \\
\text { Uilramaflao }\end{array}$ & $\begin{array}{l}\text { PSO } \\
\text { SSI }\end{array}$ & $\begin{array}{l}\text { PB-22 } \\
\text { SSE }\end{array}$ & $\begin{array}{l}\text { PG-40 } \\
\text { SLSI }\end{array}$ & $\begin{array}{l}\text { PE-26A } \\
\text { SLS| }\end{array}$ & $\begin{array}{r}\text { PE-18 } \\
\text { SLSI }\end{array}$ & $\begin{array}{l}\text { PB-SB } \\
\text { SLS }\end{array}$ & $\begin{array}{c}\text { PE-59 } \\
\text { SSI }\end{array}$ & $\begin{array}{c}\text { PB-68B } \\
\text { SLSI }\end{array}$ & $\begin{array}{l}\text { PB-70A } \\
\text { SLSI }\end{array}$ \\
\hline $\mathrm{SiO}_{2}(\mathrm{~b})$ & 573 & SOE.EB & 11.73 & 5658 & 5.27 & 53.58 & 5.29 & C5.25 & 5036 & 86.71 & 583 & 7.13 \\
\hline $\mathrm{TTO} 2\left(\mathrm{v}_{0}\right)$ & $1+3$ & $\therefore E$ & 2.40 & $1 \in 1$ & $1 . \pi$ & 11.81 & 137 & 165 &.$\angle \varepsilon$ & 1.65 & $1.6^{\circ}$ & 1.39 \\
\hline$\triangle B R O 3(\%)$ & $1 \leqslant 8^{\circ}$ & $\angle \angle 2$ & 5.52 & $2, .55$ & $1<.27$ & 369 & 1226 & 1302 & $15=4$ & $14.5 \hat{3}$ & $13<2$ & 13.93 \\
\hline $\mathrm{Fe} 203$ (ic) & $\equiv 96$ & 5.37 & $14.2^{\prime}$ & $S \subseteq 2$ & 6.72 & $3 \subseteq 3$ & $\equiv 62$ & $\in 63$ & 5.38 & $€ .49$ & 6.03 & $=.30$ \\
\hline Uno $(/ / s)$ & $\therefore 18$ & 0.98 & c. 22 & 310 & $0 . x$ & 828 & $\therefore \infty$ & 6.1.2 & $0 . x$ & c. 0 & 009 & c. 0 \\
\hline$u_{\mathrm{g}} \mathrm{O}\left(\mathrm{c}^{\prime}\right)$ & 287 & $27 \%$ & 7.9 & SER & $3<2$ & 260 & 590 & 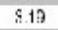 & 278 & 3.47 & 287 & 2.21 \\
\hline $\mathrm{CaO}[\mathrm{b}]$ & $5: 30$ & $5 . j 6$ & 15.52 & 566 & 5.33 & 351 & $\because 16$ & 6.63 & 5.38 & J.16 & 6.09 & $5 . x$ \\
\hline $\mathrm{Na} 20<160$ & 346 & 3.4 & 2.5 & 5213 & 3.57 & 160 & ¿6 & ¿285 & 30 & 2.0 & 3.52 & 3.22 \\
\hline $\mathrm{P} 205(\mathrm{~N})$ & $10 \mathrm{t}$ & $\therefore x$ & 2.69 & 111 & 1.35 & $3 \leqq 9$ & 182 & 1.52 & 0.34 & $C .99$ & 1.22 & $1 . x$ \\
\hline Loi [Q⿻) & $=64$ & 0.34 & C.42 & $3 \leq 0$ & 0.00 & 128 & 286 & 6.75 & $\therefore 1 \mathrm{E}$ & C.56 & $0.9^{\circ}$ & 0.92 \\
\hline \multicolumn{13}{|l|}{$\mathrm{E} \rightarrow \mathrm{O}[\mathrm{k} / \mathrm{a}$} \\
\hline \multirow{2}{*}{\multicolumn{13}{|c|}{$\begin{array}{l}\mathrm{CuO}(\mathrm{x}) \\
\mathrm{SpO} / \mathrm{s})\end{array}$}} \\
\hline & & & & & & & & & & & & \\
\hline Total (\%)] & is 27 & $10^{\circ} .60$ & 요씨 & 30.55 & g.d. & 政.10 & $1502^{\prime}$ & 50.75 & $90=8$ & 58.51 & $100 \mathrm{~J}_{\mathrm{i}}$ & 9.13 \\
\hline Ba (BPEM) & 555: & 7149 & $2 \bar{\varepsilon} 3$ & $44 i 7$ & 4478 & 7227 & $94 \dot{0} ?$ & 2214 & 4673 & $33 \div 8$ & 3200 & 5125 \\
\hline Ce (pem) & $32 \overline{7}$ & 38 & $\because \approx 0$ & $18 i$ & 210 & 473 & & & & & & \\
\hline Gu (ppmi & 5 & & & & & .5 & & & & & & \\
\hline Ga (ppmi) & & & & & & 3 & & & & & & \\
\hline La igprn] & 65 & 158 & 516 & 93 & 103 & 185 & & & & $\pi$ & & 98 \\
\hline $\mathrm{Nb}$ (pprini & 6 & $\cdot 5.6$ & $90 \%$ & 13.2 & &. & & & & & & \\
\hline Nd (ppm) & 61 & $1: 2$ & EtE. & 102 & 110 & 150 & & & & & & \\
\hline $\mathrm{Ni}(\mathrm{ppm})$ & 35 & & & 33 & & $\angle 3$ & & & & & & \\
\hline $\mathrm{Pb}$ (pem) & & 51 & ¿1 & 25 & & 32 & & & & & & \\
\hline $\mathrm{Rb}$ (ppm) & $9 ?$ & 158 & Bg & tak & 115 & 171 & 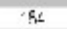 & 97 & 132 & 10 & $2 x$ & 288 \\
\hline So ipfm) & & & & & & 7 & & & & & & \\
\hline $3 \mathbf{r}(\mathrm{ppm})$ & 2327 & $\$ 698$ & 2581 & 2335 & 2400 & 339 & 1357 & $y 57$ & 2585 & 717 & 2796 & 2761 \\
\hline Thirsarit) & & 6. ${ }^{2}$ & 20.85 & 218 & 2.10 & 25 & & & & & & \\
\hline U (pprn) & & 0.27 & $1.7 y$ & 321 & & 23 & & & & & & \\
\hline$V(p \rho m)$ & 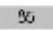 & 115 & $2 \approx 1$ & 162 & 130 & 73 & 35 & .54 & 125 & -23 & $13 T^{\prime}$ & $\leqq 1$ \\
\hline$\gamma(p \circ m)$ & $4 i$ & 34 & İz & 22 & 27 & 35 & $3 i$ & $\angle 1$ & $\gamma_{6}$ & 26 & 31 & $\bar{z}$ \\
\hline Zn ippm) & & & & & & 05 & & & & & & \\
\hline $\mathrm{Zr}(\mathrm{ppm})$ & 35 & 258 & $5 !: 4$ & 301 & 3.63 & 156 & 9 & $3 \bar{z} \mathrm{f}$ & f.54 & 78 & $2 A B$ & 64 \\
\hline
\end{tabular}

Dados Geoquímicos do Sienito Pedra Branca Obtidos por FRX. 


\begin{tabular}{|c|c|c|c|c|c|c|c|c|c|c|c|c|c|}
\hline & $\begin{array}{l}\text { PE-92E } \\
\text { SLS }\end{array}$ & $\begin{array}{l}\text { PE114A } \\
\text { SLSI }\end{array}$ & $\begin{array}{c}\text { PB 123A } \\
\text { SLS } \\
a\end{array}$ & $\begin{array}{l}\text { PB130 } \\
\text { SS! }\end{array}$ & $\begin{array}{l}\text { PB-142 } \\
\text { SLS }\end{array}$ & $\begin{array}{l}\text { PE-148 } \\
\text { SLS }\end{array}$ & $\begin{array}{l}\text { PB-169 } \\
\text { Enelave } \\
\text { Uitramifieo }\end{array}$ & $\begin{array}{c}\text { PB-174A } \\
\text { SLSI }\end{array}$ & $\begin{array}{l}\text { PB-181A } \\
\text { SLSI }\end{array}$ & $\begin{array}{l}\text { PS-19EA } \\
\text { SLS }\end{array}$ & $\begin{array}{l}\text { PB-185B } \\
\text { SLS }\end{array}$ & $\begin{array}{c}\text { PE-18sC } \\
\text { Enclave } \\
\text { Ultramafles }\end{array}$ & $\begin{array}{c}\text { PB-126B2 } \\
\text { Leucosilenito }\end{array}$ \\
\hline $5 i 02(13)$ & CODL & 5033 & & 662 & 50 & 98.5 & $\pi .20$ & 56.52 & $\operatorname{cs} \theta^{\prime}$ & 55.19 & 54.27 & 41.2 & 15.26 \\
\hline Al203(\%) & 14.30 & $-35 t$ & $16=$ & 1499 & $0 x \varepsilon$ & $C .09$ & $=13$ & 0.376 & C. $10^{\circ}$ & $3: 83$ & 0.354 & $C 2 \cdot 5$ & C02Z \\
\hline $\mathrm{Fe} 2 \mathrm{OS}^{-3}(\%)$ & 58 & 5.95 & $62:$ & $\equiv 69$ & $2 \leq ?$ & 2.9 & $\equiv 96$ & 3.20 & 333 & $2 \in 1$ & $.9 \pm$ & 10.42 & 022 \\
\hline UnO $(\mathrm{m})$ & 000 & ans & $0=\pi$ & $\therefore 0 \%$ & 451 & 5.31 & $\therefore .40$ & 6.21 & f. 86 & 560 & $4 \angle A$ & 1501 & 155 \\
\hline$u_{g} \circ \rho_{m i}$ & 287 & 3.29 & 302 & 257 & $3 \angle 1$ & 32 & 115 & $2: 2$ & \&5? & 280 & 301 & 145 & 525 \\
\hline $\mathrm{CaO}\langle \%\rangle$ & $\therefore 57$ & 3.21 & $5.7 \%$ & $16 \pi$ & 650 & C.X & 577 & 7.00 & [.83 & $3: 5$ & 8.7 & 388 & 72 \\
\hline $\mathrm{Na} 20\left[\mathrm{w}_{j}\right]$ & 5.58 & 1.2 & 3.5 & $3: 33$ & $\because 1$ & 1.11 & 567 & $\cdot .587$ & $1.7 y^{\prime}$ & 2431 & 1.393 & $12 \pi$ & $\angle 2 \mathrm{Js}$ \\
\hline $\mathrm{P} 205\langle\boldsymbol{\kappa}\rangle$ & 0.90 & .34 & $1 . \vdots$ & $=92$ & $5 \hat{3} 5$ & 59 & ־..23 & 5.30 & E.32 & 321 & $4.6 ?$ & 11.65 & 1.39 \\
\hline Loi $\langle 3,6\rangle$ & 0.56 & $\cdot \alpha$ & $0.3 \Xi$ & $=72$ & 034 & C. 45 & ¿11 & 0.32 & $C_{A \hat{3}}$ & 378 & $0.6=$ & 1.24 & 0.52 \\
\hline \multicolumn{14}{|l|}{$\begin{array}{l}\mathrm{BaO}\langle \%\rangle] \\
\mathrm{CuO}(\alpha) \\
\mathrm{SrO}(\%)\end{array}$} \\
\hline Total ('/3) & NC.TO & 9318 & 98.71 & $1062^{\prime}$ & 90 & 90.17 & (x.13 & D. 1.10 & $50 / 2$ & 93.01 & 93.51 & 58.691 & 59.37 \\
\hline $\mathrm{Bg}[\mathrm{ppm}]$ & $3 i \equiv \varepsilon$ & 6483 & $\equiv 1 \in 0$ & $332 \mathrm{C}$ & $415^{\circ}$ & $6 E c 9$ & 5034 & 7138 & $\angle E 0 E$ & 8025 & $\pm E 83$ & $25 \overline{2} 6$ & $2<27$ \\
\hline $\mathrm{Ce}[\mathrm{p} p \mathrm{~m}]$ & & & & & 346 & 560 & $22 i$ & 248 & 264 & 230 & 100 & $83 E$ & $<35$ \\
\hline Cu (ippm) & & & & & 22 & 47 & 92 & 7 & 8 & \& 6 & 20 & S纟:D & 5 \\
\hline Ga (ppr) & & & & & 19 & 17 & $\cdot 5$ & 17 & 12 & 17 & 19 & $1 \%$ & 21 \\
\hline La (ppm) & & $10 \%$ & & & 110 & 235 & $6 y$ & 182 & 79 & 187 & 111 & $5^{2} 6$ & $=28$ \\
\hline $\mathrm{Nb}$ (ppm) & & & & & 21 & 18 & $2 J$ & $\therefore$ & a & 17 & 11 & 7 & 13 \\
\hline $\operatorname{Nd}(\mathrm{pPm})$ & & & & & 139 & 200 & 12 & 152 & -36 & $10<$ & 131 & 391 & $<14$ \\
\hline $\mathrm{Mi}(\mathrm{ppm})$ & & & & & 25 & $\Xi 1$ & $0 \hat{3}$ & 34 & AC & 23 & 15 & 31 & 2 \\
\hline $\mathrm{Pb}$ [ [ppm] & & & & & 49 & $E$ & 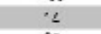 & 37 & \pm 5 & 4 & 34 & -242 & 37 \\
\hline $\mathrm{Rb}(\mathrm{ppm})$ & ${ }^{2} \hat{2} 2$ & 166 & $1 \approx 2$ & 35 & $1 \oplus$ & 45 & 95 & 224 & 78 & 22 & 218 & 1917 & 157 \\
\hline $\operatorname{Sc}(\mathrm{ppm})$ & & & & & 914 & 1f & 32 & 16 & $=14$ & $\div 11$ & $\div 14$ & 32 & $\div 14$ \\
\hline $3 \mathrm{r}$ (ppmin) & $Z 21 \xi$ & 3327 & 5282 & 1951 & 2335 & 1121 & $8^{\circ} 5$ & $\$ 403$ & 32.21 & 1322 & 2825 & 2311 & $67 b$ \\
\hline Th (ppm) & & & & & 23 & $1 i$ & 3 & 26 & $2 d$ & 3 & 21 & $=7$ & 7 \\
\hline$U_{(p p m]}$ & & & & & 16 & 站 & 3 & 3. & ¿d & 35 & 26 & $=3$ & 14 \\
\hline$V(\mathrm{pFm})$ & 27 & 90 & 131 & -30 & 92 & $\underline{\Xi}$ & 43 & 86 & -24 & 135 & 66 & $2^{2} \mathrm{C}$ & $<9$ \\
\hline$Y(\mathrm{pFm})$ & 2: & 29 & 27 & 25 & 39 & 41 & 29 & 30 & 41 & 43 & 35 & 95 & 25 \\
\hline $\mathrm{Zn}(\mathrm{ppm})$ & & & & & 92 & $\Xi t$ & $\ddot{i}_{i}$ & co & -12 & 1.2 & 72 & $23 E$ & 22 \\
\hline $\mathrm{Z} \cdot(\mathrm{ppm})$ & $4 \angle 7$ & 205 & $\leq 22$ & 393 & 545 & 50.3 & $5^{\prime}$ & 214 & 2827 & 349 & 198 & Gilf & f \\
\hline
\end{tabular}

Dados Geoquímicos do Sienito Pedra Branca Obtidos por FRX. 


\begin{tabular}{|c|c|c|c|c|c|c|c|}
\hline & $\begin{array}{l}\text { PB-209 B } \\
\text { Enchuve } \\
\text { Ultorambifleo }\end{array}$ & $\begin{array}{l}\text { PB-2009 C } \\
\text { Enclave } \\
\text { Sienitice }\end{array}$ & $\begin{array}{l}\text { PB-210 C } \\
\text { Enciave } \\
\text { Disfitios }\end{array}$ & $\begin{array}{l}\text { PE-2X0 } \\
\text { SLS }\end{array}$ & $\begin{array}{l}\text { PB-24T A } \\
\text { Enclawe } \\
\text { Monzonition }\end{array}$ & $\begin{array}{l}\text { PE-246 B } \\
\text { Enelsue } \\
\text { Dioritios }\end{array}$ & $\begin{array}{l}\text { PB-250 } \\
\text { Enelws } \\
\text { Sisnitico }\end{array}$ \\
\hline $\mathrm{SO} 02(\mathrm{*})$ & $15 \%$ & 65.13 & 1121 & क大...' & 18.13 & 5,01 & $52 \%$ \\
\hline$T_{i 0}\left(x^{2}\right)$ & 3.174 & 1245 & .629 & $.7 \pm 2$ & 2.739 & $0 r^{\circ}$ & 2.752 \\
\hline $2[203\langle \%\}$ & 7.31 & 15.49 & $2=09$ & $-3.7 t$ & 15.33 & 2079 & $1<.24$ \\
\hline$F=2003\{x\}$ & 1352 & $7: 2$ & 205 & 6.JE & 578 & $5 \equiv 8$ & $7: 1$ \\
\hline Nino $(3)$ & $0.2 \pi \%$ & c. 1.2 & $.1 \% 20$ & on?f & C. $13 \hat{\mathrm{A}}$ & 2042 & $0 . \pi n$ \\
\hline MgO $(X)$ & $6 ? ?$ & SEB & 289 & 2.37 & 437 & $1: 2$ & $35 ?$ \\
\hline $\mathrm{CaO}(\mathrm{s})$ & 1218 & 4.38 & 551 & $5.5 t$ & 140 & 3 & E.j \\
\hline $\mathrm{Na} 2 \mathrm{O}(\mathrm{\prime \prime} / 3)$ & $.3 j$ & 4.1 & 317 & 3.31 & $18^{\circ}$ & 5 & 275 \\
\hline$K 20(\%)$ & 3.5 & 5.96 & 371 & 6.Jt & 310 & 200 & 7.33 \\
\hline$P 205(Q, Q)$ & $2.5<4$ & C.527 & 0.963 & 238 & 1.615 & $52 \varsigma_{0}$ & 1.721 \\
\hline Lei $\left(\psi_{3}\right)$ & $0.3 \overline{3}$ & 0.38 & $\cdot 14$ & $0.3 \mathrm{C}$ & $C 7 L$ & 328 & 0.32 \\
\hline $\operatorname{Ban}(\%)$ & 032 & 0.48 & .34 & 0 .ิศ & 1.22 & .277 & 0.83 \\
\hline $\mathrm{CuO}(\%)$ & & & & & & 920 & \\
\hline Sro $(\mathrm{x})$ & 021 & D. 45 & .927 & 0.37 & C. 18 & .945 & 04? \\
\hline Total ("म) & $932 \mathrm{C}$ & $59 . \mathrm{z}$ & 357 & 98.i. & 51.95 & 2058 & \$o. .02 \\
\hline $\mathrm{Ba}(\mathrm{ppm})$ & $288 i$ & $42 ! 4$ & $30 i j$ & 5209 & -375 & $23 i:$ & $74 / 5$ \\
\hline $\mathrm{Ce}(\mathrm{ppm})$ & 325 & $1 z \zeta$ & $13 \hat{3}$ & $x_{4}$ & 152 & 103 & $\$ 3$ \\
\hline $\operatorname{Co}(p p m)$ & 30 & If & $x$ & 12 & 21 & 12 & 13 \\
\hline $\mathrm{Cr}$ (ppm) & $\pi$ & If & 5 & 24 & 49 & 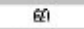 & 64 \\
\hline $\mathrm{Cu}(\mathrm{ppm})$ & 24 & 21 & F5? & 41 & 23 & $163 ?$ & 34 \\
\hline $\mathrm{Ga}(\mathrm{ppn})$ & 11 & 18 & 2 & 18 & 25 & $z 0$ & 18 \\
\hline La [ppmin) & 205 & 31 & 67 & 156 & 15 & 52 & 119 \\
\hline $\mathrm{Nb}(p p n)$ & 28 & $\therefore y$ & $<y$ & 15 & 20 & $<y$ & 11 \\
\hline $\operatorname{Nd}(\mathrm{ppm})$ & 305 & 71 & 60 & 165 & $\gamma_{2}$ & $3 i$ & 159 \\
\hline $\mathrm{Ni}(\overline{P F T})$ & 59 & 34 & $6 i$ & 29 & 40 & 40 & 57 \\
\hline $\mathrm{Pb}(\mathrm{ppm})$ & 42 & 55 & 38 & 46 & 23 & 4 & 44 \\
\hline $\mathrm{Rh}(\mathrm{ppm})$ & 100 & 141 & 222 & 167 & $x$ & 9 & 1F.5 \\
\hline So (ppm) & 32 & 14 & 2 & 16 & 3 & $1<$ & 14 \\
\hline Sr (ppmin) & 1757 & 3781 & 2257 & $\$ 15$ & ${ }^{\circ} 5 \mathrm{LC}$ & 577 & 175 \\
\hline Th [pprnin) & 21 & 11 & -2 & 19 & .5 & $1^{-}$ & 17 \\
\hline$U(p p m)$ & $=3$ & $\therefore y$ & $=3$ & $\therefore 3$ & $\approx y$ & $=5$ & $\therefore 3$ \\
\hline$V(p p m)$ & 185 & $11 \hat{\varepsilon}^{\circ}$ & 223 & 123 & .74 & 113 & 127 \\
\hline$Y$ (ppm) & 6 & 16 & 6 & 37 & 20 & 1 & 32 \\
\hline Zn (ppm) & 202 & 112 & 253 & $1 \mathrm{C} 2$ & $\cdot x$ & 113 & 114 \\
\hline Zripem) & 422 & 192 & 222 & 212 & 251 & 219 & 572 \\
\hline
\end{tabular}

Dados Geoquímicos do Sienito Pedra Branca Obtidos por FRX. 
Tabela 3: Dados Geoquímicos do Sienito Pedra Branca Obtidos por ICP-OES. 


\begin{tabular}{|c|c|c|c|c|c|c|c|c|c|}
\hline Amostra & $\begin{array}{c}\text { PB-8A } \\
\text { SLSI }\end{array}$ & $\begin{array}{l}\text { PB. } \theta B \\
\text { SLSI }\end{array}$ & $\begin{array}{l}\text { PB-25 } \\
\text { SSI }\end{array}$ & $\begin{array}{l}\text { PB-59 } \\
\text { SSI }\end{array}$ & $\begin{array}{l}\text { PB.71 } \\
\text { SLSI }\end{array}$ & $\begin{array}{c}\text { PB-92A } \\
\text { SLSI }\end{array}$ & $\begin{array}{l}\text { PB174A } \\
\text { SLSI }\end{array}$ & $\begin{array}{c}\text { PB-185A } \\
\text { SLS }\end{array}$ & $\begin{array}{l}\text { PB-229 } \\
\text { SLS }\end{array}$ \\
\hline $\mathrm{SiO}_{2}(\%)$ & 5677 & 5723 & 59.66 & 57.05 & 55.33 & 55.90 & 56.63 & 55.98 & 57.61 \\
\hline $\mathrm{AL}_{2} \mathrm{O}_{3}(\%)$ & 1373 & 1413 & $14 \subseteq 2$ & 1488 & 13.13 & 13.89 & 1335 & 14.30 & 14.20 \\
\hline $\mathrm{Fe}_{2} \mathrm{O}_{3}(\%)$ & 6.51 & 7.02 & 5.40 & 6.73 & 6.83 & 6.28 & 593 & 0.30 & 6.10 \\
\hline $\mathrm{CaO}(\%)$ & 6.01 & 5.18 & 4.43 & 5.65 & 6.22 & $5.5 \mathrm{C}$ & 6.29 & 5.09 & 5.68 \\
\hline $\operatorname{MgO}(\%)$ & 3.14 & 2.74 & 2.18 & 5.44 & 3.22 & 2.56 & 305 & 2.52 & $2 . \mathrm{s}_{1}$ \\
\hline $\mathrm{Na}_{2} \mathrm{O}(\%)$ & 3.17 & 3.38 & 325 & 3.65 & 2.32 & 3.36 & 257 & 2.54 & 3.30 \\
\hline $\mathrm{K}_{2} \mathrm{O}(\%)$ & 7.60 & 7.26 & 6.33 & 6.47 & 8.05 & 8.15 & 7.75 & 3.53 & 7.12 \\
\hline $\mathrm{MnO}(\%)$ & 0.11 & 0.10 & 0.09 & 0.11 & 0.10 & 0.11 & 0.09 & 0.10 & 0.11 \\
\hline $\mathrm{P}_{2} \mathrm{O}_{5}(\%)$ & 1.15 & 0.36 & 089 & 1.01 & 1.23 & $0.8 \mathrm{~s}$ & 131 & 0.75 & 1.21 \\
\hline $\mathrm{TiO}_{2}(\%)$ & 1.58 & 1.78 & 1.48 & 1.73 & 1.58 & 2.06 & 134 & 2.18 & 1.75 \\
\hline Loi $\left(y_{0}\right)$ & 0.44 & 0.52 & 1.59 & $0.5 \hat{5}$ & 1.77 & 1.00 & 0.45 & 1.07 & 0.34 \\
\hline Total (") & 10020 & 100.60 & 99.65 & 10079 & $\$ 9.79$ & 99.85 & $\leqslant \subseteq 14$ & 99.45 & 700.43 \\
\hline $\mathrm{Ba}$ (ppm) & 5974 & ExEO & 4423 & 4208 & 5492 & 7019 & 7466 & 8575 & 6578 \\
\hline La (ppm) & 174 & 140 & 121 & 65 & 132 & 194 & 172 & 164 & 183 \\
\hline $\mathrm{Sr}(\mathrm{ppm})$ & 3555 & 2918 & 2462 & 2011 & 4555 & 4139 & 3307 & 4157 & 2995 \\
\hline$V(p p m)$ & 25 & 91 & 45 & 84 & 24 & 112 & 53 & 164 & 113 \\
\hline$Y(p p m)$ & 24 & 15 & 27 & 24 & 7 & 33 & 26 & 37 & 33 \\
\hline$\Xi(\mathrm{ppm})$ & 138 & 171 & 223 & 151 & 214 & 473 & 140 & 295 & 165 \\
\hline
\end{tabular}


Tabela 4: Dados Geoquímicos do Sienito Pedra Branca Obtidos por ICP-MS. 


\begin{tabular}{|c|c|c|c|c|c|c|c|c|c|c|c|c|c|}
\hline Amostra & $\begin{array}{c}\text { PB-5A } \\
\text { SLS }\end{array}$ & $\begin{array}{c}\text { PB-8D } \\
\text { Enclave } \\
\text { Ultramáfico }\end{array}$ & $\begin{array}{l}\text { PB.09 } \\
\text { SSI }\end{array}$ & $\begin{array}{l}\text { 'B.22 } \\
\text { SSE }\end{array}$ & $\begin{array}{l}\text { PB-30 } \\
\text { SLSI }\end{array}$ & $\begin{array}{c}\text { PB-47B } \\
\text { SLSI }\end{array}$ & $\begin{array}{c}\text { PB92A } \\
\text { SLSI }\end{array}$ & $\begin{array}{c}\text { PB-1 } 42 \\
5 L 5\end{array}$ & $\begin{array}{c}\text { PQ-148 } \\
\text { SLS }\end{array}$ & $\begin{array}{c}\text { PB-1B1A } \\
\text { SLSI }\end{array}$ & $\begin{array}{c}\text { PB-185B } \\
\text { SL5 }\end{array}$ & $\begin{array}{c}\text { PB-185C } \\
\text { Enclave } \\
\text { Ultramáfico }\end{array}$ & $\begin{array}{l}\text { PB-18682 } \\
\text { Leucosienito }\end{array}$ \\
\hline
\end{tabular}

\begin{tabular}{|c|c|c|c|c|c|c|c|c|c|c|c|c|c|}
\hline $\mathbf{R b}(\mathbf{p p m})$ & 158 & 88.0 & 104 & 115 & 133 & 2003 & 245 & 161 & 129 & 156 & 214 & 178 & 138 \\
\hline $\operatorname{Sr}(p p m)$ & ริธดต & 2384 & 2385 & 2409 & 3208 & 3298 & 4000 & 2320 & 3534 & $31: 24$ & 3133 & 2340 & 1738 \\
\hline$Y$ (ppm) & 343 & 82.4 & 24 & 27 & 254 & 392 & 44 & 35.2 & 36.2 & 38.5 & 34.6 & 1145 & 220 \\
\hline $\operatorname{Zr}(\mathrm{ppm})$ & 258 & 594 & 329 & 363 & 116 & 320 & 599 & 513 & 464 & $13 \hat{34}$ & $1 c 0$ & $4 \hat{3}$ & 240 \\
\hline $\mathrm{Nb}$ (ppm) & 80 & 36.3 & 13.2 & & 3.15 & 21.2 & 31 & 22.7 & 8.4 & 34.3 & 21.5 & 16.9 & 220 \\
\hline Cs (ppm) & 0.83 & $1.3 \hat{s}$ & 0.43 & & 1.19 & 243 & 3.84 & 1.61 & 1.20 & 1.43 & 1.19 & 3.58 & 1.15 \\
\hline $\mathrm{Ba}(\mathrm{ppm})$ & 7148 & 2283 & $44 \pi$ & 4473 & $750 \mathrm{~g}$ & 3590 & 6810 & 4083 & 6018 & 4457 & 5690 & 2277 & 2344 \\
\hline La (ppm) & 158 & 518 & 96 & 103 & 192 & 285 & 221 & 189 & 387 & 218 & $2 \mathrm{C2}$ & 634 & 10.9 \\
\hline Ge (ppm) & $\$ 08$ & 1080 & $13 i$ & 210 & 423 & 539 & 446 & $\$ 12$ & 651 & 438 & 449 & 1409 & 446 \\
\hline $\operatorname{Pr}(p p m)$ & 379 & 132 & 25 & & 575 & 725 & 59 & 38.1 & 34.1 & 45.3 & 5.0 & $13^{\prime}$ & 5.7 \\
\hline $\mathrm{Nd}(\mathrm{ppm})$ & 152 & 485 & 104 & 110 & 229 & 223 & 238 & $10 \hat{s}$ & 247 & 178 & 180 & 756 & 225 \\
\hline Sim (ppm) & 257 & 79.9 & 19 & 17 & 361 & 362 & 42 & 25.9 & 35.8 & 28.8 & 33.2 & 94.6 & 5.1 \\
\hline Eu (ppm) & 7.11 & 19.3 & 5 & 5 & 8.52 & $\$ 00$ & 11 & 5.39 & $3.4 \hat{2}$ & 7.18 & 5.02 & 22.84 & 1.16 \\
\hline Gd (ppm) & 167 & 49.1 & 12 & & 21.5 & 18.2 & 25 & 16.2 & 16.8 & 15.4 & 15.6 & 45.5 & 4.1 \\
\hline Th (ppm) & 1.71 & 4.95 & 1 & 1 & $2 . \overline{65}$ & 198 & 3 & 1.69 & 1.82 & 1.62 & 1.78 & 4.48 & 0.66 \\
\hline Dy $(\mathrm{ppm})$ & 7.70 & 20.9 & f & & 85 & 788 & 12 & 7.43 & T.t. & 7.01 & 7.28 & $१ ९ .1$ & 3.58 \\
\hline Ho (ppm) & 1.17 & 2.36 & 1 & & 1.21 & 121 & 2 & 1.27 & 1.28 & 1.20 & 1.16 & 3.32 & 0.71 \\
\hline $\operatorname{Er}(\mathrm{ppm})$ & 3.04 & 7.48 & 2 & & 2.84 & 254 & 4 & 2.91 & $2 \pi$ & 267 & 2.34 & 6.22 & 1.76 \\
\hline $\operatorname{Tm}(\mathrm{ppm})$ & 0.32 & 0.72 & & & 0.25 & 0.30 & & 0.36 & 0.31 & 0.37 & 0.29 & 0.83 & 0.25 \\
\hline $\mathrm{Vb}(\mathrm{ppm})$ & 1.94 & $4.2 \hat{\mathrm{s}}$ & 1.57 & 1.51 & 1.79 & 177 & 2.35 & 2.25 & 2.00 & 2.19 & 1.59 & 4.56 & 1.46 \\
\hline Lu (ppm) & 0.29 & $0 . \hat{2}$ & 0 & $c$ & 0.23 & 0.24 & 0 & 0.31 & 0.28 & 0.31 & 0.20 & 0.62 & 0.17 \\
\hline $\mathrm{Hf}$ (ppm) & 5.76 & 53.3 & 7.12 & & 4.35 & 9.29 & 15.03 & 11.9 & 11.0 & 30.3 & 5.66 & 12.8 & 0.58 \\
\hline Ta (ppm) & 1.41 & 1.70 & 0.63 & & & & 2.50 & 0.78 & $0.6 \mathrm{C}$ & 1.37 & & & \\
\hline $\mathrm{Pb}(\mathrm{ppm})$ & 51.4 & 20.9 & 25 & & 19.5 & 220 & 51 & 41.6 & 45.3 & 42.7 & 23.0 & 1595 & 35.7 \\
\hline Th (ppm) & 6.19 & 20.9 & 2.18 & 2.10 & 5.19 & 111 & 2037 & 11.0 & 20.3 & 11.2 & 8.24 & 21.5 & 3.56 \\
\hline$U(\mathrm{ppm})$ & 1.09 & 2.02 & 0.21 & & 0.22 & 096 & 3.24 & 1.71 & $1 . \pi 8$ & 1.36 & 1.06 & 2.15 & 1.25 \\
\hline
\end{tabular}

Dados Geoquímicos do Sienito Pedra Branca Obtidos por ICP-MS. 


\begin{tabular}{|c|c|c|c|c|c|c|c|}
\hline Amostra & $\begin{array}{c}\text { PB-209B } \\
\text { Enclave } \\
\text { Uliraméfico }\end{array}$ & $\begin{array}{l}\text { PB-209C } \\
\text { Enclave } \\
\text { Sienítico }\end{array}$ & $\begin{array}{l}\text { PB-210C } \\
\text { Enclave } \\
\text { Dioritico }\end{array}$ & $\begin{array}{c}\text { PB-229 } \\
\text { SLS }\end{array}$ & $\begin{array}{c}\text { P日-247A } \\
\text { Enclave } \\
\text { Monzonitico }\end{array}$ & $\begin{array}{l}\text { PB-246B } \\
\text { Enclave } \\
\text { Dioritico }\end{array}$ & $\begin{array}{l}\text { PB-250 } \\
\text { Enclave } \\
\text { Sienítico }\end{array}$ \\
\hline $\mathrm{Rb}(\mathrm{ppm})$ & 95.5 & 133 & $2 \mathrm{C2}$ & 163 & 175 & 38.7 & 189 \\
\hline $\mathrm{Sr}(\mathrm{ppm})$ & 19.51 & 4008 & 2257 & 3285 & 1634 & 3797 & 4281 \\
\hline$Y(p p m)$ & 67.2 & $1 \& 3$ & 6.87 & 380 & 276 & 11.7 & 33.9 \\
\hline $\mathbf{Z r}(\mathrm{ppm})$ & 405 & 135 & 230 & 199 & 253 & 235 & 602 \\
\hline $\mathrm{Nb}(\mathrm{ppm})$ & 31.8 & 8.49 & 2.1 & 225 & 38.5 & 20.4 & 17.9 \\
\hline $\mathrm{Cs}_{3}(\mathrm{ppm})$ & 0.88 & 1.42 & 9.06 & 0.63 & 3.19 & 0.81 & 0.48 \\
\hline $\mathrm{Ba}(\mathrm{ppm})$ & 3035 & 4604 & 2887 & 3182 & 2182 & 2259 & 7894 \\
\hline La (ppm) & 321 & $\mathrm{cos} 5$ & 34.1 & 227 & 119 & 50.4 & 191 \\
\hline $\mathrm{Ce}(\mathrm{ppm})$ & 678 & 176 & 106 & 395 & $m$ & 77.7 & 899 \\
\hline $\operatorname{Pr}(p p m)$ & 95.3 & 204 & 11.1 & $47 \mathrm{~B}$ & 273 & 9.47 & 4.3 .7 \\
\hline $\mathrm{Nd}$ (ppm) & 364 & 80.5 & 41.0 & 190 & 106 & 34.8 & 125 \\
\hline $\mathrm{Sm}(\mathrm{ppm})$ & 62.8 & 135 & 5.74 & 314 & 171 & 5.61 & 30.9 \\
\hline Eu (ppm) & $11 . c$ & $4.2 \hat{j}$ & 2.04 & 8.11 & 4.6 & 3.21 & 3.27 \\
\hline Gd (ppm) & 38.6 & 8.81 & 3.74 & 159 & 11.3 & 3.93 & 19.1 \\
\hline Tb (ppm) & 3.91 & 0.57 & 0.37 & 208 & 130 & 0.47 & 1.88 \\
\hline Dy (ppm) & 16.9 & 4.42 & 1.60 & 894 & 617 & 2.28 & 3.07 \\
\hline Ho (ppm) & 236 & (.7.) & 2.26 & 132 & 103 & 0.41 & 1.16 \\
\hline $\operatorname{Er}(p p m)$ & 6.c. & 1.77 & 0.64 & 340 & 261 & 1.07 & 2.98 \\
\hline Tm (ppm) & $0.5 \mathrm{a}$ & 0.20 & 0.06 & 036 & 0.33 & 0.73 & 0.29 \\
\hline $\mathrm{Yb}(\mathrm{ppm})$ & $3.4 \bar{~}$ & 1.19 & 0.36 & 209 & 164 & 0.81 & 1.71 \\
\hline Lu (ppm) & 0.50 & 0.17 & 0.05 & 0.29 & 0.27 & 0.12 & 0.25 \\
\hline Hf (ppm) & 9.44 & 3.55 & 5.91 & 5.20 & 5.90 & 5.97 & 13.0 \\
\hline $\mathrm{Ta}(\mathrm{ppm})$ & & & 0.54 & & & & 0.44 \\
\hline $\mathrm{Pb}(\mathrm{ppm})$ & 23.0 & 500 & 29.3 & 377 & 18.2 & 40.8 & 29.1 \\
\hline Th (ppm) & 10.7 & 3.45 & 0.56 & 105 & 713 & 2.80 & 3.90 \\
\hline $\mathrm{U}(\mathrm{ppm})$ & 1.19 & C.ED & 0.16 & 104 & 249 & 0.41 & 0.90 \\
\hline
\end{tabular}

Dados Geoquímicos do Sienito Pedra Branca Obtidos por ICP-MS. 